Sounds from God-Music embedded in the human psyche of Boris Pigovat

Xi Liu

A thesis submitted to Victoria University of Wellington

in fulfilment of the requirements for the degree of

Doctor of Philosophy

Victoria University of Wellington

2020 


\section{Table of Contents}

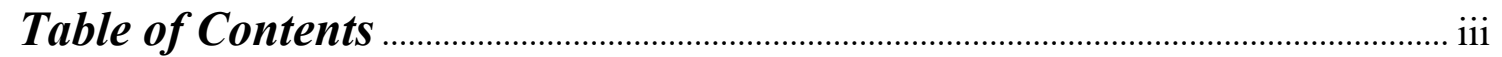

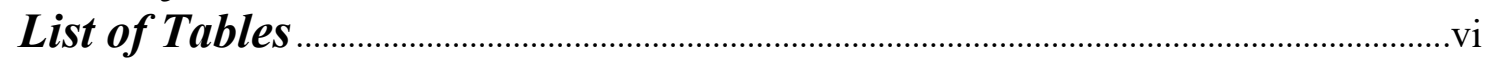

List of Links ...........................................................................................................................ii

List of Photographs...........................................................................................................

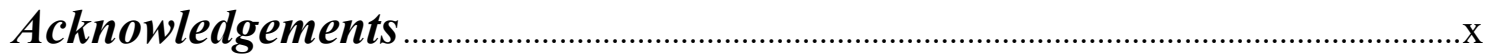

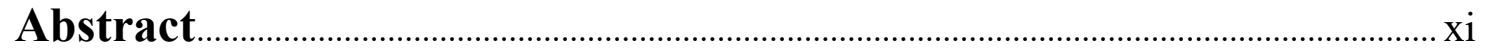

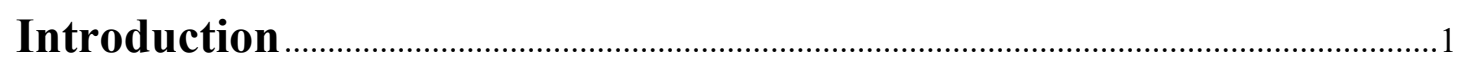

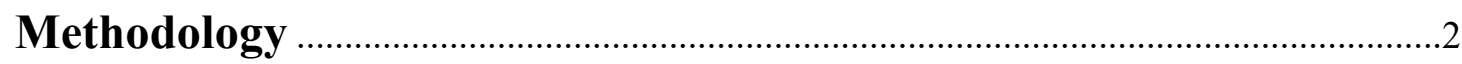

Part One:

Biography of Boris Pigovat

1.1 The early years -Odessa (1953-1968)................................................................6

1.2 Moscow-Gnessin Music College (1968-1973) ………………………………….. 11

1.3 Moscow-Gnessin Institute-Academia of Music (1973-1978).....................13

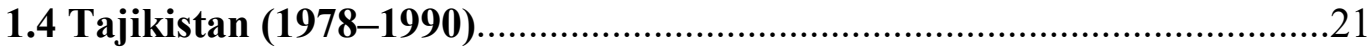

1.5 Emigration to Israel and the formation of musical style from $1990 \ldots \ldots \ldots . .23$

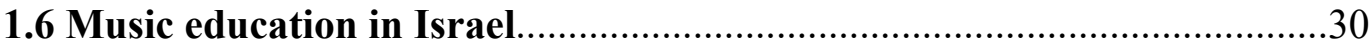

1.7 Pigovat's current situation ..........................................................................

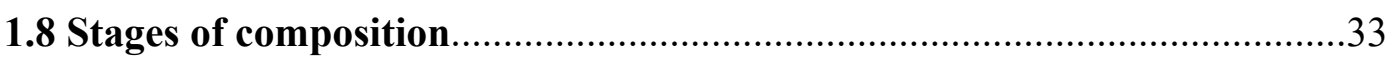

1.9 Highlights of performances of compositions................................................4

Part Two:

Repertoire Performed and Suggested Influences

2.1 Recital structure …………………………………………………………………………45

2.2 Links to the individual works performed in this project: .................................47

2.3 Notes about the works by Boris Pigovat ……………………………………………....50

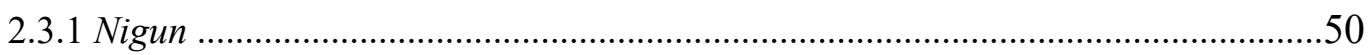

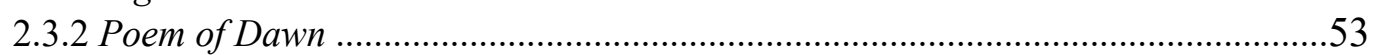

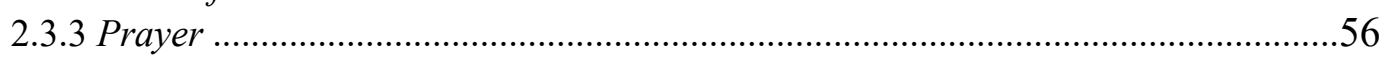

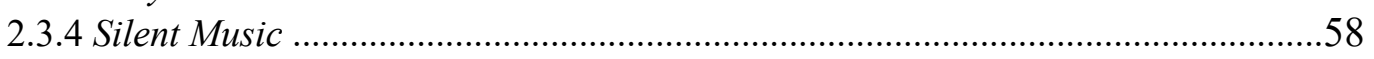




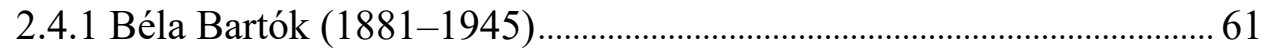

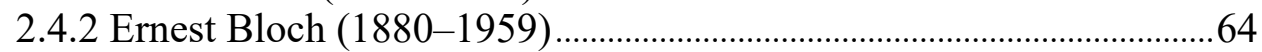

2.4.3 Mikhail Glinka (1804-1857) .....................................................66

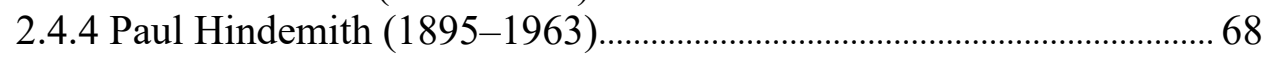

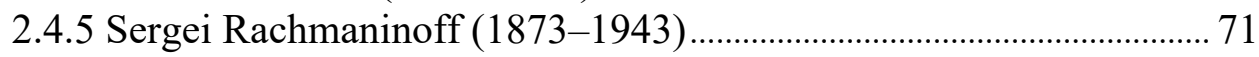

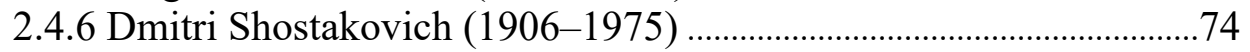

Part Three:

Boris Pigovat's Sonata for Viola and Piano

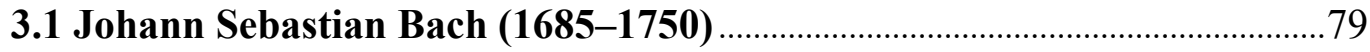

3.2 Creation and performance history of Sonata for Viola and Piano................ 81

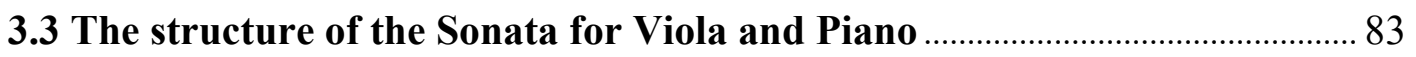

3.4 Pigovat's Sonata for Viola and Piano in the context of its predecessors before

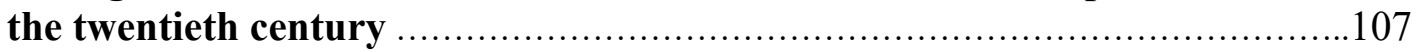

Part Four:

Holocaust Requiem

4.1 Genesis

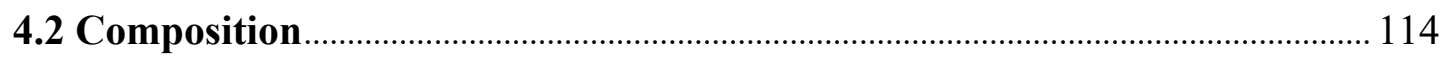

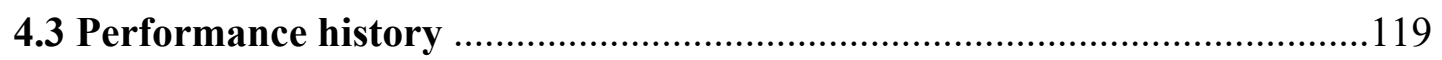

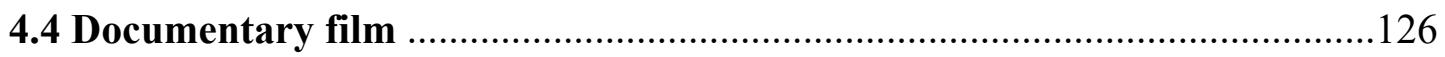

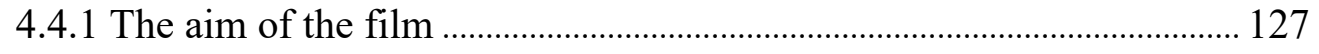

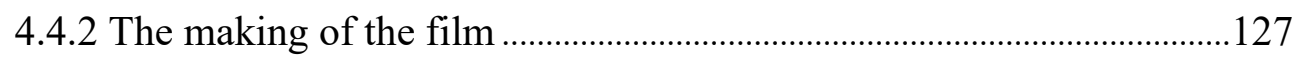

Part Five:

Reception

5.1 Holocaust Requiem 149

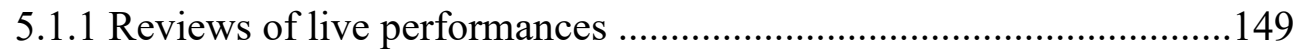

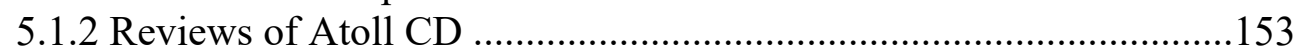

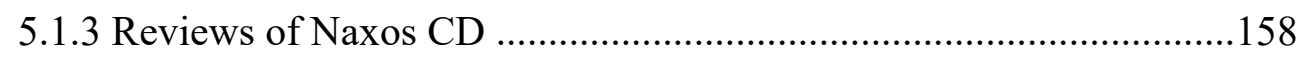

5.2 Prayer

5.3 Nigun 161 


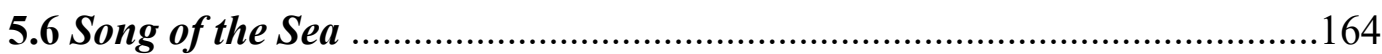

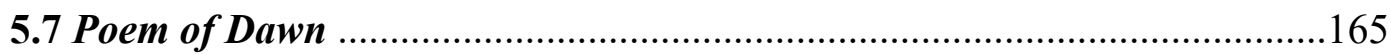

5.8 Lights from the Yellow Star (Music of Sorrow and Love) .........................168

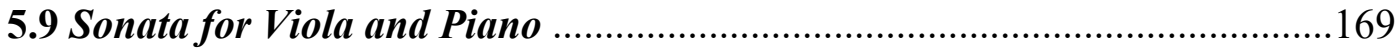

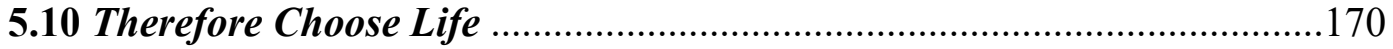

Conclusion

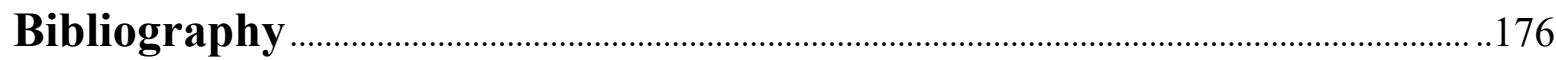

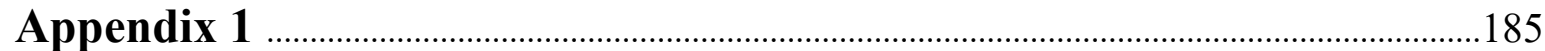

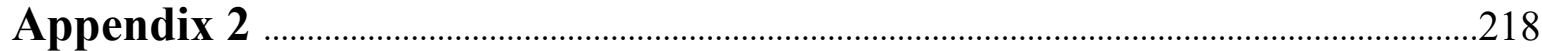

Appendix 3

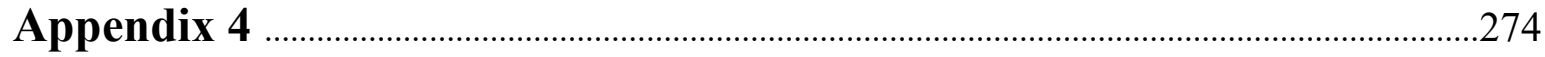

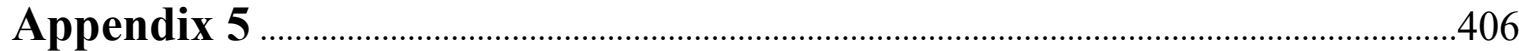




\section{List of Tables}

Table 3.1 Second movement of Sonata for Viola and Piano by Boris Pigovat 96

Table 3.2 Viola players born before 1850 categorised by country. .107 


\section{List of Links}

Link 2.1 Nigun - viola quartet

https://www.youtube.com/watch?v=9yAGEw-8jZc

Link 2.2 Poem of Dawn-viola and piano

https://vimeo.com/341272634/fc7e50b3e3

Link 2.3 Prayer - viola and piano

https://www.youtube.com/watch?v=ydMJKiprnMw

Link 2.4 Silent Music - viola and harp

https://www.youtube.com/watch?v=EnnaTVk7ZRU

Link 2.5 Sonata-viola and piano 1st movement

https://www.youtube.com/watch?v=rEEVQnAt8n4

Link 2.6 Sonata-viola and piano 2nd movement

https://www.youtube.com/watch?v=DRFWhrpVSo8

Link 2.7 Sonata-viola and piano 3rd movement

https://www.youtube.com/watch?v=dRXOwJ6VgW0

Link 2.8 J.S. Bach Sarabande from Partita in D minor - viola solo https://www.youtube.com/watch?v=75S7Y4rbM8Q

Link 2.9 Béla Bartók Concerto -viola with piano 1st movement https://www.youtube.com/watch?v=ZORpSQJrucM

Link 2.10 Divertimento for Strings

https://vimeo.com/341272893/636f311f07

Link 2.11 Ernest Bloch Suite 1919 - viola and piano 1st movement https://www.youtube.com/watch?v=qG_coq6Kd9g

Link 2.12 Ernest Bloch Suite 1919 - viola and piano 2nd movement https://www.youtube.com/watch?v=VhlaEWKwmCw

Link 2.13 Ernest Bloch Suite 1919 - viola and piano 3rd movement https://www.youtube.com/watch?v=Km02TBe9Ur4

Link 2.14 Ernest Bloch Suite 1919 - viola and piano 4th movement https://www.youtube.com/watch?v=9EuLYeyakAA 
Link 2.15 Mikhail Glinka Sonata - viola and piano 1st movement

https://www.youtube.com/watch?v=HT13N56NktY

Link 2.16 Mikhail Glinka Sonata - viola and piano 2ndmovement https://www.youtube.com/watch?v=SG8WfRbhjwg

Link 2.17 Paul Hindemith Der Schwanendreher - viola and piano 1st movement https://www.youtube.com/watch?v=9-eS9jNrVDU

Link 2.18 Paul Hindemith Der Schwanendreher - viola and piano 2nd movement https://www.youtube.com/watch?v=gJk50Vfvull

Link 2.19 Paul Hindemith Der Schwanendreher - viola and piano 3rd movement https://www.youtube.com/watch?v=n1P9tNafeMI

Link 2.20 Sergei Rachmaninov Vocalise - viola and piano https://www.youtube.com/watch?v=O7H19E4DVXE

Link 2.21 Dmitri Shostakovich String Quartet No 8 https://vimeo.com/341272677/2e30906583

Link 2.22 Dmitri Shostakovich Viola Sonata 1st movement https://www.youtube.com/watch?v=C-MLcUjetlo

Link 2.23 Dmitri Shostakovich Viola Sonata 2 nd movement https://www.youtube.com/watch?v=t-r6JUqming

Link 2.24 Dmitri Shostakovich Viola Sonata 3rd movement https://www.youtube.com/watch?v=jKXbVCWzJfY 


\section{List of Photographs}

Photo 2.1 Anna Serova with Nicolai Guerini ...................................................55

Photo 2.2 Holocaust Requiem and Poem of Dawn ........................................55

Photo 2.3 Anna Serova with the New Zealand Symphony Orchestra ....................56

Photo 2.4 The Holocaust Requiem CD was awarded the Supersonic Award ......58

Photo 3.1 Donald Maurice and Wioletta Fluda, World premiere in Krakow, 2013 (Left)

Atoll CD including premiere recording of Sonata for Viola and Piano in 2012

(Right)...

Photo 3.2 Madonna del Magnificat (1483-1485) .84

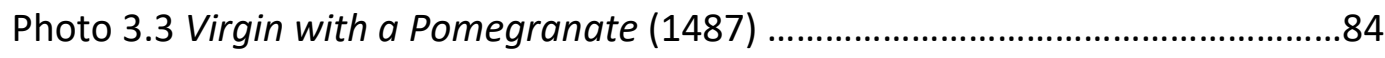

Photo 4.1 Score of Holocaust Requiem ............................................................111

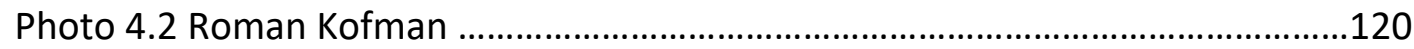

Photo 4.3 Donald Maurice with Vector Wellington Orchestra ..............................121

Photo 4.4 Donald Maurice with Duesseldorf-based Camerata Louis Spohr 124

Photo 4.5 Tatjana Mead Chamis and Manfred Honeck with Pittsburgh Symphony Orchestra. 


\section{Acknowledgements}

During the research and writing of this thesis I have received a great deal of support and assistance from many people.

I would like to express my sincere gratitude to my supervisors, Professor Donald Maurice, Associate Professor Martin Riseley and Associate Professor Gillian Ansell. I would like to thank Professor Maurice for his enthusiasm for this project, for his consistent support, encouragement and patience, and his always thoughtful comments and recommendations. Associate Professor Riseley provided me with opportunities to perform in concerts, and gave valuable advice on developing advanced technical skills on the viola. Associate Professor Ansell encouraged me to explore a wide range of interpretive ideas. I am grateful for all the advice from my team of supervisors both while preparing for performances and for their careful reading of my exegesis and their valuable feedback and advice.

I would like to express my special thanks to the great musicians with whom I was fortunate to perform my recitals (in recital order): Catherine Norton, Martin Riseley, Monique Lapins, Olivia Wilding, Fiona McCabe, Madeleine Crump, Krzysztof Sowiński, Elyse Dalabakis, Marianna Kalicka, Aleksandra Ruciak, Grant Baker, Sophia Acheson and Donald Maurice. Without their willingness to be part of this demanding repertoire, spending time in rehearsals and sharing my passion for these works, these programmes would not have been possible.

Assistance provided by Graham Kennedy is much appreciated, and I would like to thank him for his help with all the technical issues regarding recordings and his role as sound engineer in the film Lacrimosa Dies IIla.

I am particularly grateful for the assistance given by Bill McCarthy, director of Lacrimosa Dies IIla, whose professional skills in camera work, assembling all the components and editing the film, is deeply appreciated. 
Finally, I would like to thank my family in China, especially my parents, Guoqing Cao and Chunli Liu, for their constant support, encouragement and constructive criticism.

The thesis was proofread by Madeleine Collinge, to whom I am grateful for her professionalism, and advice. 


\section{Abstract}

This thesis examines the life and music of Israeli composer Boris Pigovat with emphasis on the works he has composed that feature the viola. It presents the first detailed account of his life from childhood to being an internationally respected composer. His landmark work from 1995, the Holocaust Requiem, stands amongst the most significant works of all time for viola and orchestra. While the research includes details of Pigovat's education and career, it also examines in depth the background and analytical aspects of the Holocaust Requiem and the Sonata for viola and piano, and includes video recordings by the researcher of all his works featuring the viola.

The central component of this study is the production of the film Lacrimosa Dies IIla, a documentary about the Holocaust Requiem that includes interviews with the composer, commentary by a colleague in Kyiv at the site of the Babi Yar massacre of 1941 (at which the composers grandparents and aunt were executed), and performances of excerpts of the Holocaust Requiem with the researcher as soloist with the New Zealand School of Music Orchestra, conducted by Martin Riseley. 


\section{Introduction}

While the thesis addressed several research questions, they can all be encapsulated in the single broad question:

What is the significance and legacy of the life and music of Ukranian-born Israeli composer, Boris Pigovat?

A major creative component in composition has been a longstanding part of the Victoria University PhD. Upon the introduction of the DMA to the New Zealand School of Music in 2009 a parallel pathway for both composition and performance was developed in both degrees. The DMA in performance offered the scope to present a series of five recitals accompanied by an exegesis, designed to elucidate the understanding of the repertoire and its preparation for performance and recording. The PhD, with a major component of performance, offered the opportunity to pursue a focused research area in depth, in a written thesis and to support that research with performances and, where appropriate, musical analysis.

This research from the outset clearly suited the PhD format as it has focused on the life and music of Israeli composer Boris Pigovat and the music of other composers whose music has had a clear influence on him. To date, the only PhD completion at Victoria University, with a major component of performance, was awarded in 2020 to Dr Gabriela Glapska, whose work focused on the life and music of Polish composer, Andre Tchaikowsky. As such, this thesis was groundbreaking and set a precedent for an approach for creating a thesis that provides a balance between academic research and the creative component of performance. The structure of my thesis has been modelled on the work of Dr Glapska though with some modifications, due to Andre Tchaikowsky being dead and Boris Pigovat being alive, and therefore available for consultation. 
The other major difference is the inclusion in this thesis of a documentary film. This is about Boris Pigovat's Holocaust Requiem, in which I interview the composer, perform as soloist with the New Zealand School of Music Orchestra, create the English translations and subtitles, and I serve as the film's associate producer. It is almost miraculous that the making of this film was possible. For over two years the dates of 13-16July 2020 were booked with the orchestra and venue to rehearse and film the Holocaust Requiem. On 25 March New Zealand moved into Level Four lockdown under Covid-19 government restrictions. On 27 April the restriction was reduced to Level 3 and on 13 May to Level 2 . Under all three levels it would have been impossible to assemble the orchestra. On 8 June the restrictions were lowered to Level 1 and the filming became possible once again. On 12 August Auckland was raised back to Level 3 and the rest of New Zealand to Level 2. The national alert level (except for Auckland) did not return to Level 1 until September 1. The window of opportunity in June-July played in our favour.

The thesis is presented in seven parts: Introduction, Biography, Repertoire and Influences, Sonata for viola and piano, Holocaust Requiem, Reception and Conclusion. A literature review was prepared as part of the confirmation process in 2017 but was not included in the final thesis because it focused mainly on matters relating to Jewish and Russian music history and politics, neither of which ultimately became significant elements in the degree. The focus of the eventually included sections contain references to sources where appropriate, but as all deal mostly with primary sources, it was decided not to include a separate literature review.

\section{Methodology}

Due to the very different nature of each part of the thesis, an appropriate methodological approach was developed to achieve the optimum research outcomes. 
The Biography was developed from a series of interviews I conducted with Boris Pigovat in September 2019 and through his answers to questions I sent him in advance by email, with Ethics approval from Victoria University. While there is extensive information about the works and career path of Pigovat on his own website and other published interviews, there was a lack of information about his early life and education. This 'new' biography attempts to give a comprehensive summary of his life, career and works. After completing the draft of the biography I sent it to Pigovat for his feedback and he made some requests and suggestions for accuracy. The final version was approved by Pigovat.

The methodology I employed for the Repertoire and Influences part was to explore selected works of Pigovat and works selected by composers who may have influenced him. Firstly, I compiled a list of all the repertoire by Pigovat featuring the viola. Secondly, I sought selections of repertoire by other composers to complement each of those works, to make five cohesive programmes, with the Requiem standing alone as the final project in the form of a documentary film. The aim was to find works that were from similar genres by the selected composers. The specific works did not necessarily have an obvious connection to Pigovat's music but were selected to give support to the featured work(s) by Pigovat in a balanced programme.

Links to video performances of the works performed are provided and explanations as to why the works of other composers were included. It is acknowledged that identifying influences on a composer can be very subjective, as one is looking for broad concepts and musical language, rather than specific musical quotations. However, the influence of Rachmaninoff is cited by the composer himself, and the influence of Shostakovich is unmistakable.

The methodology for the Viola Sonata section was to employ formal and descriptive analysis and to explore the background and creation of this work. These observations are a combination of personal investigation of the musical elements 
and information extracted from my interviews with Pigovat. I have also included a survey of viola players born before 1850 and their countries of birth, alongside a summary of viola sonatas composed prior to the twentieth century, to provide a context of the viola sonata genre which preceded the explosion of viola sonatas in the twentieth century, partially fuelled by the emergence of English violist Lionel Tertis and Scottish-American violist William Primrose. Of note from this survey is the predominance in the nineteenth century of this genre by German and Russian composers, and these represent the traditions in which Boris Pigovat was immersed in his most formative years.

The methodology for the Holocaust Requiem section was to create a documentary film combining elements of narration, interview, photographic images, and performance. Additional information is provided about the process of creating the film from my perspective as associate producer, translator and performer. The story of the genesis, composition, performances and the composer's own commentary are discussed, partly drawing from the work of previous researchers, but in large part drawn from my extensive interviews with Pigovat in Israel in September 2019. Excerpts of those interviews are interwoven into the film along with interviews at Babi Yar, Kyiv, with a local musician, and studio recorded videos of my own performances of excerpts with the New Zealand School of Music Orchestra.

Finally, the methodology for the Reception section was to investigate through published reviews how the music of Boris Pigovat has been received since his name has become known beyond Ukraine and Israel. His exposure through live performances outside Israel remains low, even twenty-five years after his emigration there in 1995. However, through a few well-distributed and well-reviewed recordings, we can gain some insight into how his music has been evaluated. Part of his isolation from mainstream western music is due to his own humble nature and 
lack of self-promotion, and partly due to self-publishing all his music and lacking a business background. 


\section{Part One-Biography of Boris Pigovat}

Boris Pigovat's career has been very diverse and complex. However, the trajectory of his professional path has remained unchanged, and he continues to follow his vocation with enviable perseverance. His devotion to music has been generously rewarded: his favourite works are heard in many countries of the world and he continuously spreads his positive energy to his students. Many musicians can only dream of such self-realisation in these unstable times. To date, Boris Pigovat is the composer of two oratorios, two symphonies, the Holocaust Requiem for viola and symphony orchestra, six symphonic poems for symphonic orchestra and eight for large wind orchestra, works for string orchestra and many chamber-instrumental ensembles. On his website he has written the soulful and unambiguous words: "My dream is to create until the last moment of my life..."

The following information is based on the interviews I conducted in Israel in October 2019, and the interview published in Russian by Elena Nikolaeva in 2009.The full transcript of my interview with the composer about his life and career is available in Appendix One.

\subsection{The early years - Odessa (1953-1968)}

Boris Pigovat was born on 26 October, 1953 in Odessa, Ukraine, formerly part of the USSR. The second child of a textile engineer, he had no special perceivable traits to suggest that he would become a composer, neither in the family, nor in the environment around him. Pigovat and his family lived in a factory village on the outskirts of Odessa. His father, Zelik Pigovat, worked in a cloth factory and his mother, Dvosya Kaplansky, was a doctor there in the first-aid post. Neither of them was engaged in music. His elder sister, Tamara Pigovat, played the piano. 
Zelik Pigovat graduated from an institute as a textile-processing engineer in fabric manufacturing, and he worked at the cloth factory in Odessa before the SovietFinnish War (1939). When this war began in 1939, Zelik Pigovat was drafted into the army, where he remained for ten years until 1949. He ascended through the ranks from a soldier to a junior officer, and he finished his service with the rank of major. After he was demobilised from the army, his father returned to work at the cloth factory in Odessa. His work roles alternated as a foreman, a shift supervisor, a workshop superintendent and eventually a production superintendent. Dvosya Kaplansky studied medicine and after graduating from medical school she worked as a doctor. His parents met in Orenburg in 1949, and they were married soon afterwards. They came to Odessa, where his mother worked as a doctor.

Boris Pigovat's grandparents (Chaim Pigovat and Basya Chaya Pigovat) and his aunt (Hannah Pigovat, the younger sister of his father) were victims among the tens of thousands of Jewish people executed during the German occupation of Kiev from 1941 to 1943. Chaim and Basya Chaya lived in Novograd-Volynsk, a city in Ukraine, not far from Kiev. In 1941 they all lived in Kiev, and they died on the first day (29 September 1941) of the Babi Yar executions in Kiev. The parents of Pigovat's mother (Yudel Kaplansky and Leah Kaplansky) were descendants of Polish Jews, and they lived and died in Orenburg (SW Russia).

None of Pigovat's grandparents had any musical education. His grandfathers were working men and his grandmothers were housewives. Chaim Pigovat, the composer's paternal grandfather, was a cantor in a synagogue, singing and conducting religious services there. Leah Kaplansky was very keen on Ukrainian opera and sang with pleasure what she heard. When Boris Pigovat started playing the piano, he accompanied her. Leah Kaplansky really loved music, though she could not read music.

Boris's enthusiasm for music was apparently inherited. The only professional musician among the relatives was his mother's younger brother, Mikhail Kaplansky, 
who was well known in the professional circles of the Urals and Siberia as the artistic director of the Chelyabinsk Choral Chapel-Metallurg. As such, he pursued a different career from his family. He was very interested in music and he played the accordion. He studied as a conductor and worked all his life as a choral conductor. Therefore, Boris might have gained some musical impressions or influences since he was a child. Boris's mother had told him: "When you were about four years old, you started waving your arms, and said that you wanted to be a conductor like your uncle."

Zelik Pigovat went on vacation to visit relatives in Orenburg and met Dvosya Kaplansky there in 1949. After that, they worked in Odessa, Ukraine, where Boris was born. Odessa is famous for its musical traditions and excellent performing schools, with its famous violin school named after Peter Solomonovich Stolyarsky, ${ }^{1}$ where David Oistrakh, Boris Holstein, Nathan Milstein, Samuel Furer and Mikhail Fichtenholtz studied. They were all Stolyarsky's students, and Stolyarsky himself was a student of Leopold Auer - the famous violinist of the Tsarist era. There were also good local schools, both vocal and piano. While he studied at the schools, Pigovat did not have a special relationship with these traditions, since he was not a hereditary Odessa citizen.

Boris Pigovat already wanted to conduct when he was four or five years old, as he had already listened to a lot of classical music. As a child, he was taken to the local music school for children, like his elder sister, Tamara, to enter the piano class. Boris was always attracted to the music he heard his sister play on the piano. The school's teacher said that he had good ears for learning the violin, so he studied the violin at the same time, though what he truly loved was playing the piano. He always wanted to play the piano and had a craving for this instrument. He was determined to be a young violinist, and also dreamed of becoming a pianist. Everyone knew that it was

${ }^{1}$ https://web.archive.org/web/20080517051008/http://www.moria.farlep.net/ru/almanah 02/02 11 .htm 15 December 2020. 
harder to study the violin than the piano, so there were few students coming to study the violin in this school.

Sometimes he did not like playing violin since he was required to do daily practice exercises focusing on the accuracy and the quality of sound. He often locked himself in the kitchen at home and stood in front of the music stand and drew the bow on the strings. At that time, they had to study at home constantly, but Boris was not interested in unattractive daily practising. Instead he placed a book on the music stand and pretended to be playing the violin. He read books on anything that interested him but nothing about playing a violin. As neither his mother nor father had a music education, they did not know what he was playing. The most important thing was that their child should practise, but what he was playing did not concern them. As a result, he could read books that he liked, and everyone was happy.

These seven years of "violin suffering" gave him the feeling of the instrument that helped him a lot in terms of composing. Now when he writes for strings he can always imagine how to play a particular chord or passage and try to make the part comfortable for the performers. He can understand the best way to write for the violin. It is also easier for him to write for the viola, because they are related instruments. When he writes for this instrument, he can hear it in his head and imagine how to create the music. Certainly, it happens that he sometimes writes uncomfortable passages, but he is always open to make changes and listen to the performers.

The early years of studying piano were one of the most essential components in Boris Pigovat's composing life. Normally, he does not perform concerts, but plays the piano only for writing creative works. He needs this instrument in order to compose so that he can hear musical ideas, melodic images, or melodic formulas that are in his head. Sometimes he likes to sit down at the piano and improvise when he is in 
the mood to test musical ideas. The sound of this instrument somehow guides him, and suddenly the musical materials appear. The composer said in the interview in Israel:

I have an instrument that gives me the opportunity to listen to the sound of any instrument of the orchestra. The sound of piano gives me a certain impetus for creativity. I play the piano, improvise in my boring mood, and suddenly I feel that somehow it has gone. That is, the creative process has begun. Then it begins the "black"-hard work of the composer. But the piano gives me an initial impulse.

During Boris's school years he met many outstanding teachers in different stages of studies. In the first place, he studied with a good piano teacher in the music school, Olga Alexandrovna Chichkina. He also studied with other piano teachers, but only she gave him a comprehensive understanding of the piano.

V.D. Stakhovsky, the headmaster of the children's music school where Boris studied, was another Odessa resident who was able to play violin a little. He is a man of irrepressible energy (even now he still directs the choir) and an enthusiast who was trying to find new ways of delivering children's music education. He set up a special music theory group, which included Boris, where they studied intensively. At solfeggio lessons, they sang choruses by Bach, fragments of Mozart's Requiem, and many other great musical works. Most importantly, Stakhovsky invited a teacher of harmony from the conservatory who gave lessons in composition. One such guest was Igor Mitrokhin from the Odessa Conservatory, a harmony teacher who taught composition in this children's music school, and students wrote some small pieces, variations and so on. Boris started composing for the first time and his work Spring for violin and piano won Second Prize in the Ukrainian-wide competition of children's musical creativity. 
While Boris Pigovat was studying at the music school, he especially loved the music of Rachmaninoff. He was interested in everything about Rachmaninoff. Friends even laughed at him a little, because he hung a huge poster of Rachmaninoff on the wall at his home with his biography and photographs.

In the musical life in the 1960s of Ukraine, Boris had a subscription for the Odessa Philharmonic. He heard Rachmaninoff's Second Concerto and the Scheherazade of Rimsky-Korsakov. These were vivid impressions for the young Boris as a student of age 13 or 14 .

\subsection{Moscow-Gnessin Music College (1968-1973)}

After seven years of study at the children's music school, Pigovat began study at the Gnessin Music College. Studying at Gnessin Music College was a beautiful time for Boris Pigovat. The teaching staff in the composition department was remarkable. Theoretical subjects were led by Associate Professors of the Conservatory and Gnessin Institute - B.K. Alekseev (harmony and solfeggio), V.H. Kholopova (analysis of musical works) and A.G. Chugaev (polyphony). Instrumental studies and individual classes were conducted by the postgraduate student of the Conservatory - A.S. Sokolov, the future professor of the Moscow Conservatory and Minister of Russian Culture. Pigovat studied basic composition under the guidance of O.K. Eyges - a composer and pianist, a vivid representative of the old Moscow intelligentsia. Unfortunately, these courses stopped for no apparent reason from the third year and he had to study by himself.

Pigovat's piano teacher at the Gnessin Music College, Alla Andreevna Kollegayeva, whom he greatly admired, was a student of Samuil Feinberg. She was a bright woman and possessed an artistic nature and as well as music she was fond of poetry and painting. When he played a new composition he always got a response from her 
of absolute sincerity and benevolence, but extremely strict from the point of view of artistic taste. She did not show any mercy if it was necessary to say the work was bad. Because of an accident she had had to interrupt her career as a piano soloist and became involved in teaching. It is worthwhile to note that the knowledge and basic skills Pigovat obtained at Gnessin Music College were so comprehensive that they made him feel very comfortable while studying at the Gnessin Institute and subsequently were enormously helpful in his teaching positions.

In general, Moscow of the 1970s was a golden time in terms of concert and artistic life. There were so many opportunities for Pigovat to hear interpretations from wonderful soloists and ensembles coming from all over the world. Notable orchestras from New York, London, Paris and Amsterdam came to Moscow. Moscow's vast artistic offerings made a strong impact on Pigovat, then a teenager from the city of Odessa. Everything that happened to him was fresh and interesting and he tried to obtain the best of what musical impressions could be absorbed in Moscow. In his first year in Moscow, on one occasion he bought a series of subscription tickets for concerts at the Big Concert Hall of the Moscow Conservatory. The players were all Lenin award winners -including Sviatoslav Richter, Emil Gilels, David Oistrakh, Mstislav Rostropovich and Leonid Kogan. Pigovat was very excited and looked forward to this greatly because normally he could only hear their music from recordings. He recalled this story in the interview:

I accidentally got into the performance of the Vienna Opera "Tristan and Isolde", which was an incredible event. I remember that when I came to the Big Theatre I squeezed through the crowd of free riders without any hope and just stood there. Suddenly the door opened with the words "Give me this plump boy" and the usherette dragged me into the foyer of the theatre where I got a six-ruble ticket, a ticket at one of the first rows of the stalls (that was very expensive for those times the admission fee was 20 rubles). Apparently, one of the authorities did not come and the reservation was vacant. 
As for social life, Pigovat was not a "social activist". He did not aspire to be an organiser or the centre of the company (in Russian, "company" is a group of people connected by friendships, common interests or often spending time together). He was somehow always a bit of an individual. He had a few friends, and they were very good friends. It was a circle of communication that Pigovat always appreciated. Under the Communist Party of the Soviet Union, one was obliged to take an active part in social life. One had to participate in demonstrations and take part in some social events in order to continue to study, but Pigovat did not aspire to be an "activist" at that time.

Concerning Pigovat's compositions of this period, from a rather large list there were two compositions for piano which he considered to be his first works. They are the suite The Little Prince and Sonata-Ballad. Both opuses were published by the Czech Supraphon in 1980 and the Music in Moscow in 1981, respectively. He considers The Little Prince, based on the book by A. de Saint-Exupery, to be his first composition before he received professional training, because he wrote it when he was seventeen years old and it was published after ten years. This work was partly influenced by Scriabin, because it was written during his obsession with Scriabin's works.

In his interview with Elena Nikolaeva, Pigovat commented "I am grateful to fate that I was lucky enough to communicate with such wonderful and so extraordinary teachers." ${ }^{2}$ Certainly, nobody doubted his compositional prospects when he was at the institute and those teachers were also the people who guided him to enlightenment and the fountain of creation.

\subsection{Moscow-Gnessin Institute-Academia of Music (1973-1978)}

\footnotetext{
2 Elena Nikolaeva, There is no coincidence in our lives (Moscow, 2010). Translation by Xi Liu.
} 
The approach to learning composition in Moscow encompassed a range of general requirements. For example, in the first year at the institute (conservatory), students were required to write in small forms. In the second year, they were required to write in sonata form. In the third year, they were required to write a work for a chamber ensemble. In the final year, it was necessary to write an orchestral composition.

However, in reality, in Pigovat's opinion, everything depends on the teachers. He believes that some teachers think that the more works students write, the better the results, and that students will gain writing experience and everything they write will be good.

It normally happens that when the student is talented, this talent will show itself in the end. They will write many works and obtain a strong compositional technique, and nothing will limit them. Other teachers say that students should acquire mastery of different techniques and different styles and they must be able to write in the classical style, also they must be able to be familiar with the newest trends, or the newest techniques and be able to work in any of these styles. ${ }^{3}$

Pigovat's main composition teacher was Nikolai Ivanovich Peiko. He was a student of Nikolai Myaskovsky who was a representative of the Russian composers' school. There were people who simply did not accept Nikolai Ivanovich's character and his demands, thinking he was too demanding, but he was always honest with himself in terms of what a piece of music should be. He did not hesitate to tell it as it was. Therefore, he had both many friends and many enemies. Pigovat felt lucky and always satisfied in terms of his aesthetics of musical style. What he said to Pigovat was completely suitable for him. Nikolai Ivanovich insisted that music comes from the heart, but is not invented from the head. He always said: "The origin of music is a

\footnotetext{
3 Boris Pigovat - Interview with Xi Liu on 13 September 2019.
} 
sacrament, and no one knows how this happens. It must come from the heart of the composer, and it must go to the heart of the listener." ${ }^{4}$

Pigovat studied composition with Peiko from 1973 to 1978 and then, after a five-year break, followed with three more years of correspondence-postgraduate study (as an assistant-intern). It is said that that Professor Peiko was extraordinarily strict and that it was difficult to study from him. Pigovat asked Peiko if he would agree to be his composition teacher after passing the entrance examinations of the institute. From the very beginning Pigovat had to accommodate the very special form of the professor's guidance: he brought a piano piece to the first lesson and only the first five bars from it were retained and he said: "Now you can start working." 5 This continued in different versions throughout the first year. Nikolai Ivanovich taught him to find those "true grains" from the huge number of "musical ideas" and then seek the most natural way for their development. This would create works that "captured" listeners and performers, and be interesting to play and listen to. It would also create works in which there are no "extra notes" to interfere with the whole work. In order to be built with drama, it is very important to be able to build a form.

Pigovat did exceedingly well in his studies and work and always maintained an attitude of high seriousness. However, an awkward coincidence happened during his first year of training with Nikolai Ivanovich, which brought some colour to his life. For several months Pigovat wrote a cycle of duets for violin and cello. After the exam, he got an excellent score for these works. Only a few days later, Professor Peiko cautiously enquired of him if he had heard a quintet by Dmitri Shostakovich. Although Boris Pigovat was a fanatical admirer of Shostakovich's symphonic music, he did not know that work at that time.

\footnotetext{
4 Boris Pigovat - Interview with Xi Liu on 13 September 2019.

5 Elena Nikolaeva, There is no coincidence in our lives (Moscow, 2010). Translation by Xi Liu.
} 
Nikolai Ivanovich played an entry from the Intermezzo from the Quintet and Pigovat realised with horror that the theme of one of the duets was literally "borrowed" from there - also in D minor, the same cello pizzicato and a very similar phrase in the violin part, which were in the same register as Shostakovich's. Pigovat suddenly felt his cheeks burning! This could happen to any composer, but for Pigovat this would have been an unforgettable experience. Nikolai Ivanovich did not say anything, because, apparently, he felt that the similarity was by chance and the music which Pigovat wrote turned out to be absolutely marvelous, so it was not worth giving a blow to his gifted student. Seeing Pigovat's embarrassment, Peiko began to calm him and showed examples of involuntary borrowings in the work of great composers. He was an influential teacher of Boris Pigovat at the Gnessin institute - serious but not excessively rigid.

The constant influence and guidance by this teacher also influenced the composer in other aspects. One important point that Pigovat learned from his teacher was that when considering the whole section sometimes it is necessary to edit some of the parts for the sake of the form of the composition, since it is vital to learn how to find the most appropriate form for the embodiment of the musical idea. It is required to study and select carefully from various parts of one work or different works. "Squeeze out the water," said Nikolai Ivanovich with expressive hands, in order to compare this process with the production of cottage cheese.

Certainly, the fruits via such a process of "squeezing" normally emerge after the completion of the work or even after repeated performances. For example, Nikolai Ivanovich suggested that Pigovat should remove the second (slow) movement from a four-part string quartet as it interfered with the overall orientation of the whole content from the beginning to the end. Like a "surgical operation" to Pigovat, this happened after the quartet had been performed inside the Gnessins Institute, at concerts in other places and even at the All-Union Festival of Young Composers! 
Nevertheless, it was a painful operation but quite necessary, because he agreed that this would impact on the perception of the integrity of the work. Pigovat trusted him unconditionally, because after a year of studying with Peiko he realised that he was right. Without the removed part, which Pigovat was so pleased with, the whole work turned out better. This is one of the most important lessons that Pigovat learned from him-sometimes it is necessary to reject good material in order to get the best overall outcome.

Nikolai Ivanovich had a great impact on Pigovat and was an ideal teacher for him. It was an enjoyable process for a music student who loved his teacher's music and strictly obeyed his guidance. From the beginning of the third year of study at Gnessin Institute, the instructions of Nikolai Ivanovich began to be more general, but they always accurately characterised the essence of the problem. For example: "You are already stuck with a tragedy on the first page!"6 Peiko exclaimed, and in other words his works were suffering from excessive emotion at that time. Pigovat was left with a feeling of tremendous creative resonance and a coincidence of the main artistic criteria that he had experienced during all the years of study with Nikolai Ivanovich. Even after all the reactions Pigovat experienced, he still remains calm about his teacher's harsh process of teaching and convinced by all his suggestions, and has maintained his respect and adoration for this ideal teacher.

Nikolai Ivanovich was known for the profound depth of his knowledge, not only related to music but also in other relevant aspects, especially including literature and history. His students studied at his home and when a problem arose he immediately took out notes and showed how other composers coped with this situation. They listened to a lot of music, then Ivanovich made specific analyses of these works and they often sat up late with scores of operas. The professor tried to widen their horizons of knowledge as far as possible. Although he acquainted them with works

\footnotetext{
6 Elena Nikolaeva, There is no coincidence in our lives (Moscow, 2010). Translation by Xi Liu.
} 
that he himself actually did not like, he considered the practicality of these works for their students. Many precious collections of unique documents were kept in his house, which could be only obtained by special permission in public libraries. Since Pigovat was very keen on everything concerning Shostakovich, Ivanovich gave him a large amount of material related to the campaign against formalism, comprising the full transcript of the First All-Union Congress of Composers. Pigovat's heart was shaken strongly and his eyes were opened to many things and produced a genuine revolution in consciousness after reading these materials, which made a great contribution to some of his subsequent compositions.

Some important points he learned from the class of Nikolai Ivanovich can be summarised as follows: Never compromise with yourself; it is worthwhile making the effort in your spare time to seek the best; and be able to give up what was written if it has a negative effect on the perfection of the whole. What is more essential is to be yourself and it is not worth going another way in order to adjust to fashion trends. Sometimes this can seem even more important than anything else to Pigovat.

Another important teacher who had an influence on Pigovat's composition was Heinrich Ilyich Litinsky. Certainly, the teachers of Pigovat's professor were also outstanding and world-renowned. Ivanovich was a student of Myaskovsky at the Moscow Conservatory, who was a Russian and Soviet composer and referred to as the "Father of the Soviet Symphony". Myaskovsky was awarded the Stalin Prize five times, more than any other composer. Before that, Ivanovich had studied with Heinrich Ilyich Litinsky. It was said that half of the composers of the USSR had studied with Litinsky, and the other half had studied with his former students.

Litinsky was the recognised patriarch of the Soviet composition school, and his nickname among the student-composers (and not only students) was the Great Henry. Pigovat studied polyphony with him, and Litinsky seemed to view polyphony 
as an essential part of composition. He never made any distinction between students from his composer classes and others. Litinsky was born in 1902, and he was over seventy years old when Pigovat studied with him. He was a man with an amazing soul, and people would feel good when he smiled. He was a wonderfully warm person, with a powerful aura. When Pigovat thought of the name of Heinrich Ilyich, a smile appeared involuntarily on his face:

This man radiated so much light. He had a special and caring attitude towards his students. He shared his positive energy with us so generously that sometimes I wanted to come and sit in his class - and that is all. His departure (as I said) was an appropriate ending for his whole life: he finished a new work, put a full stop, and the next morning he did not wake up. This man passed away from life with dignity. It was not a disease, nothing. A death to be envied. ${ }^{7}$

In polyphony lessons, Litinsky kept to the old teaching method of "from master to student" that was "do as I do". He showed his students what to do and how to do it. Only when students finished exercises following in his footsteps would he explain in detail what just happened and why. Litinsky preferred to "go straight to the point" in his class of polyphony, which Pigovat perceived was absolutely correct. Therefore, Pigovat always believed that he had two teachers of composition: Nikolai Ivanovich Peiko and Henrich Ilich Litinsky.

Concerning the role of polyphony in Pigovat's music, Litinsky described it as if the breathing of voices should be harmonious and natural in their development. "When a composer does not know what to do in development, he writes fugue or fugato", as Henry llyich explained the conscious introduction of polyphonic techniques and forms. Therefore, the main point that Pigovat obtained from Litinsky was to avoid stereotypical solutions. For example, in the class he suggested that, if one is writing

\footnotetext{
7 Elena Nikolaeva, There is no coincidence in our lives (Moscow, 2010). Translation by Xi Liu.
} 
the final piece for the exam in polyphony, it could be a prelude and a fugue for an orchestra. He also asked them to write a quartet, but only in polyphonic forms -such as a fugue, an invention, or a passacaglia. They wrote their own music by using these forms.

Pigovat's inspiration of orchestration and instrumentation was from Yuri Alexandrovich Fortunatov. When Pigovat regularly commuted to the Ivanovo Art Center for a seminar for young composers in the early 1980s, he first came to know the composer Fortunatov, a teacher of instrumentation and score reading at the Moscow Conservatory. They met with each other seven or eight times and each time lasted for about one month. Each time was a fairly long period of daily meetings, contact and discussions about orchestration and Pigovat tried to show his new works to Fortunatov. Fortunatov knew everything about the orchestra in general, and was described as the "poet of orchestration".

Many composers studied instrumentation with him both at the Moscow Conservatory and outside it. He taught students to understand the "soul" of instruments and to find orchestral ideas as the basis for compositions. The point of view of Fortunatov was to love every instrument of the orchestra and to seek their most expressive features, then successfully to use them to be able to abandon standard solutions. His proposed options for instrumentation seemed paradoxical, but they were designed to maximise the expressiveness of music. It often happened that the recommended version surprisingly highlighted the hidden strengths of the musical material created by a young composer. For example, once Yuri Alexandrovich advised Pigovat to add a solo trumpet to a group of high cellos; suddenly, as a result, the lametation-tinged character of the melody became the "dominant". He suggested how to make the harp sound like a prolonged pedal sound of a piano and at the same time give its timbre some kind of "unearthly" tinge. It turns out that this requires a four-sound quiet pedal of tremolo marimba. During the performance, 
Pigovat could hear that the theme received completely different expressiveness, different brightness and emotionality.

His advice about orchestration was priceless for Pigovat and he once asked Yuri Alexandrovich for advice about a quartet for trombones. Pigovat knew enough about the possibilities of this instrument, but he was convinced that this master would tell him something completely new and unexpected. The master said: "forget that you are writing for trombones, but writing a work for a cello quartet instead, then give it to trombones." ${ }^{8}$ That is it! Paradoxical advice, is not it? However, he opened up to Pigovat such resources, of which he had not thought. To this day, Pigovat still tries to do everything when he is working on an orchestral piece as if he continues to consult Yuri Alexandrovich.

In principle, Pigovat is not a fan of, and avoids, politics. As for religion, as a Jew, he is a believer, but he is not orthodox. If Pigovat had to answer the question about his attitude to religion, he would say that God created us and rules us, but we continue to live on our own, which is our choice. He has his own beliefs but respects the alternative views of others.

\subsection{Tajikistan (1978-1990)}

In 1978, Boris Pigovat graduated from the Gnessin Institute and went to work in Tajikistan. During the same time from 1983 to 1986, he still came to Moscow as what the composers in the former Soviet Union collectively called an "assistantinternship". The assistant-internship for performers and composers is actually "the third degree"- a PhD degree. To become a doctor at that time, the composer only had to write works and pass all the exams without writing a dissertation (a musicological exegesis). The performers would play concerts and the musicologists

\footnotetext{
8 Elena Nikolaeva, There is no coincidence in our lives (Moscow, 2010). Translation by Xi Liu.
} 
would write a musicological essay. In Moscow, Pigovat received the composer and theoretical education, and became a qualified composer.

In 1973, Boris Pigovat and his future wife studied on the same course in Moscow. They were married during their studies in the summer of 1975. Pigovat studied in the composition department, and his wife studied in the theoretical-musicology department. Zoya, his wife, came from Tajikistan, so when they graduated from Moscow they moved to Dushanbe (the capital of Tajikistan) and were assigned to work there. In the Soviet Union at the time, a system existed in which students could study at a college or a university without paying tuition fees, but they were obliged to work for at least three years in the place where the state had supported them. All graduates were assigned to different places of work. Pigovat and his wife were assigned to Dushanbe from 1978 to 1990.

Even though Tajikistan was in the USSR, Pigovat experienced a strong cultural shock since it was a different country, with different people, customs and norms of behaviour. It was a completely different life to Pigovat, with a much slower pace, especially compared with Moscow, and with a different mentality. For Pigovat, as a composer, the most important things that he learned from living for twelve years in Tajikistan were the principles of working with non-European musical materials. This invaluable experience was due to one person -Nabijon Abdullayev, the conductor of the orchestra of Tajik folk instruments. He was obsessed with the idea of making Shashmakom (a special unison musical artform) accessible to a wider public, both for being closer to European music and art and to add new colours of this art for the traditional listener.

Abdullayev wanted this unison music to be enriched by elements of European musical culture such as harmony, counterpoint and orchestral texture, but without losing its "specialness". He needed a composer who had professional experience of 
European background and would try to imbue it with the expressiveness of the Shashmakom, who could feel its charm and depth, then try to strengthen all of its expressive components with the help of multi-voiced and differentiated expressions. The melody was not simply to be processed, but should maximise its impact on the listener. All means of the musical language, counterpoints, harmonic structures and rhythmic figures were designed to fit organically into the general musical structure dictated by the melodic line. According to Abdullayev, the goal of the composer's work within this genre should not be self-expression, but rather to help this music not only to increase the impact on the traditional audience, but also to pave the way to the perception and the heart of new listeners.

This music made Pigovat plunge into a brand-new world and he began to feel and pursue its melodic development. It led him into a state of ecstatic enthusiasm, as well as receiving countless admirers of this art.

Pigovat had processed several Shashmakom, such as Sinakhurush, Bebochcha and Munojot. They were then recorded on the CD THEY in Uzbekistan, with solos by Barnolskhakova. ${ }^{9}$ When he saw tears in the eyes of the sound producer after recording Munojot, where the Auge is accompanied by the especially impressive sounding orchestra, Pigovat realised that he was competent for this task. This experience led Pigovat to another interpretation of world music by integrating a non-western music culture into his own. Undoubtedly, this was beneficial for him in some subsequent works, especially the symphonic poem The Wind of Yemen, which he composed in Israel. No doubt, before the acquaintance and cooperation with Nabijon Abdullayev, Pigovat could not understand Shashmakom though he had already been living in Tajikistan for almost seven years.

\subsection{Emigration to Israel and the formation of musical style from 1990}

\footnotetext{
9 Barno Iskhakova (1927-2001) was a famous Bukharian Jewish musician from Tajikistan.
} 
The year of 1990 was a major turning point for Pigovat as he was moving to another country again, Israel. This land was fascinating to him and it seemed to give him some special inspiration, which imperceptibly made him take a stylistic and qualitative leap. At first, he did not feel or understand it, and wondered if perhaps that is the wonder about why God exists and how God loves us. "Looking back on the eighteen years that I have lived in Israel, I can see a clear line of everything I created between before 1990 and after - as if they were works of two different composers," said Pigovat with conviction. ${ }^{10}$ In general, if Russia brought him up, gave him excellent education and the best teachers, then Israel provided him the opportunity of maximum self-realisation.

Boris Pigovat moved to Israel for several reasons. When he and his wife lived in Tajikistan the Soviet Union collapsed. Nationalistic tendencies began to grow, and Russians began to leave Tajikistan. Pigovat and his wife had left before the civil war took place. ${ }^{11}$ Pigovat remembered that his father had told him when he was a child: "There will be the slightest opportunity leaving for Israel, and you must be with your people." At that time, it seemed very far away for the young Boris to understand where he was and where Israel was. However, his wife's parents and ancestors adhered to Jewish traditions more than Pigovat's family. In Zoya's family, it was a tradition to talk about moving to Israel, and her relatives already lived there. Her uncle walked from Uzbekistan, through Iran and Turkey, to Israel in 1932. He was then a child but when he arrived in Israel he was an adult. So, in her family, there were ties and they often talked about Israel.

Before starting the story about the Pigovat's Israeli journey, there is an interesting experience about the original meaning of his name that should be mentioned. When Pigovat arrived in Israel he lived first on a kibbutz, and there met a woman who was

\footnotetext{
10 Elena Nikolaeva, There is no coincidence in our lives (Moscow, 2010). Translation by Xi Liu.

${ }^{11}$ https://www.c-r.org/accord/tajikistan/tajik-civil-war-causes-and-dynamics (25 September 2020).
} 
a native Pole. She told Boris that his surname "Pigovat" is a surname from the Polish word "Piegowaty". In English, it means "freckle" on the face. It was a funny story to Pigovat because he had not known about it until then. This might mean that one of his ancestors had freckles on the face. That is how Boris found out the original meaning of his surname.

Life is accompanied with complicated moments and easy ones, and this can somehow depend on the type of decisions we choose. The moment when Pigovat landed in Tel Aviv, he received Israeli citizenship. In Israel, a Jew who emigrates to Israel becomes a citizen automatically and immediately.

However, getting used to the new reality was quite complicated. Israel is a country of immigrants, and any wave of new arrivals goes through the following process. At first, there is a very complex process of "finding" oneself in a new country or in a new situation. A person needs to decide what is more important for them: either finding a job in their specialty in order to keep their old profession, or forgetting about previous occupation and only considering that they should give a good future to their family and work in any job.

In any case, everyone has the same situation; that is, to take any possible work at the very beginning. Pigovat and his wife went to work on a kibbutz. His wife worked as a carer for the elderly in a kibbutz nursing home. Zoya is also a musician with higher education. Boris worked in a shoe factory, and he moulded equestrian boots. He learned how to cast boots in a popular workshop. It was almost two years before he slowly began to work in his specialty, teaching music lessons. The state made a special programme for employing composers who are either winners of competitions or who have a higher academic degree. Boris Pigovat had both-as a winner of a competition in Budapest and as an assistant-intern who graduated from the Gnessin Institute. Therefore, he was sent to work in Kiryat Bialik in the north of 
Israel. The Ministry of Education sent him there as a part of an experimental programme.

In this system, the Ministry paid his full salary in the first year, in the second year the ministry paid two thirds of the salary and the director of the conservatory (music school) paid one third, and in the third year the ministry paid one third and the school paid two thirds. After the three years, Pigovat was offered a full-time job, which meant the programme had worked. He has worked there since 1993. Life was difficult for them, but both Boris and Zoya strove to stay in their professions. They knew that this was only a temporary process, and those were temporary jobs on the kibbutz. "It will be difficult, but it must be overcome. We did it! Quietly, little by little, and everything worked out," as Pigovat said in one of his interviews.

An interesting but quite important thing happened during that time. Pigovat began to compose while he was still working at the shoe factory. He began to write the Holocaust Requiem on a kibbutz. Although he had already started working as a musician, his earnings were very small, so he decided to return to the kibbutz and work there again. In the summer of 1994, after the work shift, there was a room with a piano, and right there Boris Pigovat wrote Dies Irae. Pigovat commented "So in principle, everything was fine, everything was aligned, and everything worked out. But at first it was difficult, yes, I agree."

In Israel, there is a saying that you can only plan before lunch time. Due to the constant high level alert of conflict, life is always intense and stressful. People never know what will happen in a few hours, so they are used to it and take it calmly. If a day is a calm day, this is very good. In the sense of creativity, Pigovat is very pleased with his life in Israel and he feels like he is living "in his place" and doing what he loves. Since emigrating he began to write differently. A special energy affected his 
creativity, and his compositional style suddenly changed. There was a sharp breakthrough in his musical styles, and he was not even aware of it at that time.

He began to compose Holocaust Requiem in 1994, four years after his arrival in Israel at the end of 1990. He finished it in January 1995. Boris told me modestly that this is a work he was afraid to approach for many years. He wanted to write such a work dedicated to the Holocaust, but he thought this theme was too big for him. If he did not have adequate composing powers to write it, then he would not manage to create such a work. It was only after several years in Israel that he realised that he could achieve this. As a composer, he really only revealed himself in Israel. His personality makes him feel guilty about complaining. It is such a wonderful thing that he finds happiness in his life.

My works have been performed in thirty seven countries, and different works in different places. When I was in the Soviet Union, I could not dream about such thing. That is, the composer's career has "gone", but most importantly, the creativity has become different. Such works as Requiem, or as, for example, a work that I wrote for the Israel Philharmonic Orchestra, a work for the Pittsburgh Symphony Orchestra - I would never have written in the Soviet Union. I was a different composer there. ${ }^{12}$

Many major works have been composed since he moved to Israel. Pigovat has also continuously pursued a distinctive style of contemporary music, although the definition of "modern" music varies greatly due to different cultural perceptions all over the world and changing times.

Does the so-called new music, with criteria established by a group of musicians who are authoritative and dominant in the music world, and express that music written by contemporaries, correspond to some standards of aesthetic, stylistic and

12 Boris Pigovat - Interview with Xi Liu on 13 September 2019. 
complicated techniques? This is still debated within organisations such as the International Society for Contemporary Music (ISCM), in which national sections are comprised of unions of composers from different countries. Pigovat proved the existence of this debate in the ISCM festival "World Music Days 2000" in Luxembourg, where his Symphonic Poem for a brass band was performed. After the concert, one German composer approached the head of the Israeli delegation and said: "This is a good piece, but it does not correspond to the direction of the festival. This is not the new music."13 Pigovat perceived that the poem was selected for performance by the organising committee of the festival. Then the chairman of the League of Israel (quite a "leftist" composer) replied: "Maybe this is not the new music, but it is the modern music."

However, such a reaction was not new for Pigovat; it had been accompanying him since his school days. While still a student, Pigovat regularly went to concerts in the Composers' House and participated in all-union student conferences and festivals of young composers. He listened to a lot of "new" music and felt completely lost.

Nowadays, stylistic pluralism is in fashion and often defined by the word postmodernism and almost no one will reproach you for being old-fashioned, but it is difficult to imagine such a postmodernist in the flowering age of modernism! At that time, it would have sounded wonderful to hear people say that one is ahead of one's time but not so nice to hear that one is retrograde, conformist and hopelessly behind one's time. Pigovat could still remember the words he read in the newspaper clipping on the wall of the Leningrad Conservatoire about his string quartet: "out of date". It was an unpleasant time for him and at that time he had not developed immunity from such criticism of the influence of romanticism (for example Rachmaninoff), which he would later develop.

\footnotetext{
13 Elena Nikolaeva, There is no coincidence in our lives (Moscow, 2010). Translation by Xi Liu.
} 
Pigovat had tried to change his style, as they say, to keep pace with the times. He studied the scores from a book of Ctirad Kohoutek about the techniques of composition in the music of the twentieth century, but after he listened to all of them again and again it brought despair, gradually and finally. It does not mean that Pigovat did not like everything he heard. Pigovat really loved many works of Schnittke, although Pigovat never considered him as a modernist, and his Cello Concerto plunged him into a state of reverential horror and some kind of mystical delight at the same time, and he was totally obsessed by his talent. Back in the late 1960s he became interested in Penderecki's works; this ultimately led him to the writing of the work "Intonation Models in the Passion from Luke by Penderecki", which became the musicological part of his doctorate. However, in most cases, the new music Pigovat listened to in concerts or in audio recordings did not convince him in the least, because he could not find a proper emotional response.

All of these were not mine and there was nothing I could do about it. I had to break myself for the sake of the conjuncture and I didn't want to do that, but to be a "stranger" it was not an easy time for me. Like Nikolai Ivanovich Peiko said about my situation: "Imagine that you are walking and carrying a beautiful crystal cup on your head, and you are attacked by dogs. You can beat them off, but you will drop a cup, and it will break. You can save the cup, but then you will be bitten." Well, I made my choice. $^{14}$

Pigovat had his own understanding of the relationship between traditional music and modern music. Pigovat has now developed a kind of immunity against attacks on the "out-of-date" perception of his compositions. Certainly, he is very happy with composing a bright, beautiful theme. He loves pure harmonic portrayals and tries to find and convey a sense of beauty and peace, because the embodiment of beauty has always existed in music and it can ennoble the human soul. However, when 
there is a need of modern compositional techniques he does not hesitate to use any means from them.

The main thing for Pigovat is the emotional impact of music on listeners and performers. If he manages to make one empathise with his works, he will choose a kind of moral purification through emotional experience to achieve the goal. In addition, his "old-fashioned" works for some reason are very popular with performers, and this is a guarantee that the compositions will be played with full commitment, and that their energy will be passed on to listeners.

\subsection{Music education in Israel}

The system of music education in Israel is different from the system in the Soviet Union. There were three stages of the musical education system in the Soviet Union. In the first stage, children studied in a seven-year music school or a special ten-year music school. After seven years, children were able to go to the next stage of music school in order to get a secondary music education. Obtaining this secondary music education enabled one to teach in a children's music school. The third stage was the conservatory, or the pedagogical institute or institute of arts. This was a higher standard of musical education, and students usually studied there for five years to receive a higher education and an additional three years for a doctoral qualification.

The system in Israel includes a lower layer and an upper layer. The lower layer of musical education is either in a music school which called "a conservatory". The music school covers ages up to eighteen years, or adults up to sixty years who want to study. This school offers some basics of performing in competitions. In addition, there is a comprehensive school in which one can choose another musical direction, such as the theory or history of music. In Russia, the conservatory is another situation, a higher educational institution like an academy. In Israel, the conservatory is just a music school that only provides the most elementary musical education. 
Students who are talented can find a private teacher. Usually, these teachers are either from the academy or from good orchestras. Such a student prepares an audition for admission to the music academy. In Israel, the professional education at music schools is not at a high level. If students want to become professional musicians, they often study with private teachers. It is very rare that children who are simply studying with a teacher at a music school immediately enter the academy. They still need to receive special training from a very good teacher.

\subsection{Pigovat's current situation}

Pigovat's current positions are as conductor of a children's orchestra, as well as a major composer for this orchestra. Pigovat has opinions about how to balance teaching and writing music for children, and writing music for professionals. He does not write works "for children"; instead he approaches his children's orchestra as an adult orchestra. Some of these works have also been performed by professionals such as the Kosei Wind Orchestra from Japan and orchestras from the United States. These works are quite difficult, and "highest level of difficulty" has been marked on some scores.

Following performances by several professional chamber orchestras in Israel, and some chamber orchestras of other countries, he made a version for viola solo for recordings made by Scott Slapin and Tatjana Mead Chamis. He also created a version for solo violin, which was performed in Hamburg. At the request of Inbal Megiddo, he wrote a version for solo cello. He wrote a new version for viola quartet at my request, which I premiered at the International Viola Congress in Poznan in 2019. At first, he rehearsed Nigun with his children's orchestra. It is another matter when he writes for a professional orchestra, as these works can be more complicated and much larger in size.

Pigovat has been working with his children's chamber orchestra since 1993.This orchestra is also a "laboratory" for him or for the adjustments of compositions, as he 
checks every sound from this ensemble. That is, when he finds something is not correct, or he hears sounds he does not like, he can immediately find a better solution. The orchestra plays all kinds of music under his direction. He knows the capabilities of his children, and therefore can process works for this specific ensemble. For instance, currently there are no violas, so instead he chooses to substitute instruments, such as a clarinet, or adding third violins to replace violas.

In terms of repertoire, in 2018 his children's orchestra played the first movement of the concerto for bassoon and symphony orchestra by Carl Maria von Weber, movements from Mozart's Piano Concertos, and compositions by Bach and Haydn. At the same time, Pigovat arranged Liszt's Liebestraum with the piano part unchanged, added an orchestral accompaniment and performed it. Many so-called classi-pop music works, such as Bemylove (N. Brodszky) were read through by the orchestra. They also have played some Israeli music. He also arranged Polka by Schnittke for viola and orchestra, for Anna Serova, and Pigovat read through this work with this orchestra, which at that time had a good viola player, who was studying at the academy, and they played it with him. Pigovat writes and arranges many pieces for them.

Boris Pigovat teaches composition lessons at a school in the city of Petach Tikva. His teaching approaches are usually conducted as follows: he writes an accompaniment for students, which they have to complete by adding a melody. Alternatively, he gives a melody, and they have to produce an accompaniment. Sometimes Pigovat writes a few initial bars, as was the approach of his previous teacher Ivanovich, and they must finish the rest of this work. In parallel, he asks them to show him only the very beginning part of their works. Therefore, if the beginning part is worth continuing, they will slowly start working on it. Pigovat also teaches his students to study various works and analyse them. He teaches them to understand how a professional composer composed specific sections in different works. 
Pigovat always rejects "imposing" styles on his students" works. His main task is to excise all that is superfluous or does not correspond to the style of the musical material. Therefore, Pigovat mainly focuses on teaching students to understand what is suitable to add to the previous materials, and what does not fit.

\subsection{Stages of composition}

Two of Pigovat's early musical preferences were Rachmaninoff and Scriabin. Pigovat had a very strong passion for Scriabin's music when he was at the Gnessin School. He listened to many of his works, and wrote a work inspired by Scriabin's Poem of Ecstasy.

His composition style is currently influenced to some degree by Shostakovich, Mahler and Tchaikovsky. Influences by Shostakovich and Mahler's works are both from dramatic expression in musical style, and in the instrumentation and the understanding of the orchestra. The influence from Tchaikovsky is mainly his concepts of symphonies. Pigovat focuses on the ability to build symphonic compositions and boost the musical energy and the musical tension from Tchaikovsky's works.

It is difficult to clearly explain a "normal" composing process for composers due to an extremely wide range of circumstances. Nevertheless, after reading Tchaikovsky's letter responding to a request to illustrate his order of composition, Pigovat felt a sympathetic response and gave his own precise characteristics of significant stages and aspects of the creative process. ${ }^{15}$ Understanding and exploring Pigovat's method of composing enables one to further comprehend his intentions in those works and to achieve an interpretation close to those intentions. Pigovat lists six basic steps in his compositional process. ${ }^{16}$

1. Emergence of the general idea of the work

\footnotetext{
15 Elena Nikolaeva, There is no coincidence in our lives (Moscow, 2010). Translation by Xi Liu. 16 Ibid.
} 
2. "Immersion" into the emotional atmosphere of the work and then "warming up"-the emotional adjustment of the work.

3. "Workshopping" the original materials - they should correspond to the general idea and emotional atmosphere of the future work.

4. Formation of the basic composition plan, which may, however, often change radically.

5. Writing a new work.

6. "Revising" the written materials.

It is necessary to illustrate that the actual steps in a new composition do not always carefully follow those above. Some steps can happen in parallel or intertwined ways in their different phases.

Therefore, in Pigovat's mind the original idea is not about a musical idea, or specifically, it is not about the musical material itself, but it is concerning the mood, images and emotions of the composer and it cannot be separated from the musical genre the composer wants to embody. Composers are simply forming the "sensation" of the future work at the beginning stage or thinking about a premonition of its appearance and the material that will be considered later. In some cases, the initial idea of a composition is born as a result of a strong emotional shock.

For example, the idea of Pigovat's Piano Sonata (1988) emerged after he watched the film Repentance by T. Abuladze, which caused a genuine emotional shock. The piece The Silent Music (1997) was born after a series of terrible acts of terrorism in Israel.

Sometimes, the set of emotions may last a very long time before the initial plan is worked out. For example, his symphonic poem Lest we forget matured for about ten years, from 1999 to 2009. 
In other cases, the idea of composition arises from the desire to portray images of literary or pictorial sources. Such examples include The Scarlet Sail for violin and piano (attributed to A. Green), The Wandering Stars for solo harp (attributed to Sholem Aleichem), Spring for piccolo and harp, Birth of Venus for violin and orchestra (attributed to paintings by Botticelli) and the first movement of the Viola Sonata Botticelli's Magnificat.

Some writing ideas emerge when the composer wants to find a counterbalance with the creation of a previous work by switching to a different emotional atmosphere, because the previous emotion has dominated him for a long time. This happened when Pigovat had already completed Lest we forget and he felt choked in the terrible atmosphere of this work. He decided to write more cloudless and beautifully romantic music, so the symphonic poem The Magic Garden appeared.

Sometimes the idea of a new composition comes from nowhere. For example, when Pigovat is working on one work, suddenly, a musical idea may come into his mind that has nothing that relates to the current work. It is a mystery of the subconscious that he does not know where it comes from and why it arises. Pigovat pointed out that the new material can suddenly awaken the idea and images of another future work, although he admitted that such situations were unusual.

All the above examples are authentic experiences of Boris Pigovat, which inspired him to compose on his own initiative, compositions coming from his direct feelings and his inner need of creation.

The emergence of another group of his works are those written on request or which were custom-made. In this case, it is very important to him to find some highlights which will inspire the idea or the character of the work. Sometimes it can be the characteristic features of the performing style of a musician (for example, the extremely warm and rich sound of a viola player). Sometimes the composer has to 
deal with some unusual ensembles that make it necessary to first find a programme which will direct all the searches to a certain associative channel and determine the images and atmosphere of the composition, allowing him to adequately use the timbre of the instrumental ensemble.

Once Pigovat was asked to write a piece for flute, bassoon and harp, with the closest work of this genre being from the time of Debussy -a work for flute, viola and harp. First, he thought that it could be a love duet with flute and bassoon, against the background of the harp, which is such an ancient and colourful instrument. This was an association with the biblical Song of Songs; hence, that was how his piece Shulamit appeared.

In terms of the balance between commissions and works that Pigovat wants to write independently, he says that he writes what he wants. Sometimes even if people tell him in which direction the composition should go, or the character should be, he writes the way he needs to. Once he received a commission for a composition for the Pittsburgh Orchestra, and the conductor wanted it to be a work of a religious nature. Pigovat came up with the idea to take a quote from the Bible: "I call heaven and earth to witness against you today, that I have set before you life and death, blessing and curse. Therefore choose life, that you and your offspring may live." However, shortly afterwards the conductor conveyed the desire that he would like Pigovat to write the music based on Psalm 150. In response, Pigovat said that this is a good idea, but suggested that the theme would be Therefore, Choose Life.

For custom-made works, in a number of cases, Pigovat primarily sought a programmatic idea which led him and prompted the search. He likes to write music with a programmatic background, although usually it is of a very general character, but it also happens that the musical material outgrows the chosen programme and its development is in conflict with the scheme. At this moment, Pigovat becomes "on 
the side" of the musical material, and he transforms or completely abandons the programme.

Sometimes a performer makes a specifically thematic commission, and the most correct way for Pigovat is to accept this as his own idea from the very beginning. The idea of this work can seem as if it is the composer's decision, and not what is requested of him. Otherwise, the idea that one's design is being imposed on can spoil the whole picture for Pigovat.

The next phase of his writing process is "heating up". Usually, it occurs when the composer is going to write works which are not by inner motivation, but by requests or commissioned. Pigovat commented "Sometimes you have to adjust yourself ahead to the second level, otherwise you will not go far".

There are several parts from symphonies of great composers, which, for Pigovat, give him a feeling of some special and creative additives existing in the music when listening. For instance, two examples can be mentioned: one is the Adagio from the Eighth Symphony by Bruckner and another is the first part (again Adagio) from Mahler's Tenth Symphony. In Pigovat's opinion, these works are so inspirational and perfect that they are literally bewitching with the power of majestic beauty, which makes his soul resonate and awakens the irresistible desire for an emotional response in any situation and state, and the need to compose. However, even if he feels this burst of creative energy, he usually does not hurry to start working. Another preliminary stage of preparation exists for Pigovat - immersing in a specific atmosphere of sound. He emphasises that this may not occur in all the works, although it happens quite often.

When Pigovat conceives a composition for any solo instrument, either with orchestra or without or for instrumental compositions, he begins to listen to a lot of music 
written for this instrument or ensemble. His goal is to learn how other composers use this instrument or ensemble. The main thing, however, is to "absorb" the timbre of the instrument and its specific features so that its sound becomes his inner essence. There should be a feeling as if the composer himself has played very well on this instrument for a long time and he can mentally recreate its sonority in every richness of sound at any time. When Pigovat writes for a specific artist, he will choose to listen to as many works of this musician's performances as possible in order to gain as exact knowledge of his or her performing style as possible and identify his or her speciality of sound.

Preliminary work also includes that the future work may require the composer to "call on someone else's territory," where he has never been before in terms of musical genre, musical style and intonation. When Pigovat was writing the Concert March for brass band, he listened to many marches in order to learn the basic standard formulas either to consciously avoid them or to use them in the future.

When Pigovat was working on Part IV of Fairy Tales with the subtitle From 1001 Nights, involving two months of listening to and interpreting much folk music of Islamic countries in which it is difficult to identify intonation, he gradually found an original way of absorbing the material. That is, to feel himself as a composer who constantly writes exactly this kind of music from the very beginning, then this musical style and awareness turns into a mode of instinct in the mind. In his opinion, this is not even a "change of masks", since the nature of the composer's ego has been split off. At the same time, he combines this with his former experience and skills of composition to build up a new sensation and consciousness of composition.

All these preliminary stages of "heating up" or adjustment to ideas slowly introduce him into a state of impatient anticipation of the next step. Then comes the next stage, which Pigovat calls "fishing" the material. It seems to him that this word most 
accurately reflects the essence of the process. After clearly understanding the emotional atmosphere of the future work, he then sits down in the front of the piano and starts to improvise - to search for "thematic grains" corresponding to the imaginative direction of the conceived work. "The situation is not pleasant," Pigovat said and he seems to feel what he needs, but he absolutely cannot imagine what it is really like. The period of the initial search can be very short, and the subsequent material literally appears from the initial search. However, if this initial search is delayed, the composer can get frustrated with the feeling of his own helplessness and inability to find the only possible and necessary material. Sometimes, it seems that the composer finally finds out what he needs and the next day he has to cross out all his work and start again.

Pigovat emphasises that it is very important not to compromise at this stage, since the fate of the whole work will depend on the grain just found. The most vital thing here is not to "falsify"; the material must fully correspond to the imaginative idea and the emotional mood of the future work. Any inaccuracy or any "slack" here will have a negative impact on the final result. Therefore, it is necessary to have special patience at this stage.

Although the following material often appears very soon after the beginning of "fishing", it is not always necessary that this will be the main theme of the work. The material may just sustain the process of composition to keep moving forward. It is like a magnet; once the composer finds out the material he needed, it will "pull" other topics.

The appropriate materials gradually accumulate and gather into different groups followed by a constructive plan of the composition. Pigovat usually redistributes all available materials and writes them into various blocks in accordance with the intended plan, then all incoming ideas are added to the block which most suits them 
and sometimes in two or three blocks at once. After this, consistent fragments of music start to emerge in keeping with the sketchy plan, which may change in the process. Pigovat insists that he is not afraid to give up materials he really likes, because they may not "fit" into the overall picture. It is very important to trust his own instinctive, internal controller in terms of the creative direction. Pigovat needs to make sure the "brick" occupies a place in the "masonry", which means that in general one element of the musical material is just one of many intended parts for this musical "building". This process is not always consistent from the beginning of the work to the end. That is, the work is in pieces with a large number of sketches.

Pigovat stresses that the process of accumulating material and constructing a detailed composing plan usually go in parallel, and materials interact with one another, although the most general construction of the work is formed in his mind and the original idea of the composition is also being considered. In general, the creative plan is not unshakable; rather, it constantly varies and is accompanied by continuously refined details. It is vital to ensure that the structure is balanced, convincing and nothing can prevent the natural development of musical materials with the composer's inner flair and his many years of composing experience.

It often happens that he plans to do one section; however, as soon as he sits down at the piano his hands "give out" something completely different or rather are subconsciously "hooked" on some melodic, harmonic or textural formulas, which may be more suitable for another section. He gives up all his intentions for this and follows this material. Sometimes, Pigovat spends a few days and nothing happens, then it is necessary to "let it go" to switch to other materials and let the subconscious work flow freely, knowing the correct decision will come back at some point. Pigovat considers that one should not worry when something stalls. As his teacher Litinsky said to his students: "If you spent five hours in front of an empty sheet of music and did not write a single note, then you spent the day usefully." 
In the process of all this long, scrupulous and somewhat painful work, a new state is gradually ripening: the composer is immersed in the material and he breathes it with the atmosphere and feels it as a part of himself. At some point, there comes a sense of a breakthrough, and the quality of the whole process changes. The sound of this material already existed in his head either of timbre, tonality, or all the attributes of the texture, but he needed time to write it down. Pigovat said that he had lost some very good themes several times just because he could not keep them in his memory, so now he does not go anywhere without music notepads.

He will not think about the details at this stage; the "fine-tuning" can be done afterwards. Now the main thing is to let the ideas flow flexibly in his mind. Suddenly, everything starts to speed up and he understands how best to solve this or that problem in the development of the material and in the construction of the form. He works as if someone is doing the dictation and as if the material leads him and he just needs to be able to listen to it. This stage presents some sort of a feverish state, which Tchaikovsky named "somnambulistic". Pigovat commented "it occurs that you jump up in the middle of the night in order to record a melodic or rhythmic formula which pulsates in your head, otherwise you will not be able to fall asleep". ${ }^{17}$

When the state of creative burning ends, the next phase is followed by "debugging" and "cleaning". Checking and adjustment of all the details, adding or removing a contrapuntal line and changing the texture - those actions of composition are the main themes considered by Pigovat at this stage. Sometimes there is only one place needing to be changed, for example one chord in the whole section, and then his feeling of discomfort will disappear.

Pigovat had a difficult time when he was working on the symphonic poem Lest we forget. This work exists in two versions: one is for symphonic orchestra and another

\footnotetext{
17 Elena Nikolaeva, There is no coincidence in our lives (Moscow, 2010). Translation by Xi Liu.
} 
is for symphonic wind band. In 1999, Pigovat went to Austria for the Mid-Europe Festival together with the Petach Tikva brass band, where they performed his Massada. An excursion to the Alps was organised after the concerts. They got to the castle "Eagle's Nest" - the Hitler's residence, where Pigovat was shocked by the realisation of the seemingly incompatible contrast between the idyllic beauty of nature and all the horror that is associated with the name of the former inhabitant of this residence. Hence, Pigovat had a general idea of the work after that visit in 1999, then he nurtured this music for almost ten years. As he said, "It was necessary to fully embody this incomparable beauty in music and show as how a worm starts to form inside of it and begins its underground destructive works, then gradually growing to the size of a monster and burying the world under itself."

This work continues the line of Holocaust Requiem, but from a different perspective. Pigovat wanted to express the self-satisfied and narcissistic face of stupidity, fanaticism and inhuman cruelty. After the work, Pigovat decided that he needed a text that would be read before the performance in order to better communicate with the audience. The content of this text is:

It was like a dream. I stood on the mountain summit and looked down to valley in the Alps. The view was astonishing, green meadows surrounded by groves, little houses and sheep herds. The pure air of the mountain seemed to be heard like the most wonderful and lovely tune. Silence and serenity prevailed at this place. Suddenly I was shocked, because I recalled that the place where I stood named "Die Kehlsteinhaus" - The Eagle's Nest. It was the place [of] a monster who brought pain and death to millions of people. The monster defiled everything it touched and its stink poisoned the pure air. This evil destroyed the hopeful world and turned it into a valley of sadness, pain and tears. If we forget it, the monster will come back. ${ }^{18}$

18 Elena Nikolaeva, There is no coincidence in our lives (Moscow, 2010). Translation by Xi Liu. 
The whole of his work Lest we forget is broken into two stages. The initial theme was conceived as beautiful romantic music in the spirit of Bruckner and Mahler. Having composed all this first idyllic section, Pigovat suddenly realised that it was somehow too sweet and luscious. It was necessary to remake it anew except for the first twelve bars of the second part; as a result it became much sterner and stylistically closer to the source, but how to translate the destruction of this image into music? Pigovat had been looking for a solution for a long time; finally, a picture appeared to him visibly:

...like one's huge and cold-blooded heart inexorably beating that destroys the previous image. Thus, one part of the orchestra continues to naturally develop a romantic theme, while the other part turns into a ram, accompany [ied] with swinging of increasing amplitude, crushing everything around itself. Finally, the ram completely destroys the beautiful and serene world and the "aggressor" makes a triumphant roar like a prehistoric predator who defeated the victims. ${ }^{19}$

Having reached this moment, Pigovat stopped all works and again plunged into the "primary source" for a long time. This time he had to look for Nazi songs and marches on the internet instead of Mahler's divine lyrics, and those materials were usually accompanied by a documentary video. In order to be seen to be alive in Germany in the 1930-1940s, Pigovat overcame the feelings of disgust and fear and listened to and watched them all. Finally, he realised how to build the continuation of this symphonic poem. The second section of this composition was to be done as a musical documentary film with quotations and pictures of marching columns, torchlight processions with exclamations of "Sieg Heil", with the flight of an armada of bombers and with burning cities. The listeners must perceive this sensation by their inner vision. So, he was already led by the material: the portrait of a smug and brazen monster with aspiration and the ability of swallowing the whole world. This is

19 Boris Pigovat - Interview with Xi Liu on 13 September 2019. 
the image that Pigovat was striving to interpret - stupidity, cruelty, bloodthirstiness and, the most terrible, inevitability. "The main thing is that the listener will not remain indifferent after listening [to] this work, so that he or she will get the point and will perceive what I felt when I was working on this composition".

\subsection{Highlights of performances of compositions}

When questioned about the most memorable moments of Boris Pigovat's career, he cited the premiere of Holocaust Requiem performed in Kiev in 2001, and the performance by Donald Maurice in New Zealand in 2008. The latter was a very significant event, and after that the commissions were completely unexpected. For instance, the Israel Philharmonic Orchestra called Pigovat and expressed that they wanted to order a new work. Music of Sorrow and Hope was performed the festival "75 years of the Philharmonic Orchestra" with the conductor Zubin Mehta. A year later Mehta conducted this work in the Philharmonic series. Another bright moment in Pigovat's career is the performance of Therefore, Choose Life by the Pittsburgh Symphony Orchestra in 2017. 


\section{Part Two-Repertoire Performed and Suggested Influences}

\subsection{Recital structure}

This section of the thesis discusses the repertoire I performed over five recitals, which included selected works by Boris Pigovat that feature the viola, alongside works by other composers who, in my opinion, may have influenced Pigovat in some way. First, the repertoire performed is listed with the works by Pigovat, followed by the other works listed alphabetically by composer, with links to the videos of the performances

The first recital, on 22 November 2017, included Poem of Dawn by Pigovat with Suite 1919 by Bloch and Quartet No 8 by Shostakovich. Both the Bloch and Shostakovich works have strong Jewish elements, and I wanted to focus on this influence early in my research.

The second recital, on 4 December 2018, included Prayer by Pigovat, Viola Concerto by Bartók and Der Schwanendreher by Hindemith. Prayer was composed between composing Lacrimosa and Lux Eterna from Holocaust Requiem. It was in one sense a sketch for viola and piano of what became the fully fledged orchestrated final movement of Holocaust Requiem. The concerto by Bartók was left at his death as a sketch only with no orchestration indicated, to be fleshed out after his death by Tibor Serly, a friend and fellow composer. The Hindemith work was composed for viola and a chamber orchestra with no violins or violas and a viola and piano version was created at the same time, and this is the version most commonly performed. The circumstances of composition of these three pieces have elements in common and it is inevitable that Pigovat would have been aware of these two works in their orchestral versions while conceiving Holocaust Requiem. 
The third recital, on 26 April 2019, included Silent Music for viola and harp, with Viola Sonata by Glinka, Vocalise by Rachmaninoff and Divertimento for Strings by Bartók (performed on 27 April 2019). This recital was split into two parts to enable me to perform the Bartók Divertimento in an orchestral concert. The inclusion of music by Glinka and Rachmaninoff was to demonstrate the very strong influence of Russian nineteenth-century music on Pigovat and, in the case of Rachmaninoff, Pigovat himself has identified this influence. Silent Music is not actually an example of this influence, as it expresses violence in a contemporary harmonic language; nevertheless, I wanted to include the examples of his Russian heritage in the larger picture of Pigovat's music. However, Bartók's Divertimento, composed when World War Two was imminent, expresses anguish and violence in the climax of the second movement. While we cannot be certain that Silent Music was influenced directly by Divertimento, we can be confident that Pigovat was aware of this work and there may have been a subconscious influence.

The fourth recital, on 8 December 2019, included Viola Sonata by Shostakovich, Viola Sonata by Pigovat and Sarabande from Partita No 2 by Bach. The juxtaposition of the two sonatas was an obvious decision, as Shostakovich is clearly the influence most noted by performers and reviewers. Notably, both sonatas are in three movements in a slow-fast-slow format: Shostakovich: Andante - Allegretto - Adagio; Pigovat: Calmo, chiaro - Con ira, Allegro molto - Misterioso. The second movement of Pigovat's Viola Sonata is a theme and variation structure with the theme at the conclusion rather than at the beginning. The origin of the theme is not revealed until the last moments, and it is an exact quote of the last moment of Bach's Sarabande in D minor. This is why I performed the complete Sarabande directly before the Sonata. I also performed Nigun in this recital, but the performance I gave at the International Viola Congress on 28 September 2019 was the world premiere of the viola quartet version and this is the performance I am including as part of the thesis. I included it in the fourth recital simply as it was necessary to have it represented in the larger picture of Pigovat's works featuring viola. 
The final performance for this thesis was encapsulated in the film Lacrimosa Dies IIla, a documentary film about Boris Pigovat and Holocaust Requiem. In this film, I am the viola soloist, assistant producer and translator. In it I interview Boris Pigovat, discussing in Russian the creation of this work and its structure. I subsequently created the English subtitles. The full account of the Holocaust Requiem and the film are discussed in Part Four.

\subsection{Links to the individual works performed in this project:}

\section{Boris Pigovat (born 1953)}

Nigun - viola quartet

Venue: Secondary Music School, Poznan, Poland (28 September 2019)

https://www.youtube.com/watch?v=9yAGEw-8jZc

Poem of Dawn-viola and piano

Venue: Adam Concert Room, NZSM, Victoria University of Wellington (22 November 2017)

https://vimeo.com/341272634/fc7e50b3e3

Prayer - viola and piano

Venue: Adam Concert Room, NZSM, Victoria University of Wellington (4 December 2018)

https://www.youtube.com/watch?v=ydMJKiprnMw

Silent Music - viola and harp

Venue: Adam Concert Room, NZSM, Victoria University of Wellington (26 April

2019)

https://www.youtube.com/watch?v=EnnaTVk7ZRU 
Sonata-viola and piano

Venue: Adam Concert Room, NZSM, Victoria University of Wellington (8 December 2019)

1st movement

https://www.youtube.com/watch?v=rEEVQnAt8n4

2nd movement

https://www.youtube.com/watch?v=DRFWhrpVSo8

3rd movement

https://www.youtube.com/watch?v=dRXOwJ6VgW0

\section{J.S. Bach (1685-1750)}

Sarabande from Partita in D minor - viola solo

Venue: Adam Concert Room, NZSM, Victoria University of Wellington (8 December 2019)

https://www.youtube.com/watch?v=75S7Y4rbM8Q

\section{Béla Bartók (1881-1945)}

Concerto -viola with piano

Venue: Adam Concert Room, NZSM, Victoria University of Wellington (4 December 2018)

1st movement

https://www.youtube.com/watch?v=ZORpSQJrucM

2nd and 3rd movements

https://www.youtube.com/watch?v=57DZcf19cfU

Divertimento for Strings - principal violist

Venue: St Andrew's on the Terrace, Wellington (27 April 2019)

https://vimeo.com/341272893/636f311f07 


\section{Ernest Bloch (1880-1959)}

Suite 1919 - viola and piano

Venue: Adam Concert Room, NZSM, Victoria University of Wellington (22 November 2017)

1st movement

https://www.youtube.com/watch?v=qG_coq6Kd9g

2nd movement

https://www.youtube.com/watch?v=VhlaEWKwmCw

3rd movement

https://www.youtube.com/watch?v=Km02TBe9Ur4

4th movement

https://www.youtube.com/watch?v=9EuLYeyakAA

\section{Mikhail Glinka (1804-1857)}

Sonata - viola and piano

Venue: Adam Concert Room, NZSM, Victoria University of Wellington (26 April 2019)

1st movement

https://www.youtube.com/watch?v=HT13N56NktY

2ndmovement

https://www.youtube.com/watch?v=SG8WfRbhjwg

\section{Paul Hindemith (1895-1963)}

Der Schwanendreher - viola and piano

Venue: Adam Concert Room, NZSM, Victoria University of Wellington (4 December 2018)

1st movement

https://www.youtube.com/watch?v=9-eS9jNrVDU

2nd movement 
https://www.youtube.com/watch?v=gJk50Vfvull

3rd movement

https://www.youtube.com/watch?v=n1P9tNafeMI

Sergei Rachmaninov (1873-1943)

Vocalise - viola and piano

Venue: Adam Concert Room, NZSM, Victoria University of Wellington (26 April 2019)

https://www.youtube.com/watch?v=O7H19E4DVXE

\section{Dmitri Shostakovich (1906-1975)}

String Quartet No 8

Venue: Adam Concert Room, NZSM, Victoria University of Wellington (22 November 2017)

https://vimeo.com/341272677/2e30906583

Viola Sonata

Venue: Adam Concert Room, NZSM, Victoria University of Wellington (8 December 2019)

1st movement

https://www.youtube.com/watch?v=C-MLcUjetlo

2nd movement

https://www.youtube.com/watch?v=t-r6JUqmihg

3rd movement

https://www.youtube.com/watch?v=jKXbVCWzJfY

2.3 Notes about the works by Boris Pigovat -condensed and reformatted from the programmes of the performances given from 2017 to 2020.

2.3.1 Nigun -version for Viola Quartet 
Venue: Poznan, Poland. Secondary Music School (28 September 2019)

https://www.youtube.com/watch?v=9yAGEw-8jZc

In Hebrew, Nigun originally meant "tune" or "melody" but now it is recognised as a group of Jewish religious songs or tunes. It is vocal music and consists of repetitive sounds instead of formal lyrics. Nigun is sung as prayers of lament, joy or victory.

Pigovat's Nigun is certainly not a happy work. He created Nigun in many versions, for string quartet, solo viola, solo violin, solo violoncello and viola quartet. The original version of Nigun, written in 1996 for string orchestra, is based on traditional Jewish music dedicated to victims of World War Two. However, in this piece, there are no themes from traditional Jewish melodies, but rather this composition is in the style and spiritual atmosphere of the ancient tunes.

Traditional patterns and repetitions are commonly used by composers so that stories of profound cultural background and distinctive nationalities can be passed on from generation to generation. As a composer, creativity cannot be completely separated from traditional consciousness. There are many traditional models that need to be observed; thus, it is very important to maintain their distinctiveness and "bloom new flowers" based on this style. In Pigovat's Nigun, he did not quote any traditional Niguns, instead evoking their ancient atmosphere in other ways. In Dubins' interview with the composer, Pigovat discussed some general ideas of composing music such as his Nigun:

First of all, you need to dive into the stylistic atmosphere, you need to listen to a lot of folk, traditional tunes, until you start to feel that this style penetrates into your blood, that it has become your own style, as if in your whole life you only wrote such music; and when you have just started feeling that, then you can begin the process of composition. Concerning the Nigun, the starting point for this work was the general idea of how to interpret the string orchestra. The first version of this work was written for this medium and a recording of one of the performances can be found on my website. I 
wanted the orchestra to sound like a single instrument, a kind of giant violin, which covers the universe. This idea has defined the texture of the score. Very often all orchestral groups, except double bass, join in a very powerful unison, or sound as two melodic lines, which is quite possible for the solo violin. This interpretation of the orchestra gave me an idea of the culmination. I decided that the giant violin should sound like an instrument playing a sarabande or chaconne for solo violin. In my opinion the combination of two such seemingly disparate stylistic models increases the expression of music. At the time I wrote Nigun, which I wrote in just one week, I didn't think of what melodic shapes, rhythms, and intervals I had used. I just tried to be very sincere and natural in the chosen style and to discard anything that could break down these boundaries. I tried to be a composer who has written just this kind of music his entire life and for whom this style is the only way of expression. Now I can analyze the various components of this piece. I can say that I used a specific mode, combining elements of the Dorian and Phrygian modes to the Hungarian gamut; that the motif I- VIV\# was the main melodic pattern of this work (by the way, this kind of motif is found in some themes of the Requiem), that the initial theme of Nigun is based on a "rocking" with the gradual expansion of the range; that the rhythmic development is based on a short motif, consisting of only two notes, which provide various options for a dizzying whirl; and so on. But at the time, when I wrote Nigun, I didn't think about it at all. I just plunged into this emotional and stylistic atmosphere; I breathed this air, and just tried intuitively to find a material that would be adequate to the ideas of composition and the chosen style. The treatment of the orchestra as a solo instrument has allowed me to prepare the versions for solo viola and for solo violin. The version for string quartet was made especially for the CD Requiem. The main difference from the orchestral version is that the initial theme is performed not in unison by all the instruments, but by the first violin solo. In this version, the Jewish character of the melody was suddenly intensified. In this way, the melody, maybe, has lost its emotional power, but gained intimacy. ${ }^{20}$

\footnotetext{
20 Jerry Dubins, 'On a Requiem of Remembrance - A Conversation with Composer Boris Pigovat', Fanfare, 35/3 (Jan/Feb 2012), 180-183.
} 
Nigun for string orchestra premiered in Israel in 1997, conducted by Horia

Andreescu. The American violist Scott Slapin recorded the solo viola version in 2008 after Pigovat arranged it. The string quartet version is on the Requiem CD (Atoll Records) made in 2010, and was recorded by the Dominion String Quartet. In 2017, the solo cello version was premiered by Israeli-New Zealand cellist Inbal Megiddo. In 2019, the viola quartet version was premiered by Xi Liu, Elyse Dalabakis, Marianna Kalicka and Aleksandra Ruciak at the 46thInternational Viola Congress in Poznan, Poland.

2.3.2 Poem of Dawn- viola and piano Venue: Adam Concert Room, NZSM, Victoria University of Wellington (22 November 2017)

https://vimeo.com/341272634/fc7e50b3e3

Poem of Dawn for viola and orchestra is one of Boris Pigovat's major works. Written in 2010, this work is dedicated to the violist Anna Serova and was inspired by a passage from the Russian historian Nikolai Kun's book Greek Myths and Legends, written in 1914. It captures a colourful tone portraying the arrival of dawn and the Sun God Helios on a peaceful day.

The morning is near... There is a faint light in the East. Aeos and Pyrios, the morning stars and harbingers of Dawn, shine brightly in the East. There is a gentle breeze. The light in the East glows brighter and brighter... In vivid colours, on rosy wings, Dawn is soaring into the illuminated sky, drenched in rosy light. Dawn pours dew from her golden urn onto the Earth, and the dew sprinkles the grass and flowers with glistening, diamond-like drops. All is fragrant, all around. The waking Earth happily greets the Sun Helios. $^{21}$

${ }^{21}$ http://pigovat.com/wordpress/poem of dawn/ (19 October 2020). 
This work has been praised by reviewers in terms of musical style and musical language. ${ }^{22}$

Recalling the Russian romantic, impressionistically tinged world of late Rimsky-Korsakov (1844-1908) and even Alexander Scriabin (1872-1915), it opens leisurely with sequined percussion [00:01] and shimmering strings [00:14] that suggest waning stars.

The viola enters [00:18] soon to be accompanied by winds hinting at gentle morning breezes. It plays an extended melody presumably representing the breaking day [00:18]. This undergoes a fragrant development where it's easy to picture grassy fields strewn with flowers.

The music builds to a lucent climax depicting Helios' arrival, and the surrounding landscape bathed in brightening rosy sunlight. As the music slowly fades into passages featuring a radiant viola set to a rapt accompaniment, one can imagine the beginning of an idyllic day in this Greek paradise. The poem then concludes in the same mood it began. $^{23}$

The premiere of Poem of Dawn was conducted by Nicola Guerini in Italy in 2013, performed by Anna Serova and the Croatian Radio and Television Symphony Orchestra.

\footnotetext{
22 Nikolai Kun, Greek Myths and Legends.

${ }^{23}$ Bob McQuiston, Classical Lost and Found (19 October 2020).
} 


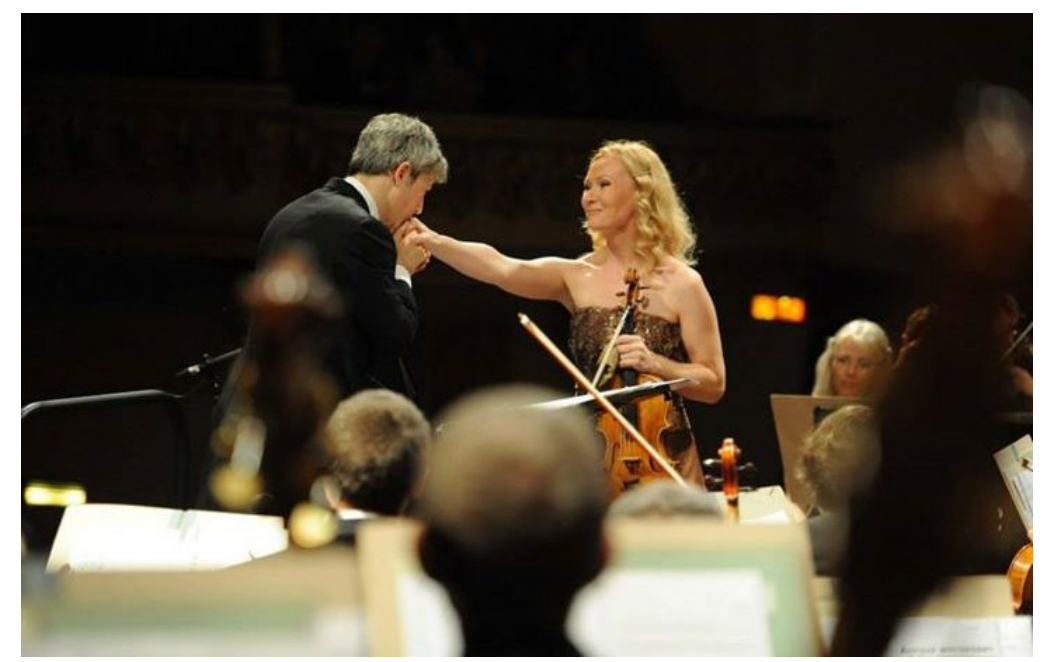

Photo 2.1 Anna Serova with Nicolai Guerini ${ }^{24}$

In 2015, a second CD was released by Naxos, including this new work by Pigovat and the Holocaust Requiem. It received the Supersonic Award from Pizzicato Magazine in the same year and was nominated for the 2016 International Classical Music Awards (ICMA).

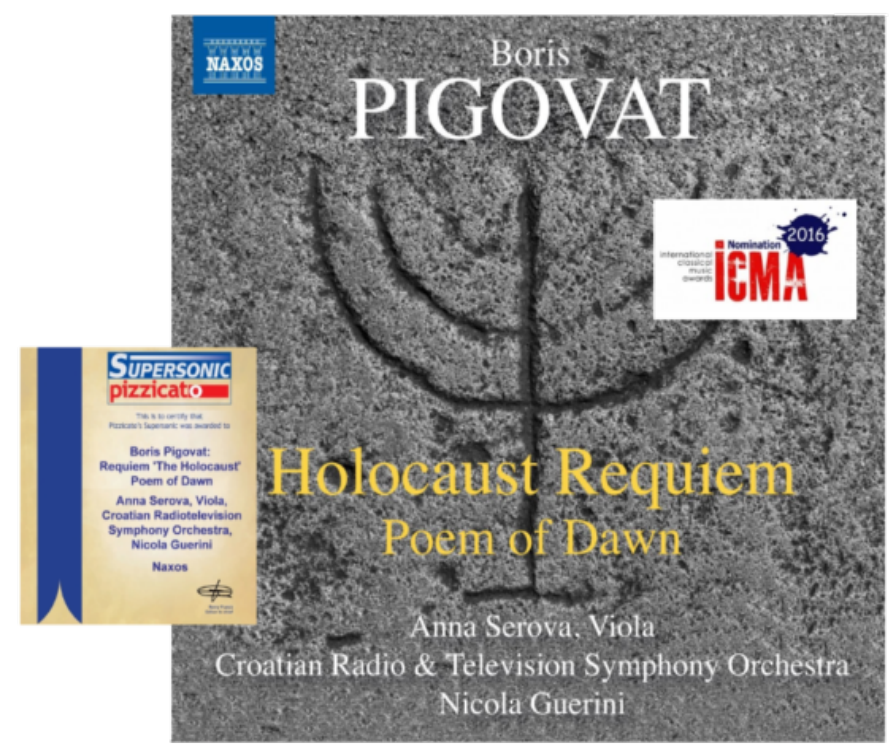

Photo 2.2 Holocaust Requiem and Poem of Dawn ${ }^{25}$

\footnotetext{
24 http://pigovat.com/wordpress/poem of dawn/ (19 October 2020).

25 http://pigovat.com/wordpress/naxos cd 2015/ (24 October 2020).
} 
In this $\mathrm{CD}$, Poem of Dawn makes an interesting juxtaposition with the melancholy and tragedy of the Holocaust Requiem.

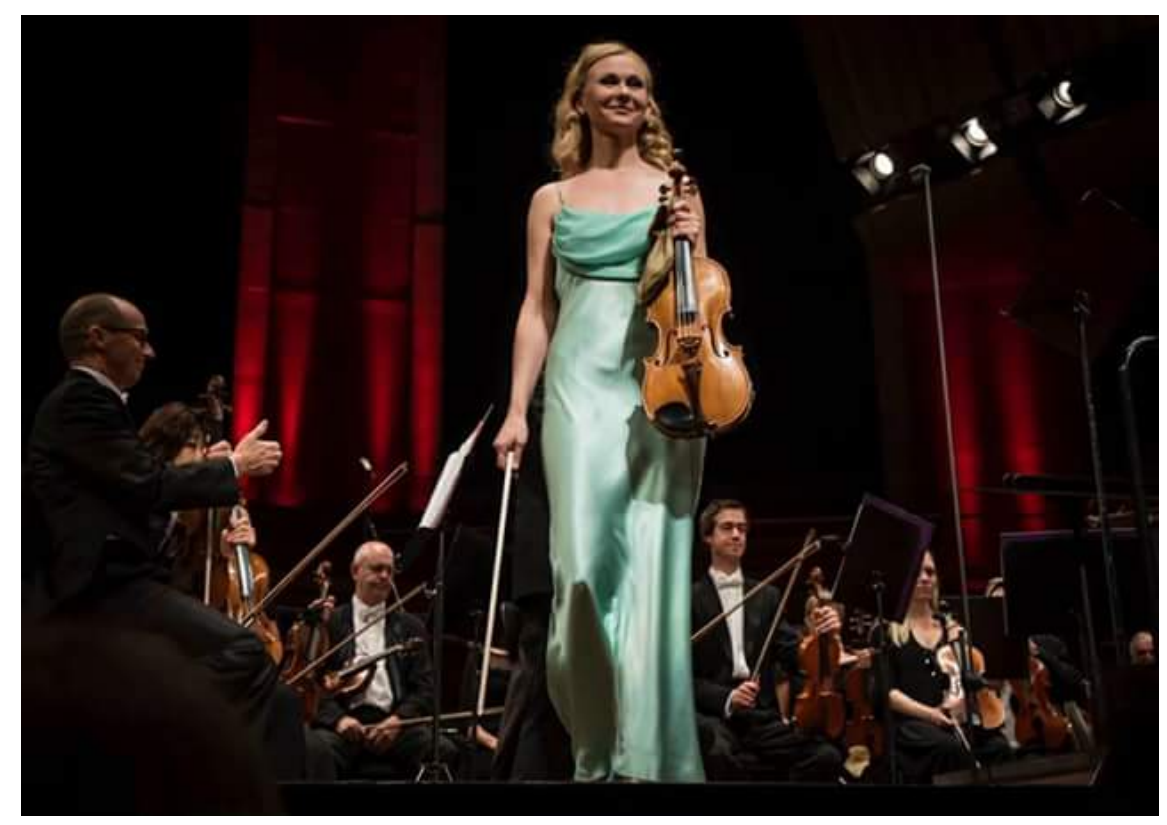

Photo 2.3 Anna Serova with the New Zealand Symphony Orchestra ${ }^{26}$

\subsubsection{Prayer-viola and piano}

Venue: Adam Concert Room, NZSM, Victoria University of Wellington (4 December 2018)

\section{https://www.youtube.com/watch?v=ydMJKiprnMw}

Boris Pigovat composed Prayer for Viola and Piano in 1994 after completing Lacrimosa, the third movement of the Holocaust Requiem. Then he continued to compose the fourth movement of Holocaust Requiem-Lux Eterna. Prayer is stylistically very similar to the Holocaust Requiem, and especially to the Lux Eterna movement, as Pigovat shares material with this movement. Pigovat quotes Shema Israel in both Holocaust Requiem and Prayer. The Shema Israel theme opens and concludes Lux Eterna.

\footnotetext{
${ }^{26}$ Anna Serova performed Poem of Dawn in the 44th International Viola Congress in Wellington, New Zealand with the conductor Hamish McKeich and the New Zealand Symphony Orchestra on 30 September 2017. Photograph from Boris Pigovat's website. http://pigovat.com/wordpress/amazingperformance-of-poem-of-dawn-for-viola-and-symphony-orchestra/ (24 October 2020).
} 
My personal reaction after playing and listening to the ten minutes of Pigovat's Prayer is that it reminds me that when people are suffering, in their inner world they are wishing for a better or even perfect vision related to themselves, or the world they live in, no matter if it is a great dream or a simple wish. In this storm of consciousness, people may experience a similar process in terms of pain, an aspiration, or an angry emotion, which are the three main moods I perceive from Pigovat's Prayer.

Shema in Hebrew means "Hear", which could be interpreted in people's lives as to listen to a "voice" from somewhere in order to follow their life trajectories. This could vary from person to person. It is a good idea for performers and listeners to first listen to the Holocaust Requiem or at least Lux Eterna in order to better understand Pigovat's expression in Prayer.

In 1995, Boris Pigovat also created Prayer for violin and piano, which premiered in 2004 by Carmit Zori (violin) and Gilbert Kalish (piano) in Carnegie Hall, New York. In 2010, Prayer for viola and piano was included in the Requiem CD launched by Atoll, performed by Donald Maurice (viola) and Richard Mapp (piano). Both violin and viola versions were published by the Israeli Music Center. In 2012, the Requiem CD was awarded the Supersonic Award by the Luxembourg classical music magazine, Pizzicato. 


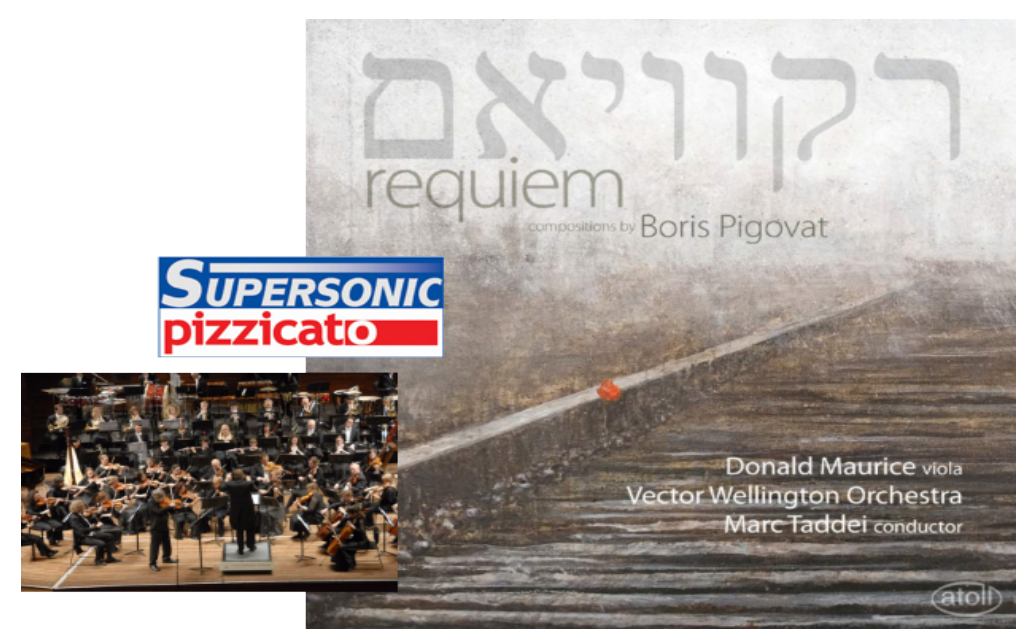

Photo 2.4 The Requiem CD was awarded the Supersonic Award. ${ }^{27}$

Pigovat describes Prayer as a "very expressionistic, dramatic, even tragic piece". In the following article, Mechen stated this work:

Donald Maurice again plays the viola, and, together with pianist Richard Mapp, gives an extraordinarily intense reading of the work. Its opening measures are meditative and hypnotic, the piano resembling a tolling bell at the outset, beneath the viola's quiet song of lament. From the darkest depths of their interaction spring impulses of lyrical flow, gentle and undulating at first, then more impassioned, Maurice's bow biting into his strings and Mapp's monumental chords imparting an epic quality to the mood of grief and suffering. The undulations return, their tones gradually dissolving into mists of quiet resignation and fortitude - altogether, a beautiful and moving work. ${ }^{28}$

2.3.4 Silent Music -viola and harp

Venue: Adam Concert Room, NZSM, Victoria University of Wellington (26 April 2019) https://www.youtube.com/watch?v=EnnaTVk7ZRU

\section{According to Boris Pigovat:}

${ }^{27}$ http://pigovat.com/wordpress/requiem cd got supersonic pizzicato award 2012/ (24 October 2020).

${ }^{28}$ Peter Mechen, Middle C CD review (15 September 2011). https://middle-c.org/2011/09/borispigovats-requiem-a-stunning-cd-presentation/ (24 October 2020). 
"Silent Music" is scored for viola and harp, and bears a separate Hebrew title of Nerot Neshama (Candles of the Soul). It also has tragic undertones, appropriate given its composition to commemorate a particularly bloody terrorist attack in 1997. Written in 1997, after the Requiem, the title of this piece is a reference to the Israeli ritual of lighting memorial candles at the sites of fatal terrorist attacks, a wordless tribute to the dead. ${ }^{29}$

Pigovat composed Silent Music in reaction to a huge emotional shock, imagining the candles, the silence, the numbness and a repetition of this tragic fate over several generations. As Pigovat has stated, "the last chords of the harp are as the sound of an alarm bell, which turns into the sound of an explosion." As described by Jerry Dubins:

Its combined sonorities of viola and harp are quite unusual, almost what I would call otherworldly. The effect, I'm sure, is what Pigovat intended to convey in this surreal, slow-moving processional of the disembodied drifting silently down an endless corridor dimly illuminated by flickering candles-a most remarkable piece of music. ${ }^{30}$

\section{Sonata for viola and piano}

See Part Three for detailed information

Venue: Adam Concert Room, NZSM, Victoria University of Wellington (8 December 2019)

1st movement

https://www.youtube.com/watch?v=rEEVQnAt8n4

2nd movement

29 Peter Mechen, Middle C (15 September 2011). https://middle-c.org/2011/09/boris-pigovatsrequiem-a-stunning-cd-presentation/ (2 November 2020).

30 Jerry Dubins, 'On a Requiem of Remembrance - A Conversation with Composer Boris Pigovat', Fanfare, 35/3 (Jan/Feb 2012), 180-183. 
https://www.youtube.com/watch?v=DRFWhrpVSo8

3rd movement

https://www.youtube.com/watch?v=dRXOwJ6VgW0

\section{Holocaust Requiem}

See Part Four for detailed information

\subsection{Complementary Repertoire Selection-influences and context}

The additional repertoire performed in this project was selected to provide some context to the musical styles Boris Pigovat was exposed to in his formative years and which arguably played some role in influencing his own compositional voice, either directly or subconsciously. Clearly this can only represent a small amount of his musical exposure, and is further limited to repertoire which features the viola in some way, and may have played a role in his decision to give the solo role to the viola in his Magnum Opus Holocaust Requiem.

The repertoire draws on examples from baroque, romantic and twentieth-century styles and contains influential elements of nationality, faith and culture, with notable prominence of Russian and Jewish heritage. The composers selected had a range of influence on Boris Pigovat, the most prominent being his compatriot Shostakovich and to a lesser degree Rachmaninoff and Glinka. The influence of Bloch may not be direct, but he was a composer who drew on similar source material. Bartok and Hindemith were immediate predecessors from Eastern and Western Europe whose music reflected the events of World War Two and both of whom composed works for solo viola with orchestra. The influence of Bach is of his pure musical genius and his use of counterpoint. 
The weighting of information about these composers is a reflection of the influence they have had, and continue to have, on Pigovat through their compositional styles and their connections to Jewish themes and themes of conflict.

Bach's Sarabande from the D minor Partita for solo violin provides the inspiration for Pigovat's Viola Sonata. See Part Three - Viola Sonata for detailed information.

\subsubsection{Béla Bartók (1881-1945)}

Concerto - viola with piano

Venue: Adam Concert Room, NZSM, Victoria University of Wellington (4 December 2018)

1st movement

https://www.youtube.com/watch?v=ZORpSQJrucM

Divertimento for Strings - principal violist

Venue: St Andrew's on the Terrace, Wellington (27 April 2019)

https://vimeo.com/341272893/636f311f07

Of the viola concerto repertoire it can be surmised that Pigovat's approach to the Holocaust Requiem was influenced by the works of Walton, Hindemith and Bartók, whether consciously or subconsciously. The emotion of Pigovat's compositions ranges from harsh and brutal to really beautiful. Many composers do not achieve this, though Bartók does to some degree. It is also significant that Bartók wrote his viola concerto immediately after World War Two had ended, and his works produced just prior to World War Two, such as the Divertimento for strings, are clearly reflective, if not pre-empting, the atrocities that were already unfolding.

Bartók was born into a generation of Hungarian artists and thinkers who began to change the cultural and political nature of Hungary. Hungary consisted of many 
ethnic groups and different languages at that time. Bartók found spiritual affinity in the countryside, engaging with the culture and music of the peasants. An ethnically diverse region such as Hungary in the early twentieth century is very suitable for comparing different musical traditions. As Bartók himself stated:

For miles on end, in these parts, there are entire villages with illiterate inhabitants, communities which are not linked by any railways or roads; here, most of the time the people can provide for their own daily wants... When one comes into such a region, one has the feeling of a return to the Middle Ages. ${ }^{31}$

Soon after Bartók's death, many of his mature works became popular modern classics, because the sound and aesthetics of Bartók's music originated from a common culture. ${ }^{32}$

Bartók began performing in Germany from 1903 and continued until 1933 when Adolf Hitler became Chancellor. Bartók became disappointed in the cooperation between the Hungarian government and the Nazis and, when he refused to perform in Germany, this aroused the suspicion of the Hungarian government. During that period, Bartók was asked to provide documents proving his race, and to eliminate the rumour that he was Jewish, but he refused. He even joined a group of nonJewish intellectuals who were protesting, when the Hungarian government began to adopt "Jewish laws". As he did not want work to go to any publishers under the Nazi regime, over that time, Bartók sent his manuscripts to Boosey and Hawkes in London. $^{33}$

\footnotetext{
31 Kenneth Chalmers, Béla Bartók (London: Phaidon Press, 1995), 157.

32 Ibid., 215

33 Béla Bartók (1881-1945). http://holocaustmusic.ort.org/resistance-and-exile/bela-bartok/ (2 November 2020).
} 
Divertimento is his penultimate work written before the outbreak of World War Two, in August 1939. Composed in only fifteen days, this work consists of three movements. The first and third movements use classical forms employing unconventional scales and irregular accents, as well as the contrast of solo quartet and ensemble passages. The second movement may indicate an inward and uncomfortable expression of Bartók during the outbreak of World War Two. The outer sections convey a sense of unease while the middle part reaches a climax of agony. Soon after composing the Divertimento, Bartók expressed great sorrow in his final quartet (No. 6), composed immediately afterwards, before departing to the USA. ${ }^{34}$

The Viola Concerto was composed in 1945, following the end of World War Two; Bartók had been in exile in the USA since 1940. The Viola Concerto was Bartók's last (incomplete) work. Although there is no definitive version, this concerto is one of the most performed viola concertos in the world. After Bartók's death, his family asked his friend Tibor Serly to help prepare the sketches of the concerto and publish it. Serly's version was widely welcomed, even though it faced charges of inauthenticity. In the 1990s, three editions appeared, one by Donald Maurice, one by Csaba Erdélyi and a third by Nelson Dellamaggiore working with Peter Bartók. The DellamaggioreBartók edition was accompanied by a facsimile of the manuscript, thus, opening discussions in terms of the authenticity of this work in its various versions. ${ }^{35}$

Due to little being known about Bartók's intentions, there are some large discrepancies between the different editions of this concerto. Each editor has very different interpretations of fingerings, slurring, bowing, dynamics and even pitches, which has caused significant differences in the subsequent performances of the

\footnotetext{
34 Malcolm Gillies, Bartók Connections: A Guide for Performers and Programmers (New York, NY: Boosey \& Hawkes, 2007), 30.

35 Donald Maurice, Bartok's Viola Concerto: The Remarkable Story of his Swansong (Oxford: Oxford University Press, 2004).
} 
piece. In preparation I worked strictly from the manuscript in order to make informed decisions about all the above-mentioned aspects, and to recover as accurately as possible Bartók's intentions. I have also taken into account the decisions made by others, in particular Peter Bartók, Csaba Erdélyi and Donald Maurice. I also consulted the suggestions made by eminent violist Atar Arad.

\subsubsection{Ernest Bloch (1880-1959)}

Suite 1919- viola and piano

Venue: Adam Concert Room, NZSM, Victoria University of Wellington (22 November 2017)

1st movement

https://www.youtube.com/watch?v=qG coq6Kd9g

2nd movement

https://www.youtube.com/watch?v=VhlaEWKwmCw

3rd movement

https://www.youtube.com/watch?v=Km02TBe9Ur4

4th movement

https://www.youtube.com/watch?v=9EuLYeyakAA

Ernest Bloch wrote his Suite 1919 for viola and orchestra in 1919, soon after the end of the First World War. While any references to war may not be apparent, the Jewishness in his writing is a pronounced influence.

Ernest Bloch composed many works that are deeply influenced by Jewish liturgical and folk music. Suite 1919 is a romantic vision of exotic places from the past. ${ }^{36} \mathrm{He}$ gave picturesque titles to the four movements of this work: In the Jungle, Grotesques, Nocturne and Land of the Sun. The Suite was an immediate success after

36 David Kushner, Ernest Bloch: A Guide to Research (New York: Garland, 1988), 36. 
he won a chamber music competition sponsored by Elizabeth Sprague Coolidge. ${ }^{37}$ Bloch later orchestrated this work. Musicologist and writer Oscar Sonneck declared that "in either version Ernest Bloch has given us the greatest work for viola in musical literature, and what is more important, one of the most significant and powerful works of our time. ${ }^{\prime 38}$ In Suite 1919, listeners can still perceive Jewish elements in some places, although this piece was not related directly to Judaism.

Bloch gave his own comments on the score about this work:

First of all, my Suite does not belong to my so-called "Jewish works," though perhaps, in spite of myself, one may perceive here and there, in a few places, a certain Jewish inspiration. It is rather a vision of the Far East that inspired me: Java, Sumatra, Borneo those wonderful countries I so often dreamed of, though I never was fortunate enough to visit them in any other way than through my imagination...

The first movement, the most complicated in inspiration and form, aims to give the impression of a very wild and primitive Nature. The introduction Lento begins with a kind of savage cry, like that of a fierce bird of prey, followed immediately by a deep silence, misterioso, and the meditation of the viola. Other motives follow, and a small embryonic theme that later assumes very great importance. All these motives will be recalled further, either in the first movement or in the following ones, with more or less transformation. The following Allegro brings a motive of joyful and perhaps exotic character which is answered by the viola...

Rather difficult to define is the second movement. It is a curious mixture of grotesque and fantastic characters, of sardonic and mysterious moods. Are these men, or animals, or grinning shadows? And what kind of sorrowful and bitter parody of humanity is

\footnotetext{
37 Programme notes from Boston Symphony Orchestra
} https://cdm15982.contentdm.oclc.org/digital/collection/PROG/id/320197 (19 October 2020).

38 David Kushner, Ernest Bloch: A Guide to Research (New York: Garland, 1988), 194. 
dancing before us - sometimes giggling, sometimes serious? I myself do not know and cannot explain...

This very simple page \{the Lento expresses the mystery of tropical nights. I

remembered the wonderful account of a dear friend who lived once in Java - his travels during the night...their arrival at small villages in the darkness...the distant sounds of curious, soft, wooden instruments with strange rhythms...dances, too...Many years have passed since my friend told me all this; but the beauty and vividness of his impressions I could never forget - they haunted me; and almost unconsciously I had to express them in music...

The last movement is probably the most cheerful thing I ever wrote. The form is extremely simply - an obvious A-B-A, the middle part being a more lyrical episode, built on motives from the other movements treated in a broad and passionate mood. ${ }^{39}$

\subsubsection{Mikhail Glinka (1804-1857)}

Viola Sonata- viola and piano

Venue: Adam Concert Room, NZSM, Victoria University of Wellington (26 April 2019)

1st movement

https://www.youtube.com/watch?v=HT13N56NktY

2ndmovement

https://www.youtube.com/watch?v=SG8WfRbhjwg

Mikhail Glinka wrote his Viola Sonata in 1825, and while it precedes Boris Pigovat's birth by more than a century, it is a good example of the national style that was still

\footnotetext{
39 Programme notes from Boston Symphony Orchestra https://cdm15982.contentdm.oclc.org/digital/collection/PROG/id/320197 (19 October 2020).
} 
popular in Russia in the mid-twentieth century and in which young Russian students, including Pigovat, would have been steeped.

Mikhail Ivanovich Glinka created a new direction for the development of Russian music and is recognised as the founder of Russian music nationalism. ${ }^{40}$ Music culture prior to this had been introduced to Russia from Western Europe, and this was the first time a unique Russian music style appeared. From then on, Russian culture began to occupy an increasingly important position in Western European culture. ${ }^{41}$

Glinka's works became an important influence on future Russian composers. In 1830, after three years of studying in Italy, Glinka decided that his mission in life was to return to Russia and revolutionise Russian music. ${ }^{42}$ His music laid a solid foundation for many Russian composers who followed him, such as Alexander Borodin, Nikolai Rimsky-Korsakov and his close friend Pyotrllyich Tchaikovsky. ${ }^{43}$

Glinka was both a pianist and a violist and in 1825 , he began to compose the viola sonata. This work came from the early days of his career, when his music had not yet reached a unique level of complexity, but it contains rich melodic ideas. Glinka and his colleagues considered this work to be his major breakthrough, marking his transition from his early academic works to his unique Russian masterpieces.

This piece was tidier than the others. I performed this sonata with Boehm and Liegle. With the latter I played viola. The composition of the romance to Baratynsky's words, "Neiskushaimeniabeznuzhdy" [Do not tempt me needlessly] appears to date from this

\footnotetext{
40 Mikhail Ivanovich Glinka https://www.belcanto.ru/glinka.html (31 October 2020).

41 Mikhail Ivanovich Glinka https://superinf.ru/view helpstud.php?id=305 (31 October 2020).

42 David Brown, Mikhail Glinka: A Biographical and Critical Study (London: Oxford University Press, 1974), 74.

43 Ibid., 303.
} 
period. This was "my first successful romance". The adagio was written later [1828], and the rondo, the theme for which was of Russian origin...I did not try to complete...Recently I used it [the rondo] in a children's polka. [Two undated autographs are preserved. The romance was first published by the firm of Petz (with no date). $]^{44}$

In 1828, Glinka wrote the second movement of the sonata, Adagio, in sharp contrast to the Allegro first movement. He started the third movement as a Rondo, which is a typical representative of many classical sonatas, but he never completed it. ${ }^{45}$ Between 20 April and 9 May 1828, while Glinka was in Moscow, he wrote the Adagio of the Sonata, "the counterpoint in this piece was quite clever." 46

\subsubsection{Paul Hindemith (1895-1963)}

Der Schwanendreher - viola and piano Venue: Adam Concert Room, NZSM, Victoria University of Wellington (4 December 2018)

1st movement

https://www.youtube.com/watch?v=9-eS9jNrVDU

2nd movement

https://www.youtube.com/watch?v=gJk50Vfvull

3rd movement

https://www.youtube.com/watch?v=n1P9tNafeMI

Paul Hindemith composed Der Schwanendreher in 1935, in the midst of the everincreasing power of the Nazi movement in Germany and its influence beyond. He came into conflict with the National Socialists in 1933, and emigrated to Switzerland in 1938.

\footnotetext{
44 Alexandra Orlova, Glinka's Life in Music: A Chronicle (Ann Arbor: UMI Research Press, 1988), 33-34. ${ }^{45}$ https://paulabrusky.com/program-notes/notes-glinka-sonata (31 October 2020).

46 Alexandra Orlova, Glinka's Life in Music: A chronicle (Ann Arbor: UMI Research Press, 1988), 46.
} 
In 1934, the German Minister of Propaganda Joseph Goebbels publicly denounced Hindemith as an "atonal noisemaker". The Nazis banned his music in October 1936. Although his music was condemned by the Nazis, Hindemith's apolitical attitude and willingness to compromise, as well as his international reputation, enabled him to have a short-lived career in Nazi Germany while he was still supported by senior Nazi officials. Because of his continued collaboration and sympathy with Jewish artists during World War Two, his music had a strong relationship with Jewish elements. ${ }^{47}$

Hindemith's music has some unique styles, and some of his works were intended to achieve social or political goals. In 1935, when Hindemith was preparing for the London premiere of Der Schwanendreher, he heard the news of the death of George V on 20 January. He quickly wrote Trauermusic for solo viola and string orchestra, as a tribute to the late King, and the premiere took place on 21 January, the night after the King's death. ${ }^{48}$

The neoclassical style in Der Schwanendreher contains elements of nationalism, at least partly motivated to appease Nazi cultural organisations. When in 1934, Hindemith was accused of condemning Hitler, his relationship with him was damaged. At the end of the year, Hindemith left his work at the Conservatory, instead going into self-exile in the Black Forest to focus on composition. ${ }^{49}$ In Der Schwanendreher, each movement is based on a separate medieval German folk song. It is translated as The Swanturner. ${ }^{50}$ Hindemith's programme notes concerning a travelling minstrel bringing "serious and joyful songs" are a kind of self-portrait and

\footnotetext{
47 Geoffrey Skelton, Paul Hindemith: The Man behind the Music: A Biography (London: Gollancz, 1975), 105-124.

48 Michael Steinberg, The Concerto: A Listener's Guide (Washington, DC: National Library Service for the Blind and Physically Handicapped, Library of Congress, 2010), 212.

49 Paul Hindemith, Der Schwanendreher (Concerto after old Folksongs for Viola and Small Orchestra), (London: Ernst Eulenburg; Mainz: B. Schott's Söhne, 1985), XII.

50 Michael Steinberg, The Concerto: A Listener's Guide(Washington, DC: National Library Service for the Blind and Physically Handicapped, Library of Congress, 2010),209.
} 
swansong as he planned to emigrate from Germany. ${ }^{51}$ This work, along with Walton and Bartók's concerto, occupies a place in the core of the viola concerto genre. It was premiered by Hindemith himself at a performance in Amsterdam on 14 November $1935 .^{52}$

\section{"Zwischen Berg und tiefel al" ("Between the Hills and the Valley")}

Zwischen Berg und tiefem Tal,

Da liegtein' freieStraßen:

Wer seinen Buhlen nicht haben mag,

Der muß ihn fahren lassen.

Fahr hin, fahr hin, du hast die Wahl.

Ich kann mich dein wohl maßen!

Im Jahr sind noch viel langer Tag,

Glück ist auf allem Gassen.
Between mountain and deep valley There runs an open road: He who does not like his sweetheart, Must let it go. Away, away, you have the choice. I can sense your welfare! There is many a long day in a year And luck is on every alley.

\section{"Nun laube, Lindlein laube" ("Now grow leaves, little linden tree, grow leaves")}

Nun laube, Lindlein, laube!

Nicht länger ich's ertrag':

Ich hab' mein Lieb' verloren,

Hab' gar ein' traurig' Tag.
Now shed your leaves, little linden!

I cannot bear it any longer:

I have lost my love,

I have such a mournful day.

\section{"Der Gutzgauch auf demZaune sass" ("The Cuckoo Sat on the Fence")}

Der Gutzgauch auf dem Zaune saß, The cuckoo sat on the fence,

51 Paul Hindemith, Der Schwanendreher (Concerto after old Folksongs for Viola and Small Orchestra) (London: Ernst Eulenburg; Mainz: B. Schott'sSöhne, 1985), XII.

${ }^{52}$ Giselher Schubert, Preface to Der Schwanendreher (Concerto after old Folksongs for Viola and Small Orchestra) (London: Ernst Eulenburg; Mainz: B. Schott'sSöhne, 1985), III-IX. 
Es regnet sehr und er ward naß.

Guck-guck, guck-guck!

Darnach da kam der Sonnenschein,

Der Gutzgauch der ward hübsch und fein.

Guck-guck, guck-guck!

Alsdann schwang er sein Gfiedere,

Er flog dort hin wohl übern See.

Guck-guck, guck-guck!
It rained a lot and it got wet.

Cuckoo, cuckoo!

Then came the sunshine, So the cuckoo was cute and fine.

Cuckoo, cuckoo!

Then it swung its wings

And flew away over lake.

Cuckoo, cuckoo!

Seid ihr nicht der Schwanendreher? ("Are you not the swan turner?")

Seid ihr nicht der Schwanendreher?

Seid ihr nicht der selbig' Mann?

So drehet mir den Schwan,

So hab' ich glauben dran.

Und dreht ihr mir den Schwanen nit,

Seid ihr kein Schwanendreher nit.

Dreht mir den Schwanen!
Are you not the swan turner?

Are you not the man himself?

Then turn me the swan,

So that I can believe it.

And if you do not turn me the swan,

Then you are not the swan turner.

Turn me the swan! $!^{53}$

\subsubsection{Sergei Rachmaninoff (1873-1943)}

Vocalise - viola and piano

Venue: Adam Concert Room, NZSM, Victoria University of Wellington (26 April 2019) https://www.youtube.com/watch?v=07H19E4DVXE

Sergei Rachmaninoff wrote Vocalise in 1912 for soprano or tenor and piano. While there is no direct connection between this work and any work by Pigovat, it is representative of the Russian music popular in the years immediately prior to the

53 Franz Böhme, Altdeutsches Liederbuch (Hildesheim: G. Olms, 1966), 257-396. 
Russian revolution in 1917 and the dramatic effect that had ultimately on the future of music under the Soviet regime.

Deeply rooted in the Romantic era and always expressing great beauty, Rachmaninoff was an early influence on Pigovat. Sergei Rachmaninoff pushed the values of the romantic era well into the twentieth century and, in his works, he was famous for his song-like melodicism, expressiveness and rich orchestral colouration. ${ }^{54}$ His first symphony has powerful gestures and an uncompromising power of expression, which were unprecedented in Russian music at the time.

Rachmaninoff often participated in the services of Russian Orthodox Churches, where he experienced liturgical chants and church bells, two characteristics which were to have a lasting effect on his future compositions. ${ }^{55}$ Rachmaninoff used unusually widely spaced chords to produce bell-like sounds. ${ }^{56}$ He frequently used themes including from the Dies Irae, usually just fragments of the first phrase. ${ }^{57}$ After the Russian Revolution, Rachmaninoff and his family left Russia, disillusioned with the political turbulence. They moved to the USA in 1918, which provided them with a more active musical scene and favourable opportunities. ${ }^{58}$

\section{Vocalise}

The original version of Vocalise is the last of the fourteen songs that Rachmaninoff wrote from 1910 and 1912. Vocalise was one of Rachmaninoff's most popular songs, composed to convey longing, homesickness, or a very personal sentiment that people do not want to reveal through words. Although originally written for voice and piano, due to its beautiful melody and lack of text, Vocalise is often transcribed

\footnotetext{
${ }^{54}$ The New Grove Dictionary of Music and Musicians (Macmillan, 1980), 707.

${ }^{55}$ Geoffrey Norris, Rachmaninoff (New York: Oxford University Press, 2001), 2.

56 Ibid., 81.

57 Ibid., 101.

58 Ibid., 54.
} 
in various arrangements for orchestras, chamber ensemble, choir and solo instruments.

From the programme notes of a San Francisco Symphony's concert about Vocalise:

The "Vocalise," last of the group, is wordless music whose calm, and whose expansive lines, capture the spirit of its birthplace. Some have called the "Vocalise" an exercise for voice, though the work is about more than pitch structures, and to do it justice a singer must have a sense of what the music is "saying" - not through words, but in gestures, inflections, and concentrated intensity of expression. Three years after completing his version for voice and piano, Rachmaninoff turned the "Vocalise" into a work for orchestra.-Larry Rothe ${ }^{59}$

Another note of a Utah Symphony performance says:

In Vocalise, the absence of words does not suggest an absence of meaning or mood. It is lushly melancholy. Russia's tradition of art songs is rich in ruminations on the difficulties and sadness of life, and in Vocalise many listeners hear a voice that sings on behalf of anyone who feels trapped by unhappiness. More than one critic has compared the melody's progress to a caged bird seeking escape, rising to near freedom and then falling back.

In rehearsing to perform Vocalise with Rachmaninoff at the piano, soprano Antonina Nezhdanova expressed regret that the music lacked text. "What need is there of words," asked Rachmaninoff, "when you will be able to convey everything better and more expressively than anyone could with words by your voice and interpretation?"60

59 Programme notes: https://www.sfsymphony.org/Data/Event-Data/Program-Notes/R/Vocalise (25 October 2020).

60 Programme notes https://utahsymphony.org/explore/2019/03/rachmaninoff-vocalise-op-34-no14/ (25 October 2020). 


\subsubsection{Dmitri Shostakovich (1906-1975)}

Dmitri Shostakovich may in many ways be considered the most direct influence on Pigovat. His Viola Sonata was his final work, written just weeks before his death in 1975. While Pigovat may himself play down both the direct and unconscious influence of Shostakovich on his own composition, its presence is undeniable in many contexts. Since the composer who most influenced Pigovat is Shostakovich, it was essential to perform music by him and the repertoire included both the Viola Sonata and Quartet No. 8.

Viola Sonata

Venue: Adam Concert Room, NZSM, Victoria University of Wellington (8 December 2019)

1st movement

https://www.youtube.com/watch?v=C-MLcUjetlo

2nd movement

https://www.youtube.com/watch?v=t-r6JUqmihg

3rd movement

https://www.youtube.com/watch?v=jKXbVCWzJfY

The Viola Sonata is dedicated to the violist Fyodor Druzhinin of the Beethoven

Quartet. In Shostakovich's later years, he suffered from a chronic disease, but he did not give up composing. He mentioned in a letter to Isaak Glikmanin in 1967: "Target achieved so far: 75\% (right leg broken, left leg broken, right hand defective). All I need to do now is wreck the left hand and then $100 \%$ of my extremities will be out of order." ${ }^{61}$ Like Shostakovich's last string quartets, the Viola Sonata is focused on morbidity, written when the composer's poor health forced him to face death. The

61 Dimitri Shostakovich \& I. Glikman. Story of a Friendship: The Letters of Dmitry Shostakovich to Isaak Glikman. Translator: Anthony Phillips. (London: Faber, 2001) 147. 
first movement was a novella, the second movement was a scherzo and the third movement, Adagio, was composed in memory of Beethoven. ${ }^{62}$ Throughout this thirty-minute work, the viola and piano are mostly in the middle and lower range.

\section{String Quartet No 8}

Venue: Adam Concert Room, NZSM, Victoria University of Wellington (22 November 2017)

\section{https://vimeo.com/341272677/2e30906583}

Although Shostakovich had no Jewish ancestry, he was very interested in Jewish culture. He believed that anti-Semitism was "a shameful superstition" when it was becoming increasingly popular in Russian society. ${ }^{63}$ What stands out significantly with Dmitri Shostakovich are his fifteen string quartets. Many of them were composed under pressure from the Soviet art standards set by the government. From the time he took office in 1928, Joseph Stalin paid much attention to the cultural life of the Soviet Union, including restrictions on musical styles. ${ }^{64}$ This strict system had an inevitable impact on Shostakovich's musical works.

Perhaps the most popular among the Shostakovich string quartets is String Quartet No 8, not only because it was completed in only three days, but also because the profound essence of this quartet refers to cultural elements, historical background and political context, and even the composer's extremely complex inner world. This work was created in the context of a worldwide anti-fascist movement after World War Two.

\footnotetext{
62 Alexander Ivashkin \& A. Kirkman. Contemplating Shostakovich: Life, Music and Film (New York: Routledge, 2016), 80.

63 Cecil Bloom, 'Dmitri Shostakovich and the Jews', Midstream 52/5 (September-October 2006).

64 Laurel Fay, Shostakovich: A Life (New York: Oxford University Press, 2005), 68.
} 
The creative intention of this quartet was considered controversial, partly due to his subtitle "To the Victims of Fascism and War", ostensibly to commemorate the Dresden fire in 1945. Shostakovich confessed to his friend Isaak Glikman: "I started thinking that if some day I die, nobody is likely to write a work in memory of me, so I had better write one myself." 65 Shostakovich used the German notation system to achieve the four-note sequence D-natural, E-flat ("Es" in German), C-natural, Bnatural ("H" in German). D-Eb-C-B is Shostakovich's musical signature, just as B-A-C-B (" $\mathrm{H}$ ") is that of Bach and again based upon the German spelling of his name, D-S-C-H from "DSchostakowitsch." The melody of this theme was used to not only to remind people about the lost Jews or the smoking battlefields, but also to remember the endless tragedy perpetrated by evil humans.

There is an example of Shostakovich's special feelings for this great work, when the Borodin String Quartet played it to him at his home and Valentin Berlinsky said:

When we finished playing, he left the room without saying a word, and didn't come back. We quietly packed up our instruments and left. The next day he rang me up in a state of great agitation. He said, “I'm sorry, but I just couldn't face anybody. I have no corrections to make, just play it the way you did." 66

Shostakovich was quoted in Volkov's "Testimony", saying that the quartet is obviously purely autobiographical, stating that "you have to be blind and deaf" to think it is about fascism, implying that this was indeed the composer's own struggle against Stalinist totalitarianism, disguised to avoid official retribution. ${ }^{67}$

\footnotetext{
65 Dimitri Shostakovich\& I. Glikman, Story of a Friendship: The letters of Dmitry Shostakovich to Isaak Glikman. Translator: Anthony Phillips. (London: Faber, 2001), 90-91.

66 Elizabeth Wilson, Shostakovich: A Life Remembered (London: Faber, 1994), 246.

67 Solomon Volkov, Testimony: The Memoirs of Dimitri Shostakovich (London: Hamish Hamilton, 1979), 156.
} 
Shostakovich chose to let the music speak for itself. With music he perceived that he was able to express everything but admit nothing. In the last public statement before his death, Shostakovich described music as "an art that is especially communicative, an art that travels all over the world without a visa and requires no translation into other languages". ${ }^{68}$

Due to the political environment and its influence on his personal life, Shostakovich also thought this was to be the last work he would wrote before he would commit suicide. Lebekinsky talked about the Eighth Quartet:

On the day of his return from a trip to Dresden, where he had completed the Quartet and purchased a large number of sleeping pills, he played the Quartet to me on the piano and told me with tears in his eyes that it was his last work. He hinted at his intention to commit suicide. Perhaps subconsciously he hoped that I would save him. I managed to remove the pills from his jacket pocket and gave them to his son Maxim, explaining to him the true meaning of the Quartet. ${ }^{69}$

This quartet lasts only twenty minutes. It consists of five movements, which are related to each other thematically. The first four notes of this quartet area musical spelling of the composer's initials, a motive which runs through the whole piece and conveys the main emotion of the quartet. The second movement is an Allegro molto, which expresses the composer's extreme anxiety. The familiar melody is a mixture of the Jewish colour, presenting a sense of ironic pleasure, and a kind of dim pleasure of Hasidic dance, as if a Jew recalled the story of his dead close friend by telling a joke. ${ }^{70}$ In the third movement, a humorous but creepy and discordant waltz can be perceived, and the composer had used a similar melody in the Quartet No. 2. The

\footnotetext{
68 Jennifer Gerstel, 'Irony, Deception, and Political Culture in the Works of Dmitri Shostakovich', Mosaic (Winnipeg) 32/4 (December 1999), 40.

69 Wendy Lesser, Music for Silenced Voices: Shostakovich and His Fifteen Quartets (New Haven: Yale University Press, 2014), 147.

70 Ibid., 155.
} 
powerful fourth movement is the peak of this quartet. It contains three different parts: a slow folk song in the cello and viola part; a beautiful and sweet melody interpreted by two violins, like two people comforting each other in adversity; and a series of three-beat "knocks" continuously breaking into the quietness in a threatening way. All the notes in the final movement are very quiet and seem to be telling the story of Shostakovich himself that everything is over, perhaps death is only temporary, but that staying with other survivors is endless pain and loneliness. ${ }^{71}$

71 Wendy Lesser, Music for Silenced Voices: Shostakovich and His Fifteen Quartets (New Haven: Yale University Press, 2014), 157. 


\section{Part Three - Boris Pigovat's Sonata for viola and piano}

This section begins with information about Bach's Sarabande from his Violin Partita No. 2, which was the inspiration for Pigovat's Sonata for viola and piano. This is followed by information about the work's creation, structure and compositional elements, based on an interview with the composer. The score of the Viola Sonata is available in Appendix Two. The full transcript of my interview with the composer about Sonata for viola and piano is available in Appendix Three.

\subsection{Johann Sebastian Bach (1685-1750)}

It is well known that Bach pursued church music throughout his life to glorify God and carried a new style of the church cantata to its highest development. The last three bars of the Sarabande section in Pigovat's Sonata are a direct quotation from Bach, and Pigovat's second movement, a set of fourteen variations, is based on these closing bars of the Sarabande.

Musically, Bach was renowned for invoking and maintaining different emotions. He was an expert storyteller as well, often using melody to reinforce the text in choral works of actions or events. In his works, Bach drew from different musical styles from across Europe, including French and Italian. His total mastery of counterpoint and fugue enabled him to create richly detailed compositions and ensures him his place as one of the greatest composers of the Baroque era, and one of the most important figures in classical music in general.

Sarabande, saraband, sarabanda (or zarabanda) is a slow dance in triple metre of Spanish/Mexican origin with the accent on the second beat. It is described as "a dance and song so loose in its words and so ugly in its motions that it is enough to 
excite bad emotions in even very decent people". ${ }^{72}$ A Sarabande is normally included in a traditional four-movement baroque suite-Allemande, Courante, Sarabande and Gigue.

The theme of Sarabande in Bach's Violin Partita No 2 occupies the first part of the movement. The first section (b.1-8) contains very exquisite and extravagant harmony.

The theme of Sarabande.
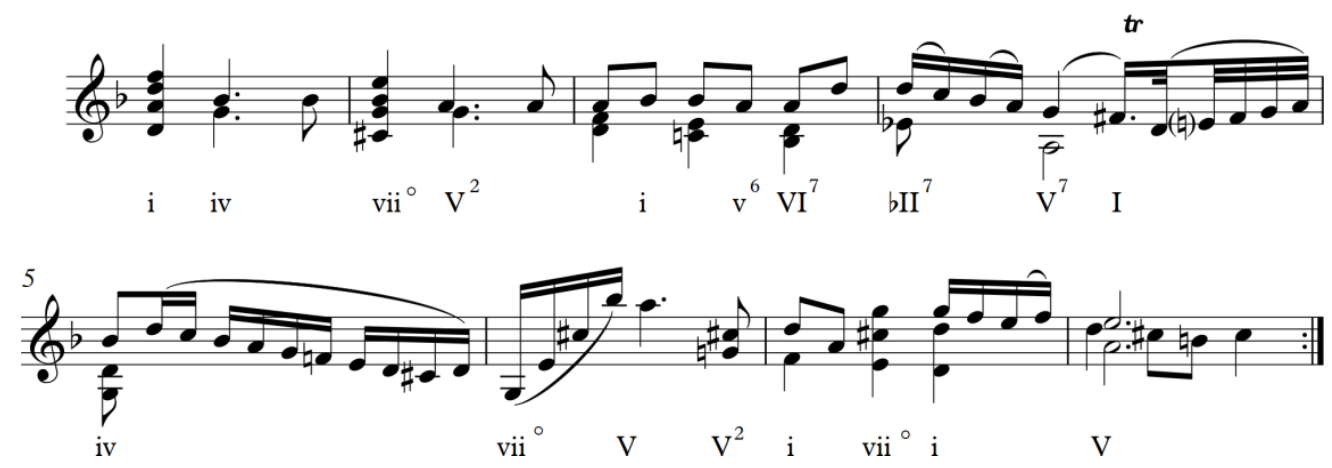

Ex. 3.1 First part of Bach Sarabande

The second part is twice as long as the first, and one might speak here not about binary but rather about ternary form. It begins with the dominant of $D$ minor ( $A$ major), resolving into the tonic of $\mathrm{D}$ major, and then modulates through $\mathrm{C}$ major into $\mathrm{G}$ minor, finishing here with a full cadence. The final eight-bar segment we can regard as the third part of the ternary form.

The second movement of Pigovat's Sonata is a set of variations based on a motive from this Sarabande. The final unaccompanied section is shown here with the direct Bach quoted in final three bars, one octave and a tone lower than in the original key of Bach.

\footnotetext{
72 Jane Bellingham, "Sarabande", The Oxford Companion to Music, edited by Alison Latham (Oxford and New York: Oxford University Press, 2002). https://thelistenersclub.com/2017/05/24/exploringthe-sarabande-over-400-years/ (23 December 2020).
} 


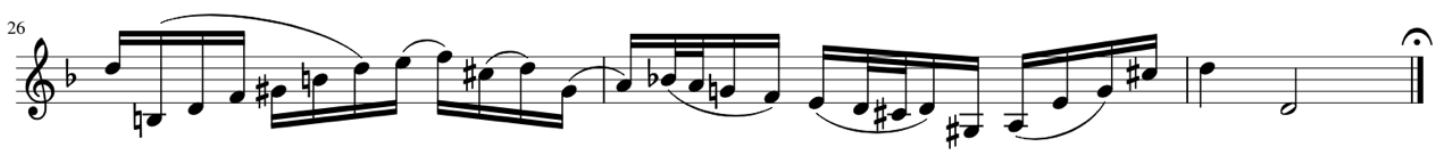

Ex. 3.2.1 The last three bars of Sarabande

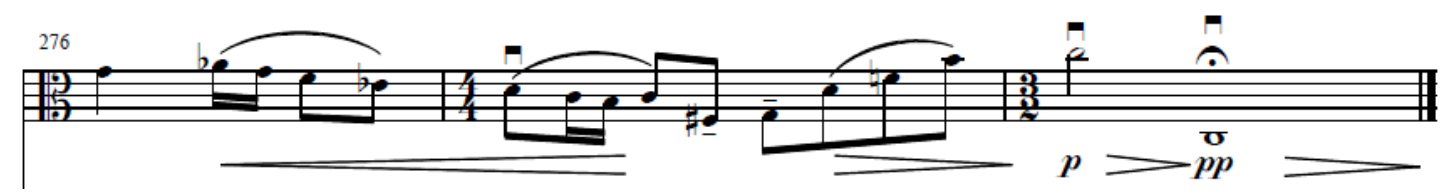

Ex. 3.2.2 Final three bars in the second movement of Sonata for viola and piano.

\subsection{Creation and performance history of Sonata for viola and piano}

Pigovat composed the Sonata for viola and piano for Donald Maurice after his performance in Wellington in 2008 of Holocaust Requiem at the Concert of Remembrance, commemorating the 70th anniversary of Kristallnacht. Pigovat was grateful to Maurice for his work in learning and promoting the Holocaust Requiem and he wanted to write a piece for him. He wrote on the score "To my friend Donald Maurice - with the deepest gratitude and respect". ${ }^{73}$ Thus, the sonata for viola was born.

Donald Maurice has worked with Pigovat since 2007 and has performed and premiered several of his compositions, including the major viola concerto Holocaust Requiem. At their first encounter in Wellington in 2008 they could communicate primarily by Pigovat playing the piano to demonstrate interpretive ideas because his English was very limited at that time.

Donald Maurice premiered the Sonata for viola and piano in 2013 at the 41st International Viola Congress in Krakow, with the pianist Wioletta Fluda. Maurice quoted by Hollingsworth:

\footnotetext{
73 Inscribed by Pigovat on the published score.
} 
The viola sonata was a gift to me, and arrived a bit at a time. Some of the first movement, then the rest, and then the second movement came in instalments. So by the time we received the third movement, the rest of the work was already well learned. The outer slow movements were very reminiscent of some of the sublimely beautiful sections of the Requiem. The middle movement was very much in the mould of the 'Dies Irae' from the Requiem. It is emotionally quite overpowering at times and the intent was crystal clear from the very first read through. I knew immediately that this was one of the most challenging yet most rewarding pieces of music in the viola repertoire - in any repertoire! $!^{74}$

When learning the piece, Maurice and his pianist, Richard Mapp, sent rehearsal sound files to Pigovat, who gave specific feedback about what he wanted. Because of his close relationship with Pigovat and very specific and deep understanding of the sonata in particular, Maurice is understandably a champion of the work. The following statement was quoted by Hollingsworth:

Everything Pigovat wrote is playable and generally idiomatic for the viola. Suggestions that it should be simplified or amended in any way should be ignored...The sonata is totally awe-inspiring - exquisitely beautiful and emotionally moving in the outer movements and incredibly powerful and riveting in the second movement, with a touch of pure genius in the way it ends. ${ }^{75}$

In giving the sonata a high evaluation, Maurice predicted it would become a wellknown part of the viola repertoire, comparing it to works by Bloch, Hindemith and Clarke, and it reminds him very much of the Shostakovich sonata.

\footnotetext{
74 Leah Hollingsworth, 'A Monument to Viola', Strings 30/5(2015), 30-31.

75 Ibid.
} 


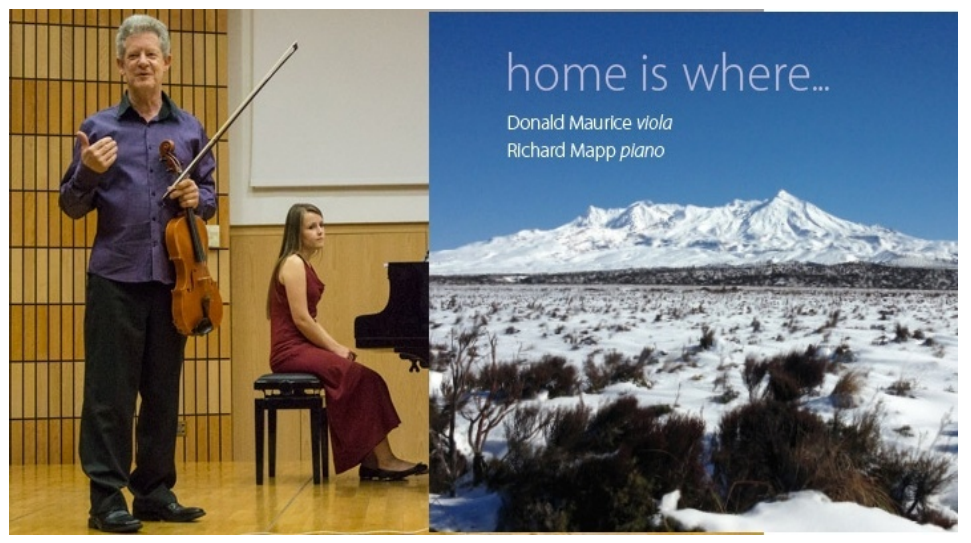

Photo 3.1 Donald Maurice and Wioletta Fluda, World premiere in Krakow, 2013 (Left). Atoll CD including premiere recording of Sonata for viola and piano in 2012 (Right).

In February and March 2015, this piece was performed at three concerts in the United States. The American premiere was in Baltimore, featuring soloists Peter Minkler (viola) and Lura Johnson (piano). Eight days later, it was performed by Lawrence Wheeler (viola) and Tali Morgulis (piano) in Houston and in March 2015 by Barbara Sudweeks (viola) and Jo Boatright (piano) in Walden, Colorado. In October 2019, I performed this Sonata with Krzysztof Sowiński (piano) at the 46th International Viola Congress in Poznan, Poland, and two months later, in Wellington with Fiona McCabe (piano).

\subsection{The Structure of the Sonata for viola and piano}

The following is drawn from my translation of the interviews with Boris Pigovat, turned into third person for clarity of expression but the content represents the explanations of the composer.

In the first movement Boris Pigovat states that he did not compose the movement in sonata form. He stressed that he did not write it in accordance with some canons or some norms that already existed; instead he wrote the first movement as a musical response to two Botticelli paintings: Madonna del Magnificat (1483-1485) at the beginning and end of the movement and Virgin with a Pomegranate (1487) in the 
middle part of the movement. Pigovat advises that this movement can be played as an independent work titled 'Botticelli's Magnificat'.

The first painting presents brightness and serenity, and the second painting describes a kind of sadness. Comparing the two paintings, with almost the same faces, however, their characters are completely different.
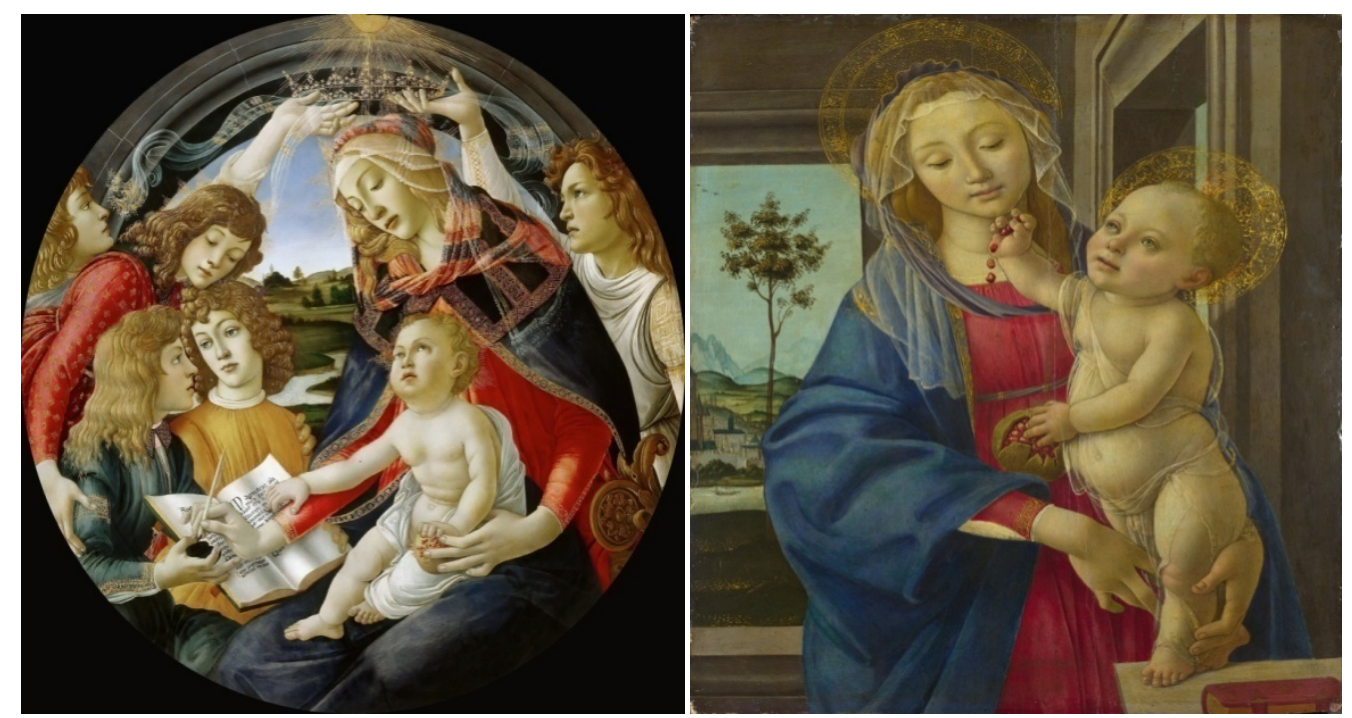

Photo 3.2 Madonna del Magnificat (1483-1485) (Left).

Photo 3.3 Virgin with a Pomegranate (1487) (Right).

Therefore, his desire to make emotional responses to these two paintings helps to understand the structure of the first movement. The first movement consists of two large sections and a short coda. Each section respectively discusses the two paintings, and the nature of the second section is much sadder than the bright first section.

A traditional three-part form ( $A B A)$ can be found in the first section: an initial theme, and some other musical materials before the initial theme returns. In the second section, there are four main different themes with some repetitions: a monologue theme, a first lullaby, a second lullaby and a romantic main theme (con mitezza). 
Because it had so many different themes, it was necessary to unify the whole structure.

When asked how he achieved that unity, Pigovat explained that, first, there is a series of harmonies presented in different places in all themes. The tonic triad is a second-dominant second chord (a harmonic pattern of bars 18-19). It is presented in a variety of places, both in the first section and in the second. It appears the first time in the second theme of the first section (bars 18-19). This harmonic sequence takes place in this way several times. It occurs in C sharp minor (bars 25-30), and again in E minor (bars 38-41).

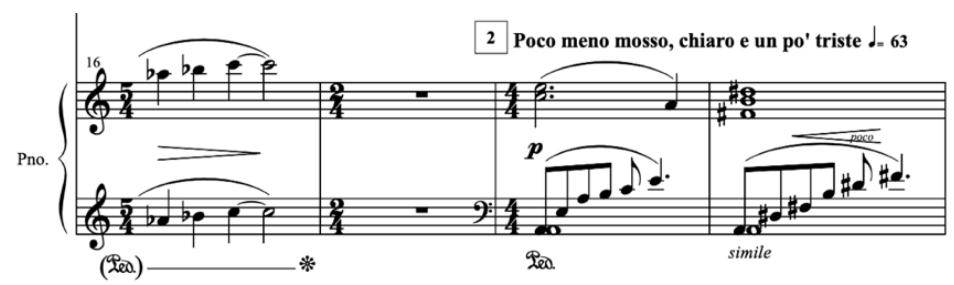

Ex. 3.3 Bars 18-19
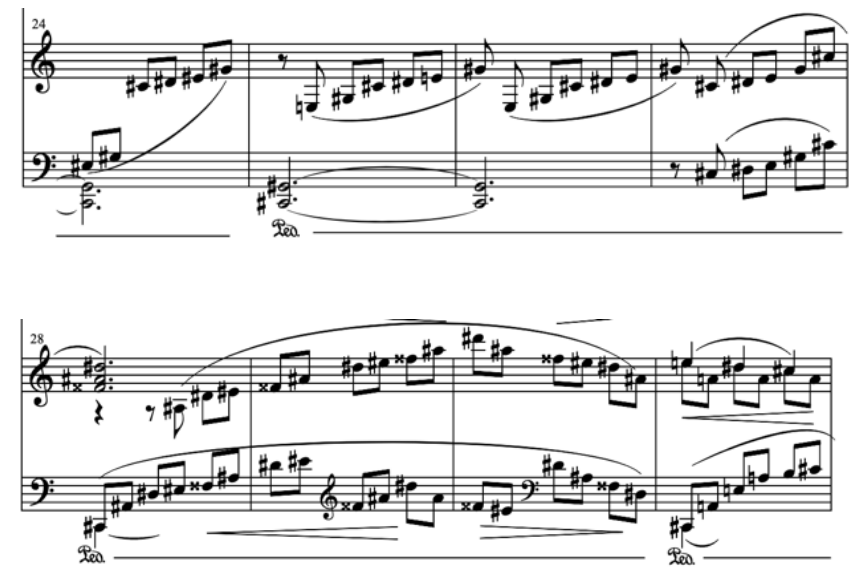

Ex. 3.4 Bars 25-30 

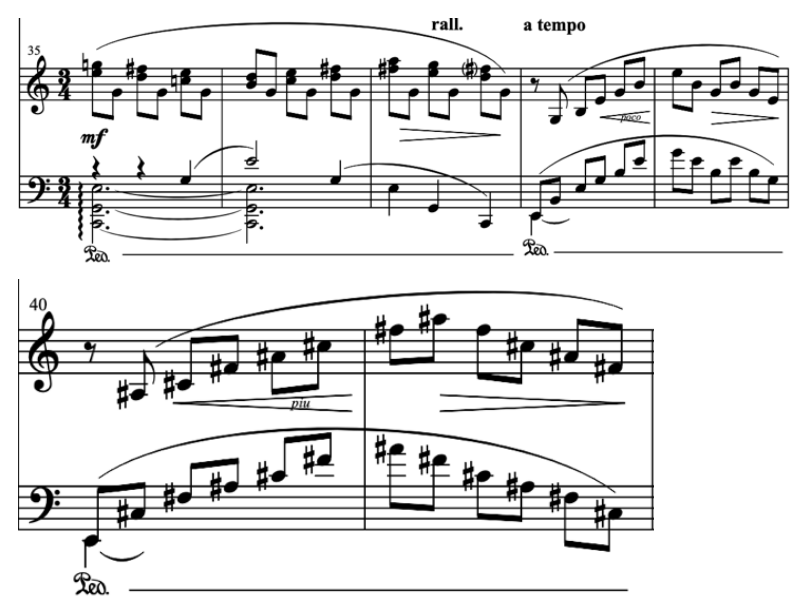

Ex. 3.5 Bars 38-41

The second unifying factor is that the initial theme consists of two elements: the first for the piano (bars 1-3), and the second is the monologue of the viola (bars 11-16). Variants of these elements appear in different places, linked by a system of bridges: there is a theme, then something new comes out, then a bridge appears (it is like a reminder of a previous theme) as something connecting, then again something new occurs, and again a bridge.

Another important point is that although the first section and the second section are different, the initial theme of the second section is based on the first section (bars 12 and 64-66). Listeners may not recognise this but this thematic connection settles in the subconscious. Thus, the work is one entity and does not fall apart, as there are always some unifying fragments.

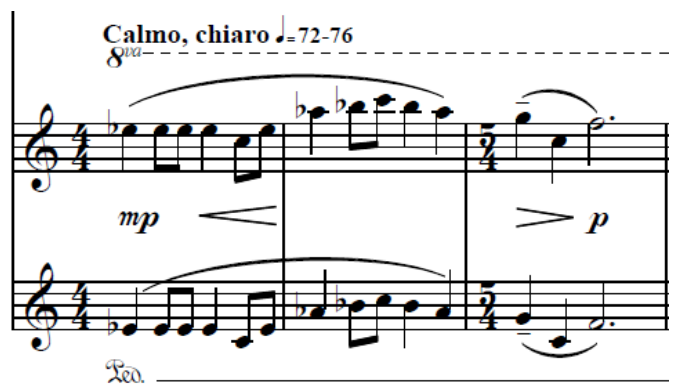

Ex. 3.6 Bars 1-3 


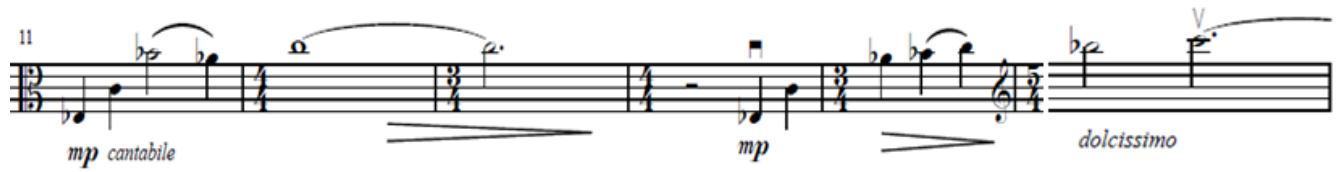

Ex. 3.7 Bars 11-16

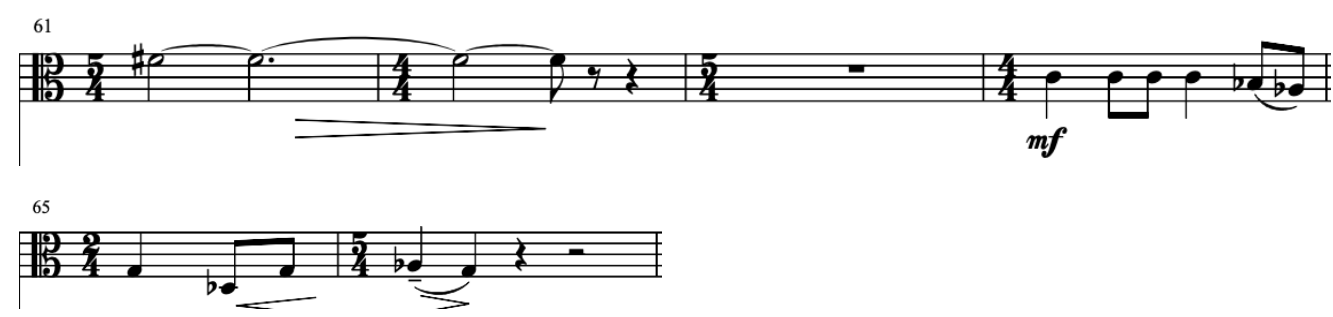

Ex. 3.8 Bars $64-66$

Regarding how the second section was built, a very important point is that some bass notes (bars 62,63) of the piano part precede the initial theme of the second section. It is like a funeral bell; this piano part immediately creates that atmosphere. In the second painting a feeling of sadness is portrayed as if the mother knows what will happen to her child in the future.

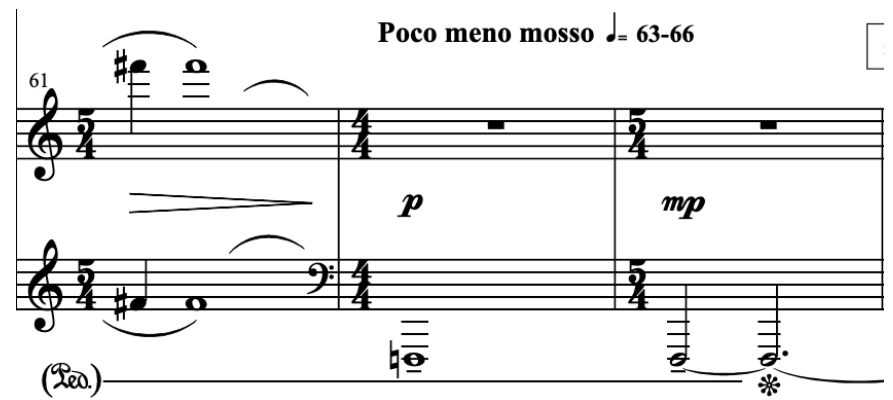

Ex. 3.9 Bars 62-63

A question may arise when hearing from bar 73: why does the composer put this long note here (bars 73-83)? Only the viola is heard here, and this pedal is no longer audible. Pigovat wanted the piano to resonate the viola sounds, thereby creating an additional reverberation for them. For this to be fully effective it is necessary to direct the viola sound into the piano. 


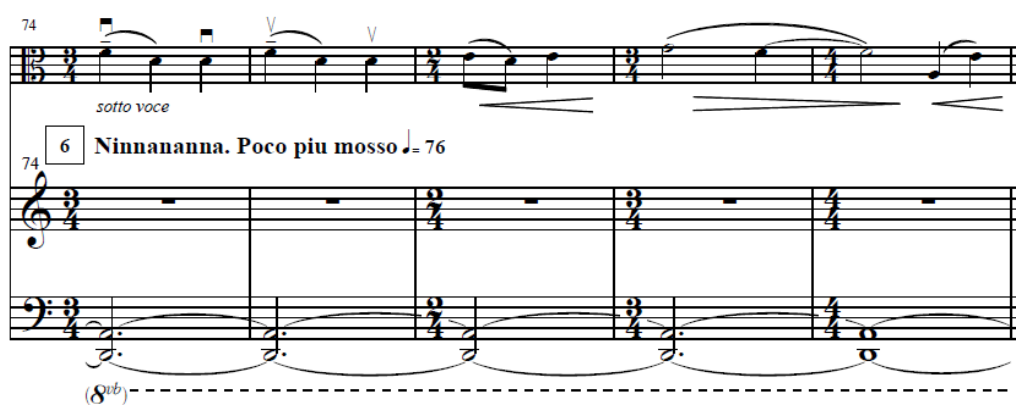

Ex. 3.10 Bars $74-78$

The second section also has two different lullabies. The first lullaby (the second theme of the second section) is a sort of traditional sad music (bars 79-85) that the mother sings for her sick baby. The second lullaby is a fairy tale (bars 103-104). This kind of lullaby has a rather long tradition in Russian music, because it recalls the time of Rimsky-Korsakov, Lyadov (Kikimore) or the early Stravinsky (The Firebird).

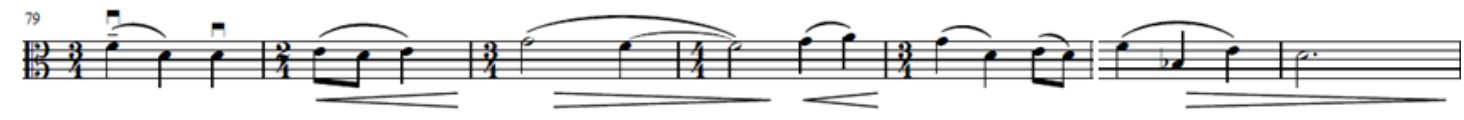

Ex. 3.11 Bars 79-85

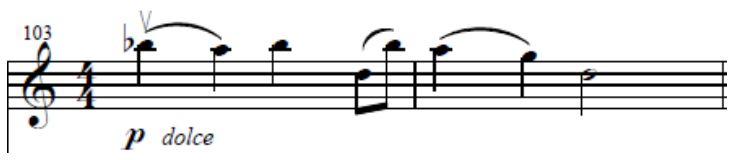

Ex. 3.12 Bars 103-104

Finally, when this lullaby ends the material of the first section, a monologue suddenly reappears (bars 117-122), and it is combined with the first theme of the second section (bars 124-126). There are two previous monologues, which are respectively in the first section (bars 11-16) and the beginning of the second section (bars 64-73). Therefore, the critical viola solo part (bars 117-138) is the culmination of this connection between the first section and the second section. When heard against the background of the E major chord (bars 139-142), the initial theme of the 
first section (bars 1-2) sounds as if this is a monologue of the second section (bars 140-141 and 64-65 are compared).

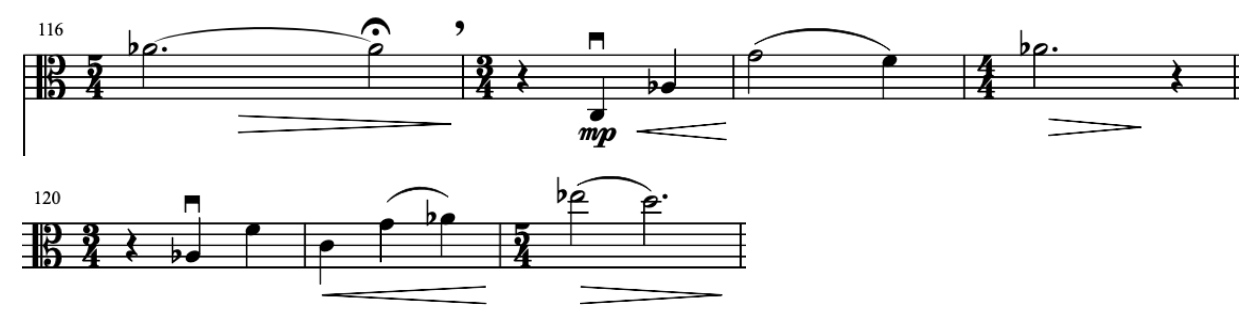

Ex. 3.13 Bars 117-122

The completely new theme (bars149-160) may seem familiar, as it starts with the same harmonic alteration - the tonic triad is the second-second chord of the dominant. It is connected to the previous material (bars 18-19).
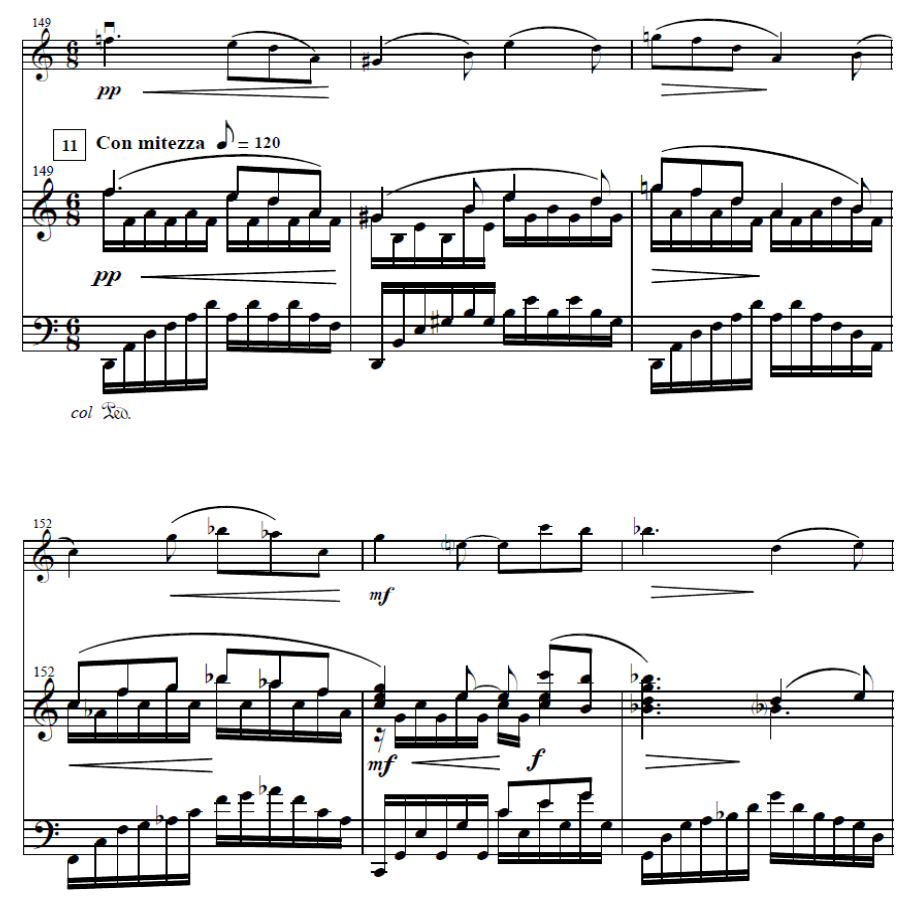

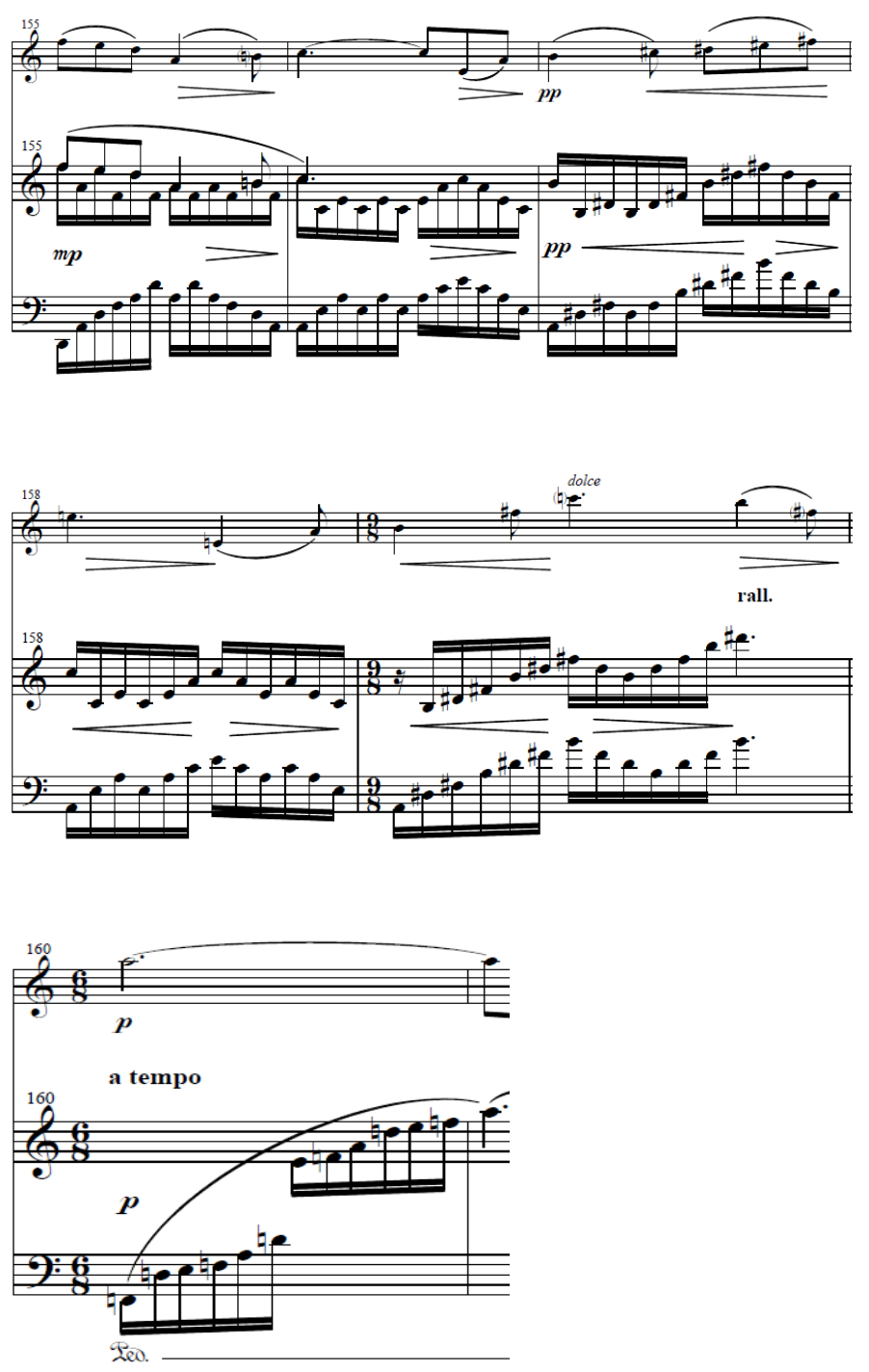

Ex. 3.14 Bars 149-160

The coda of the first movement begins in bar 164 and Pigovat considers that it is a reprise since the $A$ flat major is established in the beginning. The coda has two sections: the first is in A flat major (bars 164-171), and the second is in F major (starting from bar 172). Despite there being no themes from the beginning (neither the theme of bars 1-2 nor of bars 11-12), it seems like a reprise because the initial tonality (A flat major) is returned in the first section of the coda, and the texture of the beginning is returned in the second section. The only remaining elements are a return of the main key and a reminder of the initial texture. Therefore, the final part 
is a coda instead of a reprise, though the musical nature of the coda looks like a reprise.
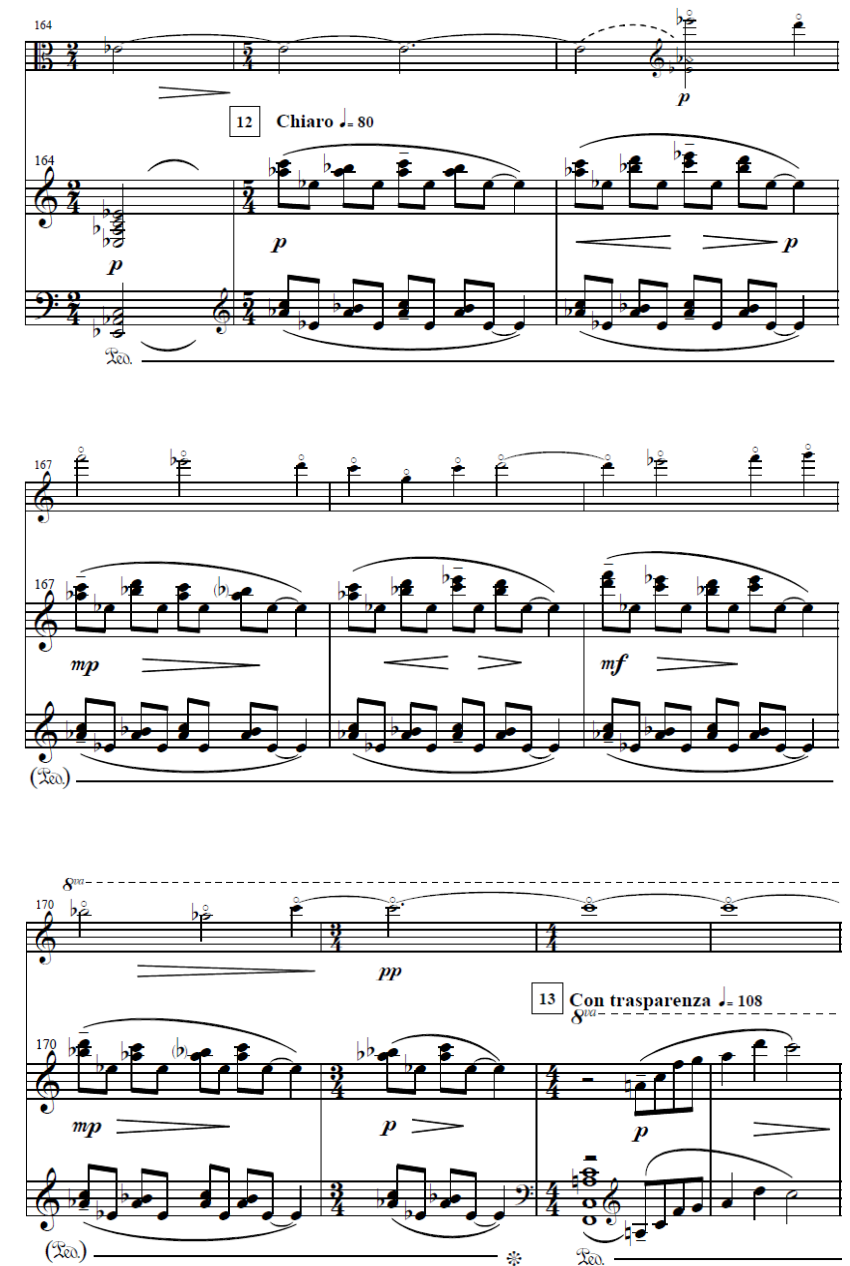

\section{Ex. 3.15 Bars 164-173}

The second movement is a kind of stylistic modulation. Pigovat wanted to write a typical toccata, starting as music of the twentieth/twenty-first century and gradually turning into a Baroque toccata, preparing for the quotation of the Bach Sarabande at the end. This movement is the stylistic climax of the whole sonata.

Only the very last three bars are a quote from Bach's Sarabande but Pigovat said that this movement was completely based on this quotation. As a result, all the previous materials were written with elements of Bach so that the whole movement 
is unified. Once Baroque features begin to appear in this music, in Pigovat's opinion, it is easier to switch from a Baroque toccata to a Baroque sarabande.

This movement was generally written in a classical form, an introduction with two contrasting elements that affect the whole movement. Figure 1 is the main theme and figure 2 is the second theme. The main theme is in $\mathrm{C}$ minor and the second is in C sharp minor. There follows a development section and then the reprise begins. In the reprise section, there is only one main theme at figure 17 , but it appears in the key of the second theme $-\mathrm{C}$ sharp minor. These are the signs of the completely pure form. It is important to note that the whole movement is written as a series of fourteen variations followed by the theme. All the material is connected either with the motives of the toccata or with the motives of the final sarabande quote. The second movement is quite independent in relation to the first movement, though some common elements of the themes are recognisable.

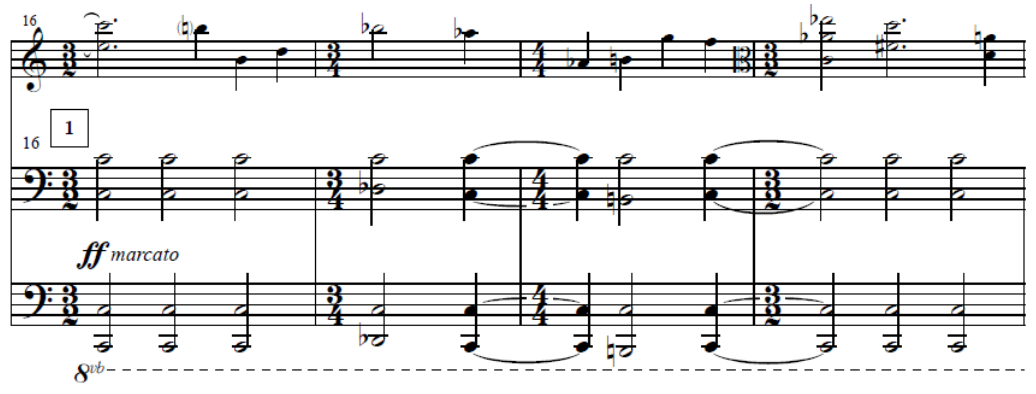

Ex. 3.16 Bars 16-19

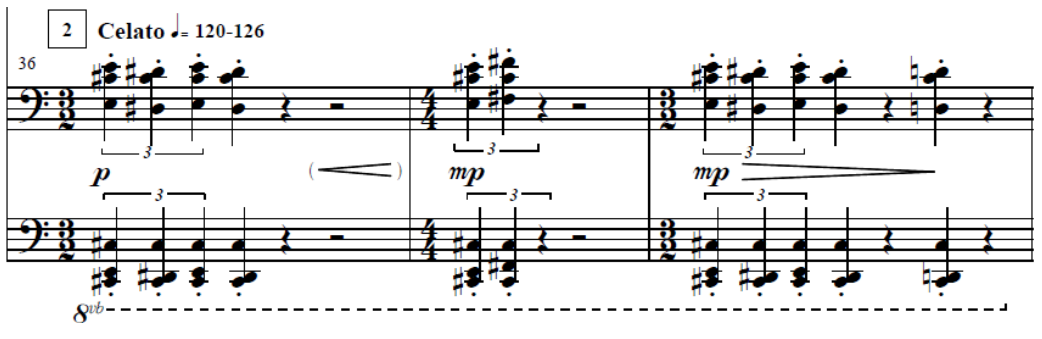

Ex. 3.17 Bars 36-38 
After the very beginning of the second movement, a process occurs, gradually introducing elements of the Sarabande theme into the material. This is vividly manifested in the middle of the development, when the texture of the solo Sarabande appears against the background of such accompaniment in bars 115-117. Most importantly, if comparing the bars 116-117 with the bars 260-261 of the Sarabande section, the musical texture is like a violin solo or a viola solo from the Baroque period.

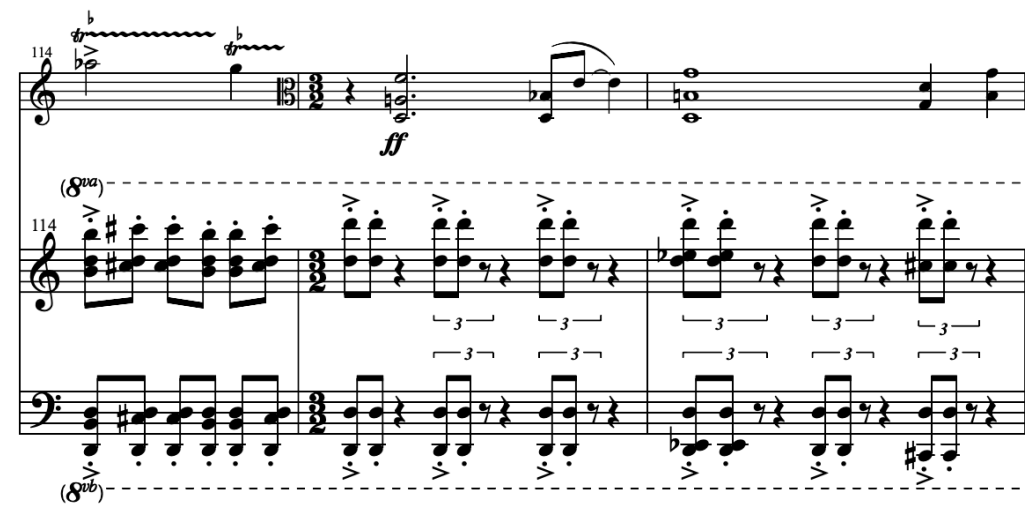

Ex. 3.18 Bars 115-116

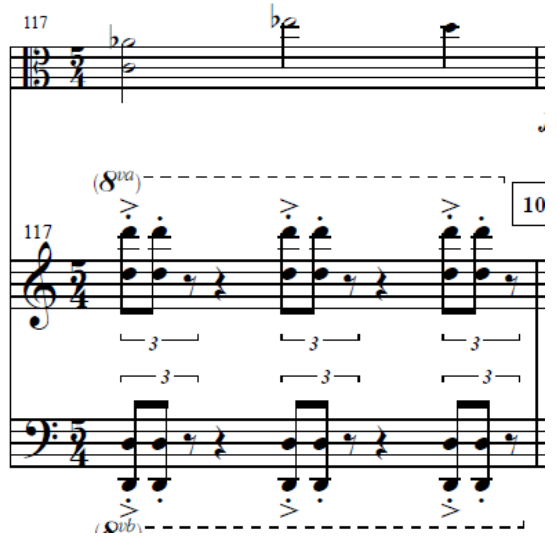

Ex. 3.19 Bar 117

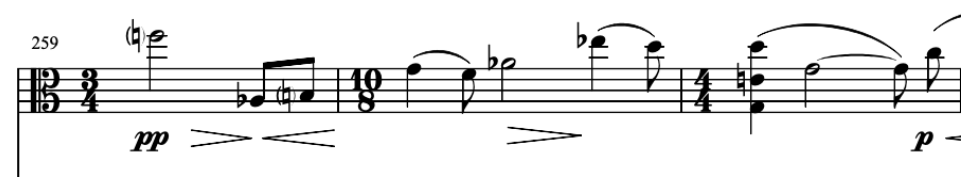

Ex. 3.20 Bars $260-261$ 
Although the second movement is quite independent in relation to the first movement, as already mentioned, a theme from the first movement appears against the background of toccata (figure 11) at bars 126 to 132 in order to connect the second movement with the first. It is very important that it appears just before the stylistic "scrapping" of the toccata occurs, when this toccata really feels like a Baroque toccata- a Baroque rhythm and character with an emphasis on the second beat and a toccata texture in the viola (figure 12). The theme from the first movement appearing before the Baroque toccata also emphasizes the importance of this "stylistic change".

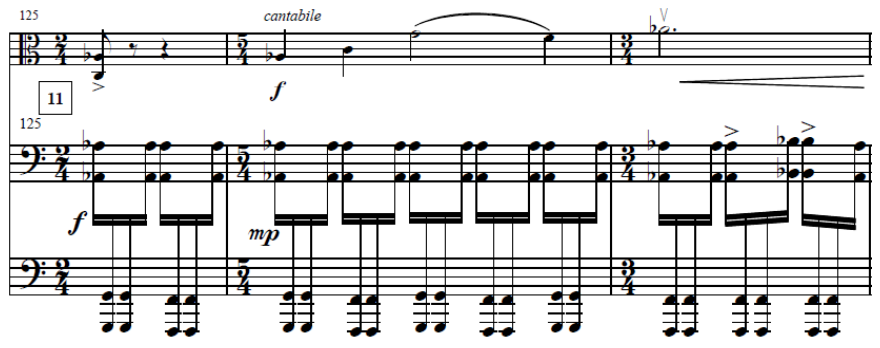

Ex. 3.21 Bars 125-127
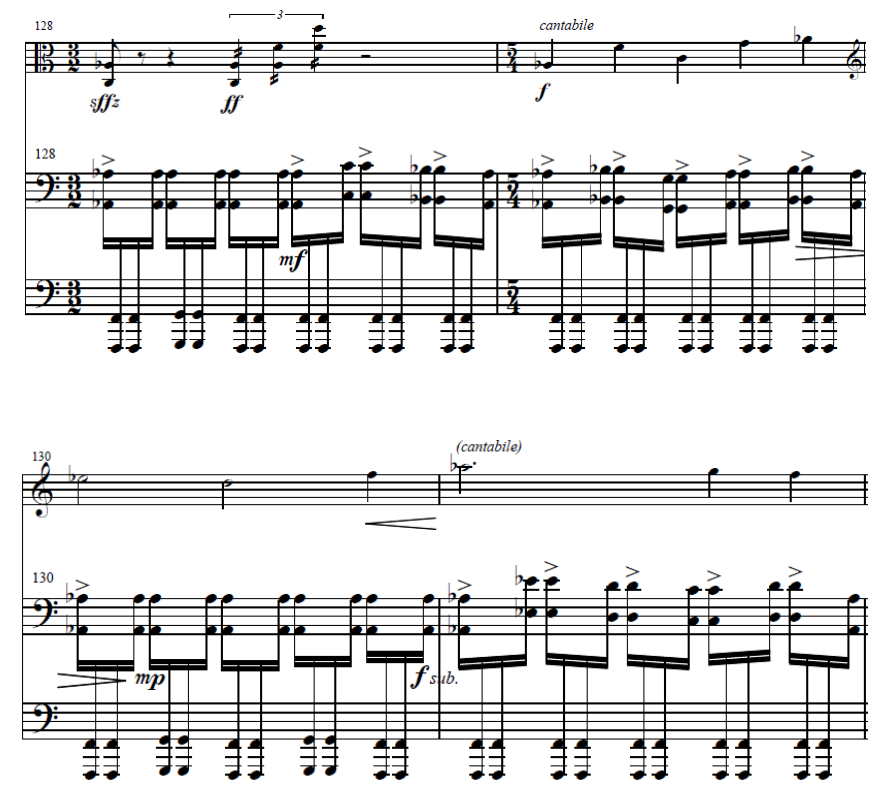


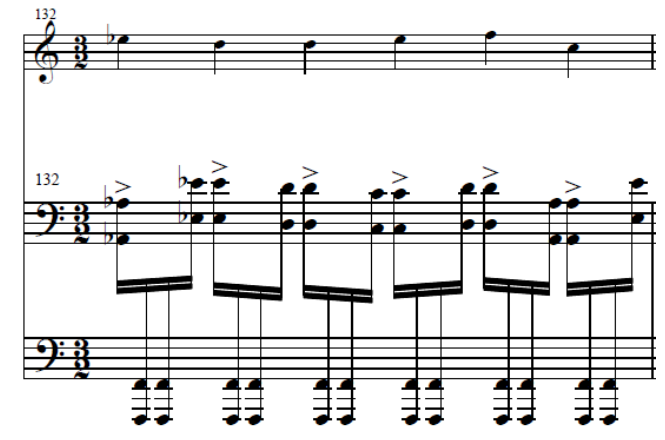

Ex. 3.22 Bars 128-132 
As the second movement is the most obvious development of the Bach theme, a concise table representation is supplied of the theme and variation structure.

Table 3.1 Second movement of Sonata for Viola and Piano by Boris Pigovat

\begin{tabular}{|c|c|c|c|}
\hline \multicolumn{4}{|c|}{ Boris Pigovat - Sonata for Viola and Piano (2012) } \\
\hline \multicolumn{4}{|c|}{ Second movement - Theme and Variations } \\
\hline Var. 1 & $1-35$ & $\begin{array}{l}\text { Piano begins with rapid } \\
\text { semiquavers Bb-A-Bb-G } \\
\text { (Ex 3.23), related to Bach } \\
\text { motive (four-semitone } \\
\text { cluster). Viola enters bar } 3 \\
\text { D-Eb-D C\# (Ex 3.24). Bars } \\
13 \text { and } 14 \text { (Ex 3.25) refer } \\
\text { to Sarabande theme of } \\
\text { bar } 252 . \text { Key is ambiguous } \\
\text { but first main theme in C } \\
\text { minor appears at bar } \\
16 \text { (Ex 3.26). Bars } 17 \text { and } \\
18 \text { (Ex 3.27) refer to } \\
\text { Sarabande theme of Bar } \\
254 .\end{array}$ & Ex. 3.25 \\
\hline Var. 2 & $36-62$ & $\begin{array}{l}\text { Piano introduces the } \\
\text { second main theme in C\# } \\
\text { minor in triplet crotchet } \\
\text { rhythm (Ex 3.28). Melodic } \\
\text { references to the Bach } \\
\text { motive. Viola plays a } \\
\text { segment of the Sarabande }\end{array}$ & Ex. 3.27 \\
\hline
\end{tabular}




\begin{tabular}{|c|c|c|c|}
\hline & & $\begin{array}{l}\text { theme in bars } 39-40 \text { (Ex } \\
3.29 \text { ) with compressed } \\
\text { intervals in a variation of } \\
\text { the Sarabande rhythm in } \\
\text { bar } 254 \text {. }\end{array}$ & 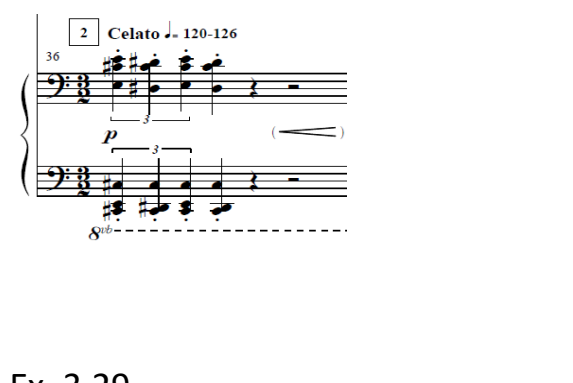 \\
\hline Var. 3 & $63-84$ & $\begin{array}{l}\text { Against an } \\
\text { accompaniment of } \\
\text { staccato quavers in Bb } \\
\text { minor, the viola plays a } \\
\text { melody with continuous } \\
\text { trills (Ex 3.30). Doubled in } \\
\text { both hands by the piano. } \\
\text { Viola plays semiquavers } \\
\text { on the opening piano } \\
\text { theme on the Bach idea, } \\
\text { piano takes over and viola } \\
\text { outlines Bach motives in } \\
\text { slower rhythm (Ex } 3.31 \text { ). }\end{array}$ & Ex. 3.30 \\
\hline Var. 4 & $85-108$ & $\begin{array}{l}\text { Viola quavers and semi- } \\
\text { quavers on the Bach idea, } \\
\text { in spiccato and detaché } \\
\text { respectively (Ex 3.32). } \\
\text { Piano returns to staccato } \\
\text { quavers in F minor in the } \\
\text { left hand and stresses } \\
\text { with sforzando on } \\
\text { significant beats in the } \\
\text { right hand (Ex 3.33). Viola }\end{array}$ & Ex. 3.34 \\
\hline
\end{tabular}




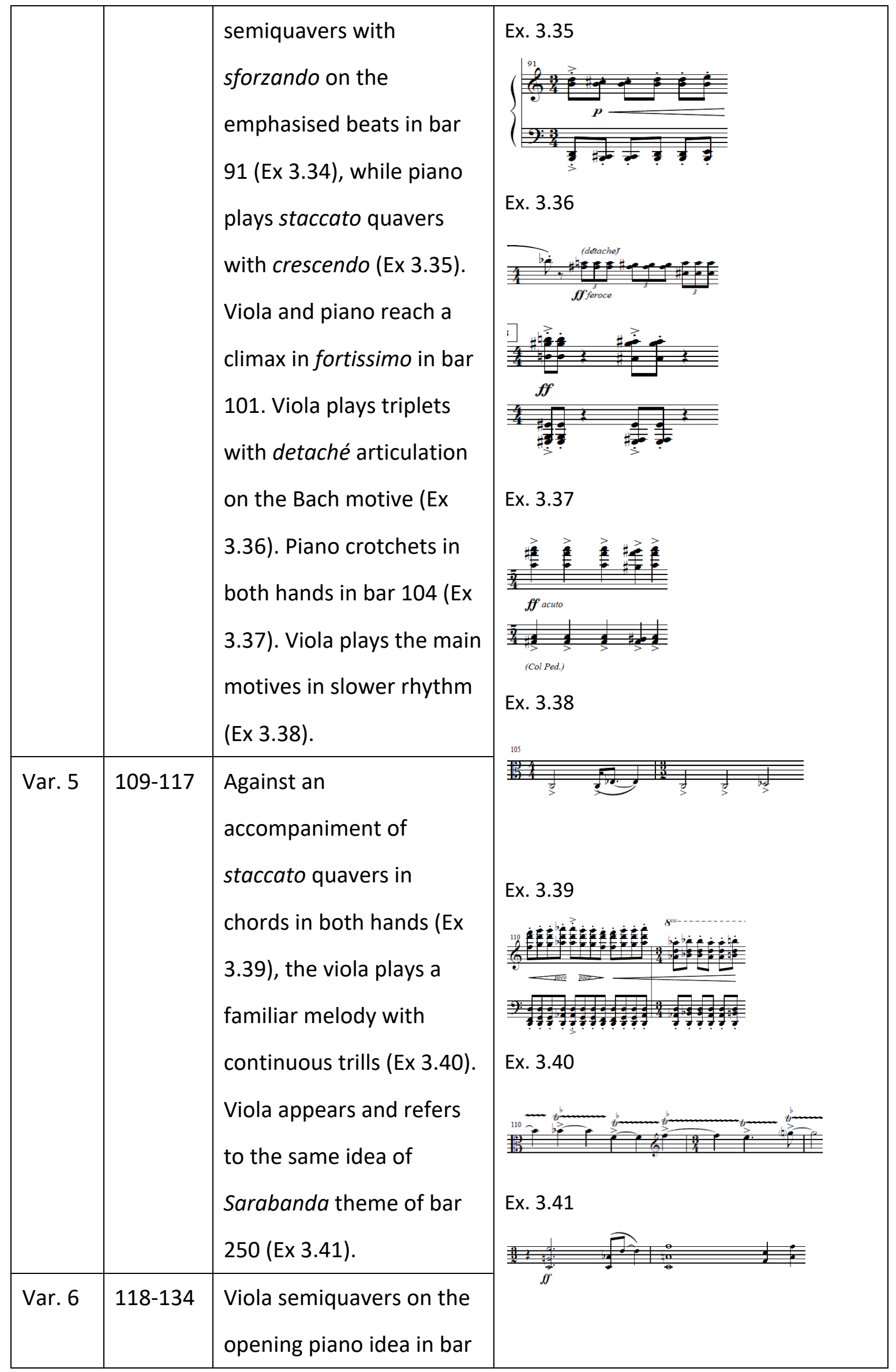




\begin{tabular}{|c|c|c|c|}
\hline & & $\begin{array}{l}\text { 118, with chordal } \\
\text { accompaniment (Ex 3.42). } \\
\text { From bar 126, viola } \\
\text { describes the opening } \\
\text { melody from the first } \\
\text { movement (first } \\
\text { movement, bar 11, Ex } \\
\text { 3.43), piano takes over } \\
\text { the semiquaver motive } \\
\text { (Ex 3.44). }\end{array}$ & $\begin{array}{l}\text { Ex. } 3.42 \\
\text { Ex. } 3.43 \\
\text { Ex. } 3.44 \\
f y\end{array}$ \\
\hline Var. 7 & $135-143$ & $\begin{array}{l}\text { Viola plays the same } \\
\text { semiquaver motive in fff } \\
\text { in bar } 135, \text { piano plays } \\
\text { chords (Ex } 3.45 \text { ). }\end{array}$ & Ex. 3.46 \\
\hline Var. 8 & $144-153$ & $\begin{array}{l}\text { Viola tremolo crotchets on } \\
\text { the opening piano idea } \\
\text { (Ex 3.46). While piano } \\
\text { plays sustained chords (Ex } \\
\text { 3.47). Both parts become } \\
\text { more intense until } \\
\text { reaching a climax in bar } \\
153 \text { (Ex 3.48). }\end{array}$ & Ex. 3.47 \\
\hline Var. 9 & $154-167$ & $\begin{array}{l}\text { Against the piano } \\
\text { background with stressed } \\
\text { quavers on the off beats } \\
\text { (Ex 3.49), the viola plays a } \\
\text { series of different } \\
\text { variations with new } \\
\text { techniques appearing, }\end{array}$ & $\begin{array}{llll} \\
\text { Ex. } 3.49 \\
\end{array}$ \\
\hline
\end{tabular}




\begin{tabular}{|c|c|c|c|}
\hline & & $\begin{array}{l}\text { such as double-stop } \\
\text { double-note triplets. (Ex } \\
\text { 3.50) Then piano reaches } \\
\text { a climax with fff in bar } 161 \\
\text { (Ex 3.51). Viola plays the } \\
\text { Bach theme (Ex 3.52). }\end{array}$ & \multirow{5}{*}{ Ex. 3.51} \\
\hline Var. 10 & $168-173$ & $\begin{array}{l}\text { Piano again stresses } \\
\text { quavers or semiquavers } \\
\text { on the off beats with } f f \text { (Ex } \\
\text { 3.53). Viola plays double } \\
\text { stops in a fast tempo, and } \\
\text { joins double-stop quavers } \\
\text { in bars } 172-173 \text { (Ex 3.54). }\end{array}$ & \\
\hline Var. 11 & $174-177$ & $\begin{array}{l}\text { Both viola and piano enter } \\
\text { a slower tempo } \\
\text { (crotchet=120) from bar } \\
174 \text { and play semi-quaver } \\
\text { on the opening piano } \\
\text { theme on the Bach idea } \\
\text { (Ex 3.55). }\end{array}$ & \\
\hline Var. 12 & $178-182$ & $\begin{array}{l}\text { Piano plays chords of } \\
\text { crotchets with estatico (Ex } \\
\text { 3.56). After viola plays a } \\
\text { chord and a scale, then } \\
\text { trills (Ex 3.57). }\end{array}$ & \\
\hline Var. 13 & 183-199 & $\begin{array}{l}\text { Piano plays the same } \\
\text { chords in first three bars } \\
\text { (Ex } 3.58 \text { ), while viola plays } \\
\text { a double-stop D and A }\end{array}$ & \\
\hline
\end{tabular}




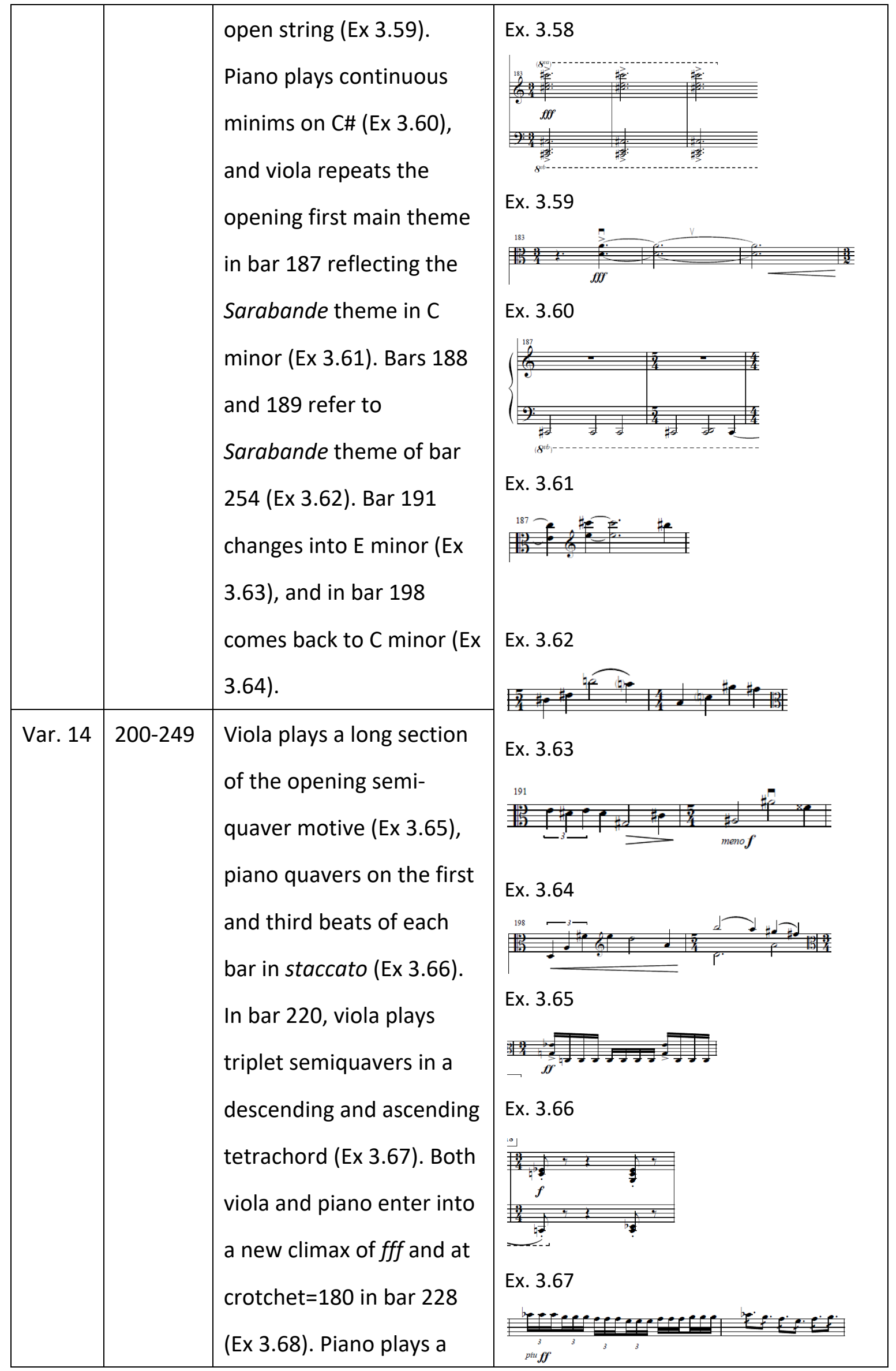




\begin{tabular}{|l|l|l|}
\hline rhythm of three quavers & $\begin{array}{l}\text { with major } 2^{\text {nd }} \text { intervals } \\
\text { (Ex 3.69), viola plays } \\
\text { double stops in a high } \\
\text { register (Ex 3.70). In bar } \\
\text { 236, viola part contains a } \\
\text { rapid scale of 19 notes in } \\
\text { one bar (Ex 3.71). After a } \\
\text { few bars of high register } \\
\text { chords, viola enters with a } \\
\text { low C, marked fff (Ex } \\
\text { 3.72). After four bars, } \\
\text { viola plays the same } \\
\text { rhythms as piano, which } \\
\text { features the beginning of } \\
\text { figure 20 (Ex 3.73). } \\
\text { Gradually, these quavers } \\
\text { reduce in dynamic until } \\
\text { arriving at the Sarabande } \\
\text { theme in bar 250. } \\
\text { See description below }\end{array}$ \\
\hline
\end{tabular}

Bach's Sarabande offers many melodic and rhythmic features that can be developed in multiple ways and the exploitation of the intervals within the range of a minor 3rd are a reference to the use of his own name $\mathrm{B}-\mathrm{A}-\mathrm{C}-\mathrm{H}$, which corresponds to the German spelling B b-A-C-B 4 . This highly chromatic feature is a main feature of the variations in Pigovat's sonata. 
The third movement of Pigovat's Sonata for viola and piano (Misterioso) is relatively short and could be regarded as a coda for the entire work. It contains new materials, along with some from the first movement.

Misterioso was composed as a series of episodes. The very beginning of the first episode (a very low piano voice imitates a distant funeral bell) recalls similar low piano voices in bars 62-63 in the first movement of the sonata.

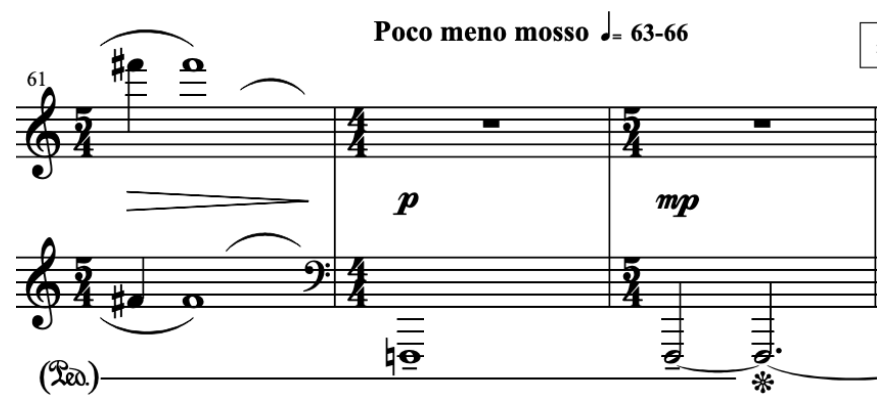

Ex. 3.74 Bars $62-63$ in the first movement

Although a new and independent theme of the first episode in the third movement sounds against the background of this "funeral bell", the relationship between this episode and the corresponding fragment in the first movement is very perceptible. Pigovat quoted the theme from the middle section of the first movement in the first episode of the third movement (compare bars 18-20 and 24-28 from the third movement with bars 64-71 from the first movement).
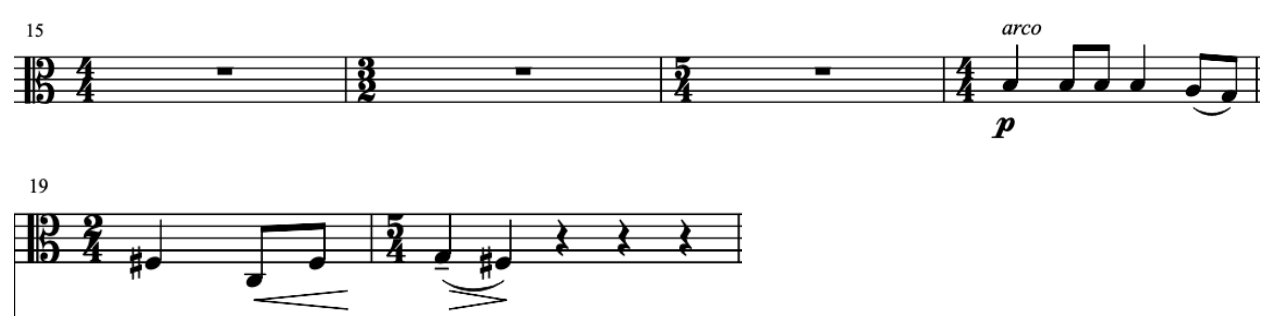

Ex. 3.75 Bars $18-20$ in the third movement 


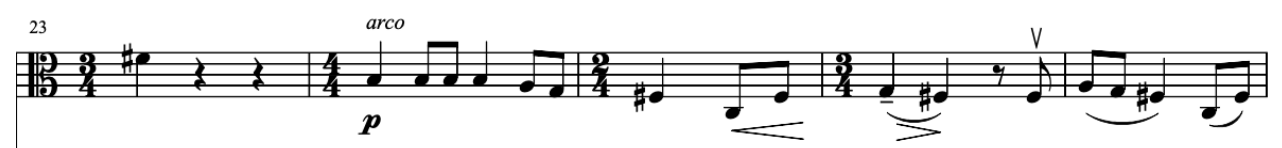

28

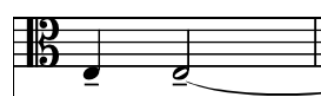

Ex. 3.76 Bars $24-28$ in the third movement

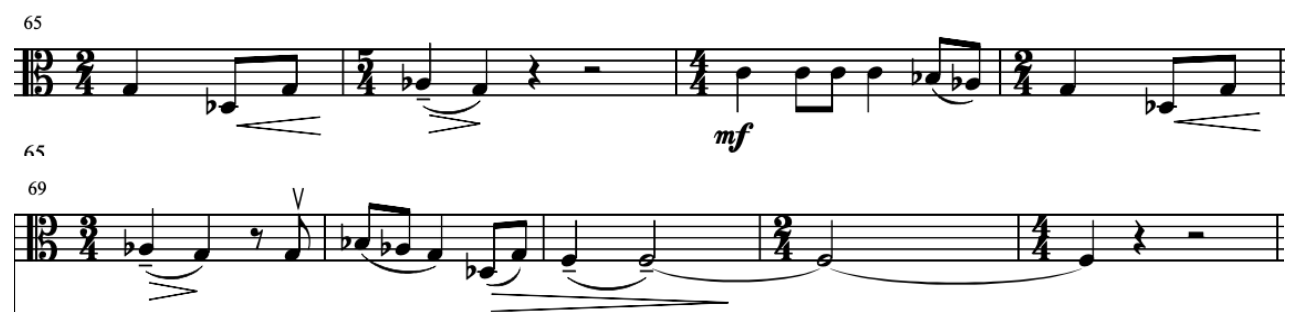

Ex. 3.77 Bars $65-73$ in the first movement

The second episode of the third movement begins from bar 30 and is based on a new theme. Materials from the first movement (from bars 18-21) are used again to end this theme (bars 45-48).

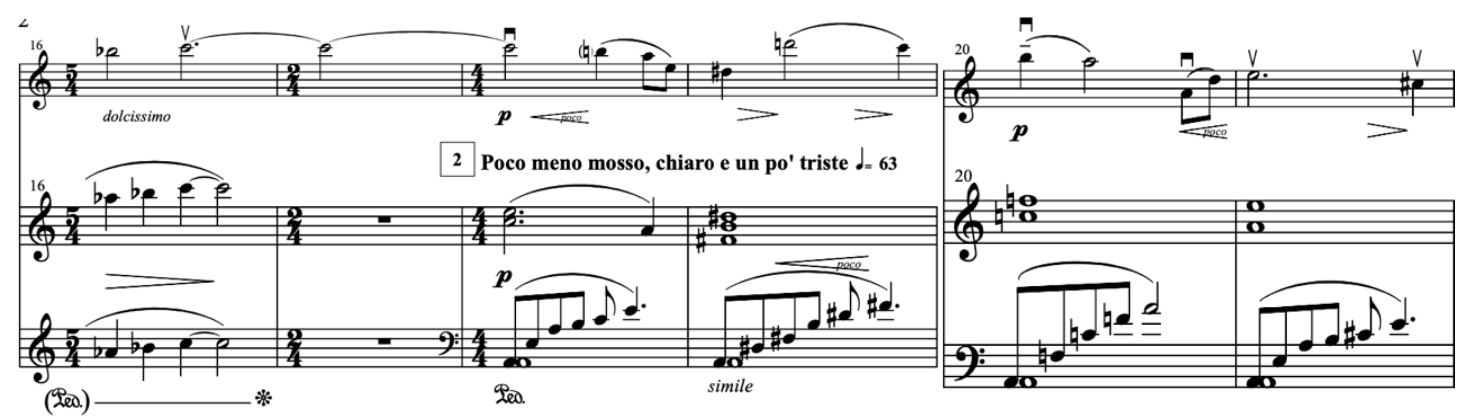

Ex. 3.78 Bars 18-21 in the first movement

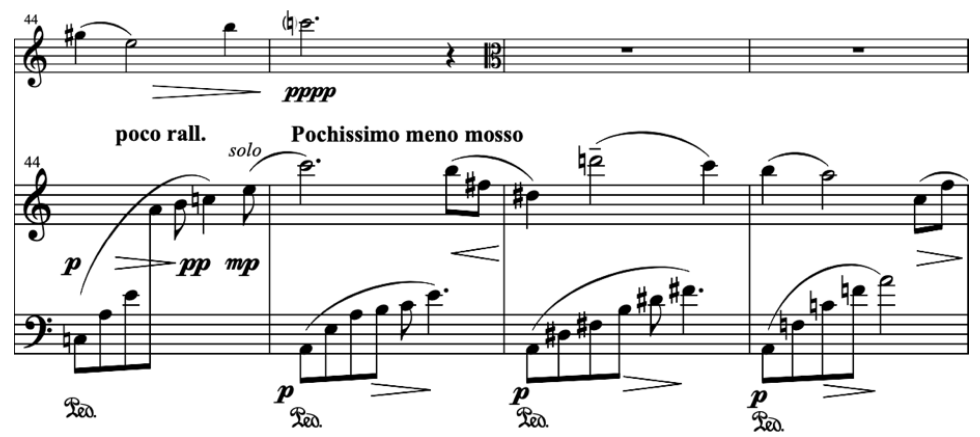

Ex. 3.79 Bars 45-47 in the third movement 
The third episode of the third movement (bars 49-63) is entirely based on materials from the first movement of the sonata. First, two themes (in bars 49-58) reflect the beginning of the first movement (see bars 1-16 of the first movement). Then (in bars 59-63) a lullaby (Ninnananna) motif appears in the high register of the viola from the middle section of the first movement (see bars 74-78).
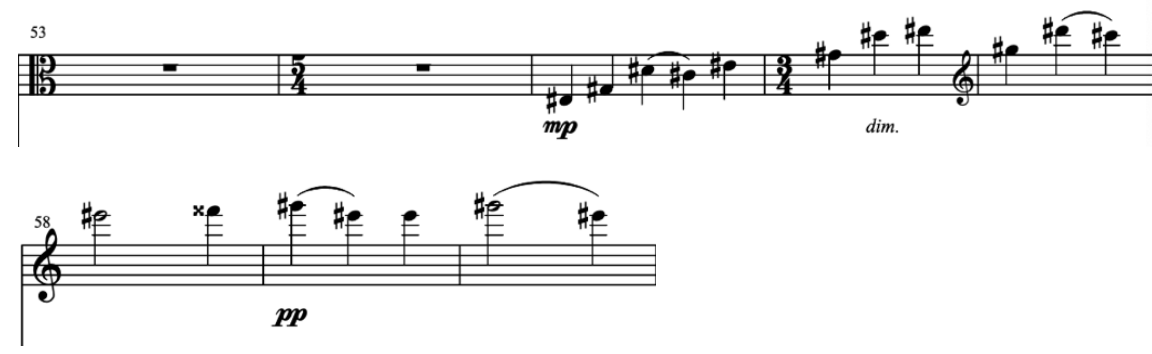

Ex. 3.80 Bars 55-58 in the third movement

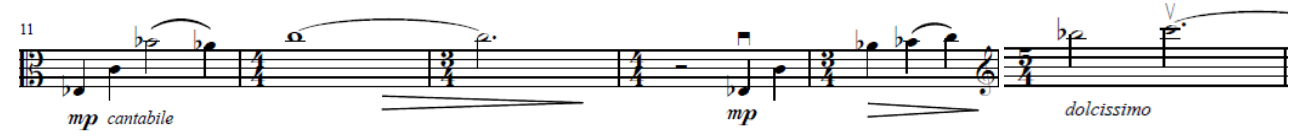

Ex. 3.81 Bars $11-16$ in the first movement

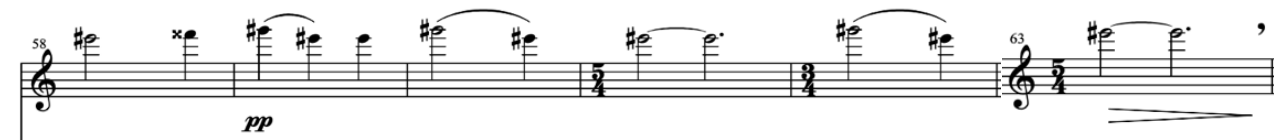

Ex. 3.82 Bars 59-63 in the third movement

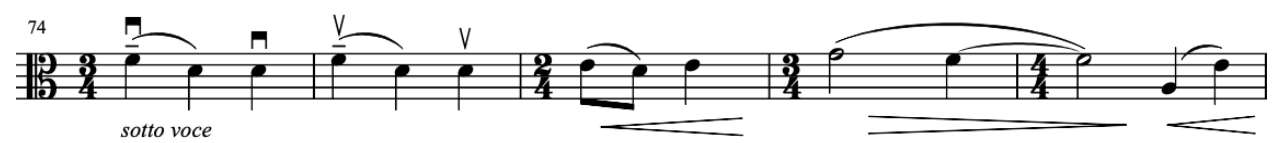

Ex. 3.83 Bars 74-78 in the first movement

The fourth episode of the third movement (bars 64-75) uses new material, which connects the style with some Russian music of the late ninteenth century. Pigovat wrote about the mood of this music: "The whole theme in figure 5 is written in character ala Anton Chekhov. It should be played with a slight sadness, very gently, 
and without any emphasis and accents" ${ }^{76}$ The main motive from the first movement emerges within this new theme (compare bars $72-74$ of the third movement and bars 11-12 of the first movement).

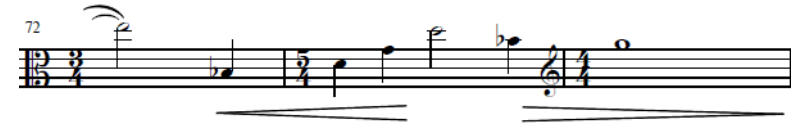

Ex. 3.84 Bars $72-74$ in the third movement

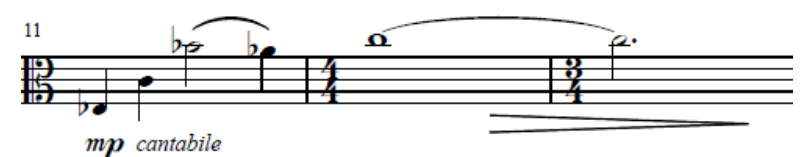

Ex. 3.85 Bars $11-13$ in the first movement

The fifth (final) episode of the third movement (bars 76-104) is similar in character to the first, and listeners hear a very low sustained voice of the "funeral bell" on the piano. This episode appears with the familiar motif, Ninnananna (in bars 90-91), from the first movement, and the main motive of the viola theme from the beginning of the first movement (in bars 95-96).

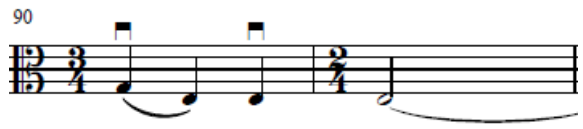

Ex. 3.86 Bars $90-91$ in the third movement

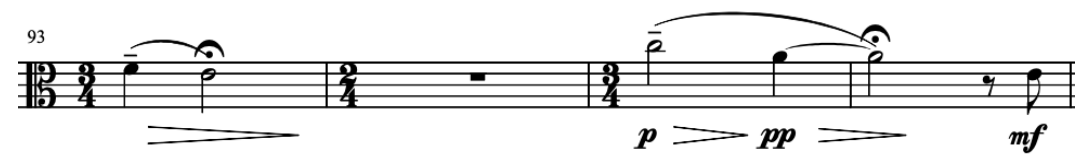

Ex. 3.87 Bars $95-96$ in the first movement

76 Boris Pigovat, letter to Donald Maurice. 
The nature of the music in the third movement embodies various shades of sadness from deep sorrow to light melancholy and light sadness.

\subsection{Pigovat's Sonata for viola and piano in the context of its predecessors before the} twentieth century

Prior to the prominence of viola soloists, Lionel Tertis (1876-1975) and William Primrose (1904-1982), the repertoire of sonatas originally written for viola is relatively small when compared to violin and cello.

In order to identify the link between prominent viola players and composers in the nineteenth century, the following summary of viola players born before 1850 is categorised by country. To demonstrate the connection between competent players and composers, this is followed by a summary of composers who wrote viola sonatas before the twentieth century. It is noteworthy that composition of viola sonatas before 1900 came mainly from Austria, Czechoslovakia, France, German, Italy and Russia.

Notable violists ${ }^{77}$ and composers of viola sonatas:

Table 3.2 Viola players born before 1850 categorised by country

\begin{tabular}{|l|l|l|}
\hline & Violists & Composers \\
\hline Austria & Joseph von Blumenthal (1782- & Joseph von Blumenthal (1782- \\
1856) & $1856)$ \\
Matthias Durst (1815-1875) & Matthias Durst (1815-1875) \\
& Franz Weiss (1778-1830) & Joseph Haydn(1732-1809) \\
& & Wolfgang Amadeus Mozart \\
& & (1756-1791) \\
& Franz Schubert (1797-1828) \\
\hline
\end{tabular}

77 Information extracted from https://en.m.wikipedia.org/wiki/List of violists (12 November 2020). 


\begin{tabular}{|c|c|c|}
\hline & & Franz Weiss (1778-1830) \\
\hline Belgium & $\begin{array}{l}\text { Louis van Waefelghem (1840- } \\
\text { 1908) }\end{array}$ & $\begin{array}{l}\text { Louis van Waefelghem (1840- } \\
\text { 1908) }\end{array}$ \\
\hline Czechoslovakia & $\begin{array}{l}\text { Heinrich Wilhelm Ernst (1814- } \\
\text { 1865) } \\
\text { František Kočvara (1730-1791) } \\
\text { Johann Král (1823-1912) }\end{array}$ & $\begin{array}{l}\text { František Benda (1709-1786) } \\
\text { Jiří Antonín Benda (1722-1795) } \\
\text { Antonín Dvořák (1841-1904) } \\
\text { Heinrich Wilhelm Ernst (1814- } \\
\text { 1865) } \\
\text { František Kočvara (1730-1791) } \\
\text { Johann Stamitz (1717-1757) } \\
\text { Johann Baptist Wanhal (1739- } \\
\text { 1813) }\end{array}$ \\
\hline Denmark & & Wilhelm Ramsøe (1837-1895) \\
\hline England & $\begin{array}{l}\text { Benjamin Blake (1751-1827) } \\
\text { William Shield (1748-1829) }\end{array}$ & William Shield (1748-1829) \\
\hline France & $\begin{array}{l}\text { Alexandre Pierre François Boëly } \\
\text { (1785-1858) } \\
\text { André Hippolyte Chélard (1789- } \\
\text { 1861) } \\
\text { Casimir Ney (1801-1877) } \\
\text { Chrétien Urhan (1790-1845) }\end{array}$ & $\begin{array}{l}\text { Alexandre Pierre François Boëly } \\
\text { (1785-1858) } \\
\text { André Hippolyte Chélard (1789- } \\
\text { 1861) } \\
\text { Édouard Lalo (1823-1892) } \\
\text { Casimir Ney (1801-1877) } \\
\text { Chrétien Urhan (1790-1845) }\end{array}$ \\
\hline Germany & $\begin{array}{l}\text { Johann Andreas Amon (1763- } \\
\text { 1825) } \\
\text { Johann Aegidius Bach (1645- } \\
\text { 1716) } \\
\text { Karl Traugott Queisser (1800- } \\
\text { 1846) } \\
\text { Hermann Ritter (1849-1926) }\end{array}$ & $\begin{array}{l}\text { Johann Andreas Amon (1763- } \\
\text { 1825) } \\
\text { Johann Sebastian Bach (1685- } \\
\text { 1750) } \\
\text { Ludwig van Beethoven (1770- } \\
\text { 1827) } \\
\text { Johannes Brahms (1883-1897) }\end{array}$ \\
\hline
\end{tabular}




\begin{tabular}{|c|c|c|}
\hline & $\begin{array}{l}\text { Joseph Schubert (1754-1837) } \\
\text { Hans Sitt (1850-1922) } \\
\text { Johann Georg Hermann Voigt } \\
\text { (1769-1811) } \\
\text { Emanuel Wirth (1842-1923) }\end{array}$ & $\begin{array}{l}\text { Federigo Fiorillo (1753-c.1823) } \\
\text { Felix Mendelssohn (1809-1847) } \\
\text { Hermann Ritter (1849-1926) } \\
\text { Joseph Schubert (1754-1837) } \\
\text { Hans Sitt (1850-1922) } \\
\text { Anton Stamitz (1750-c.1800) } \\
\text { Carl Stamitz (1745-1801) } \\
\text { Johann Georg Hermann Voigt } \\
\text { (1769-1811) }\end{array}$ \\
\hline Hungary & Sigismund Bachrich (1841-1913) & Sigismund Bachrich (1841-1913) \\
\hline Ireland & Thomas Ryan (1827-1903) & \\
\hline Italy & $\begin{array}{l}\text { Eugenio Cavallini (1806-1881) } \\
\text { Niccolò Paganini (1782-1840) } \\
\text { Alessandro Rolla (1757-1841) } \\
\text { Antonio Rolla (1798-1837) } \\
\text { Giuseppe Torelli (1658-1709) }\end{array}$ & $\begin{array}{l}\text { Bartolomeo Campagnoli (1751- } \\
\text { 1827) } \\
\text { Eugenio Cavallini (1806-1881) } \\
\text { Niccolò Paganini (1782-1840) } \\
\text { Alessandro Rolla (1757-1841) } \\
\text { Antonio Rolla (1798-1837) } \\
\text { Giuseppe Torelli (1658-1709) }\end{array}$ \\
\hline Poland & & Henryk Wieniawski (1835-1880) \\
\hline Russia & $\begin{array}{l}\text { Mitrofan Belyayev (1836-1904) } \\
\text { Vasily Bessel (1843-1907) } \\
\text { Hieronymus Weickmann (1825- } \\
\text { 1895) }\end{array}$ & $\begin{array}{l}\text { Mikhail Ivanovich Glinka (1804- } \\
\text { 1857) } \\
\text { Ivan Yevstafyevich Khandoshkin } \\
(1747-1804) \\
\text { Hieronymus Weickmann (1825- } \\
1895)\end{array}$ \\
\hline USA & & Fidelis Zitterbart (1845-1915) \\
\hline
\end{tabular}

Of course, after the arrival on the scene of Tertis and Primrose, there was an explosion of new viola sonatas by composers in the English-speaking world, 
contributing to the parallel dramatic increase across Europe. While Pigovat's Sonata for viola and piano (2013) fits squarely into the twenty-first century, it sits stylistically very comfortably among the well-known late nineteenth- and twentiethcentury works for viola and piano such as Bax, Bloch, Clarke, Goedicke, Hill, Hindemith, Rachmaninoff, Shostakovich and York Bowen. 


\section{Part Four - Holocaust Requiem}

The film Lacrimosa Dies IIla is the central component of this PhD thesis. I am the viola soloist, assistant producer, translator and creator of subtitles. The film, focused on Holocaust Requiem and the story of Babi Yar, is an integral and essential part of the thesis and the written component that follows avoids duplication of my interviews with the composer as much as possible. The full score of the Holocaust Requiem is available in Appendix Four. The full transcript of my interview with the composer about Holocaust Requiem is available in Appendix Five.

\subsection{Genesis}

Ukrainian-born composer Boris Pigovat emigrated to Israel in 1990 and there his composition career began to blossom. In 1995 he composed Holocaust Requiem, which resulted in him being awarded the ACUM Prize (Israeli ASCAP), ${ }^{78}$ and in 2000 he was awarded the prize of the Prime Minister of the State of Israel. In 2002, he received his PhD degree from Bar-Ilan University of Israel.

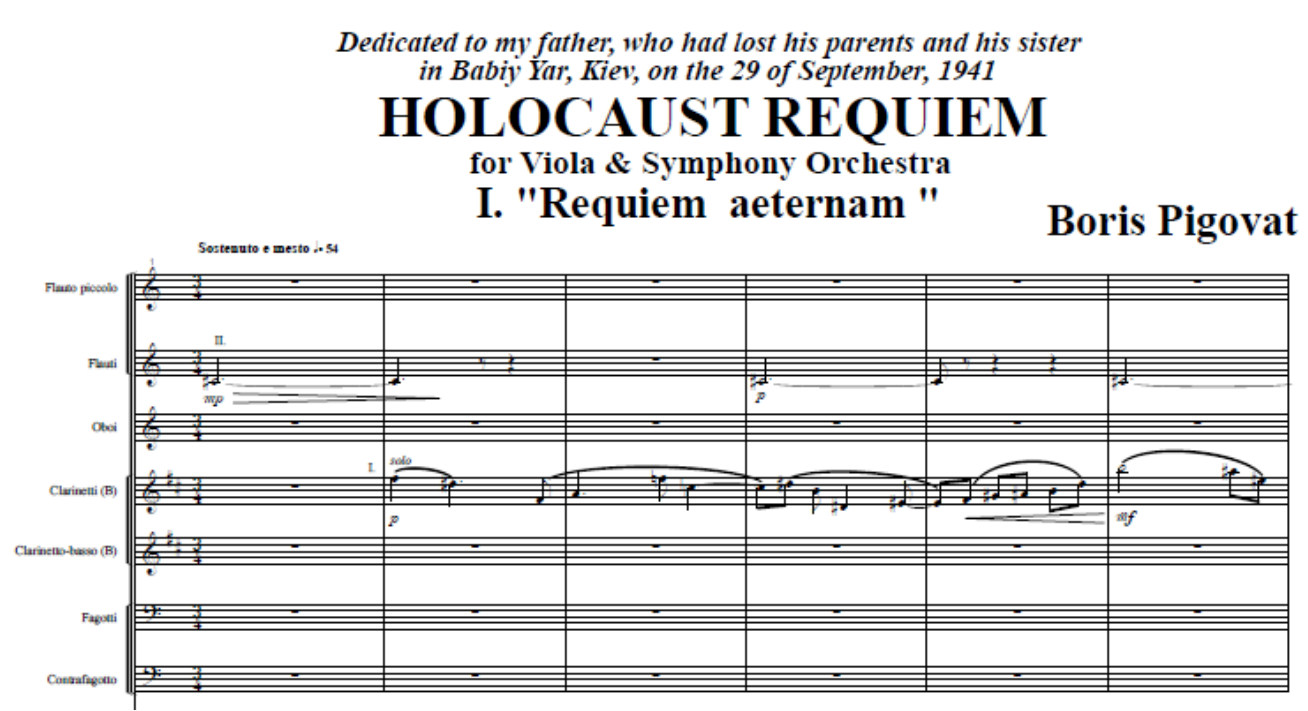

Photo 4.1 Score of Holocaust Requiem

78 ACUM -Society of Authors, Composers and Music Publishers in Israel. ASCAP -The American Society of Composers, Authors and Publishers. 
The first time Boris Pigovat went to Babi Yar was at the age of nine. He and his father visited the grave of his grandfather, grandmother and aunt, who died in the Babi Yar massacre in 1941. However, he was too young then to be fully aware of the significance of the Holocaust. When Pigovat was fifteen years old, he read a book in a public library about the Documents of the Nuremberg Trials, which was translated from German. He was shocked by some terrible photos depicting crimes of the Holocaust. Pigovat was by then truly aware of the gravity of the Holocaust and realised that he wanted one day to write something about the genocide.

Pigovat over time worked through creative stages as part of his preparation to compose this work. The works produced during this process were more connected with the general tragedy of World War Two rather than being specific to Babi Yar. He wrote the choral work "Khatyn" when he was a student of the Gnessin Institute. It is about the Belarusian village, which was completely destroyed by the Nazis. Pigovat submitted this work to the Soviet All-Union competition in 1975 and it won the first prize.

Pigovat's "Symphony No 1" titled "Memorial" is another example of the preparatory stage of the Holocaust Requiem, and was written in memory of victims who died in World War Two. However, this work is not specifically about the Holocaust, since such a music theme might not have been approved for a performance in the Soviet Union at that time. Besides, Pigovat considered that he was not yet ready to develop the theme of the Holocaust as a Requiem, although he had already learned more about it. He sensed that he could not yet write something worthy of this huge tragic event. At the same time, Pigovat set out to increase the intensity of the sensation concerning the Holocaust. Finally, after three years since arriving in Israel, suddenly, he felt that he was ready to take on this challenge.

Yuri Gandelsman, the principal violist of the Israel Philharmonic Orchestra, had studied in the Gnessin Institute a few years earlier than Boris Pigovat. He had asked 
Pigovat to write something for him, but with no special requirements. ${ }^{79}$ Pigovat realised that this was the missing piece that allowed him to see a complete picture of the Holocaust Requiem. He changed his initial idea of having a soloist, chorus, speaker and orchestra in his Holocaust Requiem into composing this work without texts, but as if with texts.

Boris Pigovat realised that using the viola as the primary element to express the Holocaust Requiem could have a special role in describing the war and the Holocaust. Pigovat believes that the viola has a very deep and warm sound, and it is very intimate, like a human voice. What he truly wanted to present in the Holocaust Requiem was expressiveness rather than sparkle, and the timbre of the viola would be very intimate. Pigovat considers that the viola is very close to the soul and close to the heart.

So, it seems that Pigovat used the viola in this work as a result of a long journey. His original creative intention was a choral work, but instead it became "a tragic orchestral work in the form of a concert-symphony for viola and orchestra". ${ }^{80} \mathrm{He}$ had already begun to build the textual basis for the Holocaust Requiem, but at some point, he realised that the Holocaust subject with the text as the main medium might be superficial and would interfere with his creation.

Pigovat was born twelve years after the atrocities at Babi Yar had happened, and it seemed more and more distant from the larger European picture of the Holocaust. Pigovat could not find a proper text to express the horrors he wanted to portray in his work, as no words could depict those horrible things that had occurred. He thought that texts would be a distraction from the music that he wanted to create, and the audience might pay more attention to the words than the music. It was more important for him to give the listener a pure musical message conveying

\footnotetext{
79 Yuri Gandelsman did not ever perform Holocaust Requiem as by the time it was completed he had emigrated to the USA.

80 Roger Wilson, 'Rest eternal', New Zealand Listener (Online) 216/3576(2008), 47.
} 
emotion, rather than through texts. In Pigovat's view, with textual information dominating the emotional information of music, "the deeper layers in the listener's heart would not have been stimulated. I wanted this work to have a more direct emotional impact on the audience". At the same time, he did not want to give up the style of a Requiem to write a symphony. Pigovat had to find another solution, so he began to think about the orchestral Requiem.

Pigovat used the solo viola to express grief, and wrote separate musical phrases in which the rhythm and melody of Latin words from the Requiem text, such as the Dies Irae, can be clearly heard in various instrumental solos. It became "a work of great intensity and vividly straightforward in its graphic depiction of ghastly events: gunshots, breaking glass, the tumbling of bodies into the Babi Yar ravine, falling tears." ${ }^{81}$ Therefore, the viola can play any kind of music in this work, and actually replaces everything related to the human voice.

\subsection{Composition}

The words Requiem Aeternam, Dies Irae, Lacrimosa and Lux Eterna may be perceived as an awestruck or a mystical feeling by audience and performers. Pigovat hopes that listeners consider this work not only for its religious contents, but as a general expression of different emotions, such as sorrow, horror, fear, anger, grief, despair and hope.

Pigovat did not directly quote traditional Jewish folk music in the Holocaust Requiem, though he did insert the theme from the traditional melody, Shema Israel, and the ancient Dies Irae motif throughout the work.

81 Roger Wilson,'Rest eternal', New Zealand Listener (Online) 216/3576(2008), 47. 


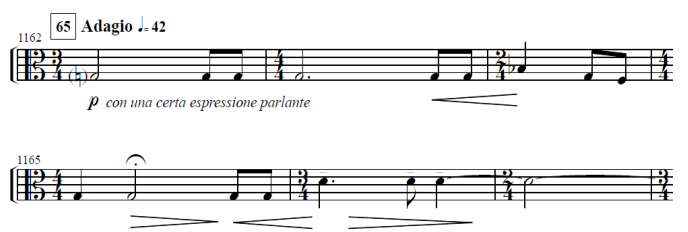

Shema Israel
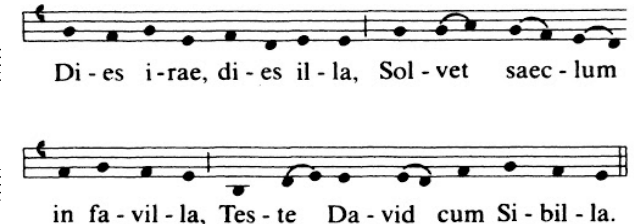

Holocaust Requiem is imbued with different melodic elements of Jewish music in different layers of texture, which create a wide range of atmospheres, in particular using motive formulas typical of the old Hassidic melodies. Pigovat composed Holocaust Requiem with deep and personal resonance, and the fundamental purpose of this composition is to awaken the soul of the listener.

Boris Pigovat wanted to evoke an emotional response from the listener such that they feel the suffering and pain of the war and a sense of hope in the aftermath from his music. For example, the beautiful final movement, Lux Eterna- the eternal light leads from suffering to purification, which the ancient Greeks called the catharsis. Pigovat is deeply convinced that a vivid and expressive melody, based on tonal harmony, has not lost its value. For him any technique is only a means, not a goal. He can use various modern compositional techniques to achieve the desired result without any problem. Pigovat stated: "Maybe to some degree my style seems oldfashioned, but I am long resigned to it. This is my way and I sincerely follow it." 82 Pigovat hopes that Holocaust Requiem not only affects listeners emotionally, but also performers. Donald Maurice said that when he performed this piece, he had to persuade himself "do not cry!" 83 Pigovat believes and hopes that if the performer feels this way, it is more likely the listener will also feel it. His goal of creation is to

82 Jerry Dubins, 'On a Requiem of Remembrance - A Conversation with Composer Boris Pigovat', Fanfare 35/3 (Jan/Feb 2012), 182.

83 Boris Pigovat - Interview with Xi Liu on 13 September 2019. 
create a sense of empathy so that anyone who listens to this work has a similar feeling as he had when composing it.

I was born after the Holocaust. I have not witnessed these atrocities, but I believe that there is a genetic memory of the people, because I feel this pain even now. I knew that I had to write this part of the Requiem, to depict by means of music this ruthless conveyor of death, to try to express the feelings of horror, helplessness, pain, and despair experienced by those who lived and died in this terrible time. If the listener feels the pain and shudders, I would consider my task accomplished. After completing the Dies irae I realized that I could not write the traditional Lacrimosa; there is no space for a quiet sadness and resignation; no tears remained. What did remain? The shout, the strong anger, the pain of an open wound, the powerless groan and oblivion in the quiet insanity, and only then appear tears. ${ }^{84}$

Boris Pigovat's Holocaust Requiem was dedicated to his father and was written in honour of his grandparents and aunt, who were among the 33,871 victims slaughtered at Babi Yar near Kiev on September 29 and 30 in 1941, the largest single massacre of Jews in the Holocaust. However, in Pigovat's cognition, he did not write it only to remember his family, or the victims of Babi Yar, but more generally about the Holocaust and all the victims of World War Two. Awareness of the Holocaust was particularly acute for Boris Pigovat, because of the losses in his family. It took him two years to complete the composition of Holocaust Requiem. The day after Pigovat finished writing Holocaust Requiem, his father died, and he felt that it was as if he had been waiting for him to finish it.

Holocaust Requiem consists of four movements, which express Pigovat's deep emotional response to the Holocaust: Requiem Aeternam (deep sorrow), Dies Irae (horror, fear and suffering), Lacrimosa (grief) and Lux Eterna (hope). The occurrence and the impact of this tragic event occupy the whole work, but especially Dies Irae

\footnotetext{
84 Jerry Dubins, 'On a Requiem of Remembrance - A Conversation with Composer Boris Pigovat', Fanfare 35/3 (Jan/Feb 2012), 181.
} 
and Lacrimosa as they directly portray the events of the Holocaust, whereas the Requiem Aeternam and Lux Externa take a kind of before and after role. Pigovat quoted a sentence from the Lamentations of Jeremiah to depict the Dies Irae: "Outside, the sword killed my children; inside, it was famine". 85

The Requiem Aeternam reveals a world of fear and terror with the effect of the full orchestra.

The clarinet slowly yields to the viola, also plaintive and dark in color, but with a stronger and growing sense of urgency. The trap has been set: the auditorium assumes the figurative aura of a packed boxcar enroute to Babi Yar with the door slammed and locked-there is no escape. Pigovat runs a stylistic gamut from tonal to expressionistic with hints of Berg and Shostakovich as he gradually unfolds his nightmare. Though instrumental throughout, there are times one can hear "Re-qui-em" among the many busy layers of musical texture. ${ }^{86}$

Pigovat considers that it is important to put various musical motifs with related elements to support a more complete work. In Requiem Aeternam, three motifs are developed in a variety of fragments of themes. These themes are described by Pigovat as "a", "b" and "c" in the film Lacrimosa Dies Illa. The elements frequently occur in the introduction, the exposition, the development and the reprise of the main theme in the first movement.

The Dies Irae is telling the story of the Holocaust- the day turning the world to ashes. The composer described this movement in detail in the film. This following extract is from a review by Bruce Reader:

Soon the orchestra hammers out the theme before leading on with a tormented, anguished viola part. The orchestra heads insistently forward occasionally falling back

\footnotetext{
85 From Prophets, in the Old Testament of the Bible.

86 Dwight Pounds, 'Boris Pigovat: Requiem "The Holocaust" for Solo Viola and Orchestra [Recording Review]', Atoll ACD27/1 (2011), 68.
} 
only to rise ever more violently forward. This is music of some violence and impact. The piano joins with percussion to lead the music ahead with an almost manic stance. There are discordant phrases as the music reaches a pitch. Timpani sound out over the orchestra as the pitch is held by high strings and brass. Low strings then chunter forward until falling into silence, leaving just a piccolo with a lovely little motif to quietly end with hushed rustling strings. ${ }^{87}$

The Lacrimosa is full of grief, anger, madness and tears, making it quite different from the normal Requiem Lacrimosa, which would normally focus on the tears and sorrow. The opening viola's high register portrays great agony as if a person is screaming. Pounds stated:

The natural flow of tears comes only with a two-minute traditional Lacrimosa that closes the section. The strings enter with a most affecting melody, slow, quiet and reserved and gently holding a melancholy reserve. ${ }^{88}$

The theme Shema Israel in the horn solo leads directly into the final movement with a warmer atmosphere created when the orchestra joins. Lux Eterna is based on Pigovat's Prayer for viola and piano with many beautiful passages. It is seen as the only positive and uplifting movement of the whole Holocaust Requiem, while at the same time paying tribute the victims. Denton commented: "Mourning dominates the final Lux aeterna, with thoughts of 'Grant them eternal rest, O Lord' as the viola takes up the story in a final mood of sorrow." 89

As the following extract is from a review by Dwight Pounds:

\footnotetext{
87 Bruce Reader, Naxos CD Review. http://theclassicalreviewer.blogspot.com/2015/07/borispigovats-holocaust-requiem-proves.html (21 November 2020).

88 Dwight Pounds, 'Boris Pigovat: Requiem "The Holocaust" for Solo Viola and Orchestra [Recording Review]', Atoll ACD27/1 (2011), 68.

89 David Denton, David's Review Corner, June 2015.
} https://www.naxos.com/reviews/reviewslist.asp?catalogueid=8.572729\&languageid=EN (5 November 2020) 
Pigovat marks the end of the horror with haunting and uplifting melodies and harmonies - tonal and poignant, with lingering layers of transcendental glory and agony. The Requiem concludes as the solo viola intones one final reference to the Shema Yisrael. ${ }^{90}$

In Pigovat's final words in the film, he states:

It is like an appeal to God so that the souls of the dead go to a bright paradise. That is, a request from the souls of the dead had been given the "eternal light". The nature of the music should be connected with the souls of the dead. The music character in this movement should be clean, calm, and beautiful. ${ }^{91}$

\subsection{Performance History}

The world premiere of Holocaust Requiem for Viola and Symphony Orchestra took place in Kyiv, Ukraine in October 2001, at the 60th anniversary memorial evening dedicated to the Babi Yar tragedy, where Pigovat's grandparents and aunt were killed. It featured the National Symphony Orchestra of Ukraine with Cologne-born Rainer Moog (viola), directed by Roman Kofman (Professor of Conducting at the Tchaikovsky National Academy of Music, Kyiv).

90 Dwight Pounds, 'Boris Pigovat: Requiem “The Holocaust” for Solo Viola and Orchestra [Recording Review]', Atoll ACD27/1 (2011), 68.

${ }^{91}$ See Appendix Five - Full transcript of the interview with Boris Pigovat about Holocaust Requiem. 


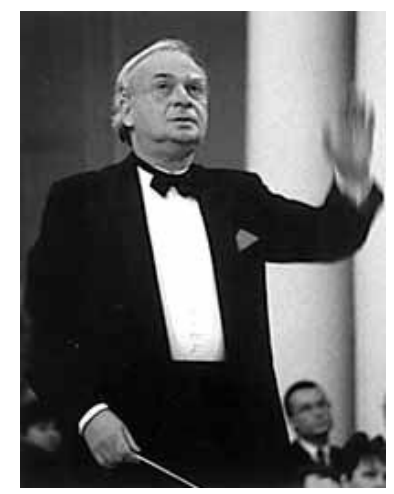

Photo 4.2 Roman Kofman

It had special meaning for Pigovat to have the premiere of his Holocaust Requiem in the place where he was born and where the atrocities had happened, commemorating the history and building a cultural bridge between countries through the music with a German soloist and a Ukrainian conductor.

On 9 November 2008, Holocaust Requiem was performed for the second time, in Wellington, New Zealand, at the Concert of Remembrance on the 70th Anniversary of Kristallnacht. It featured the Vector Wellington Orchestra with violist Donald Maurice (Professor of Music at the New Zealand School of Music), conducted by Marc Taddei (musical director of Orchestra Wellington, formerly the Vector Wellington Orchestra). A detailed biography of Donald Maurice can be accessed at his website. ${ }^{92}$

\footnotetext{
${ }^{92}$ https://www.donaldmaurice.org/bio (27 November 2020).
} 


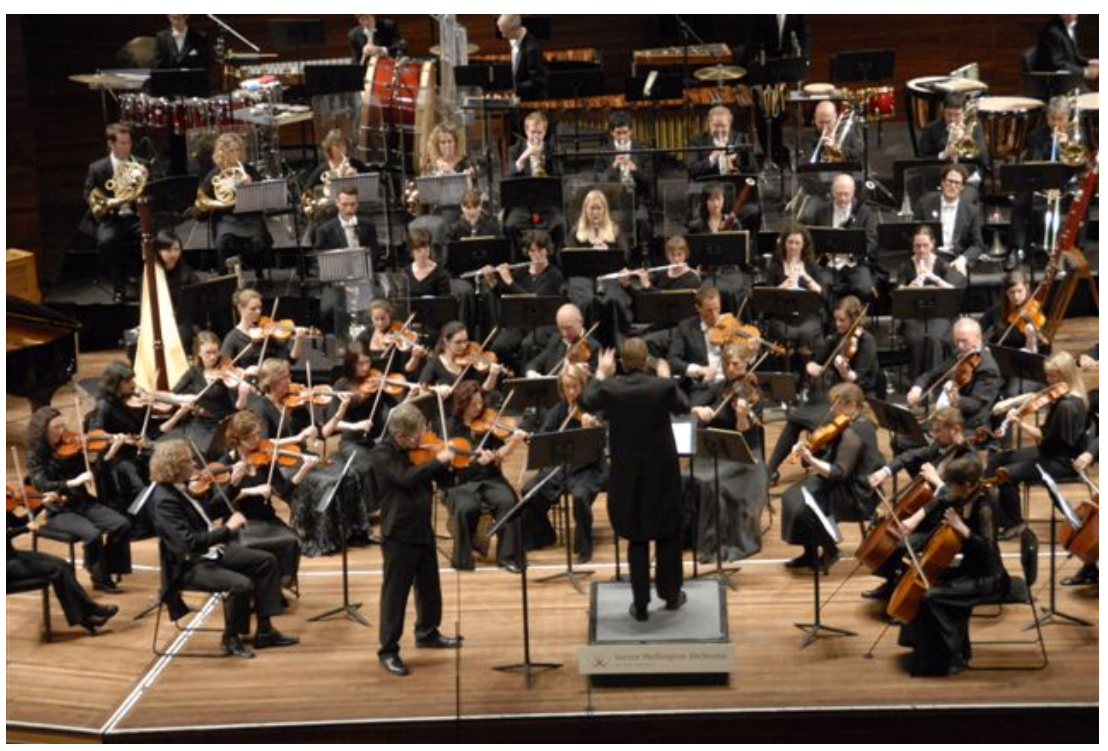

Photo 4.3 Donald Maurice with Vector Wellington Orchestra

The dates 9 and 10 November 1938 have been identified as Kristallnacht- the "Night of the Broken Glass"-when Nazi supporters attacked Jewish people in Germany and Austria and torched their assets and synagogues. The Concert of Remembrance was reported as an unforgettable evening, as can be noted from the numerous reviews included in Part Five- Reception

In November 2010, a live recording by Radio New Zealand of the Holocaust Requiem from the Concert of Remembrance was released by Atoll Records. Pigovat and his works were not widely known internationally at that time, though he had been awarded awards and prizes, including the 1988 International Composers Competition in Budapest, and both the Requiem CD and the Song of the Sea were awarded the ACUM Prize. The awarders of these prizes had to call the Israel Composers Union to find out who Pigovat was. ${ }^{93}$ An extract was reviewed by Mechen what the concert was happening on this work:

Donald Maurice's solo playing vividly captures the music's gamut of supplicatory emotion, while Marc Taddei and the orchestra provide an accompaniment richly-mixed

93 David DeBoor Canfield, 'PERSISTENCE: University of St. Thomas Commission Series, Vols. IV-VI', Fanfare 39/5 (May/Jun, 2016). 
with ambiences of faith and trust, doubt and fear. From Ligeti-like string-clusters come sudden intrusions of light and energy, menacing, gutteral-throated strings and ghoulish figures on what sounds like a bass clarinet. Deep, seismic percussion ignites an outburst that galvanizes the whole orchestra, and brings the solo viola into conflict with forces of darkness. ${ }^{94}$

In 2011, Donald Maurice performed Holocaust Requiem two more times, marking the 70th anniversary of the Babi Yar massacre, firstly in the Wellington Town Hall on 29 September and secondly on 15 October at the concert hall of the Musikhochschule Würzburg, at the 39th International Viola Congress in Würzburg, Germany.

The Wellington performance in 2011 was presented on 29 September, the date of the Babi Yar massacre, conducted by Kenneth Young, with the New Zealand School of Music Orchestra. Donald Maurice took the solo role in this performance.

The concert featured the theme of facing conflict through music. The other three works included in this programme were Anthony Ritchie's Remember Parihaka, responding to the 1881 event between Taranaki Māori and British soldiers; Schelomo (Solomon) by Ernest Bloch for solo cello and orchestra, a work written in response to the horrors of World War One, with the cellist Inbal Megiddo, NZSM's newly appointed lecturer in cello; and John Psathas's Luminous, in memory of a friend overwhelmed by the cultural dislocation she experienced emigrating to New Zealand from China. ${ }^{95}$

Facing conflict through music not only attracted audience from the general public, but also young listeners from the University, a relatively small but strong group. The

\footnotetext{
94 Peter Mechen, 'Boris Pigovat's Requiem - A Stunning CD Presentation', Middle C (15 September 2011). https://middle-c.org/2011/09/boris-pigovats-requiem-a-stunning-cd-presentation/ (5 November 2020). ${ }^{95}$ SOUNZ In Remembrance - facing conflicts through music.https://sounz.org.nz/events/2203 (27 November 2020).
} 
theme has become a valuable part of the curriculum in higher education in music so that university students become aware of the power music can have in conveying history.

The invitation from the German Viola Society to give the German premiere of Holocaust Requiem at the final gala concert of the International Congress in Würzburg in 2011 featured the Düsseldorf-based Camerata Louis Spohr, conducted by Bernd Fugelsang. This was the inaugural concert of this orchestra, which has continued to flourish. Bernd Fugelsang, an experienced oboist and ensemble manager, had been building a network of professional colleagues from well-known orchestras in the Rhineland around him since his studies:

This created a solid core of musicians who played together for many years. In the long run, however, it was not effective to see the respective formation made up of the same orchestral musicians play under different names over and over again, depending on the organizer's "assignment" or at different church concerts. Bernd Fugelsang had been planning for a long time to turn these orchestral formations into a permanent, large formation. So to form an orchestra with the same name and sound - under the same name. ${ }^{96}$

The programme also included Louis Spohr's great grand-daughter, Estelle Spohr, who was soloist in Bruch's "Romance for viola and orchestra" and "Concerto for clarinet, viola and orchestra". The concert was recorded and broadcast on German radio. The New Zealand Ambassador to Germany, His Excellency Mr Peter Rider, attended the performance.

96 http://camerata-duesseldorf.de/der-kuenstlerische-leiter/ (27 November 2020). 


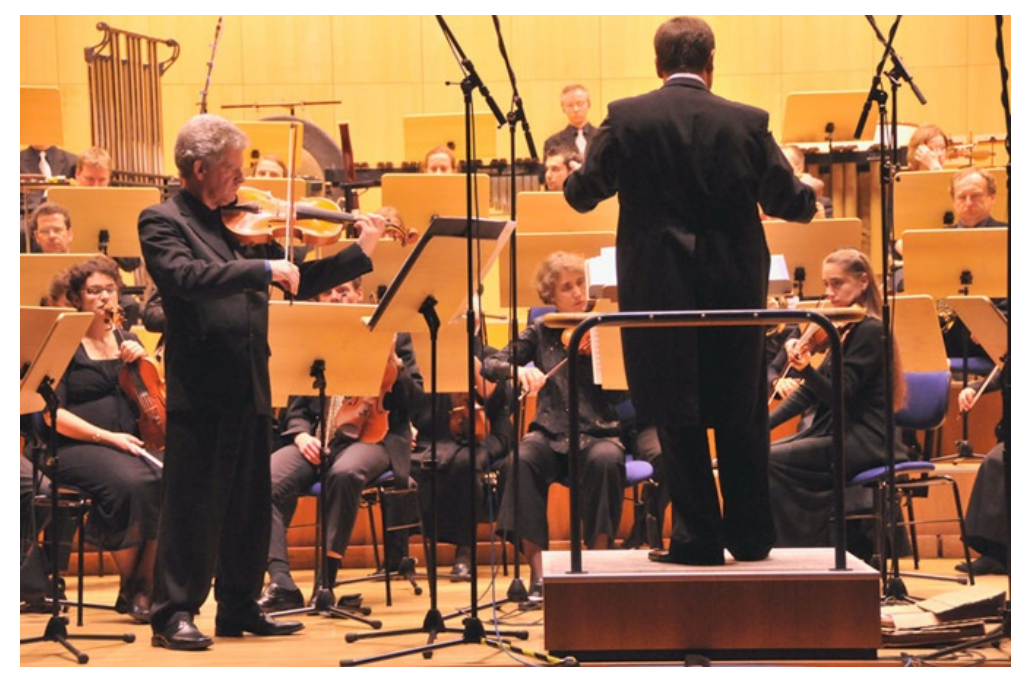

Photo 4.4 Donald Maurice with Duesseldorf-based Camerata Louis Spohr.

In 2012 the Requiem CD was awarded the Supersonic Award by the Luxembourg classical music magazine, Pizzicato. Soon after this, there was an interesting story about Boris Pigovat responding in an interview about the process of working with Donald Maurice on the Holocaust Requiem:

... began a few months before our personal meeting at the rehearsals. We had discussed the solo part through e-mail messages, and then checked our joint solutions in rehearsal without an orchestra. The main problem was in the ratio of the fast tempos and articulation. There were a few places in the score where it was simply impossible to play passages with the articulation I wrote in the tempo I wanted. And the choice depended on what was more important for the character of the music in this place of the score, the tempo or performing techniques. In most cases, I changed the tempo designations, but sometimes the rate remained unchanged, and I changed the method of playing. These problems arose even at the rehearsals before the premiere of Requiem in 2001 in Kiev, but then I was busy with the orchestral score and the general problems of interpretation, and therefore gave the soloist the freedom of choice. Another group of changes was associated with the peculiarities of interpretation - having the viola play flageolets above a background of celesta and strings in the last section of the Lux Aeterna, for example - in order to achieve a colder, detached sound; or playing the last notes of the solo part on the open strings for the same purpose. In these cases, I have 
given freedom of choice to the soloist, but I didn't put these changes into the score. Actually, I want to say that our discussions were always very helpful to me. ${ }^{97}$

In February 2014, the fourth movement of Holocaust Requiem, Lux Aeterna, was performed by Tatjana Mead Chamis.

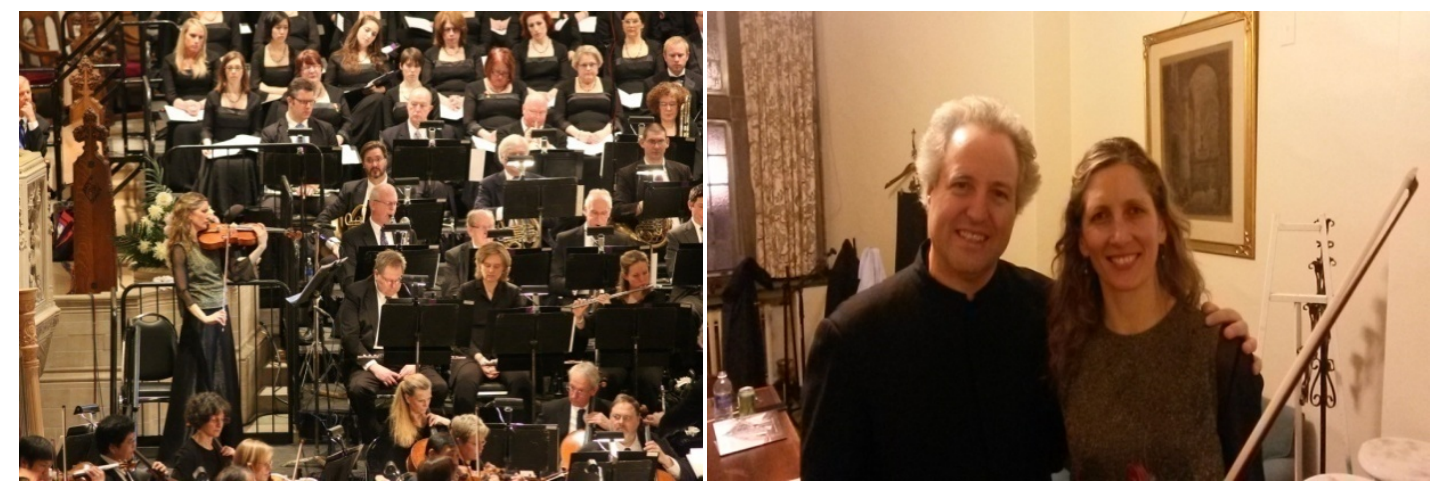

Photo 4.5 Tatjana Mead Chamis and Manfred Honeck with Pittsburgh Symphony Orchestra.

Kanny stated that the collaboration among the composer, the conductor and the musician in an article:

Honeck first became aware of Pigovat's music when the symphony's associate principal violist Tatjana Mead Chamis told him about the composer's Requiem - The Holocaust. Honeck came to love the piece and led the symphony in a performance of its Lux Aeterna movement with Chamis as soloist at a Music for the Spirit concert in 2014 at East Liberty Presbyterian Church. ${ }^{98}$

In June 2015, "Holocaust Requiem- Poem of Dawn" was launched by NAXOS Records, featuring the Croatian Radio and TV Symphony Orchestra, with soloist Anna Serova, conducted by Nicola Guerini. After Anna Serova had listened to Holocaust

97 Jerry Dubins, 'On a Requiem of Remembrance - A Conversation with Composer Boris Pigovat', Fanfare 35/3 (Jan/Feb 2012), 182.

${ }^{98}$ http://pigovat.com/wordpress/lux aeterna pittsurgh/ (27 November 2020). Mark Kanny, a classical music critic at Trib Total Media. 
Requiem on the Atoll $\mathrm{CD}$, she told Pigovat that she wanted to perform and record this work.

Russian-Italian violist Anna Serova has received some compositions dedicated to her in recent years by some important contemporary composers, including Boris Pigovat. She is now a highly sought-after concert musician in some of the most important concert seasons and festivals in Italy and abroad. Anna Serova is Professor of Viola and Chamber Music at the Lorenzo Perosi International Academy in Biella. ${ }^{99} \mathrm{I}$ am honoured that I had the opportunity to have a master class with her in the 44th International Viola Congress in 2018, after she performed "The Three Altos" Gala Concert with the New Zealand Symphony Orchestra at the Michael Fowler Centre in Wellington. In the master class, I played Poem of Dawn, which Pigovat dedicated to Anna Serova, and she gave much good advice on the viola sound and musicality of this work.

In summary, the complete Holocaust Requiem has been performed live four times, once by Rainer Moog in Kyiv (2001), and three times by Donald Maurice, in Wellington (2008 and 2011) and in Wuerzburg (2011). There are three recordings, one with Rainer Moog of the 2001 performance (not released commercially), one with Donald Maurice of the 2008 performance (released by Atoll in 2010) and one with Anna Serova of a studio recording (released by Naxos in 2014).

\subsection{Documentary film}

The film Lacrimosa Dies IIla, created in 2020, focuses on the creation of Holocaust Requiem. It features my interviews with the composer in Israel in October 2019, an on-site video of Valentyna Bugrak at Babi Yar telling the story of the massacre, and sections of Holocaust Requiem performed by me with the New Zealand School of

99 Naxos CD notes. https://www.naxos.com/person/Anna Serova/222177.htm (27 November 2020). 
Music Symphony Orchestra, conducted by Martin Riseley. As well as being the soloist in this film, I was also the assistant producer, translator from Russian and Ukrainian, and creator of the subtitles.

\subsubsection{The aim of the film}

The film makes the music more accessible to listeners and a future source for study and analysis, both from the sense of sight and sound, and to provide a deep understanding of the story through the commentary of the composer. It also places the significance of the contemporary composer Boris Pigovat and the messages behind this music into a twenty-first-century context by raising the profile of the composer and Holocaust Requiem.

As a violist, I recognise the significance that his Holocaust Requiem is not a usual Requiem with choir and texts, but instead features a solo viola and a large orchestra with many other featured solo instruments enabling the characteristics of each to have its voice. Lacrimosa Dies IIla, through recording Pigovat's music, and having the composition discussed in his own words, conveys the message that while we must not forget about the brutality of war and specific tragic events, life must continue with hope and love.

\subsubsection{The making of the film}

When I started the journey of my PhD study in 2017, the film provided the opportunity for the most significant case study in this $\mathrm{PhD}$ and the dates were booked with the orchestra for the week of 13 July 2020. We could not imagine then that breaking news in early 2020 would be that a global pandemic had begun in China and would throw our plans into uncertainty. On 21 March the New Zealand Government introduced a four-level alert system to help combat Covid-19. Two days 
later the government announced that New Zealand was to move to Level 3 immediately and into Alert Level 4 full lock down on 25 March. I felt at that moment that it was unlikely we would be able to make the film on the planned dates, and my supervisor and I began to develop a Plan B with a scaled-down approach, assembling and filming smaller groups of the orchestra with social distancing, and presenting a more analytical look at the work, assuming the country would be at Level 2 by July.

On 13 May New Zealand moved to Level 2, which meant our Plan B became possible. On 8 June the country moved to Level 1 as there were no more active community cases of Covid-19 in the country from the reports of Ministry of Health. Once borders were reopened there were almost daily cases of Covid-19 in quarantine but no community transmission. The recording of the film was successfully conducted exactly on the original timeline on 13,14, 15 and 16 July 2020. On 12 August, due to a community outbreak, Auckland moved back into Level 3, and the rest of the country moved into Level 2. It was as if God had opened a window for us to film the orchestra and then closed it again. The country did not return to Level 1 again until 21 September.

The interviews with Boris Pigovat took place in Israel on 14 September 2019, about three months before the coronavirus pandemic started to spread outside China. I was both excited and nervous that I could interview Pigovat in his home. Everything went very well during the interviews, and he discussed the score of Holocaust Requiem in depth. We also discussed the Viola Sonata in great detail. It was a precious experience to learn more about his life and the music of Boris Pigovat, and selected sections of the interviews form an important and crucial role in the film.

After finishing the visit to Israel, I continued on to Poznan, Poland to attend the 46th International Viola Congress, with the goal of bringing his works to an international stage. During the congress, I presented a lecture recital including a world premiere 
of Nigun for viola quartet in a version created specifically for this event by Boris Pigovat. For this premiere I collaborated with Wellington-based violist Elyse Dalabakis, and Poznan-based violists Marianna Kalicka and Aleksandra Ruciak, and in his viola sonata with Poznan pianist Krzysztof Sowiński.

After the viola congress, I had a few days remaining in Poland before departing for Wellington, and I took the opportunity to visit the Auschwitz-Birkenau concentration camps near Krakow, which were operated by the Nazis in occupied Poland during World War Two. As a human being, I was shocked by the photographs and the atmosphere created by these harsh places, even though I knew that these camps were only the visible manifestation of a greater evil. Nevertheless, it is impossible to imagine the horror of what truly happened in the atrocities. I took many photographs to record the different functions of the camps, including the trucks and the railway tracks, knowing they might be used in the film.

During the lockdown in March-April 2020, I knew it would be a challenge to record the film, since organising such a large orchestra would be completely impossible under Levels 2, 3 or 4. Nevertheless, I was determined to overcome the difficulties and attempt to take advantage of the time staying at home. First, I translated all the Russian texts from the interviews into English. Meanwhile, I studied and developed a skill of editing all the videos with insertion of the English subtitles. This was very challenging for me, as I had to listen to the videos many times in order to make sure each duration of the subtitle matched with the corresponding picture.

As we moved to Level 1 just five weeks before the planned filming dates there was a great deal to be done to be ready. Access to the music scores had been impossible under lockdown and once we had the green light on 8 June to proceed, we made the decision to create a new set of parts from the PDFs my supervisor had received from Pigovat in 2008. This enabled us to print only the sections we would be filming. 
My supervisor was the producer of the film and I was the assistant producer. We carefully worked out exactly which sections we needed to film and created a detailed plan of how we would achieve that in the very tight schedule on 13-16 July 2020.

\section{REQUIEM for Viola and Orchestra \\ A film about Boris Pigovat's Holocaust Requiem \\ Rehearsal Schedule}

July $13,3-5 \mathrm{pm}$

Read through everything as below

July 14, 3-3.45pm - Filming

Requiem Aeternam (bars 31-91)

Viola, Fl(3), Cl(2), Bn(2), Trpt(2), Harp, Marimba, Timp, Strings

July 14, 3.50-5pm - Filming

Requiem Aeternam (bars 162 - end)

Viola, $\mathrm{Fl}(2), \mathrm{Ob}(2), \mathrm{Cl}(2), \mathrm{BCl}, \mathrm{Bn}(2), \mathrm{CBn}, \mathrm{Hn}(4)$, Trpt(3), Trom(3), Tuba, Harp,

Piano, Timp, Cassa, Tamtam, Piatti, Campane, Strings

July 14, 5-6pm - Filming

Lacrimosa (bars 880-937)

Viola, Campane, Fl, BCl, Bn(2), CBn, Hn(4), Timpani, Tamtam, Strings

July 15, 12-1.30 pm - Filming

Lacrimosa 768-879

Solo viola 
July 16, 3-6pm - Filming

Transition from Lacrimosa to Lux Eterna (complete)

(bars 938-end)

Viola, $\mathrm{Fl}(2), \mathrm{Ob}(2), \mathrm{Cl}(3), \mathrm{Bn}(2), \operatorname{Hn}(4)$, Trpt(3), Trom(3), Tuba, Vibraphone, Harp,

Timp, Celeste, Campanelli, Strings

This plan and the score were sent to Bill McCarthy, the film director in Auckland, and Graham Kennedy, the sound engineer in Wellington, so that they could plan meticulously all the camera positions and microphone placements.

On 13 July the orchestra rehearsed all the sections to be filmed for three hours and Graham Kennedy worked out the optimum placements of microphones. On 14 July we had cameras positioned, two fixed and one roaming, and began filming from the outset of the session, which was two hours. Each section had been carefully marked out to allow for three or four takes to provide an audio master and a range of camera angles. On that day all the excerpts from Requiem Aeternam were filmed. It was a three-hour session on 15 July and the complete solo viola section of Lacrimosa was filmed. On 16 July all the excerpts from the Lux Eterna were filmed plus the sections from Lacrimosa with solo viola, timpani and bass, and the sections linking the Lacrimosa to the Lux Eterna in a three-hour session. The Dies Irae was not filmed because this movement portrays the actual atrocities of the Holocaust; therefore, it was decided to use the soundtrack from the Atoll CD while projecting images of Holocaust memorial sites.

\section{The Babi Yar interview}

Very soon after the filming was completed our attention turned to Valentyna Bugrak in Kyiv, Ukraine. The original plan was for Donald Maurice to travel to Kyiv in June 2020 on his way to the International Viola d'amore Congress in Riga, Latvia. While in 
Kyiv he was scheduled to attend a screening of his film Christoph Graupner - viola $d^{\prime}$ amore and more, perform a concert with violist Valentyna Bugrak and a Kyiv chamber orchestra, and visit Babi Yar, where he was to film an interview with Valentyna in which she would respond to a list of questions he had prepared and sent her. He was to ask the questions in English and she was to respond in Ukrainian. We devised the questions so that Valentyna would tell the story of what happened there on 29-30 September 1941, how the ravine has been turned into a commemoration site and how it affects the residents of Kyiv in the present day.

It was a very well developed plan but then Covid-19 intervened. It had become clear by April that Donald Maurice's visit to Europe could not happen and that Plan B had to be put in place. This plan would require Valentyna to hire a local camera operator to go with her to Babi Yar and respond to the questions, which she had been sent. The script that was sent to her was as follows.

Donald: Standing here today at Babi Yar, only four miles from the centre of Kyiv, it's difficult to imagine that in 1941 this tranquil setting was the location of one of the world's most horrific atrocities. What was once a deeply wooded ravine with a small stream running through it is now filled in, making it hard to imagine it as a massed graveyard.

Among the victims of this massacre were an aunt and the grandparents of Boris Pigovat. It was against this background, and all the other horrors of World War Two that his Holocaust Requiem, was conceived. The world premiere of the Holocaust Requiem took place in Kiev on the October 2, 2001 at the Memorial evening commemorating the 60th anniversary of the Babi Yar tragedy. It was performed by German viola soloist Rainer Moog and the Symphony of the Ukrainian National Philharmonic Society conducted by Roman Kofman. 
I am joined here today by Valentyna Bugrak, a viola player from Kyiv, and would like her to tell us a little about the significance of this site for Ukrainians, especially those from Kyiv.

Valentyna: Suggested reply. Probably almost anyone from Kyiv will have a personal story to tell about this site, either through their parents or grandparents having lost family or friends in the massacre in 1941, or simply by learning about what happened here only 80 years ago and feeling the impact of that event when visiting what is now a beautiful and peaceful park.

Donald: Could you tell us what actually happened here in 1941.

Valentyna: Suggested reply. Summarise in your own words the events of September 39-30, 1941, speak for as long as you like.

Donald: Valentyna, please share with us what effect it has on you personally as a local, to visit this site?

Valentyna: Suggested reply. Speak freely for as long as you like.

As is demonstrated in the film, Valentyna spoke so well and was so thoroughly prepared, we decided it was unnecessary to include the questions, which would have to have been filmed in Wellington and edited in to her video. We believe the end result is better than the original Plan A. The videos she provided could be broken up into shorter segments that we could use to weave the whole film into a musical portrayal of the Holocaust and the special significance of the Babi Yar massacre in its genesis. At our request the cameraman, Roman Strakhov, also provided us with footage of the site without any voice, for use in the opening section where we listen to the first ninety seconds of Holocaust Requiem from the Naxos CD. 


\section{Translation and subtitles}

The process of translation from Ukrainian to English and the insertion of subtitles began as soon as we received the footage from Valentyna. Except for help in looking up and obtaining ideas from an electronic dictionary, I found that some Ukrainian words and pronunciations are similar to Russian. For example, the word "children" in Russian is "дети", and in Ukrainian is "діти". Some grammatical expressions are similar as well - when I knew what they stood for in Russian, I could understand more or less what they meant in Ukrainian. As Russian and Ukrainian sometimes sound different, I had to listen several times to match the subtitles with the pictures. Also, I asked Valentyna to check if the subtitles and the pictures matched. The translations and placement of subtitles of the Pigovat interviews were relatively straightforward, as I am fluent in Russian.

\section{The editing phase}

The final stage of creating the film was the editing work by the director, Bill McCarthy, following the plan I had developed with Donald Maurice, the producer. While we had worked out the overall structure of the film, there were many pieces to this puzzle to fit together and a great deal of finessing to be done.

The pieces of the puzzle included:

- a refined audio track for each section recorded by the orchestra

- selection of camera shots for every moment of the filmed orchestra

- videos with Boris Pigovat

- videos with Valentyna Bugrak

- dozens of photographs of Holocaust memorial sites

- multiple sound tracks from the Atoll CD

- opening image of American photographer Dwight Pounds's Auschwitz 


$$
\text { photograph }
$$

- credits at the end of the film.

The first step was to listen to all the audio takes from the filming sessions with the orchestra. These sequences were sorted into the correct order by Graham Kennedy, with identifiers at the front of each section to facilitate synchronicity of visuals.

The second step was to lay down the complete audio, with every component, to establish the duration of the film. This took a great deal of time and involved two visits to Auckland by Donald Maurice to work with Bill McCarthy. During these visits, many of the selections of camera shots were also made.

The third stage was to select and insert photographs of Holocaust memorial sites to be added to the selections of the Dies Irae, which were broken up by interview commentary by Boris Pigovat. These photographs were selected from the private collection Dwight Pounds (by permission) and from the Pixabay website, which allows free use of the selected images.

The fourth stage was to add the opening Auschwitz image and the closing credits, to refine all the dissolves between sections, and to adjust audio levels for consistency throughout the film.

The final step was to determine the best and most flexible format for distribution. We decided to use $\mathrm{H} 264 \mathrm{mp} 4$ format and in the first instance to transfer this on to a flash drive. From 2022 the film will be made available for free viewing on YouTube. During 2021, the 80th anniversary of the Babi Yar massacre, the film will only be available in public and private settings by arrangement with the producer. 


\section{Plan of sequence of the film with subtitles}

* Opening title page

* First section of Requiem Aeternam with Atoll CD and Babi Yar scenes

Bars 1-30

* Valentyna

Video 3

I will start the story from the place where everything happened: Babi Yar.

According to Cartographic Data, one of the largest and deepest ravines in the territory of Kyiv used to lie here. In the publications of the early twentieth century, this area was called Kyiv Switzerland. But for about eighty years, Babi Yar has been associated with the horror of the Nazi occupation during 1941-1943. The territory of Babi Yar stretches for $2.5 \mathrm{~km}$. With a total area of over 30 hectares, the Nazis chose this place for the mass shootings of civilians.

No concentration camps had so many people shot in one incident. In two days, 29 and 30 September, the Nazis killed 33,871 people here.

Video 4

On 19 September 1941, the Nazis defeated the Red Army in Kyiv. Then, after 20 September, according to documents, the Nazis took hundreds of people to be shot every day. During the occupation, almost all Kiev residents with Jewish status were killed. The Nazis created a false impression: there were explosions and fires on the central street of Kyiv -- Khreshchatyk, which were blamed on the Jewish population of Kyiv. In fact, the retreating Soviet troops had laid explosives in dozens of houses 
in the city centre. However, there would be no fires and explosions - there would be another reason to eliminate the Jews, because of the political direction of the Nazis. The decision to take measures to exterminate the Jews of Kyiv was made in the Verkhmat. After that, 2,000 copies of this order were printed in Ukrainian, Russian and German with the following text:

Video 5

All Jews of the city of Kyiv and its environs are to gather on Monday, 29 September 1941 at 8 o'clock at the Street Melnikov-Doktyrevskaya (near the cemetery). Everyone should bring money, documents, linen and so on. Whoever disobeys this order will be shot. Whoever occupies a Jewish dwelling or plunders items from these dwellings will be shot.

\section{Video 6}

The rumours spread by the Nazis that Jews should be relocated to their historical homeland did not arouse suspicion. They were told to take food for three days, and to take water, money and valuables. The freight railway station Lukyanivka was not far from the ravine. Several trains were brought to the freight station. In this way, the Nazis created the appearance of a Jewish Deportation outside Kiev. On 29 September 1941, Jews from all over Kiev marched with their belongings and children to the gathering place. They kept in a whole column. There were many nonJews in the crowd. There were representatives of mixed marriages, and many acquaintances and relatives accompanied the Jews. Patrol borders stood along the ravine and the nearby streets. For those who crossed the border there was no turning back.

Video 7

Under the order of the Nazis, people compiled their belongings and documents. Everyone was shot by the executioners. People were counting on the resettlement 
being better than what they had. They were forced to undress, and put on the edge of a deep cliff and shot. Even women and children were killed. Shouts and shots - all these were muffled by the roar of the plane circling over the cliff, and the music that was heard. The people who came here had no idea what was waiting for them. It was a carefully planned action by the Nazis to exterminate the Jewish population. *** It is known that more than 22,000 people were shot on the first day alone. In two days, 33,871, not including children under three years old - they were not counted at all. No other concentration camp had killed so many people in one day.

* Second section of Requiem Aeternam with Lucy and NZSM Orchestra

\section{A Bars31-91}

* Boris discusses Requiem Aeternam

I didn't set out to write a three-part form, a sonata form or some other traditional form. There are practically no traditional forms in Requiem. What did I want? I wrote a sequence of different episodes, in some cases, I returned back to write sections when I felt that it was necessary, but I did not want to write in some standard form.

In order for the work not to "fall apart" in perception, it is necessary to combine various ideas with some elements, some connecting elements. Such elements are three motives found in a variety of ideas. The first motive is like this (the clarinet motive is played in bars 6-7), suppose we denote it as Motive "a". The second motive (Motive "b") can be added under it. It's like a rhythm of singing the word Requiem with a sequel - Requiem Aeternam (Figure 2 is played). The third motive (motive "c") appears a little later, and it is very important for the development (bar 122 is played), this is from the beginning of the development section, downward movement in minor seconds. In principle, this third motive was actually born from 
the first motive ("a"), because if you remove the jumps, you will get down in minor seconds ( $a$, a flat, G, f sharp). But here this leap (A-flat - E-flat) is very important, therefore it is a separate motive (motive "a").

The first climax appears (Figure 11), and the viola has a theme with the motif "a" twice and at the end with the motif "c". Figure 12 is the second climax with the motif "a". This is how the development section ends.

Next comes the reprise of the first section, we can find motif "a" again, but there is a very bright insertion of motif "c" (bar 233 is played).Then it continues with the " $b$ " motif (Requiem) twice in bars 247-248 and 251.

All the materials of the first movement are somehow permeated by these three motifs: the "a" motif, which appears in one idea, then in another, then at the beginning of the idea, then in the continuation of the idea, the " $b$ " motif is Requiem, and the "c" motif is the movement in seconds. Sometimes they appear in the development, and sometimes they become part of the melodic theme, and then this motive increases (bars 210-212).

* Third section of Requiem Aeternam with Lucy and Orchestra

B Bars 162-175

C Bars 176-185

D Bars 186-202

E Bars 203-223

* Valentyna

Video 8 
This is a monument to the "Menorah", dedicated to the memory of the Jewish civilian population of Kiev killed in Babi Yar during the German-Soviet war.

Video 9

Here are written the following words on this stone near the monument:

"The voice of thy brother's blood crieth unto me from the earth."

Video 10

For two years in a row, the shootings continued at Babi Yar. The shadow of Babi Yar hung over Kyiv for two years during the occupation. Anyone could be arrested for any violation and sent to the ravine.

The documents reveal the information that there were five gypsy camps, members of the organisation of Ukrainian nationalists, more than 700 patients of the psychiatric hospital named after Pavlov, and 25,000 prisoners of war from a nearby concentration camp.

Video 11

But the Nazis' crimes did not end there. In the summer of 1943, the Nazis set themselves the goal of destroying traces of crime. Suicide squads of prisoners were recruited. They excavated the bodies and set fire to the furnaces set up in the Babi Yar ravine. They were all burned inside it.

\section{Video 12}

Some people managed to escape, some children managed to escape from the bullets of the Nazis. These people, having survived to our time, are increasingly talking about the horrors of that tragedy.

Video 1 (3) 
This is a monument for children who were shot at Babi Yar. A monument in memory of the lives that were cut short during the German-Soviet war, before they could grow up.

Video 2 (4)

This is another small monument with the following words written on it:"Tens of thousands of Jewish people were shot at this place during the German occupation of 1941-1943".

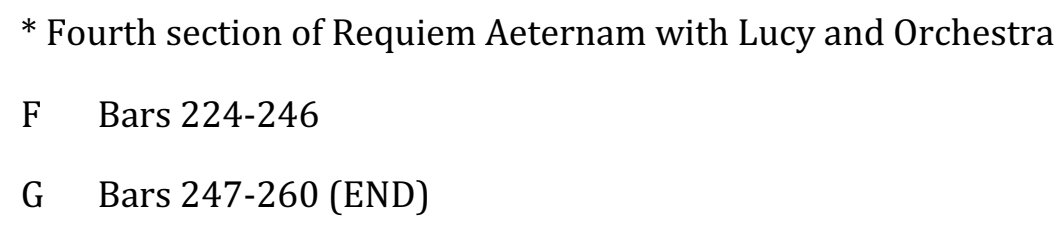

* Boris discusses Dies Irae

The second movement ("Dies Irae"), in fact, is the story of the Holocaust. This is not an understanding of the Holocaust, but a story about it. I would like to simply cite the words from "Dies Irae" as a character of music and as an image of music - "Day of Wrath", the day will turn the world to ashes. At the same time, in the Jewish memorial prayer Izkor, which is read in memory of those who died in the Holocaust. It is said: "Remember the rivers of blood pouring like water." And another phrase that may reflect the nature of this work: "The sword is ruining outside, and the spectre of death is inside", this is from the "Lamentation of Jeremiah." I felt some kind of inner horror when I wrote it.

There are two stylistic layers. On the one hand, this is the theme of "Dies Irae", which can actually be the subtext (in the traditional text of the Latin prayer). I tried to make it as if the choir sings with the text (the theme from c.17 is played and hummed). The theme of "Dies Irae" takes place several times in the second 
movement. On the other hand, a theme appears that can be subtext at the culmination (figures 37-39) with the words of the Jewish prayer "Shema Israel" (the theme of bass notes 571-577 is played and hummed).

In addition to these themes, a lot of music appears with pronounced Jewish intonation and Jewish dance. However, at the same time, the main feeling that I tried to convey in music is the feeling horror of what is happening. Besides, it's important to emphasise the feeling of MECHANISM of this horror, that it is a murder MACHINE, a machine that grinds human lives and human destinies. I tried to convey this mechanism here, too.

Dies Irae - Atoll CD section Part 1(0-3'34") with Dwight Pounds and Pixabay memorial sites photos.

Dies Irae turned into some kind of "devilish dance." In general, this part is built in such a way as to gradually bring the music to the "Dance of Death" - "Danse Macabre" (in French) - (Dance of Death - English). It turns out a dance like a polka Dies Irae turns into such a dance (bars 449-450 are played again), and this gradually leads to such a similarity of the Waltz of Death. At first (figure 34 is played) it was the element " $c$ " along with ostinato. But the most important waltz begins in figure 42 when such a waltz rhythm is given (the piano part is played) the sarcastic waltz and added the ostinato band, and it sounds like the Death Waltz. Dies Irae - Atoll CD section, Part 2 (7'05'-10'34") with Dwight Pounds and Pixabay memorial sites photos.

Finally, the last episode that is very important to me is the ending of the second movement. The rhythm of the heartbeat is depicted starting from bar 696 to show how many hearts of people are combined into one huge heart beat. Gradually this heart beat begins to die.

I even asked a doctor, a cardiologist, "What does the heart beat look like, what are the last beats when it dies?" He told me this: "At some point it becomes like the rhythm is depicted as in bars 740-744. I passed this beat to the bass drum part (the 
bass drum part is played from the figure 47) to try to convey this rhythm of a dying heart as he told me.

What is the original reason of this episode? This episode is associated with a fragment from the book Life and Fate by Vasily Grossman. One terrible moment describes how a huge number of people are driven into a gas chamber, and how gradually they died. An awful place! This image had been emotionally acting in my mind. Now I tried to convey this feeling in this work here after I read it. Dies Irae - Atoll CD section, Part 3(10'35"-end) with Dwight Pounds memorial sites photos.

* Boris discusses Lacrimosa

Now, the third movement should be crying - Lacrimosa. At first I wanted to write the traditional "Lacrimosa" - quiet music with intonations of tears and crying. However, at some point I felt that after the horrors I tried to portray in the second movement, it is impossible to go to the usual "Lacrimosa". A person cannot just cry, be strangled by the anger, or be strangled by the pain. No tears here! So this formed the concept of the third movement. At the beginning, music should express the pain, the anger, and the despair. When the despair is already expressed - all the forces go to this crying, there is no more strength left, remains only the moan powerlessly (figure 49, starting from bar 862).

When nothing is left and everything is "burnt out", a person wants to forget himself to go into oblivion. He is going crazy or some kind of temporary insanity, and such a strange waltz begins (bars 880-881 are played). As if a person is "not in himself", he is "not in this world."

* Lucy performs Lacrimosa Part 1

First Chimes then: 


\section{H Bars 769-792 \\ I $\quad$ Bars 793-838 \\ J $\quad$ Bars 839-858}

When I was doing this fragment, I remembered a scene from Prokofiev's opera "Semyon Kotko". In the story, a moment when one man is executed, and his bride who was supposed to marry him cannot accept that he died. She walks around him, around his body. She lost her mind and said: “No, it's not Vasillyok. No, it's not Vasillyok." She does not believe that her fiancé died. This is a feeling of some kind of madness. Or like Ophelia, she goes crazy because she is shocked by the death of her father.

I tried to convey the same feeling here (bars 880-888). At the beginning is just very strange music, and at some point it turns into a waltz (bars 896 - 901 are played). At some point this madness obsession leaves and again an explosion of emotions, and returns to reality (figure 51).

Only after this explosion of emotions, when everything fades away tears "open". Only after all this horror, the energy of anger and the emotion of pain have "splashed out", it is the time for crying. Then the music of the typical "Lacrimosa" appears from the very beginning. I tried to somehow reflect the mood of the Mozart "Lacrimosa" (bars 919-920).

Lucy performs Lacrimosa Part 2

Bars 859-860 (timpani)

K $\quad$ Bars 861-879

L $\quad$ Bars 880-901

M Bars 902-918

N Bars 919-937

\footnotetext{
* Boris discusses Lux Eterna
} 
The fourth movement, "Lux Aeterna", was supposed to be the lightest and most serene part of the entire work. This is the final part of the Requiem; therefore, some moments from the whole composition should be reflected here. At the same time, for this movement the perception is "tired" from the abundant repetition of the elements that took place in the first three movements ("a", "b", “c", "d"). Therefore, as a composer, I had a need to write a completely new material for the music. There are actually four new themes.

The first theme begins with the accompaniment, the viola enters with this theme in the figure 54 (bars 957-963 are played and so on). After this first new theme, another new theme appears, which was not listened before (bars 975-982 are played).

* First section of Lux Eterna with Lucy and Orchestra

O (R) Bars 938-976

P Bars977-984

Q Bars985-993

Boris discusses Lux Eterna

After this, another new theme appears in figure 60. This is an alto solo on the background of the harp (bars 1052-1059 are played ... and so on).

The key of $\mathrm{C}$ sharp major is adjusted, and new theme begins. There is a celesta - an instrument that was not previously in this work, appears for the first time of this timbre paint. It is perceived as something completely new. Against the background is the C sharp major (Lydian E flat major, bars 1111-1119 are played).

Actually, this is just the background for the theme, but the theme from the second movement appears next with a completely changed character. That theme in the second movement (figure 22) was energetic (bars 349-353 are played). Now in the 
fourth movement, this theme is completely ephemeral in a very high register (the beginning of this theme is played - bars 1120-1124). Someone prefers to play it with a large vibrato in a high register, Donald decided to intensify the "incorporeal" paint that it is something "unearthly" and played all with flagollets. I accept with both. The main thing is that the nature of this theme is completely different than it was in the second movement.

Why does this theme appear here (theme from the second movement)? Because this is already the coda of the fourth movement, and at the same time it is the coda of the whole composition. The coda should collect materials from different places of the whole work. Therefore, using the theme of the second movement here is my conscious compositional decision. Since this work is about the Holocaust, about the fate of the Jewish people, and this theme is with a vibrant Jewish character.

Therefore, I decided to give it here, it was a conscious choice.

* Second section of Lux Eterna with Lucy and Orchestra

S Bars 1027-1051

* Third section of Lux Eterna with Lucy and Orchestra

T Bars 1052-1078

Boris discusses Lux Eterna (quoted text)

After this section ends with the celesta and this theme, the very last section of this coda begins. What [does] it include?

On the one hand, the viola part is the theme of "Shema Israel", which appeared in the climax of the second movement (bars 571-577), then it was between the third and fourth movements (bars 938-943) - completed "Lacrimosa" and connected with the fourth movement (the horn, bars 938-943 are played). Now the third time in the end, it is the viola solo (figure 65 is played). It was singing as if with the text 
Requiem (bars 1168-1169 are played). At the very end, two lines of this composition are connected: on the one hand, it is the traditional Requiem, on the other hand, it is a work about the Holocaust of the Jewish people with the theme "Shema Israel".

You asked that it is like "a better life" referring to the image of the fourth movement. No, this is just like an appeal to God so that the souls of the dead go to a bright paradise. That is the "eternal light" (Lux Aeterna). (The Russian translation of the Latin text that Pigovat gave me is read.) (Then the text from the Jewish prayer "Izkor", which I also have, is read out).It should be clean, calm, beautiful music, this is about music character. That is not how you thought that "this is the best life after the war." No, this is all connected with the souls of the dead. Simply this is a request that the souls of the dead had been given the eternal light, the nature of the music should be connected with this.

Fourth section of Lux Eterna with Lucy and Orchestra

U Bars 1079-1134

V Bars 1135-1161

W Bars 1161-End

Valentyna

Video-Coda

Most Kyiv people who survived from the shootings tell about their own tragedies. This is the pain of the city of Kyiv, which will remain in the memory of Kyiv people forever. There are a lot of materials and eyewitness stories widely available now, and tears roll down from my eyes as I look at them. Every Kyiv person has a story related to the acquaintances, the neighbours, or the family members who left and did not return in those days. This tragedy happened eighty years ago. Today, it is even difficult to imagine the horror that happened not so long ago. Unfortunately, these people will not return back. But what we need to do is always remember that. 
We must not forget that we are all creators of the history. And when we think of the tragedy of Babi Yar, we must remember these figures - about 100,000 innocent civilians were killed. We must honour the dead, be aware of the scale of the tragedy, and try to prevent it from happening again.

* Screen fades to black then music from Prayer and credits run 


\section{Part Five- Reception}

This section aims to summarise reviewers' reactions to CDs and live performances of Boris Pigovat's compositions. After browsing a number of reviews, readers will likely perceive that his works have been highly praised by musicologists, musicians and audiences. The reviews generally respond positively to his compositional style, technique, vision and musical expression. While the primary intention here is to extract reactions to the compositions, inevitably the reviews also comment on performers' interpretations. A short statement is provided about the works not covered elsewhere in the thesis.

The works included in chronological order of compositions are as follows:

Holocaust Requiem (1994-1995)

Prayer (1994)

Nigun (1996)

Silent Music (1997)

Winds of Yemen (2000)

Song of the Sea (2005)

Poem of Dawn (2010)

Lights from the Yellow Star (2011)

Viola Sonata (2012)

Therefore, Choose Life (2017)

\subsection{Holocaust Requiem}

\subsubsection{Reviews of live performances.}


On 2 October 2001, Pigovat's Holocaust Requiem premiered in Kyiv, Ukraine, where Pigovat's grandparents and aunt were killed in the 1941 Babi Yar massacre. The concert was hosted by the National Philharmonic Society of Ukraine on the 60th anniversary of the massacre. Boris Pigovat had direct communication with the conductor and the musicians: "He praised the musicians highly. 'It is very important that they accepted my music and treated it warmly. One sees this attitude listening to their rendition of the Requiem,' he said." 100

The following extract provides the conversation between the Ukrainian Philharmonic director, Roman Kofman, and Boris Pigovat in their collaboration on this piece. Roman Kofman wrote that:

The tragic theme is eternal in the arts and it is a powerful source of inspiration for composers, musicians, and painters. I'm sure that the Holocaust Requiem has a great future. Boris Pigovat's composition is very sophisticated, but it isn't flowery or pretentious. It is simple but not primitive, it is frank and heartfelt, an outstanding work. ${ }^{101}$

In 2008, Holocaust Requiem was given its second performance in Wellington, New Zealand. The concert was a remembrance of the 70th anniversary of Kristallnacht, and generated comments from multiple newspapers, magazines and social media.

In the case of the Israeli work it seems scarcely credible that an audience assembled to recall one [of] the 20th century's worst affronts on humanity were hearing the 2nd ever public performance of Pigovat's Requiem; music conveying colossal power, numbing sorrow, and an aura of reconciliation...Using purely orchestral forces this 46-minute

100 Tetiana Polishchuk, 'Music of Sorrow And Hope', The Day. https://day.kyiv.ua/en/article/culture/music-sorrow-and-hope (3 November 2020). 101 Tetiana Polishchuk, Music of Sorrow And Hope', The Day. https://day.kyiv.ua/en/article/culture/music-sorrow-and-hope (3 November 2020). 
symphonic-concerto encompasses ear-splitting anguish, horror and confusion -tolling tintinnabulations mark the outset of unspeakable atrocities while abject grief is heightened by sonorous lamentations of the solo viola; a role of unusually formidable demands.

The Vector Wellington Orchestra clearly found this taxing work well within its métier, and viola soloist Donald Maurice negotiated the unrelenting technical minefield with a performance of both furious bravura and unassailable beauty.

Wellington's concert of remembrance was a time for ennobling of the fallen and chastening of a surviving generation. Few of those in attendance are likely to forget. $^{102}$

Some reviewers commenting on Pigovat's Holocaust Requiem recalled

Shostakovich's works, especially the 13th symphony, with the same theme-Babi Yar. Garth Wilshire described this work in the Capital Times: ${ }^{103}$

This was a powerful concert on the day of the 70th Anniversary of Kristallnacht, the horrendous "Night of the Broken Glass", amongst the earliest of the atrocities inflicted on the Jewish population by the Nazis.

Special was the performance of The Holocaust Requiem written by Odessa-born, now Israeli resident, composer Boris Pigovat, who had been brought to New Zealand by the State of Israel for this, only the second ever performance, of his profoundly moving work...Pigovat's music is evocative and disturbing in its depiction of the Holocaust. With styles reminiscent of other Russian composers, including the rich melancholy of Shostakovich, the compositional style is still distinctly Pigovat's own. Intense and strongly assured, it is a life-affirming piece that makes a telling statement with subtlety. I want to hear it again and it deserves further performances.

102 Howard Smith, 'Rare Provenance Kristallnacht Remembered', Classical Music Daily (13 November 2008). http://www.mvdaily.com/articles/2008/11/kristallnacht.htm (3 November 2020).

103 Garth Wilshire is a Wellington-based music critic who writes for Capital Times and online media. 
The Vector Wellington Orchestra spent a lot of time preparing this work and it showed.

They played with intensity and passion and, under Marc Taddei's powerful direction, pulled out all the stops. ${ }^{104}$

Roger Wilson reviewed Pigovat's Holocaust Requiem as having a film score quality: ${ }^{105}$

There is no text, but the contours of the requiem's Latin words are clearly discernible in various instrumental solos. It is a work of great intensity and vividly straightforward in its graphic depiction of ghastly events: gunshots, breaking glass, the tumbling of bodies into the Babi Yar ravine, falling tears.

There are plenty of thunderous percussion and aggressive brass, screeching discords of horror and a diabolical danse macabre, but the work is at its most haunting when only a few instruments are playing together. And throughout can be heard the plangent keening of the solo viola, part of huge virtuosity magnificently played by Donald Maurice, who knew how to exploit the instrument's full tonal palette.

Unsurprisingly, the Holocaust Requiem has a nod or two at Shostakovich's 13th Symphony, also on the theme of the Babi Yar murders, while the solo string writing owes something to Bloch as well as traditional klezmer music.

But Pigovat, who was present at this month's concert, has gathered all this together into something quite original and deeply felt, with all the immediacy of a brilliant film score but with no need for pictures. The quiet serenity of the ending, drifting along with viola and celeste, was extraordinarily moving: peace after violence and the hope of better things for humanity. ${ }^{106}$

104 Garth Wilshire, 'Moving Music', Capital Times (December, 2008).

http://www.pigovat.com/reviews/CapTimes-Requiem-NZ-2008.pdf (3 November 2020).

105 Roger Wilson is a Wellington-based professional singer and music critic who writes for the New Zealand Listener and local media.

106 Roger Wilson, 'Rest Eternal', New Zealand Listener (Online) 216/3576 (2008), 47. 
The reviewer, John Button, ${ }^{107}$ examines the differences between two works Pigovat's Holocaust Requiem and Brahms's A German Requiem (the other work in this concert). He also highly praised Pigovat's music with several contrasts with the musical style of other works by contemporary composers.

Perhaps it was Brahms' perceived position in opposition to Wagner, and requiem that takes a less liturgical approach than was traditional, that was seen to make his work a conciliatory counterbalance to Pigovat's graphic work. In the event, the two works, for all the differences that separated them, worked well together...Boris Pigovat's The Holocaust Requiem uses some of the parts of the requiem mass as the basis for a purely instrumental work. It is not a concerto but rather, a concertante work, like Berlioz Harold in Italy, in which the viola is a commentator, only speaking in conventionally soloistic fashion in the cadenza of the Lacrimosa.

The music is harrowing and tense, and very Russian in sound. Echoes of contemporary composers such as Denisov, Kanchelli and Gubaidulina can be heard, as well as the inexorable tread of Shostakovich in the Dies Irae, but the voice of the composer remains highly individual. Balancing the violence, anger and tension is the conciliatory beauty of the Lux Aeterna that rounds out a work of deeply felt power.

The performance was stunning. Marc Taddei drew his forces together with enormous precision - better than in the recording of the work I listened to - and his orchestra responded brilliantly. But the hero was violist Donald Maurice, who gave a performance of great eloquence.

The composer, who was present, must have been delighted. ${ }^{108}$

\subsubsection{Reviews of Atoll CD}

\footnotetext{
107 John Button is a music critic for the Dominion Post newspaper in Wellington.

108 John Button, 'Taddei's Interpretation Delights', Dominion Post (11 November 2008).

http://www.pigovat.com/reviews/Requiem-Review-NZ-2008.png (3 November 2020).
} 
In November 2010, two years after the remembrance concert in Wellington for the 70th anniversary of Kristallnacht, the live recording of this concert was released by Atoll Records. Comments about the Holocaust Requiem appeared from many reviewers.

Dwight Pounds is a well-known musicologist, research historian and viola player. His recording review in the Journal of the American Viola Society focused on Holocaust Requiem for solo viola and orchestra, and explores Pigovat's highly programmatic score and the depiction of its various emotions. Pounds discusses thoroughly the details of his brilliant choice in terms of instruments and combinations of the orchestra in each movement of this piece. This is an important review for understanding Pigovat's works concerning their musical style and musical emotion. The author makes the comparison with Mozart's Requiem and works of Hindemith and Shostakovich, and he suggests that Pigovat's third movement Lacrimosa is a near antithesis to that in Mozart's Requiem. It is important to note that Pounds raises questions and he asserts that Pigovat's viola concerto may challenge the place of the Walton and Bartók.

Pigovat's highly programmatic score is the preparation of a very knowledgeable composer whose choice of instruments and combinations is at once creative and appropriate to each of the unfolding sections and the various emotions they depict. Though ever mindful of the solo viola part, even in low range, he is never hesitant to use the full orchestra-including full components of brass, percussion, and a piano-for effect, but does so in a manner in which the orchestra and soloist are never competing with one another for the listener's attention. These qualities are evident even in the opening measures of part I. ${ }^{109}$

109 Dwight Pounds, 'Boris Pigovat: Requiem "The Holocaust" for Solo Viola and Orchestra [Recording Review]', Atoll ACD 27/1 (2011), 68. 
In a letter from Donald Maurice to Pounds, Maurice wrote "I am not overstating when I say that I believe this is the most significant work ever written for viola and orchestra. Of course it may take the viola community 5-10 years to catch up with the fact that the Walton and Bartók have been seriously challenged."110 This provokes related questions such as: "Will the Pigovat Holocaust Requiem indeed challenge the Walton and Bartók concerti? Will ten years be sufficient to answer the question?"

Pounds refered to this work in the Atoll Recording review:

In a larger sense, whatever postulations I might submit regarding this work are completely irrelevant. Reflecting on the 2008 "Concert of Remembrance" in Wellington, Donald Maurice wrote in a letter to me, "It was a privilege to be part of an occasion at which there were seven ambassadors present and at which the German Ambassador publically offered an apology to the Israeli Ambassador for the atrocities of World War II." Was the soloist himself unaffected-Maurice continued: "The performance was in 2008 but is indelibly etched into my memory. Many people were in tears. I myself said, 'I must not cry!'” Commenting on the composition's future and potential for effecting change, he observed, "It needs to be performed often as a reminder of the effects of war and the circumstances that precipitate one culture wanting to dominate or annihilate another." ${ }^{111}$...Ever mindful of the potential for excess in passing judgment on a new composition, I likewise must put myself on the same line and in all honesty state that Boris Pigovat's Requiem "The Holocaust" arguably is the most significant composition for viola and orchestra I have heard in at least a decade, possibly longer. What I perceive as a paucity of religious/spiritual music featuring a solo viola has been of personal concern for some time, and therefore I must admit to some possible bias in this regard. That said, it would appear that the Pigovat compositions in this album contribute significantly to filling whatever void might exist in this area. Allow me to add

110 Donald Maurice, letter to Dwight Pounds, 10 December 2010.

111 Ibid. 
parenthetically, even at the risk of being considered chauvinistic, that the solo viola is the perfect medium for expressing Pigovat's profound musical thoughts in his Requiem. ${ }^{112}$

Two writers, David DeBoor Canfield ${ }^{113}$ and Jerry Dubins, ${ }^{114}$ gave positive comments on Pigovat's Requiem CD in Fanfare magazine.

This CD is warmly recommended, even though the Requiem makes the following works seem anticlimactic. That is not due to any deficiency in them, but a tribute to the powerful impact produced by the Requiem. I really wish the disc had concluded with that work; one really needs a good five minutes of silence upon its conclusion before one is ready to hear another piece of music. ${ }^{115}$

Dubins speaks directly about the connection and the contrast between Boris Pigovat's Holocaust Requiem and Shostakovich's Babi Yar Symphony (No. 13), asserting that both recall the same horrors, but the musical portrayal of the more direct impact of the Babi Yar massacres on Pigovat's own family is more shocking and personal than that of Shostakovich. Dubins also stressed that Pigovat's work is more shocking as it is as if hearing a vivid filmed music of the horror scenes with inspired imagination.

The music is expectedly dark, tragic, and grim. The Dies irae, for example, begins with a gradually accelerating chugging figure that serves as an-all-too-vivid reminder of the

\footnotetext{
112 Dwight Pounds, 'Boris Pigovat: Requiem "The Holocaust" for Solo Viola and Orchestra [Recording Review]', Atoll ACD 27/1 (2011), 69.

113 David DeBoor Canfield is an American composer, entrepreneur, founder of the business, Ars Antiqua, and music critic for Fanfare magazine.

114 Jerry Dubins is a music critic for Fanfare magazine.

115 David DeBoor Canfield, 'Pigovat: Requiem, "The Holocaust” for viola and orchestra', Fanfare 35/3 (Jan/Feb 2012), 184. http://fanfarearchive.com/indices/itop/performers/taddeimarc.html (4
} November 2020). 
locomotives pulling the rail cars loaded with their consignment of human cargo en route to the camps.

Given Pigovat's Russian roots, one might reasonably expect certain similarities to and echoes of Shostakovich's "Babi Yar" Symphony (No. 13), which recalls the same horrors. But the more direct impact of the Babi Yar massacres on Pigovat's own family provides an almost you-are-there, reporter's perspective into the unspeakable atrocity that is at once more immediate and more up close and personal. His musical portrayal is more shocking, more hair-raising, and more visceral than Shostakovich's score. In fact, if you didn't know the agenda behind Pigovat's Requiem, you might well imagine you were listening to a movie soundtrack for the scariest, most gruesome, most bloodcurdling horror film you've ever seen. I know that calling upon the word "cinematic" to describe a piece of music is often taken to be a criticism of its reliance on superficial effects and its lack of emotional authenticity. But if I use the word in connection with Pigovat's Requiem, it's to describe the chilling imagery and cold fear it summons up in projecting the vivid, palpable, and unbelievably real imagery of a movie filmed in 3D. Never have I heard orchestral instruments used in such ways to achieve such ends...This is a most extraordinary release. I guarantee it contains music like you've never heard before and that will leave you emotionally shattered and physically drained. It's hard to evaluate the performance of the Requiem by the Vector Wellington Orchestra or the reading of the score by conductor Marc Taddei, as there's nothing to compare it to. All I can say is that the performance and the recording are stunning, impactful, and overwhelming. ${ }^{116}$

Peter Mechen commented that this is a stunning CD released by Atoll Records, ${ }^{117}$ and that it is worthy to provide another chance to hear this great work for people who did not attend the concert.

116 Jerry Dubins, 'Pigovat: Requiem, “The Holocaust" for viola and orchestra', Fanfare 35/3 (Jan/Feb 2012), 185-186.

117 Peter Mechen is a music critic and co-founder of Middle C, a Wellington-based online music review website, and a regular contributor to Radio NZ spoken reviews. 
I believe the concert is included under the umbrella of a "Rugby World Cup Event" - if so, one salutes the organizers' enterprise!

Atoll Records deserves the heartfelt thanks of people like myself who weren't able to attend that Wellington performance of the Requiem in 2008 for making the recording commercially available. It was at the time splendidly captured by Radio New Zealand's David McCaw and his engineer Graham Kennedy - as one might expect, the music generated plenty of visceral impact, all of which comes across with startling force in Wayne Laird's transfer to CD. It presents soloist Donald Maurice, with conductor Marc Taddei and the Wellington Orchestra working at what can only be described as white heat - the coruscations of parts of the Dies Irae movement are searing, to say the least - and the effects upon listeners in the hall must have been profoundly disturbing in their impact...Not only does this recording deserve to be heard and savored, but the oncoming Town Hall concert (September 29th - see above) featuring the Requiem, should be an entry on everybody's calendar. If something of the spirit of this recording can be replicated (albeit with a different orchestra and conductor) the occasion will be stunning, unmissably spectacular. ${ }^{118}$

\subsubsection{Reviews of Naxos CD}

In June 2015 , Holocaust Requiem was recorded by Naxos, performed by violist Anna Serova, with the Croatian Radio and TV Symphony Orchestra, conducted by Nicola Guerini, which has been highly praised by many musicians, reviewers, listeners and classical music followers.

Boris Pigovat's Holocaust Requiem proves to be a magnificent work of depth and high emotion in a new performance on Naxos by violist Anna Serova with the Croatian Radio

\footnotetext{
118 Peter Mechen, 'Boris Pigovat's Requiem - A Stunning CD presentation', Middle C (15 September 2011). https://middle-c.org/2011/09/boris-pigovats-requiem-a-stunning-cd-presentation/ (5 November 2020).
} 
and Television Symphony Orchestra conducted by Nicola Guerini...This is a magnificent work of depth and high emotion that is immensely rewarding. ${ }^{119}$

Some comments from the Amazon website of the Naxos recording follow:

Pigovat's Holocaust Requiem may prove to be one of the three finest masterpieces ever written for viola, with the Bartók and Walton Viola concertos. It now primarily needs time and exposure and to become known in contemporary 21st century literature. ${ }^{120}$ Dwight Pounds

A large and increasing body of music and literature offers remembrances of the Holocaust. The challenge such music and literature faces is to be emotionally compelling and fresh without relying upon clichés. The Holocaust Requiem by Boris Pigovat amply succeeds as a commemoration of the Holocaust and as a work of music...This recording was my first experience with Pigovat's music...The work is serious and melancholy nearly throughout. The writing for viola and for the orchestra often has a vocal character. The orchestration is full and effective with large roles for strings, percussion, trombone, horn, clarinet and flute. There are long solo sections of lament for the viola, passages for the orchestra, and many passages in which soloist and orchestra collaborate...The CD was recorded in 2013-2014, and it includes the composer's own edited liner notes. The Holocaust Requiem is a moving effective work of remembrance,

119 Bruce Reader, 'Boris Pigovat's Holocaust Requiem Proves to be a Magnificent Work of Depth and High Emotion in a New Performance on Naxos by Violist Anna Serova with the Croatian Radio and Television Symphony Orchestra Conducted by Nicola Guerini', The Classical Reviewer (24 July 2015). http://theclassicalreviewer.blogspot.com/2015/07/boris-pigovats-holocaust-requiem-proves.html (4 November 2020).

120 Dwight Pounds. Reviewed on Amazon on 17 December 2017. https://www.amazon.com/BorisPigovat-Holocaust-Requiem-Poem/dp/BOOHHJETQS?ie=UTF8\&*Version $*=1 \& *$ entries $*=0$ (5 November 2020). 
and the viola-orchestra performance throughout the $\mathrm{CD}$ is compelling. ${ }^{121}$ Robin Friedman

In spite of the more dramatic Dies Irae, Boris Pigovat's Holocaust Requiem is a music of striking serenity, beauty and depth, becoming highly emotional in the performance by violist Anna Serova and the Croatian Radio Television Symphony Orchestra. ${ }^{122}$ Remy Franck

The instrumental timbre in both works is characterized by steely highs in forte passages, an acceptable midrange, and clean bass. The latter is quite substantial in the Requiem, which calls for a large percussion section. This recording of the work beats the only other currently in the catalog. Moreover, there's no distracting audience noise, and it's widely available at a bargain price. ${ }^{123}$ Bob McQuiston

This is a magnificent work of depth and high emotion that is immensely rewarding...Pigovat is a remarkably fine orchestrator. Poem of Dawn makes a fine contrast to the melancholy, passion and tragedy of the Requiem. Nevertheless it is the very fine Holocaust Requiem that I will return to most often. Anna Serova proves to be a first class soloist with the Croatian Radio and Television Symphony Orchestra under Nicola Guerini turning in first class performances.

The recording is excellent and there are authoritative and informative booklet notes from the composer. ${ }^{124}$ Bruce Reader

\footnotetext{
121 Robin Friedman. Reviewed on Amazon on 18 July 2015. https://www.amazon.com/Boris-PigovatHolocaust-Requiem-Poem/dp/BOOHHJETQS?ie=UTF8\&*Version* ${ }^{*} 1 \& *$ entries $*=0$ ( 5 November 2020). 122 Remy Franck, Pizzicato, October 2015. https://www.naxos.com/reviews/reviewslist.asp?catalogueid=8.572729\&languageid=EN (5 November 2020).

${ }^{123}$ Bob McQuiston, Classical Lost and Found, August 2015. https://www.clofo.com/Newsletters/C150831.htm (5 November 2020).

124 Bruce Reader, The Classical Reviewer, 24 July 2015. http://theclassicalreviewer.blogspot.com/2015/07/boris-pigovats-holocaust-requiem-proves.html (5 November 2020).
} 


\subsection{Prayer}

Some comments about Pigovat's Prayer are presented in the Atoll Records CD from a review from Fanfare magazine:

The six-minute Prayer for viola and piano casts the same spell as does the Requiem, although not so powerfully, given the more limited tonal resources provided by the two instruments. Written between the composition of the third and fourth movements of the Requiem, it actually served as a prototype for the Lux Eterna, to which it bears expressive and dramatic resemblance. ${ }^{125}$ David DeBoor Canfield

Mechen commented on Prayer in Middle $\mathrm{C}$ and mentioned the close relationship with Holocaust Requiem:

The three pieces accompanying the Requiem on this disc all have connections or commonalities of some kind with the major work. The first, Prayer, for viola and piano, probably has the closest relationship with Requiem, as it was written when the composer had finished the latter's Lacrimosa and was preparing materials for the fourth part, Lux Eterna. The music thus breathes much the same air as does the Requiem, with one of its themes actually used in the Shema Israel section of Lux Eterna...The undulations return, their tones gradually dissolving into mists of quiet resignation and fortitude - altogether, a beautiful and moving work. ${ }^{126}$ Peter Mechen

\subsection{Nigun}

125 David DeBoor Canfield, 'Pigovat: Prayer for Viola and Piano', Fanfare 35/3 Jan/Feb 2012), 183.

126 Peter Mechen, 'Boris Pigovat's Requiem - A Stunning CD presentation', Middle C (15 September 2011). https://middle-c.org/2011/09/boris-pigovats-requiem-a-stunning-cd-presentation/ (5 November 2020). 
Some reviewers have commented on the creative style of Nigun, and mentioned that it may remind people of Shostakovich, but Pigovat's Nigun definitely has its own distinctive style.

Nigun for string quartet is the only work on the CD not to feature the viola, although it certainly includes one. It is a rhapsodic through-composed single-movement work of nine minutes' duration. Although quoting no traditional Jewish melodies, it has clearly grown from the roots of its composer's heritage in its use of certain intervals and melodic contours... The work was originally written in 1996 for orchestra but is performed here for the first time on CD in its version for string quartet. Shostakovich's well-known E-Minor Piano Trio comes to mind in some of the repetitive noodling around the interval of an augmented second. But that has become such a cliché of Middle Eastern music, real or imagined, it's hardly worth mentioning. Pigovat's Nigun is definitely his own unique creation. ${ }^{127}$ Jerry Dubins, David DeBoor Canfield

...being, in psychological terms, assailed by anxieties at an early stage in its progress, the composer using the quartet's antiphonal voicings to create a kind of overlying effect, as textures pile on top of, or slide beneath, other textures. Figurations and tempi intensify as the piece proceeds, the Dominion Quartet's players "blocking" their sounds together for some marvellously massive-sounding chords, before continuing what feels like a fraught interaction, mercifully worked-out in the time-honored manner, but leaving one or two sostenuto voices to gradually expel their last reserves of breath and melt their tones into the stillness of the ending. ${ }^{128}$ Peter Mechen

\subsection{Silent Music}

127 David DeBoor Canfield and Jerry Dubins, 'Pigovat: Nigun for string quartet', Fanfare 35/3(Jan/Feb 2012), 184-186.

128 Peter Mechen, 'Boris Pigovat's Requiem - A Stunning CD presentation', Middle C (15 September 2011). https://middle-c.org/2011/09/boris-pigovats-requiem-a-stunning-cd-presentation/ (5 November 2020). 
Silent Music is one of the works on the Atoll Record CD. Reviewers had some similar feelings about the end of this work.

Like its discmates, it has tragic undertones, appropriate given its composition to commemorate a particularly bloody terrorist attack in 1997. The piece ends with some stunning indeed, terrifying-special effects on the harp. ${ }^{129}$ David DeBoor Canfield

Silent Music is scored for viola and harp, a felicitous combination of complementary tones and timbres, one l'd never before imagined. Written in 1997, after the Requiem, the piece commemorates the practice in Israel of people lighting candles for burning at places where there have been fatal terrorist attacks, one such occasioning this piece. The music's beauty almost belies the composer's sombre intent, though towards the end of the piece some repeated agglomerations of notes on Carolyn Mills's harp grow through a disturbing crescendo towards a moment of intense pain, whose feeling resonates throughout the concluding silences. ${ }^{130}$ Peter Mechen

\subsection{Wind of Yemen}

Boris Pigovat composed Wind of Yemen for Symphonic Wind Band in 2000. It is based on traditional tunes and dance melodies of Yemenite Jews. This work includes two movements: the first movement depicts a Yemenite desert landscape, and the second movement is about the Yemenite folk celebration.

It was a challenge for Pigovat, since he had encountered Yemenite Jewish folklore for the first time. Therefore, he remembered the advice of his teacher, Yuri

\footnotetext{
129 David DeBoor Canfield, 'Pigovat: Silent Music for Viola and Harp', Fanfare 35/3 (Jan/Feb 2012), 184.

130 Peter Mechen, 'Boris Pigovat's Requiem - A Stunning CD presentation', Middle C (15 September 2011). https://middle-c.org/2011/09/boris-pigovats-requiem-a-stunning-cd-presentation/ (5 November 2020).
} 
Alexandrovich Fortunatov, when he was a young composer. Pigovat spent three months listening to a lot of recordings of Yemenite Jewish folk music in order to acquaint himself with the characteristics of its melodic and rhythmic patterns.

This work had been successfully performed many times by different orchestras all over the world. In 2000, Wind of Yemen was premiered by Michael Delman and the Petach-Tikva Conservatoire Symphonic Band. In 2003, it was performed by the Kosei Wind Orchestra, conducted by Douglas Bostock at the Asian Music Festival. It was performed in 2009 at the WASBE conference by CAM Bétera, conducted by Luis Serrano Alarcón; in 2010 in a festival in Mano, Bunol, Spain, by CIM La Armónica de Buñol (Valencia), conducted by Frank De Vuyst; in 2015 at the WASBE conference, by the National Youth Symphonic Band of Israel, conducted by Motti Miron; and in 2018 at the Singapore International Band Festival, by the Orchestra Collective of Singapore, conducted by Yibin Seow.

Tim Reynish presented a positive review on The Winds of Yemen:

I also enjoyed The Winds of Yemen by Boris Pigovat, with its evocative ethnic music. He has a superb website with details of his music, including the Song of the Sea, premiered in Carnegie hall by Murray State University Wind Ensemble conducted by Dennis Johnson. As I reported in a recent homepage, this work was a great success in its recent German premiere, conducted by Michael Kummer, and I have no doubt that The Winds of Yemen will join it as a fine example of this composer's music. ${ }^{131}$ Tim Reynish $^{132}$

\subsection{Song of the Sea}

131 Tim Reynish, WASBE 2009 Conference, July 2009. http://www.timreynish.com/conferences/wasbe-2009.php (5 November 2020).

132 Leading conductor of wind ensembles in the UK appointed to Royal Northern College of Music. 
In 2005, Boris Pigovat composed Song of the Sea for the conductor, Dennis Johnson. In the same year, this work was premiered by Johnson with the Murray State University Wind Ensemble at Carnegie Hall in New York and, later in the summer, the conductor again performed Song of the Sea at the WASBE Conference in Singapore. This work won the 2005 ACUM Prize. In 2009, Song of the Sea premiered in Germany, conducted by Michael Kummer with the Munich Academic Wind Orchestra.

Conductor Dennis Johnson ${ }^{133}$ voiced his opinions about this work:

Boris Pigovat is a bright, fresh voice in the world of wind band composition. His "Song of the Sea" is an original tone poem written for myself and the Murray State University Symphonic Wind Ensemble and was premiered in a special performance in Carnegie Hall on March 29 of 2005 . This dramatic work captures the beauty and majesty of the open sea as well as its darker and more ominous mood during a ferocious storm. The work carries the listener on a journey through calm and tempest and ends with a grandiose climax that rivals any of the great programmatic composers of this or any era. The wind ensemble and I thoroughly enjoyed the preparation and performance of this masterful work as did the exhilarated crowd in Carnegie Hall that called us back three times. "Song of the Sea" deserves to be on all collegiate and (technically proficient) high school band programs throughout the world. It is a masterpiece for wind band..$^{134}$

\subsection{Poem of Dawn}

Poem of Dawn is the other major work recorded for the Naxos CD in 2015. This CD review provides a brief analysis of Poem of Dawn in terms of Pigovat's technical

\footnotetext{
133 American mathematician and composer. Credited with composing the first truly minimal composition in 1959.

134 Reviews from Boris Pigovat's website. http://pigovat.com/wordpress/song of the sea_2005/ (5 November 2020).
} 
accomplishment on orchestration. Poem of Dawn makes a great contrast with the melancholy and passion of the Holocaust Requiem.

The celeste opens with a little motif before strings and viola enter, the viola bringing a fine melody. Together with the orchestra a fine flowing, undulating melody is developed, Serova bringing a lovely rich tone. There are hushed harmonics from the viola before the music picks up in dynamics with moments of fine instrumental detail, especially for woodwind and brass, woven into the orchestration. There are some particularly beautiful moments when the sound billows up in the orchestra in this unashamedly romantic score. Eventually the music reaches a fine romantic climax in the orchestra as dawn arrives. The viola returns as the music falls back in a beautifully orchestrated, hushed passage. As the music slowly moves forward, there is some particularly fine writing for the viola before a beautifully hushed coda with celeste, viola and orchestra. ${ }^{135}$

An Amazon reviewer from the USA showed great enthusiasm and highly recommended Pigovat's Poem of Dawn:

Oh, My God! - One Of The Most Exquisitely Beautiful Pieces Ever Written.

I am referring to Pigovat's rapturous "Poem of Dawn," which knocked my soaring soul out of its body and had me (still has me!) playing it repeatedly.

If you love the music of Claude Debussy and have found yourself swooning over Ernest Chausson's "Poeme de l'amouret de la mer," you're sure to fall irretrievably in love with this work. I even detected a slight hint here and there of the Romantic side of Nikolai Myaskovsky, plus a hidden dash (believe it or not) of Miklos Rozsa ("Thief of Bagdad"), plus a fleeting moment from James Bernard's "She" (1965), plus lots of other "can'tquite-put-my-finger-on-it" Hollywoodish film score music.

135 Bruce Reader, The Classical Reviewer (24 July 2015).

http://theclassicalreviewer.blogspot.com/2015/07/boris-pigovats-holocaust-requiem-proves.html (5 November 2020). 
This is a poignant little masterpiece that should have had its place in the concert repertoire long ago. (And don't be at all surprised if you think you're hearing the true essence of the Viola for the first time, thanks to the brilliant, sensitive playing on the part of Anna Serova.)

Please, dear listener - allow yourself to fall madly in love with Boris Pigovat's "Poem of Dawn." It's so overwhelmingly replete with the most intimate moments of unutterable joy, that the experience is almost "painful" to the soul. ${ }^{136}$

Another reviewer described this work as being quite conventional:

In contrast to the Holocaust Requiem, the "Poem of Dawn" is written in a somewhat conventional, late Romantic musical style. It captures the rise of dawn and sunlight on a peaceful day. The work opens with a light texture and gradually swells to a lavish orchestral, lush part welcoming the day. This is a beautifully textured, lyrical work. Its main interest lies in the viola solo and in Serova's lyrical and beautiful performance on her instrument. ${ }^{137}$

The reviewer David Denton ${ }^{138}$ commented:

By total contrast, the Poem of Dawn, composed for the distinguished violist and soloist on this disc, Anna Serova, is a warm natured tone poem in the Romantic tradition, its message one of love and beauty. Remembered on disc four and more decades ago, the famous Zagreb Radio Orchestra is the renamed orchestra that is providing a high impact

\footnotetext{
136 Joel Kovacik, Amazon music (19 August 2015). https://www.amazon.com/Boris-Pigovat-HolocaustRequiem-Poem/dp/BOOHHJETQS?ie=UTF8 $\& *$ Version $*=1 \& *$ entries $*=0$ ( 5 November 2020).

137 Robin Friedman, Amazon music (18 July 2015). https://www.amazon.com/Boris-Pigovat-

Holocaust-Requiem-Poem/dp/BOOHHJETQS?ie $=$ UTF8 $\& *$ Version* $* 1 \& *$ entries $*=0$ ( 5 November 2020).

138 Official reviewer for Naxos Records.
} 
Holocaust Requiem and the gorgeous sounds for the land in paradise created for the Poem. A thought provoking release much recommended. ${ }^{139}$

\subsection{Lights from the Yellow Star (Music of Sorrow and Love)}

In 2010, Pigovat wrote Lights from the Yellow Star for a commission from Matthew J. George -conductor of the University of St Thomas Symphonic Wind Ensemble. The work is based on books and paintings written by the Holocaust survivor Dr Robert $\mathrm{O}$. Fisch. It consists of five movements: Introduction, When the Stones weep, 1956, Silent Music and Song of Love and Hope. The premiere took place in Minneapolis in 2011, and Dr Fisch attended this performance. He read some excerpts from his books during each part of this composition. His paintings were demonstrated on a large screen during the performance. Matthew J. George and the University of St Thomas Symphonic Wind Ensemble later recorded this work, which was released in 2016 by the Innova label, as part of their album Persistence.

This review commented on Pigovat's various orchestration uses and their effects in different places of this work:

His use of extended solo statements - at different times by xylophone, flute, alto flute, bass clarinet - after sections of violent peroration are particularly effective in the telling of the story of a Hungarian Jewish boy's experiences in the Holocaust and the 1956 Hungarian revolt. So is his extensive use of wordless vocalise. Sadly, the painfully overwrought finale, with its now-amplified voice lifted above the waves of ecstatic brass, leaves a decidedly maudlin final impression. The boyish-sounding soprano Casey Barker, with her superb sense of pitch and line, is excellent in any case. ${ }^{140}$

\footnotetext{
139 David Denton, David's Review Corner (June 2015). https://www.naxos.com/reviews/reviewslist.asp?catalogueid=8.572729\&languageid=EN (5 November 2020).

140 Ronald E. Grames, 'PERSISTENCE: University of St. Thomas Commission Series, Vols. IV-VI', Fanfare 39/5 (May/Jun 2016), 34.
} 
This author emphasises that the Holocaust survivor - Dr Fisch, the protagonist of this work - and his life is depicted vividly by Pigovat through lyric contrast in its different parts:

Lights from the Yellow Star: Music of Sorrow and Love by Boris Pigovat is one of many works written by numerous composers in remembrance of the Holocaust. Consequently I assume that the Yellow Star of the title refers to the Stars of David that Jews in the 1930s in Nazi Germany were required to wear. Pigovat has written at least one other Holocaust work himself, a very effective Requiem that I reviewed very positively back in 35:3. In the present work, written in tribute to Holocaust survivor Dr. Robert Fisch, one hears moments of tender lyricism contrasted by martial music with strikingly somber overtones. The work also has its upbeat sections (including its optimistic conclusion), intended to depict the triumphs of Fisch's life. At 40 minutes, this is the longest work heard in this set, and is at the same time the most powerful and striking in its impact. ${ }^{141}$

This reviewer gave positive comments on a macro-scale in various parts of this work:

Again, there is a highly expressive soloist, this time Casey Barker; this is a meditation on the Holocaust, and here a wordless soprano presents a high lament against sustained low notes that speaks volumes. Pigovat invokes expanses such as Copland or Virgil Thompson might work with. If the second movement, "When the Stones Weep," is rather cinematic, it is certainly emotionally extreme. The march music of the third panel, "1956," focuses on the Communist crackdown in Hungary. It ends quietly: The control of the instrumentalists in the present performance is simply awesome. ${ }^{142}$

\subsection{Viola Sonata}

141 David DeBoor Canfield, 'PERSISTENCE: University of St. Thomas Commission Series, Vols. IV-VI', Fanfare 39/5 (May/Jun 2016), 36.

142 Colin Clarke, 'PERSISTENCE: University of St. Thomas Commission Series, Vols. IV-VI', Fanfare 39/5 (May/Jun 2016), 42. 
Boris Pigovat's Viola Sonata was written in 2010 and was dedicated to Donald Maurice. Donald Maurice has worked with Pigovat since 2007 and has performed or premiered his compositions several times, including the major viola concerto Holocaust Requiem. Maurice also gave a high evaluation of this piece, predicting it would become a well-known part of the viola repertoire, comparing it to works by Bloch, Hindemith and Clark. He commented on this work:

The middle movement was very much in the mould of the 'Dies Irae' from the requiem. It is emotionally quite overpowering at times and the intent was crystal clear from the very first read through. I knew immediately that this was one of the most challenging yet most rewarding pieces of music in the viola repertoire - in any repertoire! It is monumental...Everything Pigovat wrote is playable and generally idiomatic for the viola. Suggestions that it should be simplified or amended in any way should be ignored...The sonata is totally awe-inspiring, exquisitely beautiful and emotionally moving in the outer movements and incredibly powerful and riveting in the second movement, with a touch of pure genius in the way it ends. With more exposure, this piece has the potential to become a well-known part of the viola repertoire. ${ }^{143}$

\subsection{Therefore Choose Life}

Therefore Choose Life was a commission by the Pittsburgh Symphony Orchestra (PSO) in honor of Manfred Honeck's tenth season as a music director. The work premiered on 22 September 2017 at Heinz Hall in Pittsburgh, conducted by Manfred Honeck.

This work was inspired by a passage from Deuteronomy 30:19: "I call heaven and earth to record this day against you, that I have set before you life and death, blessing and cursing: therefore choose life, that both thou and thy seed may

143 Leah Hollingsworth, 'A Monument to Viola', Strings 30/5 (Dec 2015),30-31. 
live..."144 Pigovat says "I tried to express the feeling that life (with all its pain, suffering, and tragedies) is Beauty, Hope, Light, and Love."145

Therefore Choose Life was written as a free symphonic poem, and it has no quotes of Jewish liturgical music; only the theme of flutes and clarinets in the coda indicates the Song of Songs of morning prayers or psalms.

Mark Kanny was a classical music critic of the Pittsburgh Tribune Review from 1999 to 2016, and previously wrote for the Pittsburgh Post-Gazette, New York Times and other publications. He wrote in this article:

The 11-minute symphonic poem is meditative but well varied at slow tempos, starting with a strong statement by the strings that conveys concern and aspiration. It leads to a section expressing some of life's pains before turning to its antithesis - a beautiful and lushly scored section lifted by the light of a flute solo. Those principles alternate until the gentle ending by solo flute over a soft marimba tremolo. Pigovat's language is within a traditional context, yet personal. His orchestration is masterly in its contrast of depth, airiness, and sensitivity to texture. The new piece received a vivid performance and was well received by the audience. ${ }^{146}$

Another review by Mark Kanny about Song of the Sea in Trib Live quoted Manfred Honeck's comments on Pigovat's works and character:

144 Mark Kanny, 'Pittsburgh, Honeck Start 10th Season With A Premiere', Classical Voice North America (25 September 2017). https://classicalvoiceamerica.org/2017/09/25/pittsburgh-honeckstart-10th-season-with-a-premiere/ (5 November 2020).

145 Boris Pigovat - Interview with Xi Liu on 13 September 2019.

146 Mark Kanny, 'Pittsburgh, Honeck Start 10th Season With A Premiere', Classical Voice North America (25 September 2017). https://classicalvoiceamerica.org/2017/09/25/pittsburgh-honeckstart-10th-season-with-a-premiere/ (5 November 2020). 
When I conducted the Israel Philharmonic, I got to know him a little more and started looking at other pieces he's written ... I wanted to do more with him. So I was very happy when he agreed to write something new for this season. I think his musical language is very beautiful. It has Russian depth and enormous emotions, but he is also a very, very humble man. ${ }^{147}$

In summary, as the above reviews demonstrate, the music of Boris Pigovat has been universally praised and, while it has not been noted as being overly progressive, it has taken the styles of his immediate predecessors, especially Shostakovich, to new heights.

147 Mark Kanny, 'New Pieces Mark Manfred Honeck's 10th Season with the PSO', Trib Live (20 September 2017). https://archive.triblive.com/aande/music/new-pieces-mark-manfred-honecks10th-season-with-the-pso/ (5 November 2020). 


\section{Conclusion}

The primary aims of this research project were to create a more comprehensive account of Boris Pigovat's life and career than has previously been available, to investigate his compositions which feature the viola, to review how his music has been received and to make his Holocaust Requiem accessible to a wider audience by a creating a documentary film. The methodologies employed for the five parts of the thesis enabled each to be thoroughly examined and presented to the musicalogical community and I believe have made an original and significant contribution to the body of knowledge about this composer and his music.

Part One offers a new biography, which has greatly increased the information available about Boris Pigovat's life, such as his early enthusiasm for playing the piano; information about the teachers who influenced him; why he and his wife moved to Tajikistan and worked there for three years; the several stages he experienced after arriving in Israel - from "finding himself" to his current career situation; information about the education system in Israel; the significance that the second movement of Holocaust Requiem was composed while he was working in a kibbutz in Israel; and important performances of compositions by him. The existing biographical information about Boris Pigovat was related mainly to his career and compositions.

Part Two-Repertoire and Influences consists of recitals including all the works by Pigovat featuring the viola, juxtaposed with selected works by other composers who have arguably influenced him. These performances are available through links to the videos. The notes about these performances discuss his creative background. It includes complementary repertoire selection and how the selected composers may have influenced him. The composer himself identifies Bach and Rachmaninoff as direct influences, and, while he may not readily acknowledge Shostakovich, he in my 
opinion played a major role in the essence of the music and motivation of Boris Pigovat. The influence of Bartók, Bloch, Glinka and Hindemith is more tenuous and it is suggested that Pigovat would have familiarised himself with the works they wrote for viola while preparing his score for Holocaust Requiem.

In Part Three -Viola Sonata, Bach and his Violin Partita No. 2 are discussed initially, since the last three bars of second movement of the sonata are quoted from this work. The genesis and performance history describe how Pigovat works with musicians when discussing the creation of a new composition. In the interview with Pigovat, he discussed aspects of structure. My discussion of the first movement is based on the information provided by Pigovat regarding the themes and transitions and how they create an overarching structure. The second movement is presented in a table format, which clearly represents the development of the Bach theme into a set of fourteen variations. The final movement functions as an epilogue to the complete sonata, and the discussion of it is drawn from information supplied by the composer. Part Three concludes with a discussion placing the sonata into the context of this genre by identifying its principal composers before the twentieth century, and some of Pigovat's immediate predecessors and contemporaries.

Part Four-Holocaust Requiem is the central component of this thesis and comprises four components. "Genesis" provides the history of this composition including several preparatory stages. "Composition" presents Pigovat's aims and intentions in composing this work, its musical style and the story conveyed in each movement. "Performance history" provides information about four live performances and three recordings. "Documentary film" is the major contribution to the whole thesis, and discusses the objectives and process of making the film.

Part Five - Reception reviews the reaction of music critics of live performances and recordings. My research has only found reviews of ten of Pigovat's works: 
Light from the Yellow Star, Nigun, Poem of Dawn, Prayer, Holocaust Requiem, Silent of Music, Song of the Sea, Therefore Choose Life, Viola Sonata and Winds of Yemen.

This research project has contributed significantly to the body of knowledge about the life and music of Israeli composer, Boris Pigovat. It provides a solid base for future scholars to explore the wider repertoire through the lens of analysis, performance, recording, performance history and the background of individual works, and a deeper appreciation of this composer's interpretation of history, belief systems and philosophy of life, and how he endeavours to portray these elements through music. 


\section{Bibliography}

\section{Books}

Böhme, Franz. Altdeutsches Liederbuch. Hildesheim: G. Olms, 1966.

Brown, David. Mikhail Glinka: A Biographical and Critical Study. London: Oxford University Press, 1974.

Chalmers, Kenneth. Béla Bartók. London: Phaidon Press, 1995.

Fay, Laurel. Shostakovich: A life. New York: Oxford University Press, 2005.

Gillies, Malcolm. Bartók Connections: A Guide for Performers and Programmers. New York: Boosey \& Hawkes, 2007.

Grove, George. The New Grove Dictionary of Music and Musicians. Macmillan, 1980.

Hindemith, Paul. Der Schwanendreher. London: Ernst Eulenburg; Mainz: B. Schott'sSöhne, 1985.

Ivashkin, Alexander \&Kirkman, A. Contemplating Shostakovich: Life, Music and Dilm. New York: Routledge, 2016.

Kushner, David. Ernest Bloch: A Guide to Research. New York: Garland, 1988.

Lesser, Wendy. Music for Silenced Voices: Shostakovich and His Fifteen Quartets. New Haven: Yale University Press, 2014. 
Maurice, Donald. Bartok's Viola Concerto: The Remarkable Story of his Swansong.

Oxford: Oxford University Press, 2004.

Norris, Geoffrey. Rachmaninoff. New York: Oxford University Press, 2001.

Orlova, Alexandra. Glinka's Life in Music: A Chronicle. Ann Arbor: UMI Research Press, 1988.

Schubert, Giselher. Preface to Der Schwanendreher. London: Ernst Eulenburg; Mainz:

B. Schott's Söhne, 1985.

Shostakovich, Dimitri \& Glikman, I. Story of a Friendship: The Letters of Dmitry Shostakovich to IsaakGlikman. Translator: Anthony Phillips. London: Faber, 2001.

Skelton, Geoffrey. Paul Hindemith: The Man Behind the Music: A Biography. London: Gollancz, 1975.

Steinberg, Michael. The Concerto: A Listener's Guide. Washington, DC: National Library Service for the Blind and Physically Handicapped, Library of Congress, 2010.

Volkov, Solomon. Testimony: The Memoirs of Dimitri Shostakovich. London: Hamish Hamilton, 1979.

Wilson, Elizabeth. Shostakovich: A Life Remembered. London: Faber, 1994.

\section{Articles}

Bloom, Cecil. 'Dmitri Shostakovich and the Jews'. Midstream 52/5 (SeptemberOctober 2006). 
Canfield, David DeBoor. 'PERSISTENCE: University of St. Thomas Commission Series'. Fanfare 39/5 (May/Jun 2016), 32-44.

Canfield, David DeBoor. 'PIGOVAT: Requiem, "The Holocaust" for viola and orchestra'. Fanfare 35/3 (Jan/Feb 2012), 183.

Canfield, David DeBoor. 'PIGOVAT: Silent Music for viola and harp'. Fanfare 35/3 (Jan/Feb 2012), 184.

Clarke, Colin. 'PERSISTENCE: University of St. Thomas Commission Series'. Fanfare 39/5 (May/Jun 2016), 40-42.

Dubins, Jerry. 'On a Requiem of Remembrance - A Conversation with Composer Boris Pigovat'. Fanfare 35/3 (Jan/Feb 2012), 180-183.

Dubins, Jerry. 'PIGOVAT: Requiem, "The Holocaust" for viola and orchestra'. Fanfare 35/3 (Jan/Feb 2012), 185-186.

Gerstel, Jennifer. 'Irony, Deception, and Political Culture in the Works of Dmitri Shostakovich'. Mosaic (Winnipeg) 32/4 (December 1999).

Grames, Ronald E. 'PERSISTENCE: University of St. Thomas Commission Series'. Fanfare 39/5 (May/Jun 2016), 32-34.

Hollingsworth, Leah. 'A Monument to Viola'. Strings30/5 (1 Dec 2015), 30-31.

Pounds, Dwight. 'Boris Pigovat: Requiem "The Holocaust" for Solo Viola and Orchestra [Recording Review]'. Atoll ACD27/1 (2011), 68. 
Wilson, Roger. 'Rest eternal'. New Zealand Listener (Online) 216/3576 (2008), 47.

\section{Reviews}

Button, John. 'Taddei's interpretation delights'. The Dominion Post (11 November 2008) <http://www.pigovat.com/reviews/Requiem-Review-NZ-2008.png>. 3 November 2020.

Denton, David. 'PIGOVAT, B.: Requiem, "The Holocaust" / Poem of Dawn (Serova, Croatian Radio and Television Symphony Orchestra, Guerini)'. David's Review Corner (June 2015)

<https://www.naxos.com/reviews/reviewslist.asp?catalogueid=8.572729\&languagei $\underline{d=E N>} .5$ November 2020.

Franck, Remy. 'PIGOVAT, B.: Requiem, "The Holocaust" / Poem of Dawn (Serova, Croatian Radio and Television Symphony Orchestra, Guerini)'. Pizzicato (October 2015)

<https://www.naxos.com/reviews/reviewslist.asp?catalogueid=8.572729\&languagei $\underline{d=E N>} .5$ November 2020.

Kanny, Mark. 'New Pieces Mark Manfred Honeck's 10th Season with the PSO'. Trib Live (20 September 2017) <https://archive.triblive.com/aande/music/new-piecesmark-manfred-honecks-10th-season-with-the-pso/>. 5 November 2020.

Kanny, Mark. 'Pittsburgh, Honeck Start 10th Season With A Premiere'. Classical Voice North America (25 September 2017)

<https://classicalvoiceamerica.org/2017/09/25/pittsburgh-honeck-start-10thseason-with-a-premiere/>. 5 November 2020. 
McQuiston, Bob. 'Pigovat: Holocaust Requiem, Poem of Dawn;

Serova/Guerini/CroatR \& TV SO [Naxos] RECOMMENDED BEST FIND (1 CD)'. Classical

Lost and Found (August 2015)

<https://www.clofo.com/Newsletters/C150831.htm\#P150828>. 24 October 2020.

Mechen, Peter. 'Boris Pigovat's Requiem - A Stunning CD Presentation'. Middle C (15 September 2011) < https://middle-c.org/2011/09/boris-pigovats-requiem-a-

stunning-cd-presentation/>. 24 October 2020.

Polishchuk, Tetiana. 'Music of Sorrow and Hope'. The Day (9 October 2001)

<https://day.kyiv.ua/en/article/culture/music-sorrow-and-hope>. 3 November 2020.

Reader, Bruce. 'Boris Pigovat's Holocaust Requiem Proves to be a Magnificent Work of Depth and High Emotion in a New Performance on Naxos by Violist Anna Serova with the Croatian Radio and Television Symphony Orchestra Conducted by Nicola Guerini'. Naxos CD (24 July 2015)

<http://theclassicalreviewer.blogspot.com/2015/07/boris-pigovats-holocaustrequiem-proves.html>. 21 November 2020.

Reynish, Tim. 'WASBE 2009 Conference'. TimReynish (July 2009)

<http://www.timreynish.com/conferences/wasbe-2009.php>. 5 November 2020.

Smith, Howard. 'Rare Provenance Kristallnacht Remembered'. Classical Music Daily (13 November 2008).

<http://www.mvdaily.com/articles/2008/11/kristallnacht.htm>. 3 November 2020.

Wilshire, Garth. 'Moving Music'. Capital Times (December2008).

<http://www.pigovat.com/reviews/CapTimes-Requiem-NZ-2008.pdf>. 3 November 2020. 
CD and Concert notes

Boston Symphony Orchestra. 'Ernest Bloch Suite for viola and piano'.

<https://cdm15982.contentdm.oclc.org/digital/collection/PROG/id/320197>. 19

October 2020.

SF Symphony. 'Rachmaninoff: Vocalise'. <https://www.sfsymphony.org/Data/EventData/Program-Notes/R/Vocalise>. 25 October 2020.

Utah Symphony. 'Rachmaninoff - Vocalise, Op. 34, No. 14'.

<https://utahsymphony.org/explore/2019/03/rachmaninoff-vocalise-op-34-no-14/>. 25 October 2020.

Naxos CD. 'Anna Serova'.

<https://www.naxos.com/person/Anna_Serova/222177.htm>. 25 October 2020.

\section{Websites, Blogs and Social Media}

Belcanto. 'Mikhail Ivanovich Glinka'. <https://www.belcanto.ru/glinka.html>. 31 October 2020.

Bio. 'Donald Maurice'. <https://www.donaldmaurice.org/bio>. 5 November 2020.

Boris Pigovat's website. <http://pigovat.com/wordpress/>. 25 October 2020.

Brusky, Paula. 'Glinka Sonata'. <https://paulabrusky.com/program-notes/notes-

glinka-sonata>. 25 October 2020. 
Camerata Louis Spohr. 'Bernd Peter Fugelsang, conductor'.

<https://translate.google.co.nz/translate?hl=en\&sl=de\&u=http://camerataduesseldorf.de/der-kuenstlerische-leiter/\&prev=search\&pto=aue>. 27 November 2020.

Conciliation Resources. 'The Tajik civil war: Causes and dynamics'. <https://www.c-r.org/accord/tajikistan/tajik-civil-war-causes-and-dynamics>. 25 October 2020.

Friedman, Robin. Amazon music. <https://www.amazon.com/Boris-PigovatHolocaust-Requiem-Poem/dp/B0OHHJETQS?ie=UTF8\&*Version $*=1 \& *$ entries $*=0>.5$ November 2020.

Kovacik, Joel. Amazon music. < $\underline{\text { https://www.amazon.com/Boris-Pigovat-Holocaust- }}$ Requiem-Poem/dp/B00HHJETQS?ie=UTF8\&*Version*=1\&*entries*=0>. 5 November 2020.

Music and the Holocaust. 'Béla Bartók (1881-1945)'.

<http://holocaustmusic.ort.org/resistance-and-exile/bela-bartok/>. 25 October 2020.

Pounds, Dwight. Amazon music. <https://www.amazon.com/Boris-PigovatHolocaust-Requiem-Poem/dp/B00HHJETQS?ie=UTF8\&*Version* $=1 \& *$ entries $*=0>.5$ November 2020.

SOUNZ. 'In Remembrance - facing conflicts through music'. <https://sounz.org.nz/events/2203>. 27 November 2020. 
SuperInf. 'Compositions of Mikhail Ivanovich Glinka'.

<https://superinf.ru/view helpstud.php?id=305>. 31 October 2020.

Wikipedia. 'List of violists'. <https://en.m.wikipedia.org/wiki/List of violists>. 5 November 2020.

\section{Primary sources}

Score Sonata for viola and piano

Score Holocaust Requiem

Unpublished recordings:

Holocaust Requiem recording with Rainer Moog of the 2001 performance.

Unpublished photos:

Photo 2.1 Anna Serova with Nicolai Guerini

Photo 2.2 Holocaust Requiem and Poem of Dawn

Photo 2.3 Anna Serova with the New Zealand Symphony Orchestra

Photo 2.4 The Holocaust Requiem CD was awarded the Supersonic Award

Photo 3.1 Donald Maurice and Wioletta Fluda, World premiere in Krakow, 2013

(Left)

Atoll CD including premiere recording of Sonata for viola and piano in 2012 (Right)

Photo 4.1 Score of Holocaust Requiem

Photo 4.2 Roman Kofman

Photo 4.3 Donald Maurice with Vector Wellington Orchestra

Photo 4.4 Donald Maurice with Duesseldorf-based Camerata Louis Spohr

Photo 4.5 Tatjana Mead Chamis and Manfred Honeck with Pittsburgh Symphony

Orchestra 
Personal letters and emails between Boris Pigovat and Donald Maurice, between Donald Maurice and Dwight Pounds, and between Boris Pigovat and Xi Liu. 


\section{Appendix 1}

The full transcript of interview with Boris Pigovat about his life and career

Xi Liu: Please tell about your family and the careers they have pursued?

Boris Pigovat: My father graduated from an institute as a textile-processing engineer in a fabric manufacturing and worked at the Cloth Factory in Odessa before the War. When the Finland War began in 1939, he was drafted into the army and he remained in the army until 1949. That is from 1939 to the 1949, ten years he was in the army. He began to be as a soldier, then a junior officer, and he finished his service (after the war) with the rank of major.

After 1949, he was demobilized from the army and returned to work at a Cloth Factory in Odessa. He continued to work as a foreman, then a shift supervisor, a workshop superintendent, a production superintendent. He grew up as a specialty in his career at the Odessa Cloth Factory.

Mom studied as a doctor, she graduated from a medical school, and then worked as a doctor.

After they met in Orenburg in 1949, they got married. Mom came with dad to Odessa, where she worked as a doctor.

Xi Liu: Where did your grandparents' come from, birth and death?

Boris Pigovat: Regarding where they were born, for me it's hard to tell. There are no documents, I do not know. I know that my father's parents lived in NovogradVolynsk, it is a city in Ukraine and it is not far from Kyiv. They both lived in Kyiv, and they died on the first day of Babi Yar executions in Kyiv on September 29, 1941 when Germans began the executions in Babi Yar, then both my father's parents and his younger sister were killed. 
As for my mother's parents, they are generally Jews from Poland (Polish Jews), and I don't know how they got to the Urals and Orenburg. Orenburg is a city near the Urals, in the center of Russia. They lived there for a very long time, and as far as I know they died in Orenburg as well. This is what all I know about my grandparents.

Xi Liu: What was your grandparents' musical background?

Boris Pigovat: They had no musical education. My grandfather was a shoemaker, and he made and repaired shoes. He was a craftsman - a shoemaker. This is father's father. My mother's father was a locksmith, he worked with metal. Their wives were housewives, and they did not have a specialty. They raised children, and kept the household. But according to the stories of my father, I know that his father was a cantor in the synagogue. He sang in the synagogue, and he conducted religious services.

Through my mother's side, I know that my grandmother liked the Ukrainian operas very much. What she heard in her life, she sang with pleasure. When I started playing the piano, I accompanied for her. She absolutely did not know notes or musical notation. She knew nothing but she really loved the music and sang it. The enthusiasm towards music was apparently inherited. In any case, my mother's brother first received a different specialty. He was very interested in music and he played the accordion. He studied and became a conductor, and he worked all his life as a choral conductor.

Therefore, I had some musical impressions since I was a child. I don't remember it myself, but my mother later told me: when I was 4 years old, I became and started waving my arms, and said that I wanted to be a conductor like my uncle. There was some kind of influence. But it is not true to say that my grandfathers and grandmothers had the musical education. 
Xi Liu: Your grandparents may live under the revolution of the czar, big changes might happen. How did your grandparents live through under the revolution of the czar?

Boris Pigovat: I can't say anything, I don't know. I just don't know, and I can't answer this question.

Xi Liu: Where did your parent meet each other?

Boris Pigovat: Just after the war in 1949, my dad came on vacation to visit relatives in Orenburg, and my mother lived in Orenburg.

I was born in Odessa (where my parents later worked) in 1953. In generally, Odessa is a city famous for its musical traditions and good performing schools, above all - a violin school. It has the famous school named after Peter Solomonovich Stolyarsky, which David Oistrakh, Boris Holstein, Nathan Milstein, Samuel Furer and Mikhail Fichtenholtz studied from. They are all Stolyarsky's students, and he was a student of Auer - the famous violinist of the Tsarist era. There was also a good vocal school and a good piano school. That is, Odessa was a city of musical traditions. However I did not have a special relationship with these traditions, since I am not a hereditary Odessa citizen. My parents came to Odessa, but they were not born in Odessa.

Xi Liu: How old were you when you first became involved in music and what sort of music did you like at that time?

Boris Pigovat: It's hard for me to say how old I was when I first came across music. If say that I already wanted to conduct when I was 4 or 5 year-old, then I already had listened to some music.

I don't remember now, I can't say. I know that when I entered the music school I played the piano, but they told me that I had good ears for the violin. Everyone knew that it's harder to study on the violin than on the piano. So I was sent to study on the 
violin, and I loved the piano. What kind of music did I like? While I was in music school, I really loved Rachmaninoff. I was interested in everything about Rachmaninoff. They even laughed at me a little, because I hung a huge poster of Rachmaninoff on the wall at home with his biography and photographs. I was a big fan of Rachmaninoff, and I loved his music very much.

Xi Liu: What instrument(s) did you play in your early childhood?

Boris Pigovat: Actually I have answered this question, I was taught the violin, but I always wanted to play the piano. I had a piano at home, and my elder sister studied piano at the same school with me. What she did on the piano I hear, and the piano always attracted me.

How did I study on playing the violin? We had to study at home constantly, but I was not interested. I took a book, put it on the music stand and started to play the violin. I read Dumas or something else, some kind of adventure, something that interested me, and pretended to be playing. Neither mom nor dad had a musical education, they did not know what I played. They know that I should play, and what I play is not important. As a result, everyone was happy, and I read what I wanted.

I really loved the piano and I always wanted to play the piano, a craving for this instrument. But in fact, had being studied the violin for 7 years gives me a lot in terms of understanding this instrument. I can feel the best way to write for the violin. I feel better to write for the viola, because these are related instruments. People ask me why can I write for viola? Because even when I write, I kind of hear this instrument, and I can "feel" this instrument, I can imagine how to do it. 
Of course it happened that I wrote very uncomfortable things, they told me and I changed, I listened to the performers. When Donald or Anna Serova asked me to change something, I will listen to them. This (learning the violin) gave me a lot, I feel this string instrument, and it helps me a lot.

Xi Liu: Was there any family member engaged in music?

Boris Pigovat: Firstly, my uncle was a musician, and I had an older sister who studied the piano at a music school, so I heard everything what she did as she did. It was all on my ears, and it also pushed me to want to practice the piano.

Xi Liu: Who taught you piano at the various stages of learning?

Boris Pigovat: I had a good teacher in the music school, and her name was Olga Alexandrovna Chichkina. I had different teachers, can I say that only she gave me an amazing feeling of the piano, understanding of the piano. After two and a half years I already at the Gnessin school, I was fortunate enough to study with Alla Andreevna Kollegaeva. She was a student of Feinberg, and she was a pianist with a great future. However, because of an accident she had to interrupt her career as a piano soloist and do only teaching. In addition to being an excellent pianist, she perfectly knew literature and painting.

When I arrived from Odessa to Moscow, I was a provincial. I was from Odessa, and not from the center of Odessa, but from the outskirts Slobodka. Alla Andreyevna taught me a lot. She instilled in me a taste for painting and literature. She had a perception to the music very well. I showed her my first compositions. She was a great critic, and she did not mercy if it was necessary to say that was bad, it was not interesting that something had not worked out there. She always said that. But I am 
very grateful to her, she taught me how to have a feeling for the music and the piano, and understand how to write for the piano.

Xi Liu: Do you still perform piano and what other instruments can you play?

Boris Pigovat: In principle, I do not perform in concerts. I use the piano only to compose. I belong to the composers who should hear what they do. And even if I hear something in my head, I can feel that some thoughts coming out, some musical ideas, even some melodic images, melodic formulas and so on. I still need this feeling on the instrument. In addition, I tune in to compose for an instrument - I improvise in the mood that I need to work on some compositions. Since when the work begins, it is not always comes out the musical material. If there is a mood that I can imagine what I want to write, but no musical materials coming out yet, and in this case I would sitten down at the piano improvising a bit, and the sound of the instrument helps me. It somehow guides me, and suddenly the musical material appears. What's more, I can work with the piano in different tones. I have an instrument that gives me the opportunity to listen to the sound of any instruments of the orchestra. The sound of piano gives me a certain power for creativity. I play the piano to improvise in my boring mood, and suddenly somehow I feel that it has gone. That is, the creative process has begun. Then it begins the "black", hard work of the composer, but the piano gives me an initial impulse.

Xi Liu: At what age did you start composing, were you self-taught at first, when did you first have composition lessons?

Boris Pigovat: I was lucky in my life in the sense that the director was a very initiative person in our school of music. He really wanted to promote children's music education in every possible way, and he invited a composition teacher to the music school. He invited Igor Mitrokhin from the Odessa Conservatory, a teacher of 
harmony who taught composition in our country. We wrote some small pieces, variations, and so on.

I wrote one piece entitled "Spring" for violin and piano and sent it to the AllUkrainian contest of children's creativity. I have already graduated from this music school and have entered the Gnesinsky College, and I was informed that this piece received the second prize at the All-Ukrainian competition. I did not remember this piece at all. The real first works, which I consider to be my own works among the many ones I already wrote at Gnessin, are two works that were later published (when I became an "adult" composer). One is the Exupery Suite for piano "The Little Prince" (it was published by SUPRAPHON in the Czech Republic), and the other is the Sonata Ballad for piano, which was published in Moscow. These works were published when I already studied at the Gnessin Institute, and also was a member of the Union of Composers.

Although these are the very first works, I recognize them as my works and not just as student works.

Xi Liu: Which years did you live and study in Moscow?

Boris Pigovat: I entered in the Gnessin School of Music in 1969. I studied there for four years from 1969 to 1973, in 1973 I entered the Gnesins Institute and studied there until 1978. In 1978, I graduated from the Gnessin Institute and went to work in Tajikistan, but I still came to Moscow because I went to the graduate school there. In the Soviet Union, composers called it "assistant-internship". This is what you are doing with Donald right now. What the assistant-internship was called for performers and composers is actually "toarshlish" (Hebrew- translation: a third degree), a doctor. As a doctor for the composer, that is, without writing a dissertation, without a thesis (musicological work), he or she only writes works and passes all sorts of exams - with the writing of his works. And for the performers, it is to play concerts. Musicologists should write a dissertation, a musicological research. 
This was so called "graduate school." We called it "assistant-internship" and I studied it from 1983 to 1986.

Xi Liu: What was the approach to teaching composition in Moscow?

Boris Pigovat: The approach was not special. That is, there were general requirements: for example, in the first year at the institute or the conservatory he or she must be able to write small forms, in the second year he or she must be able to write a sonata, in the third year, he or she must be able to write a work for a chamber ensemble, and so on. He or she finishes necessary training with an orchestral composition. That is, the farther the harder. These were general requirements for the program training. However, in reality, everything depended on the teachers. Each teacher acted in accordance with his style, with his own feeling, with the school that he himself had received at one time.

There were two main types of teachers, maybe even three. Some teachers thought that the more the student writes, and the better results the student obtained. The student will gain writing experience, and everything he or she writes is all good. That is because if he or she is a talented person, his talent will show itself in the end. He or she writes a lot of works and will obtain the composition's techniques, and nothing will limit him or her.

Other teachers said that the student should be mastered at different techniques and different styles. They must be able to write in the classical style, must be able to write in the system of the new Viennese school, must also know the newest trends (directions), the newest techniques and be able to work in any of these techniques.

There were such teachers as my teacher (deceased) Nikolai Ivanovich Peyko. He believed that it was necessary to teach the student to find genuine musical grains, to give up something from what has been already written so that what remains is truly worthy to be called music. This should be a work that "captures" the listeners and 
performers, a work that will be interesting to play and listen to. This should be a work in which there are no "extra notes", there is nothing interfering. The work must be built in its drama, and therefore it is very important to be able to build a form. He taught, and sometimes taught very hard to be able to refuse what has been already written.

An article is published about an interview in the book "Processes of Musical Creativity", I give two examples. In my first year studing with him, when I proudly brought a finished piece for piano to him, he marked the first five bars and said that these five bars were worthy of working on them, and told me to drop everything else.

Only left the first five bars from the whole work!! It also happened that he took the composition to the places, where the composition was played inside the Gnessin Institute, it was also performed at other concerts, then it is performed at the AllUnion Festival of Young Composers, and even after that he said to me: "Do you know here the second part is superfluous." This composition is a string quartet, and the quartet has four movements.

I was pleased to write good music, but at the same time I felt that in general something turned out to be a bit much and bulky. I could not throw away the whole part! It was painful! And he said: "Throw it away!"

I trusted him unconditionally, he said to remove and I removed. Although it hurt, it was hard. A year later, I realized that he was right. The work got better without this part, though I was so pleased with this part! I thought it worked out well, but without it, the whole work turned out better. This is one of the most important lessons that I learned from him - you need to be able to refuse the good one in order to get the better one. 
Xi Liu: What was your experience in school life - social, sports, academic subjects, music?

Boris Pigovat: As for sports, I immediately "remove" this question. I am not a sports person at all, and I've never been involved in sports from my childhood.

As for social life, I was not a "social activist". I did not aspire to be an organizer, and I did not aspire to be in the center among friends. Somehow I was always a bit individualistic.

I had a few friends, but we were very good friends. It was a circle of communication that I always appreciated. It was what we were obliged to take an active part in social life because of the Communist Party of the Soviet Union at that time. We had to go to demonstrations and take part in some events. We had to do this in order to continue to study, but at the same time I did not aspire to be an "activist".

In music, I tried to get the best of what musical impressions could be obtained in Moscow. I went to concerts in the Great Hall of the Conservatory, I tried to get tickets of the guest performers who came in Moscow and it was called "Break Through", we stood in line at night for tickets of concerts or performances by visiting famous artists - students took turns replacing each other and stood in line. For example, the Stockholm Opera (Sweden) came, brought the "Nibelungen Ring". When I was a freshman and just arrived in Moscow, I accidentally got to the performance "Tristan and Isolde", which was brought by the Vienna Opera. It was something phenomenal! I listened to many wonderful performers' interpretations. I listened to beautiful orchestras - the New York orchestra came, the London orchestra came, the Paris orchestra came, the Concertgebouw orchestra came from Amsterdam. It was the golden time for music in Moscow. Therefore, I tried to get the maximum of what I could get to absorb the maximum of impressions.

Xi Liu: Do you have brothers and sisters? Are you the youngest or the oldest? 
Boris Pigovat: I am the youngest, and I have only one elder sister. Just as I said that she studied at a music school, and now she lives in Los Angeles.

Xi Liu: What is the original meaning of your name?

Boris Pigovat: I have not known about the origin meaning of my surname for a long time, and it was very interesting. When I first arrived in Israel I lived in a kibbutz, and there was one woman who was a native of Poland. She said that my surname Pigovat is a surname that comes from the Polish word piegowaty. In English, it is the word "freckled" (on the face).

It was interesting to me when I was first told about this, but I have not found out it for sure for a long time. Using Google I found it turned out that "freckled" was "piegowaty" in Polish. This means that one of the ancestors was with freckles. So that is how I found out the origin meaning of my surname.

Xi Liu: Ukraine became independent in 1991. What was the life and music like in Ukraine in 1960 ? Do you identify yourself as being Ukrainian or Russian or both? Do you have a bad feeling about Ukraine or Russia? Do you go to Ukraine or Russia now or not visit anymore?

Boris Pigovat: I can start from the last question. I don't go either to Ukraine or to Russia. I was in Russia in 2008, and in Ukraine I would have been at the premiere of Requiem in 2001, because there was a performance of Requiem in Kyiv on the 60th anniversary of Babi Yar. The Requiem premiere was there, and this disc that I gave you is just a record from there, from the premiere in Kiev. That is, I was there before, now I do not go there. I have no bad feelings either in relation to Ukraine or in relation to Russia, because they gave me a lot: I was born there, I lived there, I studied there, and I got an excellent composer education there. In fact, Ukraine is my childhood, and I received the composer education in Russia. I studied with the 
best teachers, and I am very grateful to Russia for this. I became a composer there, in fact.

And what Ukraine was like in the 60s - I can say little about this from the point of view of musical life, because I was a schoolboy, and I studied at a music school. Well, I remember that I had a subscription to the Odessa Philharmonic, and there I listened to Rachmaninov's Second Concert and the Scheherazade of RimskyKorsakov. As a student when I was the age of 13 or 14 , these were very vivid impressions. In my opinion, the cultural life was at a good level by that time. What happened in Moscow was nothing to compare with, as I said there had great performers.

Xi Liu: What was your experience in learning about politics and religion?

Boris Pigovat: In principle, about politics I'm not a fan of politics, and I stay away from politics. As for the religion, I am a believer, but not orthodox.

If there is a question about my attitude to religion, in this sense I am a believer that is God who created us all and who rules us. We continue to live on our own, this is our choice. What we want, we do so.

Xi Liu: How did you meet your wife?

Boris Pigovat: I entered the Gnesins Institute in 1973, and my wife entered the Gnesins Institute the same year. I studied at the composer department, and she studied at the theoretical department - musicology. In fact, we attended the same classes, and we studied together. After two years, we decided to get married. We started to study in 1973, and we got married in the summer of 1975. After we graduated, we went to work in Tajikistan. Zoya (my wife's name) is from Tajikistan, and we were assigned to work there. In the Soviet Union, such a system existed: we studied for free, we did not pay for the tuition, but we were obliged to work at least three years in the place where the state sent us. All graduates were assigned to 
different places of work. We were assigned to the city where Zoya came from, the capital city of Tajikistan - Dushanbe. From 1978 to 1990, we worked in Dushanbe.

Xi Liu: Was the whole process of immigrating to Israel complicated or easy? How long did it take? How long did you have to live in Israel before you became a citizen?

Boris Pigovat: I quickly answer the last question. The moment I got off the plane, I received citizenship. In Israel, this is it: a Jew who comes back to Israel, he immediately becomes a citizen. That is, you do not have to wait for anything. I left the plane as an Israeli citizen.

The process of getting used to the new reality is quite complicated here. But the fact is that Israel is a country of immigrants. And any wave of immigration goes through this: At first - a very complex process of "finding" oneself in a new country or in a new situation. A person decides what is more important for him - to find a job in his specialty, and to keep his specialty, or to forget about everything and only think that he needs to give a good future to children and go to work for any jobs, and does not try to do his own profession.

In any case, everyone has the same thing at the very beginning. All are taken for any works. When I arrived in Israel, we went to a kibbutz. My wife worked for caring for the elderly in a kibbutz nursing home. She is a musician, and she is also with higher education like me. She worked to care for the elderly, and I worked in a shoe factory. I molded equestrian boots. And this work - it had been almost two years before I slowly (little by little) began to work in my specialty - some music lessons. Both Zoya and I strove to stay in our specialty. We knew that this was temporary, and this was a temporary work. It will be difficult, but it must be overcome. We did it. Quietly, little by little, and everything worked out. Everything worked out, both her work and mine. Here the most interesting - I began to compose while I was still working at a shoe factory. I began to write the Requiem in a kibbutz. That is, it turned out like this - I already started working as a musician, but my earnings were small, very small, and 
in the summer I agreed that I would come to the kibbutz and work in the kibbutz again. In 1994, the critical situation was such that I had to go to a kibbutz to work in the summer, there was a room with a piano, and after the work shift I went there and wrote "Dies Irae". That is, I wrote the second movement of the Requiem in a kibbutz.

So in principle, everything was fine, everything was aligned, and everything worked out. But at first it was difficult, yes, I agree.

Xi Liu: What is the life now in Israel? Relax or tense? How is your current job going (in a high school)? How do you balance writing music for children and music for professionals?

Boris Pigovat: We do not have a quiet life, our life is always intense. In Israel, they say that you can only plan before lunch time. You never know what will happen in a few hours. Therefore, we are all getting used to it. If there is a calm day, it is very good. You can never know what will happen tomorrow, and what will happen the day after tomorrow. There can be always some surprises. Therefore, we can say that we have a calm, stressful life. That is, it is tense with us, but we are used to it, and we take it calmly. It is quiet now, right? Now there are no explosions, no bombs.

Xi Liu: And other difficulties?

Boris: Well, life here is always quite complicated, but the question is whether choose a quiet life or a busy one. A person never knows what awaits him in the near future.

In the sense of creativity, I am very pleased with my life in Israel, because I began to write differently here. My composition style somehow suddenly changed, and I feel that there is some kind of special energy in this country. There is a special energy that affects creativity. 
Regarding how do I balance writing music for children and music for professionals. Well, firstly, I do not write for children. I wrote "Nigun" for string orchestra in the first version for my children's orchestra. I wrote it in seven days, in a week. It was played with a children's orchestra for the first time. Then it was played by several professional chamber orchestras in Israel, and then it was played by chamber orchestras of other countries. Then I arranged a version for viola solo that Scott Slapin and Tatjana Mead Chamis recorded it. I arranged a version for violin, and it will be performed in Hamburg at the festival in a month. I arranged a version for cello at the request of Inbal Meggido.

Under the request of Donald Maurice, I arranged a version for the quartet, and then I arranged a version for the quartet of violas - that you should play. Now yesterday I did a rehearsal with my children's orchestra - reading "Nigun", and they tried to play it. That is, I never make a discount on the fact that this is a children's orchestra. I don't make discounts on the fact that these are children - in terms of the nature of music and ease of perception. It is another matter when I write for a professional orchestra, there may be works much larger, larger in size, everything can be more complicated there. But for children, I don't just write, I write for them as if they were adults, but the level of ownership of the instrument is much lower.

Xi Liu: Do you conduct choirs or the orchestra or do chamber music?

Boris Pigovat: I work with a children's string orchestra, or rather, this is a chamber orchestra, because I am adding a little wind instruments there now. I have been doing this since 1993.

For me, this children's orchestra is my "laboratory". That is, I check everything there, since when I immediately get the sound, I understand what kind of character is needed there. If something sounds not right as I would not like, I immediately change and do what I need at this point. This is a laboratory, which is for testing compositions. 
Xi Liu: What sort of music do the children usually do? Do you work on like Brahms or Beethoven as well?

Boris Pigovat: We play all kinds of music. Since I know the capabilities of my children in this orchestra, I have to process the works for this specific orchestra. Now, let's say, I do not have violas in the string orchestra, and I have to make replacement parts or make a clarinet instead of a viola, or add in the third violin. These are changes regarding the scores of the orchestra. In terms of repertoires, last year, we played the first movement of the concerto for bassoon and symphony orchestra by K.M. Weber, movements from Mozart's Piano Concertos, and we played compositions by Bach and Haydn. At the same time, I took the Libestraum List (the beginning is played), and left the piano part unchanged coming up with the accompaniment of the orchestra to this piano part. We play music - something called classi-pop, such as "Bemylove" (N.Brodszky) (the fragment is played), and there is more in that style. We play Israeli music, and besides, for example, I did "Polka" for Schnittke for Anna Serova, which is for viola and orchestra, and then I conducted "Polka" with this orchestra. I have a good viola player in the orchestra, who is studying at the academy now, and we played with him.

That is, the repertoires can be very different. Since I am a composer and simultaneously lead this orchestra, I can do any pieces for them that are called "sewing" and prepare a musical score for them in any style what is necessary for them.

Xi Liu: Do you teach composition and if so what is your approach to this?

Boris Pigovat: I teach composition at a school in the city of Petach Tikva. Usually, at the beginning I do such exercises: I write an accompaniment for them, and they have to come up with a melody. Or I give a melody, and they have to come up with an accompaniment. Or I give a few initial bars, and they should come up with the sequence. In parallel, I ask them to bring some kind of beginning for their works. 
Remember how I talked about Peiko, that he left only the first five bars from everything? And he said that one can work with it.

In parallel with this, we look at various works and analyze them. I teach them to see how another composer, a professional composer, to make a particular place in the work.

That is what is being built on my teaching system. I do not "impose" some style or something else on their works. Whoever wants something, he could bring. My task is to cut off all that is superfluous or whatever it does not correspond to the style of the musical material: that is, one started some materials, and then he suddenly continued with something that "does not fit" with the previous material or contradicts to it. The student still does not feel this, and his style has not worked out or formed. Therefore, my task is to teach him to understand what suits the material, and what does not fit.

Xi Liu: What is your job and what does it require you to do?

Boris Pigovat: Well, I already answered. In one place, I work as a conductor of a children's orchestra, and at the same time I compose for this orchestra. In the other place, I am a composer-in-residence, that is (to say more precisely in Russian) a "court composer", a composer working at the institution. I teach composition there.

As a "composer-in-residence", I write for ensembles - for orchestras, or for chamber ensembles. For example, I wrote a lot for a brass band in a conservatory in Petah Tikva, which is so-called music school in Israel. This is a very good brass band that won prizes at festivals and competitions in Europe. I write for them without any discounts on the fact that these are children. I write such compositions for them that they do not know it is difficult, or rather they understand that is hard, but they do not know how hard it is. It is played by orchestras like Kosei Wind Orchestra from Japan, or orchestras from the United States. It turns out that these works are quite 
difficult things, and they put the "highest level of difficulty" on the score. The children do not know this!

Again, this brass band in the Petah Tikva Conservatory is a laboratory for me, I play all with them, and it goes out into the world. Most of the premieres of my works for a brass band played with this particular children's orchestra.

Xi Liu: Which places and when did you live before emigrating to Israel?

Boris Pigovat: Odessa is my childhood, Moscow is my study years, and I worked in Dushanbe before leaving for Israel.

Xi Liu: Why did you move to Israel?

Boris Pigovat: Well, there are several reasons. On the one hand, the Soviet Union collapsed. In Tajikistan, where we lived, nationalistic tendencies began to grow, that is, the Russians began to leave from there, because such conditions were created. It almost began a civil war, but we left before the civil war.

I remember that my dad told me as I was a child: "There will be the slightest opportunity leaving for Israel, and you must be with your people." At that time, of course it was very far away for me to understand where I was and where is Israel. However, Zoe (my wife), her parents and ancestors adhered to the tradition more than that in my family. There was a tradition especially since her relatives lived in Israel. Her uncle walked from Uzbekistan, through Iran, and through Turkey to Israel (then Palestine) in 1932. He was a child and arrived in Israel with adults. So there were some ties with Israel, and they always talked about Israel.

Xi Liu: Did you work on a kibbutz at any stage?

Boris Pigovat: When we first arrived in Israel, we went to the kibbutz. It was the first home program as I said, I worked at a boot factory. I worked there for almost two years, learned to work well with boots, learned to cast these boots in a hot 
workshop. Well, I began to work a little bit as a musician, because the state made a special program for employing composers who are either laureates of competitions or who have a third academic degree - a doctor. I got both as a laureate of a competition in Budapest and as a person who graduated from the Gnessin assistantinternship - this is a composer doctor's degree. Therefore, under this program, I was sent to work in Kiryat Bialik in the north of Israel where I continue to work with the orchestra. The Ministry of Education sent me there as part of the experimental program. There was such a system: the ministry paid my salary in the first year, in the second year the ministry paid $2 / 3$ of the salary and the director of this conservatory (music school) paid $1 / 3$, in the third year the ministry paid $1 / 3$ and this school paid 3/3. Over three years I "took root" there and they offered me a full-time job, which meant the program had worked out. Well, as you can see, I stayed there, and I have been working there since 1993.

Xi Liu: How has your life been in Israel?

Boris Pigovat: Good. I live well, live comfortably, and I feel this is "in my place." I feel like I am living in my country, in my place, doing what I love. Despite all the difficulties, I try to compose well. Here I was "revealed". When I compare my works that were written before moving to Israel, with those works that were written in Israel, it is like works written by two different composers.

There was a sharp breakdown in style, and I did not even feel it at that time. I came to Israel, and I wrote Requiem four years after my arrival. I arrived in Israel at the end of the year in 1990, and in 1994 I already wrote Requiem and finished it in January in 1995. This is a work that I was afraid to approach for many years. I wanted to write such a work dedicated to the Holocaust, but I felt this theme was too big for me, I did not have such composing powers to do this, and I just did not manage to create such a work. 
Only having arrived here, and after several years, I realized that I could. As I said earlier, this land has a special energy. That is, as a composer, I really find myself here. I, as they say, feel guilty to complain. Recently, I counted up that my works were played in 37 countries. Different works in different places, but I counted in 37 countries where my works were performed. When I was in the Soviet Union, I could not dream about it.

That is, the composer's career has "gone", but most importantly, the creativity has become different. Such works as Requiem, or as, for example, a work that I wrote for the Israel Philharmonic Orchestra, a work for the Pittsburgh Symphony Orchestra - I would never have written in the Soviet Union. I was another composer there.

Xi Liu: What is the education system like in Israel?

Boris Pigovat: The system of music education in Israel is different from the system that was in the Soviet Union. How was it in the Soviet Union? There was a children's seven-year music school, and besides that, there were special ten-year music schools. After seven years you can go to a music school to get a secondary special music education, and with this secondary music education you can already go to teach in a children's music school.

The school is the second stage in the system of music education. The third stage is the conservatory, or the pedagogical institute, or the institute of arts. This is a higher standard of the school stage, and students usually study there for five years and receive higher education. In the Soviet Union people did not say that there are degrees of a bachelor or a master. There was only a doctor degree, and only candidates and doctoral dissertations.

Now in Israel, there is a music school that can cover the age of 18 years, and adults can study at the same school, up to 60 years whoever wants to and so on. This school gives some basics of the performing competitions. If a person is talented, he 
can find a private teacher to study. Usually these teachers are either from academies or musicians from good orchestras.

In addition, there is a comprehensive school in which students can choose another musical direction. For a student does not study to play the instruments, he studies in a music school called the conservatory. In Israel, the music schools are called the conservatories, and do not to be confused with the conservatory in Russia. In Russia, the conservatory is a higher educational institution, it is like an academy.

In Israel, the conservatory is just a school. This is a school for children, but in which adults can study. This is a school that provides only the most elementary musical education.

Those who study in a comprehensive school, where there is a musical direction (in Hebrew - "megama") - the theory (history) of music. Students study either with a private teacher, or at the conservatory.

This is the lower (basic) layer of education, and the upper layer goes further, it is the academy. A person can study the first (academic) degree, the second degree, and the third degree in an academy or a university - that is, the degree of the bachelor, the master and the doctor. This is such an education system. By the way, in the Soviet Union, when we graduated from the conservatory, it was considered as if we had received a second degree. When diplomas were reissued (confirmed) here in Israel, those who had a diploma of graduating from the conservatory received a certificate (document) from the Ministry of Education that they had a second (academic) degree (master).

Xi Liu: What about music education at school and at university?

In Israel, music education is not very professional. Students who want to continue to study music professionally, they often study with private teachers. It is very rare that 
a student who is simply studying with a teacher at a music school then enters the academy. He or she still needs to receive special training from a very good teacher.

Xi Liu: Composition style: Who influenced you?

Boris Pigovat: They are Shostakovich, Mahler and Tchaikovsky. Here are three composers. Moreover, Shostakovich and Mahler's works are both with dramatic and tensional in musical style.

There is less influenced on style of Tchaikovsky, but more concept of symphonic: the ability to build a symphonic composition boosting the musical energy and the musical tension. This is with Tchaikovsky, and he is a global figure. Mahler and Shostakovich are the same plus some purely stylistic moments, even in instrumentation and the understanding of the orchestra.

Xi Liu: What are your later teachers' names? Are they famous? Why you go to those teachers and what are they famous for?

Boris Pigovat: My main composition teacher was Nikolai Ivanovich Peyko. He is a student of Myaskovsky, and he is a representative of the Russian school. At the same time, this person (I already said a little about him today) is a very strict man and somewhere even tough in a sense. There were people with whom he did not have a relationship and people who simply "did not accept" him - did not accept his character and his demands. He was too demanding, but he was always honest with himself, in terms of what, in his opinion, a piece of music should be. He did not hesitate to say as it is. Therefore, he had many friends and many enemies. But I was lucky in how I felt in terms of style - the aesthetics of style, I just like him. That is, what he said to me was completely suitable for me, I was always satisfied. Therefore, I even agreed to have some painful things in my work - if I refuse something and I "throw it away", because I knew he was right! What I was trying to refuse, I had not decided to "throw out" some musical material from a work, but he was right. He was 
a great teacher - very tough and principled. In fact, he made me a composer. It was also very important for him that music "comes from the heart", but not "from the head", it is not invented, but it is "from the heart". He always said: "The origin of music is a sacrament," no one knows how this happens. It must "come from the heart" of the composer, and it must "go to the heart" of the listener. This is one teacher.

The second teacher is Heinrich Ilyich Litinsky. I studied polyphony with him, but he seemed polyphony as the second composition. We wrote such things from him - for example, if this is the final piece in polyphony, in free style this is a prelude and a fugue for an orchestra, or we wrote a polyphonic quartet. We actually wrote a quartet, but only in polyphonic forms: there was a fugue, there was an invention, and there was a passacalia, and we wrote our own music by using these forms. What else Litinsky was glorified for - half of the composers of the Soviet Union studied with him. He was, in my opinion, born in 1902. That is, when I came to his class, for us we were young, but he was considered an old man, he was over 70 years old. I remember we celebrated his 75th birthday. Yes exactly. If he was born in 1902, and we studied with him before 1978, then he was 75 years old in 1977 . So we celebrated his 75 years, I remember.

So they said that half of all composers of the Soviet Union studied with him, and the second half studied with his students. That is, in fact, he is the patriarch, the founder of the entire composer school. Even my teacher Peiko studied at the Myaskovsky Conservatory, and he also studied at the Litinsky School.

What else Litinsky was known for, or rather, how important he was for me is that he was a man with an amazing soul. People would feel good with his smile when they came to him. He was an amazingly warm person. It was just great, and students just wanted to come to him in class and sit there. You do not to bring any materials, and you come to his classroom and just sit there. He had a wonderful aura. 
This man passed away from life with dignity. In his old age, he was in his house and composed, when he finished composing a quartet, put an end to it, and the next morning he did not wake up.

It was not a disease, nothing. A death is to be envied.

The third teacher - I met him when I left for Tajikistan there he joined the Union of Composers, and through the Union of Composers we were sent to the Ivanovo House of Art for a seminar of young composers. In one of those months, this seminar was conducted by a professor (no, he was not yet a professor, he was an assistant professor at the Moscow Conservatory). A person who knew everything about the orchestra in general, who was the "god of the orchestration", who was the "poet of the orchestration", and he was just an assistant professor, not a professor. He was already an acting professor, and then became a professor - Yuri A. Fortunatov. This is a person, from whom many composers studied instrumentation both at the Moscow Conservatory and outside it. He taught to understand the "soul" of the instrument. In our education, the orchestration was academic. I was engaged in this discipline the same with Nikolai Ivanovich Peiko, he taught us instrumentation, that is, the orchestration. He taught me to make orchestration very well, so that the orchestra sounds good, that everything works out, that everything is beautiful. I did not compose for an orchestra, but I composed for my music and took into account the orchestra.

What did Fortunatov teach? He taught to find orchestral ideas as the basis for composition. He taught us to feel the peculiarities of each instrument, and found such orchestral solutions that pushed us to search for new thematic ideas. He cited the following as an example - we are used to having bassoons at the bottom, flutes at the top. So he took Stravinsky's "Sacred Spring" and showed the bassoon (the beginning is played - the bassoon solo is in high register) - the high bassoon, and somewhere there is a low flute. It sounds completely different. He showed many 
such examples when it is necessary to use the instrument where we are not used to, but where it will sound bright well.

Sometimes his small advice suddenly highlighted a completely different color in a familiar, already existing theme. In the interview (an article by Elena Nikolaeva), I mentioned how in one theme that sounded on high cellos, and he advised me to add a bass. I would never have thought of that! Suddenly during the performance, I heard that the theme received a completely different expressiveness, a different brightness and emotionality.

Xi Liu: What is the balance between commissions and works that you want to write? Boris Pigovat: Firstly, I do not have many commissions. It happened that basically I wrote what I want. When people asked a work from me, I was happy to write. This was not a paid work. They asked me to write, and they said they would play it, and then I started writing. On the other hand, I knew for whom I wanted to write. I knew for which composition (or ensemble) suit for which artist. Then I wrote what I want.

Sometimes this also happened - as the case with the Israeli Philharmonic, or with the Pittsburgh Orchestra. I received a commission for the composition of the orchestra, the composition of the performers, and only it was timing works. Again, I wrote what I wanted.

Sometimes even if they told me in which direction the composition, character, and so on should be, then anyway I turned it the way I needed.

In Pittsburgh, the conductor wanted it to be a work of a religious nature. I came up with the idea to take a quote from the Bible, a very definite quote - "Therefore, Choose life?". There is a big phrase, and its ending is "Choose life"! Shortly afterwards he conveyed his desire that he would like me to write music based on the Psalm 150. 
In response, I wrote that this was a good idea, but I would suggest such a theme "Choose Life". He made my decision (my proposal), and I wrote what I wanted.

In many cases, when you received a commission, in order for you to feel that you are writing what you can or what you want, you must initially "accept" (perceive) this work as if you want to write for this composition (ensemble of instruments) or for these specific performers.

The idea of this work can be made to seem as if it is your decision of writing, and not what is requested to you, therefore you write such a work. That is your decision! I had a work for flute, bassoon and harp. This, however, was not a paid commission, and it was a request from the performers. They needed a work namely for such a composition.

I started to think - the constitution of flute, bassoon and harp leads to an unusual composition. What is a harp? Harp is an ancient instrument, and flute and bassoon are a duet. So this can be something ancient, and some kind of duet against the background of an ancient accompanying instrument. What kind of duet? - The Love.

Where do we have a harp mention? - Harp of David. The "Song of Songs" was from the son of David, King of Solomon. This was how the composition "Shulamith" appeared. This work was based on the biblical Song of Songs. Thus, the unusual composition (list of instruments) that I had to use, I perceived it as mine, as if I wanted it myself, and I found an idea for this composition (ensemble). After that I was already completely free - I wrote as I wanted.

Therefore, the question of organizing here consists only in the fact that you need to accept (perceive) the request as if it were those frames that you choose for your composition. After that, everything goes (turns out) easily.

Xi Liu: What are the great moments (highlights) of your career? 
Boris Pigovat: The brightest moments are: first of all, the premiere of Requiem performed in Kiev (2001). And then the performance of Requiem by Donald Maurice happened in New Zealand. This was a very bright event.

After that, the commissions were completely unexpected. I didn't even expect it. Suddenly they called me from the Israel Philharmonic Orchestra and said that they wanted to order this work. It was like a miracle to me. This performance at the festival "75 years of the Philharmonic Orchestra" performed by the orchestra with Zubin Meta. After that, a year later he played this work in the philharmonic series.

The latest news (a bright moment in my career) is an order from the Pittsburgh Symphony Orchestra, and the piece "Therefore, Choose Life!" performed by the Pittsburgh Symphony Orchestra. So these are the main points (moments) in my musical career.

Xi Liu: How do you know how to write so well for the viola?

Boris Pigovat: It's hard for me to say. I just know that I feel this instrument. I feel this instrument can be considered just like I feel a violin. The fact that once I played the violin and I can understand some basics of this instrument - I feel it. Besides, I really like viola. I love viola even more than violin and more than cello, because this instrument, on the one hand, has very deep sound, and on the other hand, is very intimate. It is like a human voice.

Xi Liu: What were your early musical preferences and who were your musical influences?

Boris Pigovat: We have already talked about this. Early preferences are Rachmaninoff ... Ah, I forgot to say: (at the beginning -) was Rachmaninoff, and after that at the Gnesin's school I had a very strong passion for Scriabin. I listened to a huge amount of his works, I wrote a work on Scriabin's "Poem of Ecstasy", and even 
made a report about "Prometheus" and "The Poem of Ecstasy" at the Scriabin Museum. It was almost a painful hobby, like an obsession. After Rachmaninov, suddenly it was Scriabin. And then everything went somewhere - Shostakovich appeared! Now, my musical preferences are Shostakovich, Mahler and Tchaikovsky.

Xi Liu: What is the name of your first composition? Can you talk a little about it?

Boris Pigovat: My very first composition that I consider to be the one from what I did before professional training is a suite the "Little Prince" by Exupery. I even seem to remember how it sounds. "Once upon a time there lived the Little Prince. He lived on a planet that was a little larger than himself" (a fragment from the beginning of the suite's first act is played). This is the theme of the Prince (the continuation of the first act from the suite is played). Well, and so on. I feel like it was a little influenced by Scriabin. This was written in the "Scriabin" period.

Well, this is my very first composition, and this composition, which later (when I, as I said, was an "adult" composer) was published by the SUPRAFON publishing house in Czechoslovakia (now it is the Czech Republic). I wrote this work when I was 16 year old. Suite "The Little Prince" based on the tale of Antoine Saint-Exupery.

Xi Liu: In what order do things happen when you are composing a new work? For example: melody, rhythm, structure and so on.

Boris Pigovat: This question is very difficult to answer by this way in the interview, but it is completely described in this blue book. It is an interview with Boris Pigovat in an article written by Elena Nikolaeva (in the collection PROCESSES OF MUSIC CREATIVITY, Issue 11, Moscow 2010). They asked me to write specifically about the creative process. In this article, I first refer to Tchaikovsky, because what he said is actually what is happening to me. And I (in this article) simply indicated by points, that is what is the order of all these processes. How did this article complete? I received questions through email, and then I sat down and formulated the answers 
with a long thought. That is, this article was completed by correspondence. That is, every word is verified.

Xi Liu: At what age did you become aware of the Holocaust?

Boris Pigovat: In fact, in my opinion, at 9 or 10 year old, I already went to Babi Yar with my father, to the grave of my grandfather and grandmother. I was not very aware of the Holocaust then. That is, there were some stories with my father.

At the age of 15, I found the book "Documents of the Nuremberg Trials" in the public library. When I saw those terrible photos and I was shock. I read these documents translated from German - it was awful! I really felt it, and since then I had the thought that I should write something about it.

I had some stages to "approach" to this. They were more connected with the general tragedy of World War II. As a student of the Academy (that is, the Gnesins Institute), I wrote the choir poem Khatyn. This is about the Belarusian village, which was destroyed by the Germans - completely burned. By the way, I sent this poem to the All-Union competition and received the first prize (back in my student years).

My first Symphony is subtitled "Memorial", in memory of those who died in World War II. However, this is not specifically about the Holocaust. Why? In the Soviet Union, a music theme with Holocaust might not have been passed for the performance. Besides, it was like a preparatory stage. For raising the very theme of the Holocaust - such a great work as Requiem, and I was still not ready, although I had already learned about the Holocaust. The more I read, the more I learned about it. However, there was no feeling that I "matured" as a composer, that I could write something worthy of this tragic event. I did not want to just write something as they say "sign in", and I did not want to decrease the intensity of this sensation. I really wanted to write a work about the Holocaust, but it got put off all the time. Only after three years arriving in Israel I suddenly felt - "yes, I can!" And then I did it. 
Xi Liu: Were any of your other relatives, apart from those at Babi Yar, lost as a result of the Holocaust?

Boris Pigovat: No, there are no other relatives who died in the Holocaust, only my grandfather, grandmother and aunt (my father's younger sister). They died on the same day (September 29, 1941 - the first day of the massacres in Babi Yar).

Xi Liu: To what extent did these family losses have an influence on the Requiem?

Boris Pigovat: You know, when I wrote Requiem, I did not write about my family, although I dedicated Requiem to my father, indicating in the dedication "I dedicate to my father, who lost his parents and sister on September 29, 1941 in Kyiv." But I did not write this work about my family, and I did not write about Babi Yar. It was later said by many people that this work was dedicated to Babi Yar, but it is not only about Babi Yar. It is generally about the Holocaust, and this is not only about my family. My family is a small grain of sand in these 6 million people. I wrote about all of them. The knowledge of the Holocaust precisely lived in me because there was such a loss in my family.

Xi Liu: Why did you choose viola as the primary element to express the Requiem? What is the role of the viola as soloist in a work about war and the Holocaust? It plays motives ranging from violence to great beauty - who or what is this representing?

Boris Pigovat: Why viola? I already said that I love viola more than a cello or a violin, because viola is like an embodiment of a person. This is an instrument with a very deep sound. It has a very "human" sound, a very warm and soft sound.

There is no "concerto" sound in the Requiem. The violin has "concerto" sound, and the cello has a wonderful warm sound. "Concerto" is sparkling, and I did not need shine here in Requiem. I needed expressiveness, and viola's expressiveness is 
absolutely kind of intimate. That is, it is very close to the soul, and close to the heart. Other instruments may not do this.

However, in principle, I use the viola in this work as a result of a long journey. At the beginning I just wanted to write Requiem for the choir and the orchestra. Then at some point I realized that even if I find a special text dedicated to the Holocaust, it will interfere with my creation, because the text will distract from the music that I want to make. Listeners will pay more attention to the text.

It was more important for me to give a purely musical "message" emotionally. I had to emotionally influence the listener through music, and not through the text.

I decided to make a work without text, but as if with text. Therefore, I wrote separate musical phrases. The text seems to be "heard" in "Dies irae", or say in "Requiem aeternam". I still wanted to write without text, and to write an orchestra piece. However, something else was missing for the full picture, and I needed something "personal".

When the principal violist of the Israel Philharmonic Orchestra asked me to write something for him, he did not say a large or small one, just write something for him. We have known each other since the time of the Gnessin School, and he was just a few grades older than me. He studied at the Gnessin School, and then at the Gnessin Institute. That is, we constantly "crossed paths." Then our paths diverged - he stayed in Moscow, and I left for Tajikistan, and then we met in Israel.

So he asked me to write something for him. I realized that this is "something" I wanted to write to be the very instrumental Requiem without a choir and without a reader. Instead of a choir and a reader, there will be the viola, since it replaces a person, a human voice. That is how I choose viola for the Requiem. 
Therefore, the viola can play everything! It can play any kind of music there, because it replaces the reader, and the choir. Instead of a solo voice, viola actually replaces everything related to the human voice.

Xi Liu: In summary what did you hope the Requiem would affect audiences about the war and Holocaust?

Boris Pigovat: Of course, it is the most important. What do I want? In order for the music to evoke an emotional response from the listener, so that he felt this pain, felt this suffering. This beautiful "Lux Aeterna" - eternal light leads suffering to purification. What the ancient Greeks called the catharsis. Not only affecting among listeners, but also among performers. I read one interview of Donald, he played some fragments of Requiem, also he played the Sonata, and talked about Requiem. He said when he played, he persuaded himself - "just do not cry!" That is, he almost cried when he played some moments in Requiem. He said about this in an interview. I just read it, and he did not tell me about it. I just saw in one interview what he was telling that he was persuading himself - "Don't cry!"

If the performer feels this way, how will the listener feel it? This is what I need. My goal is to make empathy so that anyone who listens to this can feel it. It evokes an emotional response in the listeners that he feels what I felt when I wrote this work.

Xi Liu: Which viola repertoire did you listen to/study before writing Requiem?

Boris Pigovat: It is difficult to say something here, because when I wrote Requiem, I was in such conditions that I did not have the opportunity to listen and study something. Well, I heard the Schnittke viola concert on the radio. Before that, I knew from the viola repertoires in the Soviet Union: Berlioz "Harold in Italy" and Bartok's Concerto for viola. I heard nothing and did not know anything, absolutely nothing. I completely did not know the music of Hindemith (his works for viola). From the works of Hindemith, we studied "Ludus Tonalis" for piano and the symphony "Artist 
Matis" in the Soviet Union. That is all I heard and knew. I did not know anything from his viola music. One of the violists suddenly told me that in a cadence I "took" Hindemith's solo from his Sonata for viola (a fragment from the $3^{\text {rd }}$ movement of Requiem is played), but I did not know this composition of Hindemith when I wrote Requiem. This means that some ideas "rush in the air." That is, there is some kind of common musical language of the era, and the composers "grab" something here and there, something "comes" to them. At that time I just did not know this composition whether it was Sonata op. 25 of Hindemith, or something else - I do not remember. And suddenly a German violist wrote to me that "you wrote this piece under the influence of Hindemith's sonata." Well, what can I say if I did not know about this work at all then. It happens! 
Appendix 2

Score of Sonata for viola and piano

Boris Pigovat

\section{SONATA}

for Viola \& Piano

2012 
To my friend Donald Maurice - with the deepest gratitude and respect SONATA

for Viola \& Piano

I

Boris Pigovat
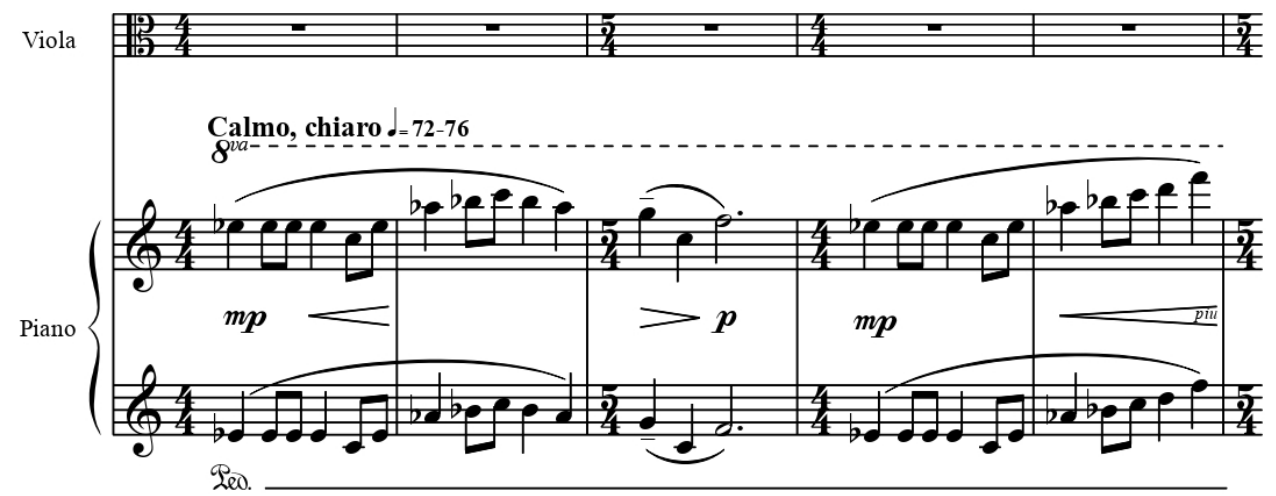

6

Vla.
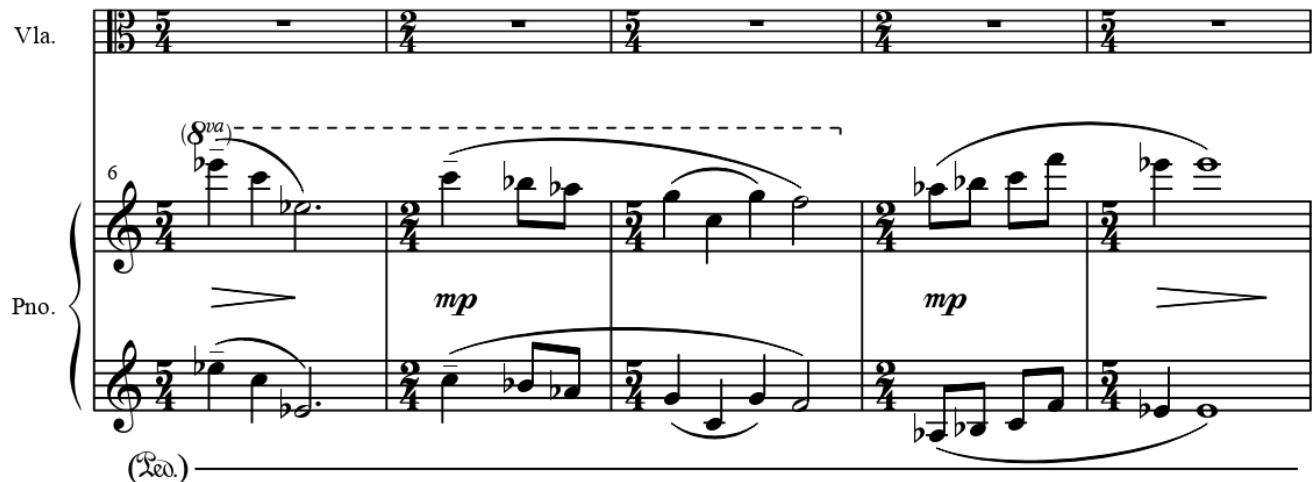

(200)

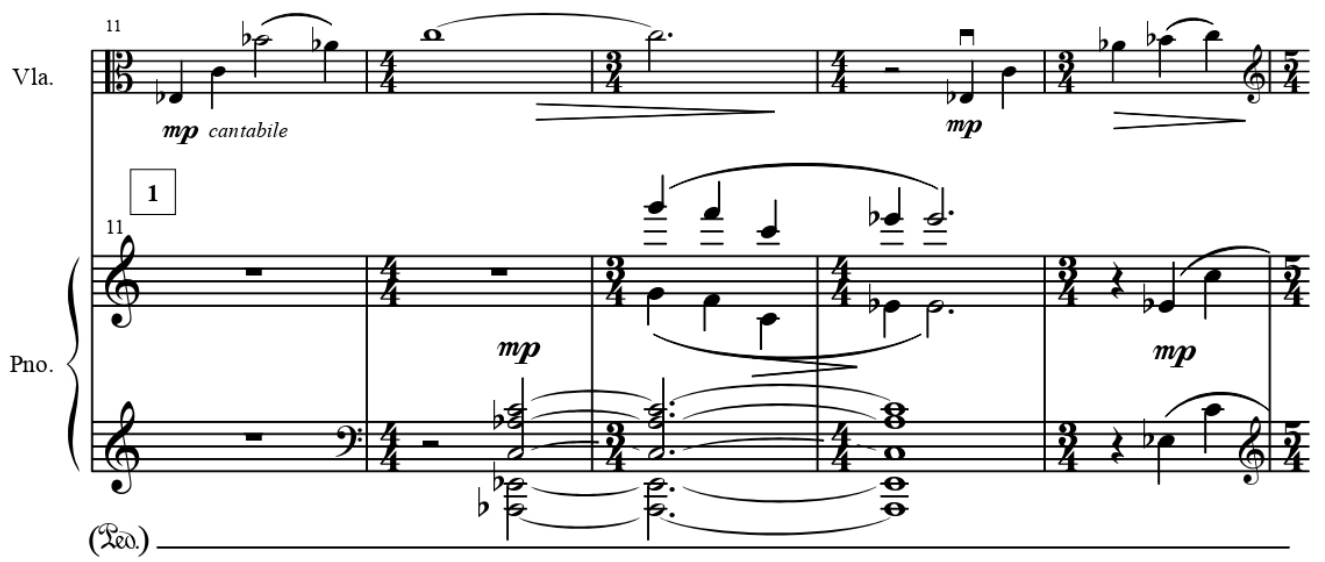

2012 Boris Pigovat 

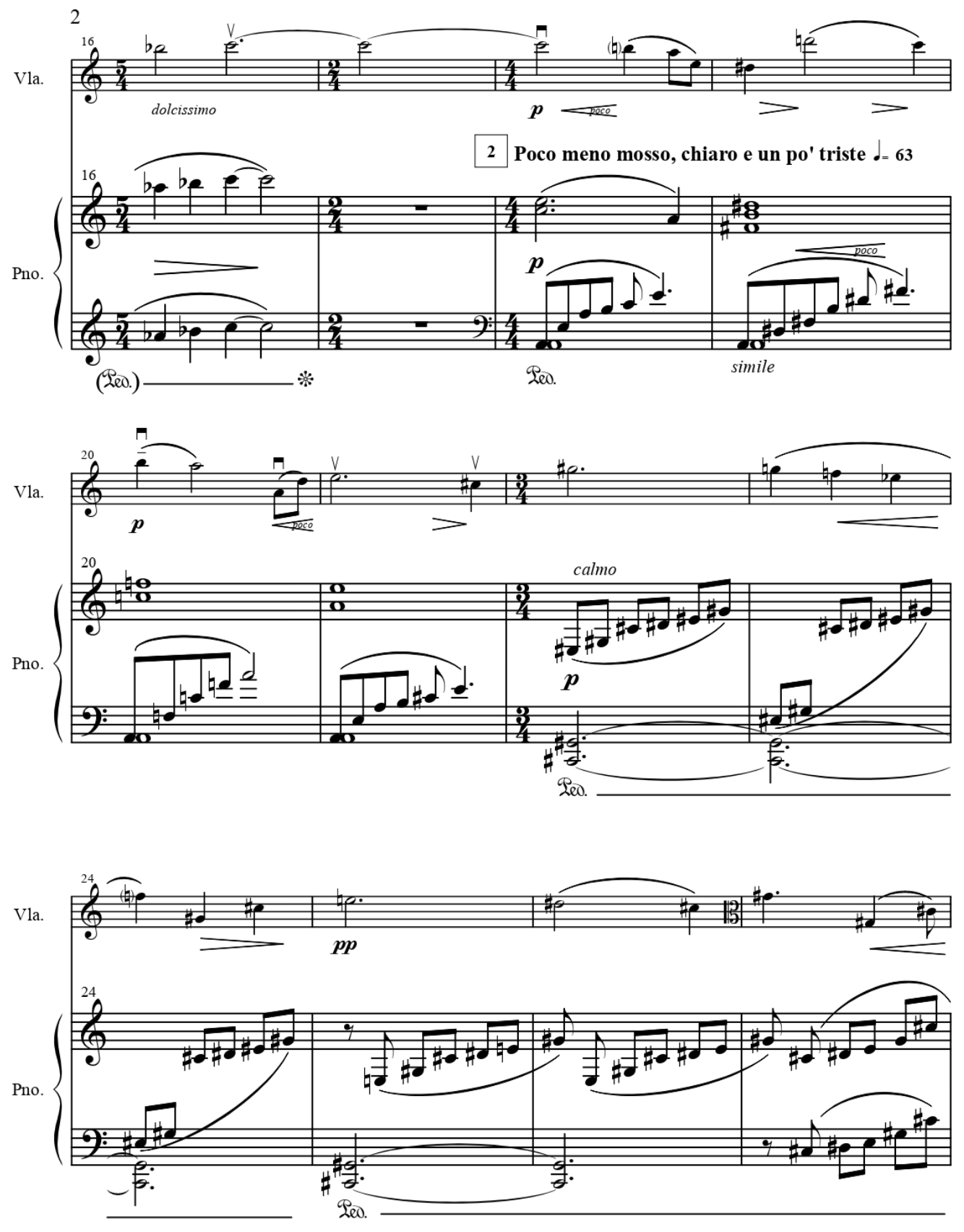

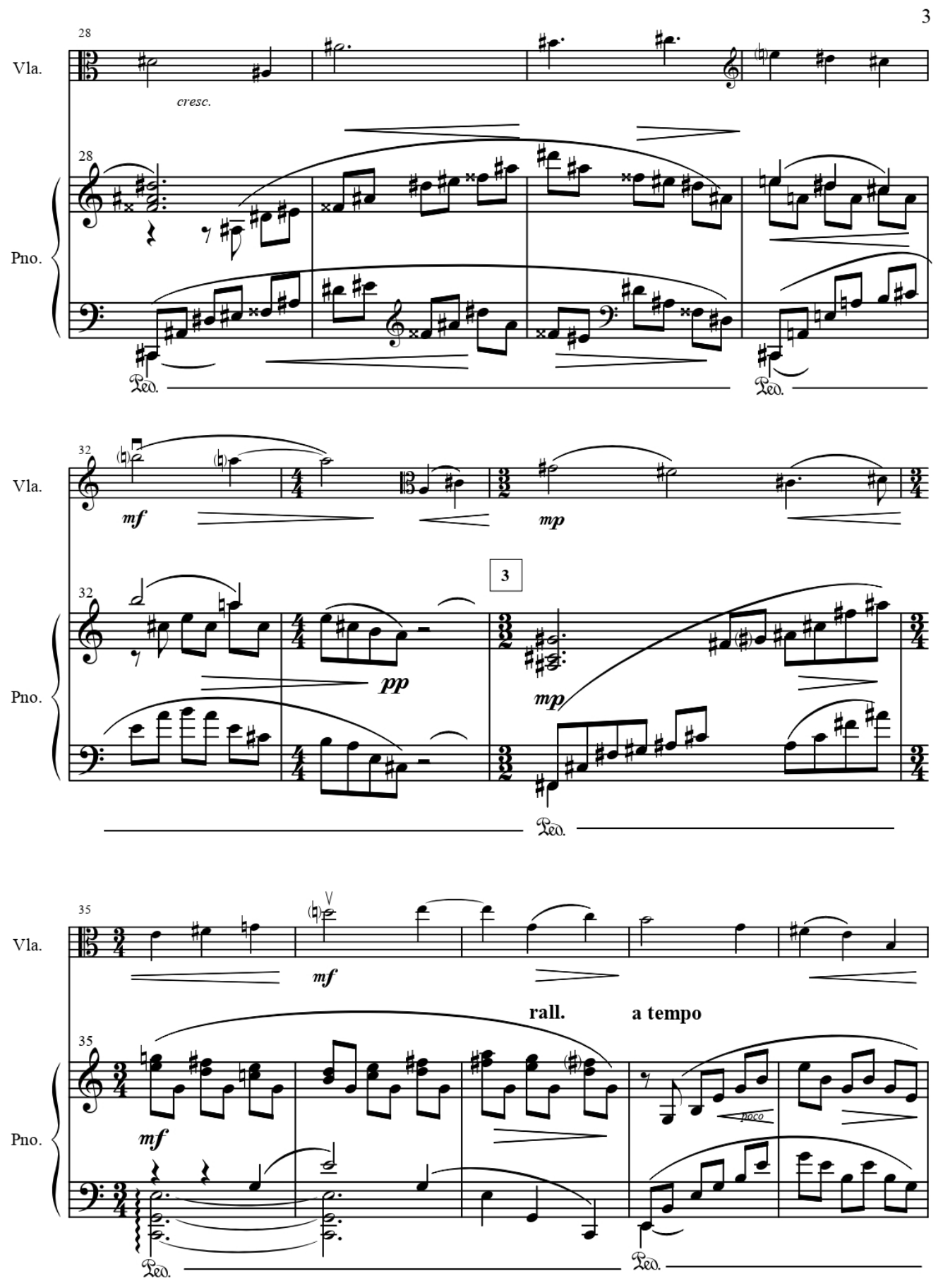

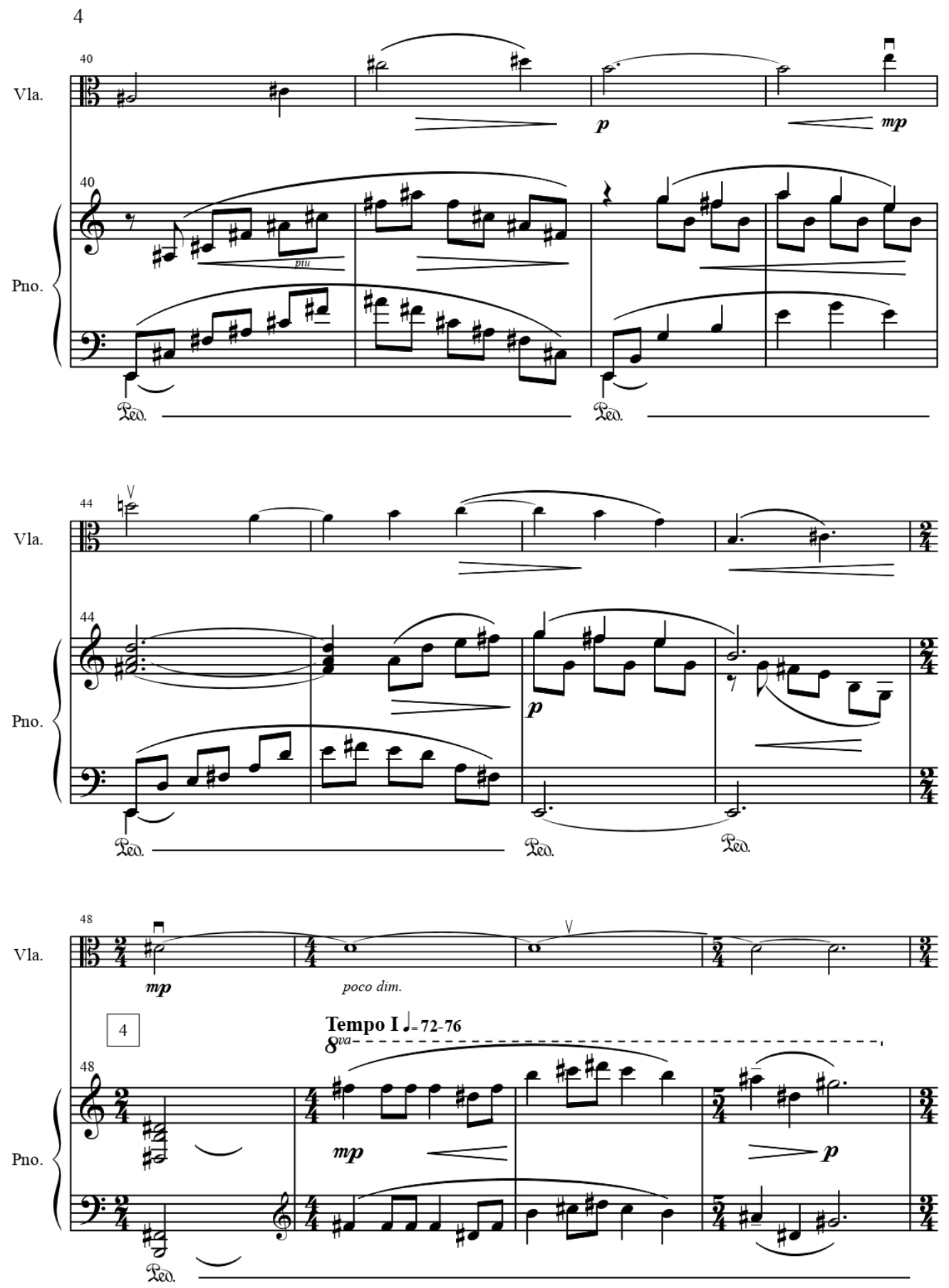

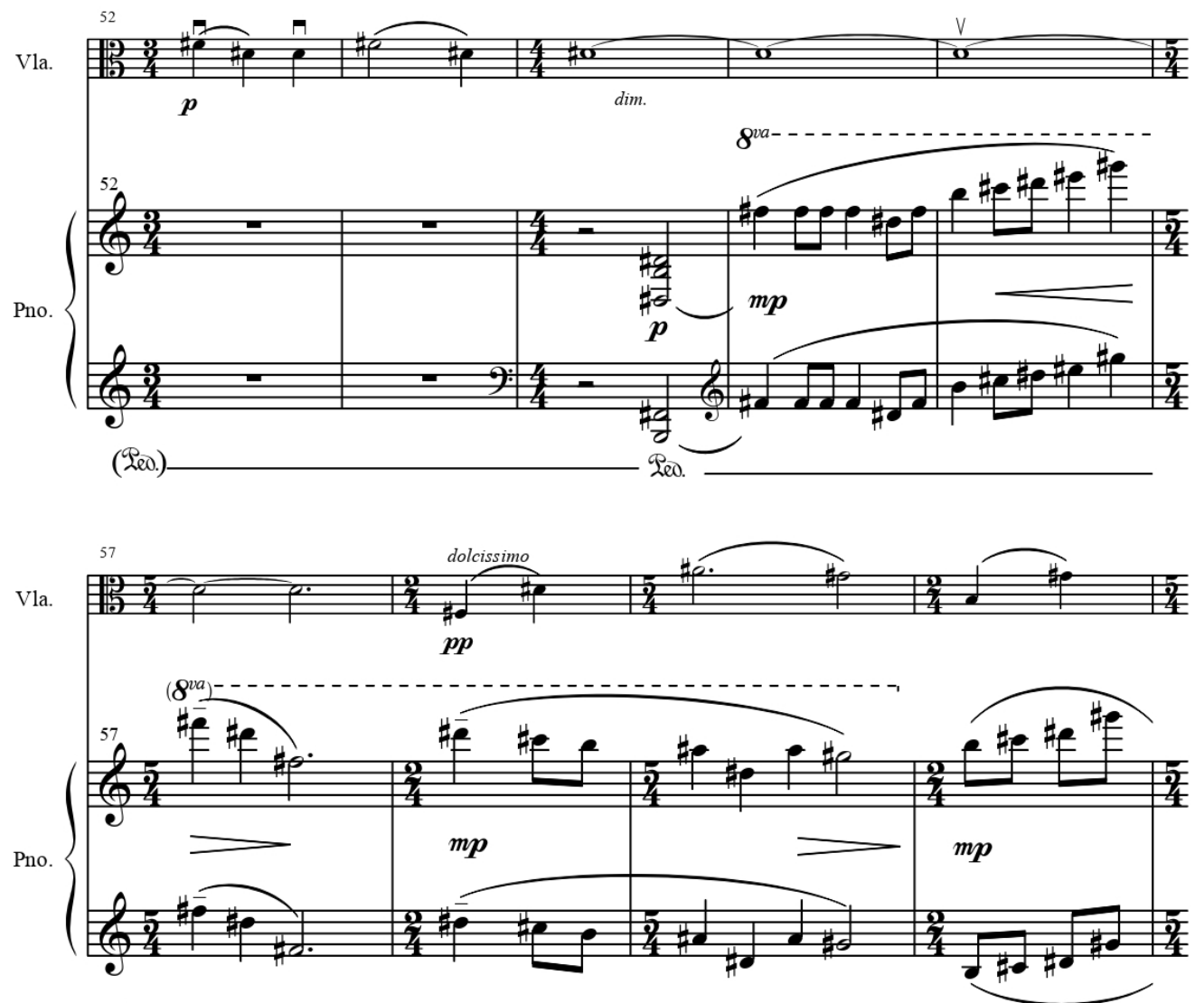

(200)

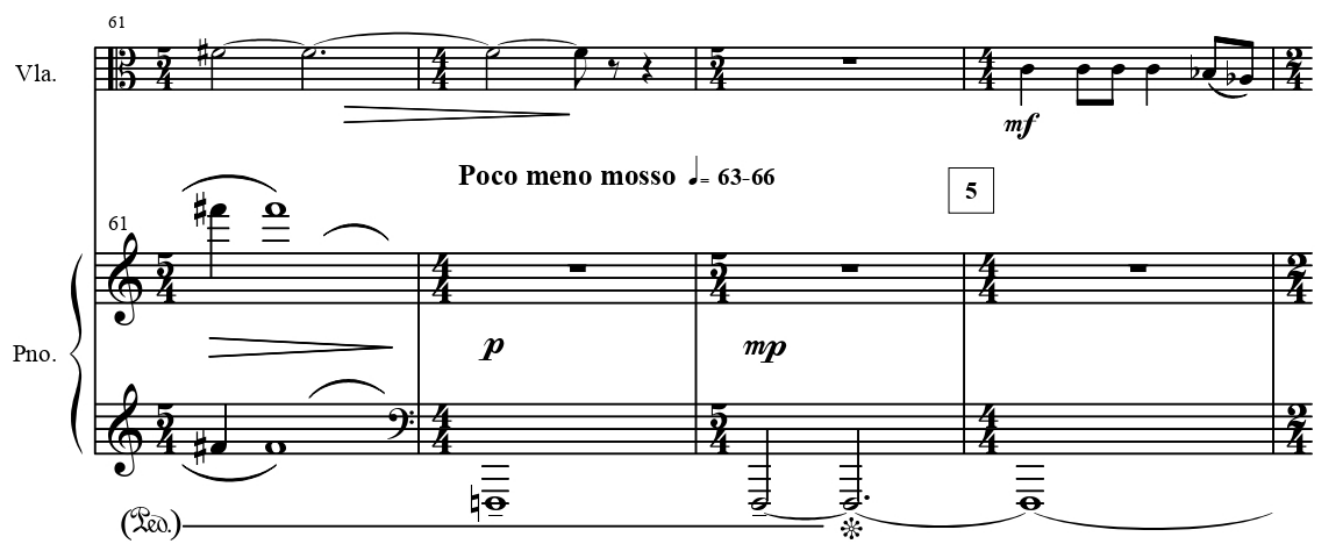



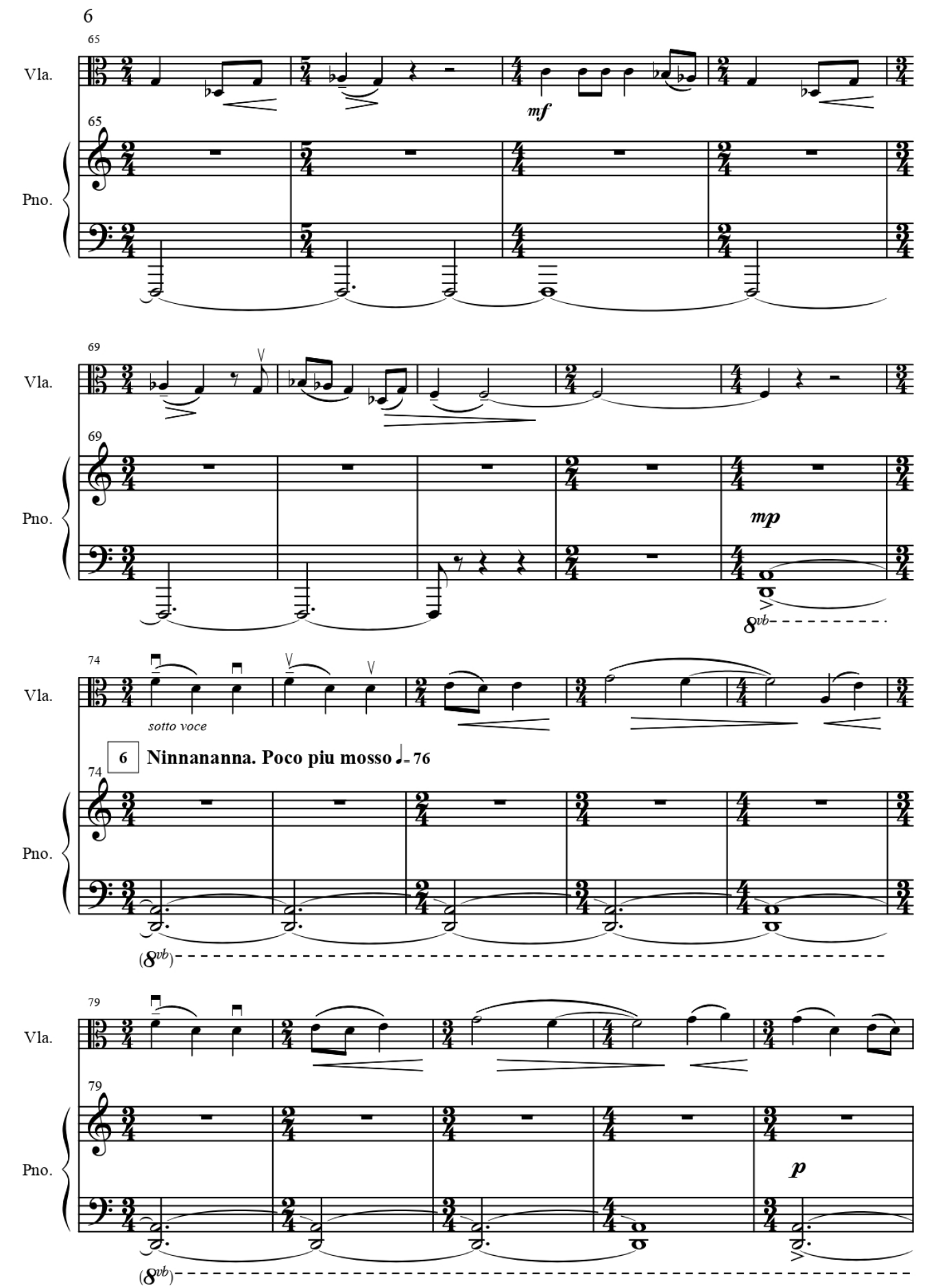

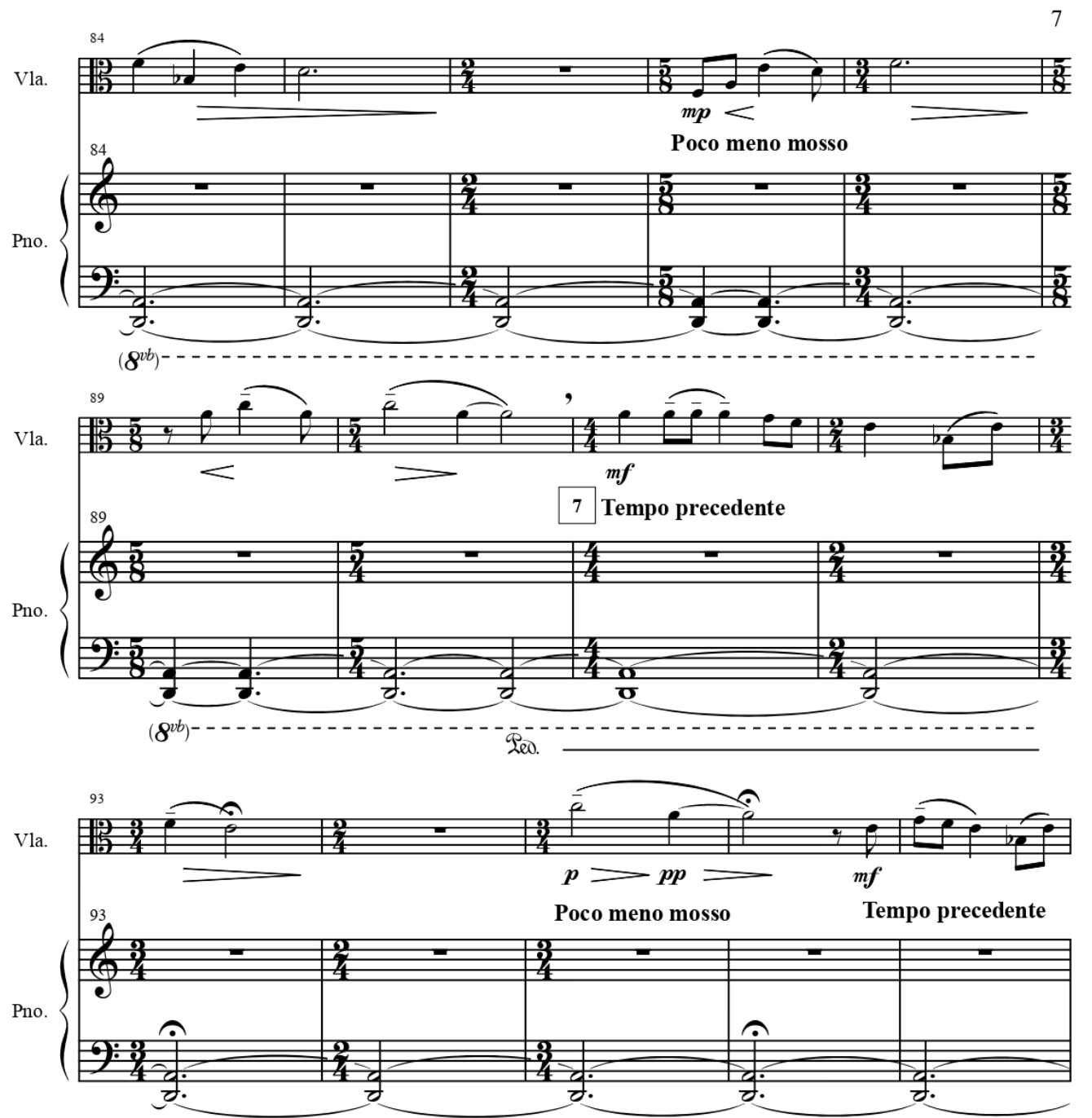

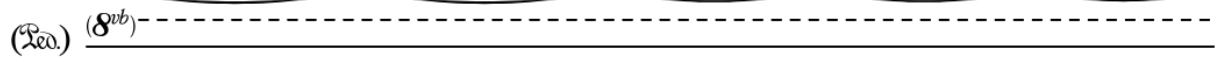

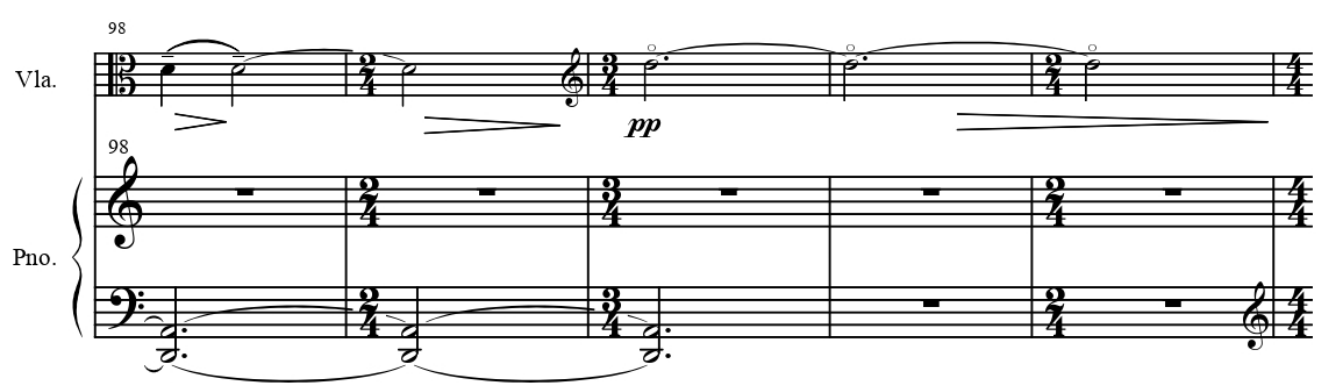

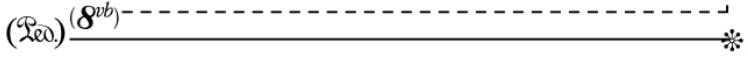


8

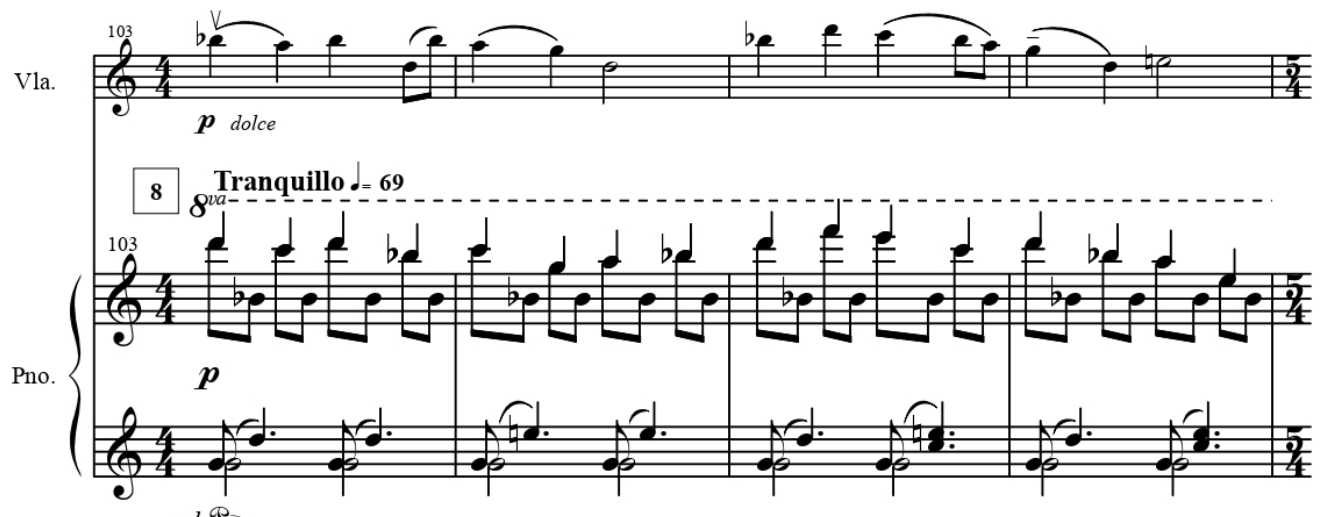
col Seo.
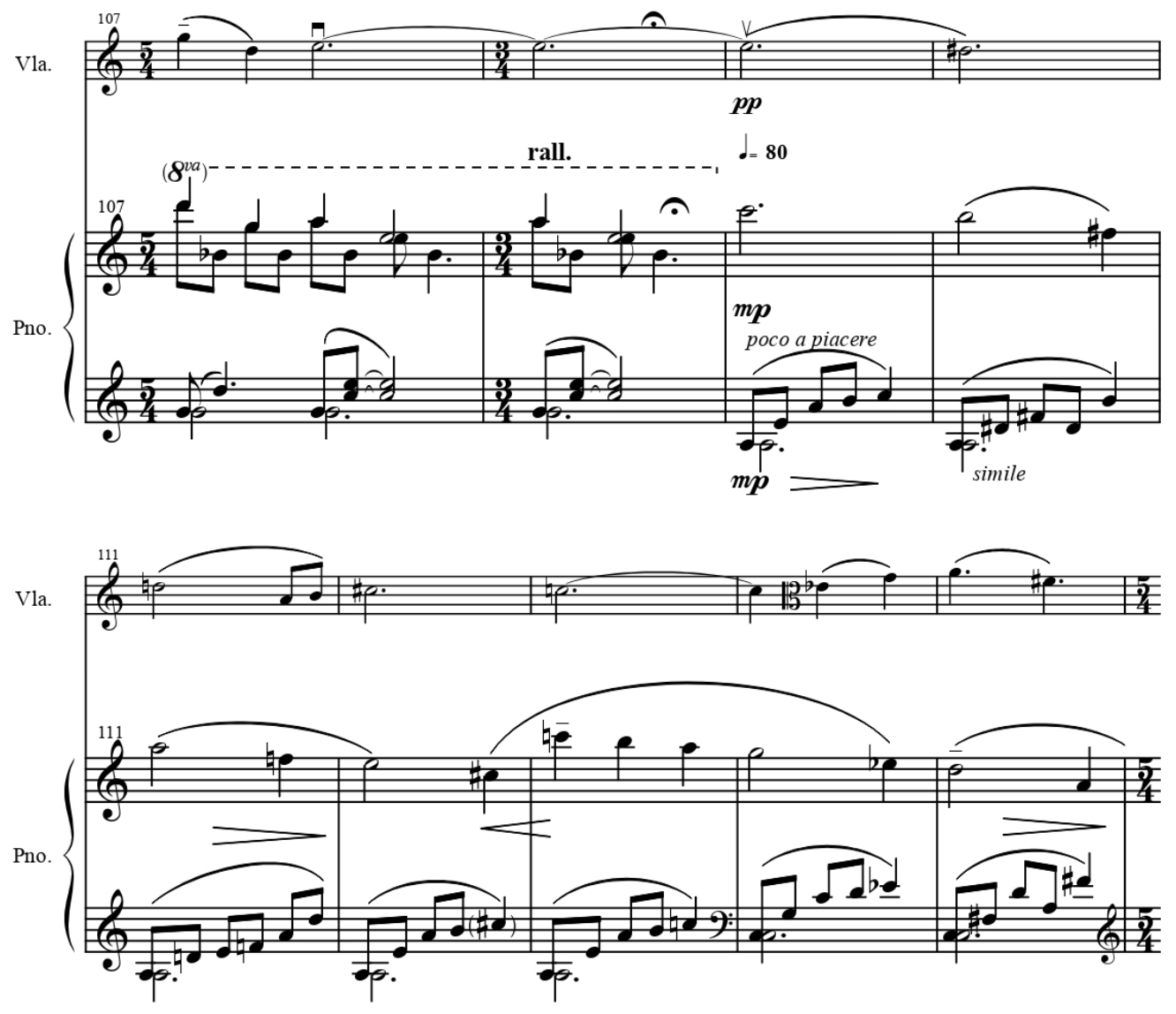
9

Vla. $\frac{116}{116}$

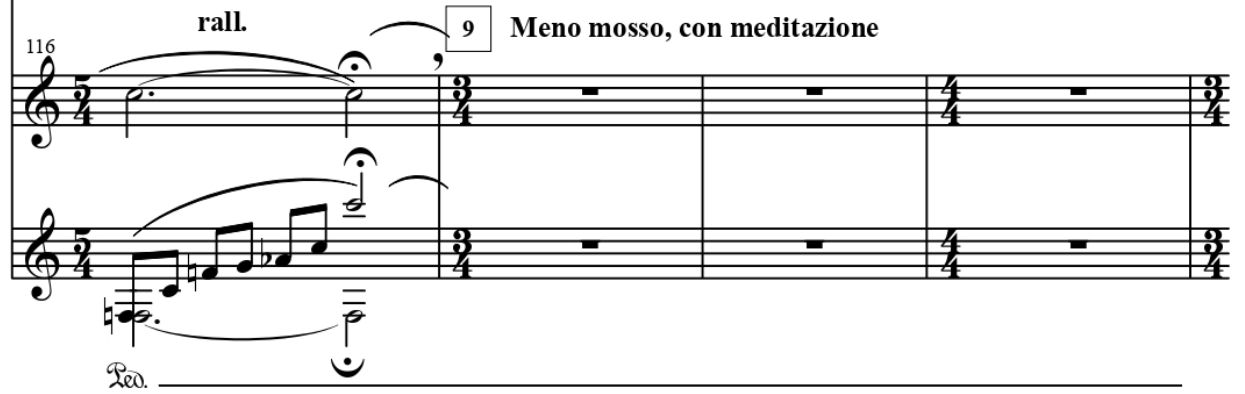

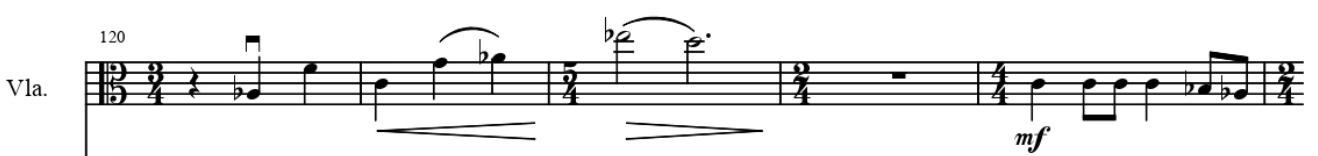

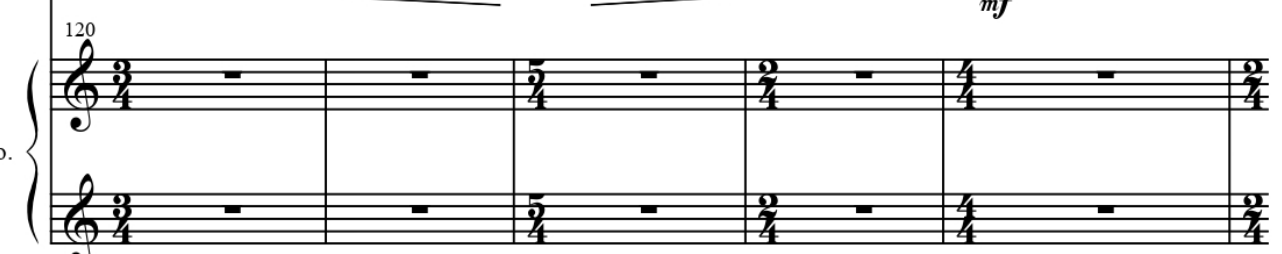

( 200.$)$

*

Vla. Pno.

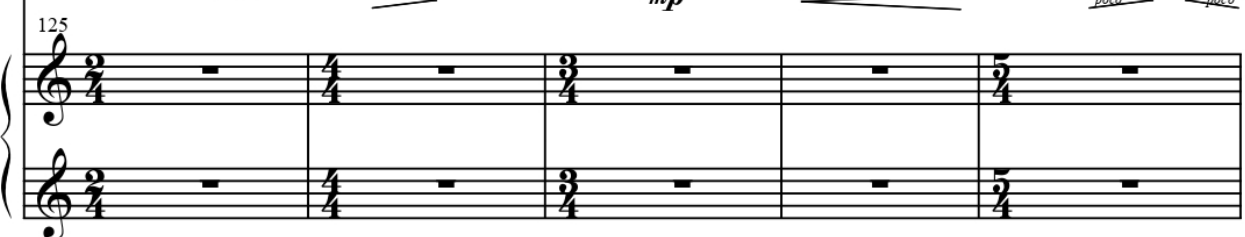

Vla.
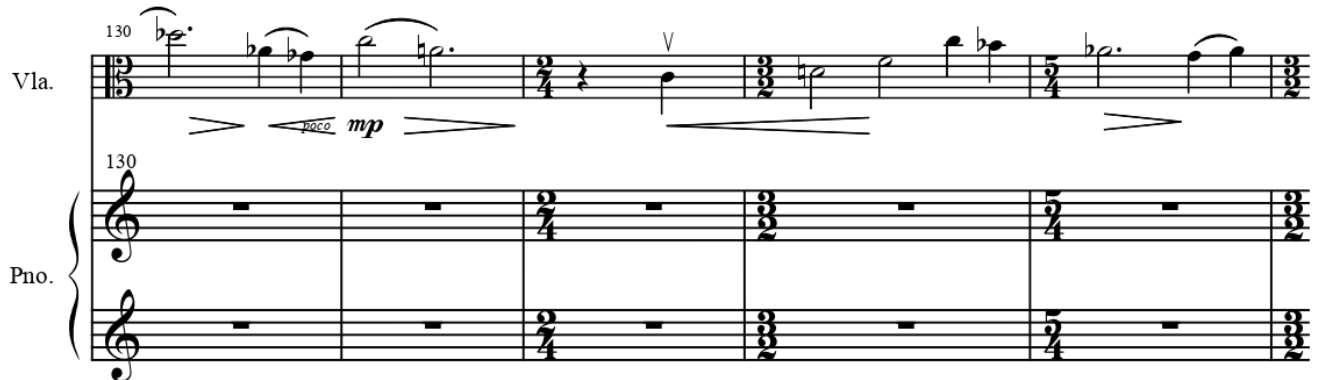
10
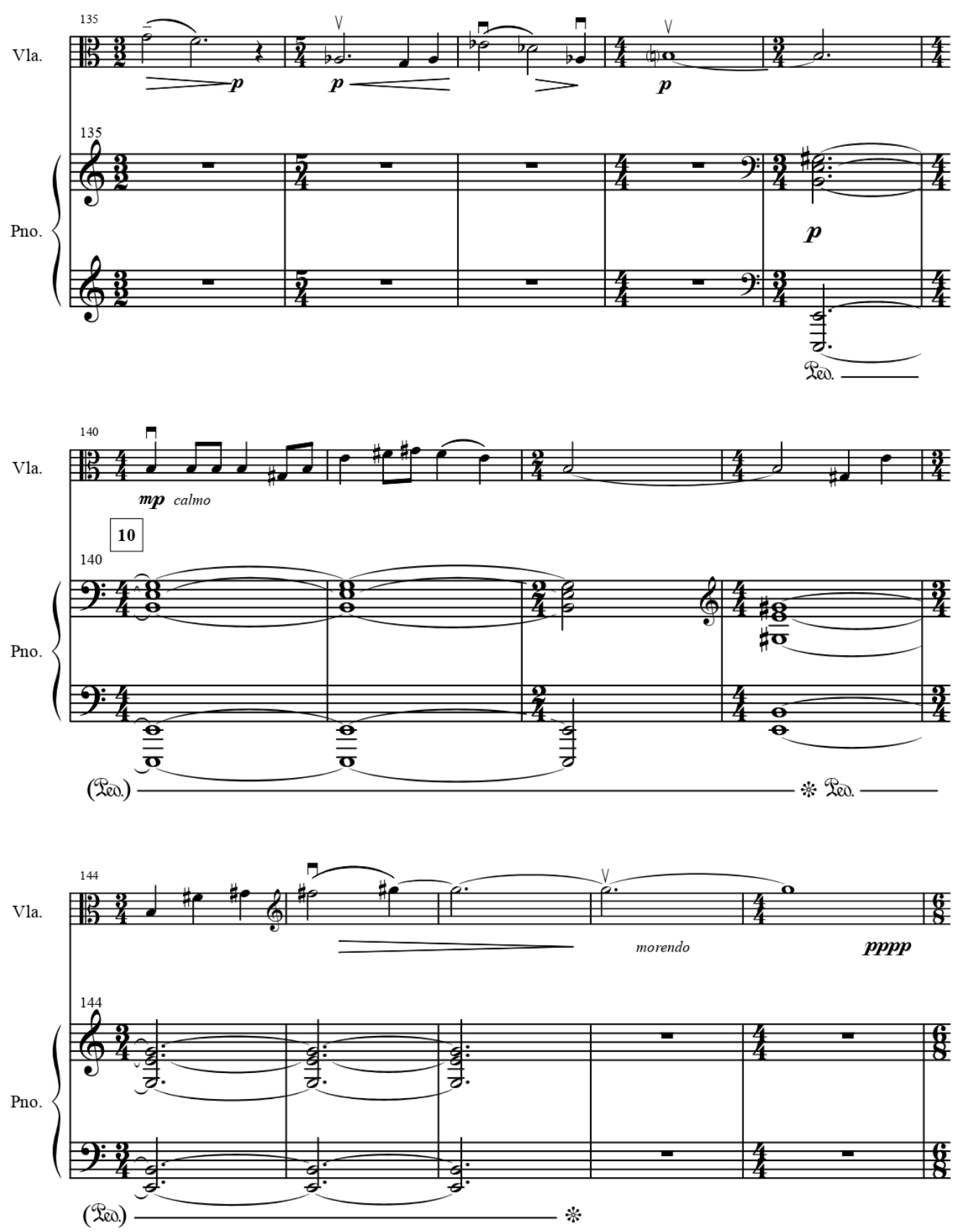


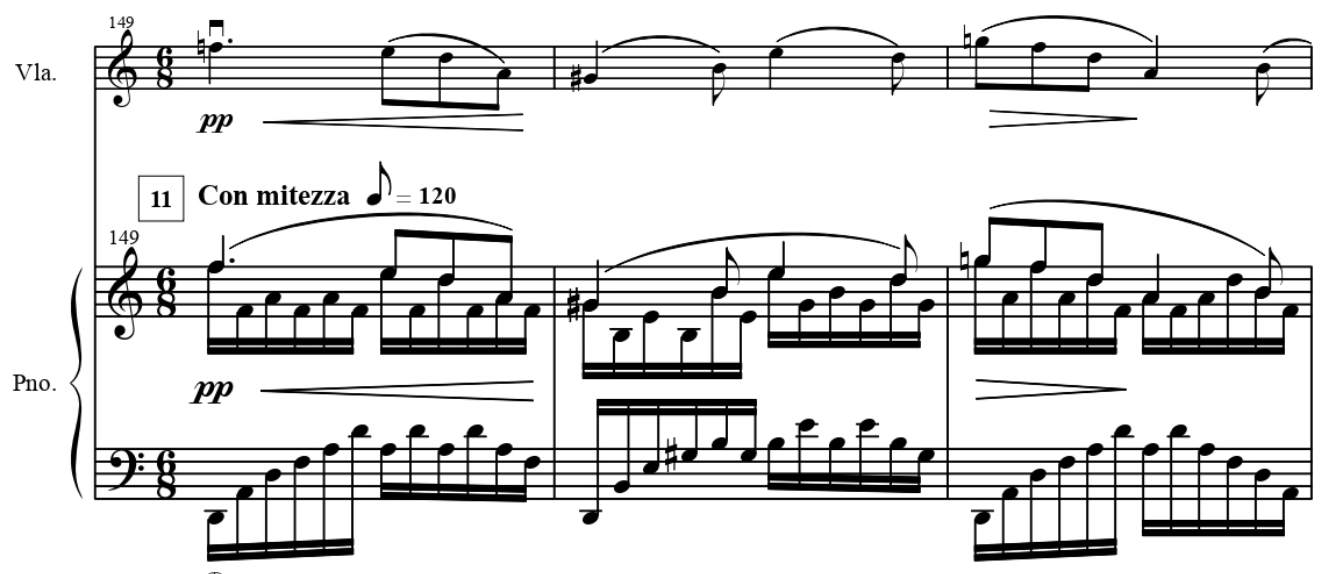

col Teo.
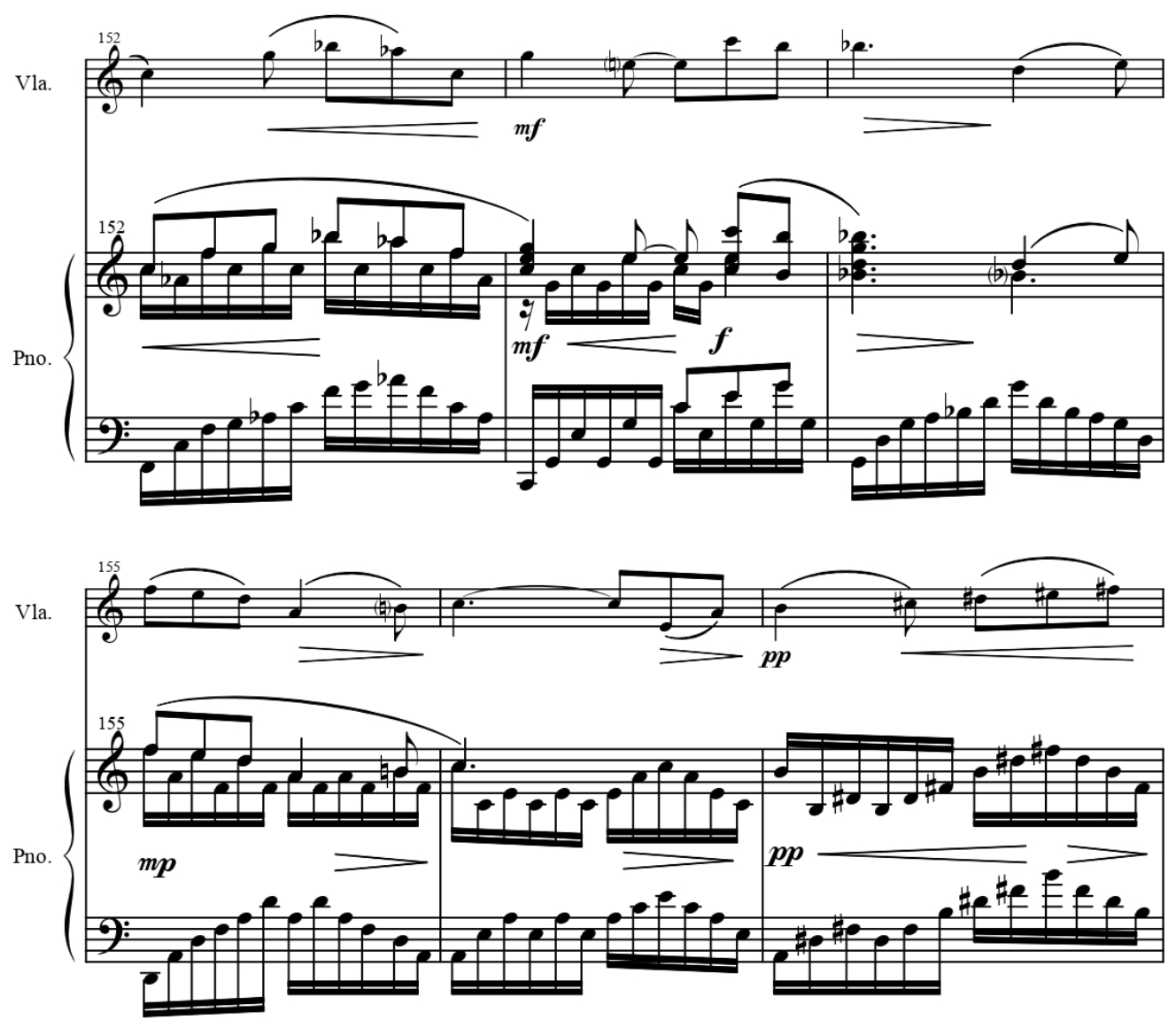
12
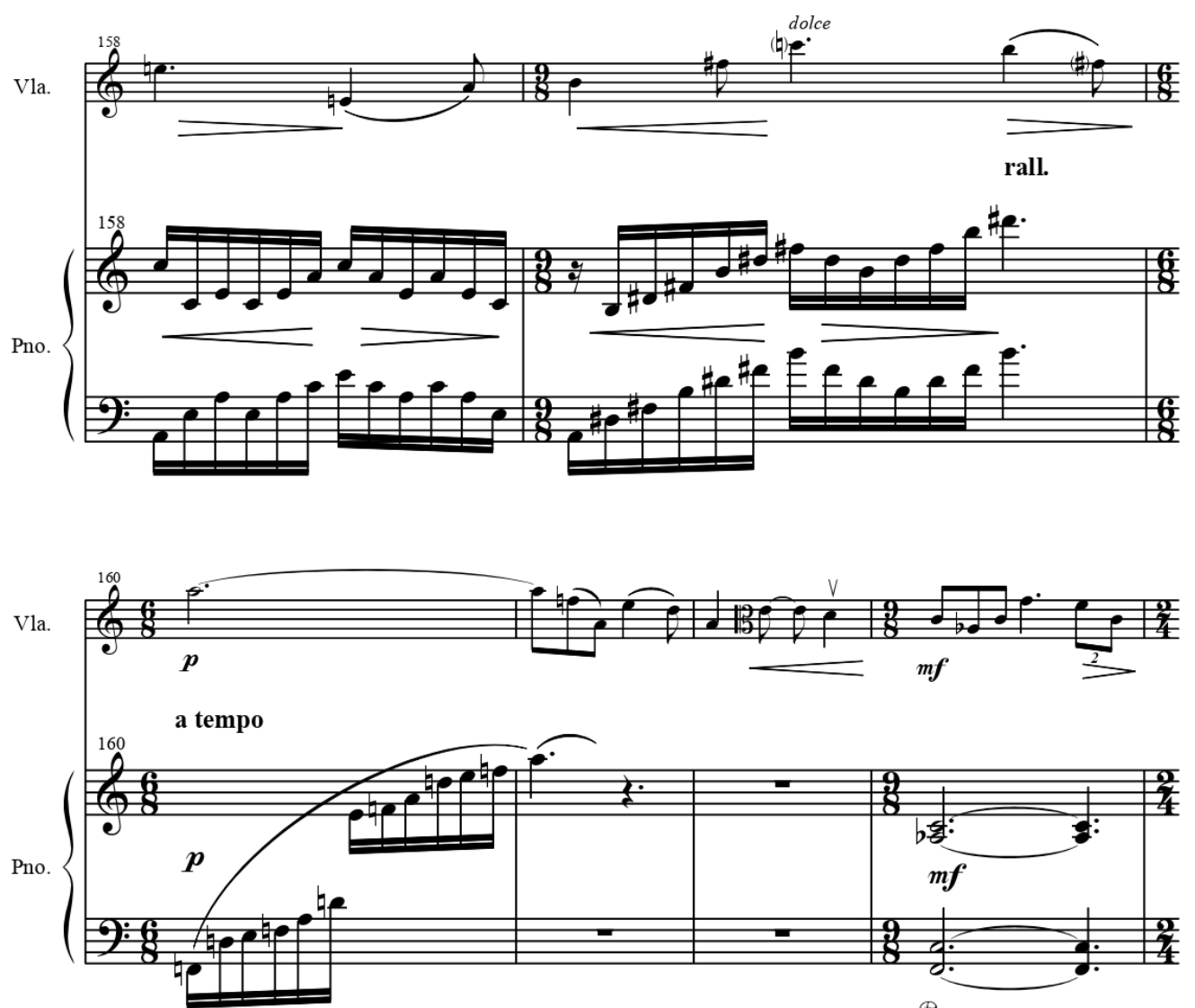

Po.

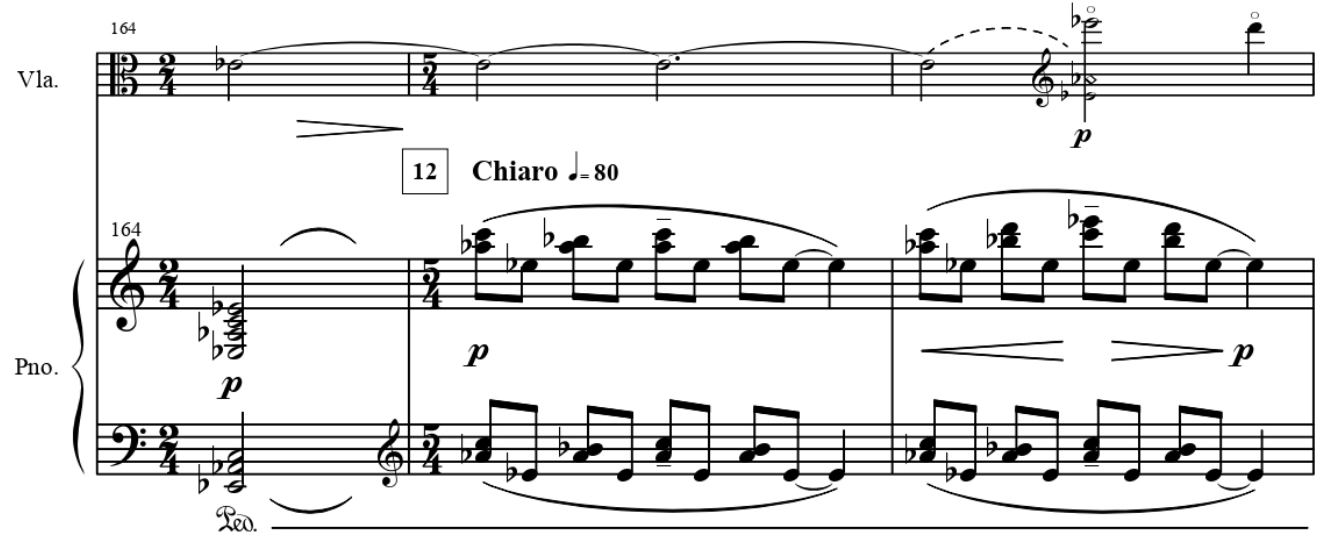




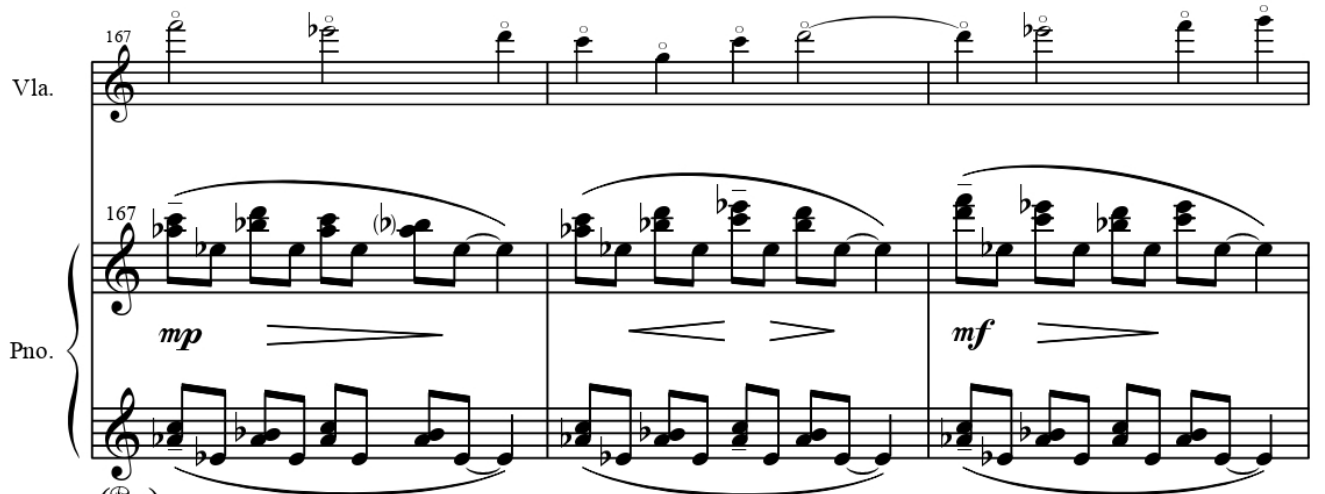

(200.)
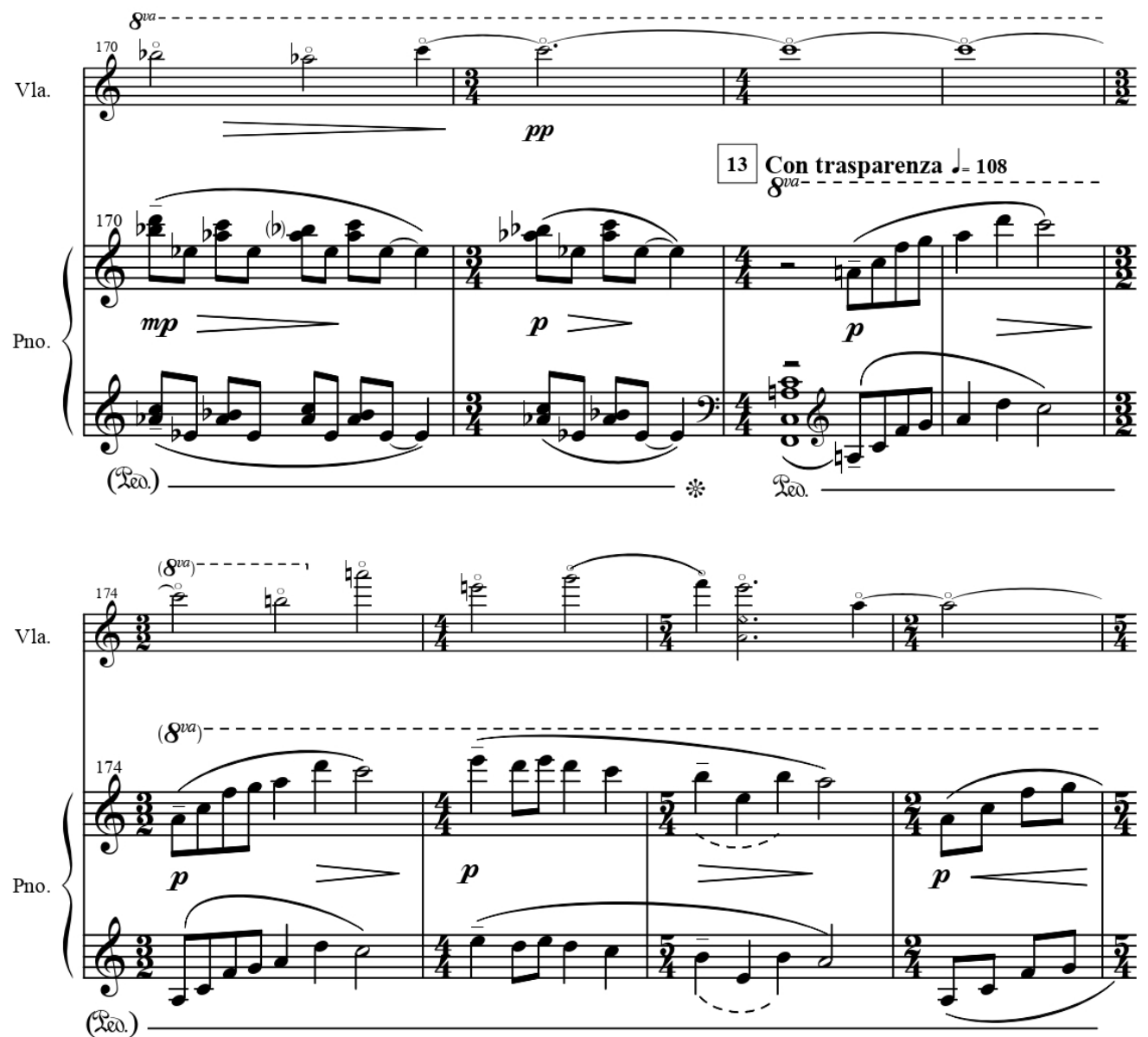

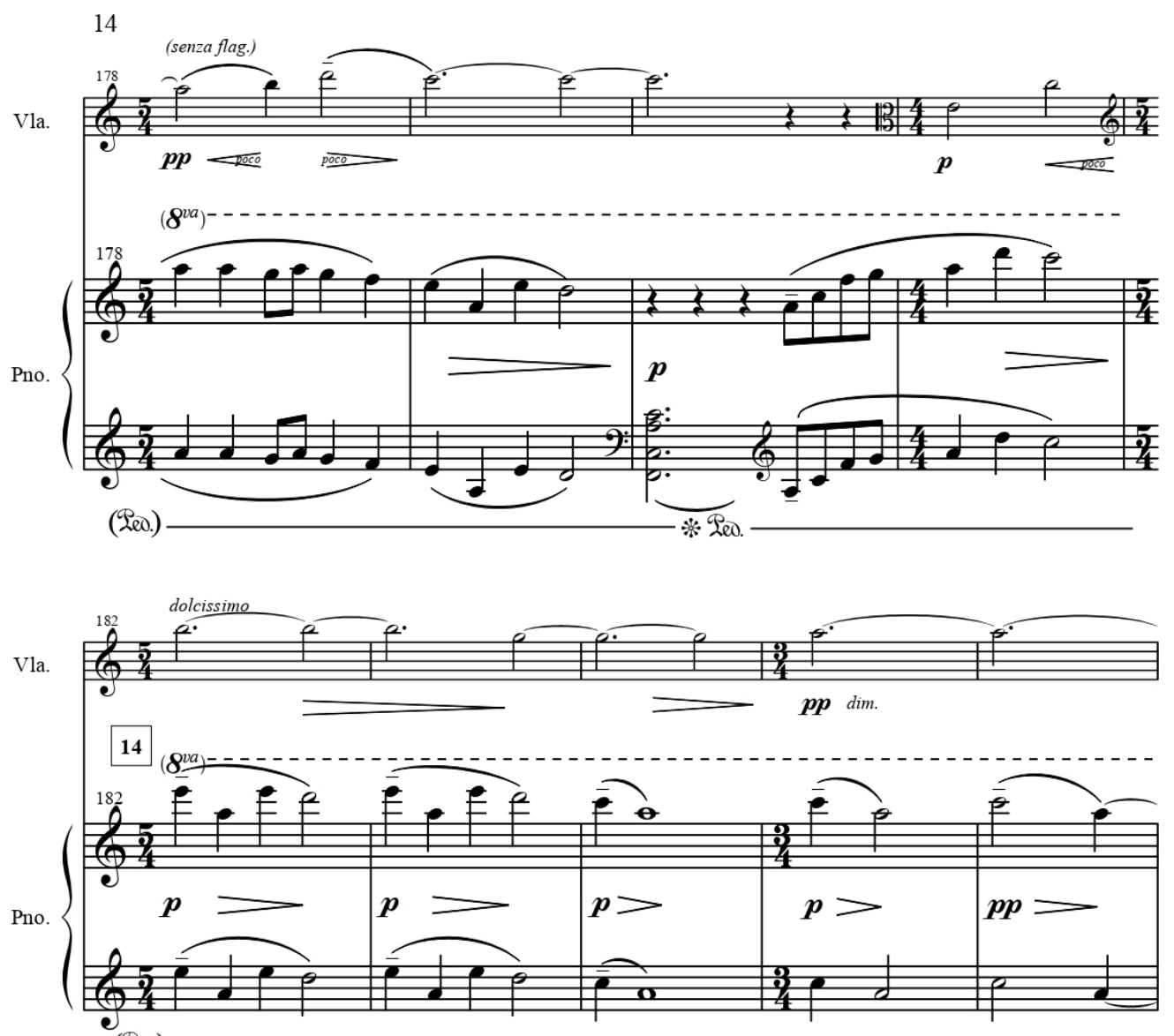

( 200.$)$

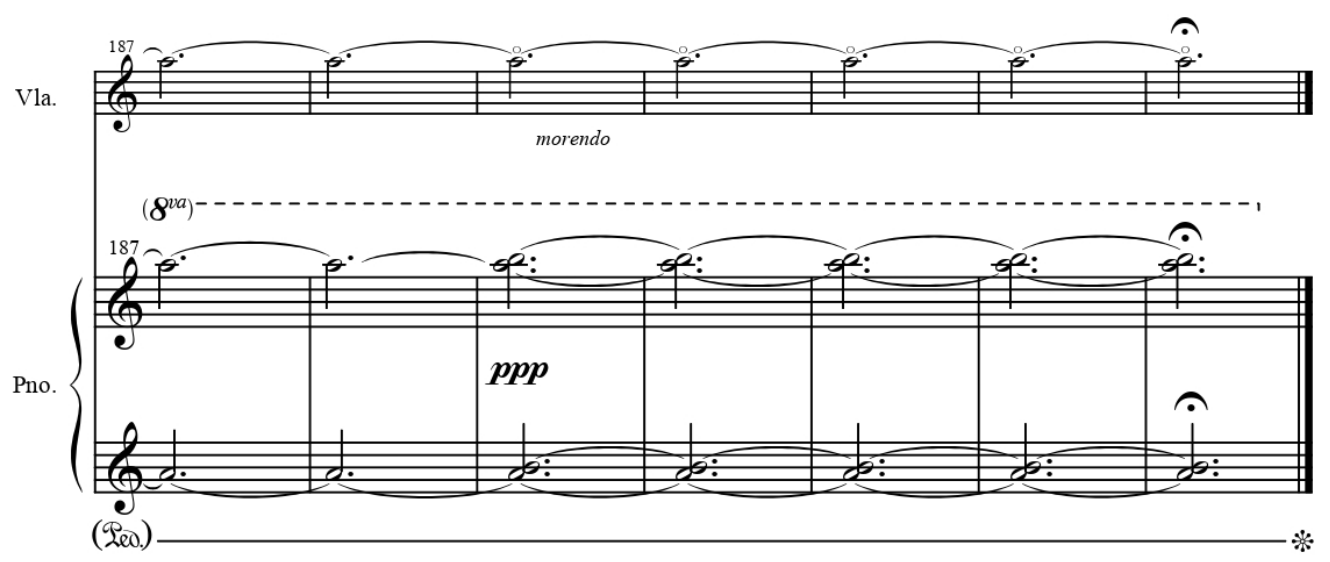




\section{II}
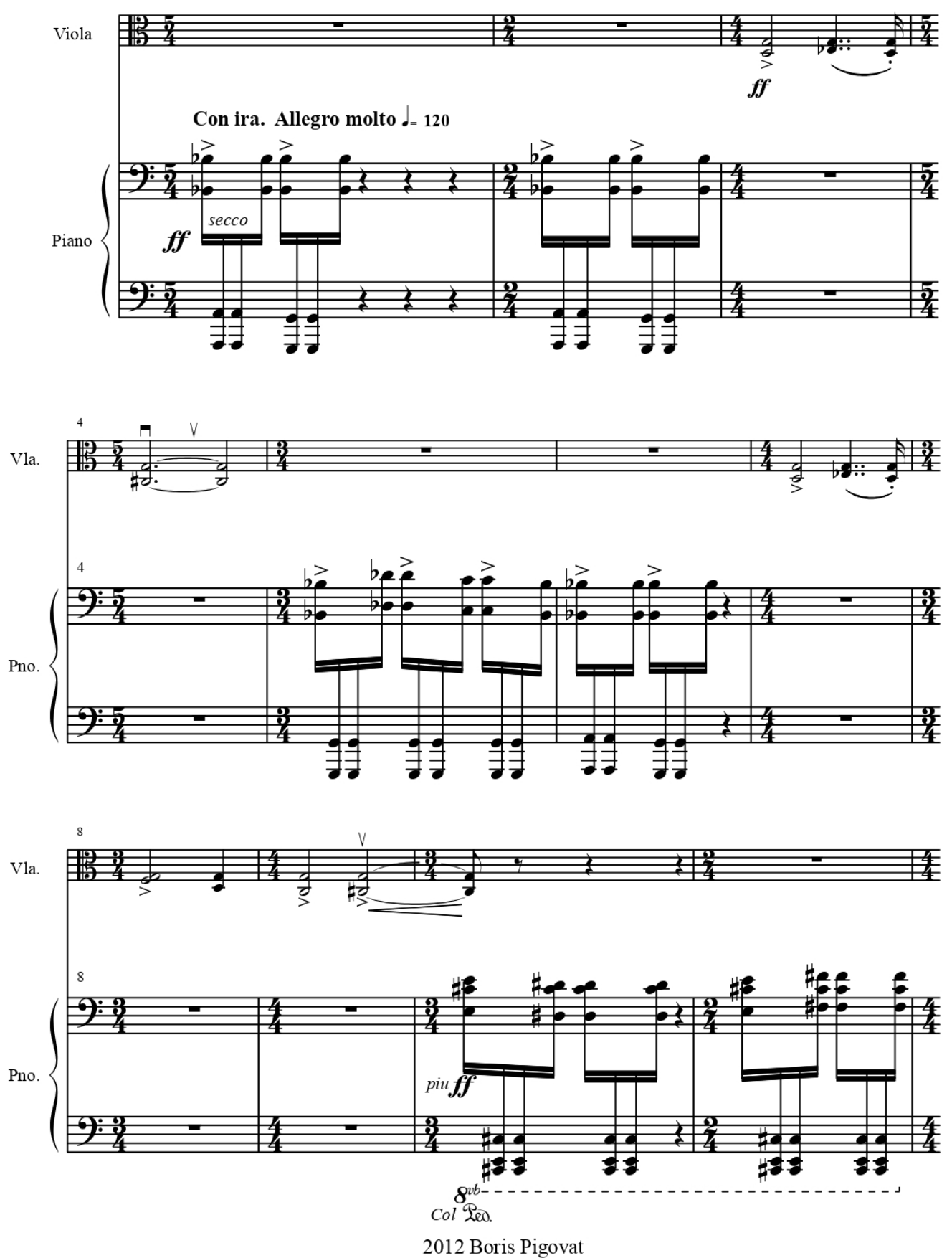

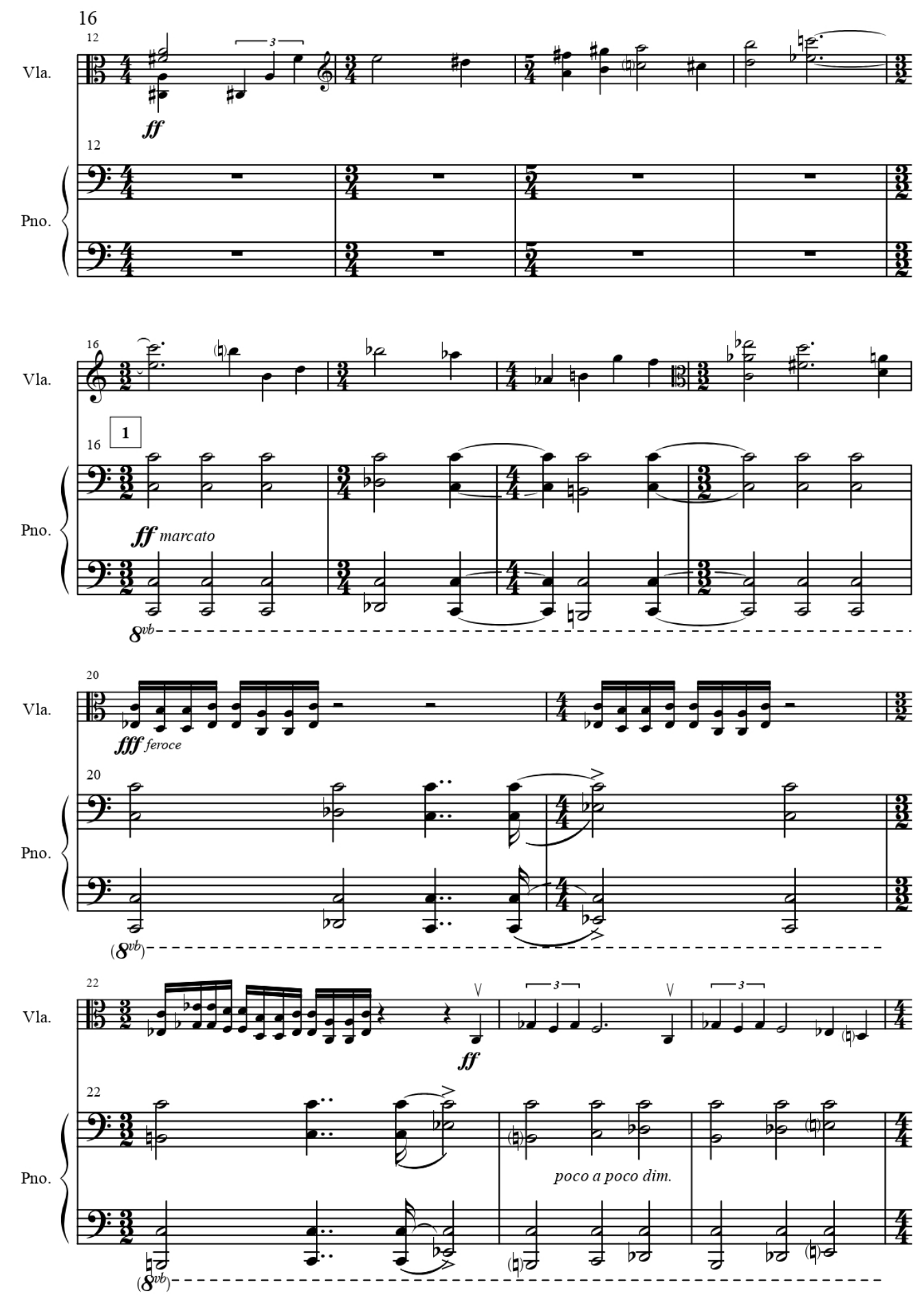


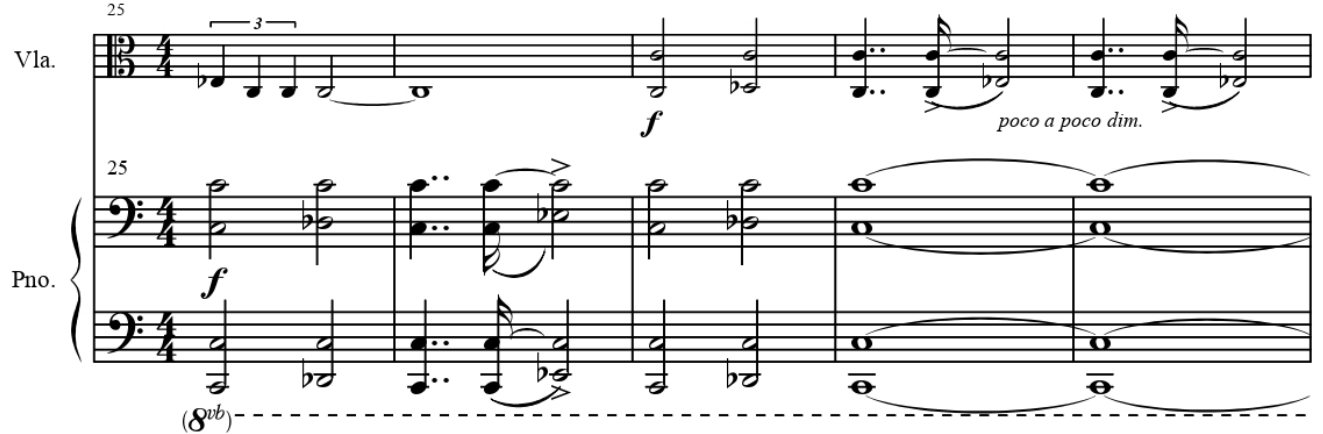

Vla.
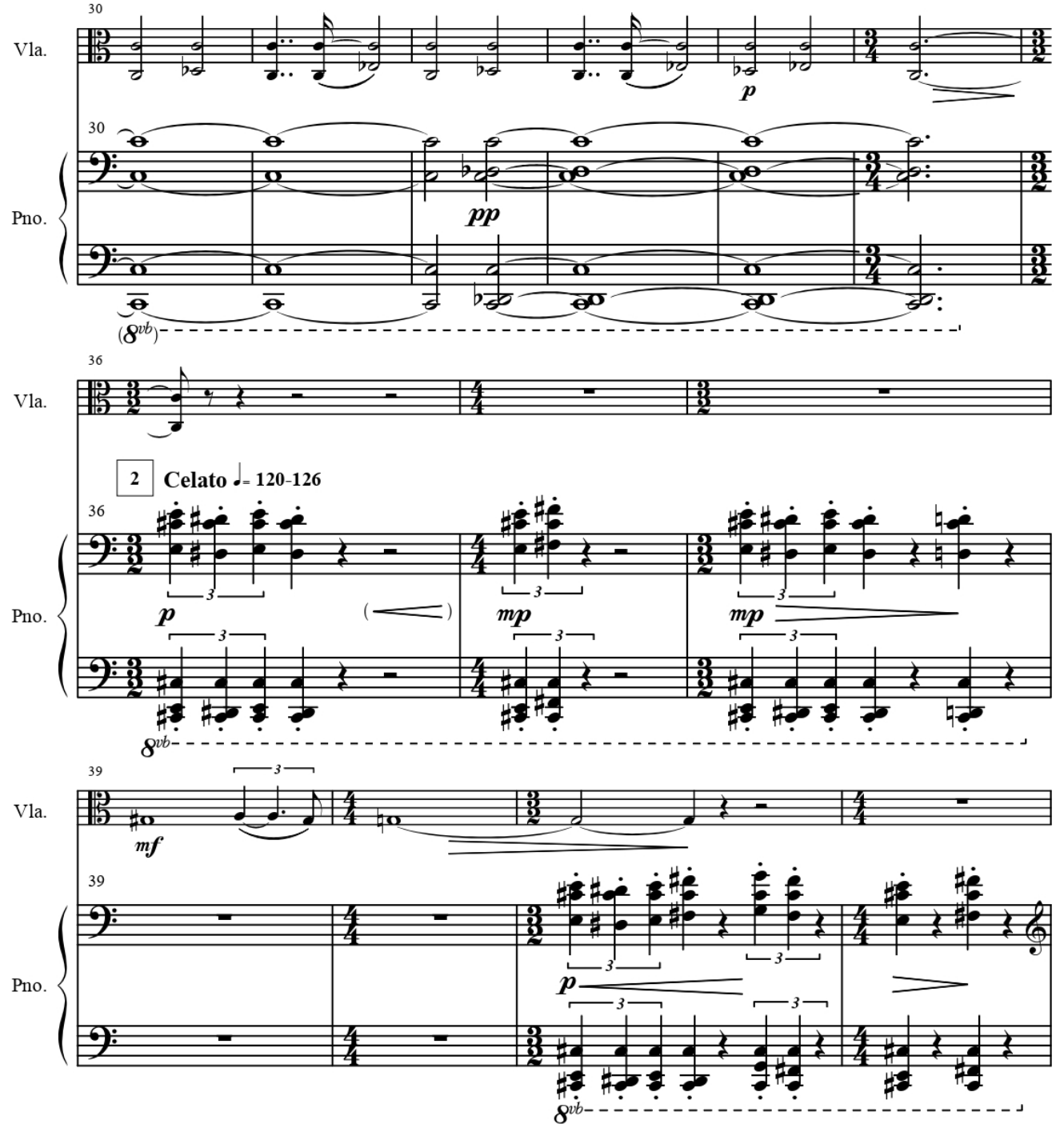

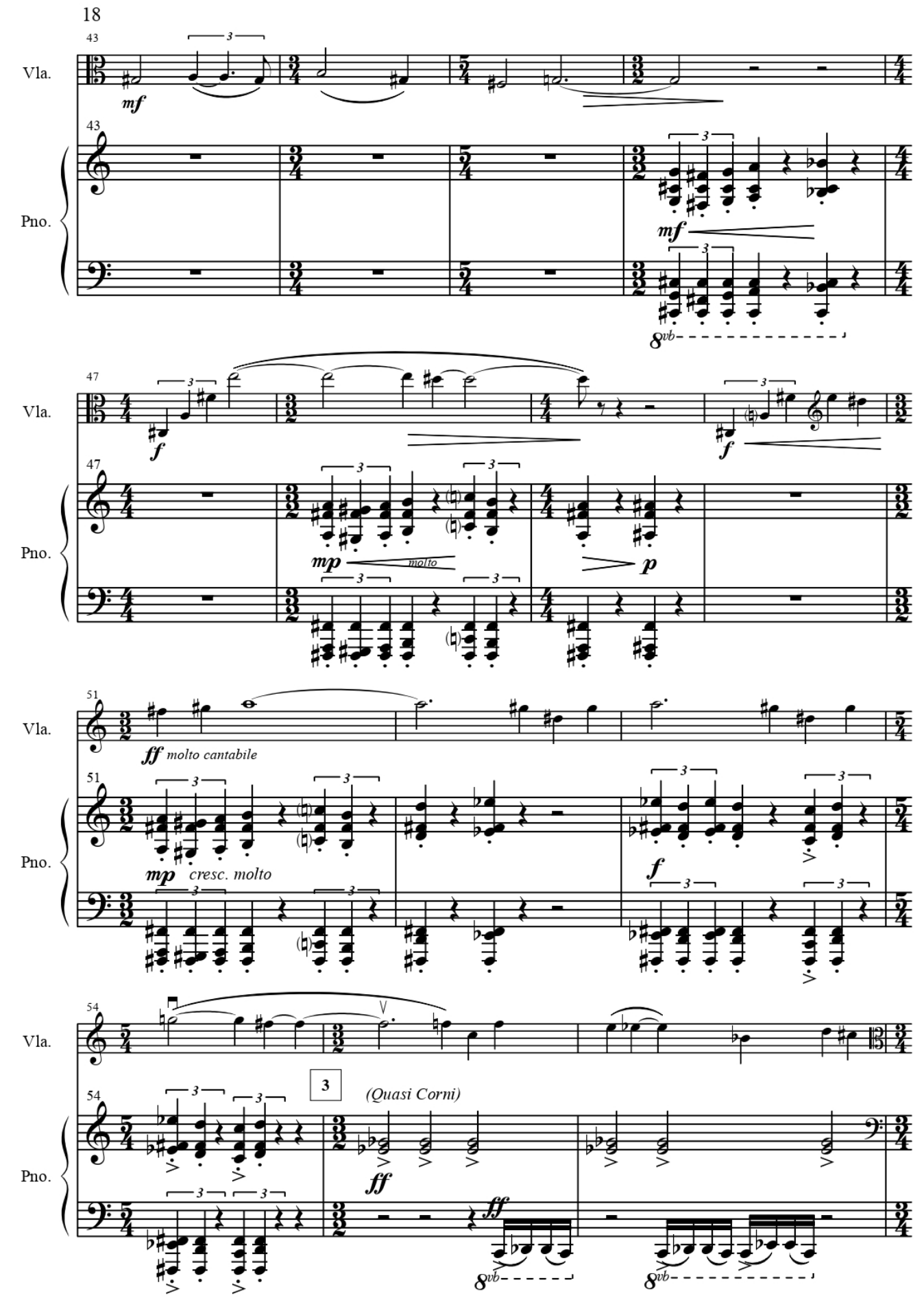
成- 8
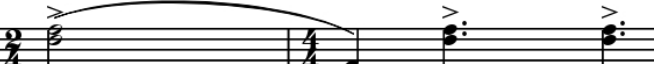

ff sempre

57
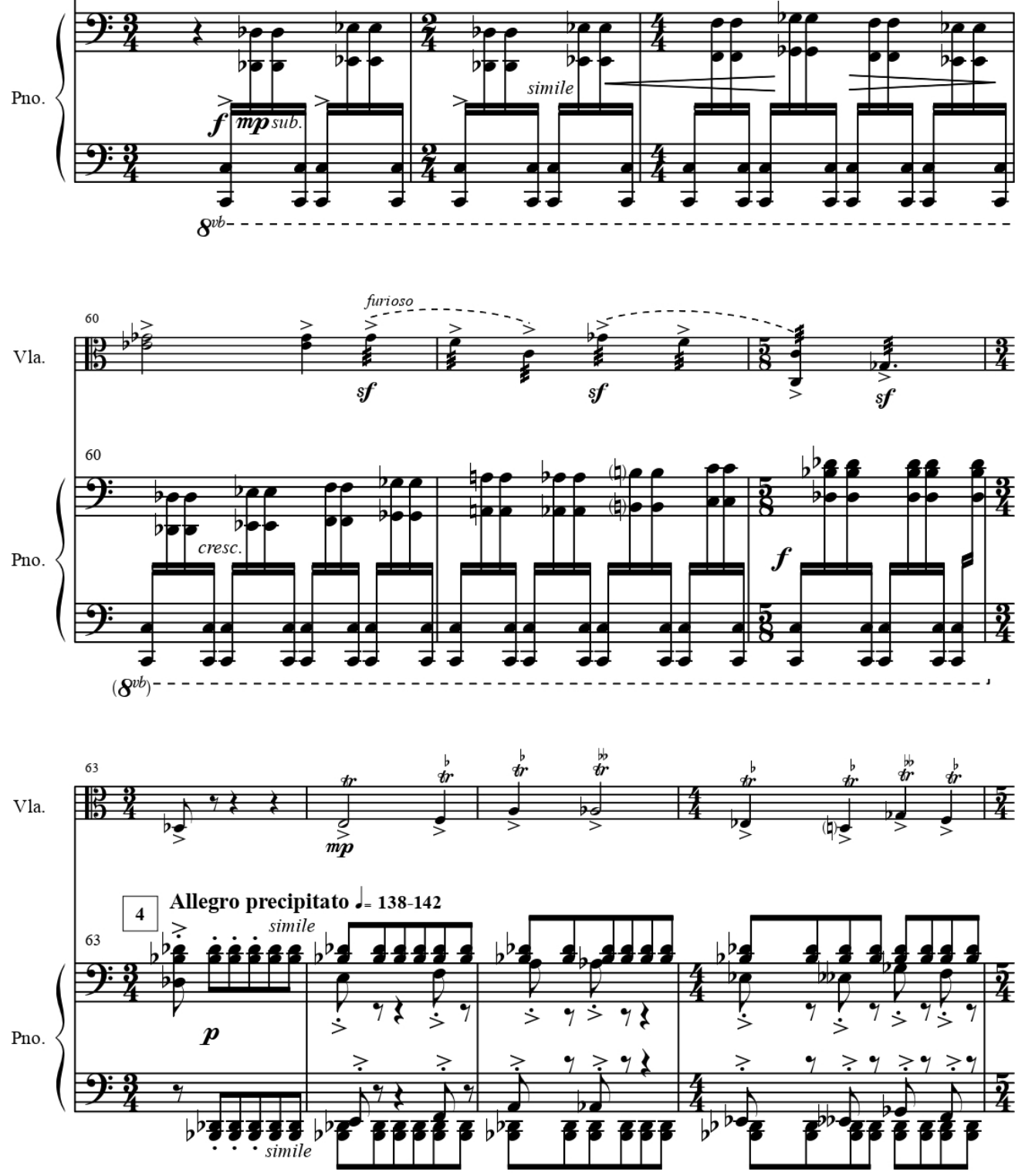
20
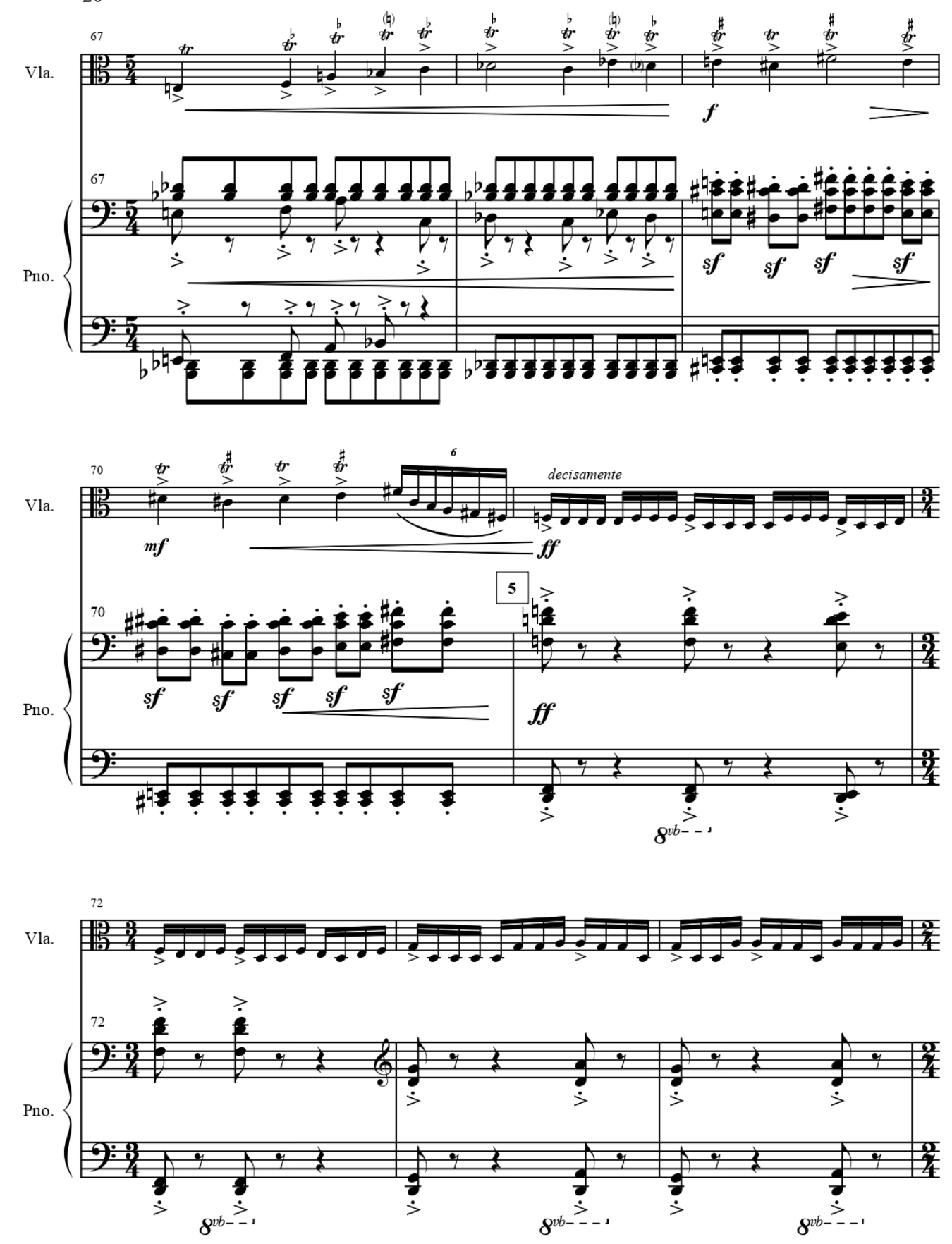

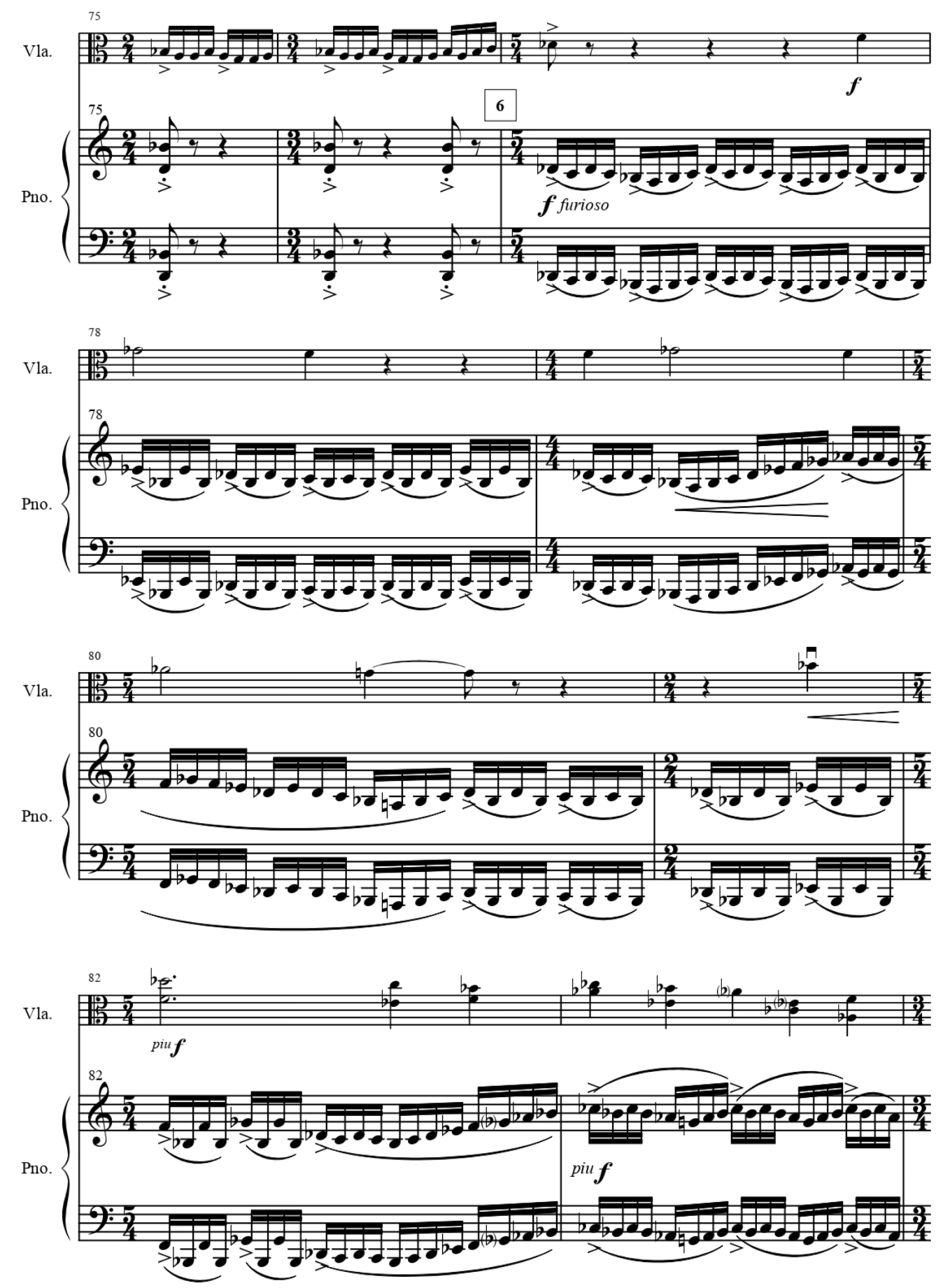


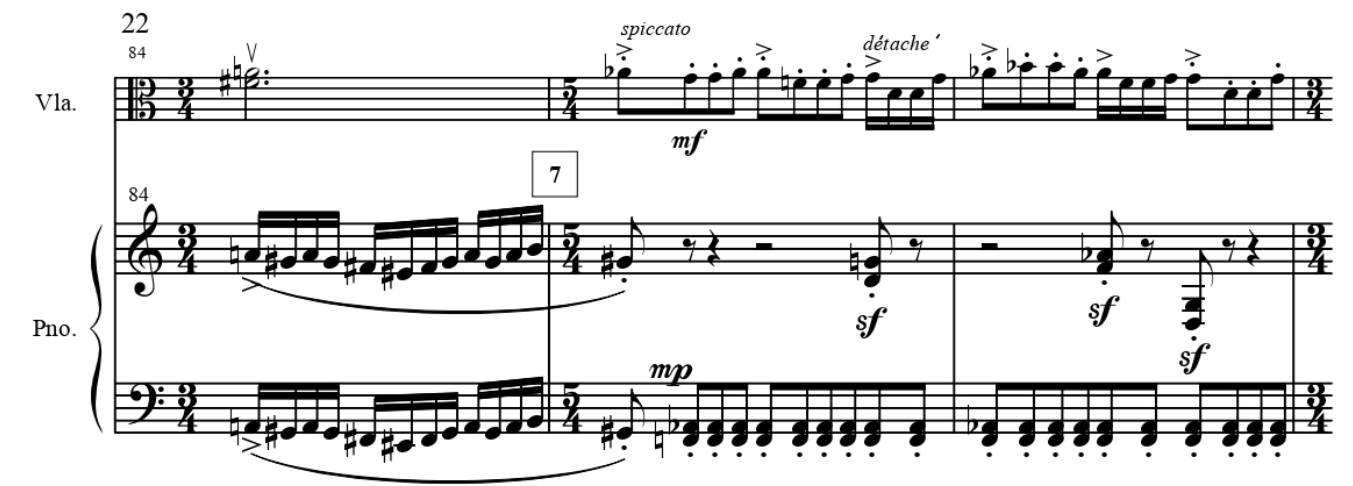

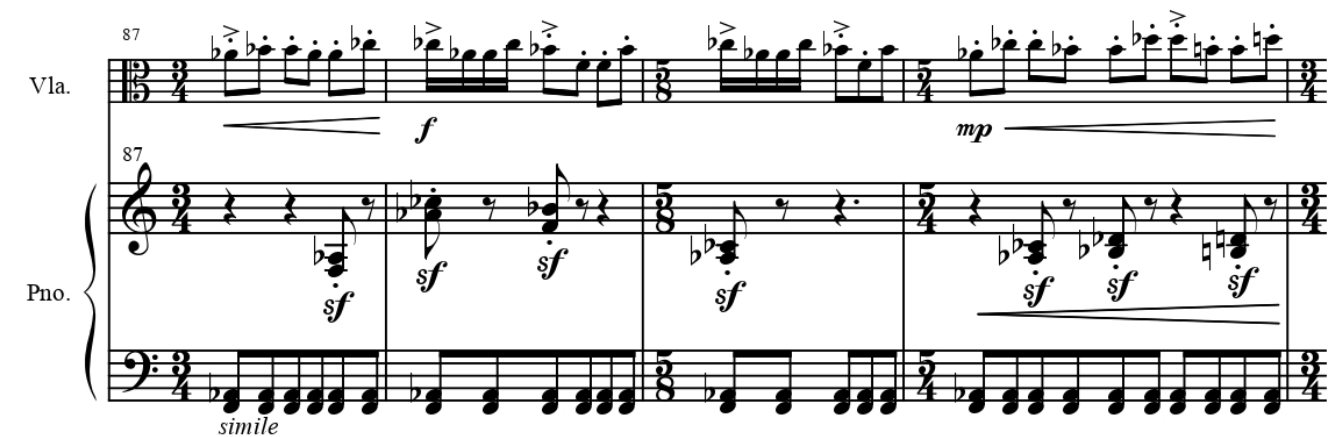
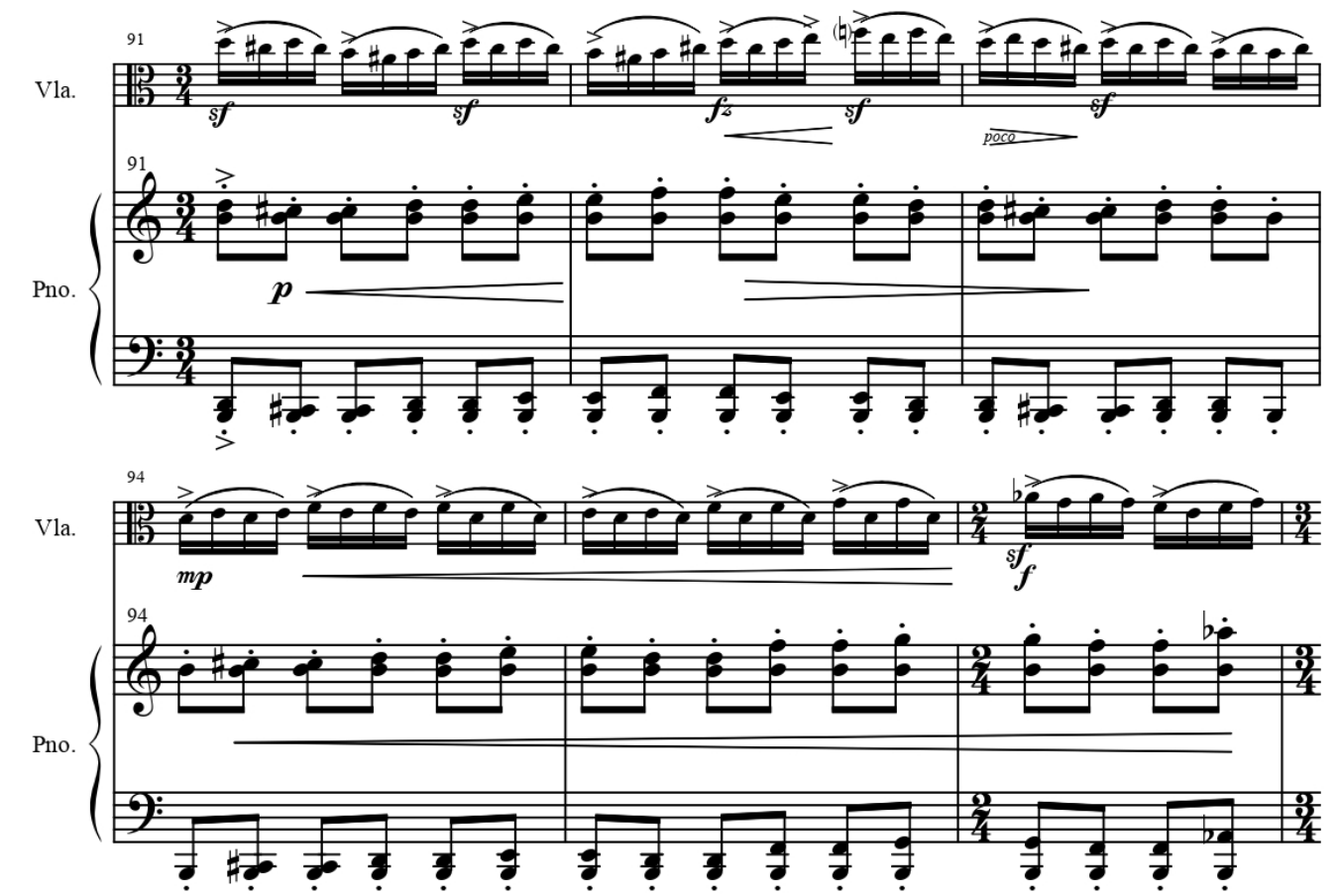

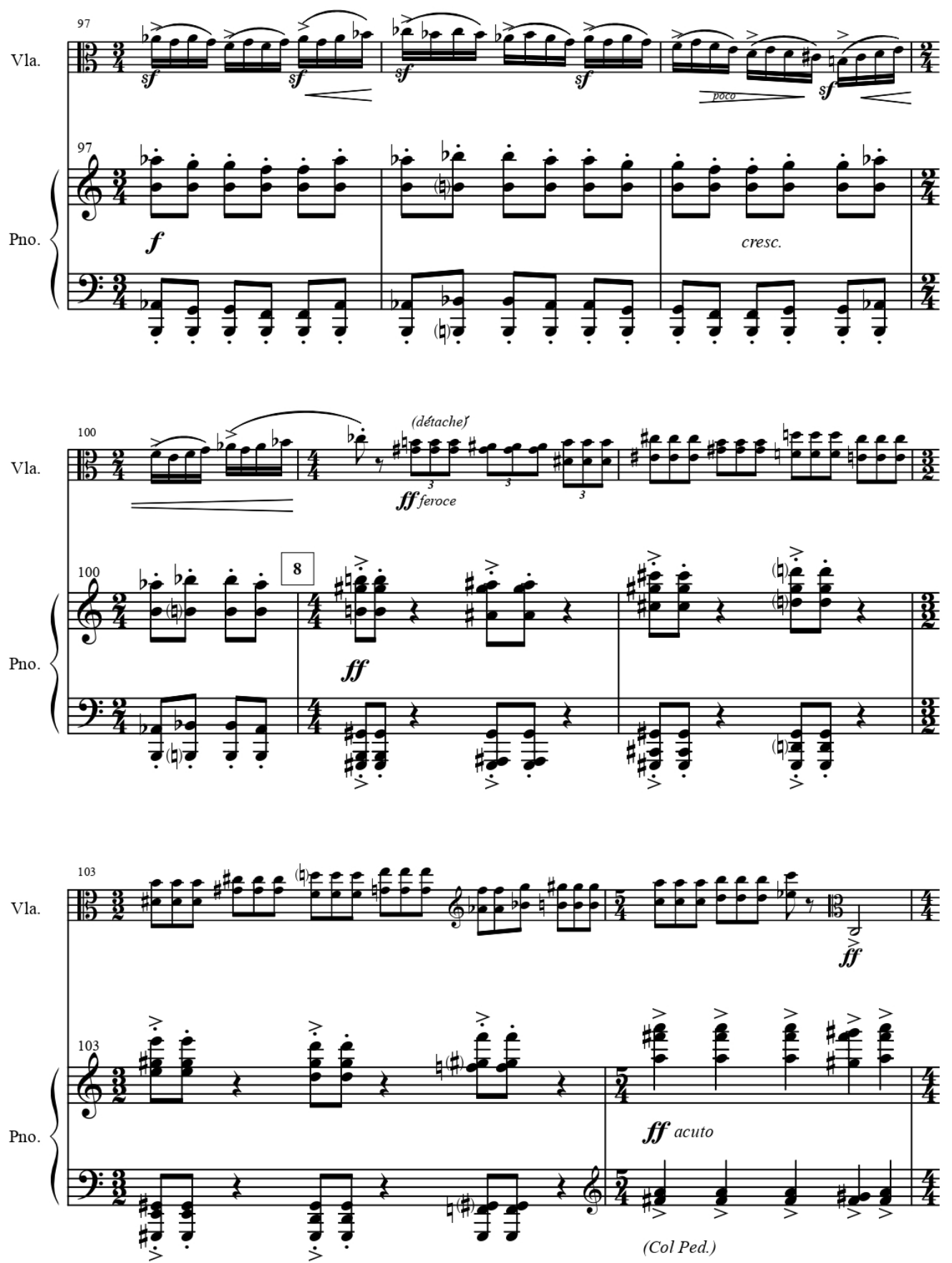

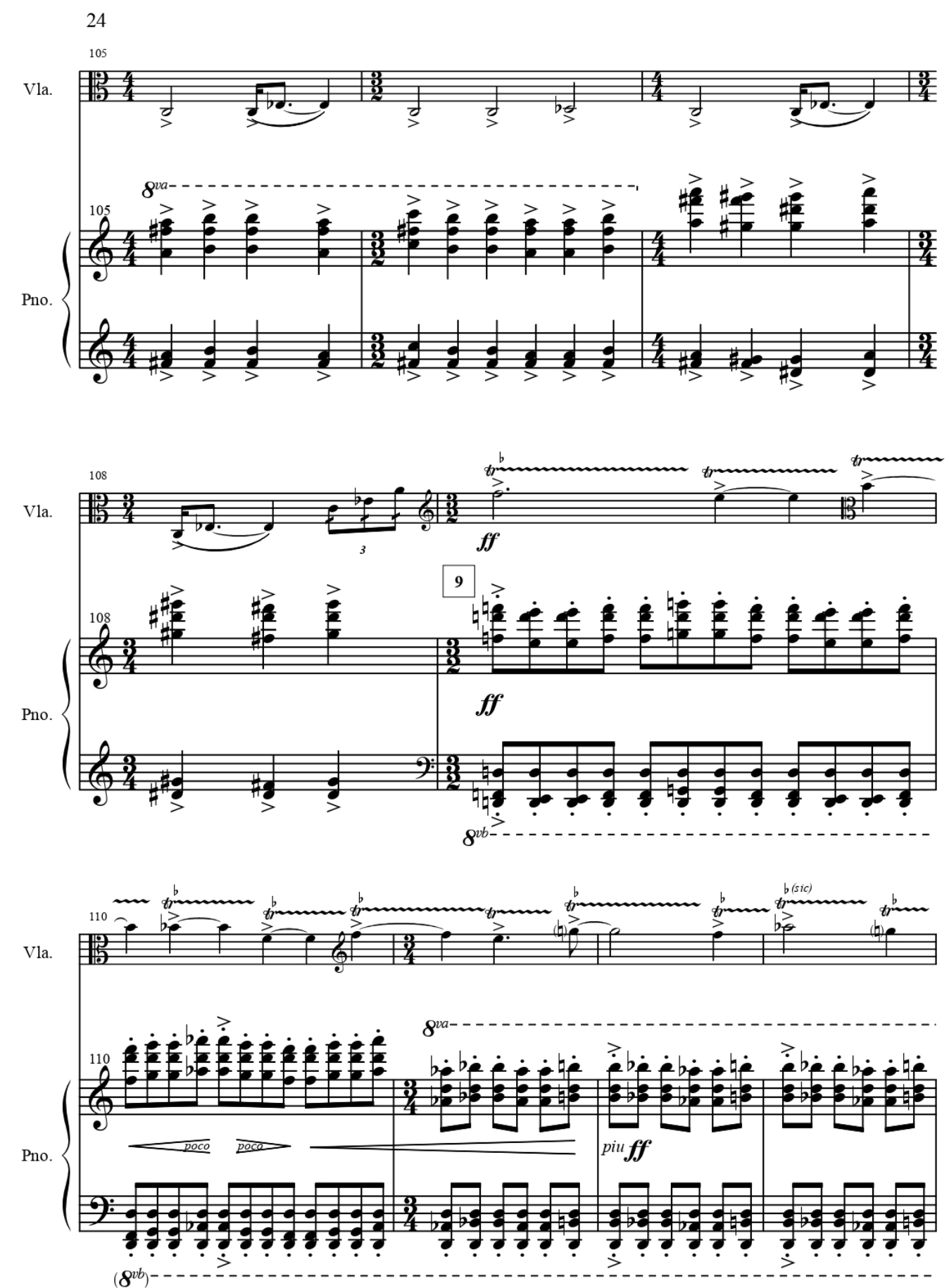

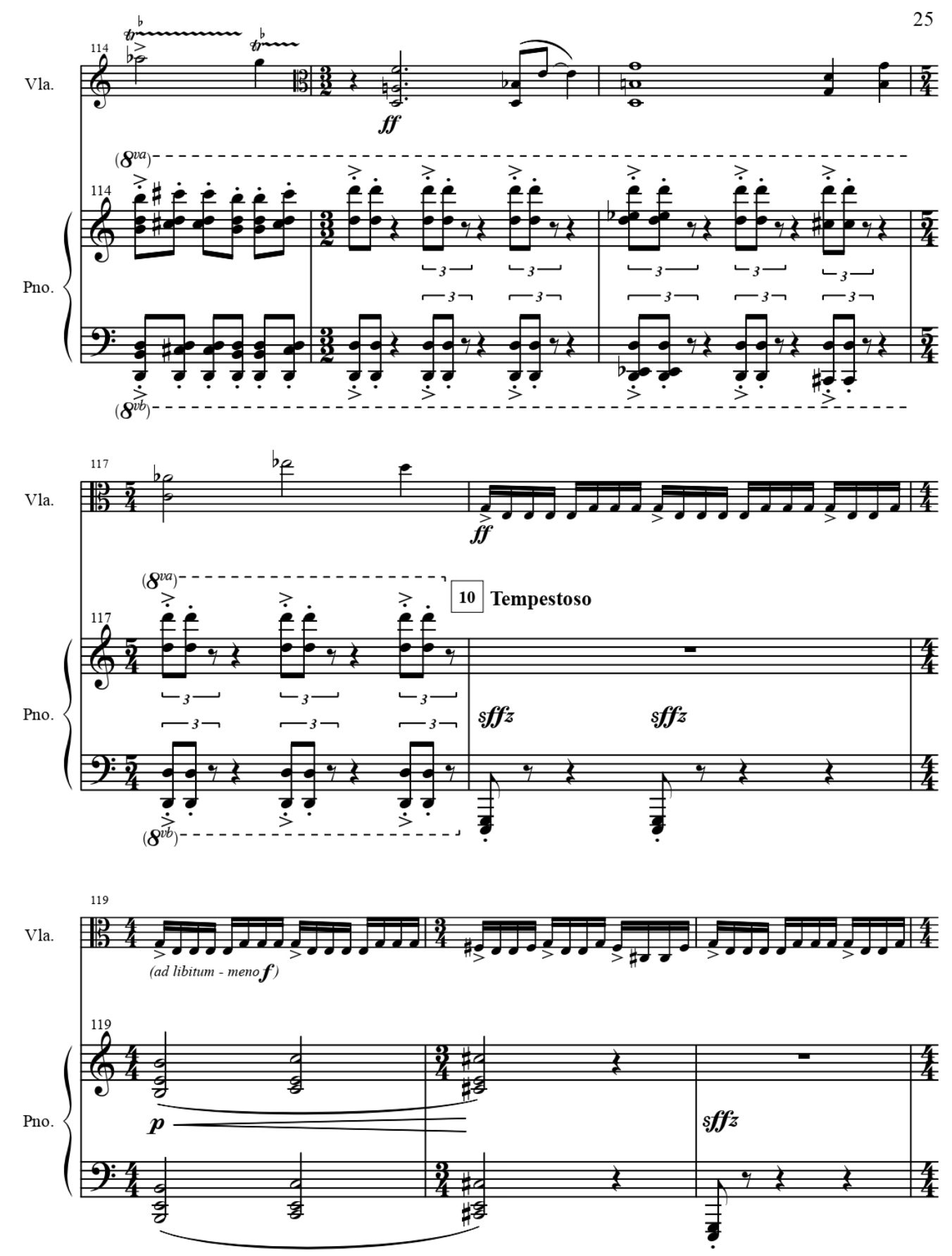

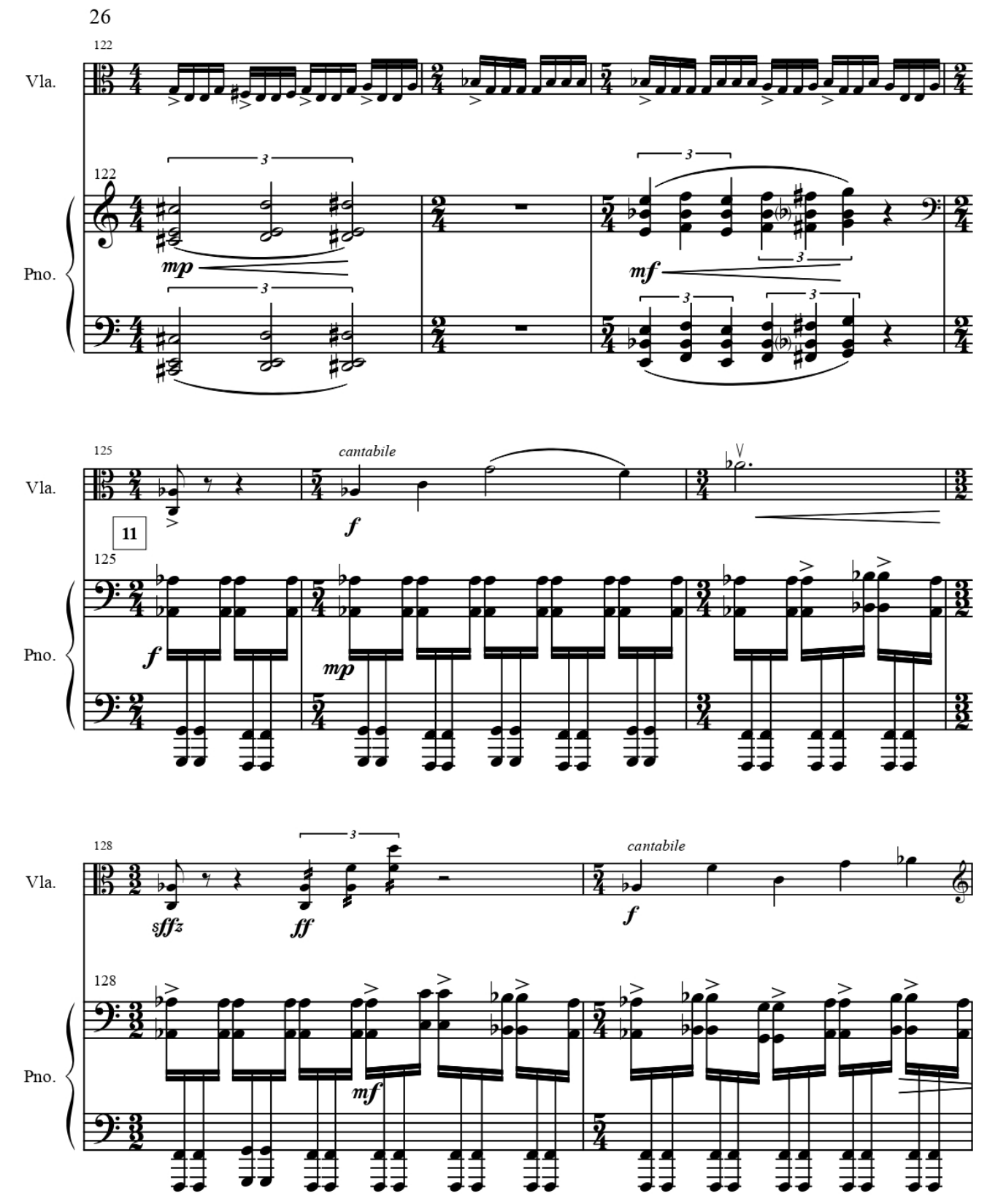

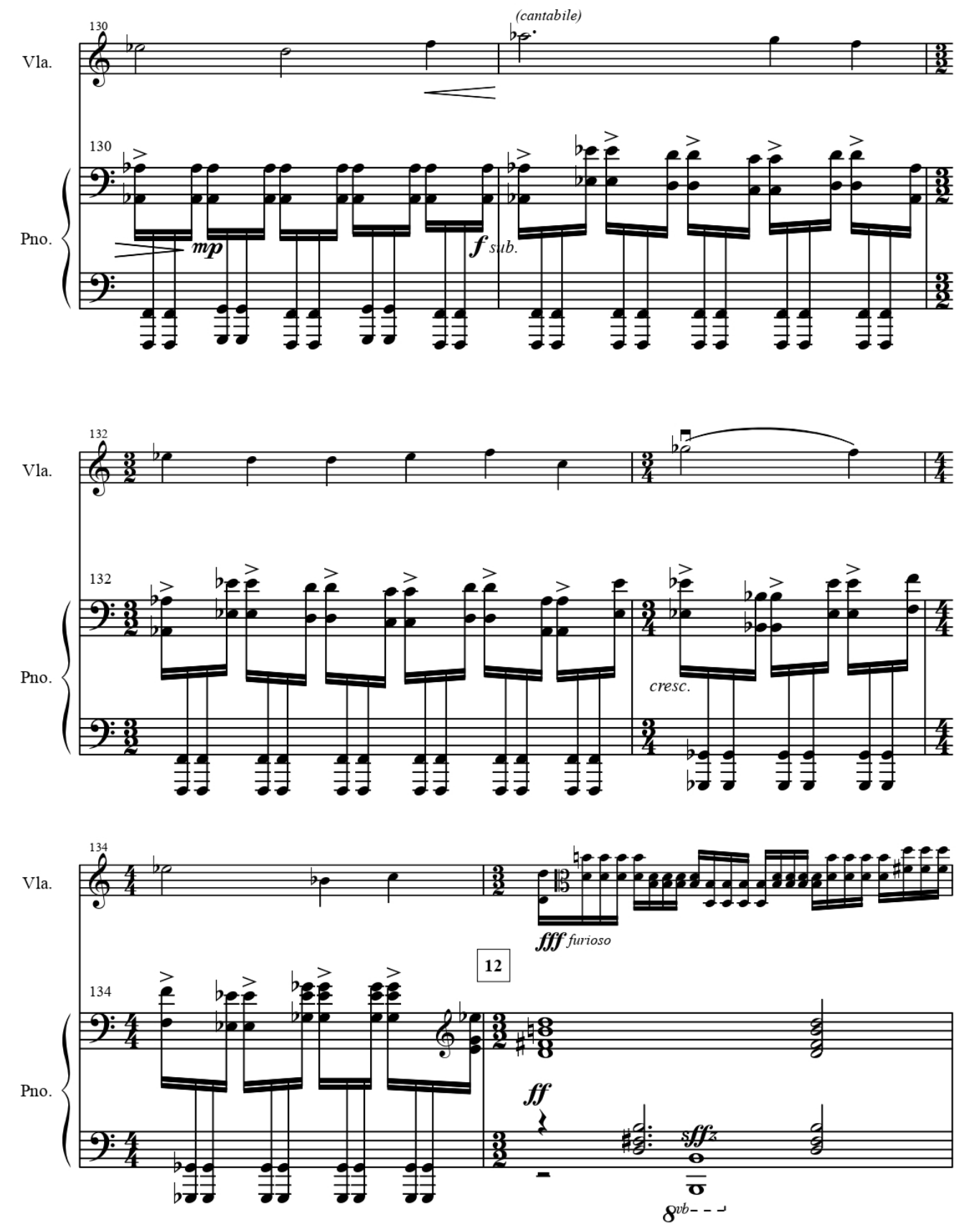

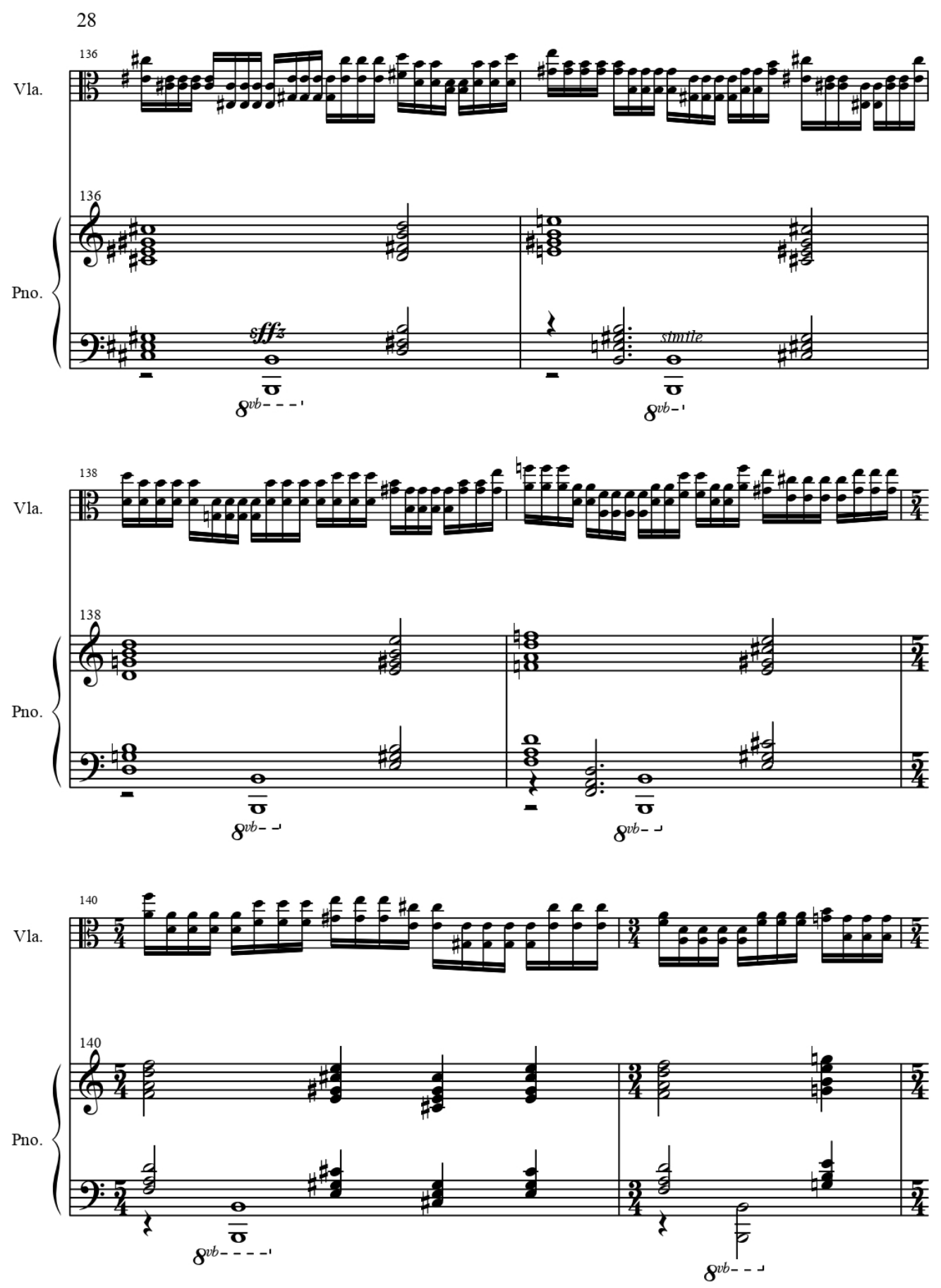
Vla. 

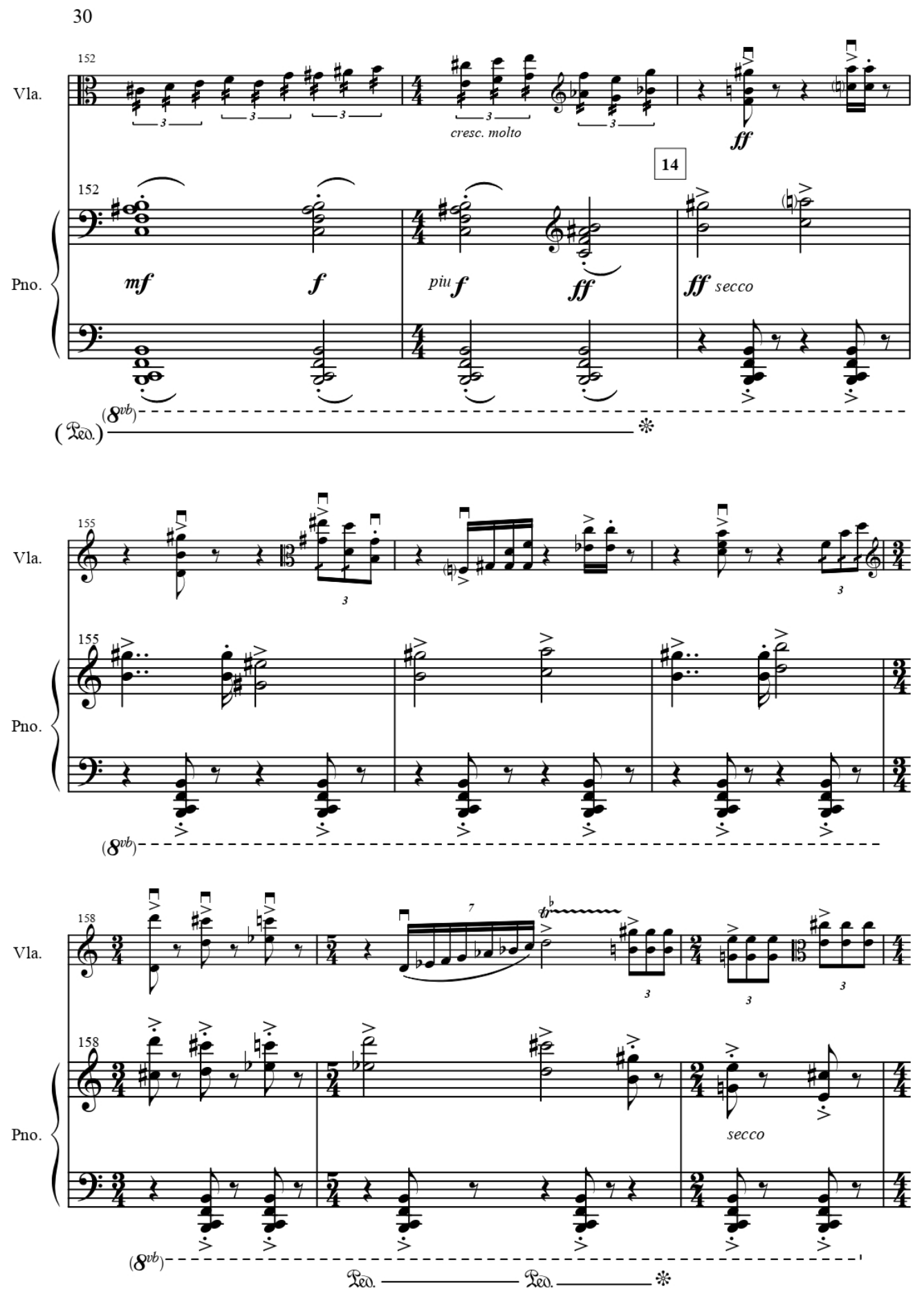

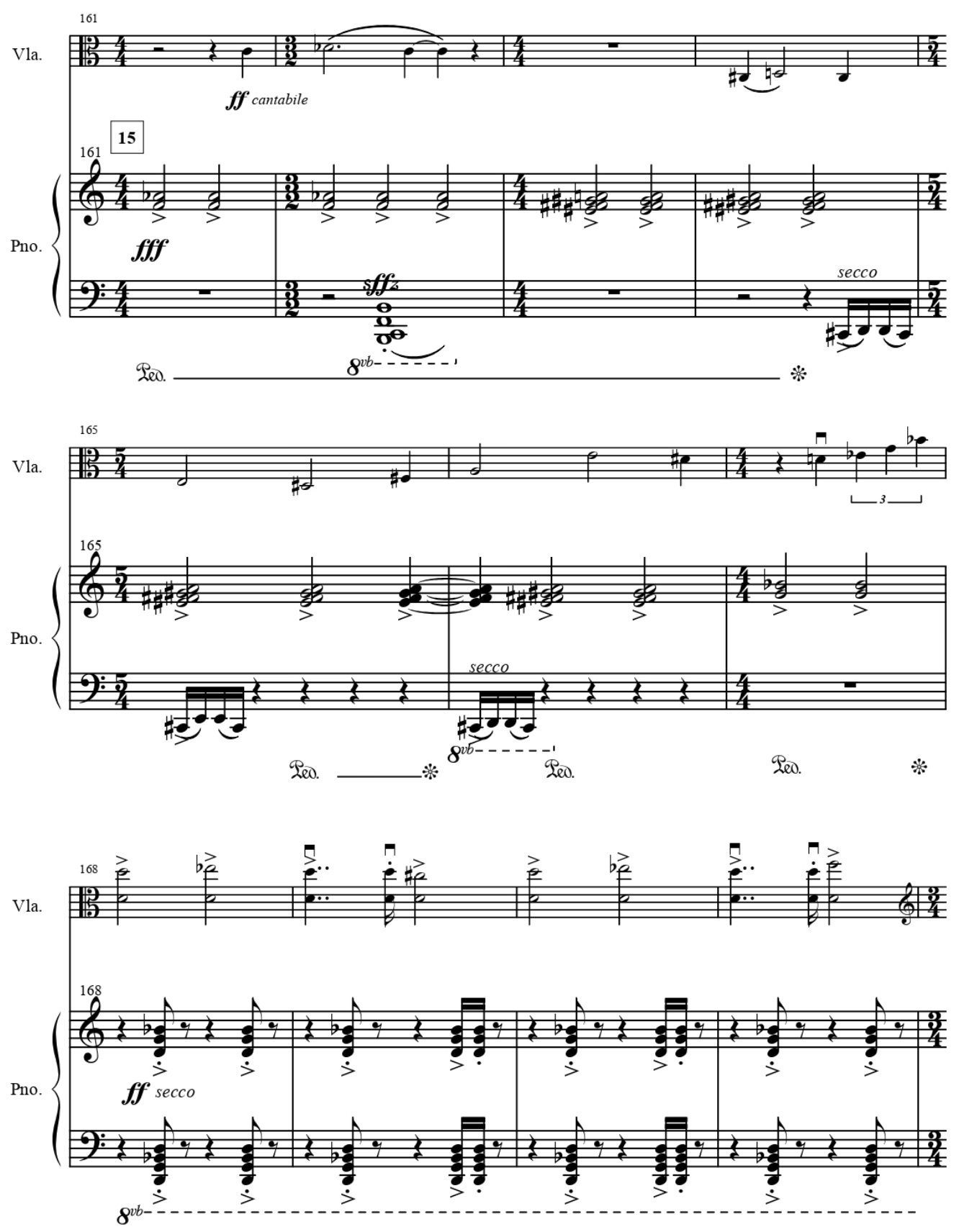
32
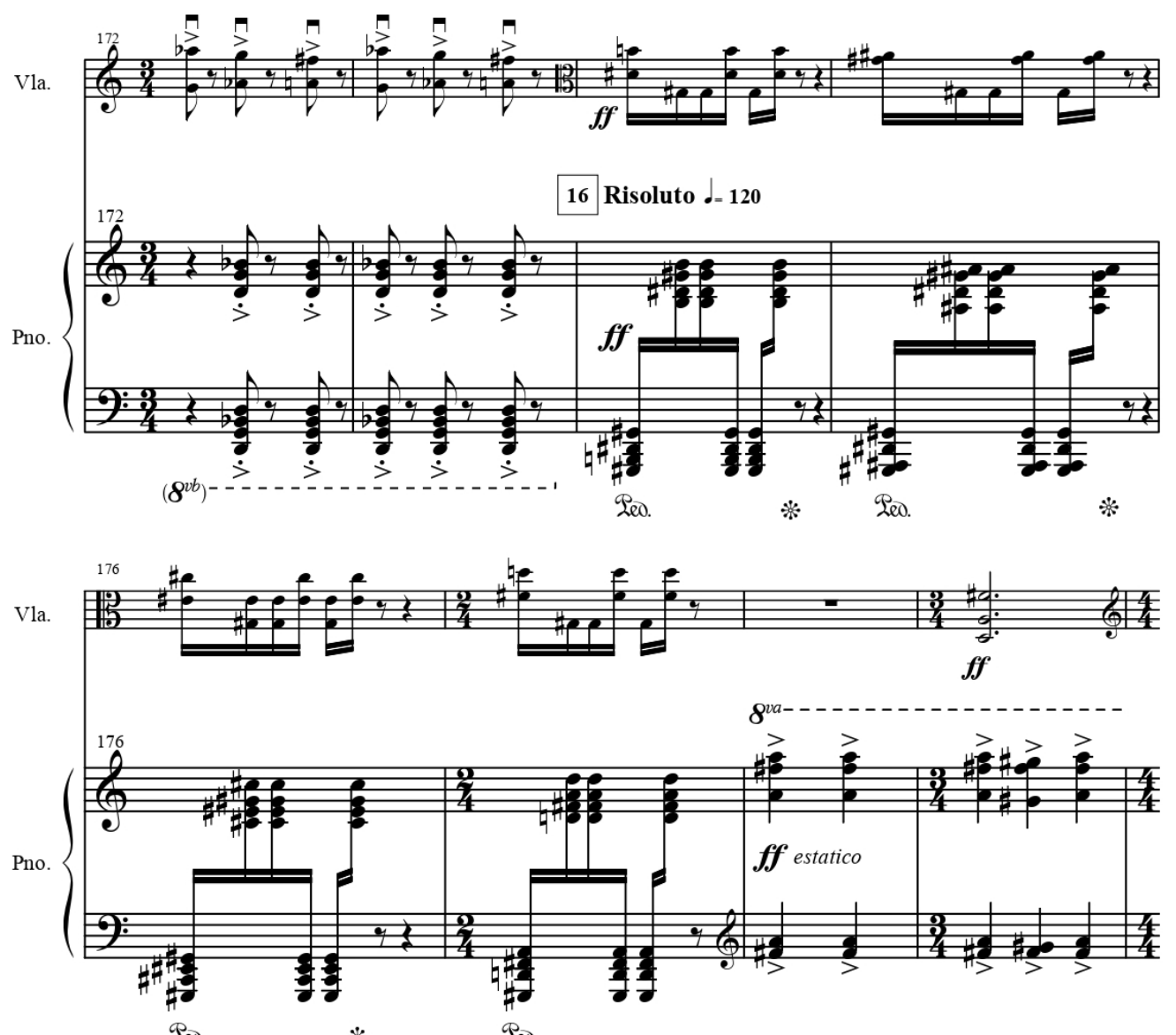

Peo. $*$

2eo.

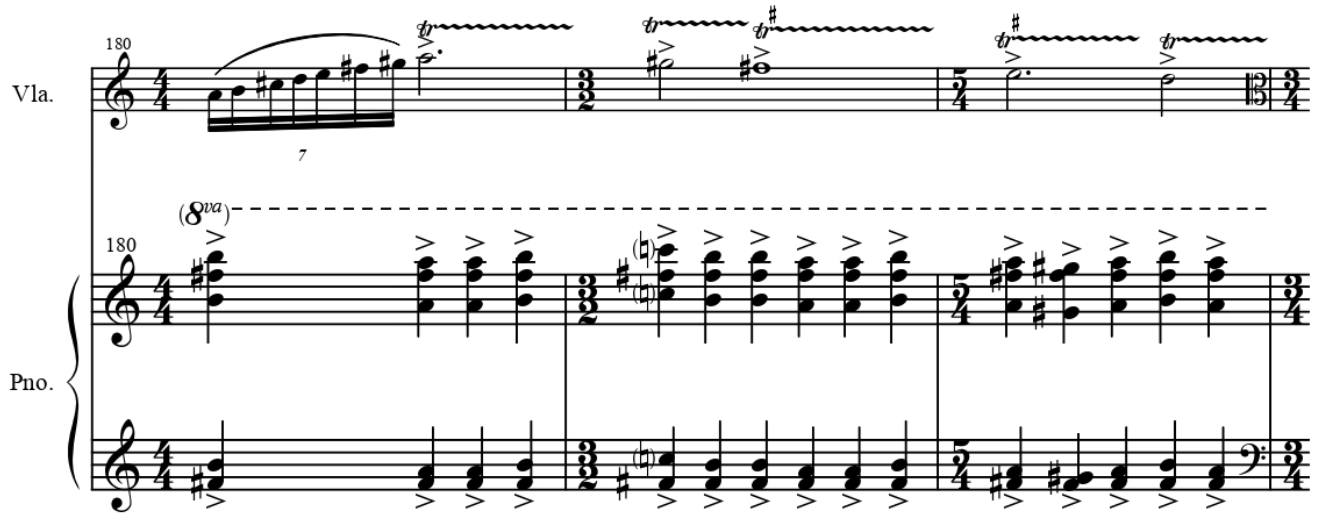

Col Peo. 

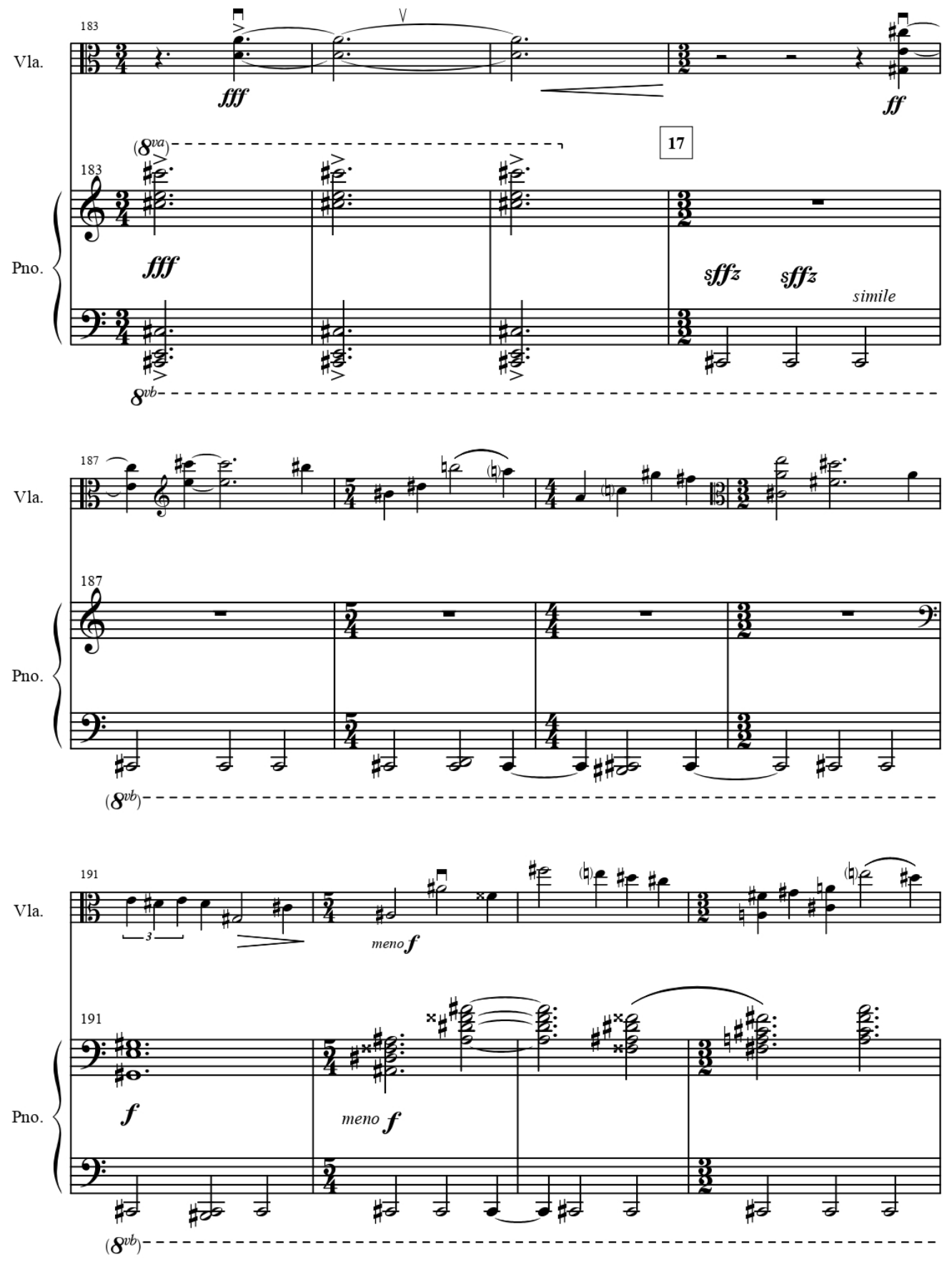

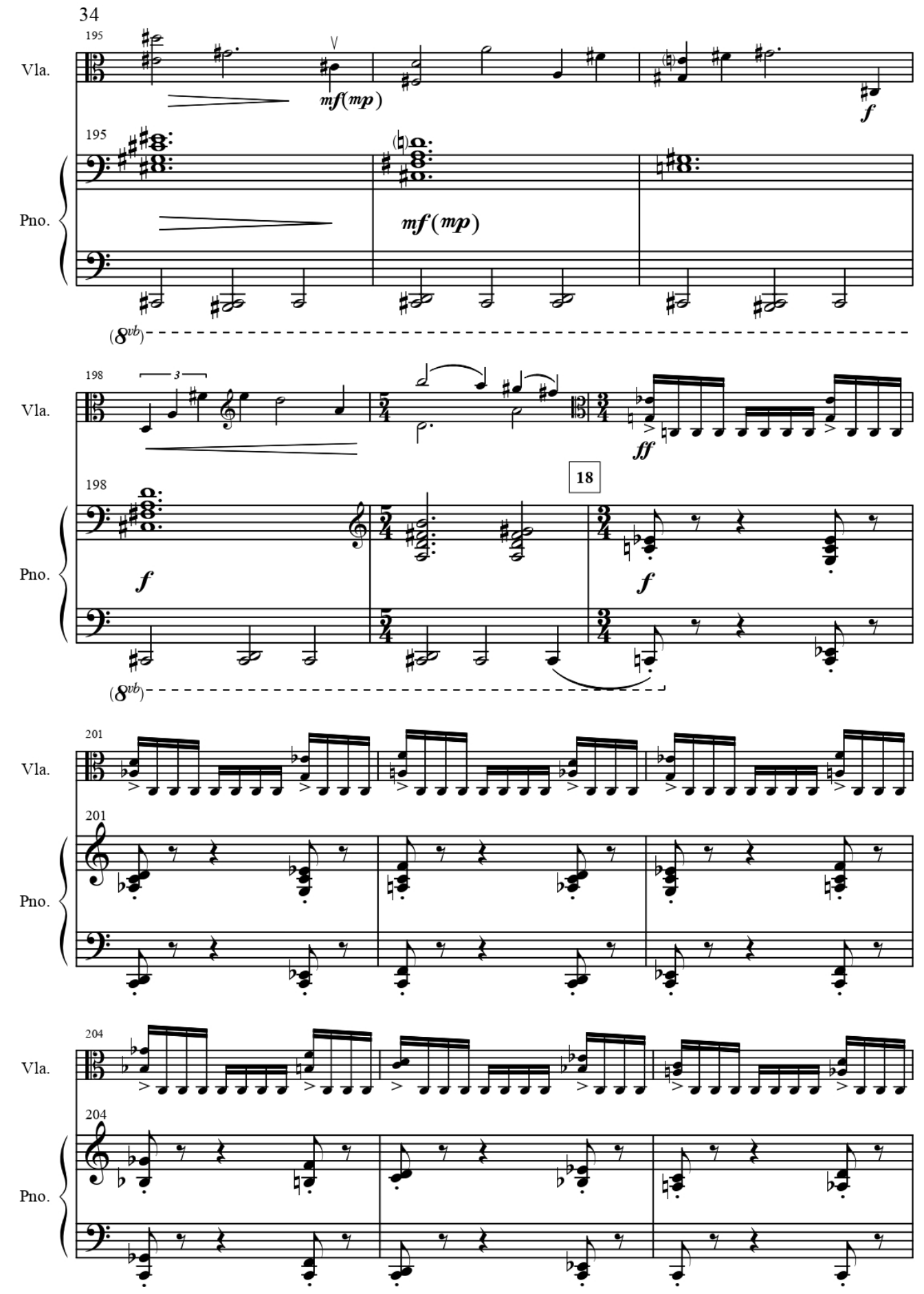
Vla

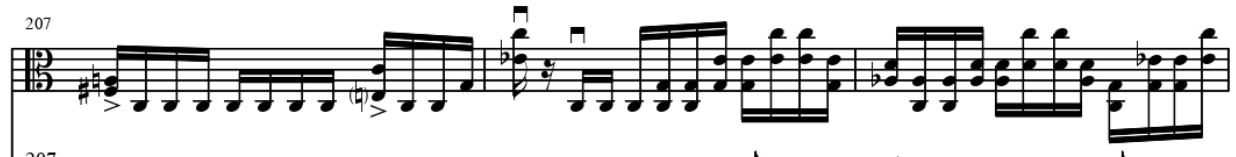

no.

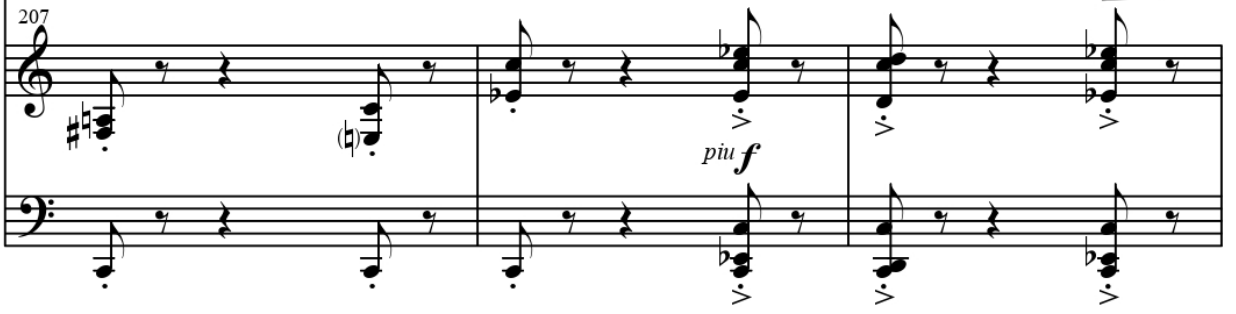

Vla.
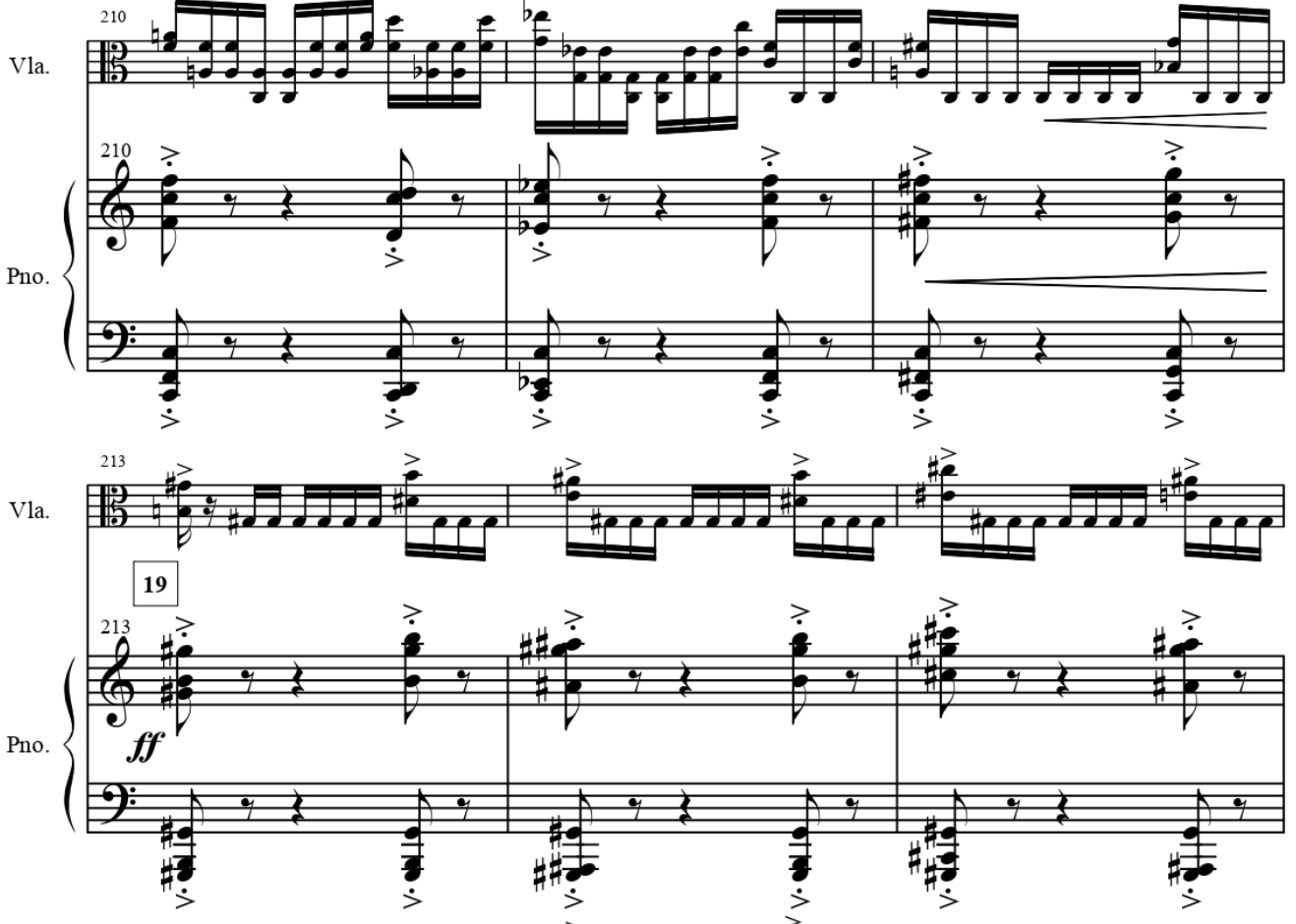

Vla.

216

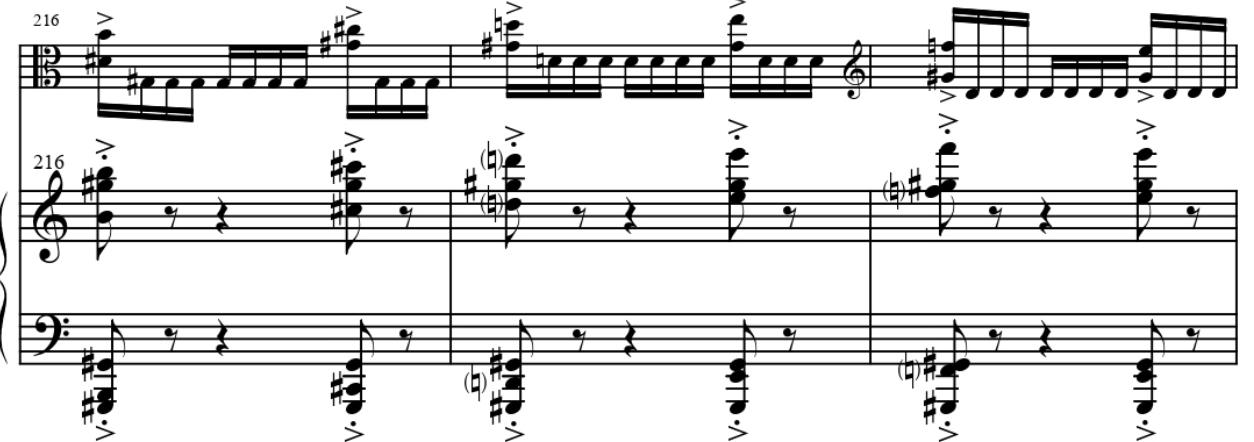



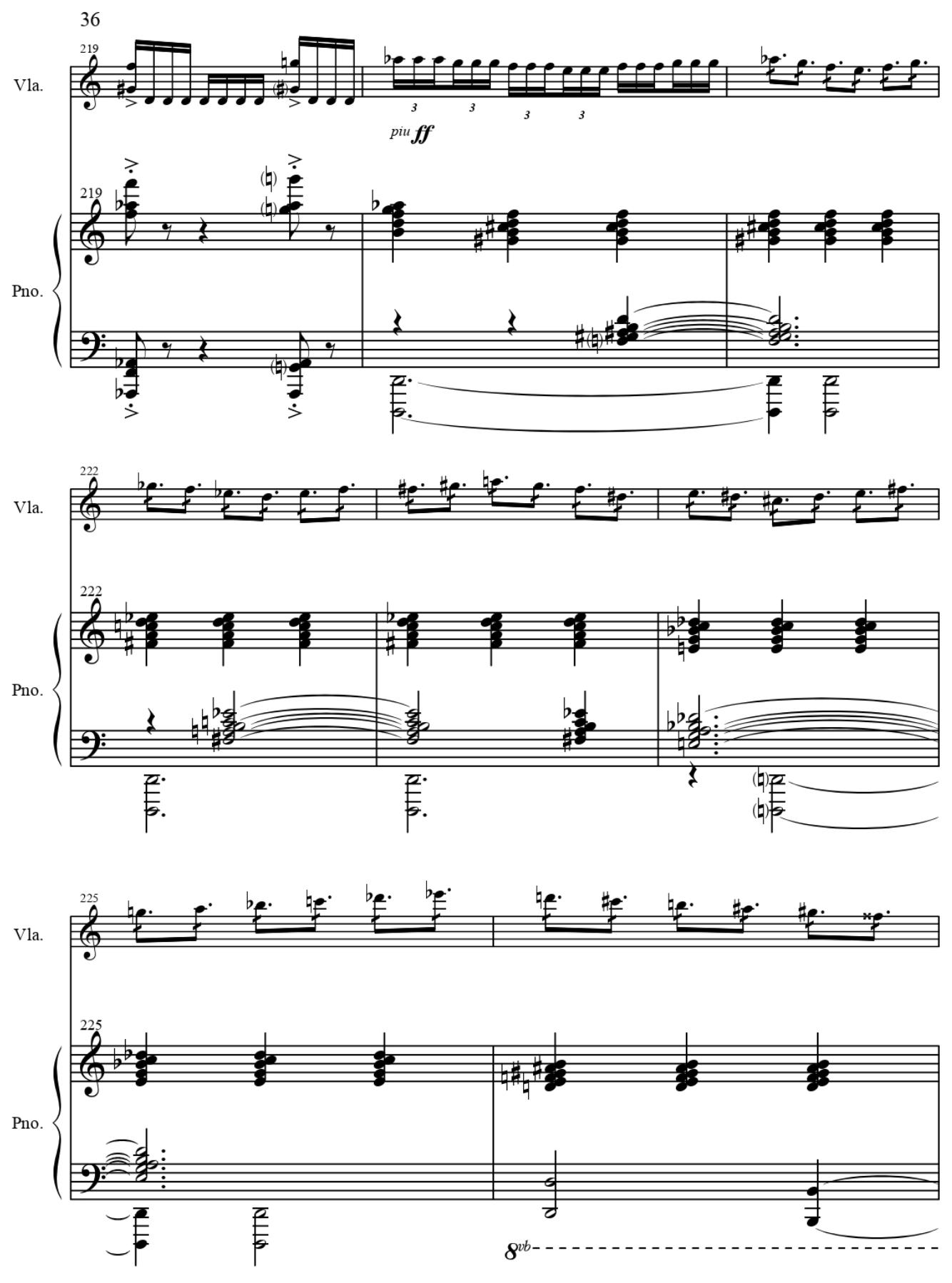

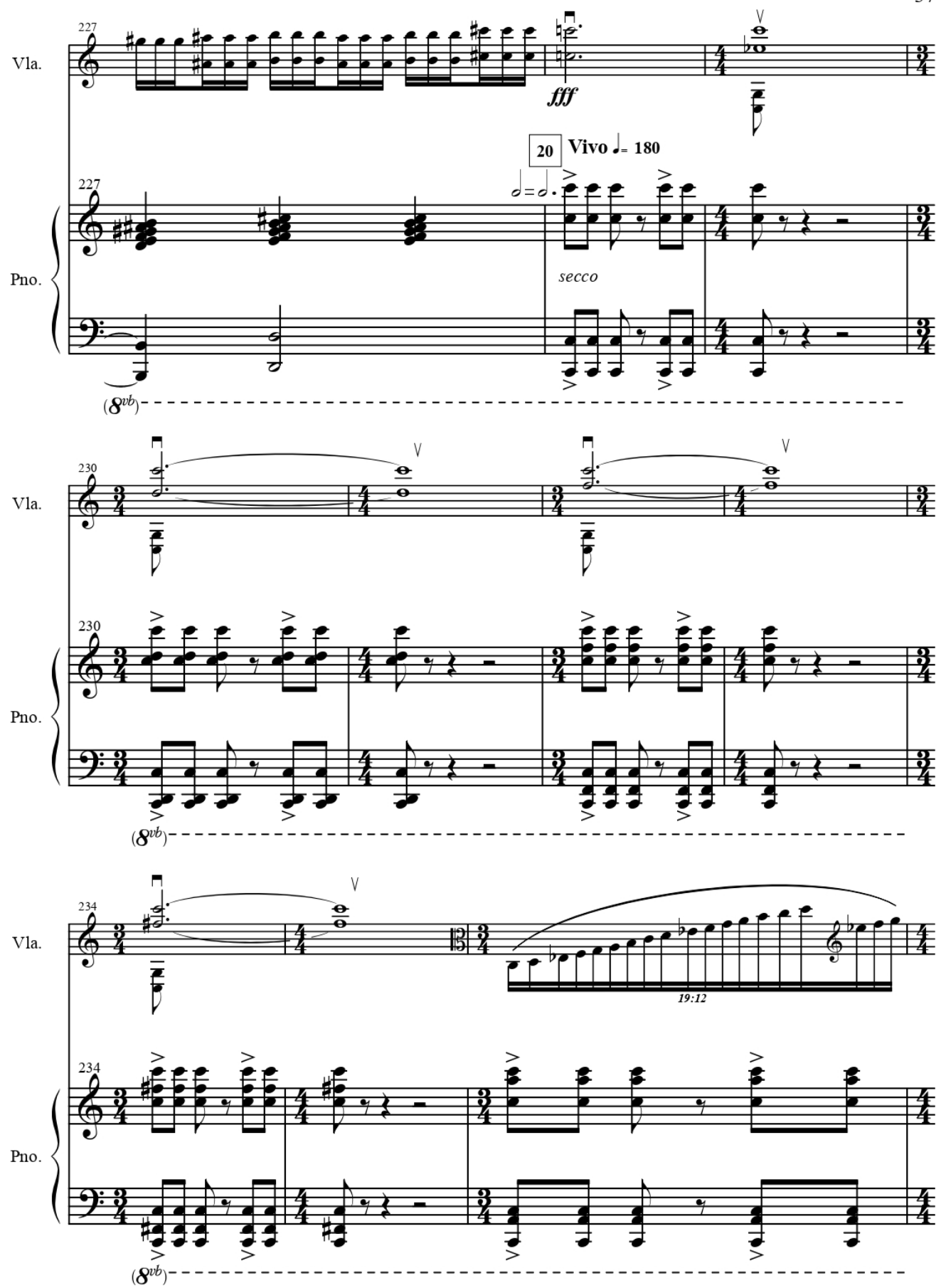

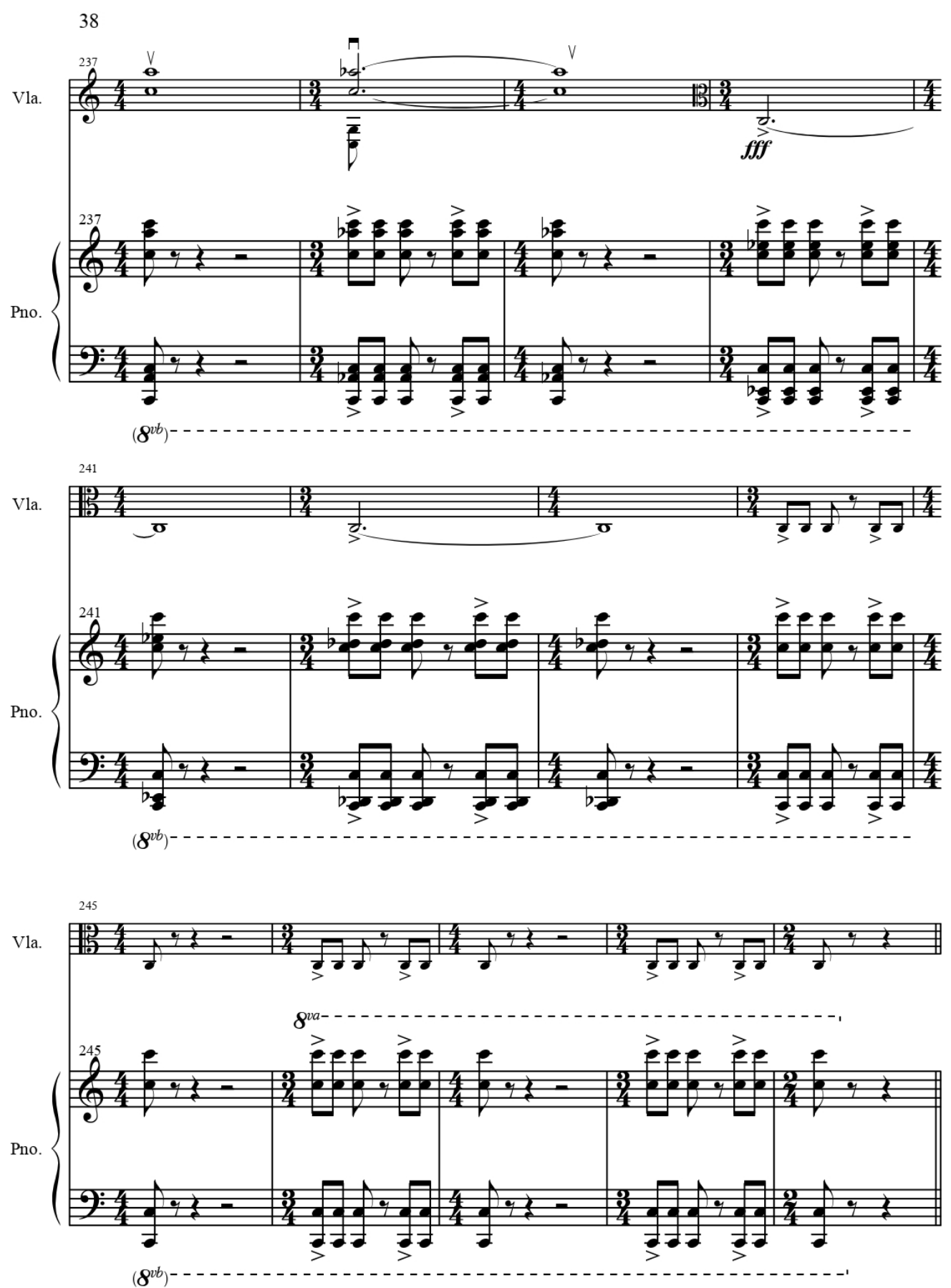

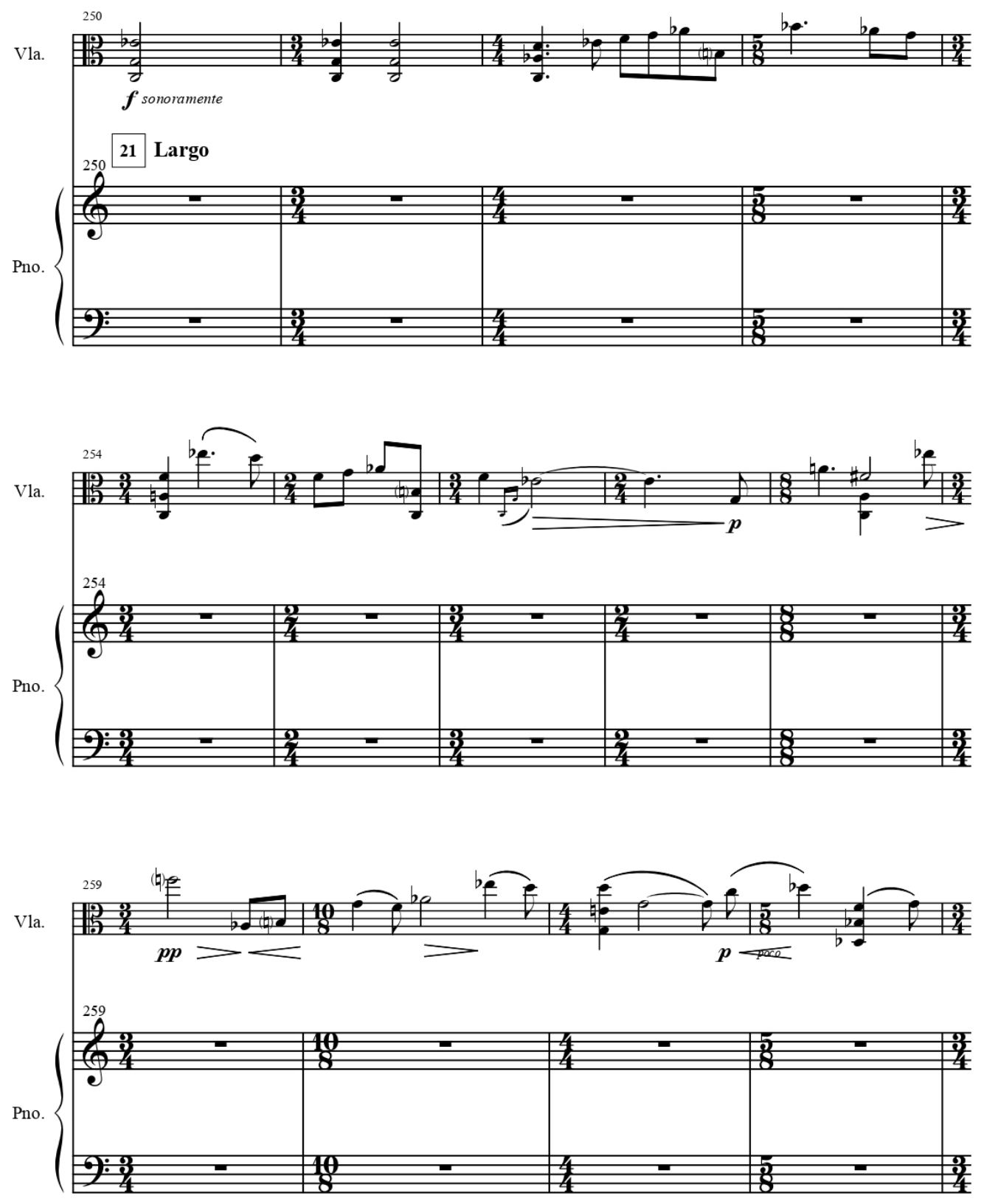

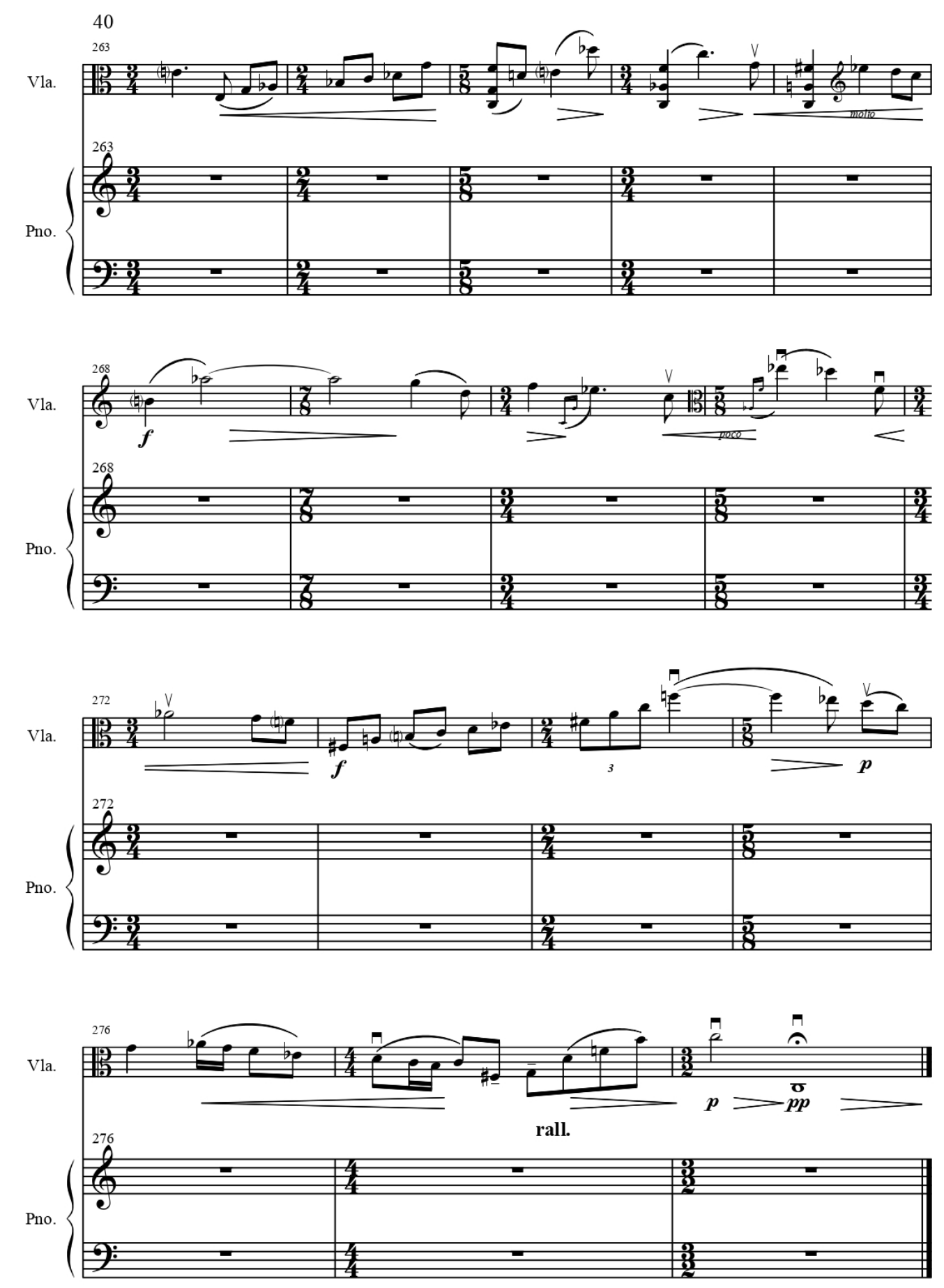

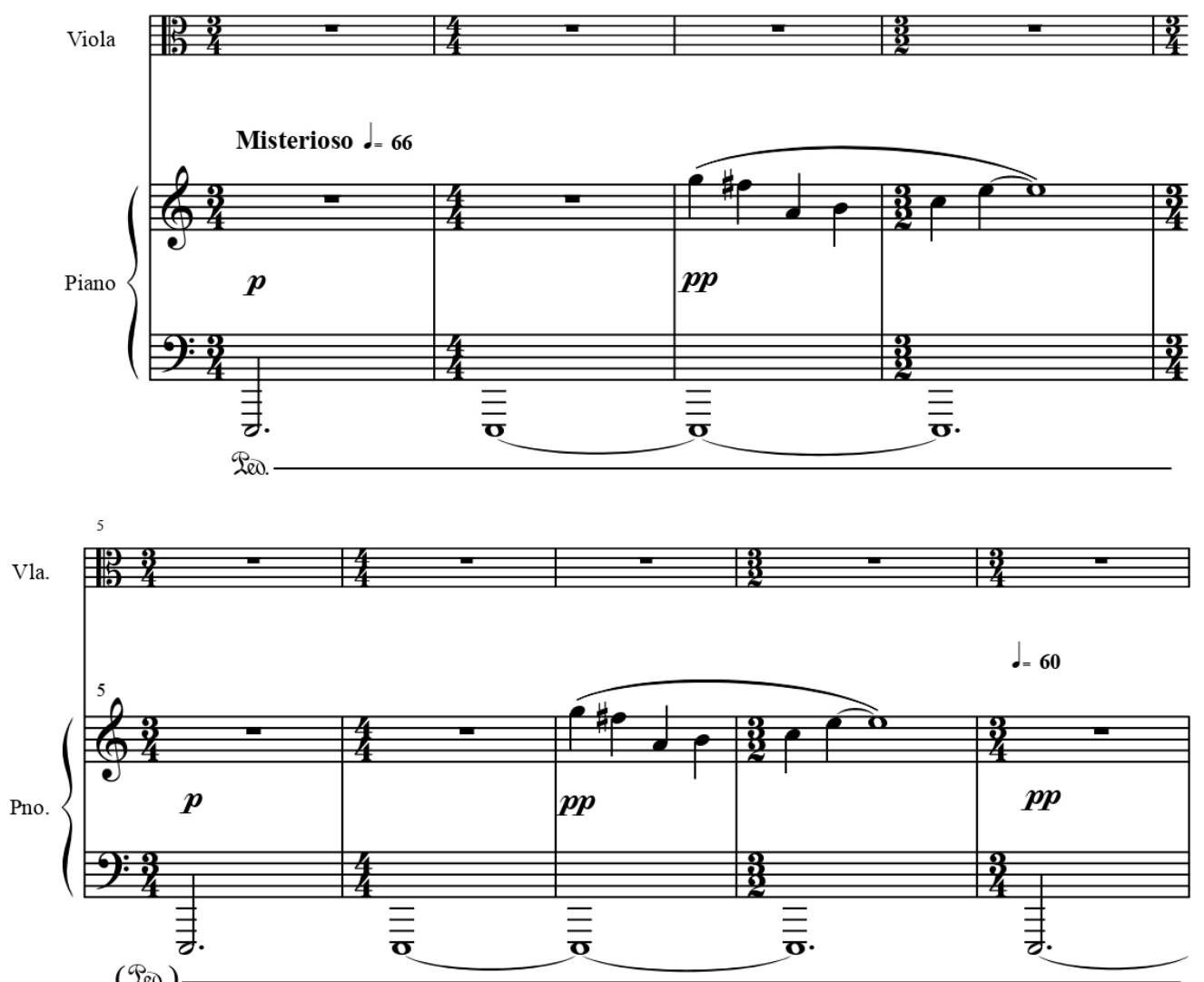

( $\left.{ }^{200}\right)$

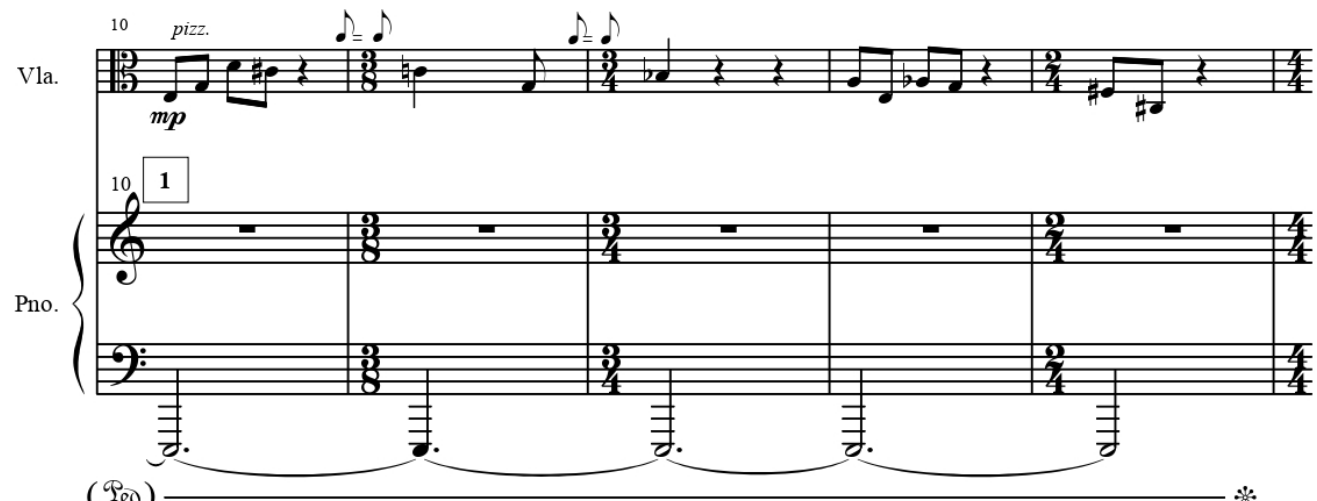

2012 Boris Pigovat 

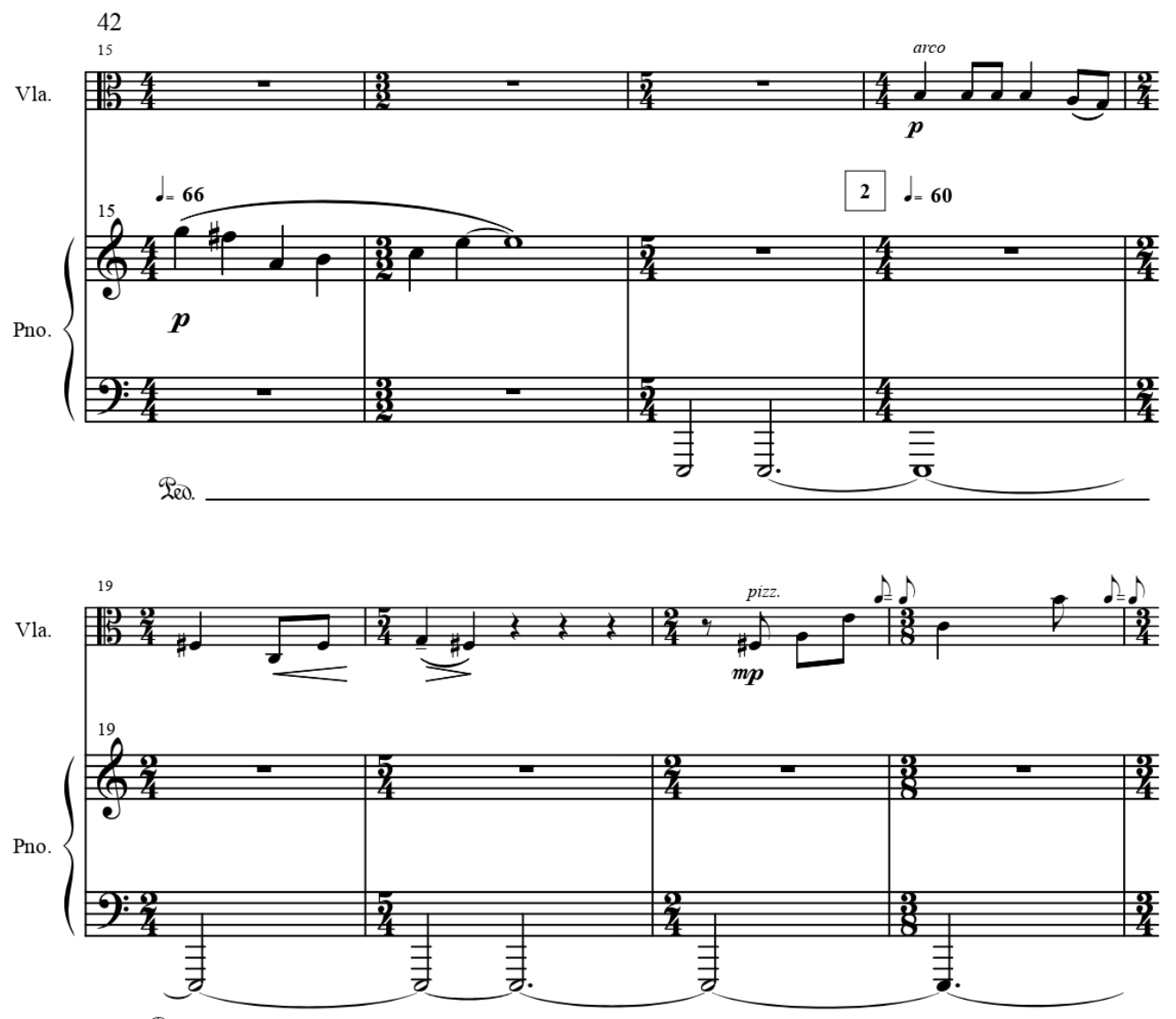

(200.)

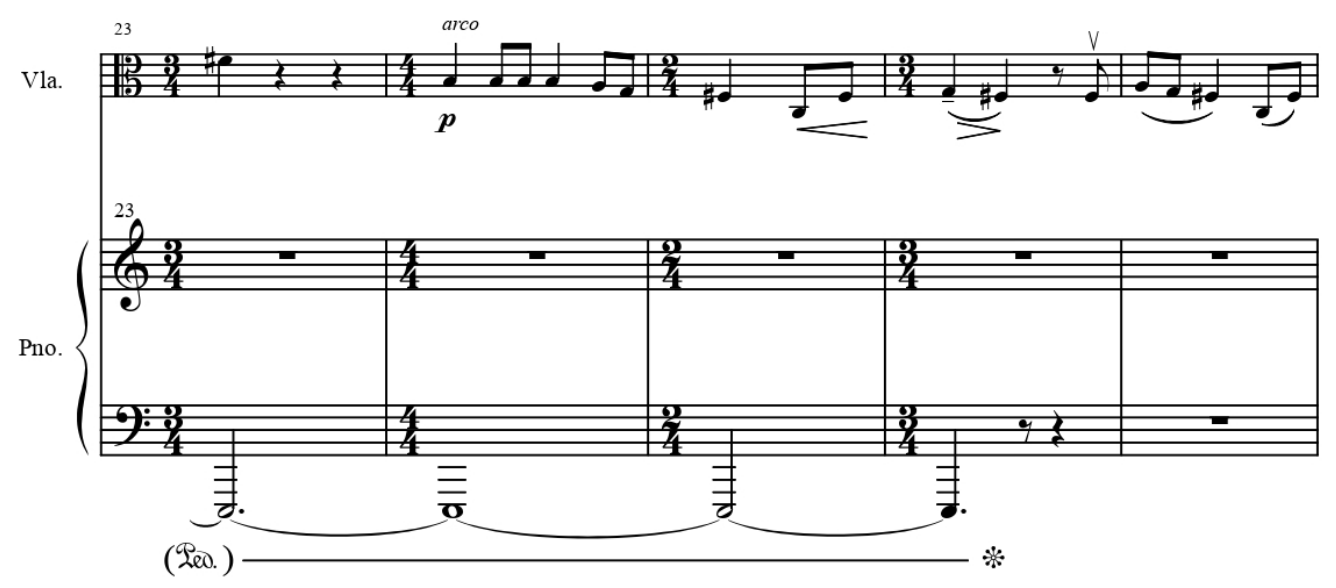



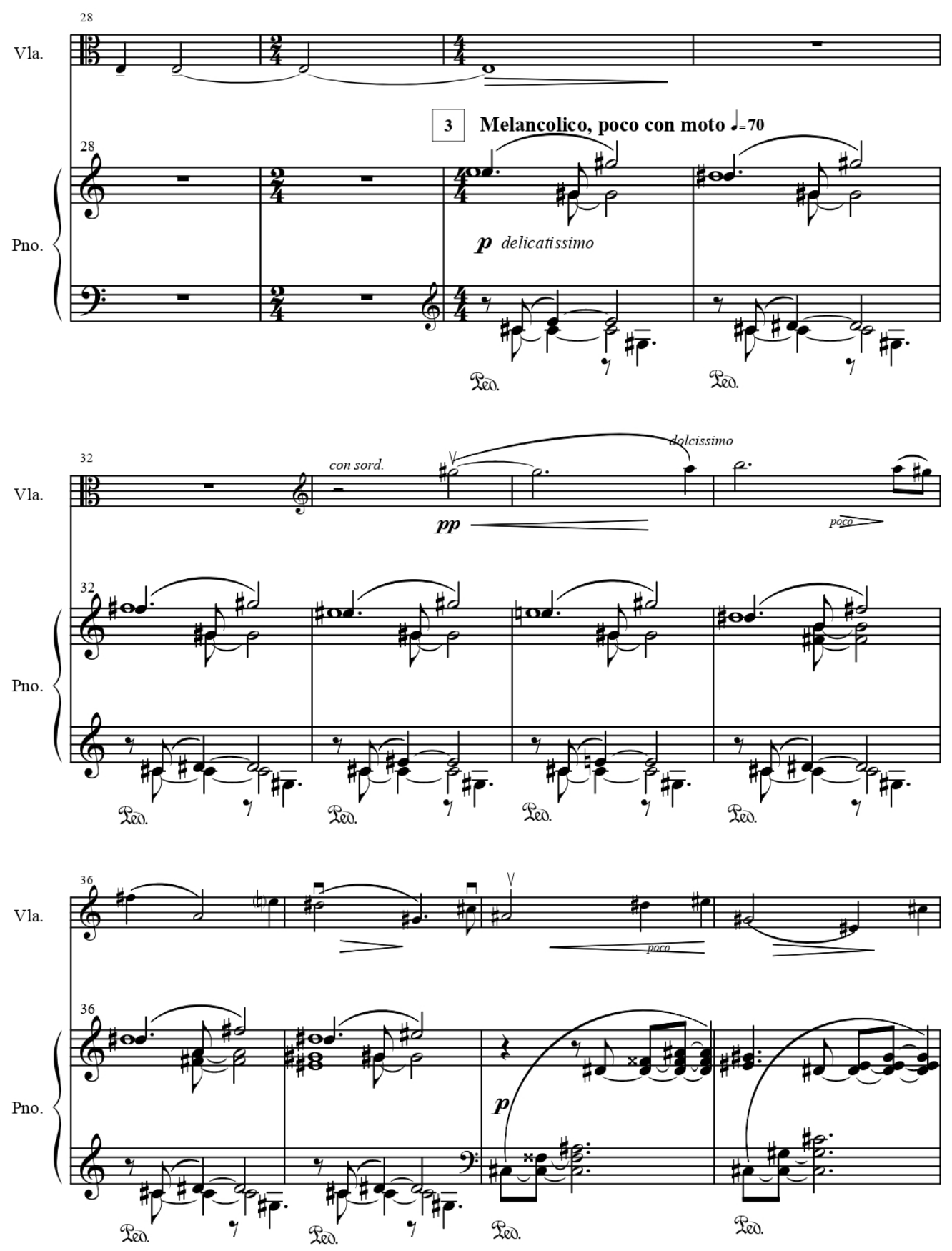


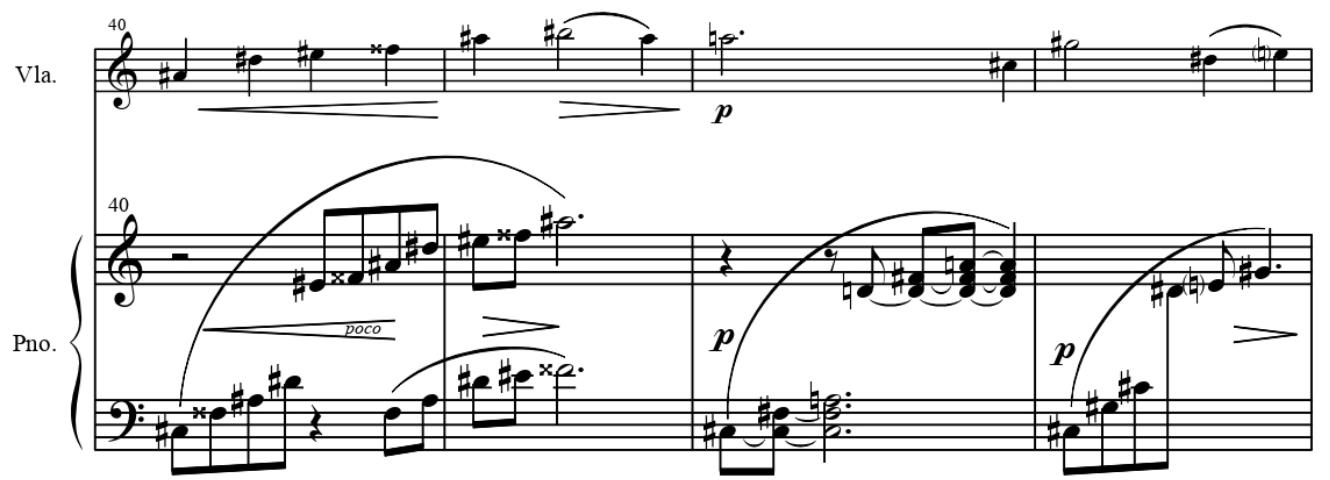

Teo.

Seo.

Teo.
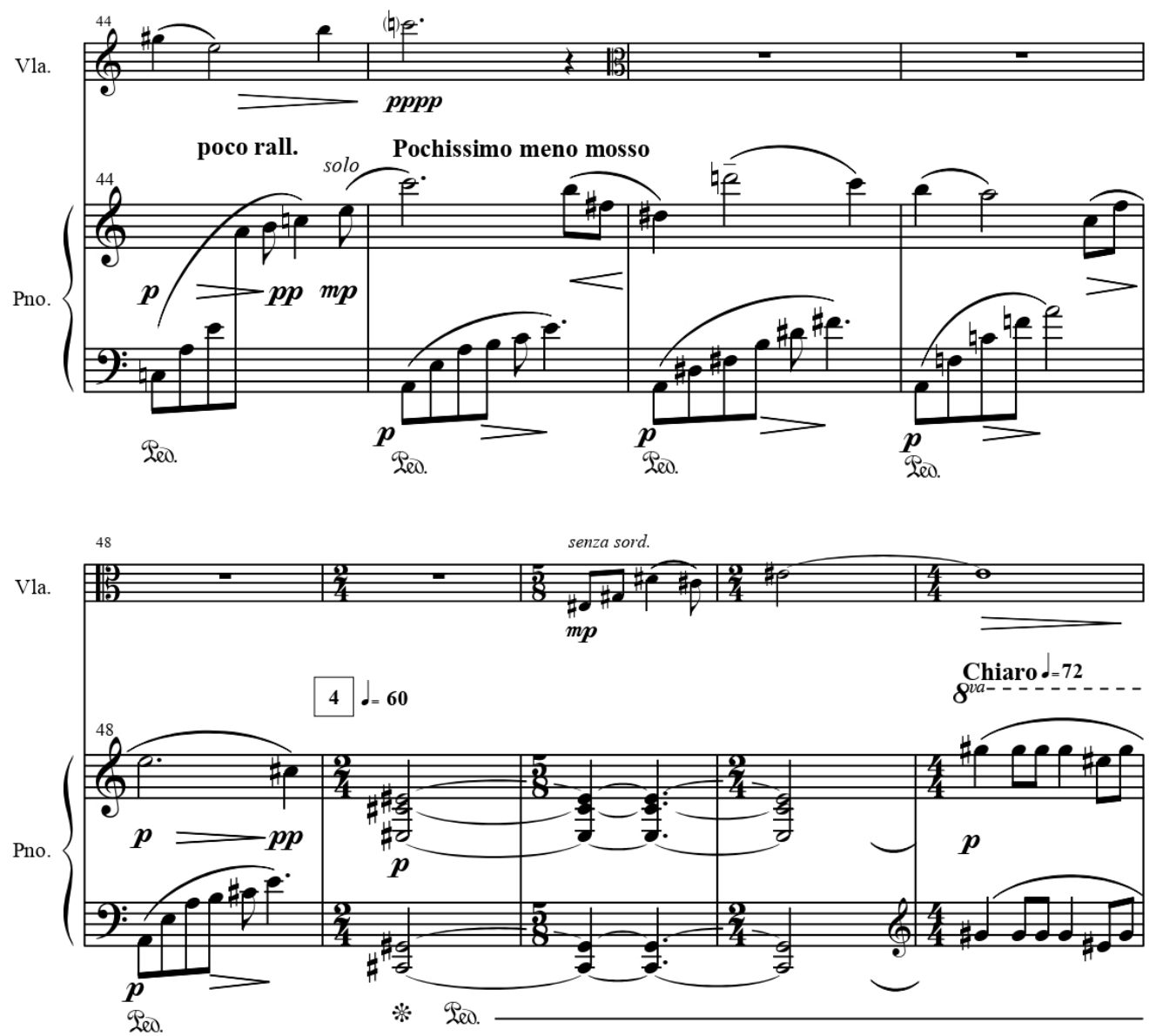

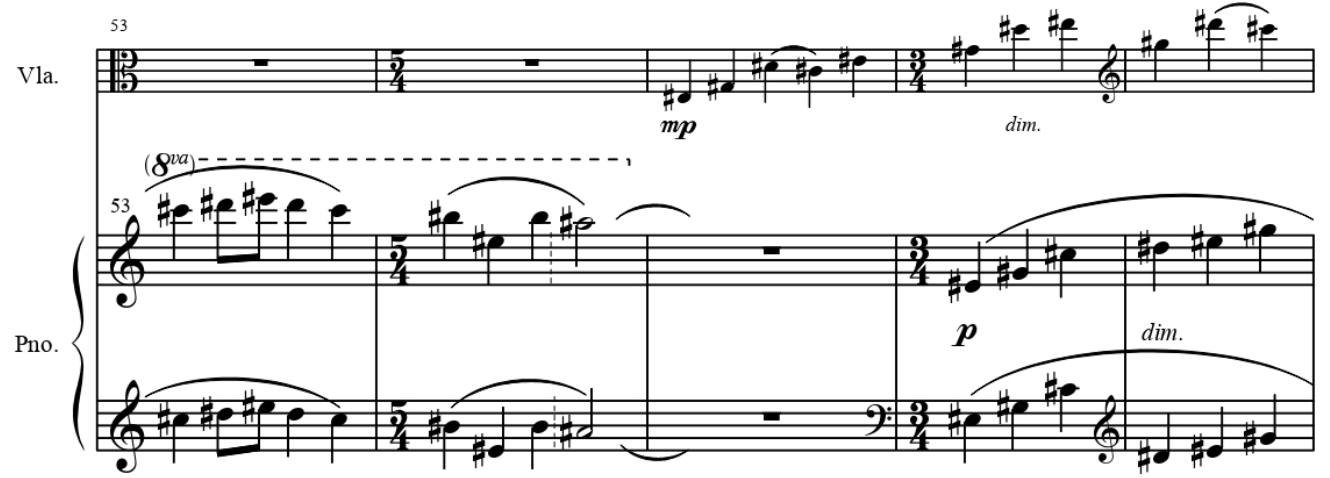

(200)

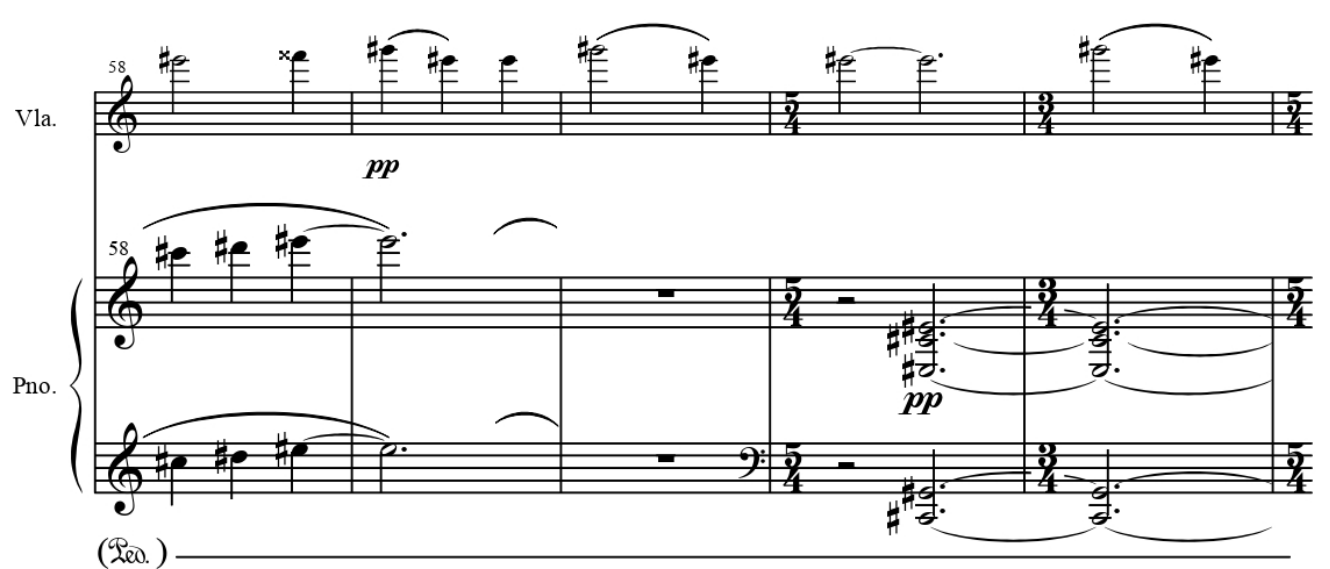

(200.)

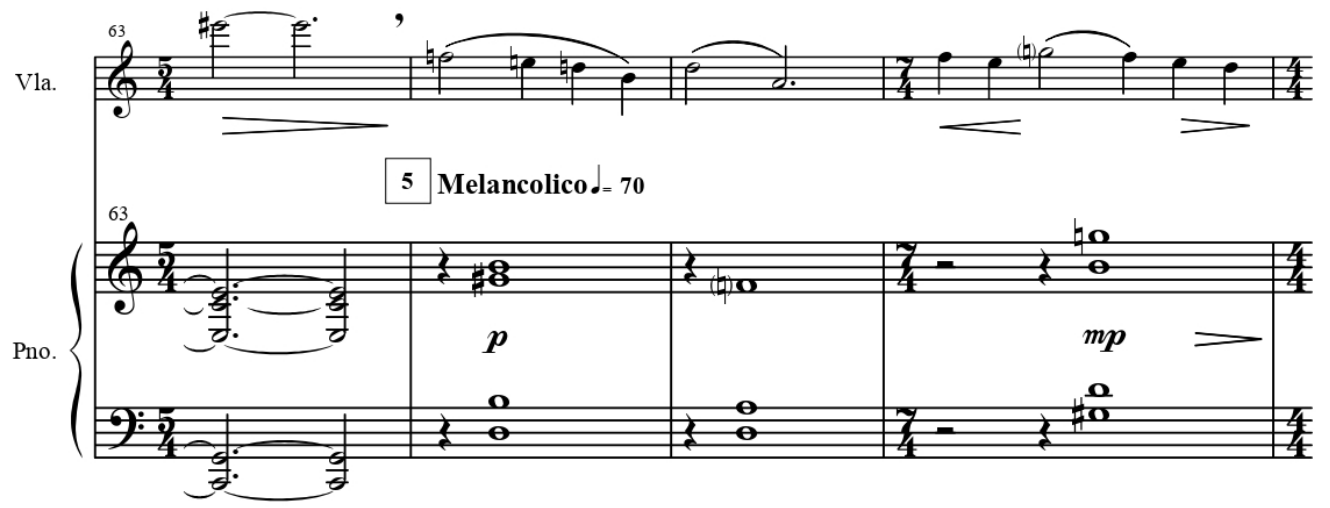

( 200.$)$

* (col Ped.) 

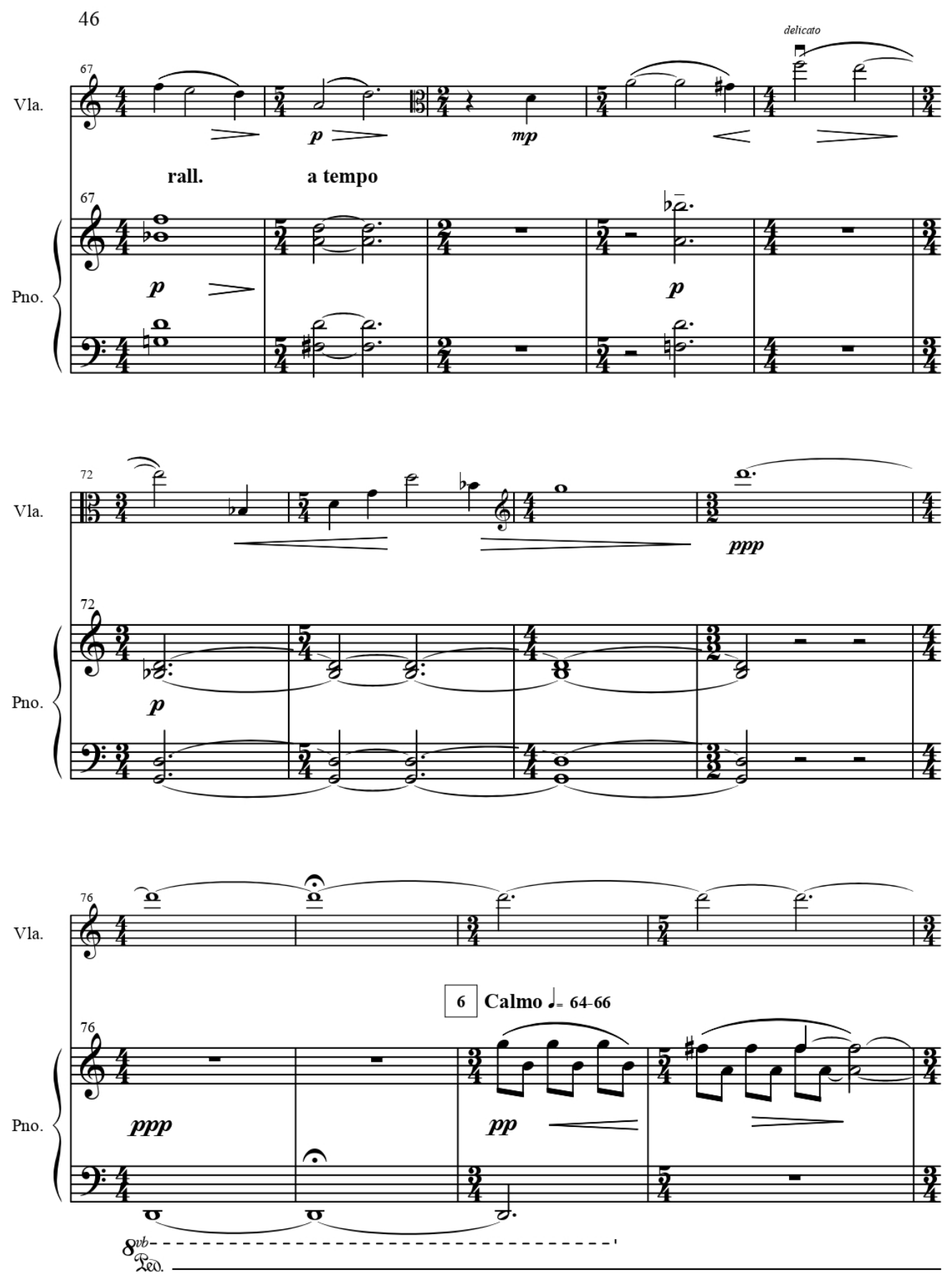

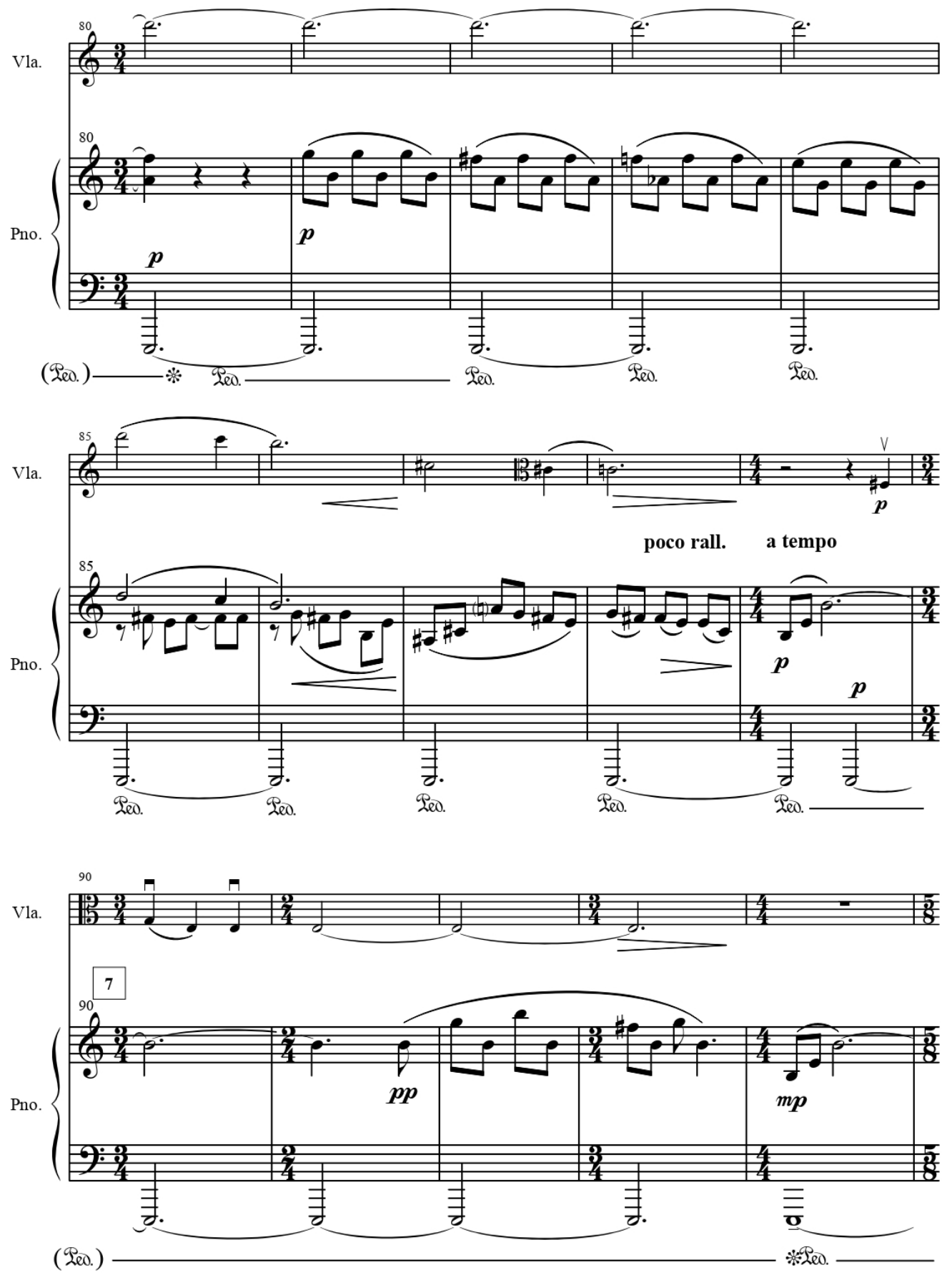

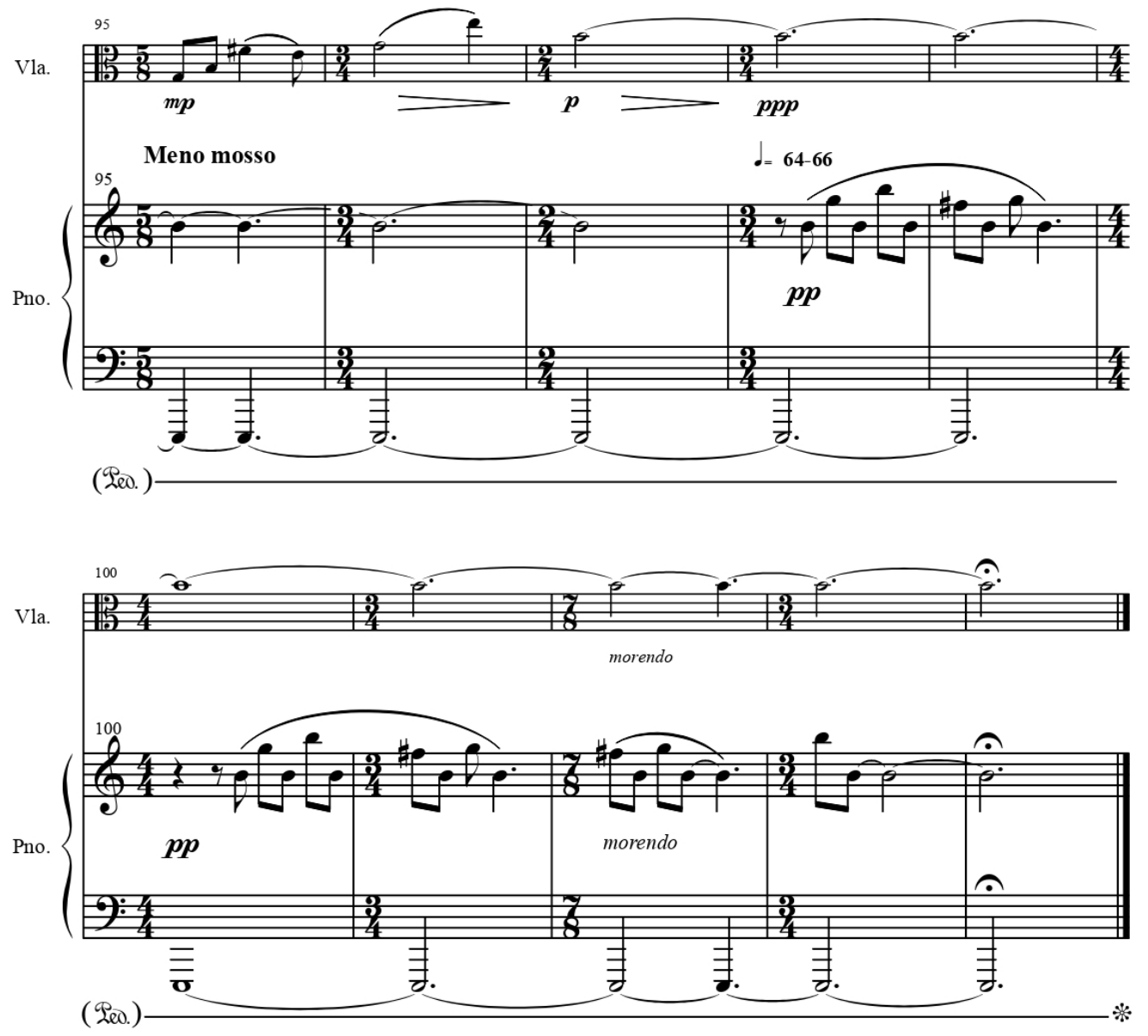


\section{Appendix 3}

The full transcript of interview with Boris Pigovat about the Sonata for viola and piano

Xi Liu: Is the first movement in sonata form? If the answer is no, then what is the structure of first movement? If yes, where does the first subject come, where does the second sub come...the development, the recap, the structure of how is the first movement put together? Each single paragraph of what key they are in?

Boris Pigovat: The answer is no, because I did not try to write in accordance with some canons or some norms already existed, if these are the contents of the first movement, then it should be as a sonata form. No, I wrote the first movement as a musical response to two Botticelli paintings. One of them is called "Madonna del Magnificat" (1483-1485) and the second is called "Madonna with pomegranate" ("Madonna della Melagrana" "Virgin of the Pomegranate", 1487). The first picture presents a kind of brightness and serenity, and the second picture has a lot of sadness. Comparing two pictures, almost same faces, but the characters are completely different.

Therefore, the desire to make emotional responses to these two paintings helps to bring about the structure of the first movement. The first part is also performed as a separate piece called "Botticelli's MAGNIFICAT" - a piece for viola and piano.

How do the two paintings affect the structure of the first movement? In fact, the first movement consists of two large sections: the first section is talking about the first painting, the second section is the second painting, and the nature of the second section is much sadder than the bright first section. Then there is a little coda. I will talk about the coda later.

You can still see somewhere a traditional form in the first section, a three-part form $(A B A)$, there is an initial theme, then some others, and the initial theme returns. In 
the second section, there are four different themes though there are some repetitions: the monologue theme, the first lullaby, the second lullaby, and the romantic big theme. (I don't even know how to define it - Con Mitezza).

Four different themes, in general it turns out there are six different themes in this work, this is quite a lot. So, as a composer, I have the task to ensure that the whole structure does not collapse, does not fall apart, and the forms are unified, if the music can be listened and making sense, it is somehow necessary to unite everything.

How to combine them? There are two ways in this work. On the one hand, almost in all themes one way or another, there is one harmonic revolution presented in different places. The turnover is this: the tonic triad is a second-dominant second chord (a harmonic pattern of bars $18-19$ is played). It is presented in a variety of places, both in the first section and in the second. The first time it appears in the second theme of the first section (bars 18-19 are played). Then this revolution takes place several times in this thread. It takes place in a key in C sharp minor (bars 25 30), and it takes place in a key in E minor (bars 38-41).

The second unifying moment is that the initial theme consists of two elements: the first one is for the piano (bars 1-3), and the second is the monologue of the viola (bars 11-16). One way or another, these elements in different places slightly appear, are given a hint. It is allowed to build such a system of "bridges". There is a theme, then something new material comes out, then a "bridge" appears (like a reminder of a previous theme) as something connecting, then again something new one, again a "bridge".

Another important point is that although we can see that the first section and the second section are different, the initial theme of the second section is made on the basis of the first section (bars 1-2 and 64-66 are played). A person may listen to them and not understand that there is a connection, but this (thematic connection) settles 
in the subconscious. Therefore, it seems that the work is one, and the form does not "fall apart", since all the time there are some unifying moments.

Now, regarding how the second section was built. A very important point is these basses (bars 62, 63 are played), which precede the initial theme of the second section. It is like a funeral bell, this piano part immediately creates the right atmosphere. As well as in this picture ("Madonna and Pomegranate" is meant) - a feeling of sadness, as if the mother knows what her child will have in the future.

Now regarding this moment (bar 73 is played). The question may arise: why does the composer put this long note here (bars 73-83)? If only the alto is heard here, this pedal is no longer audible. The thing is that I wanted the piano to resonate viola sounds, thereby creating an additional reverb for the viola sounds.

What is the characteristic of the second section? Here I have two different lullabies. The first lullaby (that is the second theme of the second section) is kind of traditional (bars 79 - 85 are played), it's like the baby's sickness - the sad music that the mother sings. The second lullaby is such a fairy tale (bars 103-104 are played). This type of lullaby has a rather long tradition in Russian music, because it is enough to remember such things with Rimsky-Korsakov, you can remember Lyadov (Kikimore), and you can also recall the early Stravinsky (The Firebird). Finally, what I wanted to say here, when this lullaby ends the material of the first section suddenly appears - a monologue (bars 117-122), and it is combined with the first theme of the second section (bars 124-126). There was a monologue (in the first section at bars 11-16) and another monologue was the beginning of the second section (bars 64-73). Therefore, the large solo piece (bars 117-138) at the viola is the culmination of this connection between the first section and the second section. When against the backdrop of the E major chord (bars 139-142), the initial theme of the first section (bars 1-2 are played) now sounds as if this is a monologue of the second section (bars 140-141 and 64-65 are compared). 
This completely new theme (bars149-160) which for some reason seems familiar, because it starts with the same harmonic turn - the tonic triad is the second-second chord of the dominant. It does not seem alien to the previous material (bars 18-19).

Here we come to the fact that the coda (bar 164) begins. Or rather it seems that this is not a coda but a reprise, because the A flat major is established which the key that was in the beginning. But at the same time, this is still not a reprise but a coda. The coda has two sections: one in A flat major (bars 164-171), and the second in F major (starting from bar 172). Why does it seem that this is a reprise? On the one hand, the initial tonality (A flat major) is returned in the first section of the coda, and the texture of the beginning is returned in the second section. But the most important thing is that there is no theme of the beginning. There is neither the theme of this (bars 1-2 are played) nor the theme of this (bars $11-12$ is played). That is there is no reprise of those, but only a return of the main key and a reminder of the initial texture. Therefore, this is not a reprise, this is a coda. Though the music nature of the coda looks like a reprise. This is the first movement of the Sonata.

Xi Liu: What is the way of finishing the Bach theme in the second movement? What does every variation relate to the Bach theme, what are the clues? What is the variation of, what does the variations mean? Because the variation is always based on the theme, so how does each variation connect to the theme, please explain? 3rd movement: (E minor) is the third movement just a coda to the whole Sonata? (ABA?)

Boris Pigovat: First of all, I must say that in fact the second movement was written for its last section - Sarabande. But there are only three bars in this Sarabande actually belong to Bach. This is the ending (bars $276-278$ are played). So the task here is to write all the previous material for the Sarabande so that the whole part is not strange. It should be written in the style of Bach, although in principle, it is not Bach music. However, it was important for me to write it in such a way that no feeling of the last three bars was something inconsistent, it should have been organized. 
The second movement is a kind of stylistic modulation. I started to write it as the typical toccata music of the $20-21$ centuries, and I have to come back to the Sarabande. How could this happen? First of all, I gradually turned the modern toccata into the Baroque toccata, then in my opinion Baroque features appear in this music, after that it's easier to switch from Baroque toccata to Baroque saraband. This is on the one hand.

On the other hand, this movement was generally written in a classical form (you can see the form from here: an introduction with two contrasting elements that affect the whole part, figure 1 is the main theme, figure 2 is the second theme). The main one is in $\mathrm{C}$ minor, the second is in C sharp minor. The next is a development section, and then reprise begins. In reprise part there is only one theme - the main one (figure 17), but it goes in the key of the second theme - C sharp minor. But these signs are all purely formal. In fact, it is more important that the whole part is written as a chain of episodes - 15 episodes in which the material is connected either with the motives of the toccata or with the motives of the future Sarabande. My task was to gradually prepare the appearance of Sarabande music. Some intonations appear which then suddenly turn out to be the intonations of Sarabande. Even already in the most important theme in bars 13-14 (bars 13.14 are played, and then 16-19 - the part of the viola), those intonations that will later be in Sarabande. Suppose that I played in bars 13-14, will be in Sarabande part in bars 251-252, in bars $17-18$ here we get bar 253 , and the same thing - here is the continuation, say in bars $259-260$.

After the very beginning of the second movement, we can see a similar process of how gradually elements of the Sarabande theme are introduced into the material. This is especially vividly manifested in the middle of the development, when the texture of the solo Sarabande appears against the background of such accompaniment (bars 115-117 are played). Most importantly, if we compare the bars 116-117 with the bars 260-261 in Sarabande, the type of texture itself is already as if a piece for violin or viola solo from the Baroque period. 
By the way, I would like to note that despite this second movement is quite independent in relation to the first movement, suddenly a theme from the first movement appears against the background of toccata (figure 11 is played) - in order to connect the second movement with the first, so that these parts feel like kindred in some sense, although they are completely different in music. However, the theme of the first movement is introduced here to turn out the ear recognised, the ears recognise and feel that this second movement is a continuation of the first. Bars 126 to 132 are a theme from the first movement. It's very important that this appears just before the stylistic "scrapping" of toccata occurs, when this toccata really feels like a Baroque toccata - a Baroque rhythm and character with an emphasis on the second beat and a viola toccata texture (Figure 12 is played). The theme from the first movement appears before the Baroque toccata is also emphasizing the importance of this "stylistic change". By the way, if we talk about connections with the first movement, harmonies from the first part that are familiar to us appear in this Barocco Toccata, which are bars 135-136 - tonic triad and second dominant chord seconds.

Now we continue to see how the gradual formation of music for Sarabande goes further in this development. Again, even at such dissonances (bars 165-166), motifs suddenly appear in the viola part are close to Sarabande bars 259-260. Finally, when we come to a climax of the reprise, at first it simply repeats the main theme but in a sharp sharp minor. 
Appendix 4

Full score of Holocaust Requiem

\title{
Boris Pigovat
}

\section{HOLOCAUST REQUIEM}

For Viola \& Symphony Orchestra

\author{
SCORE
}

1994-1995 


\section{Orchestra:}

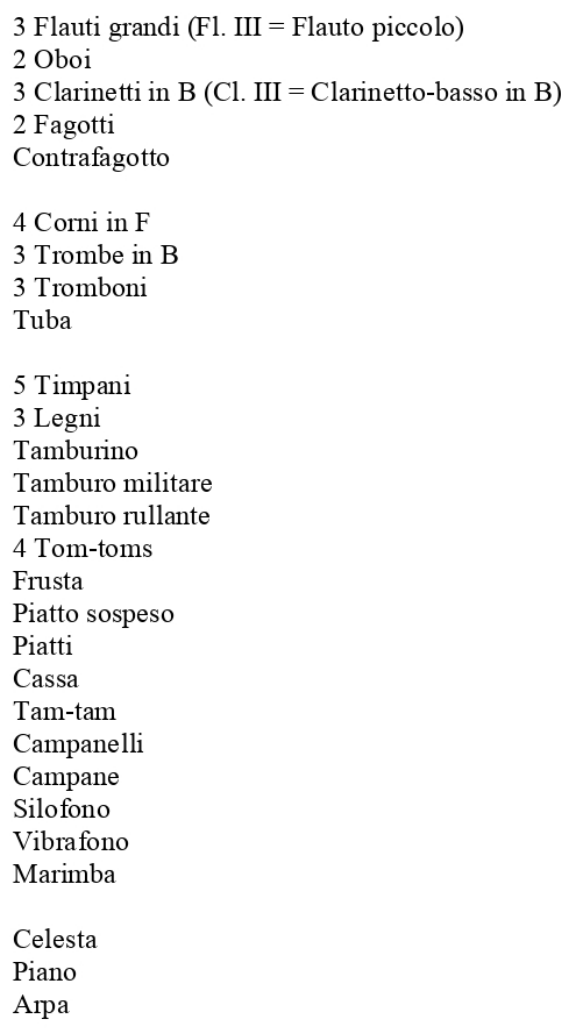

Viola sola

Violini I

Violini II

Viole

Violoncelli

Contrabassi 
Dedicated to my father, who had lost his parents and his sister

in Babiy Yar, Kiev, on the 29 of September, 1941

HOLOCAUST REQUIEM

for Viola \& Symphony Orchestra

I. "Requiem aeternam"

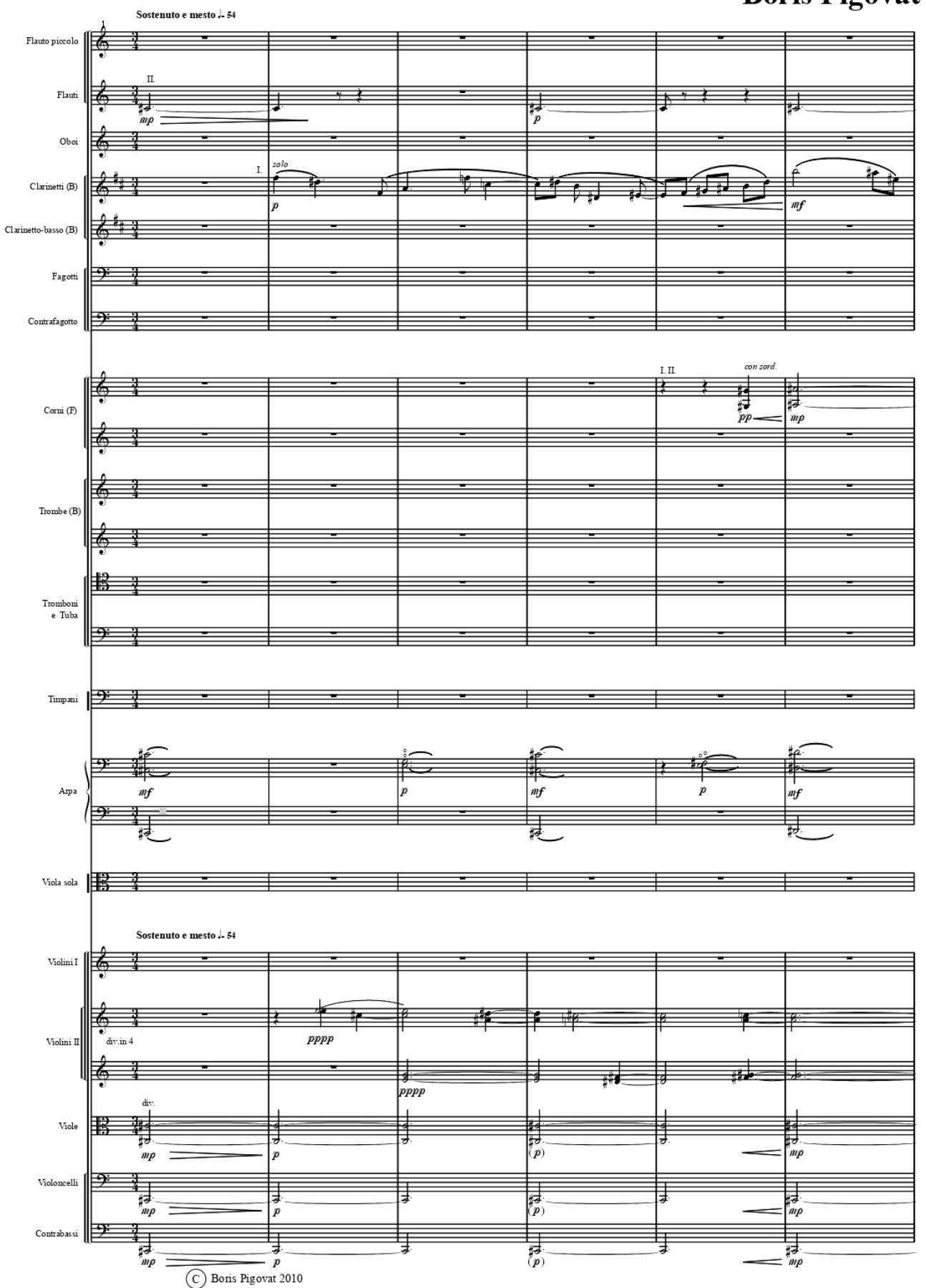




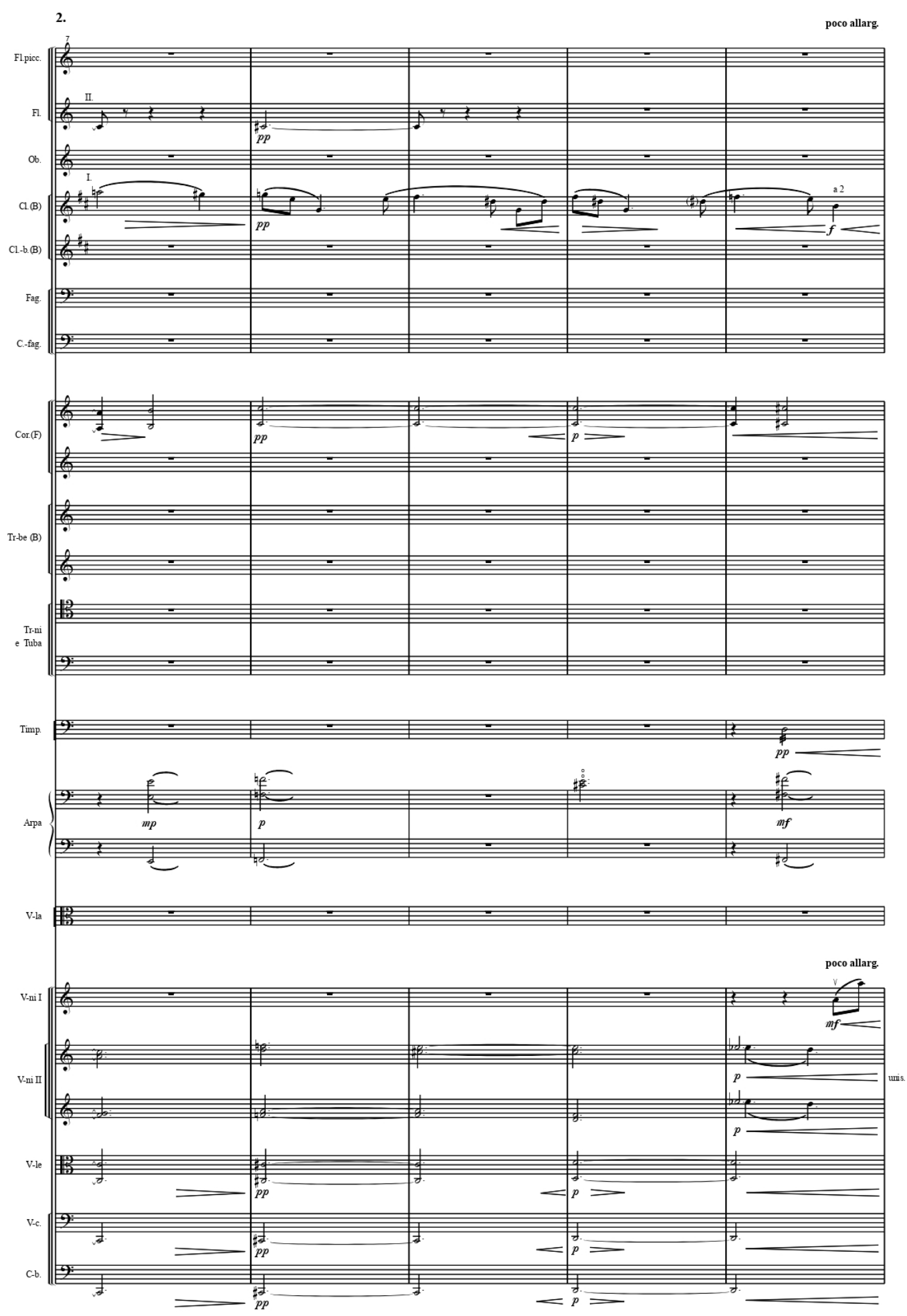




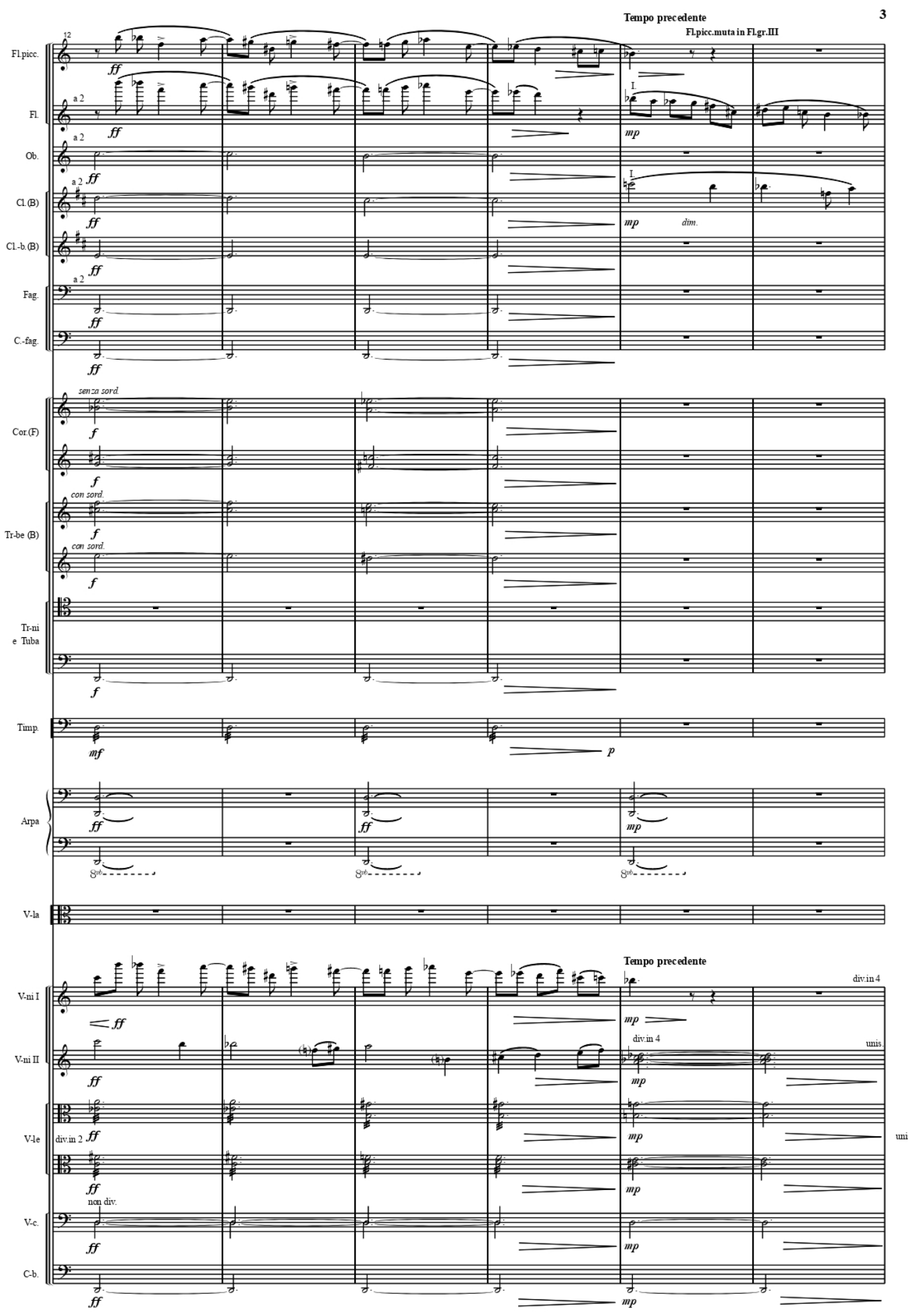



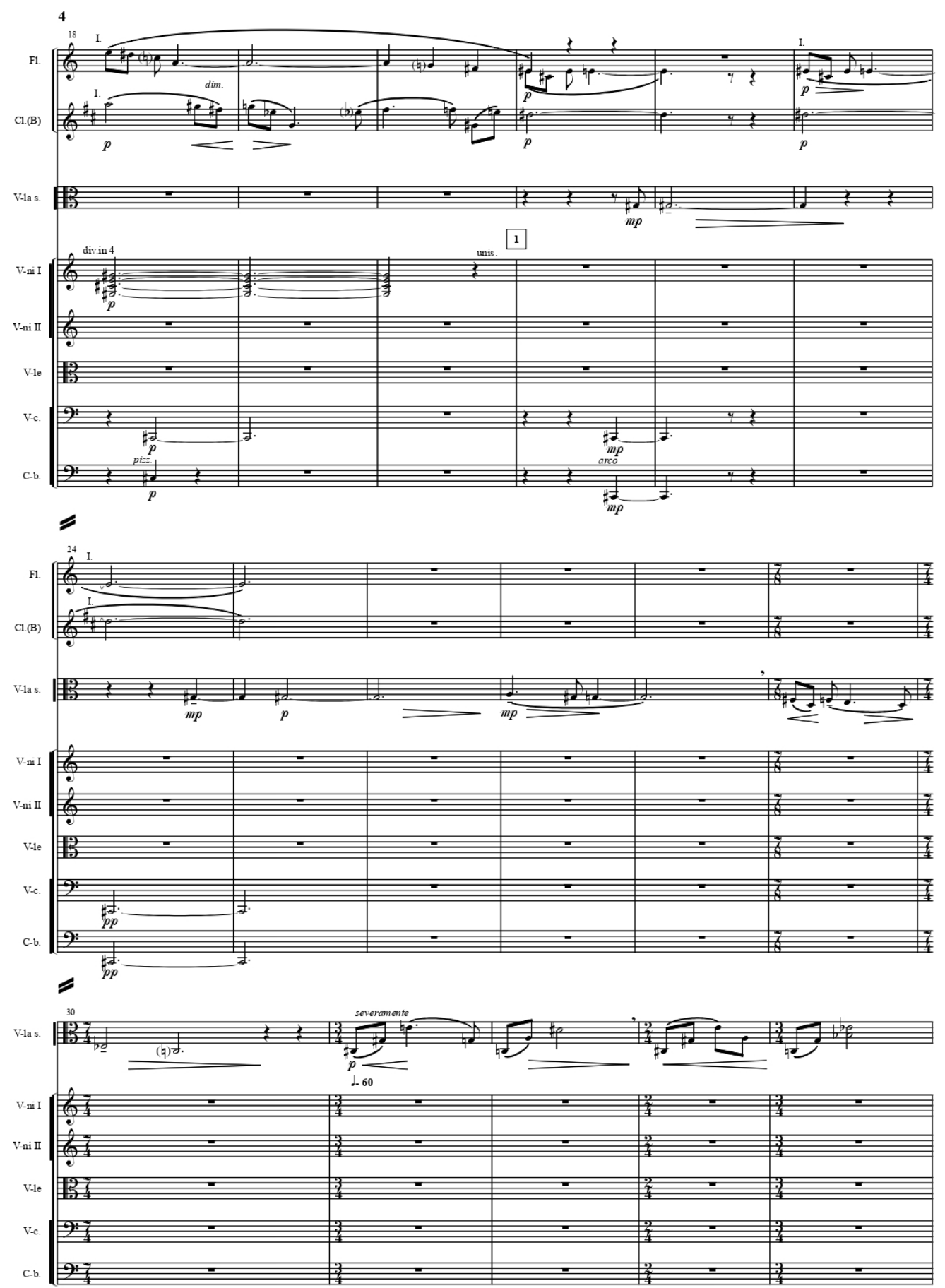

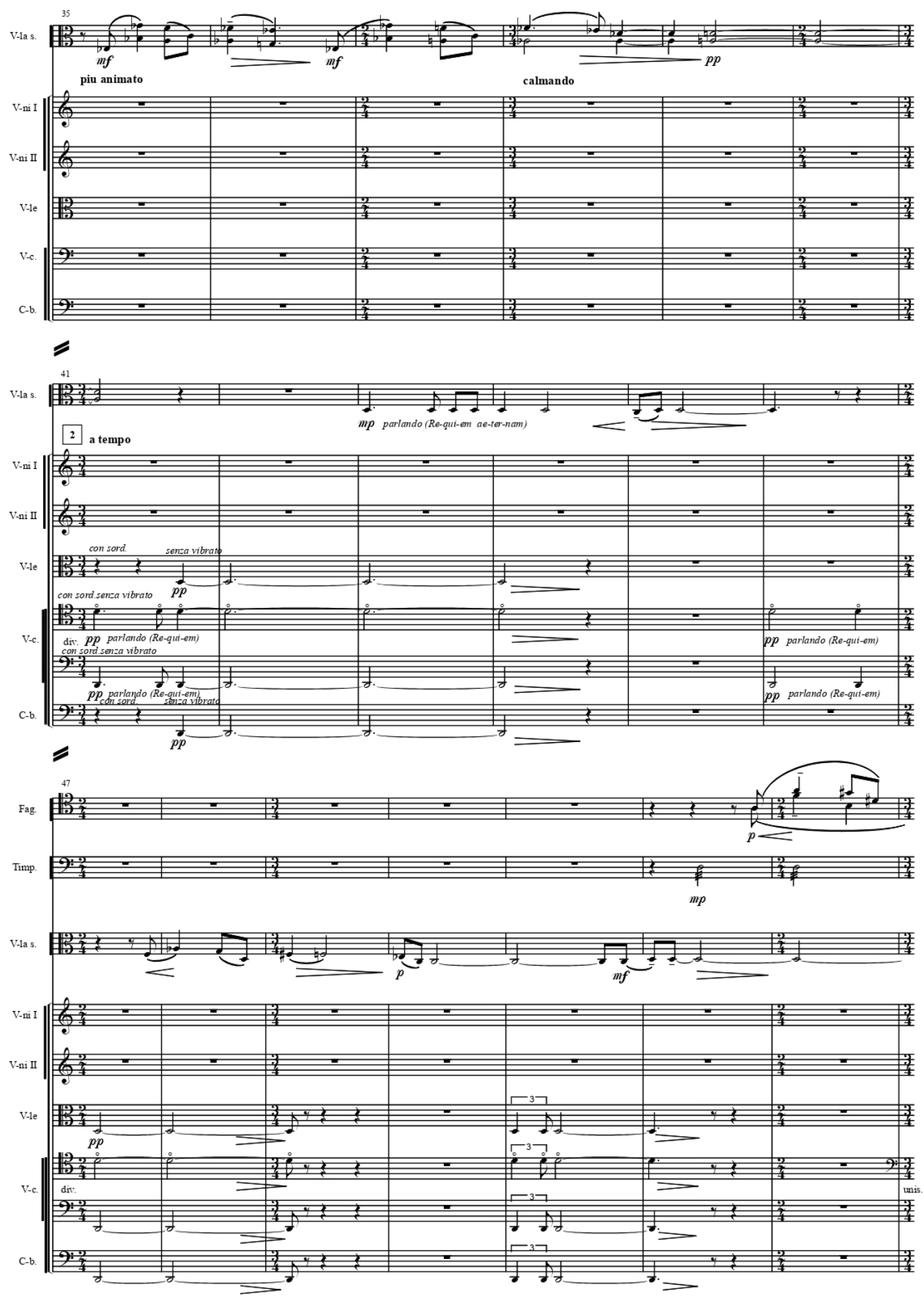


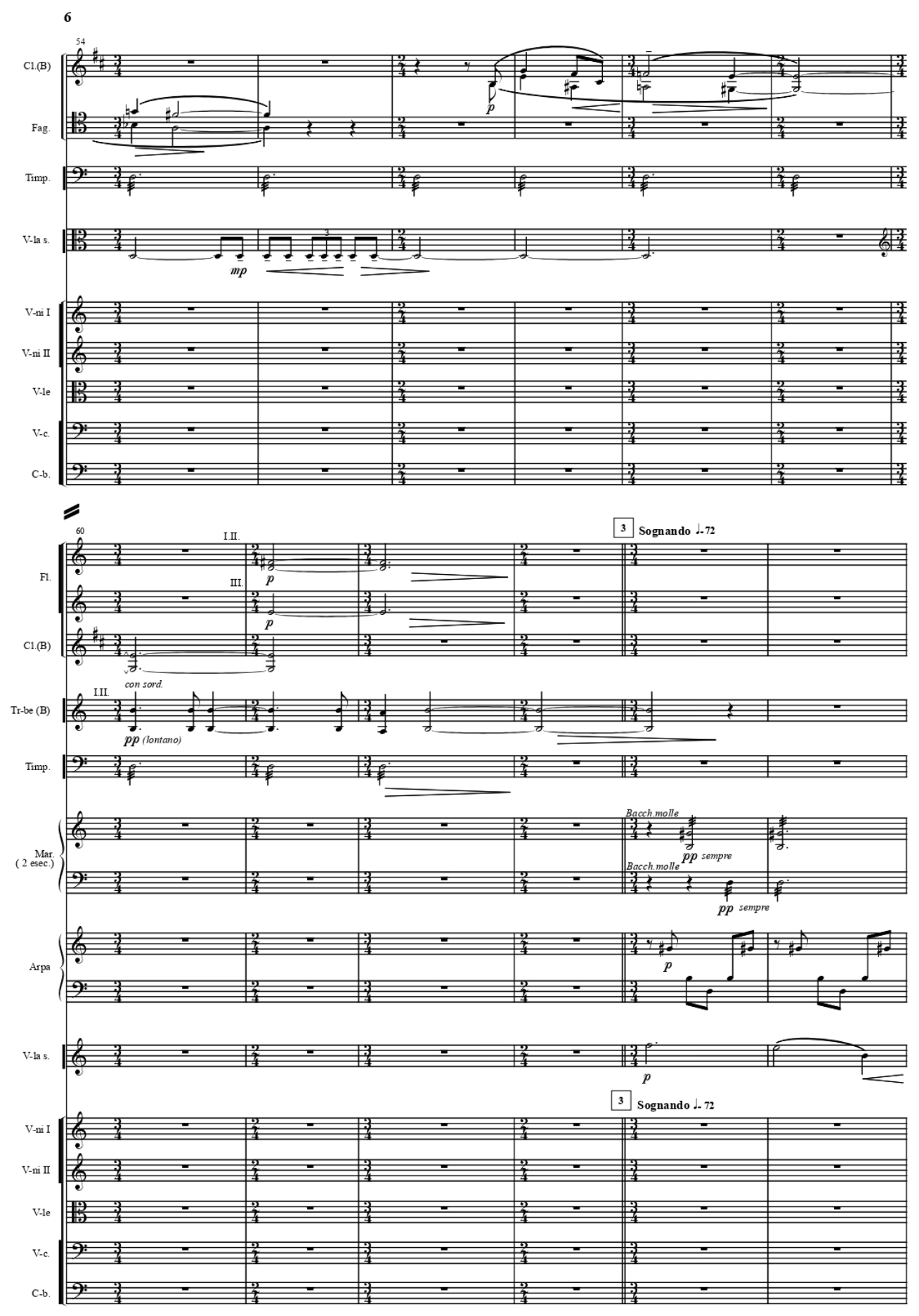



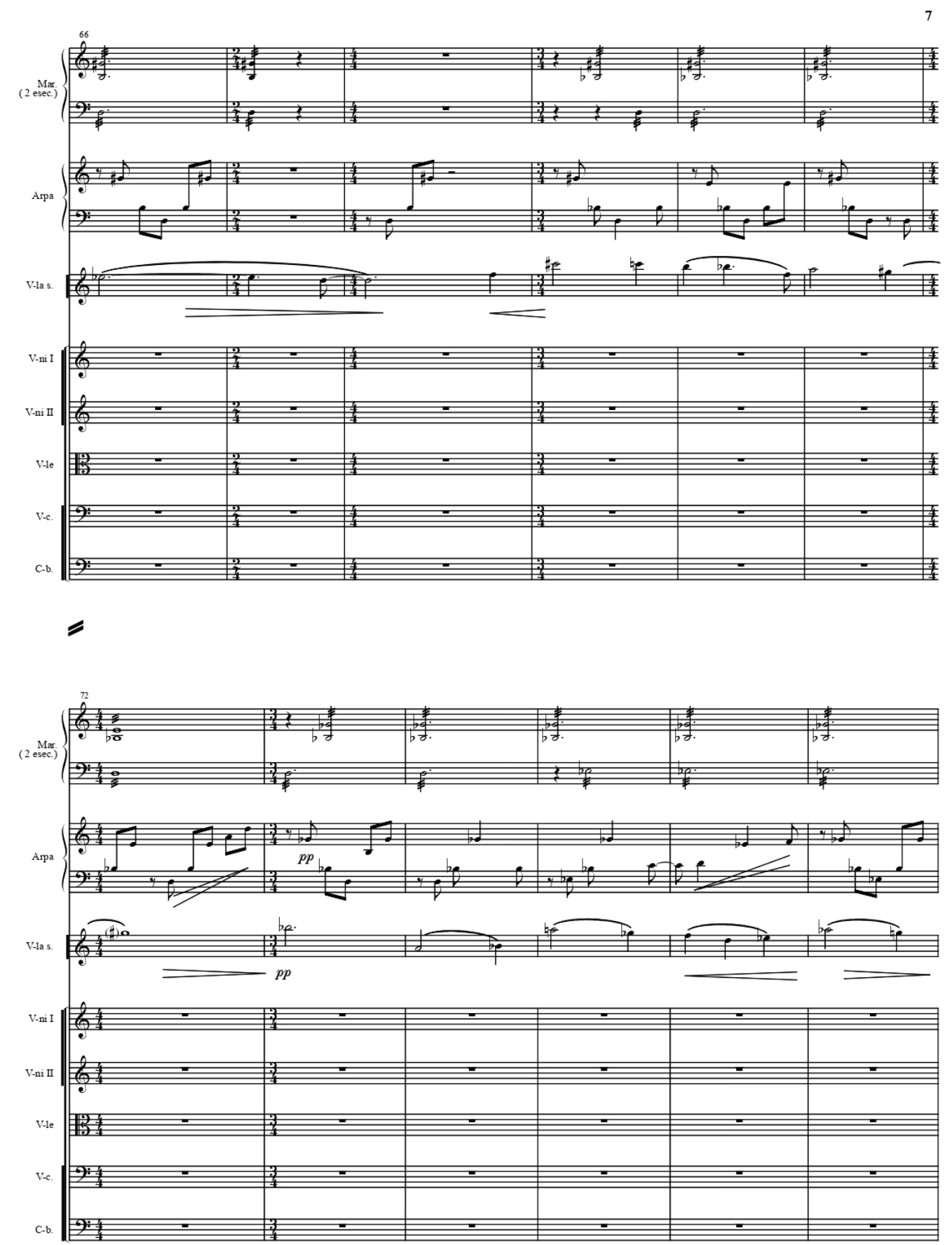


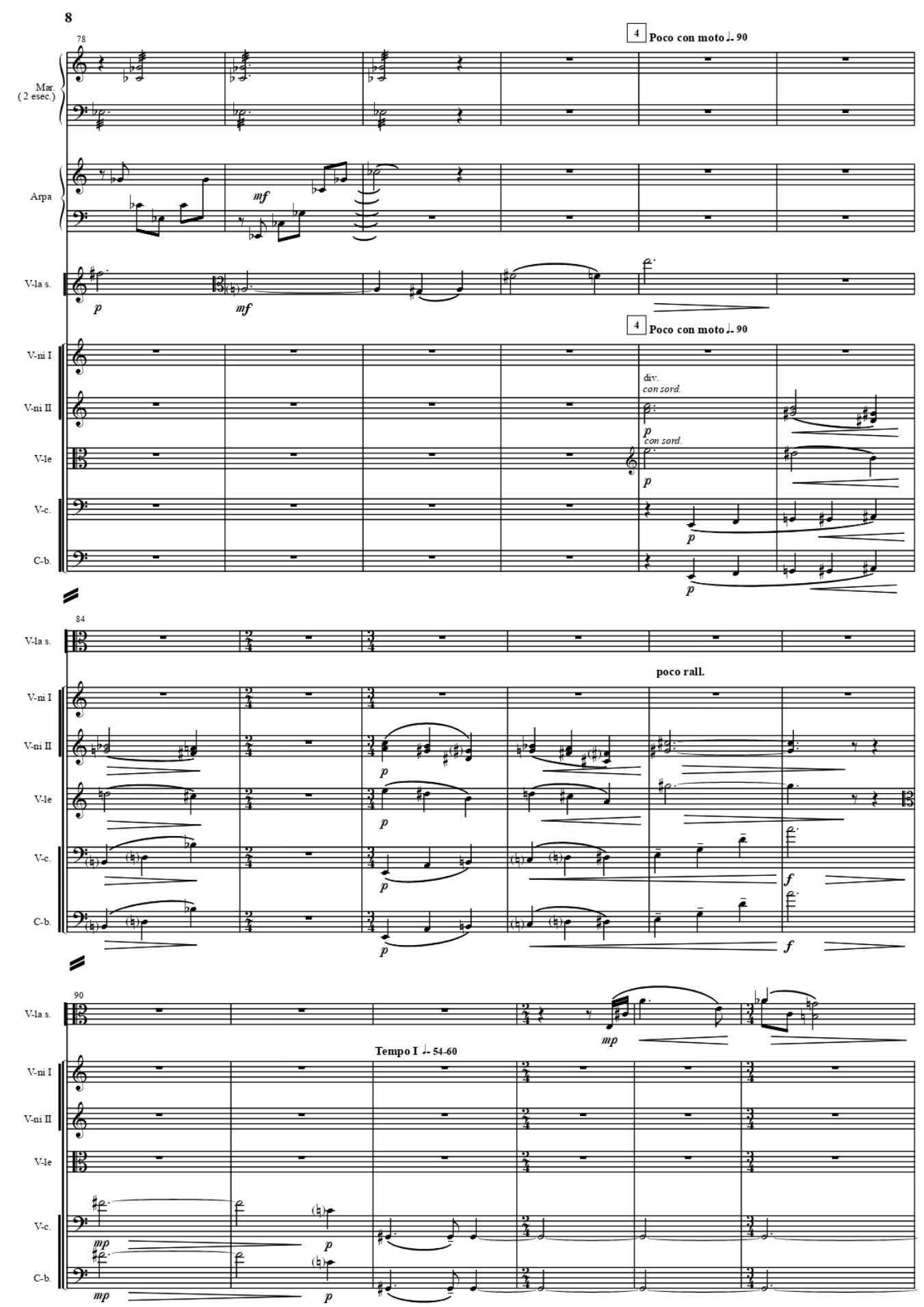




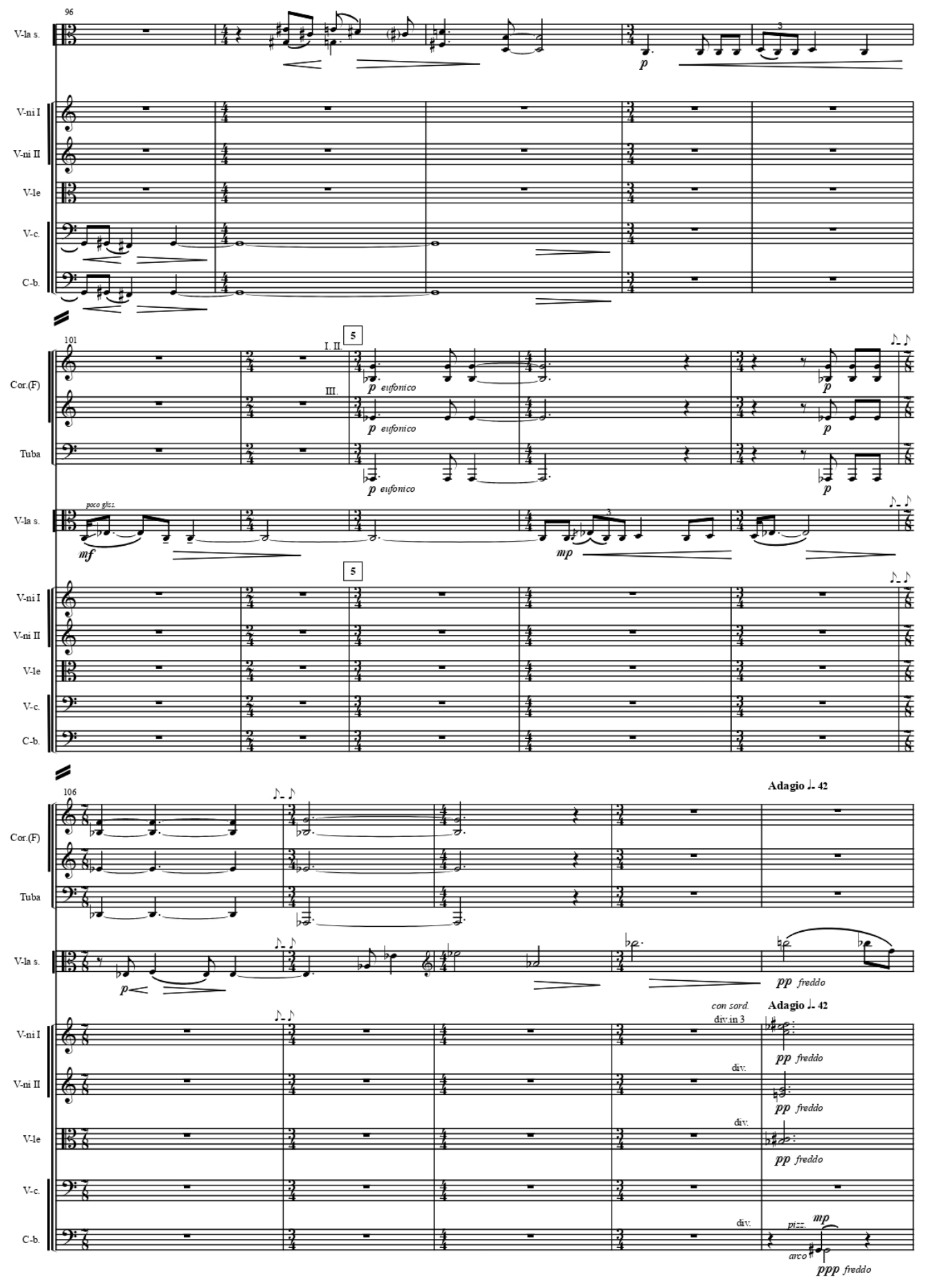



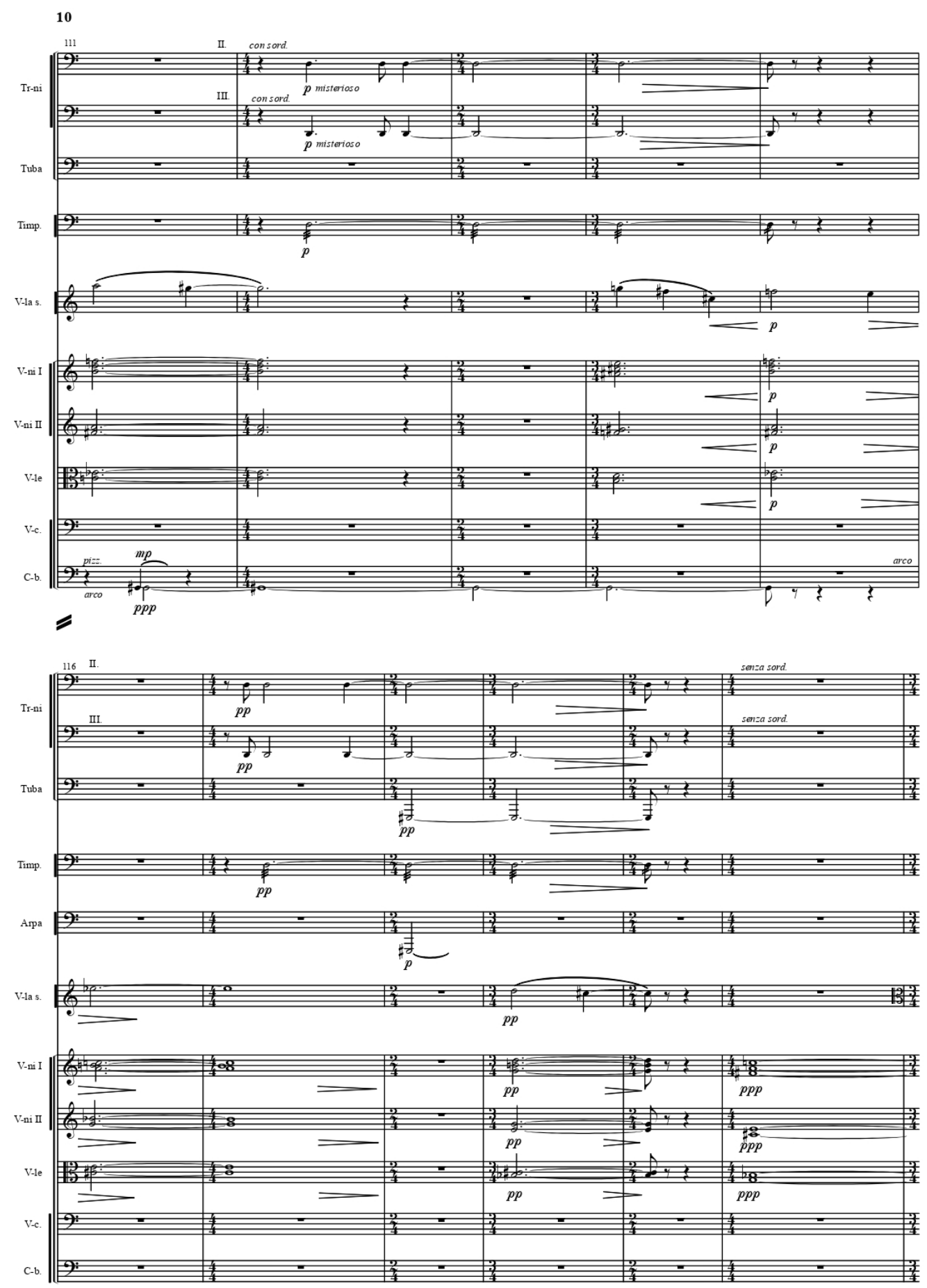


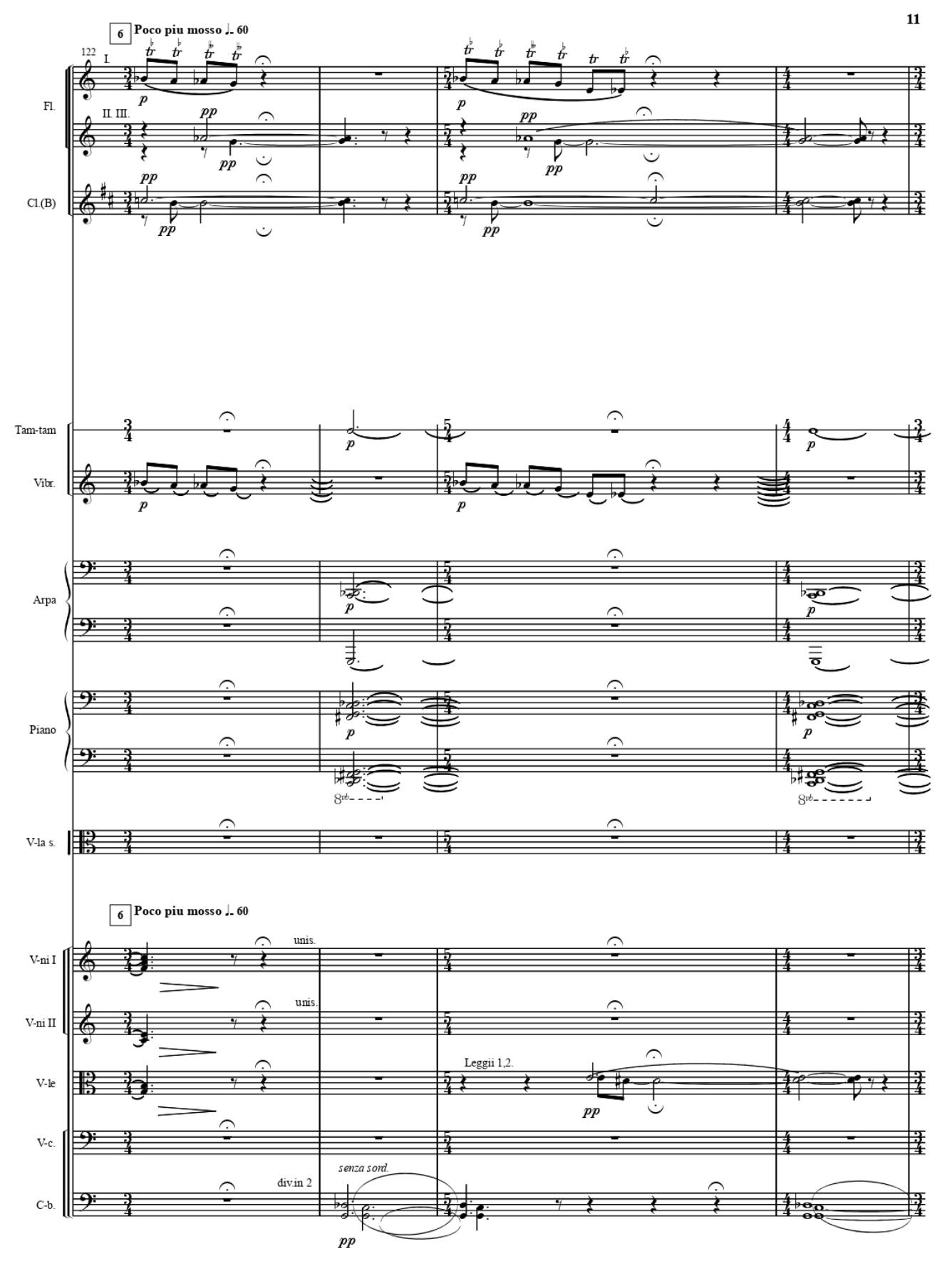




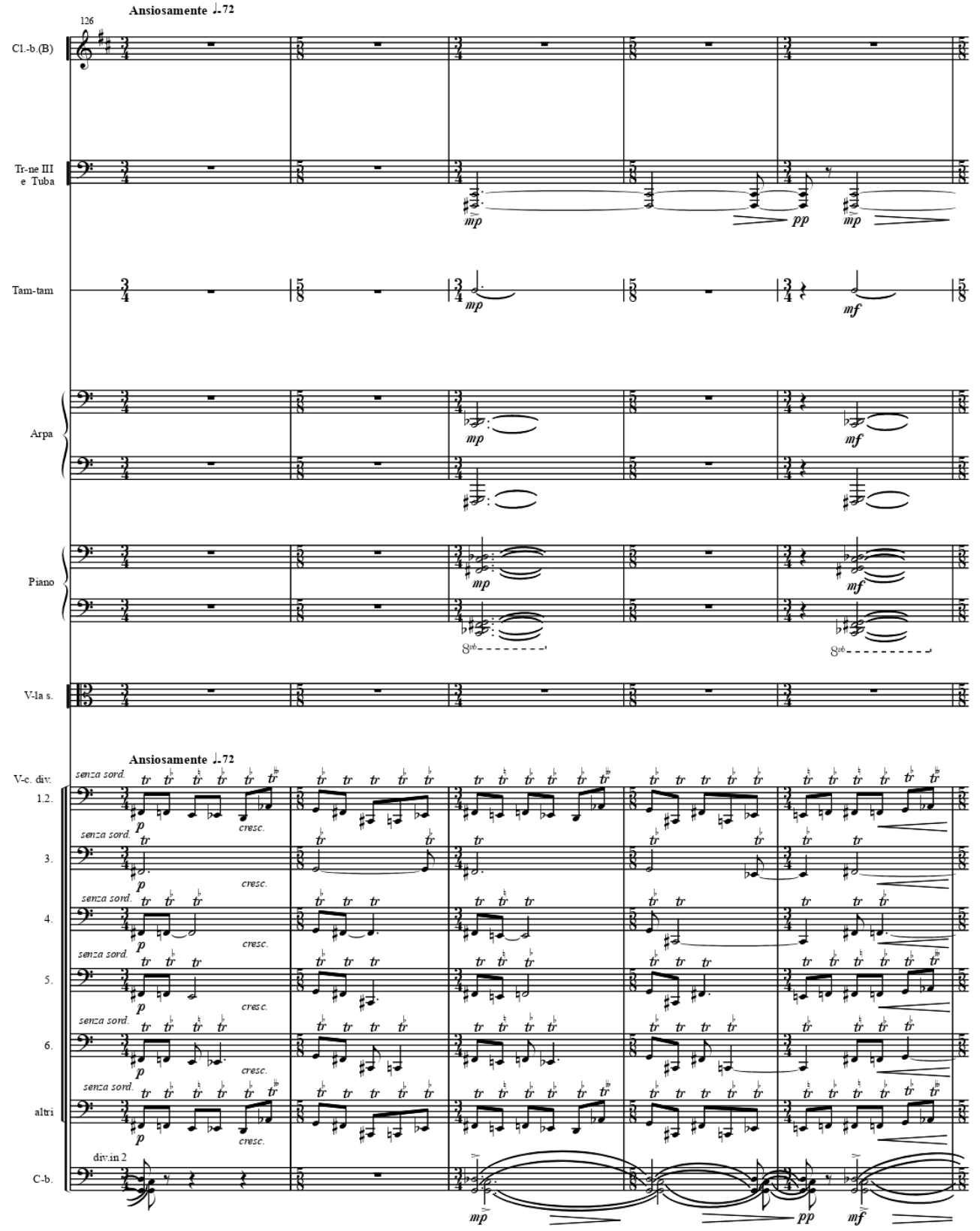



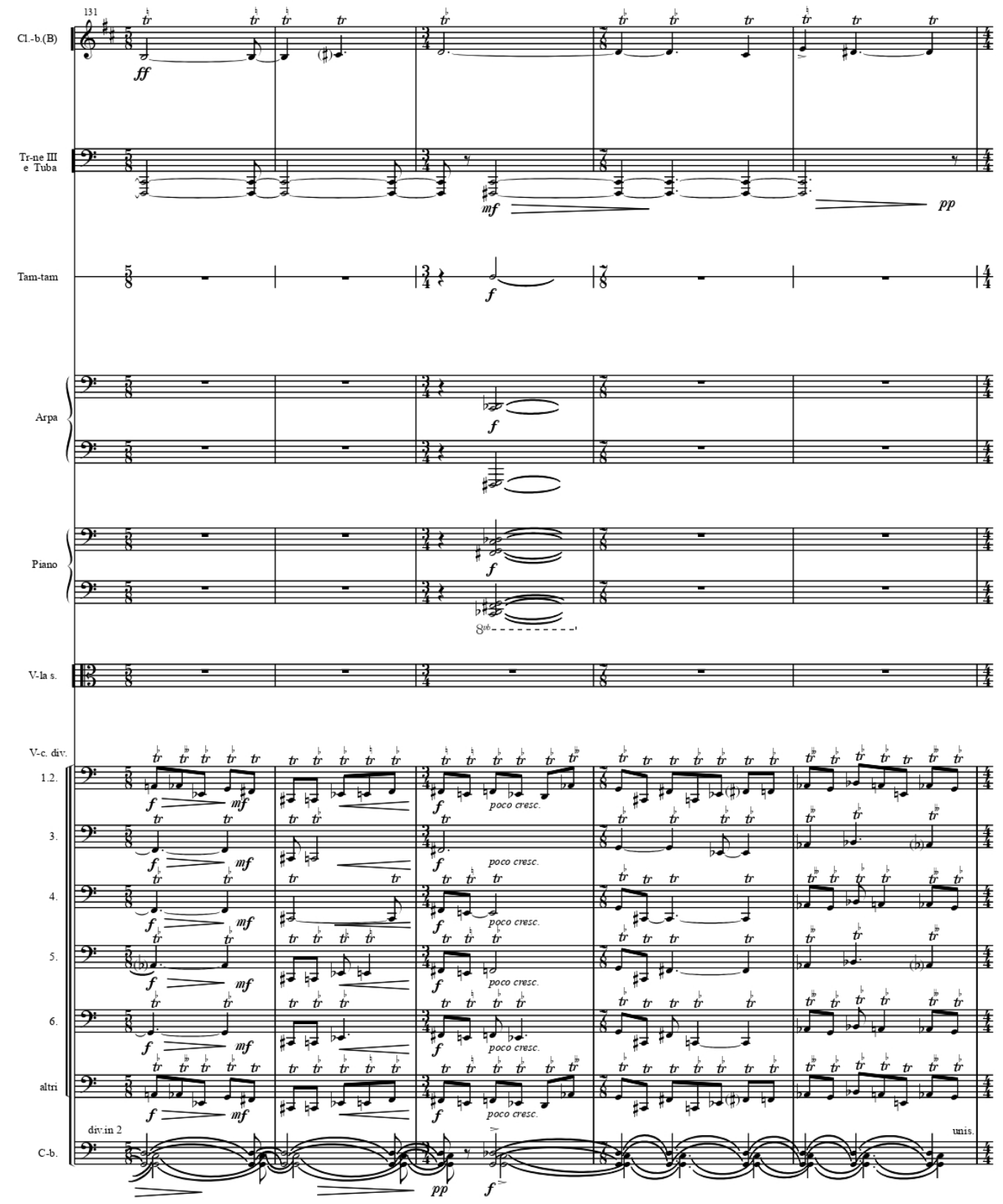


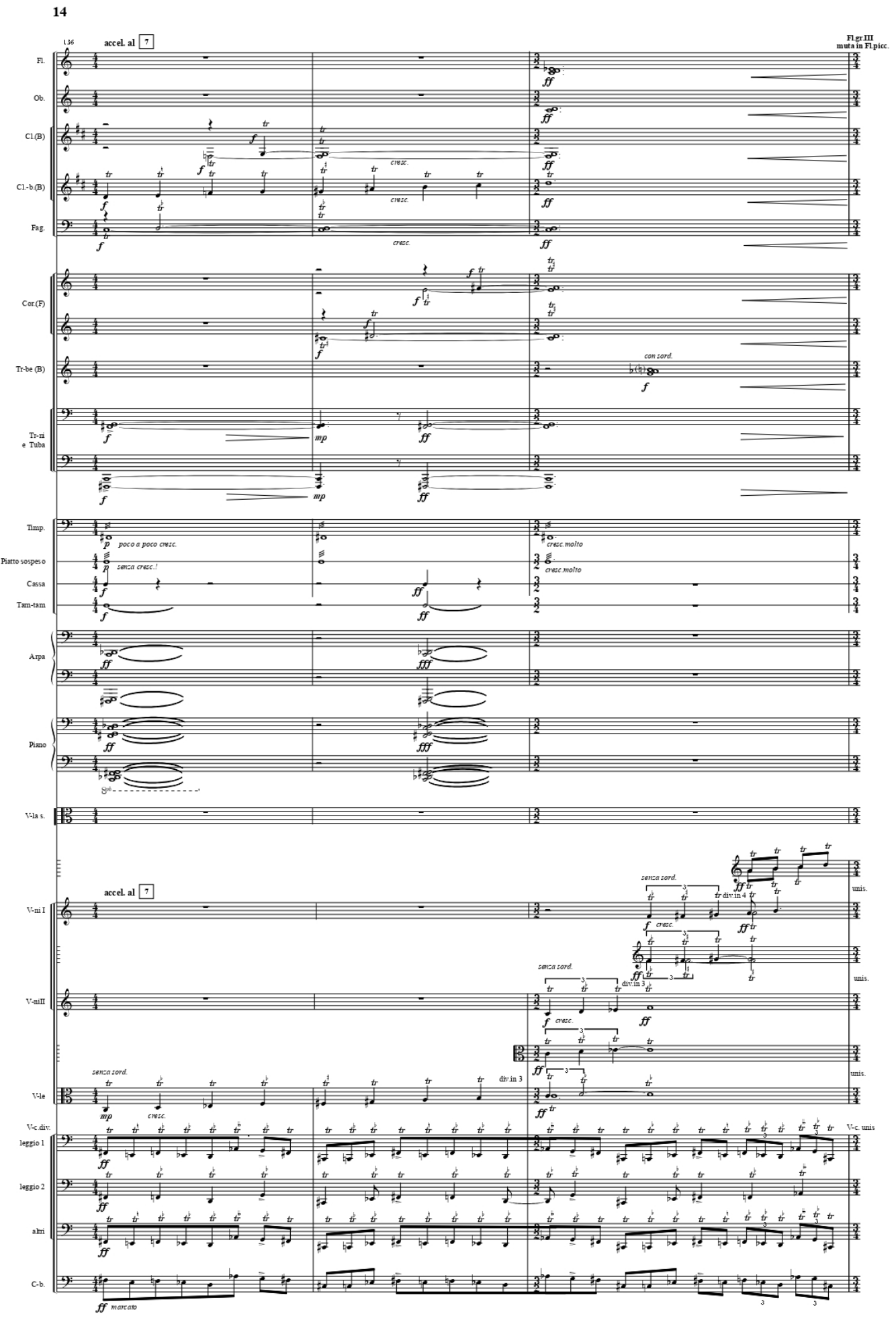




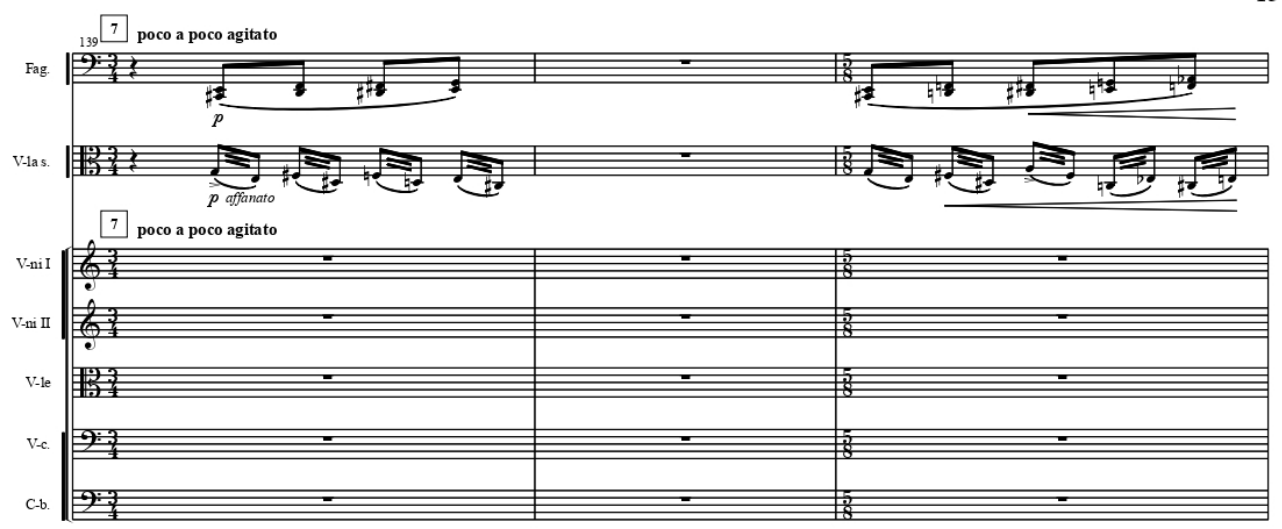

rag

Vas.
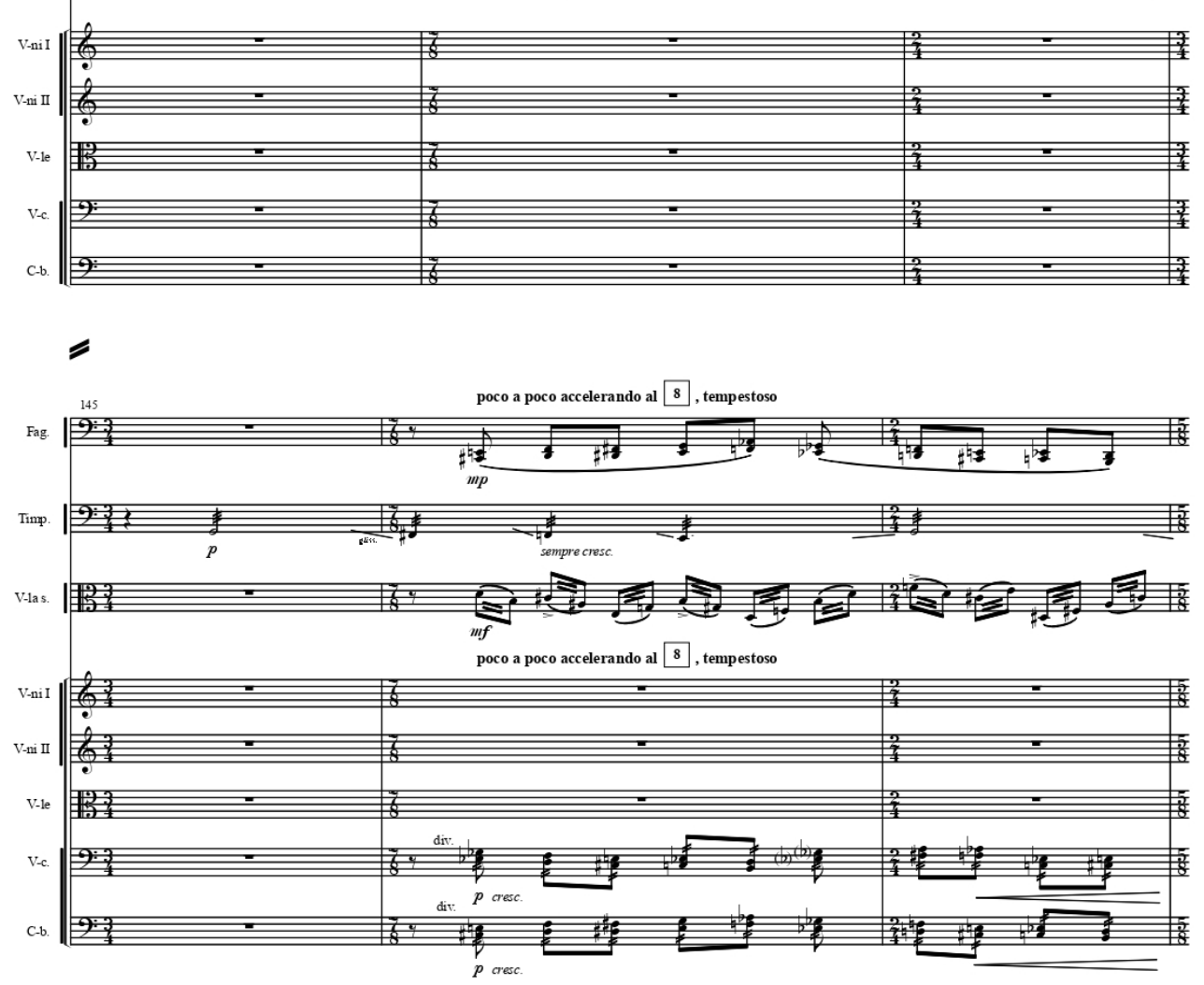
V.las.

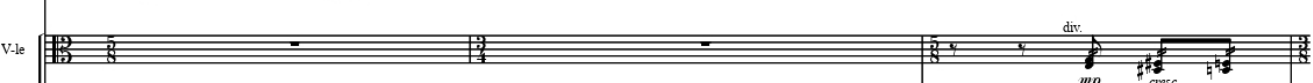
V.c.

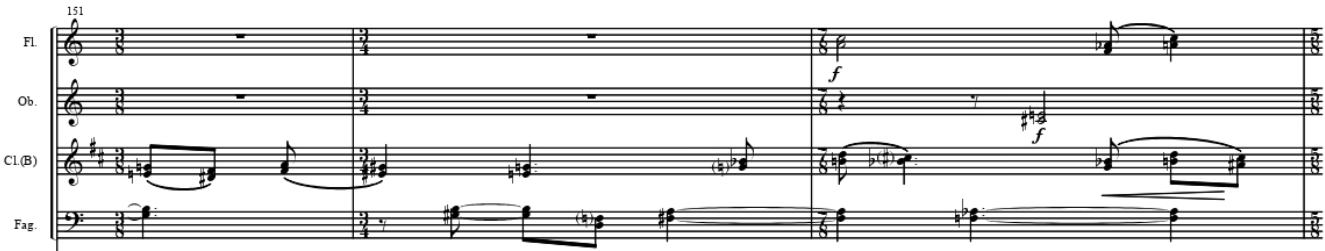

Tor

Timp.

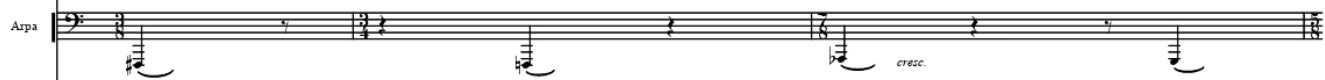
Va. V.le vec

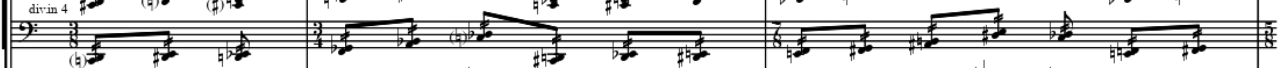
dirin 4 (1) 


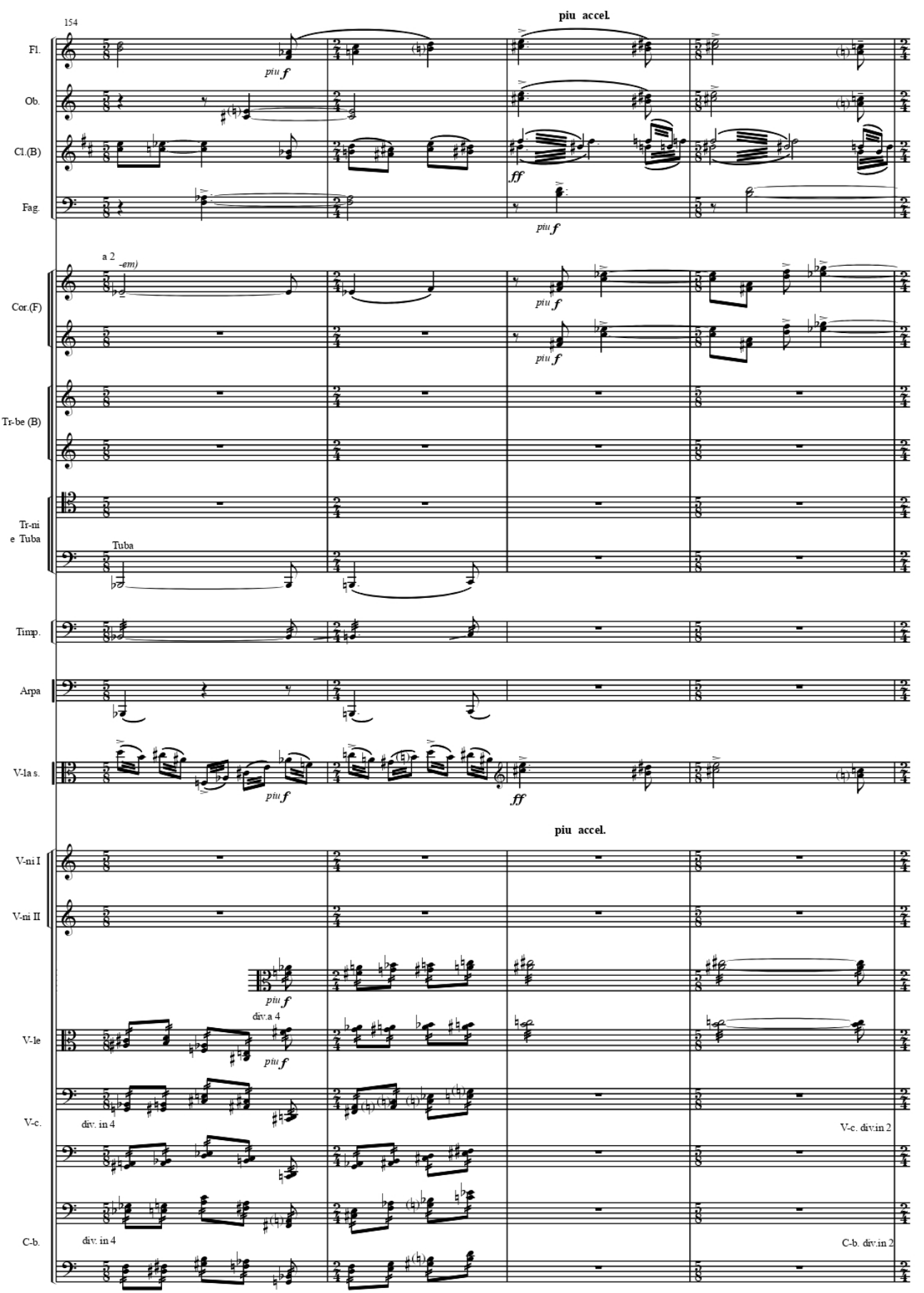




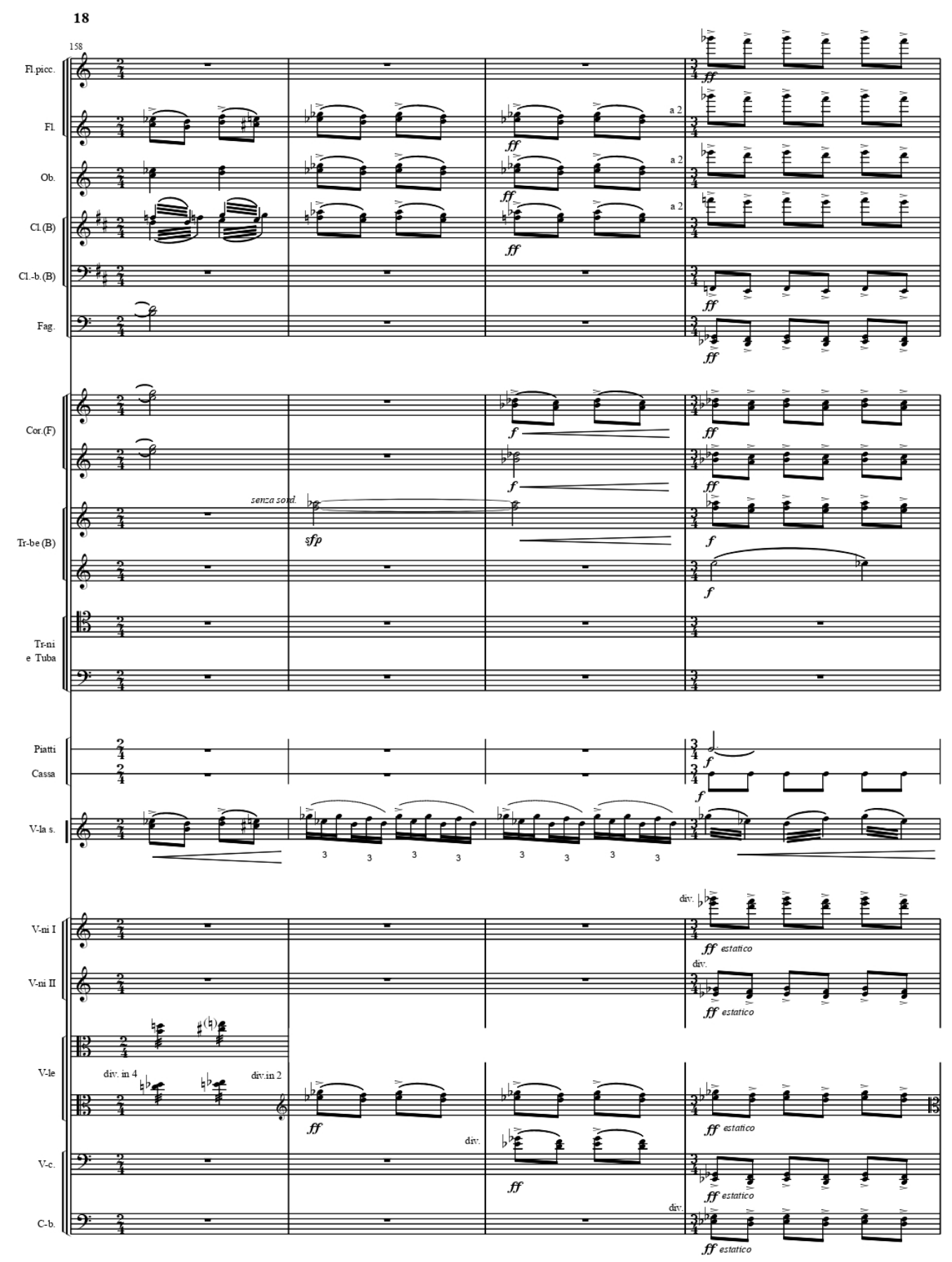



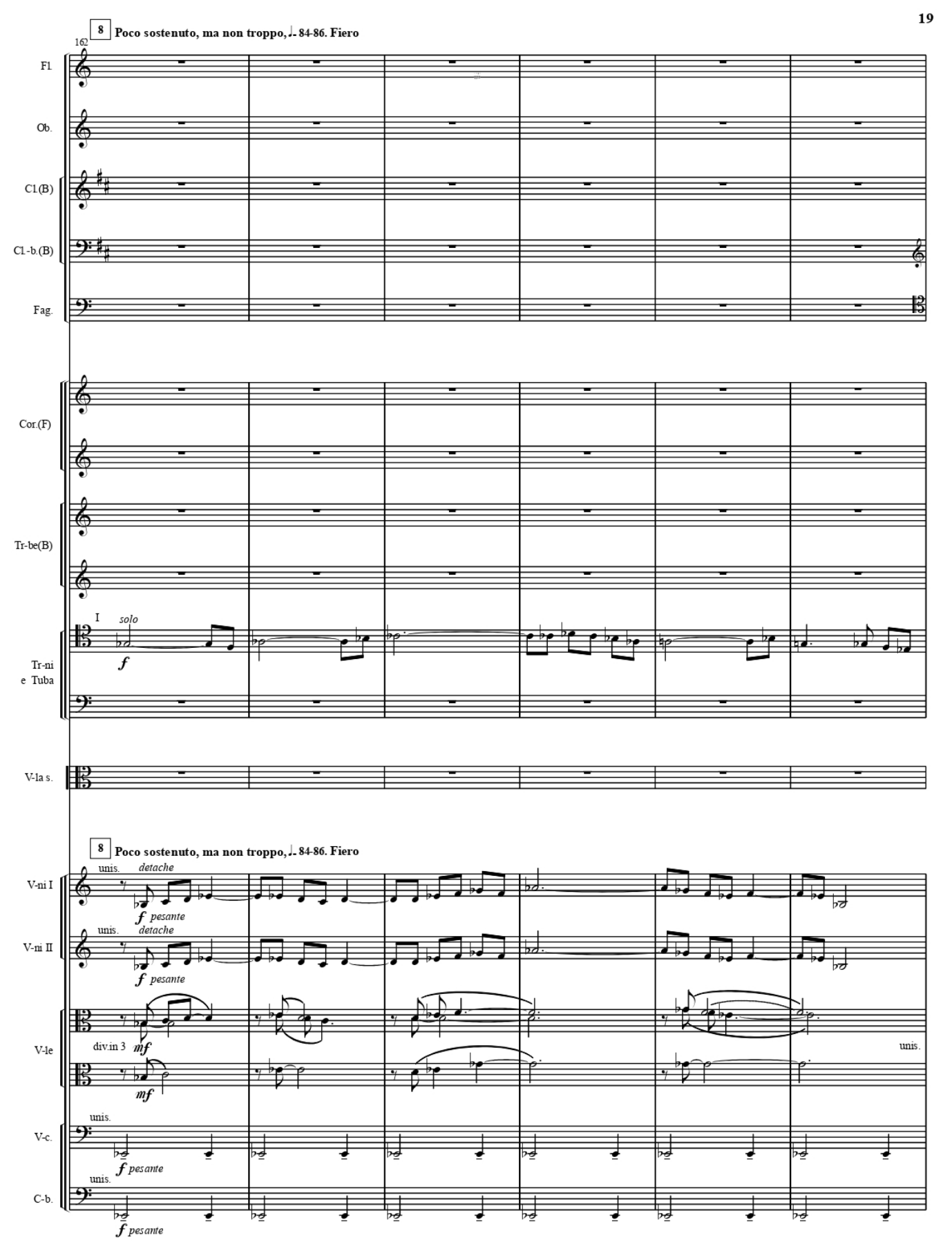


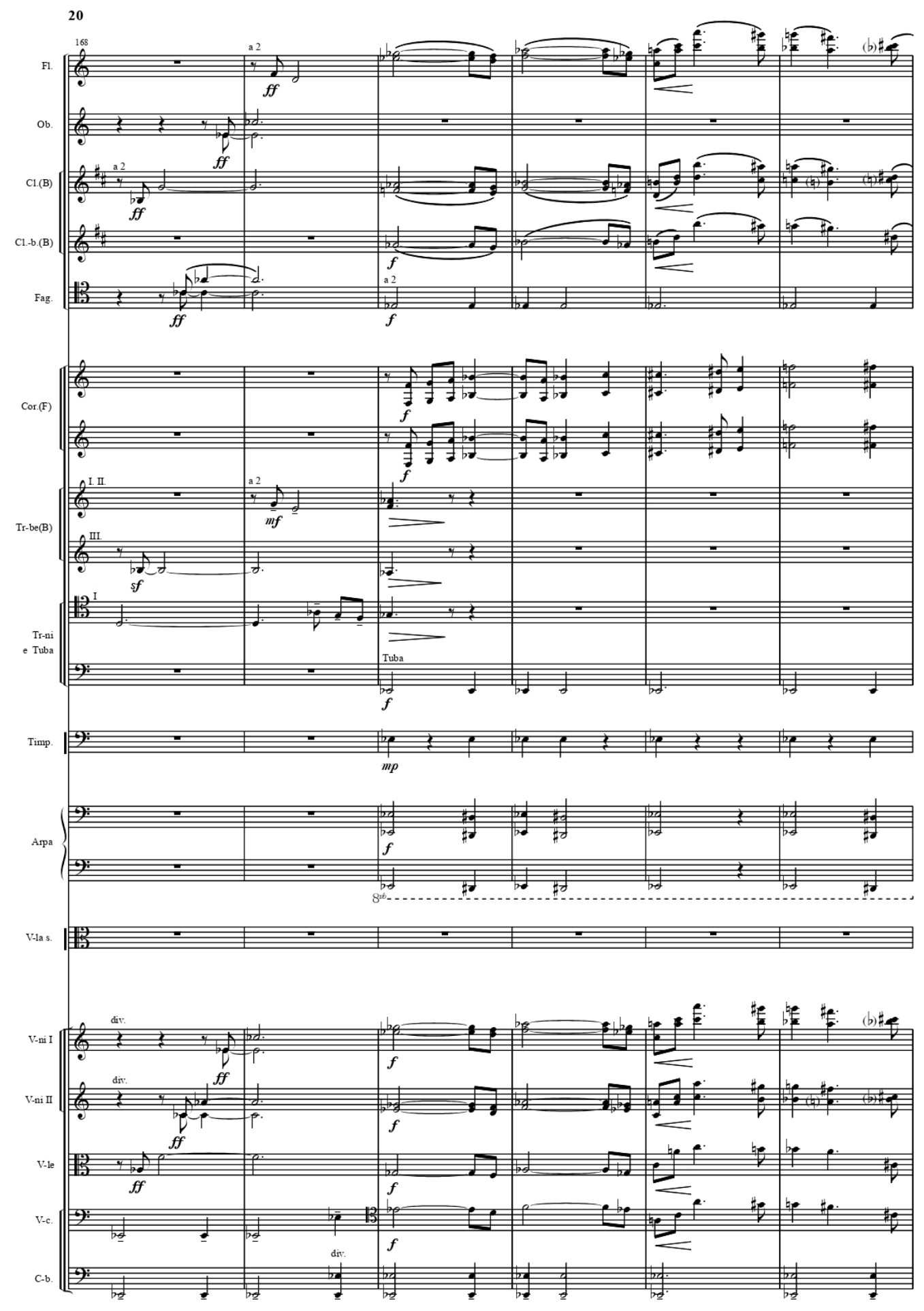




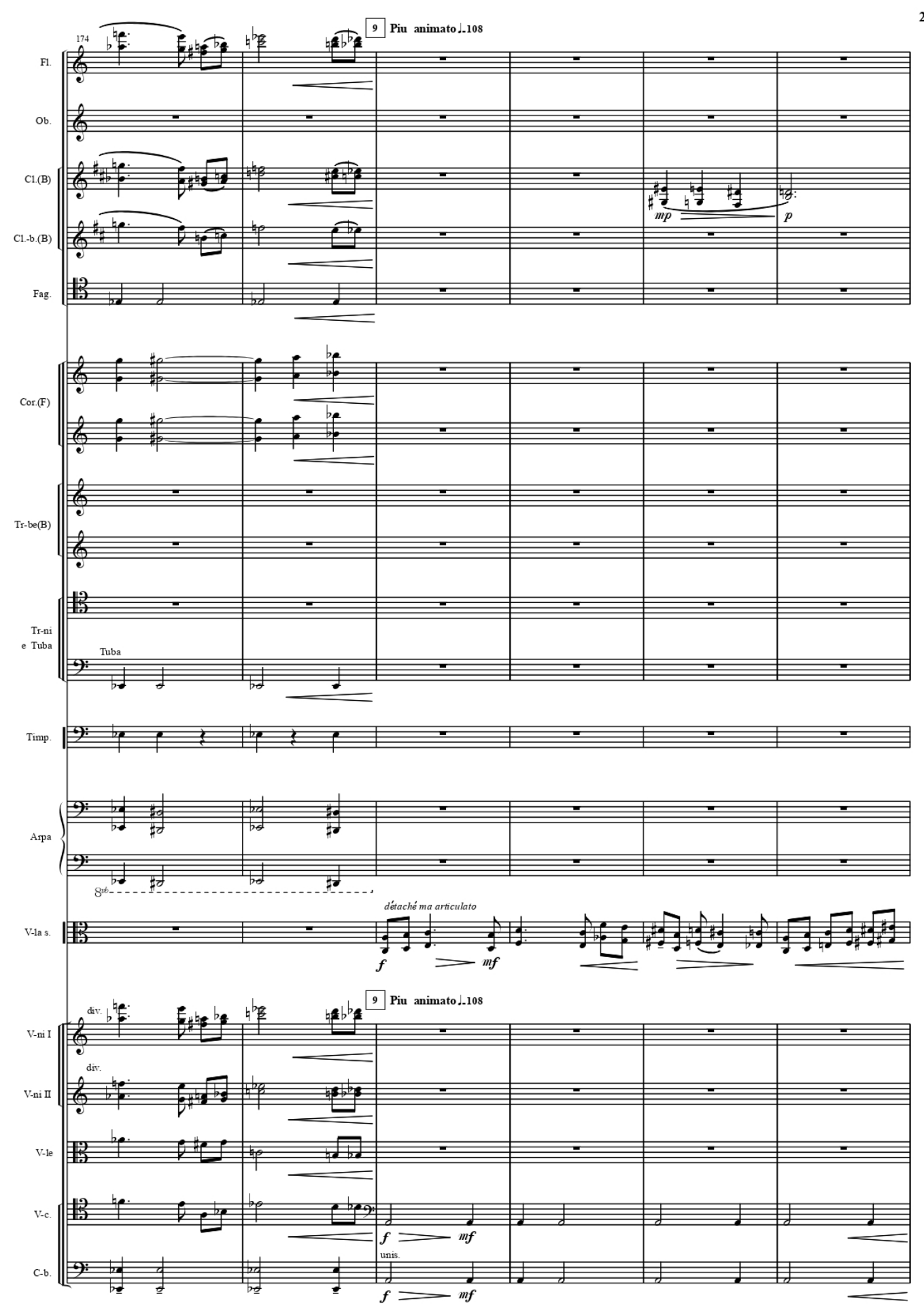




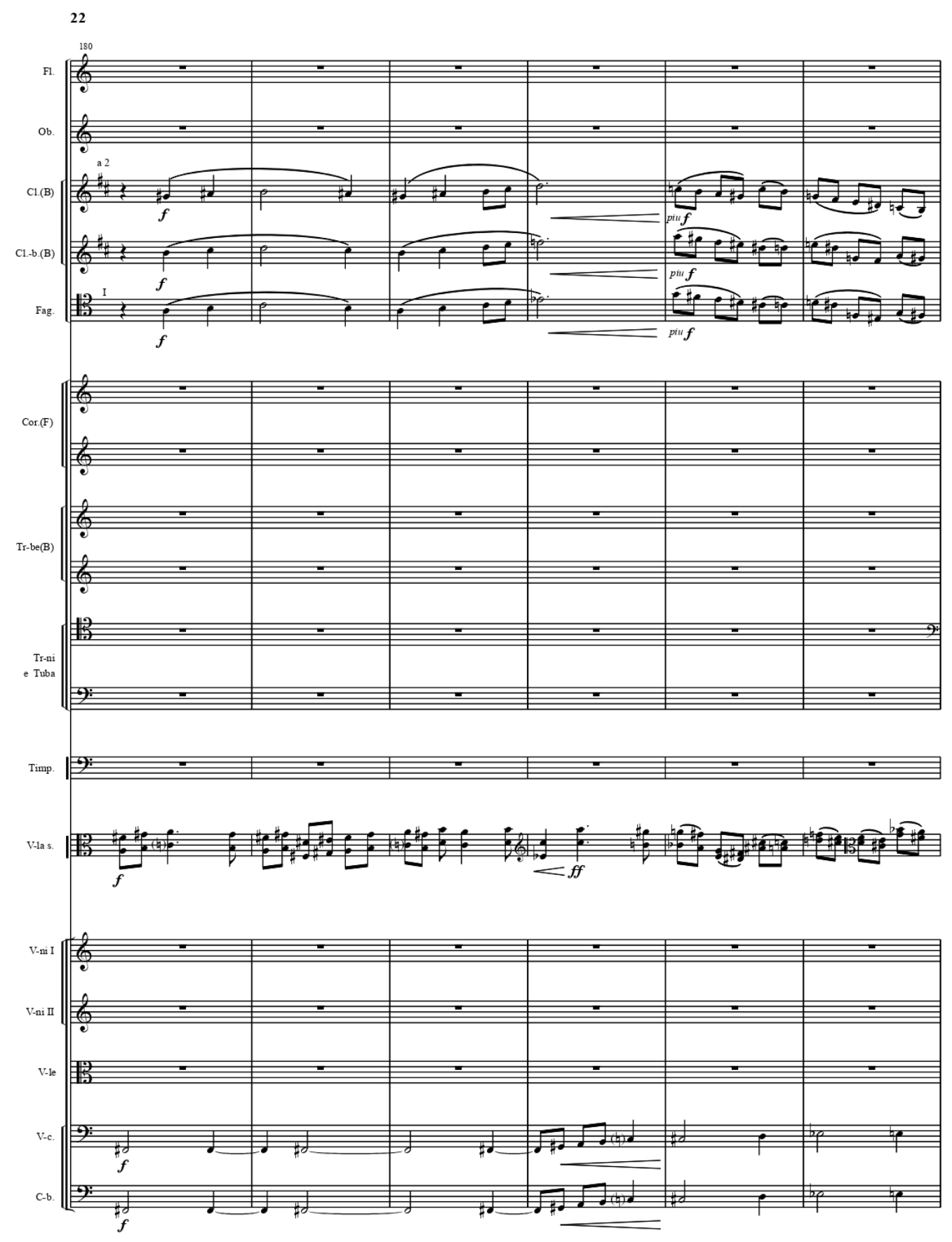




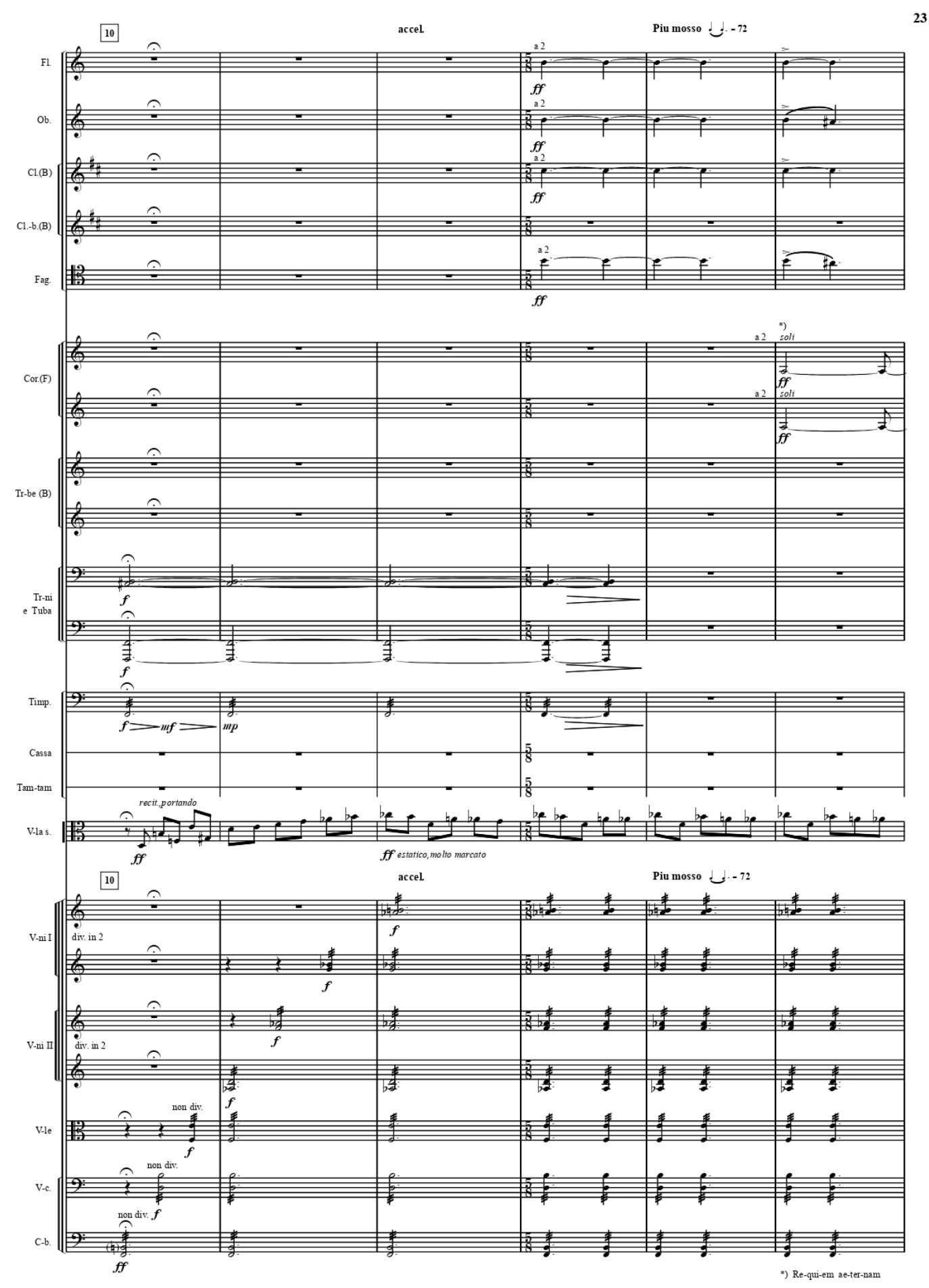




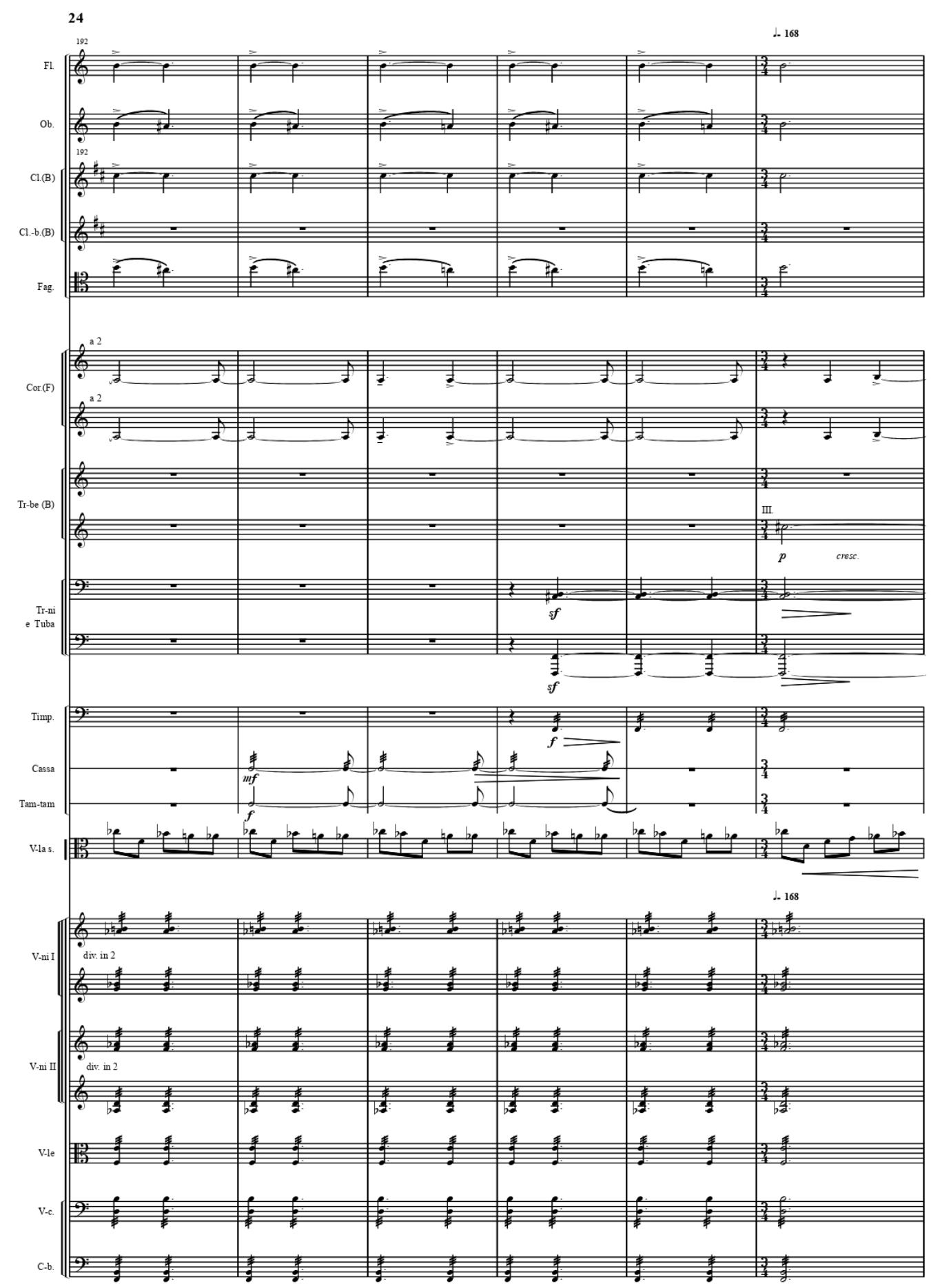




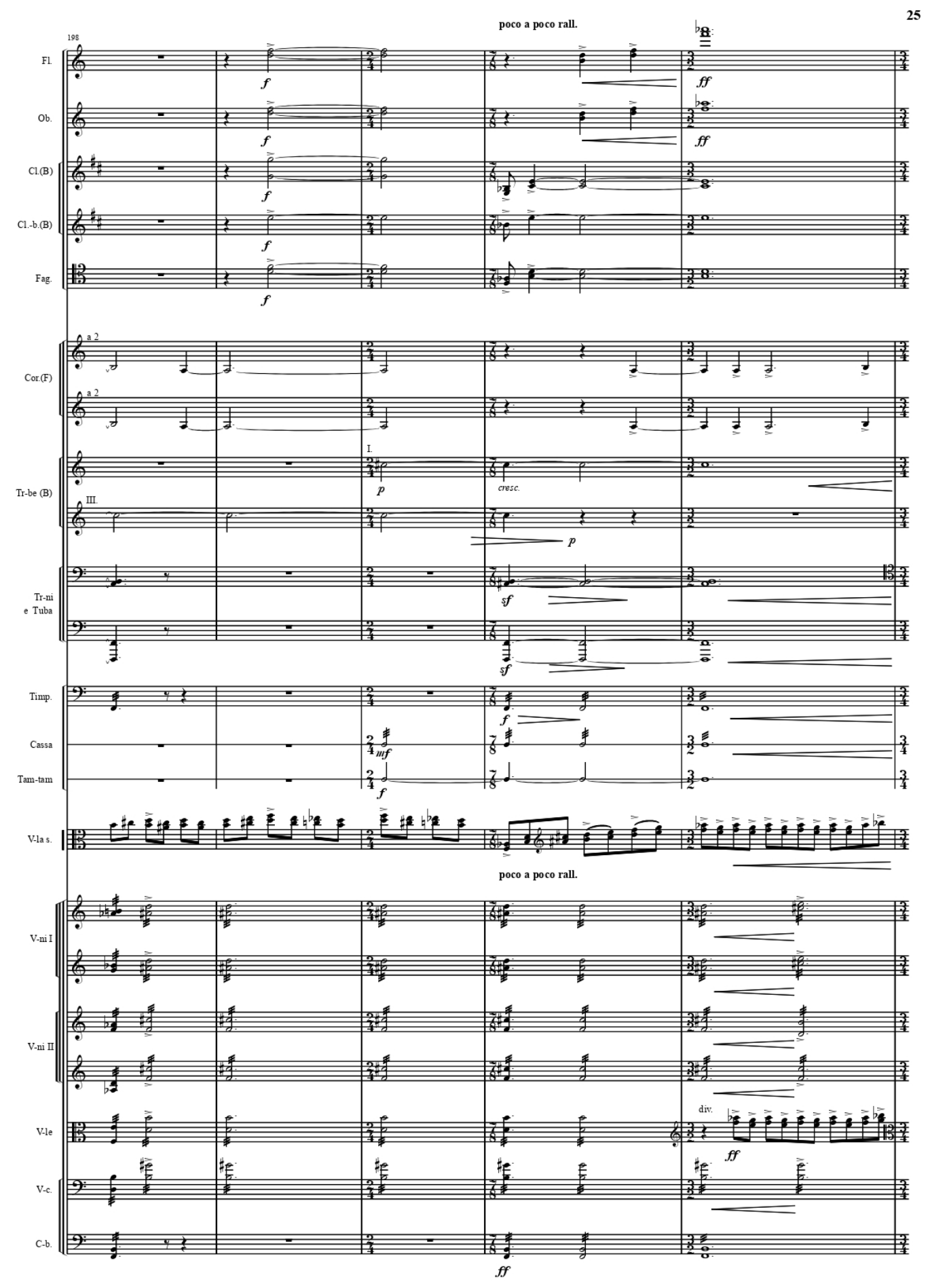




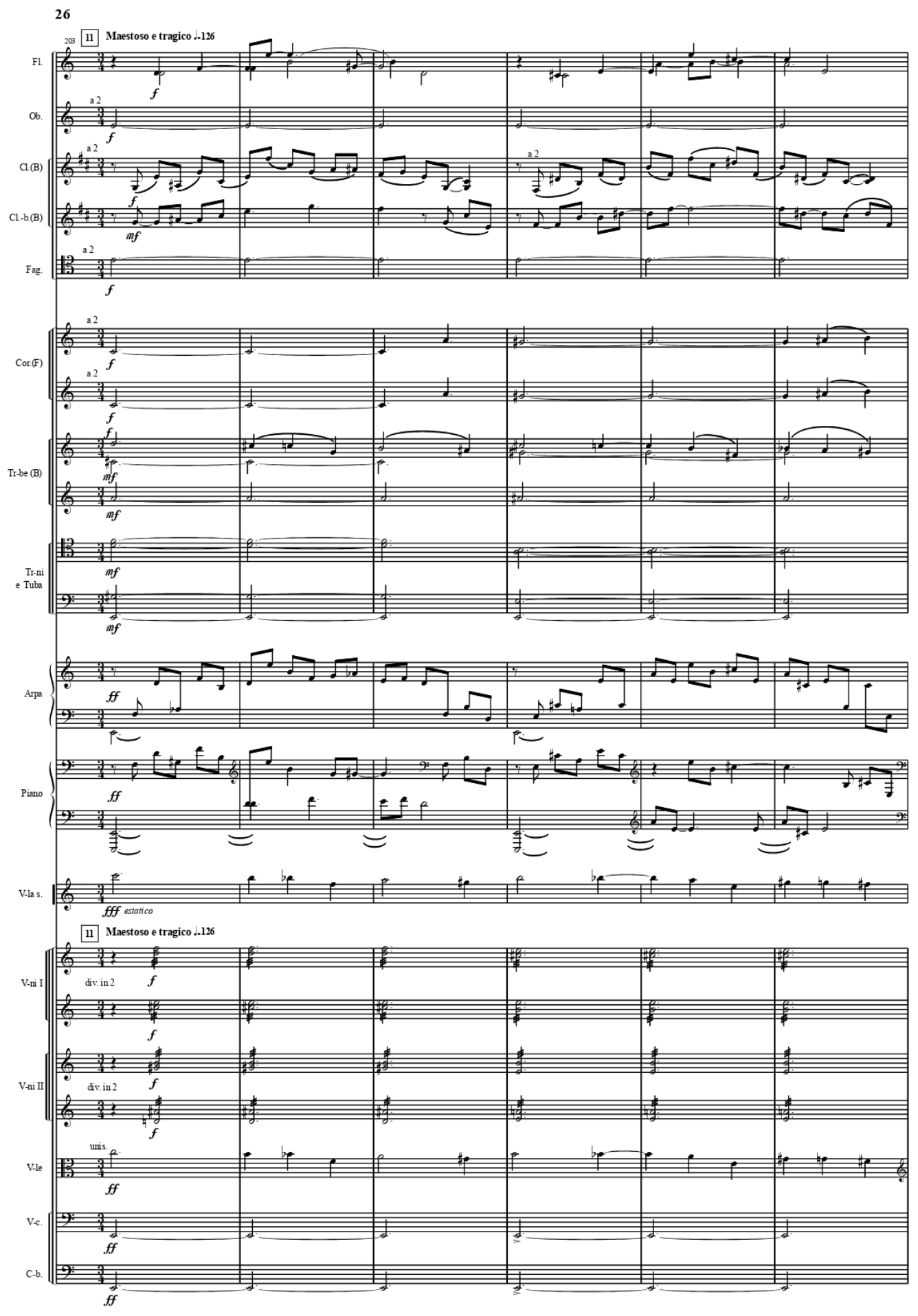




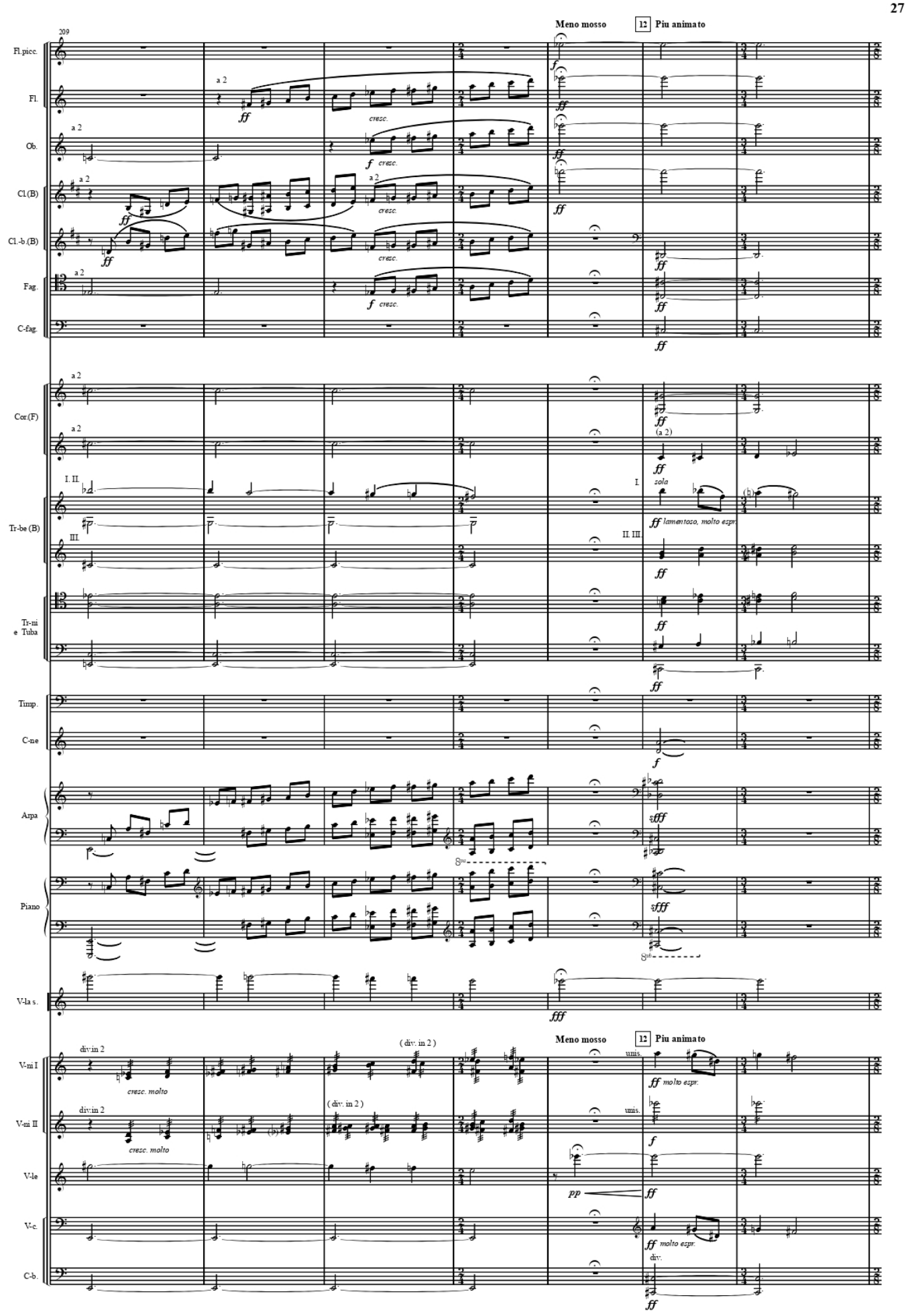




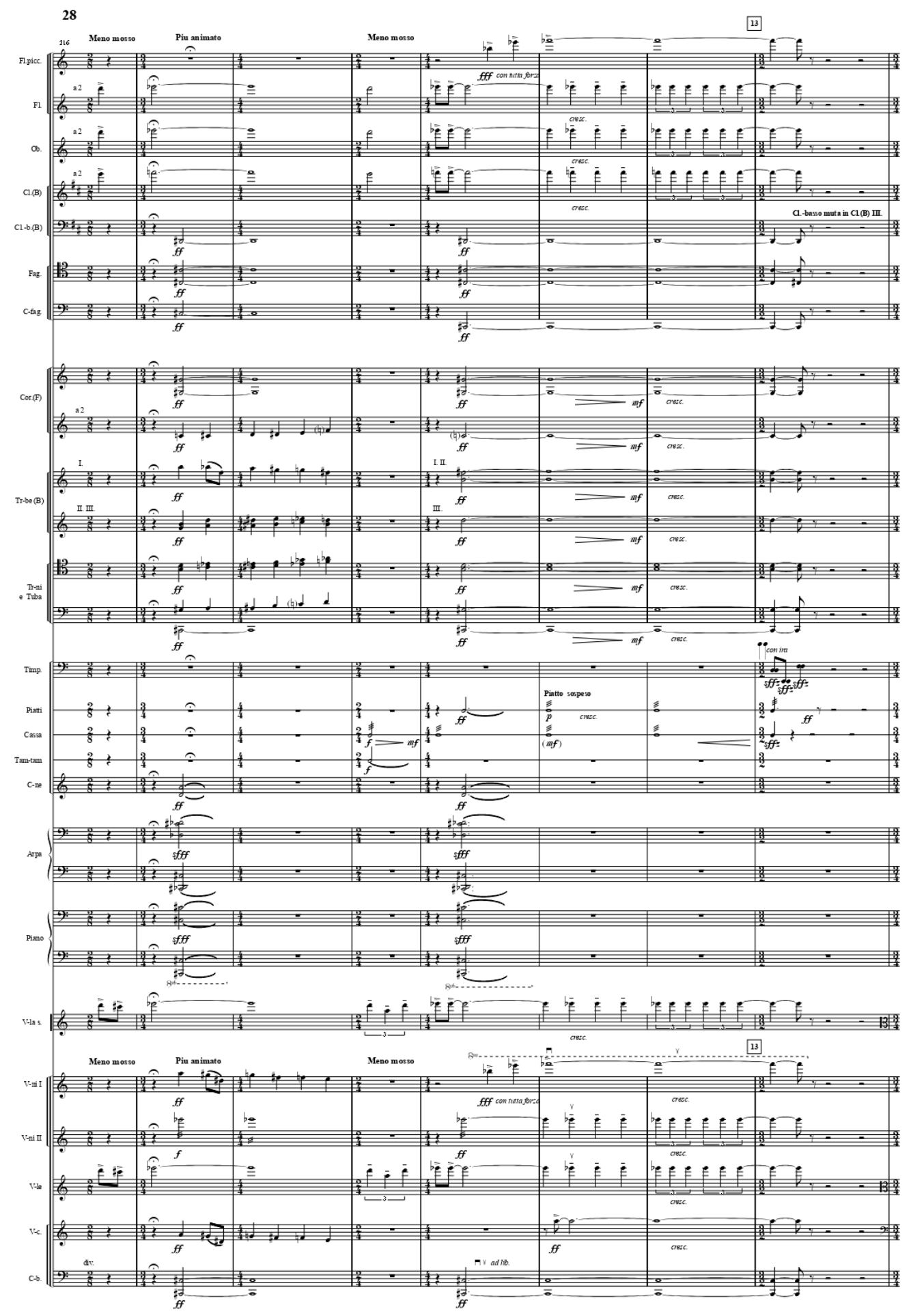




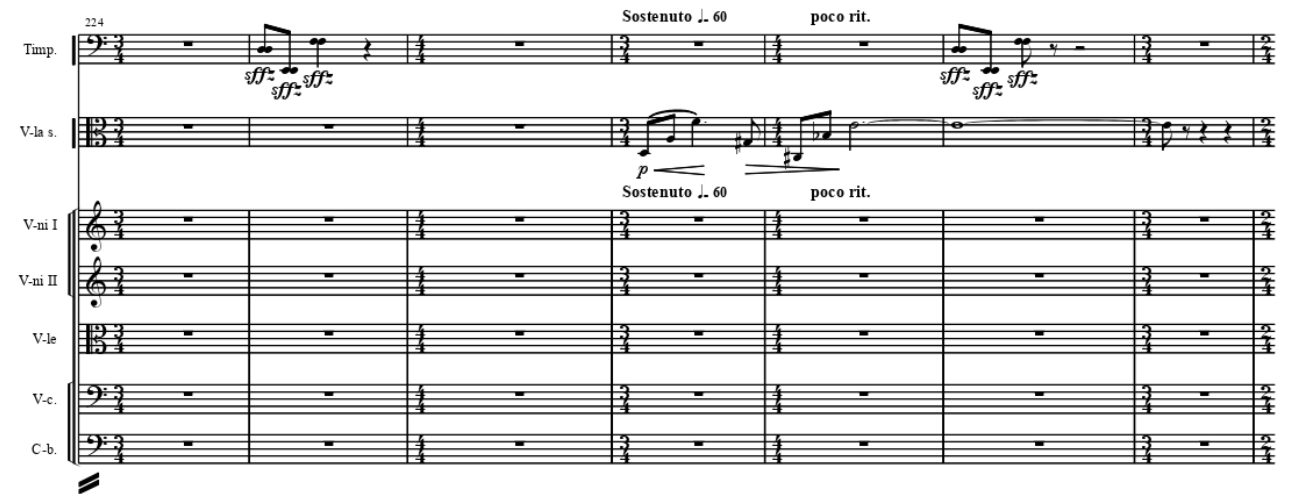

V.as.

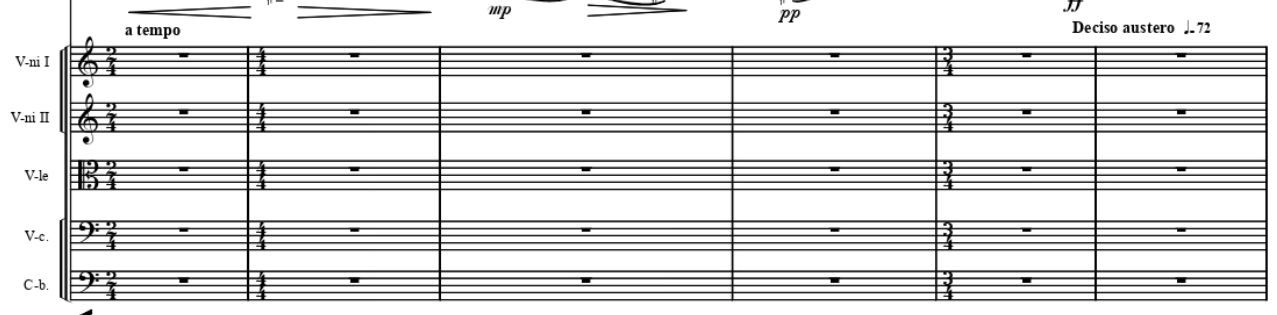

V.a. .
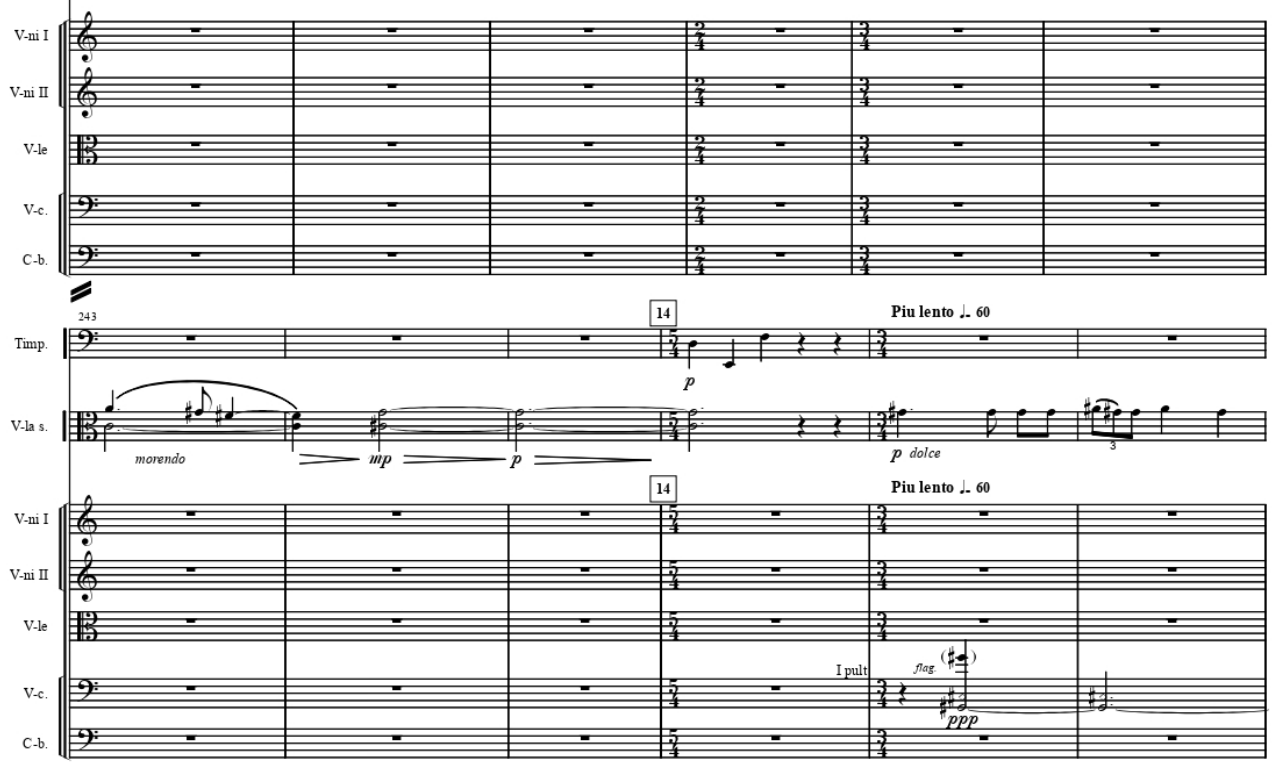


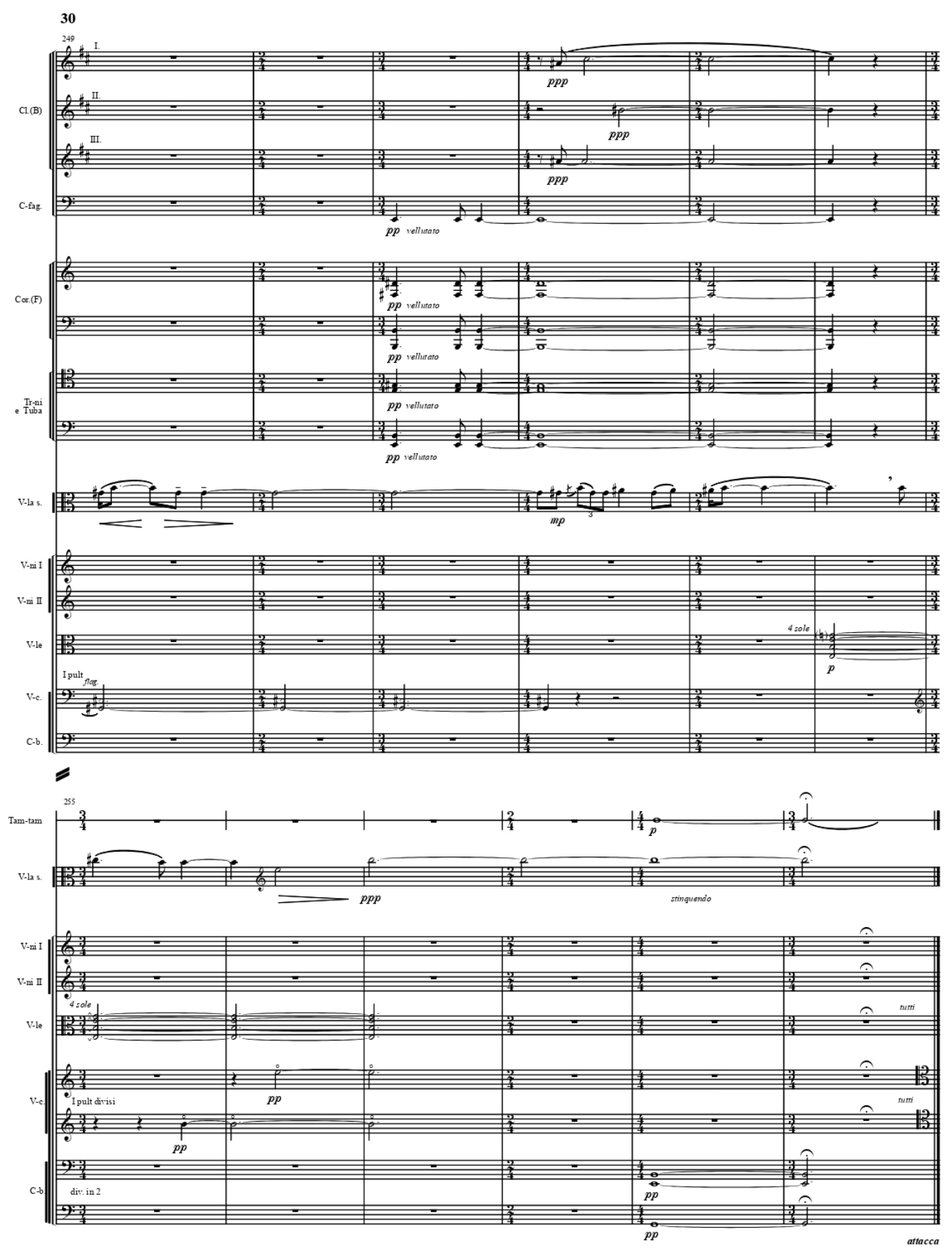




\section{II. " Dies irae "}
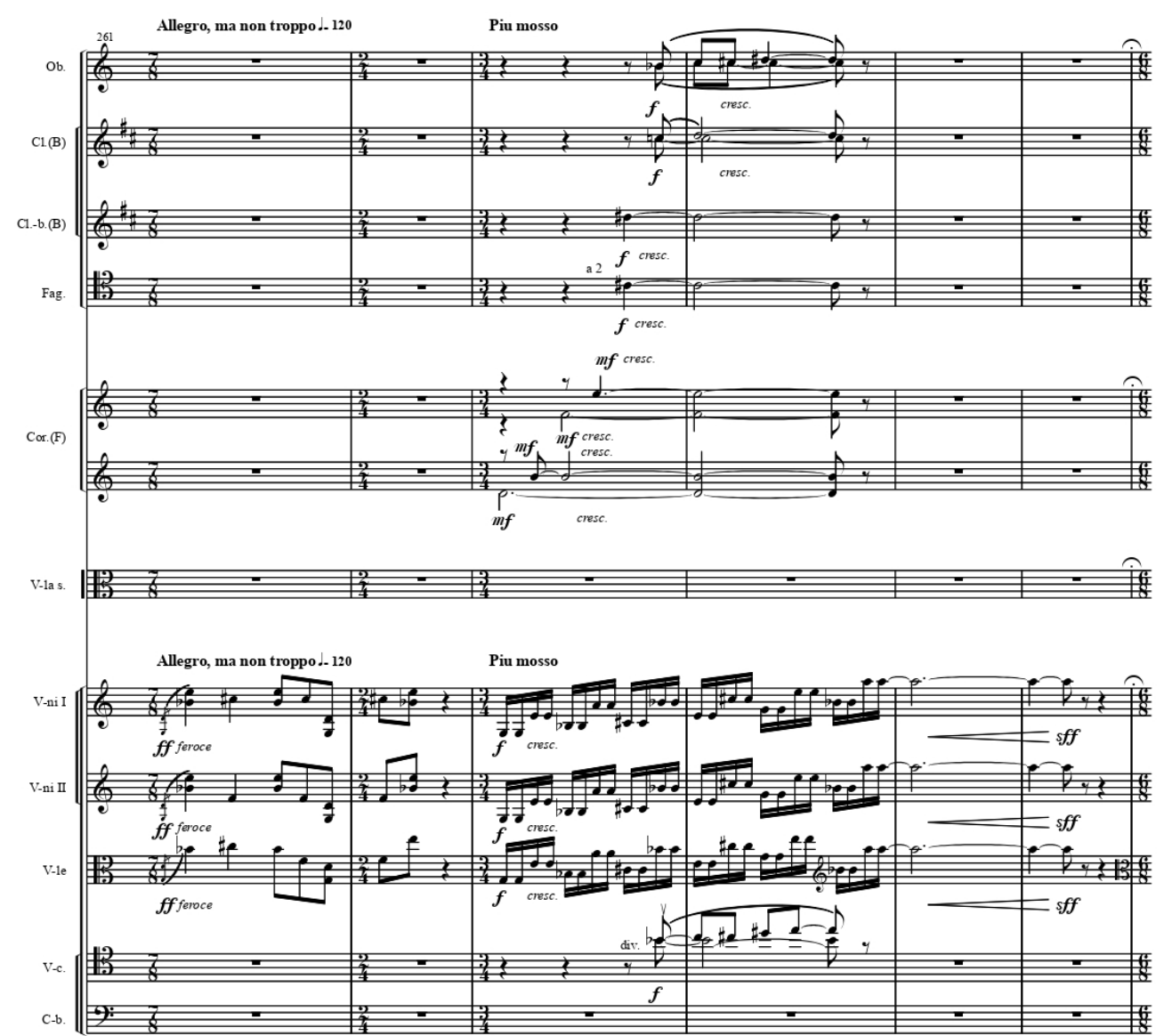

V.has

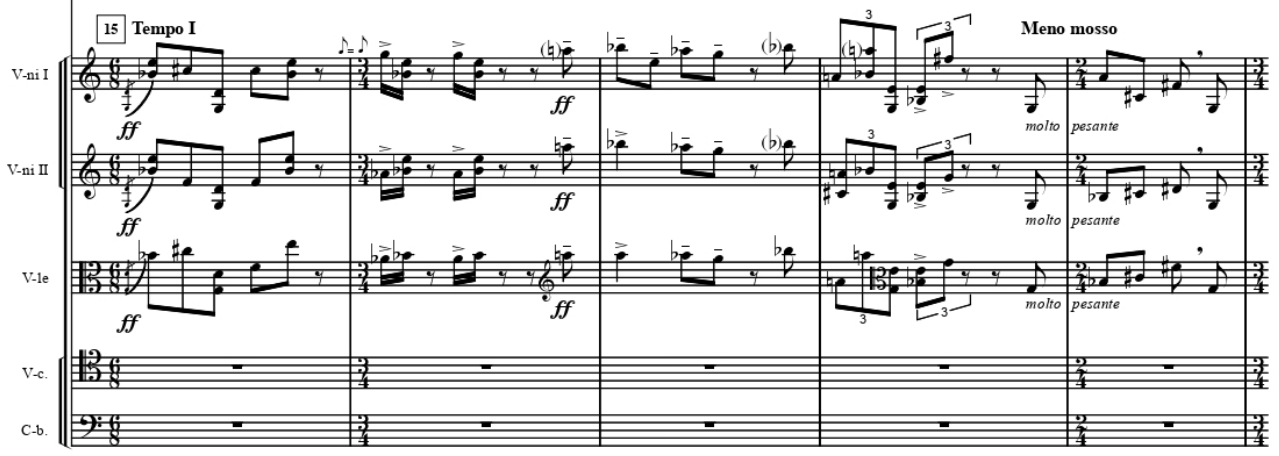




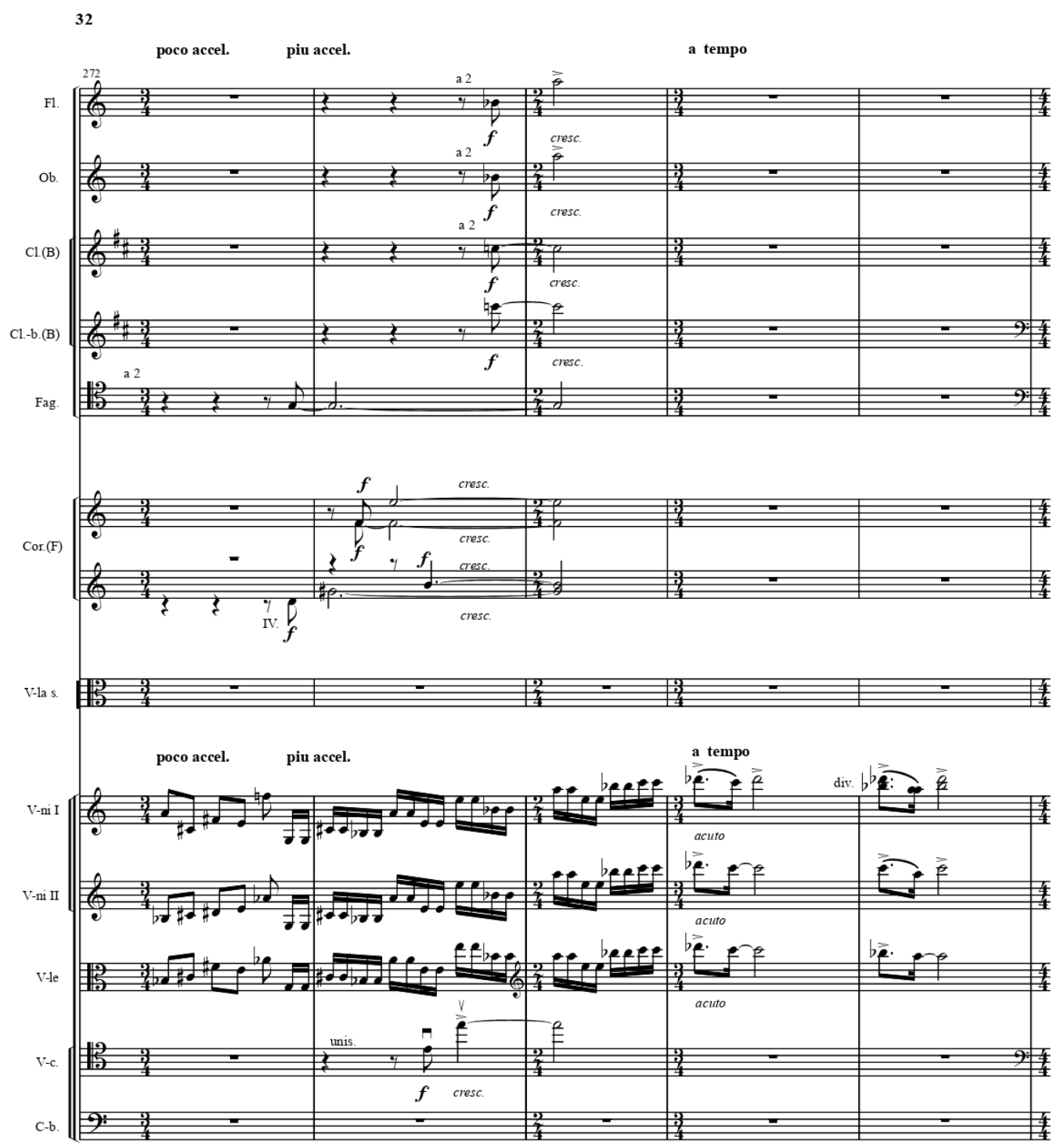




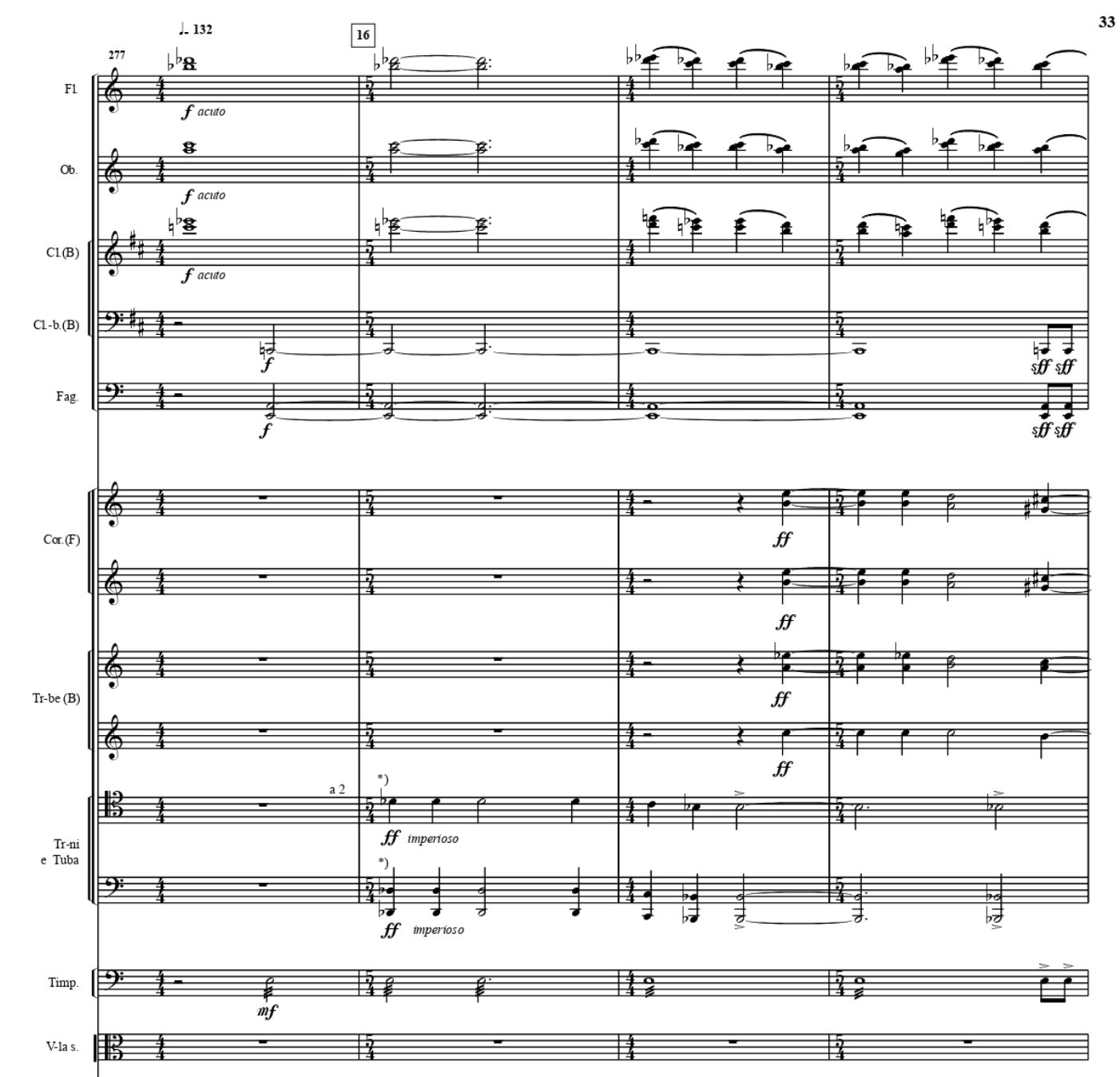

33

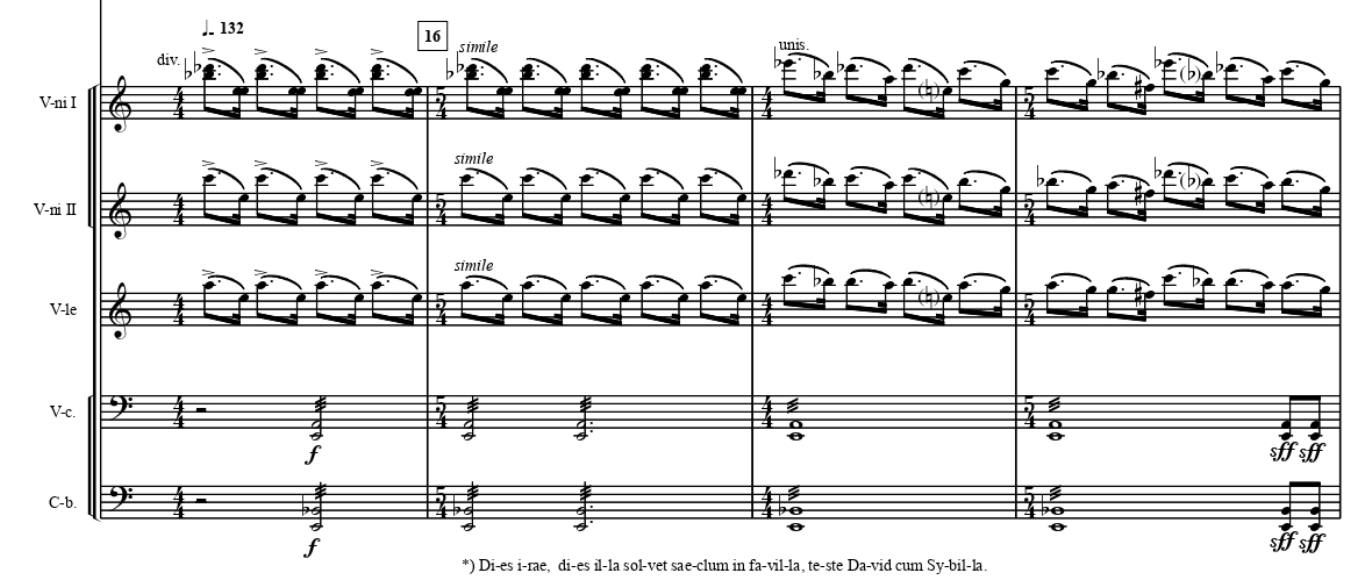




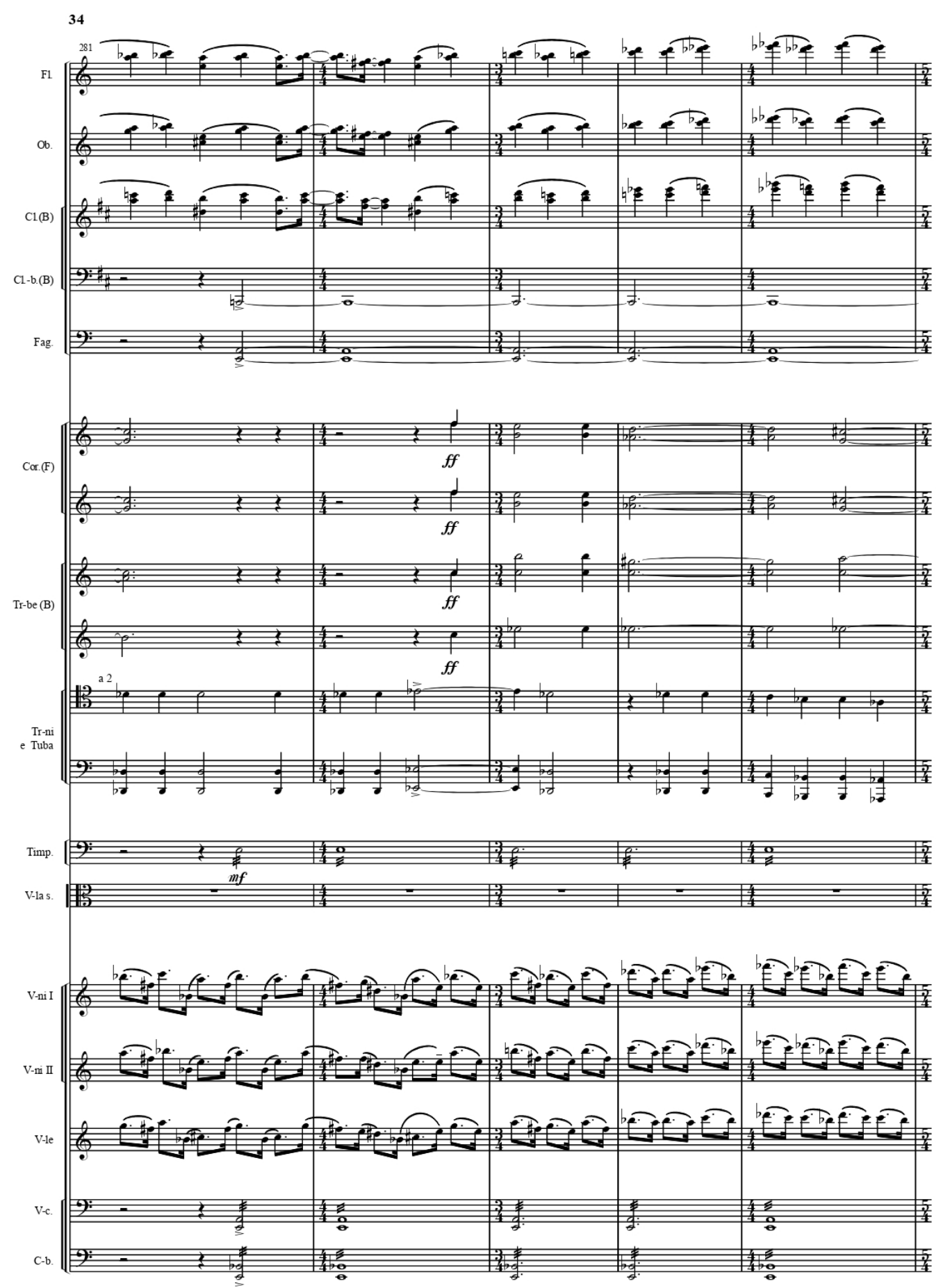



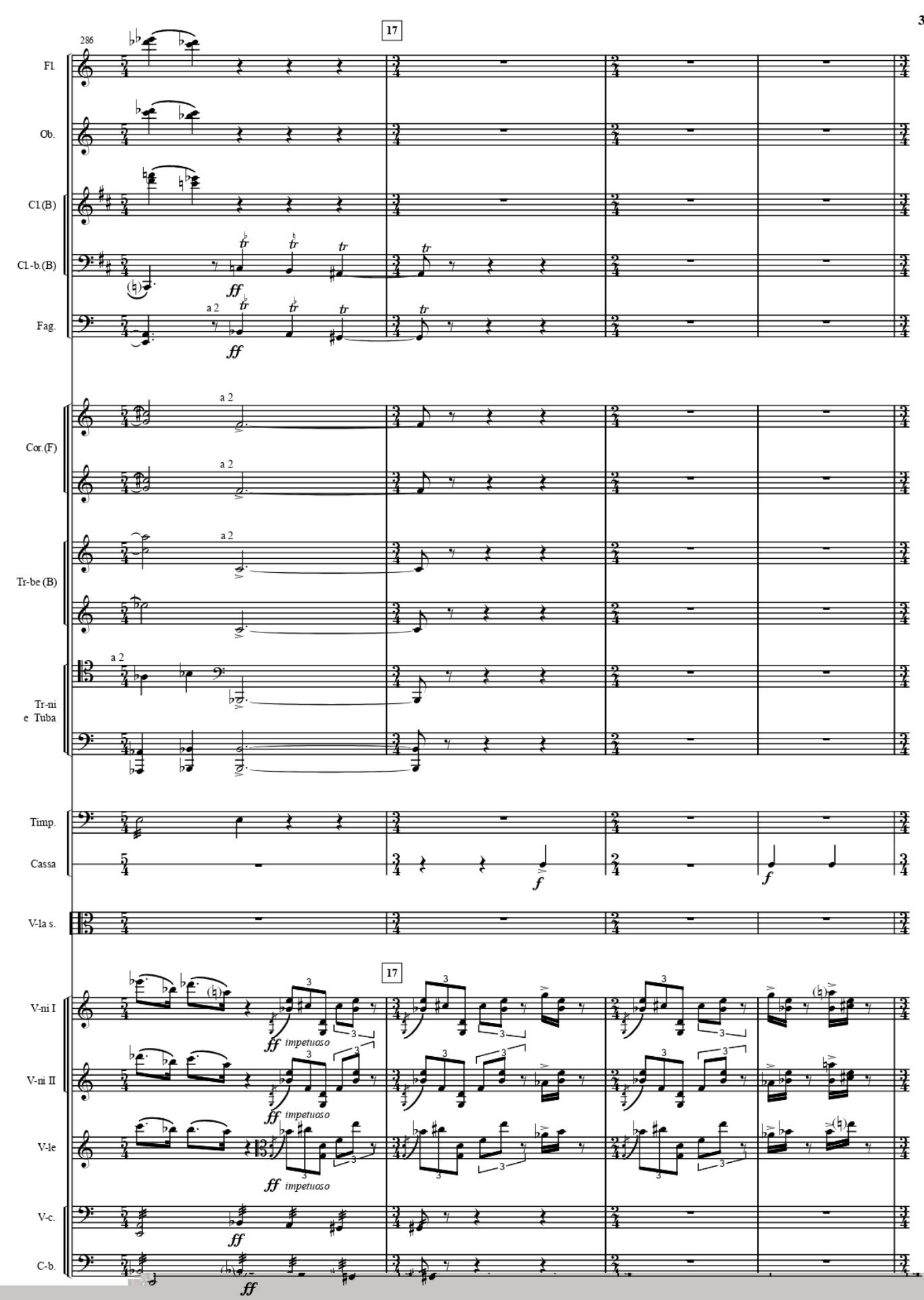


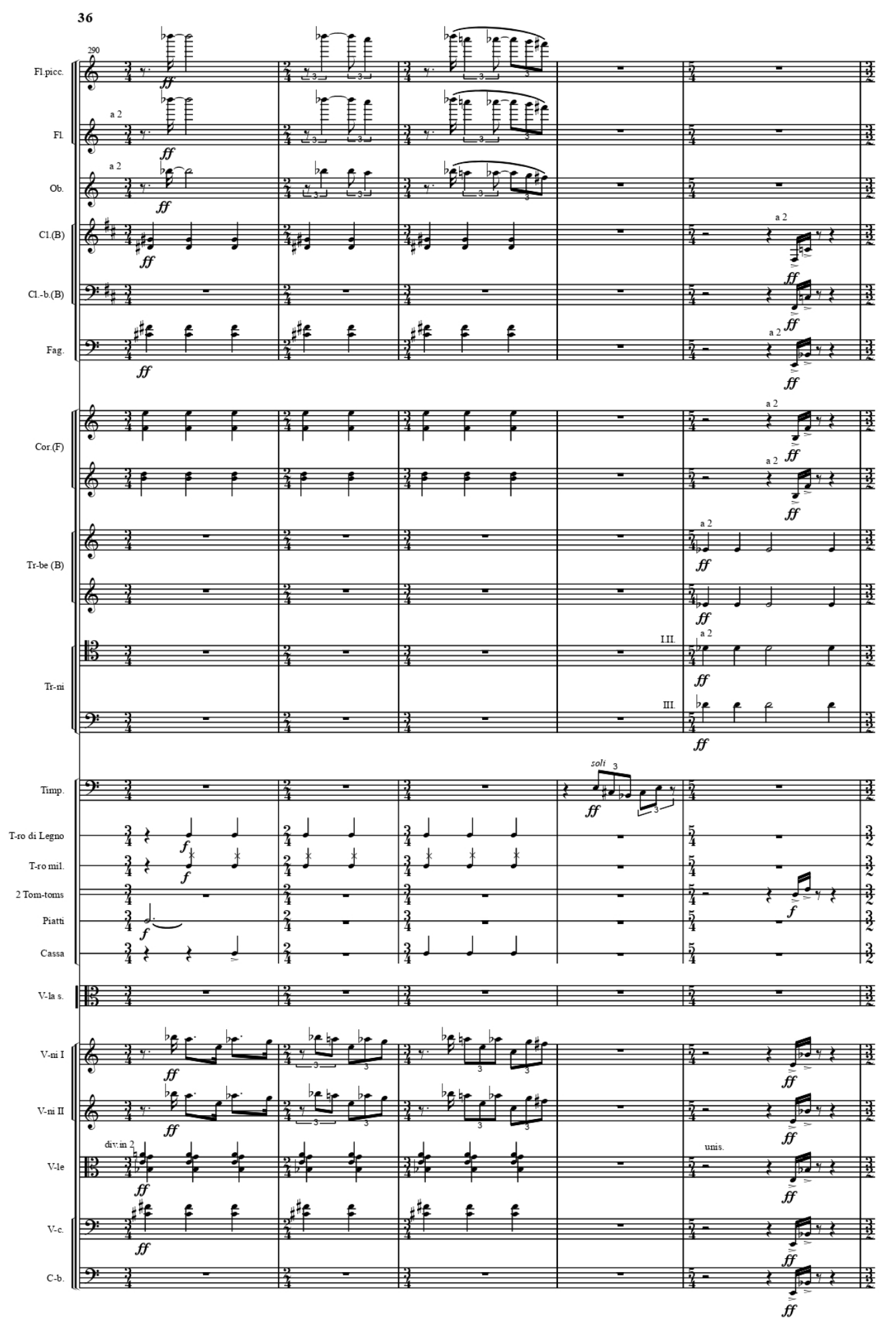



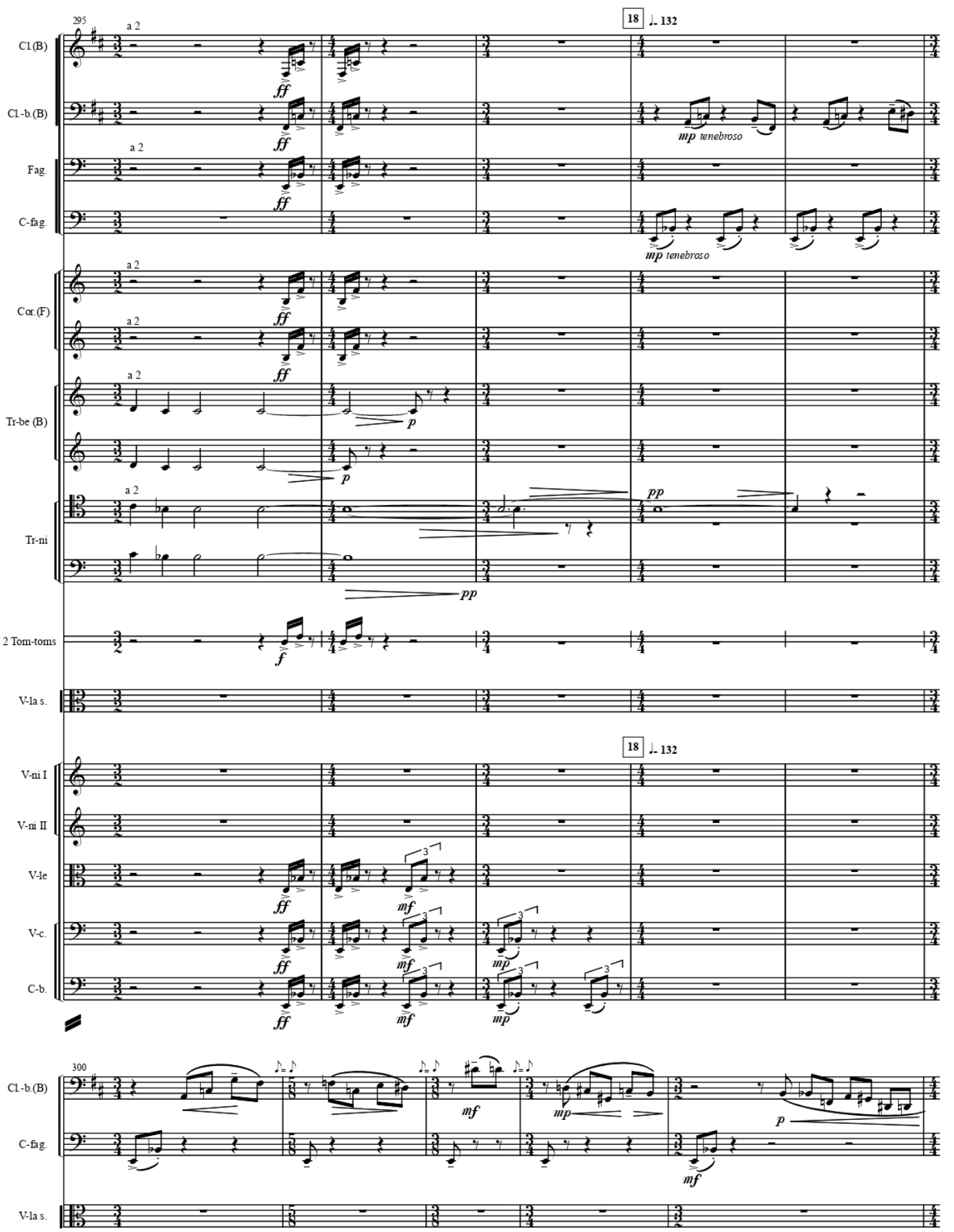


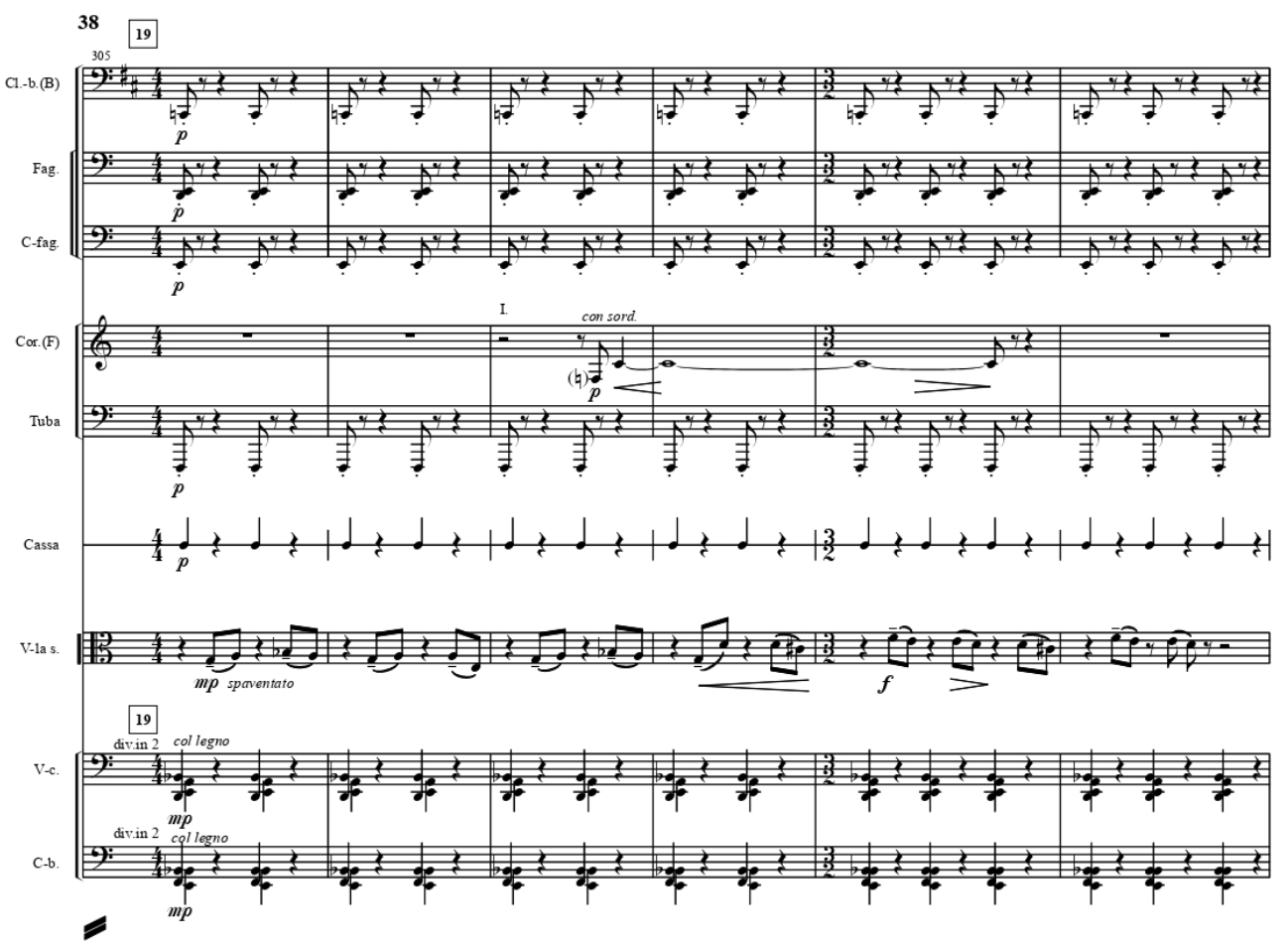

C.-B(B)

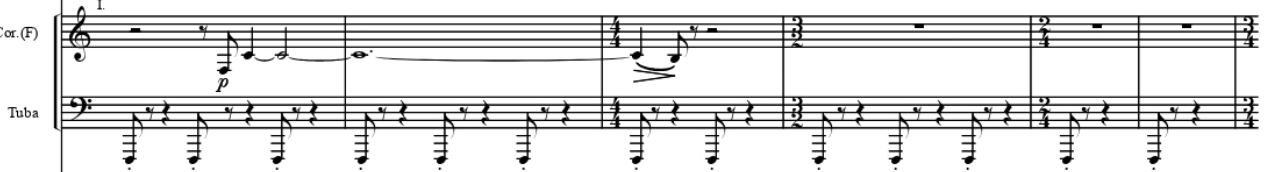

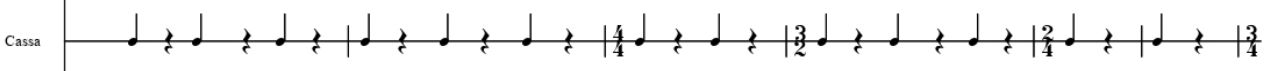

V.as.

20

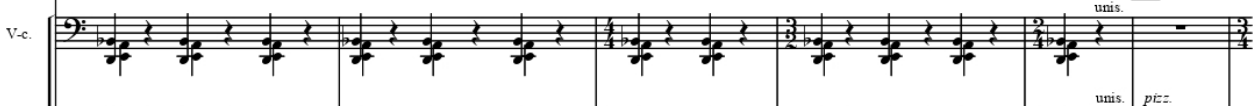

c. . 

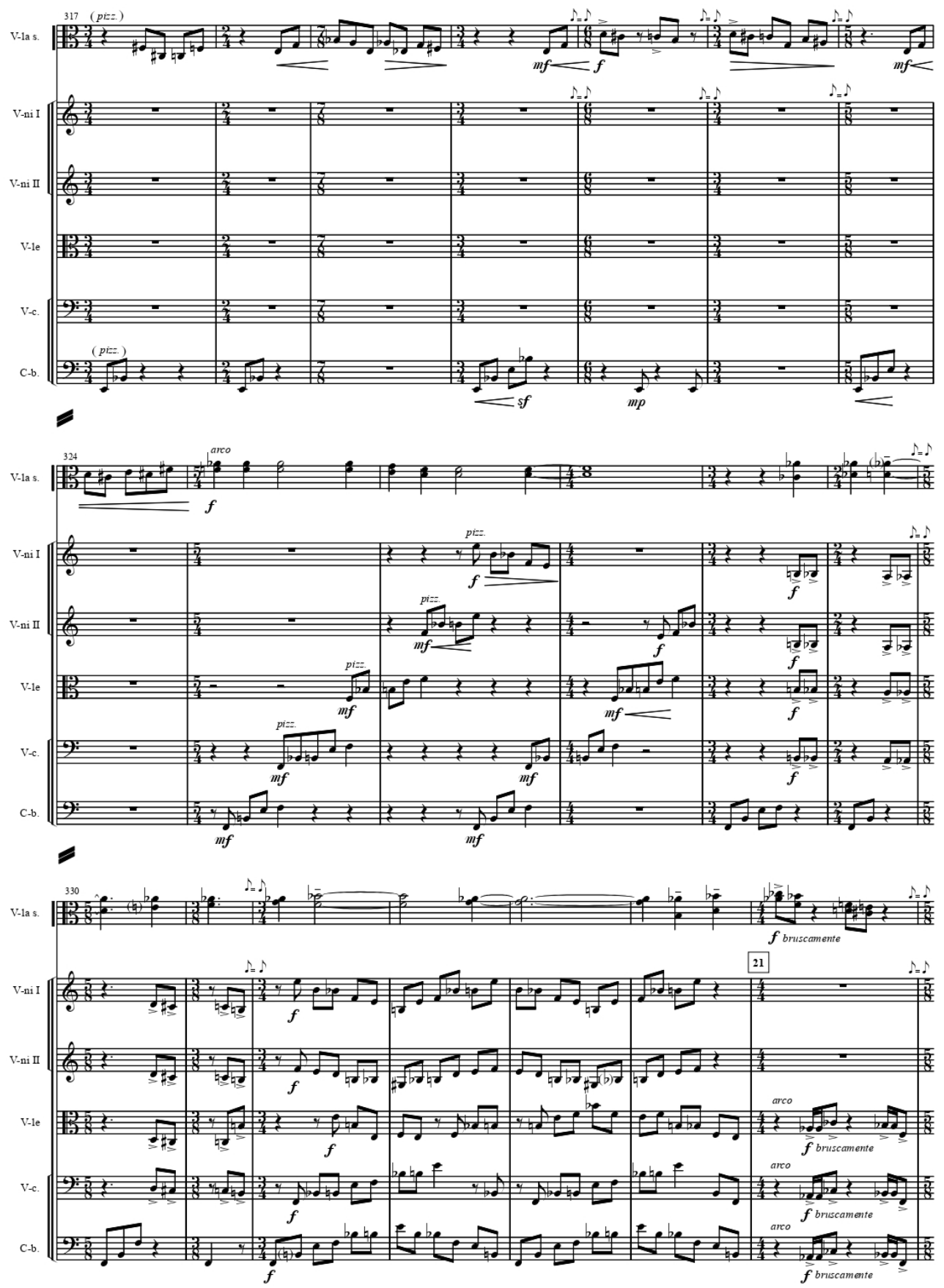

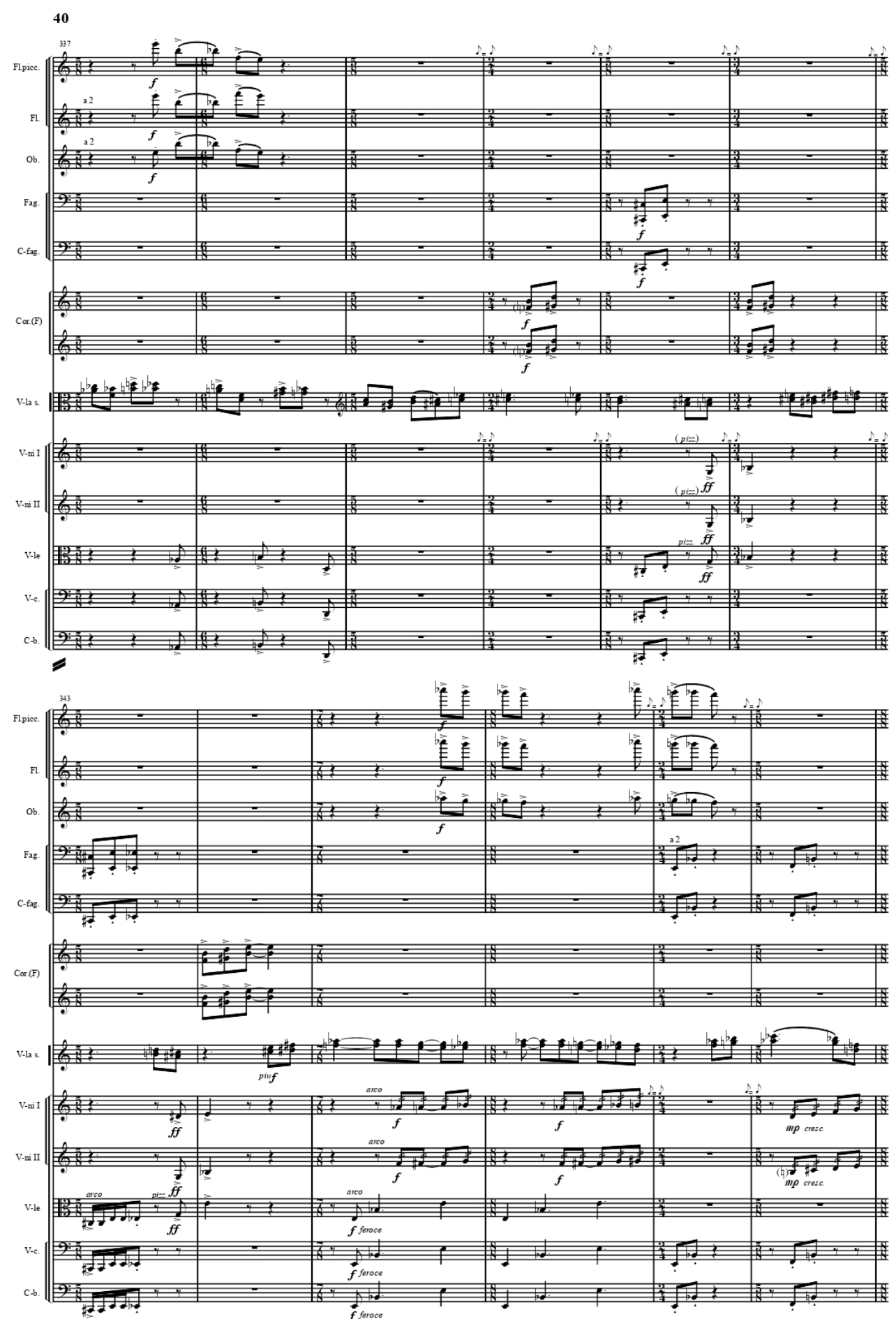
22

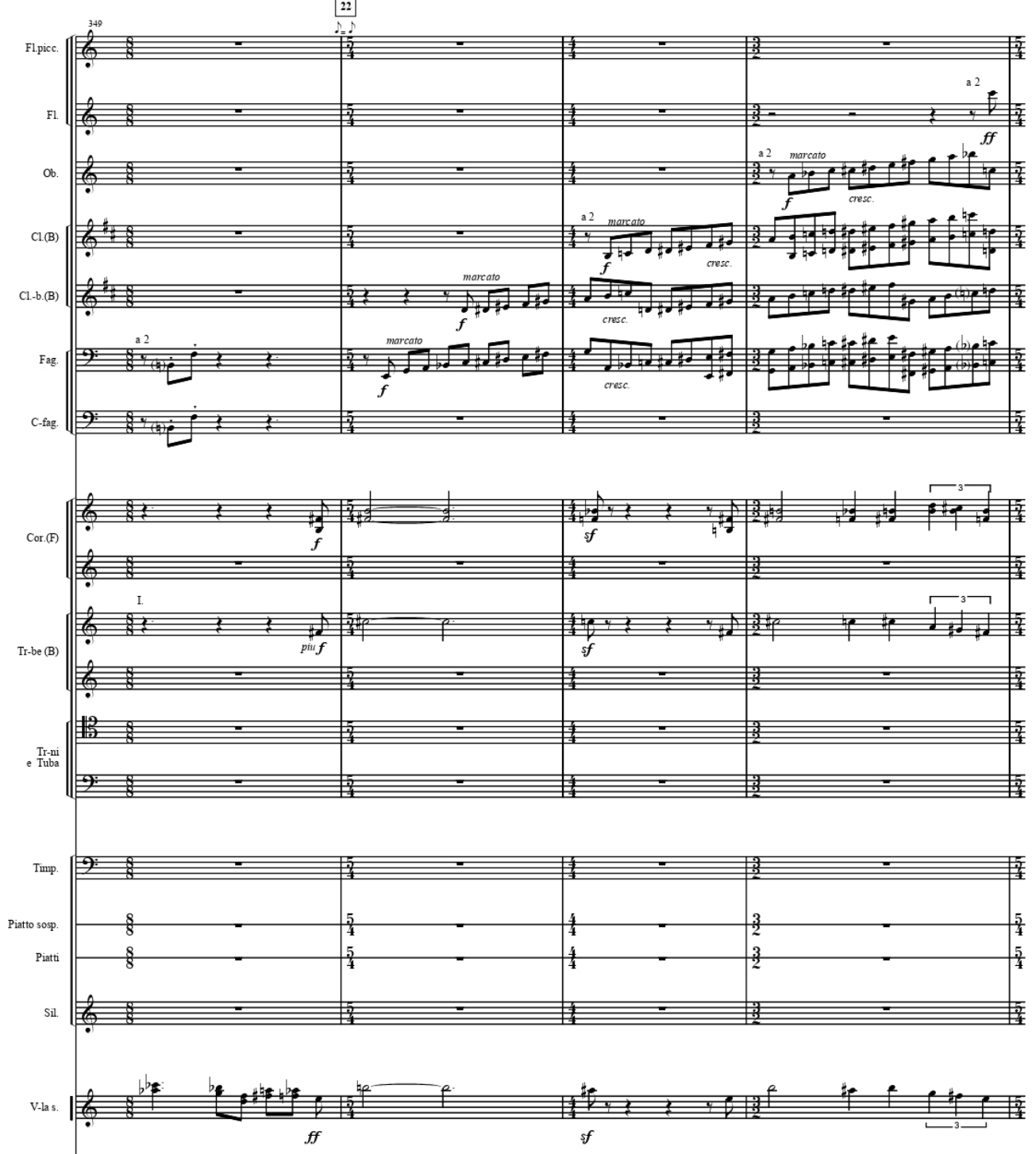

22

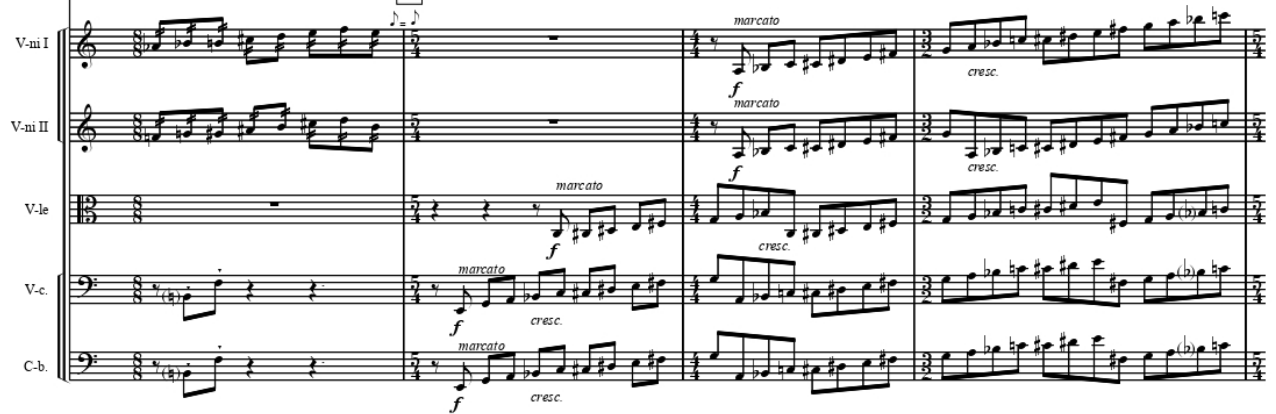




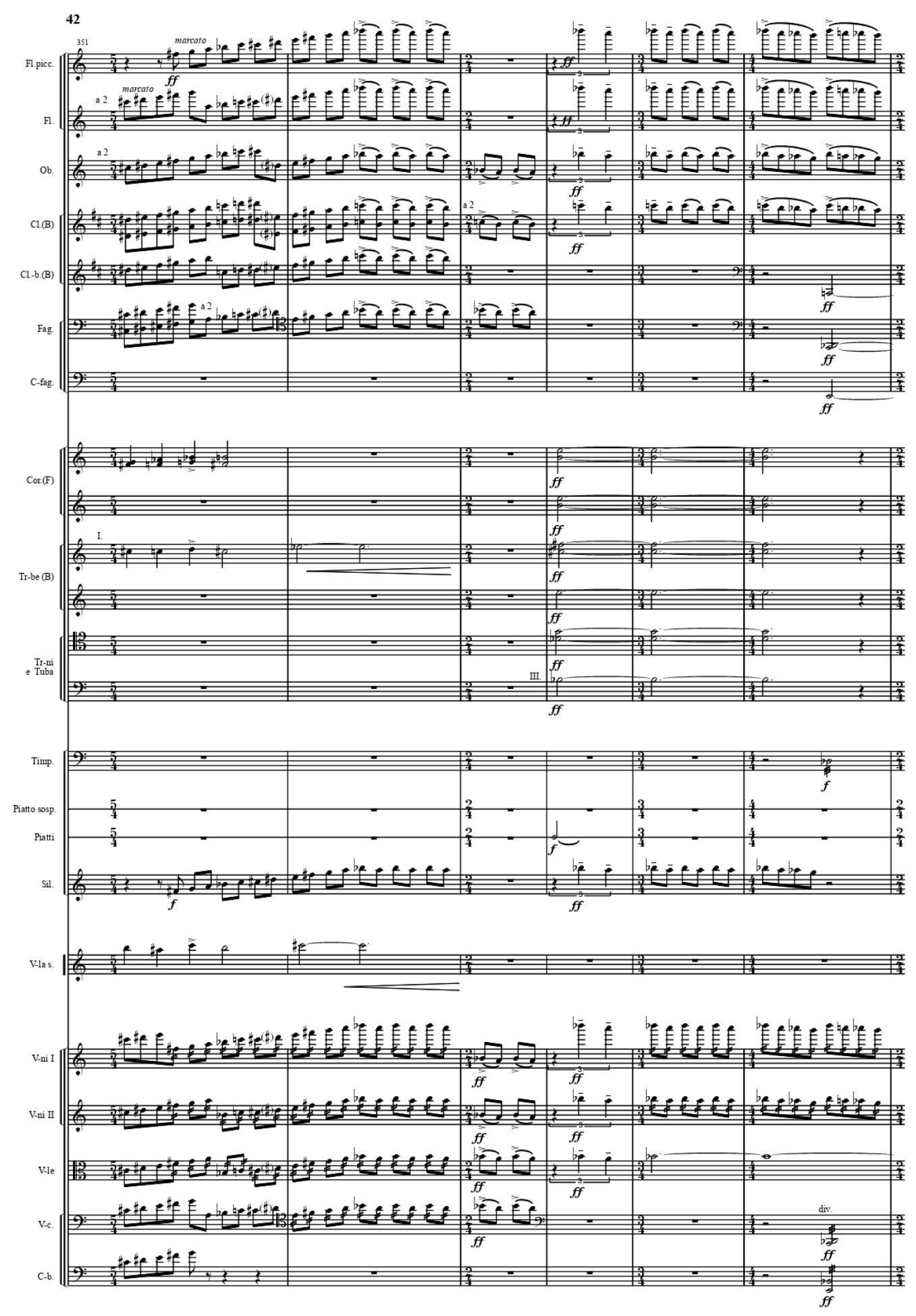




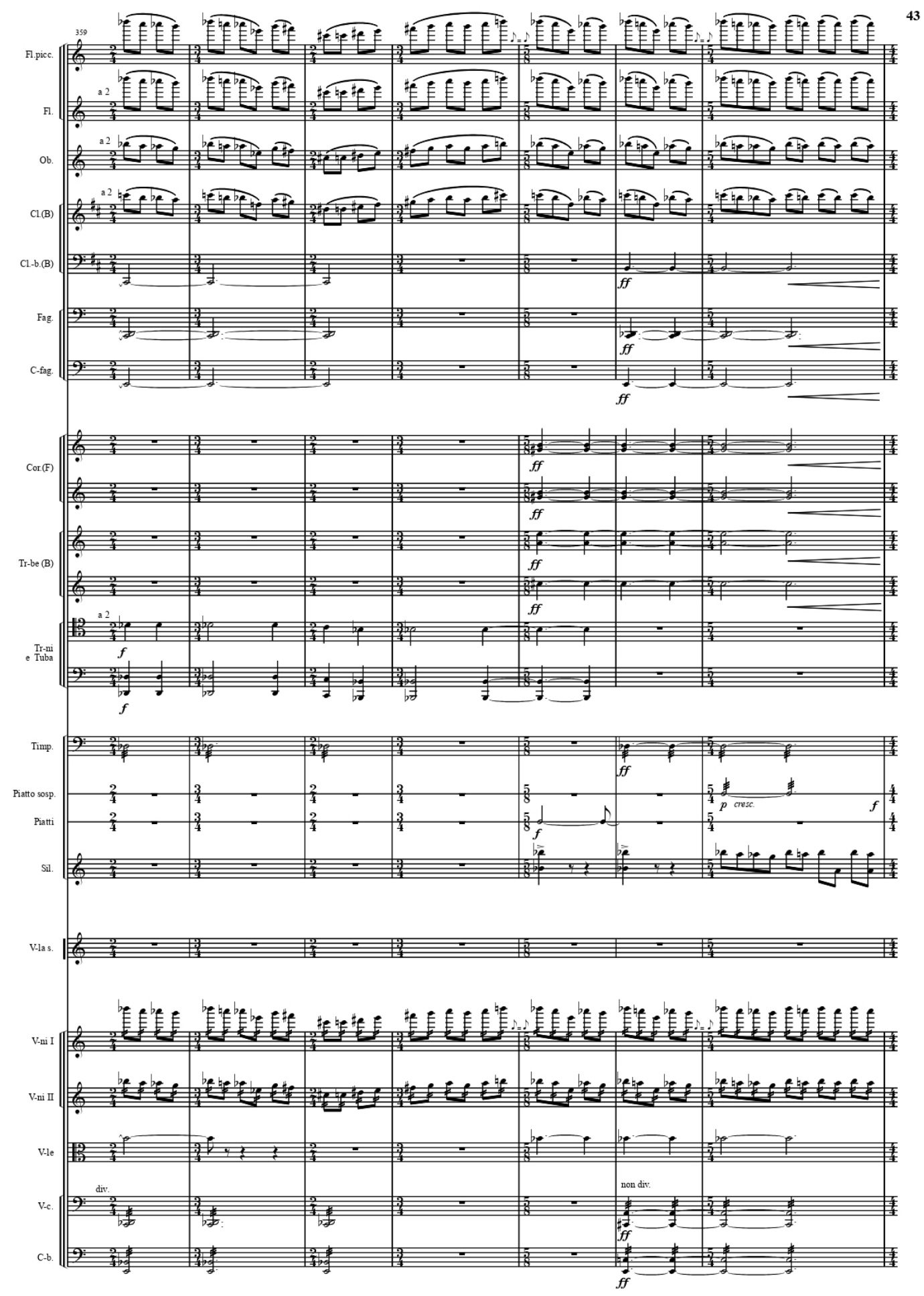




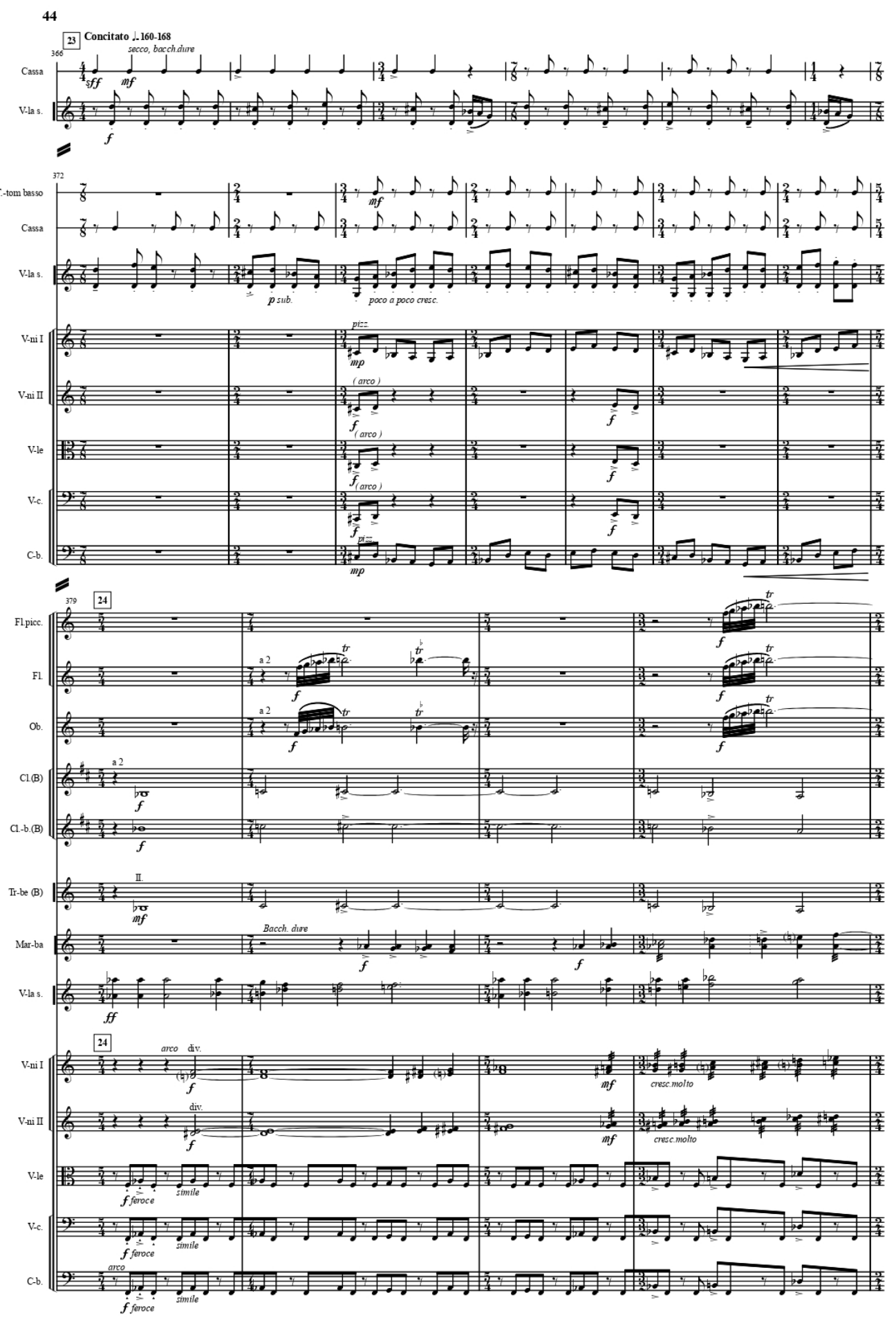




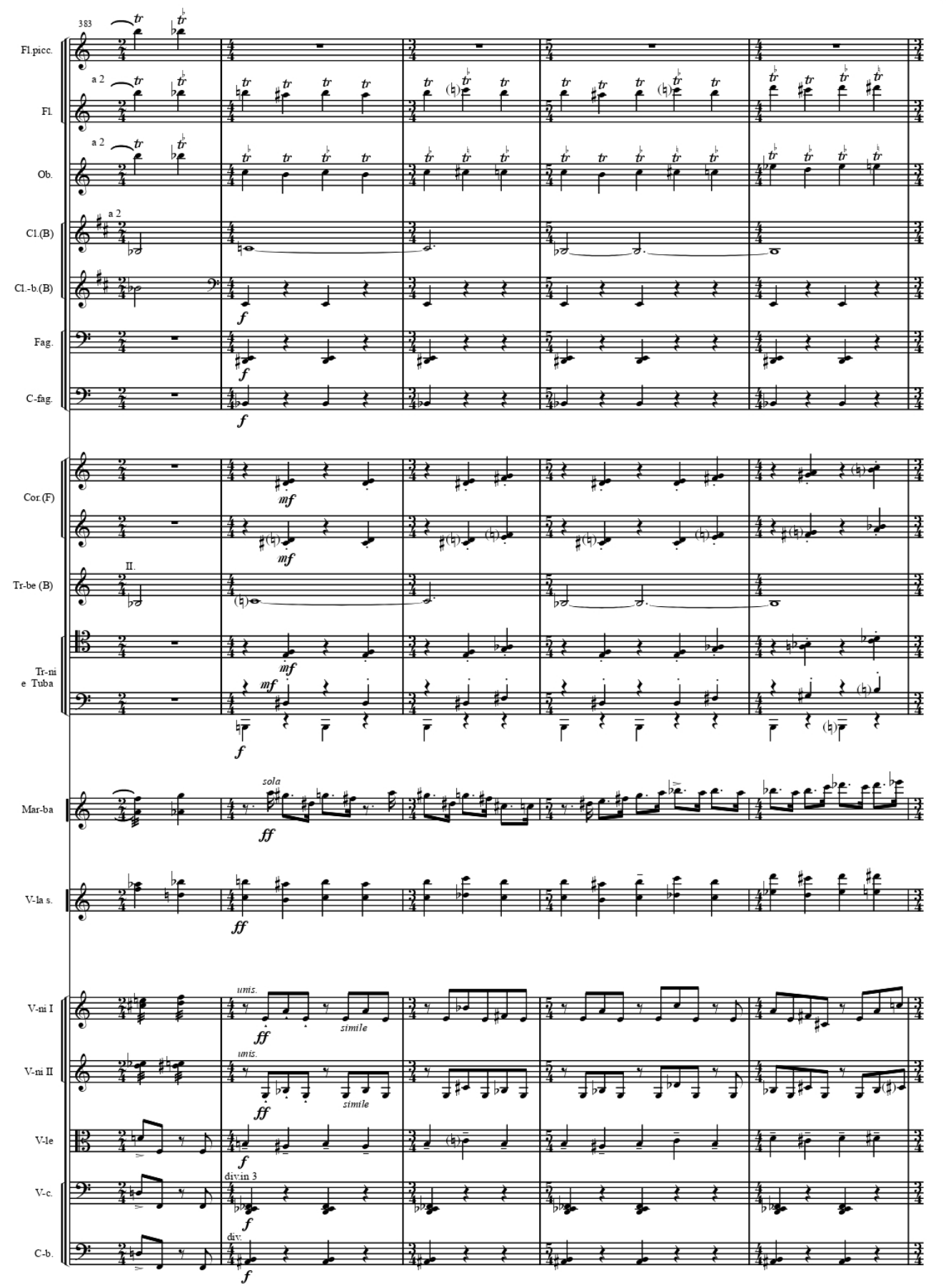




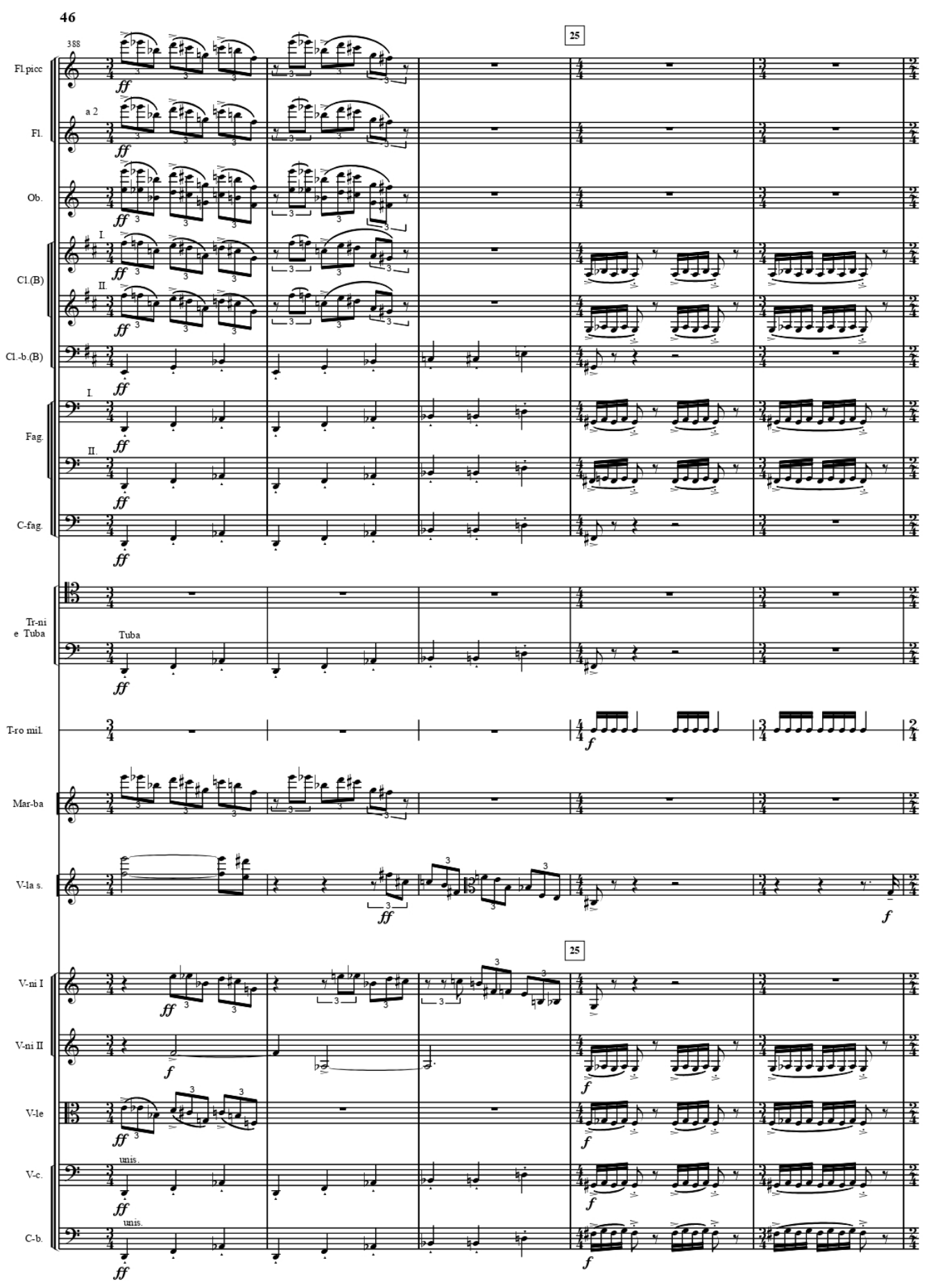



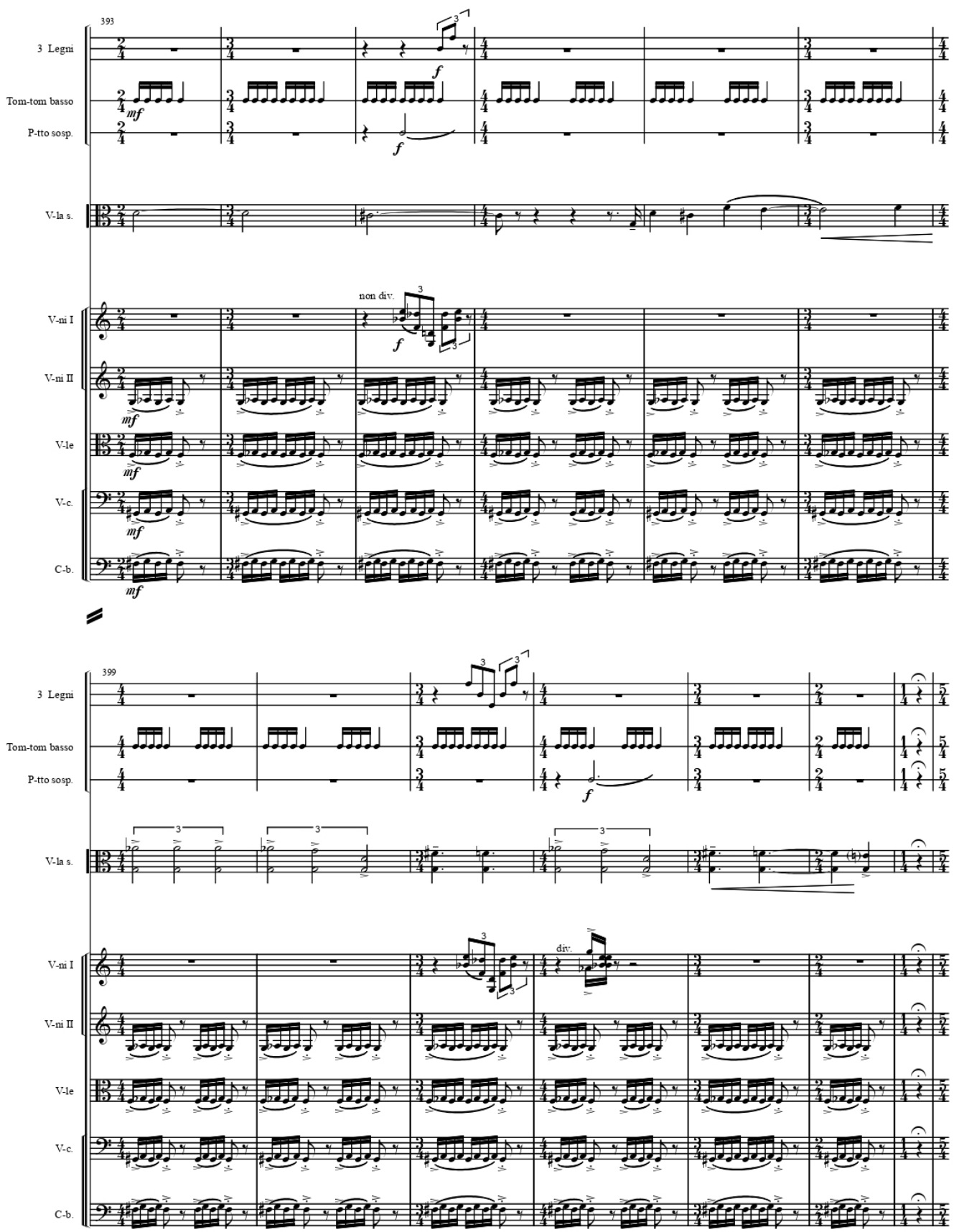


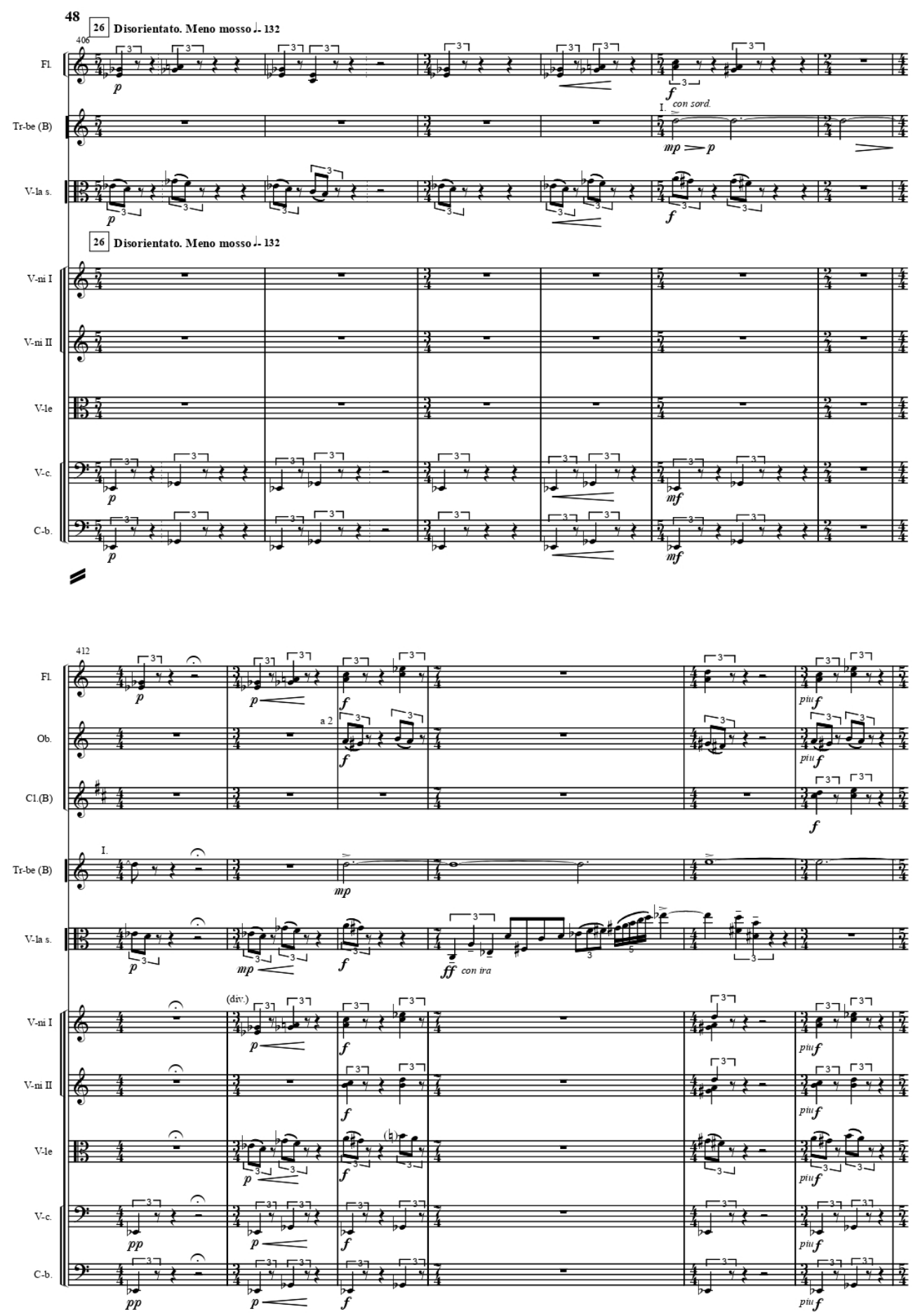



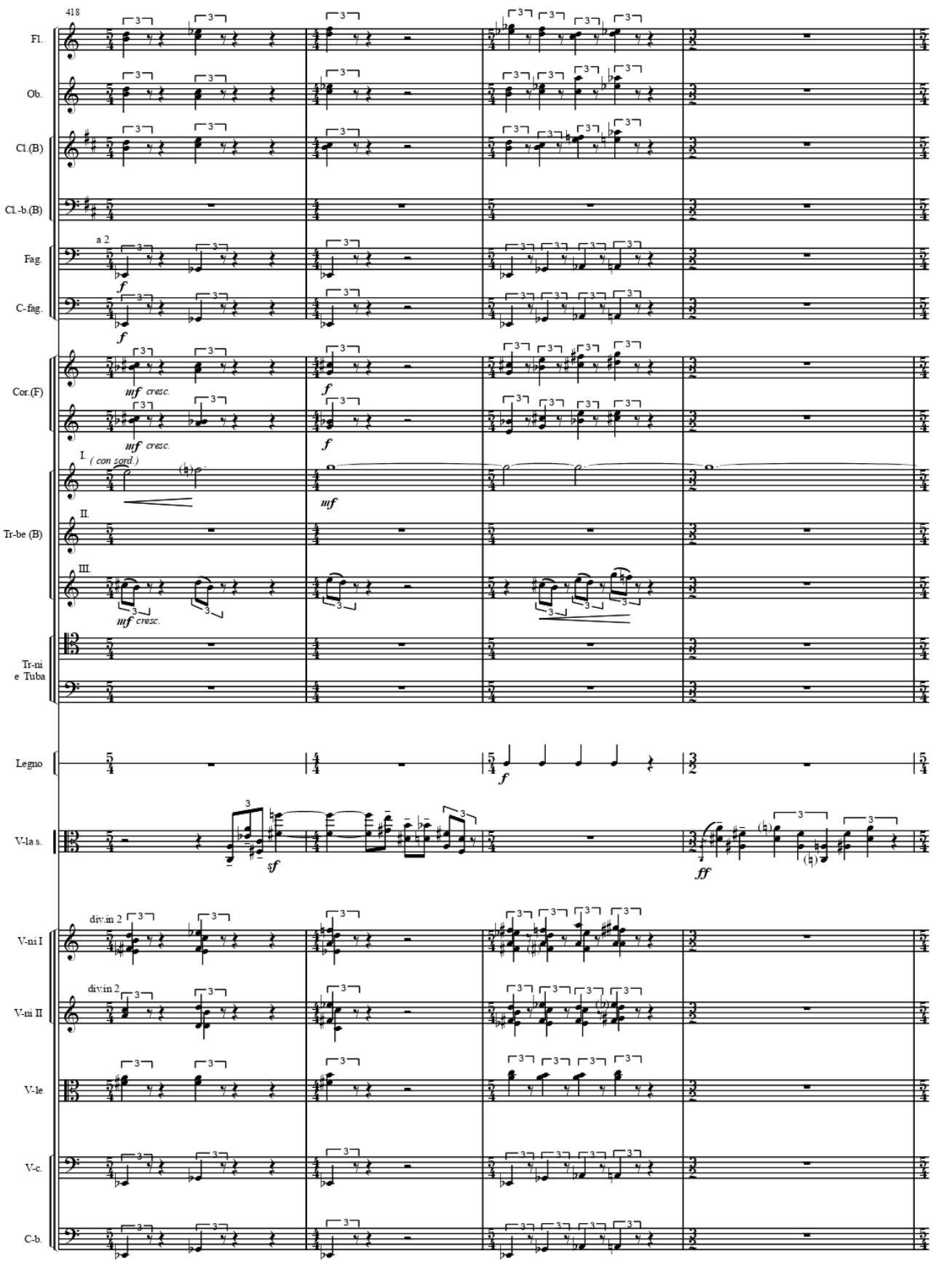


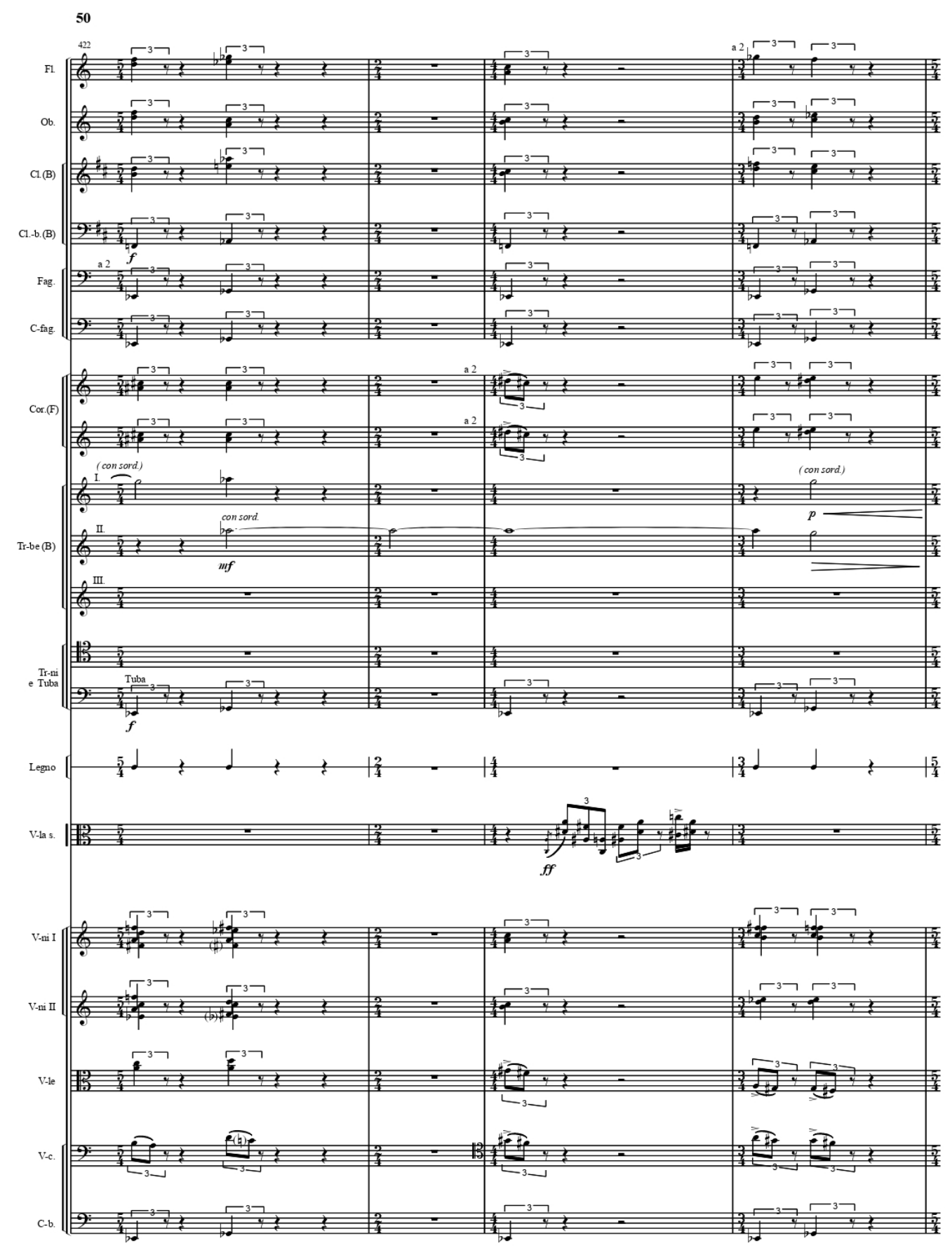


27

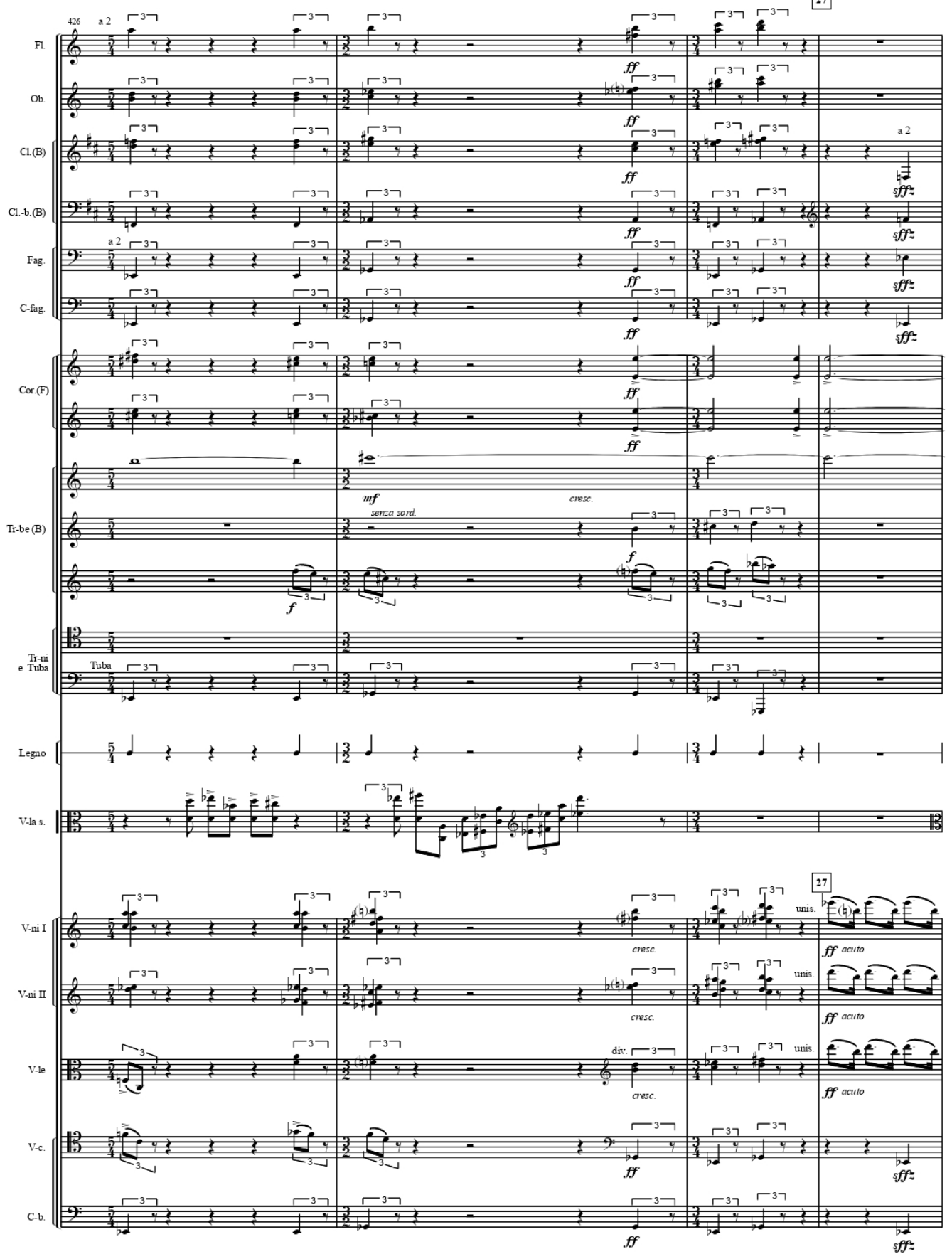




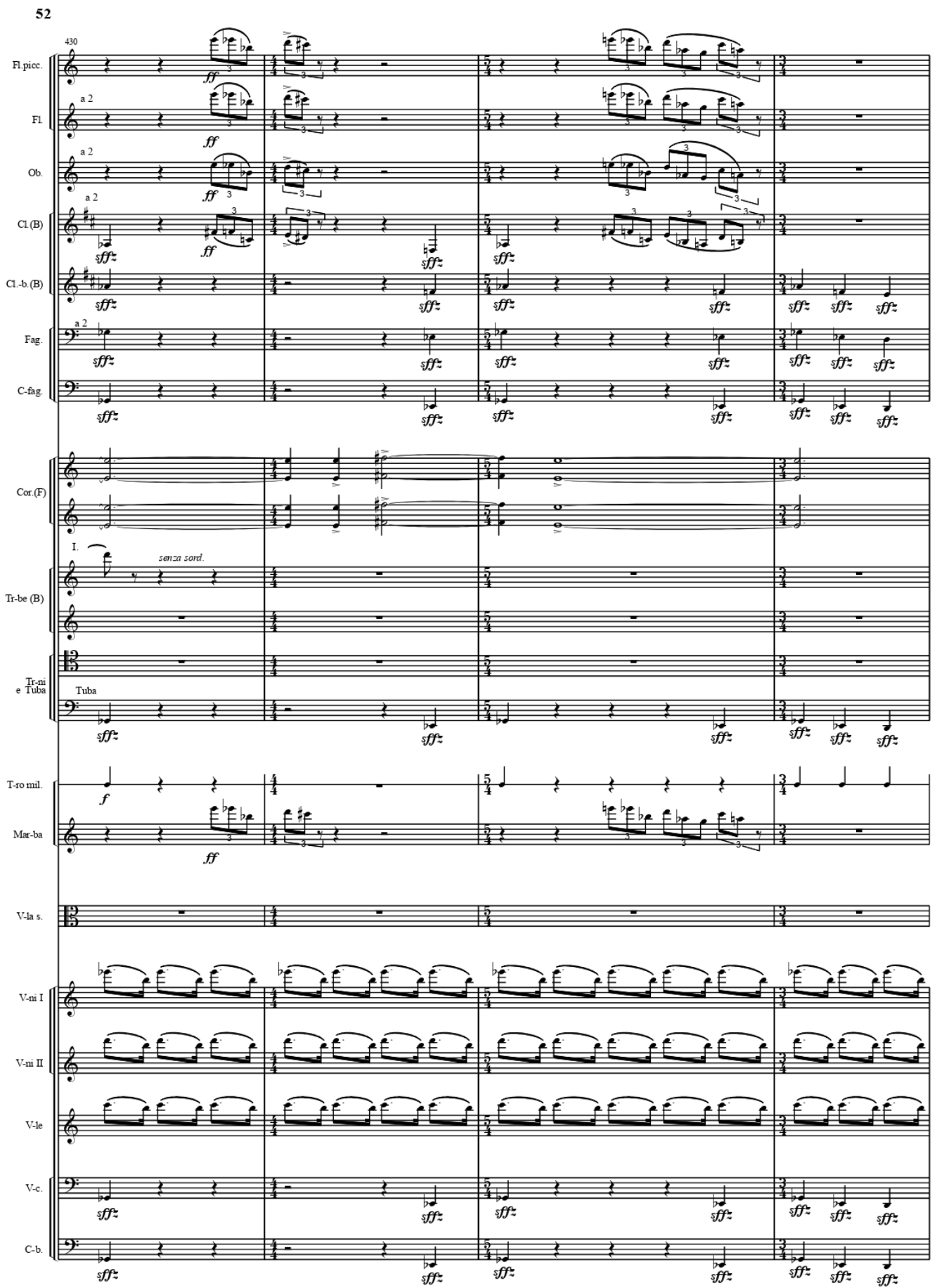




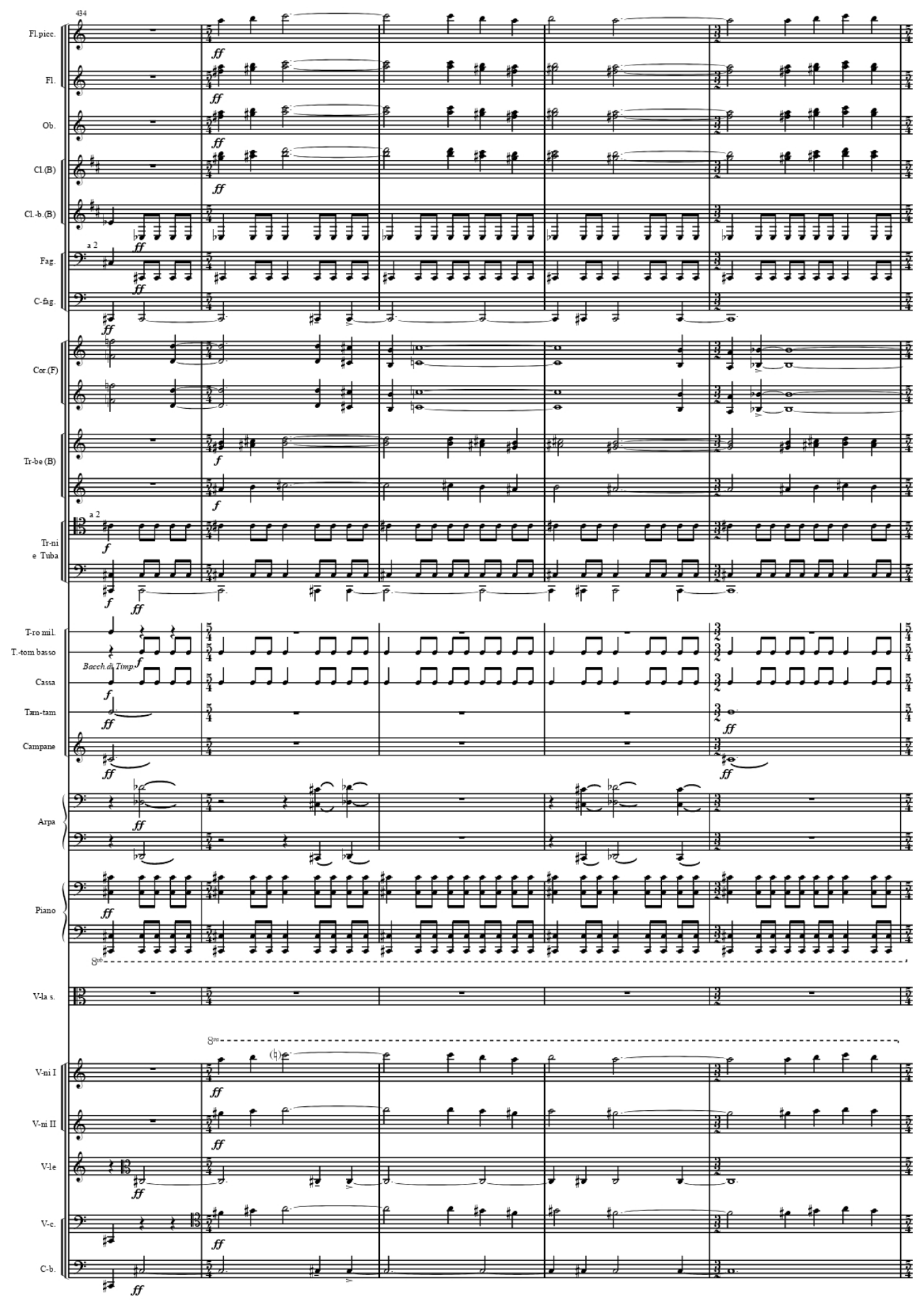




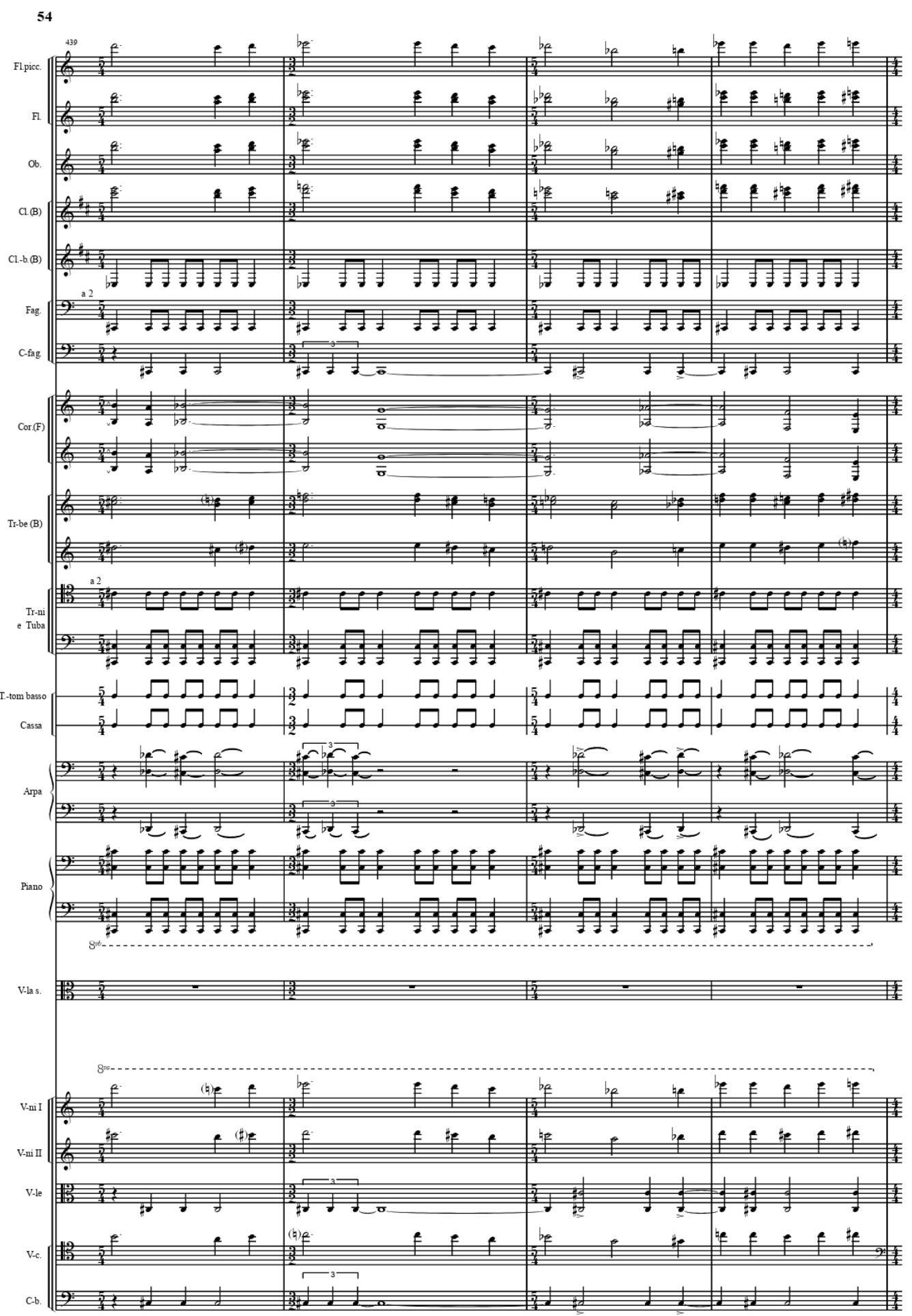




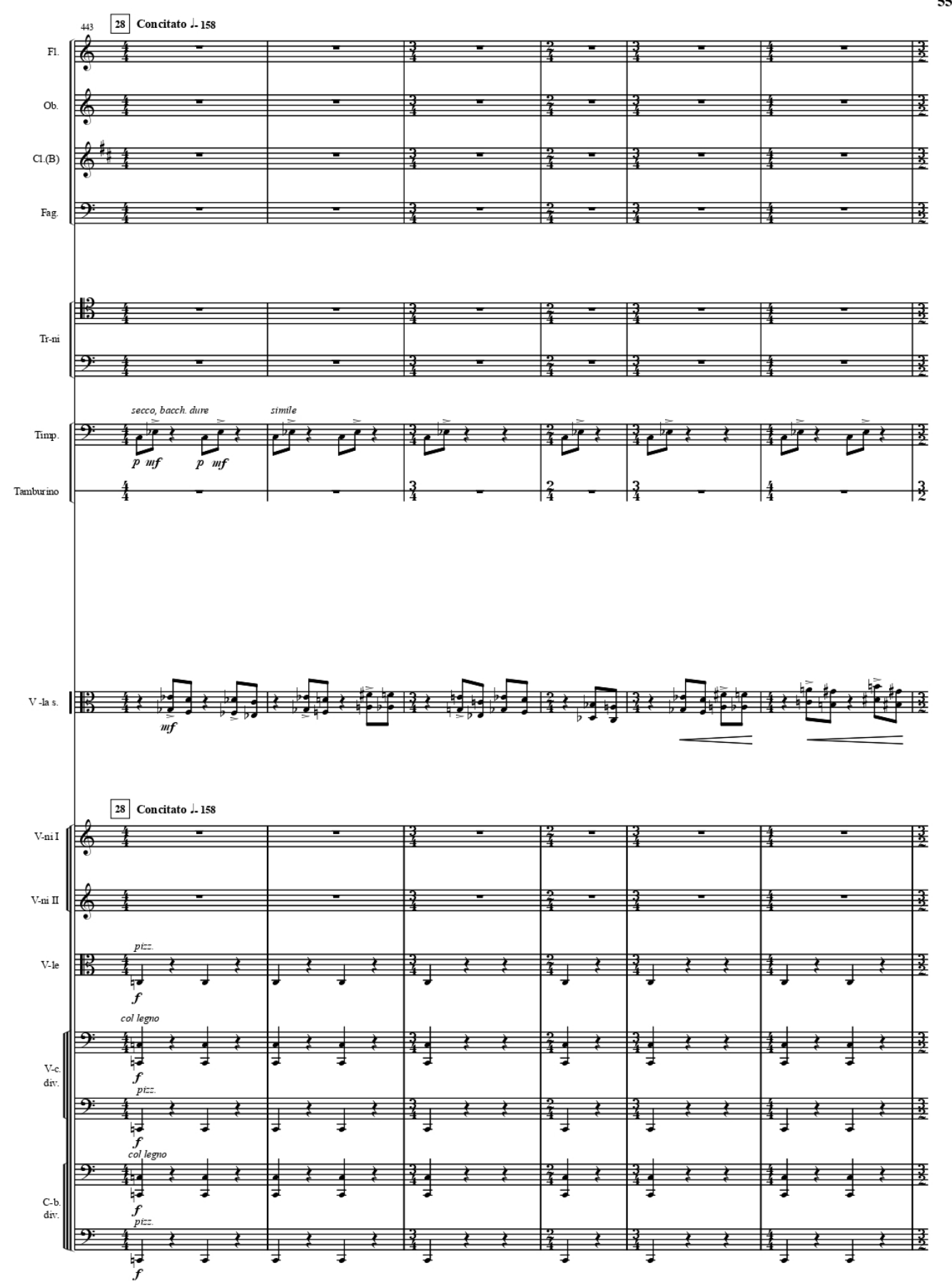




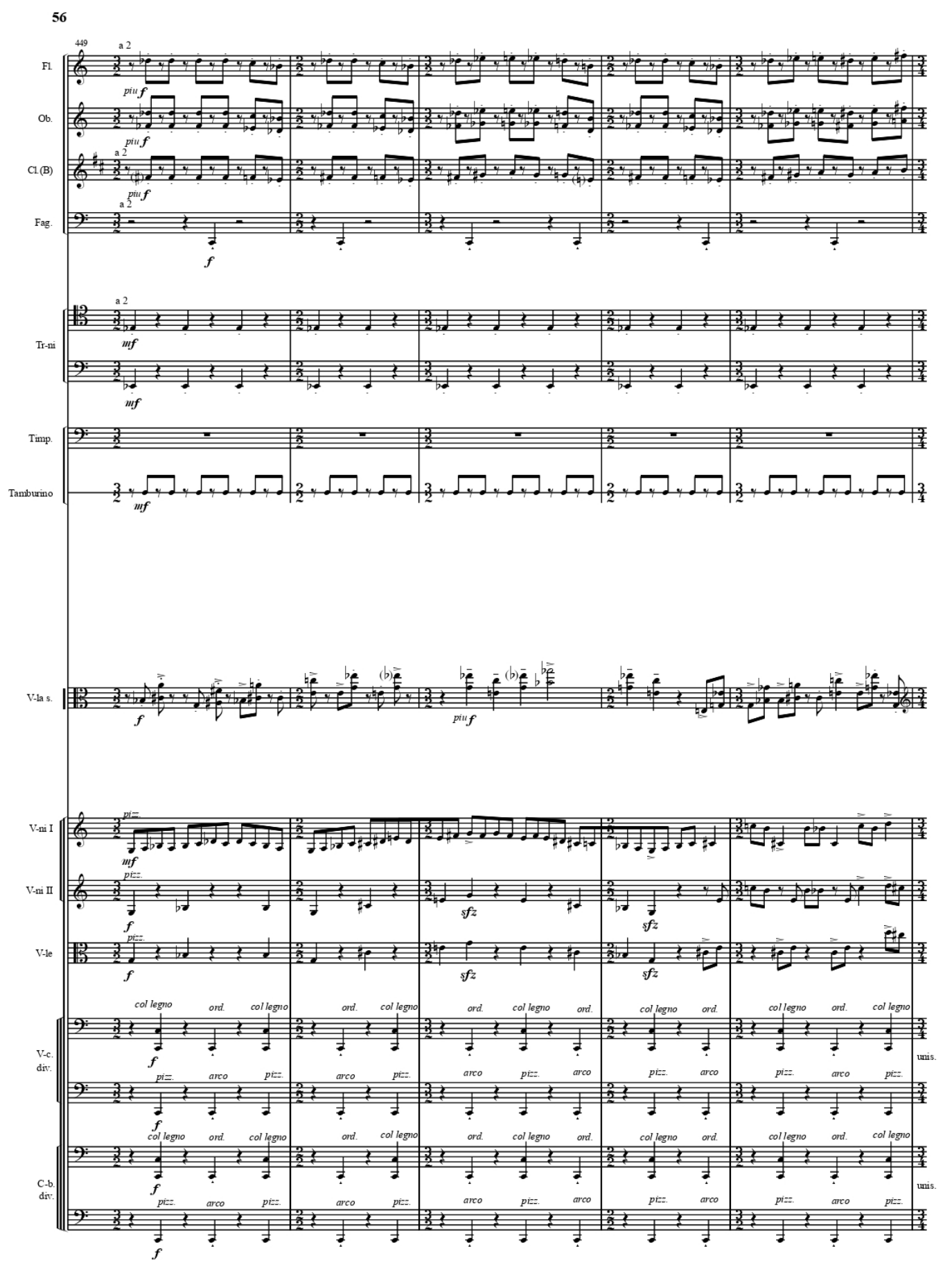


29.

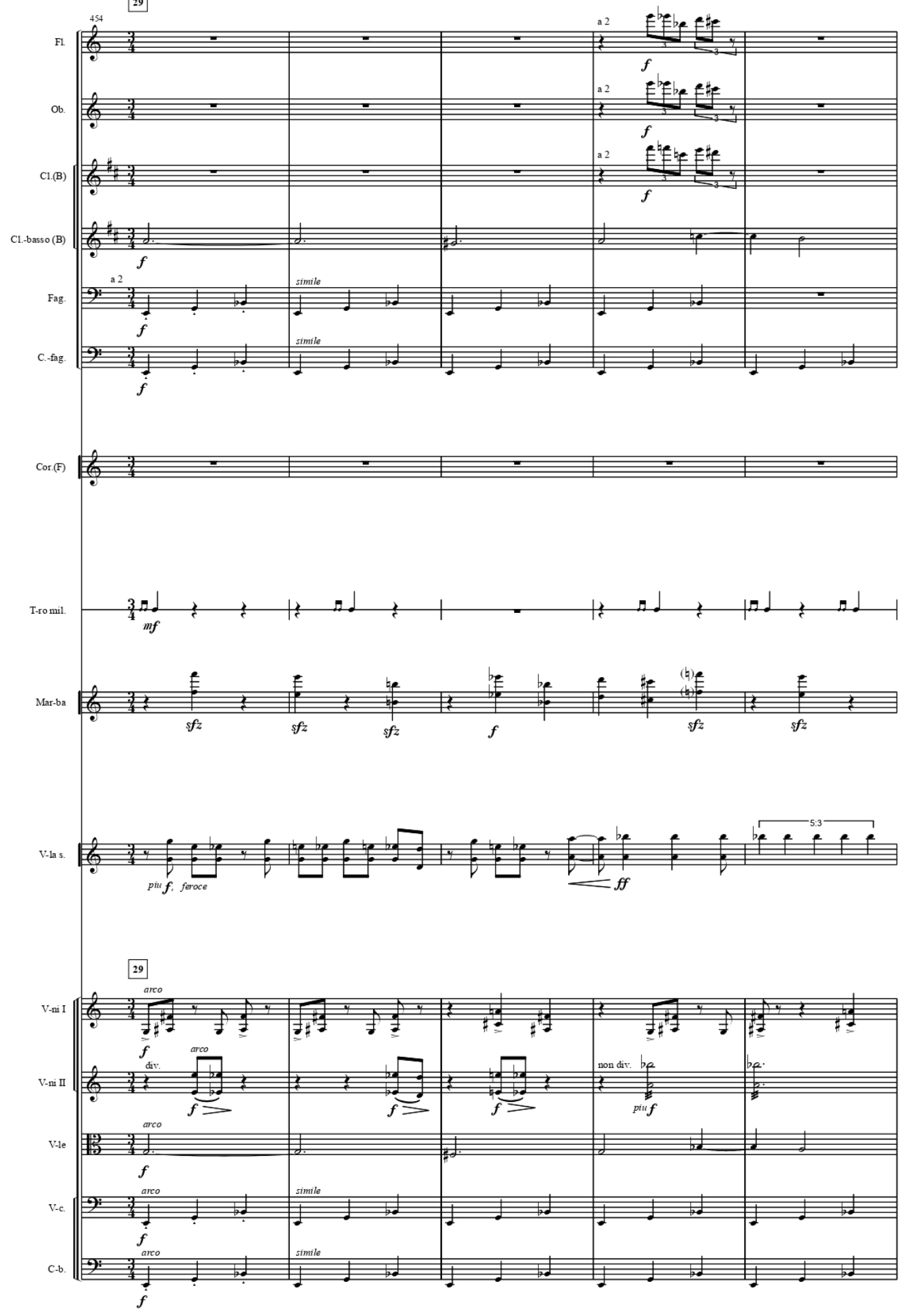




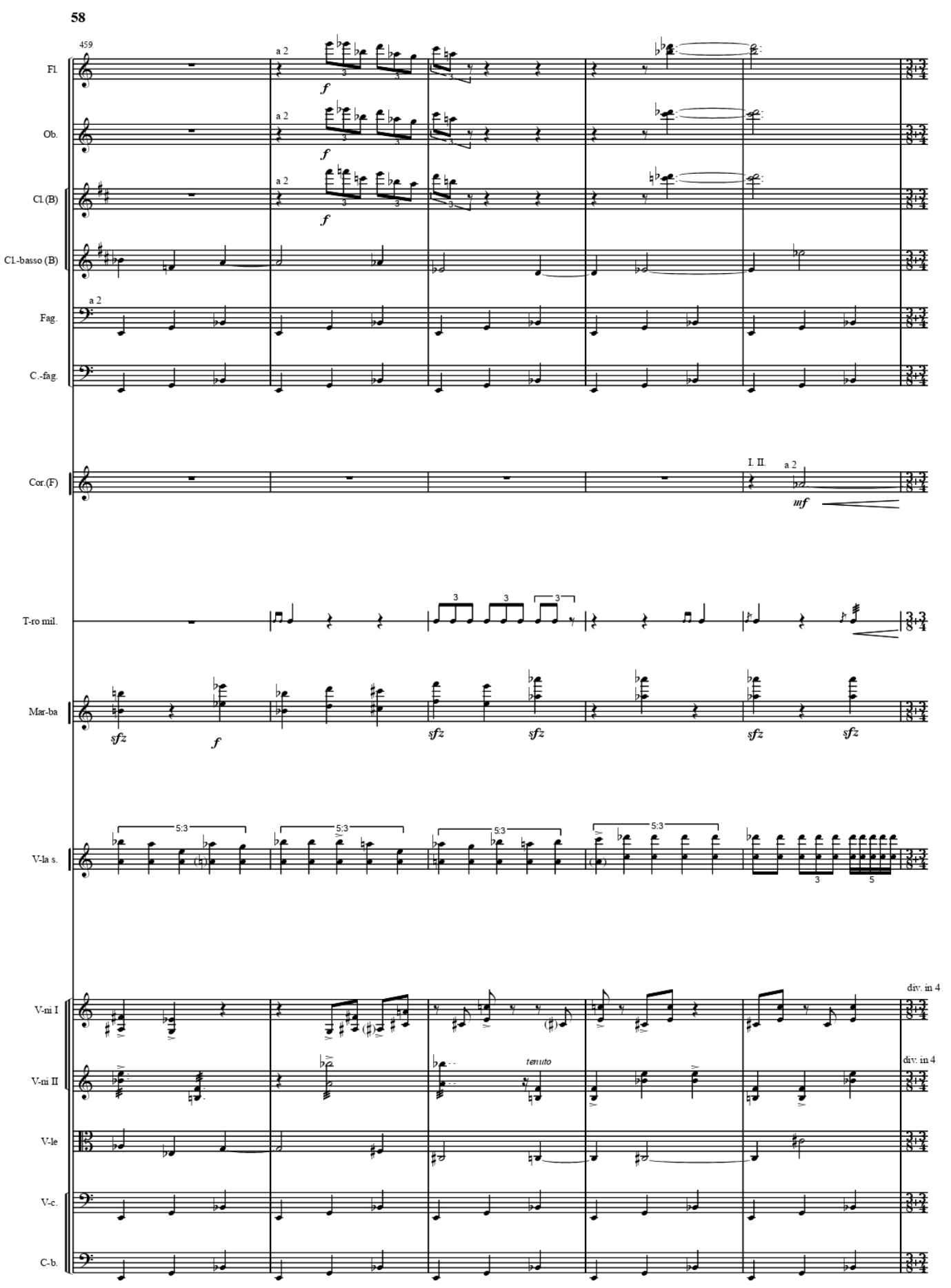




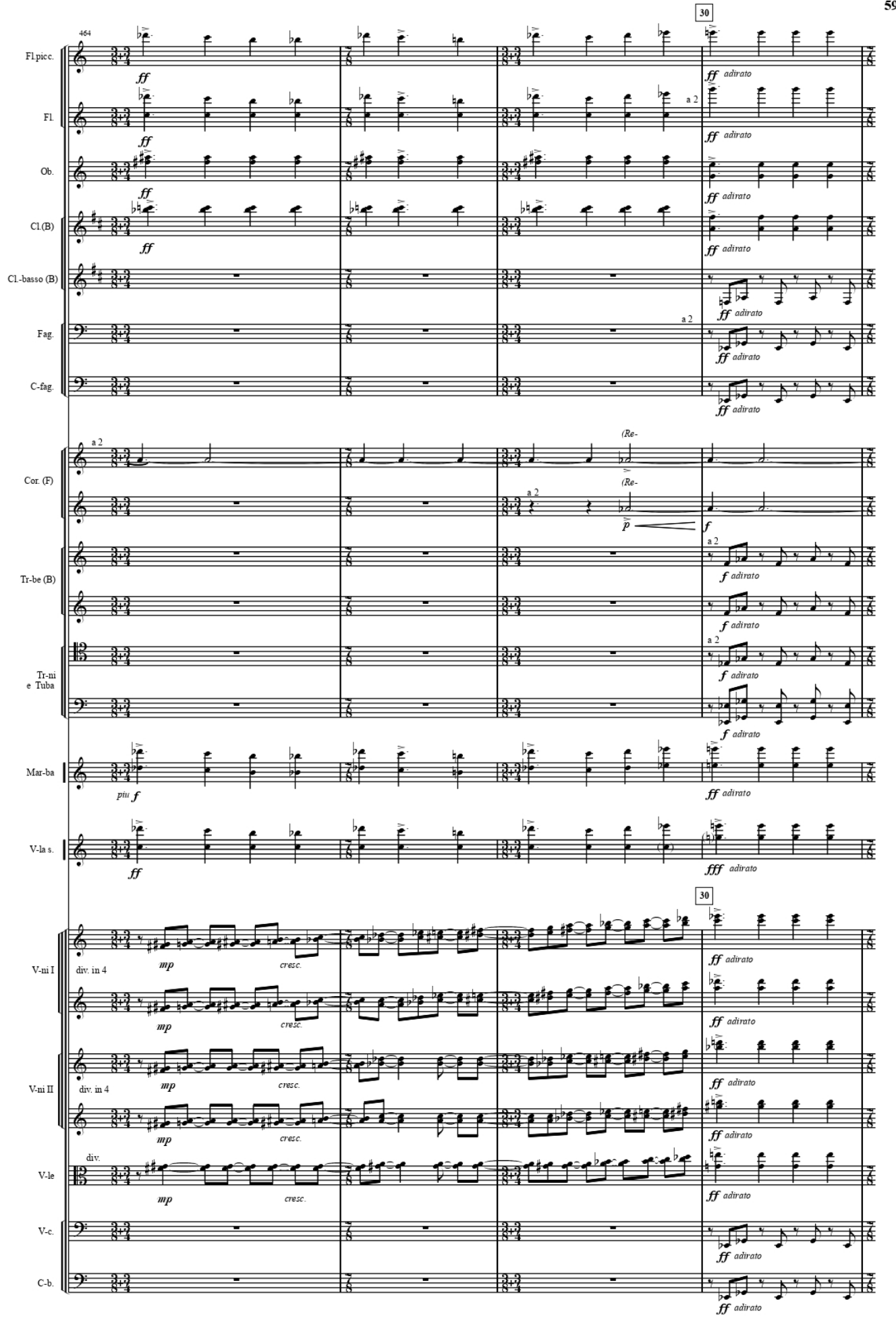




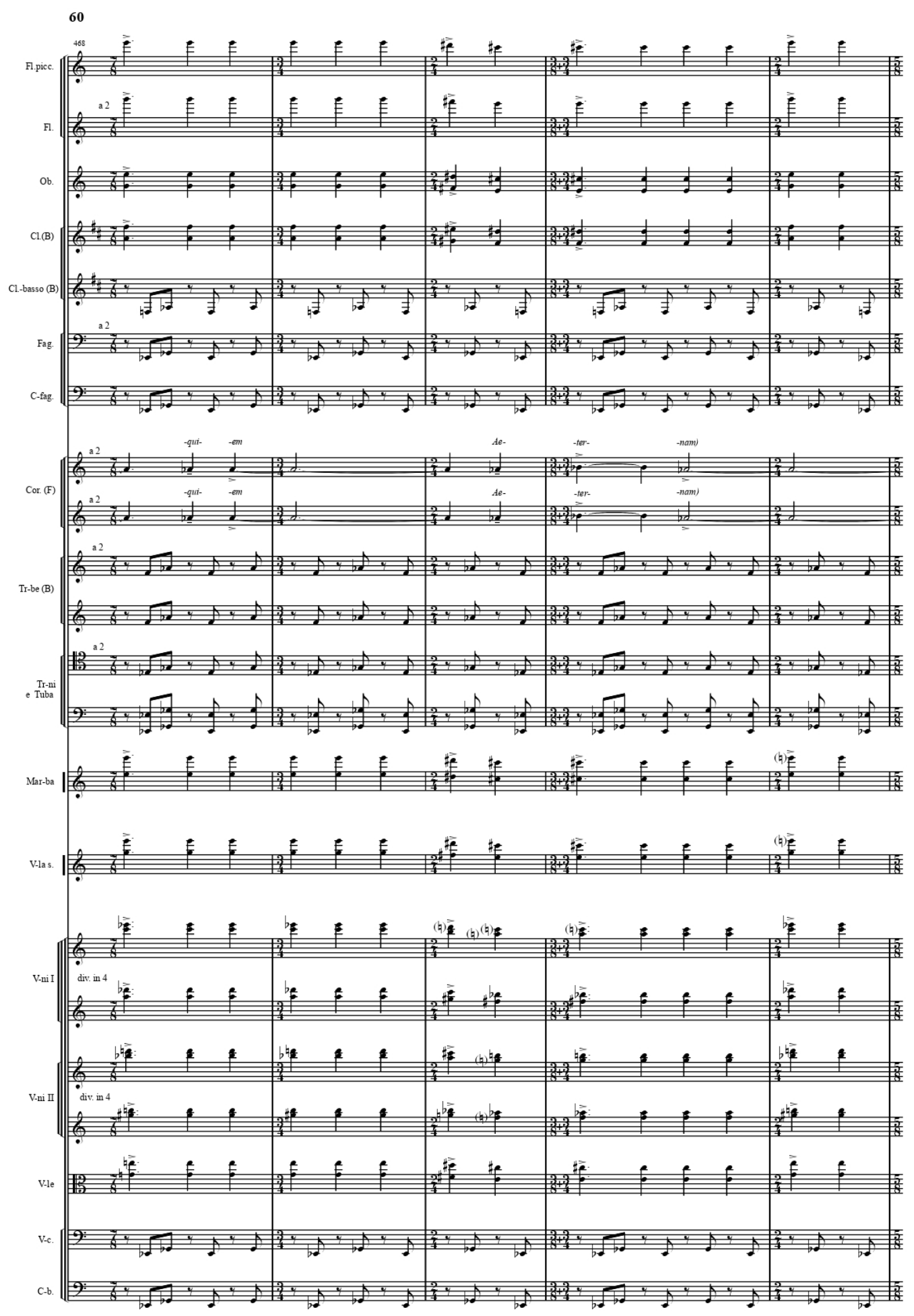




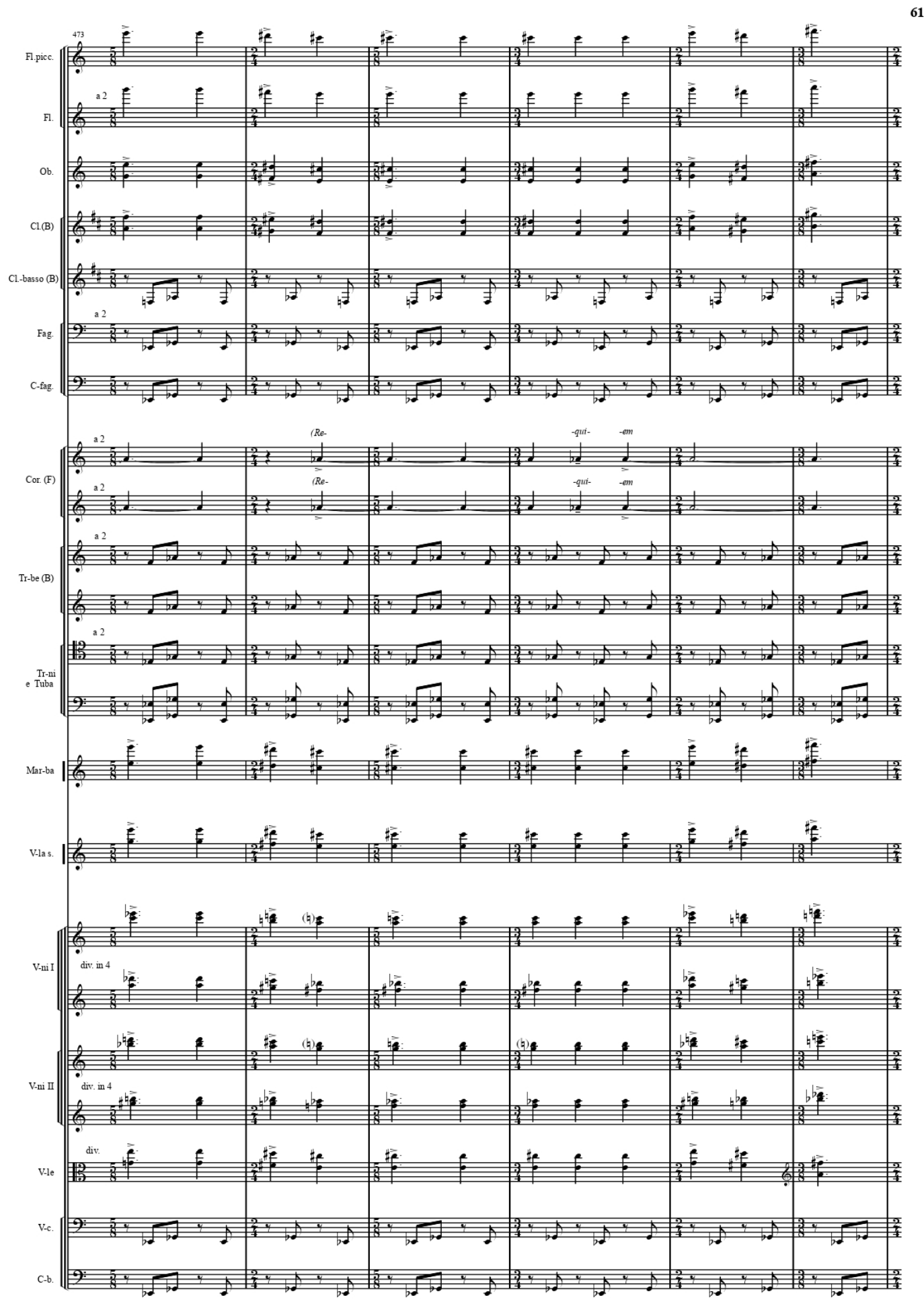




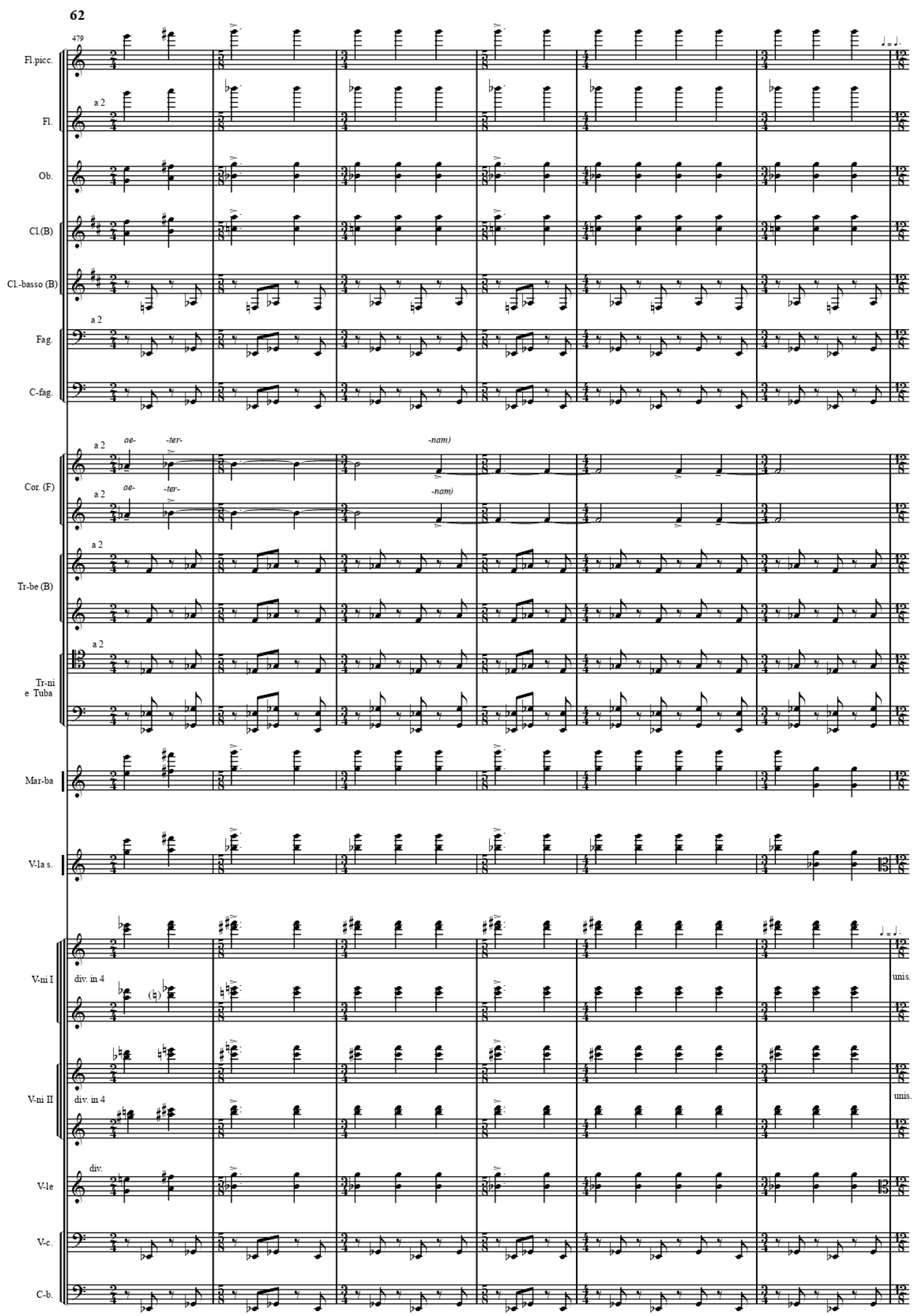



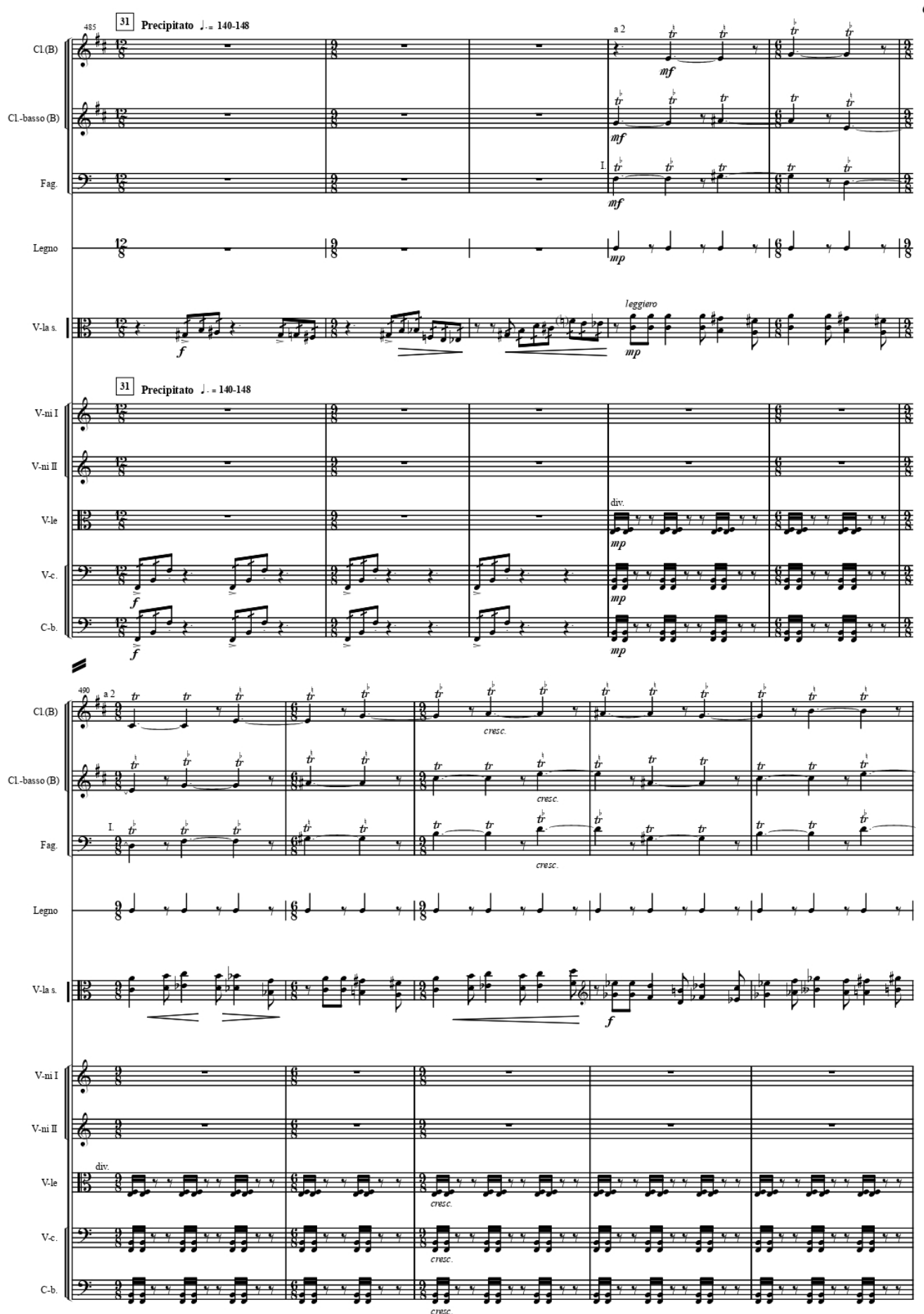


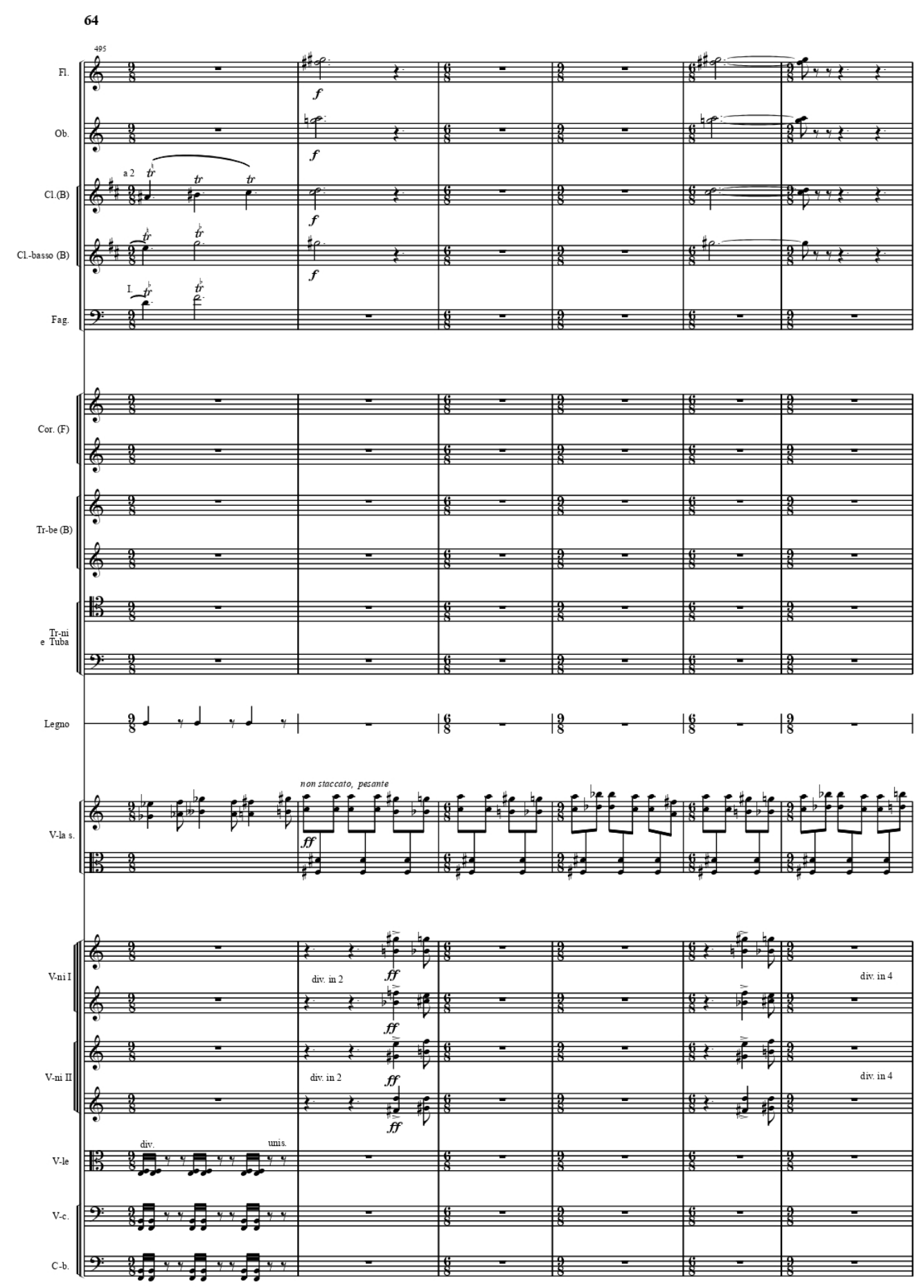



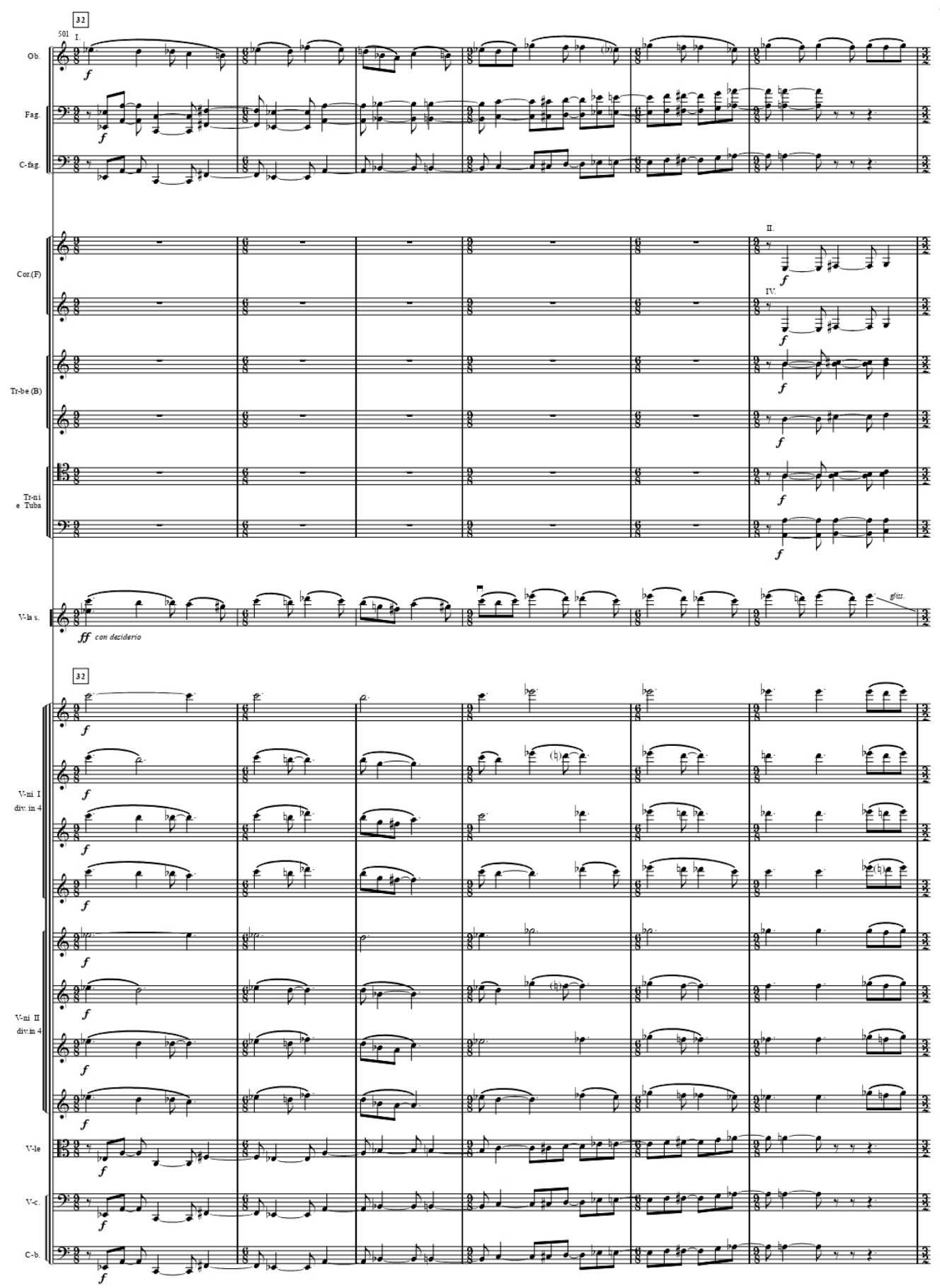


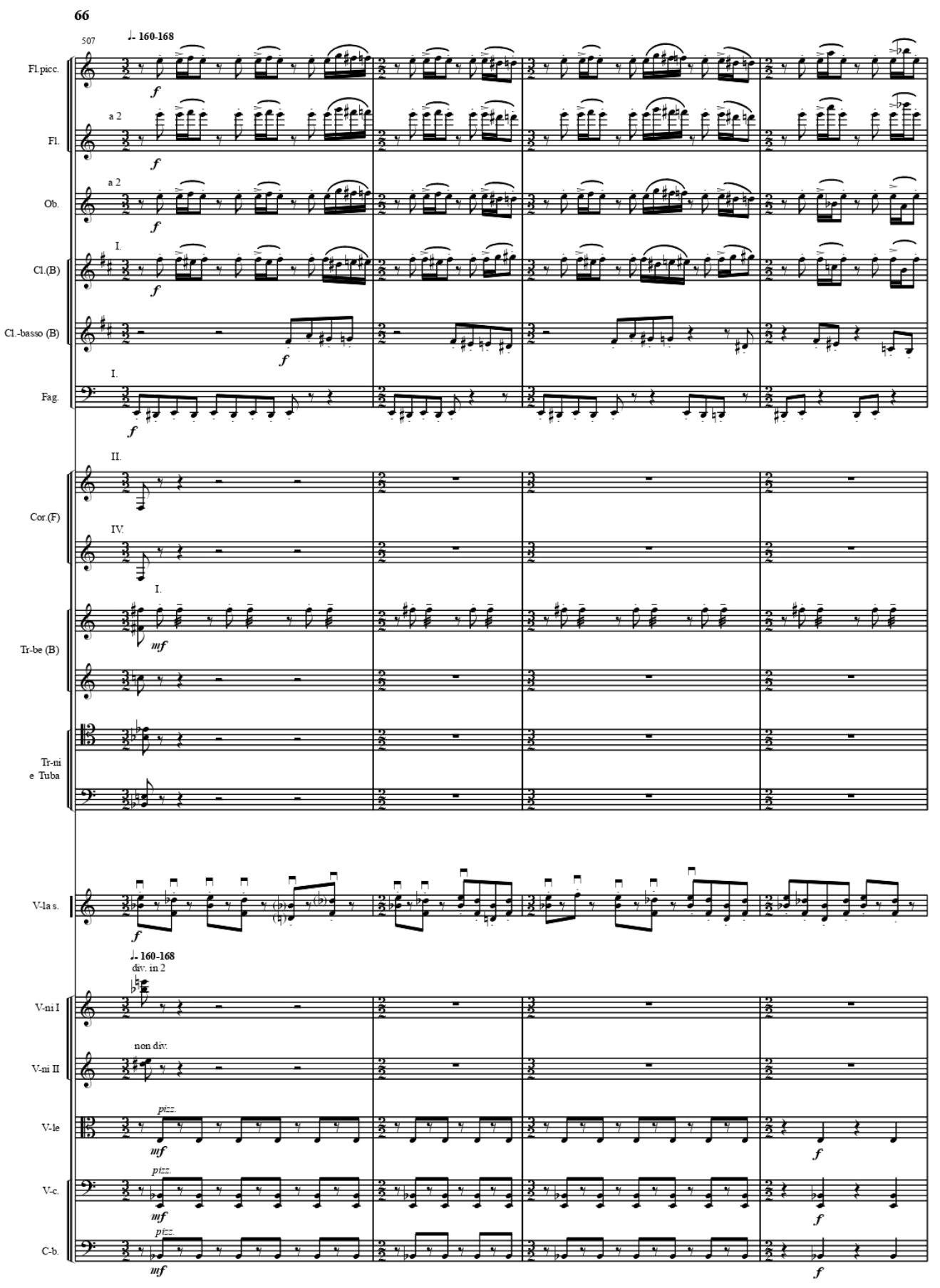


33 Con slancio ${ }_{1.1} 152$

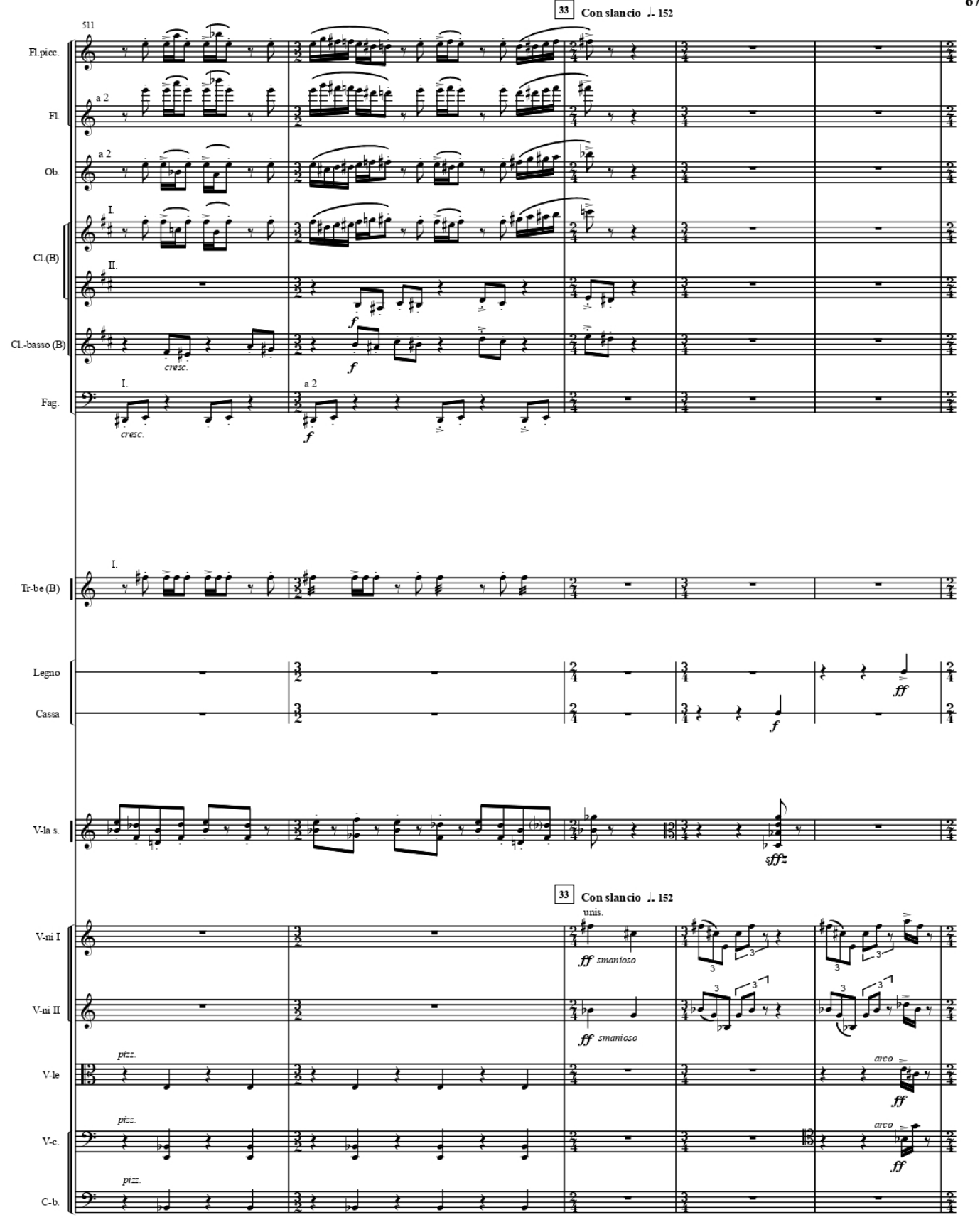




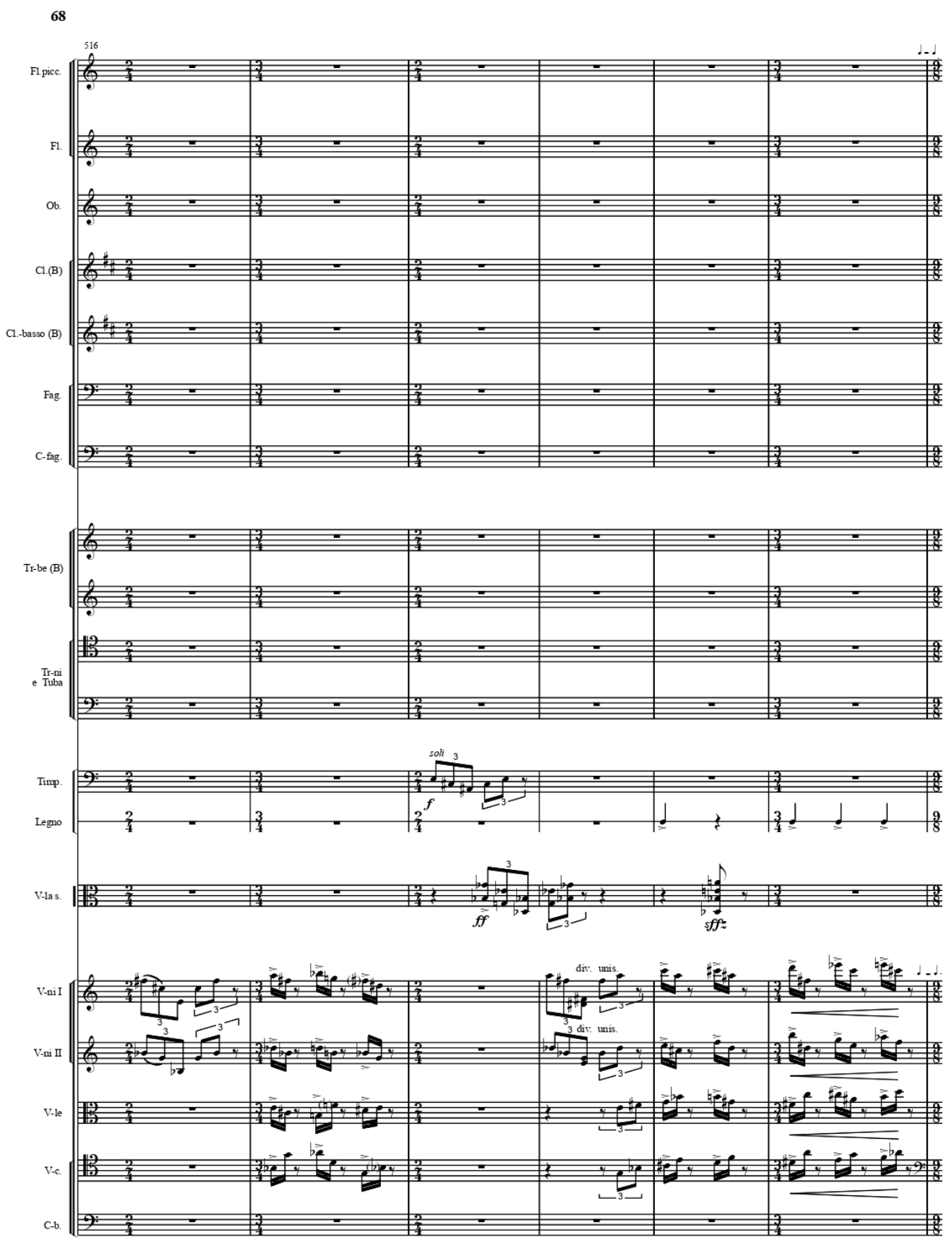




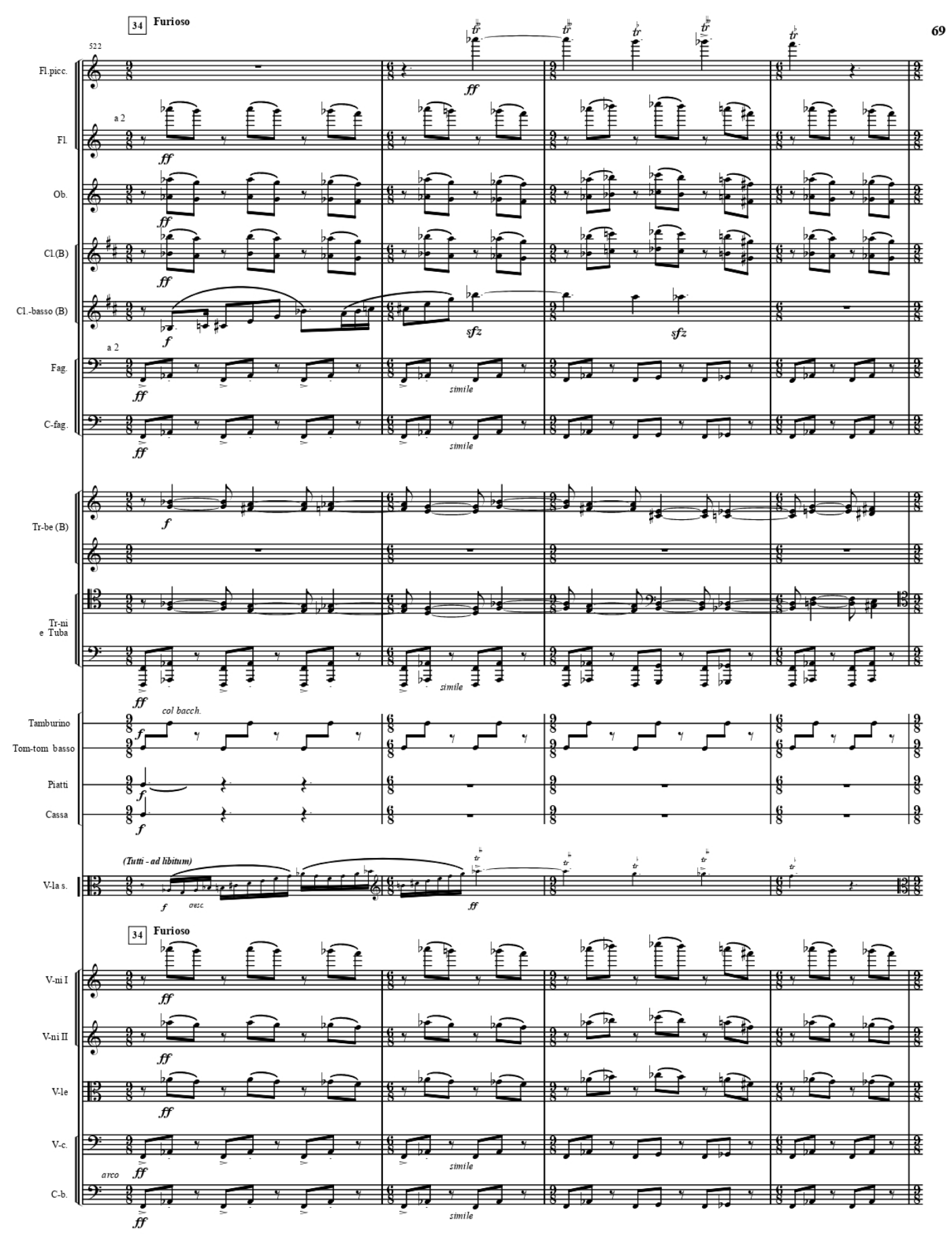




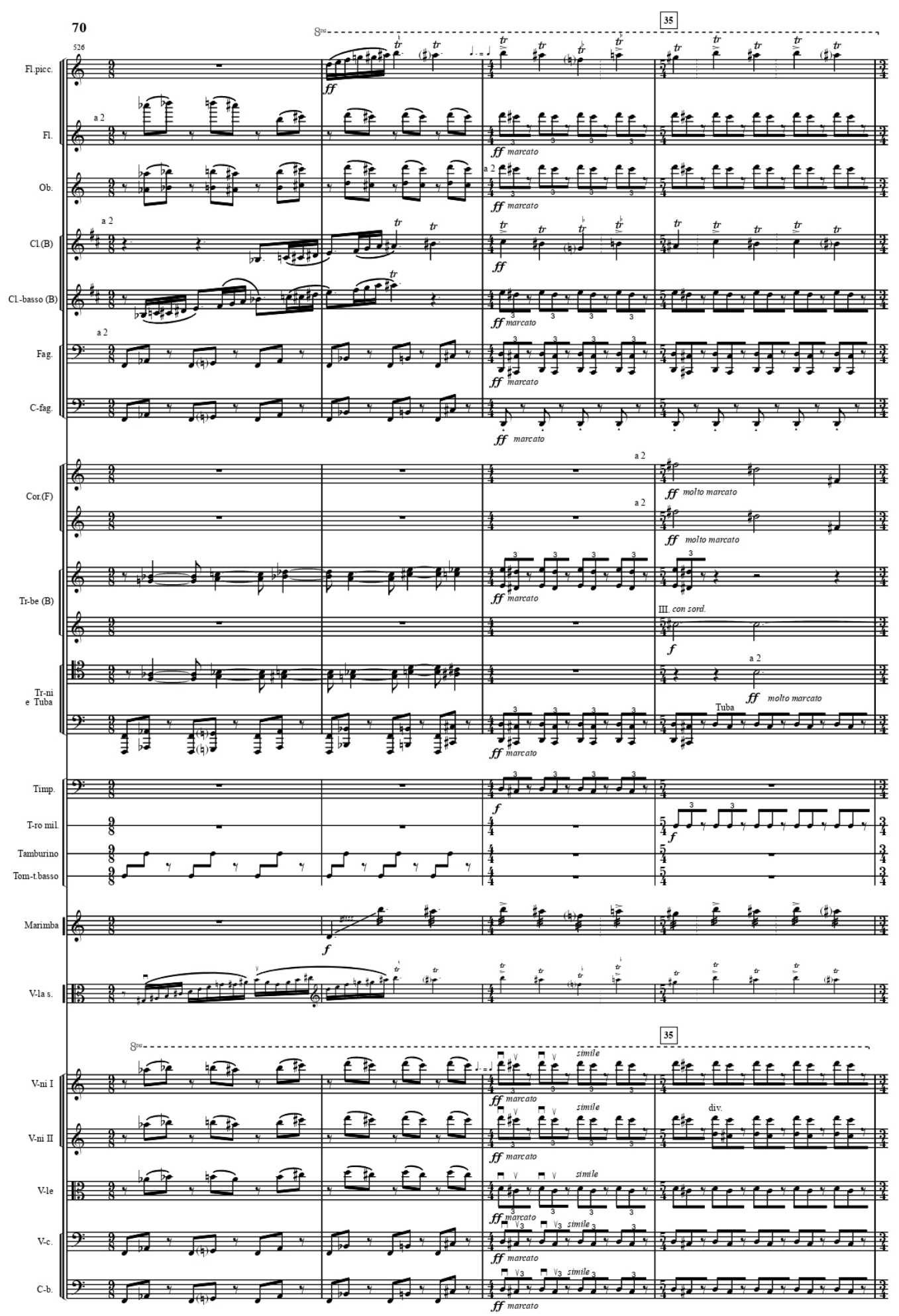




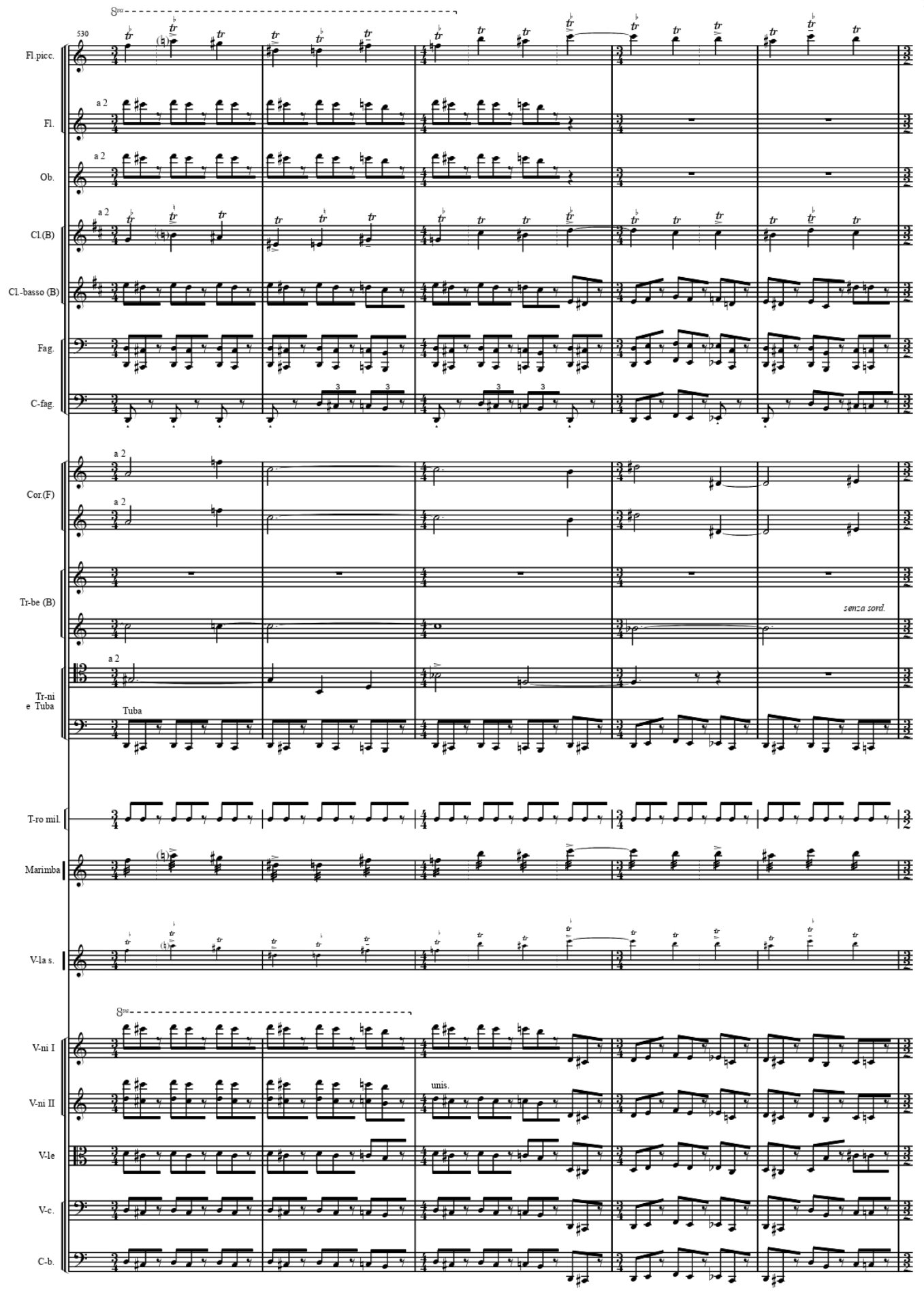




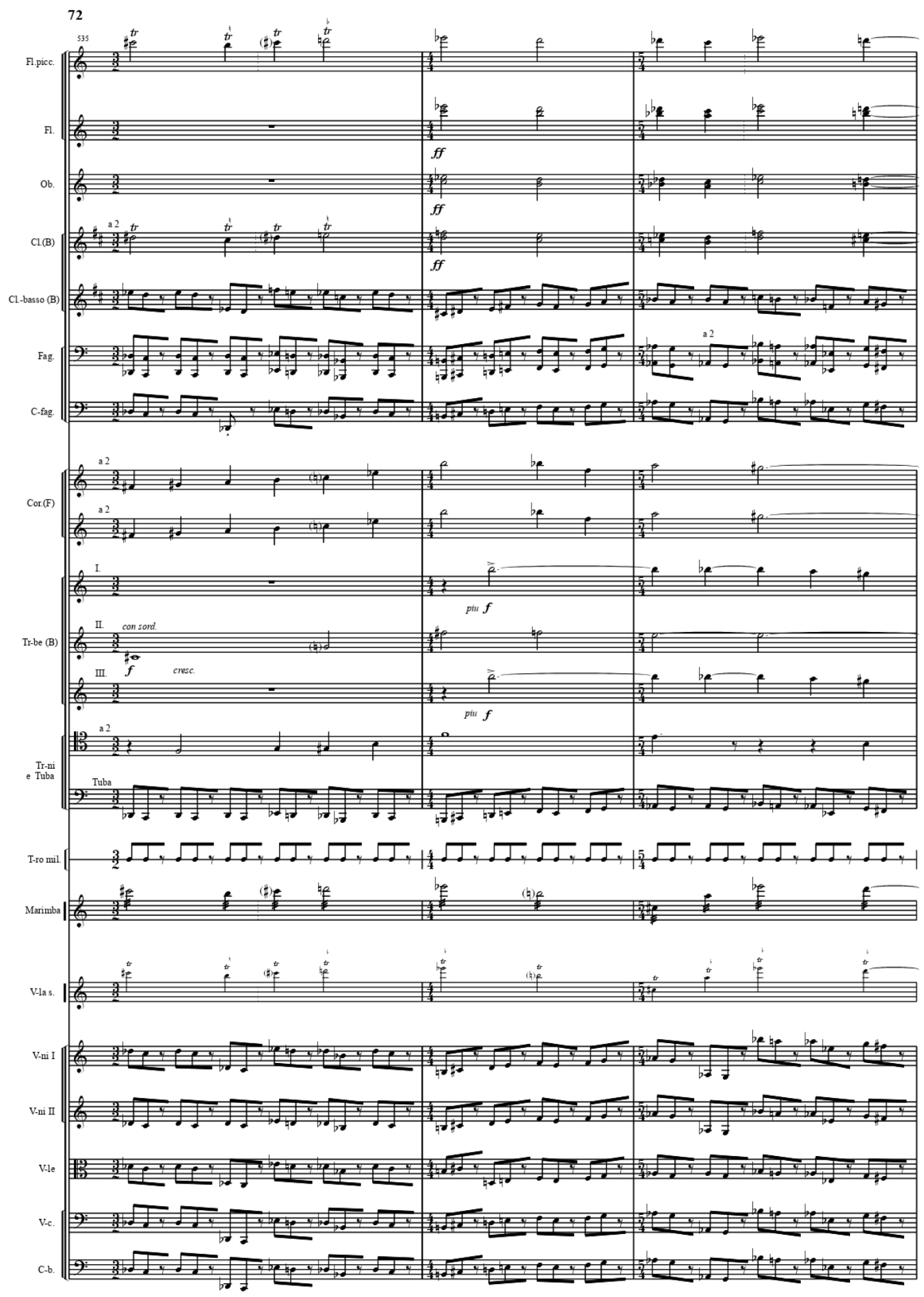




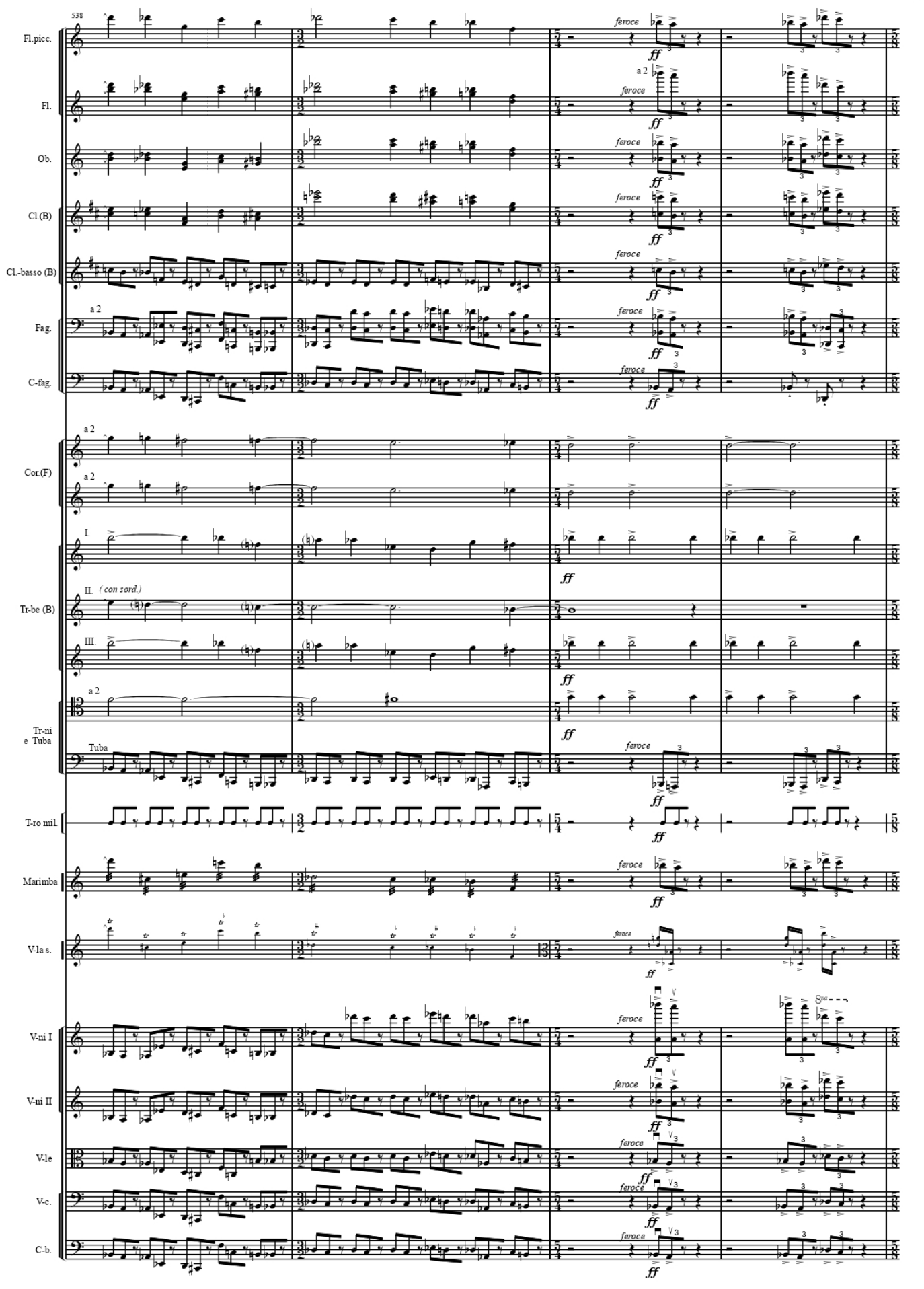




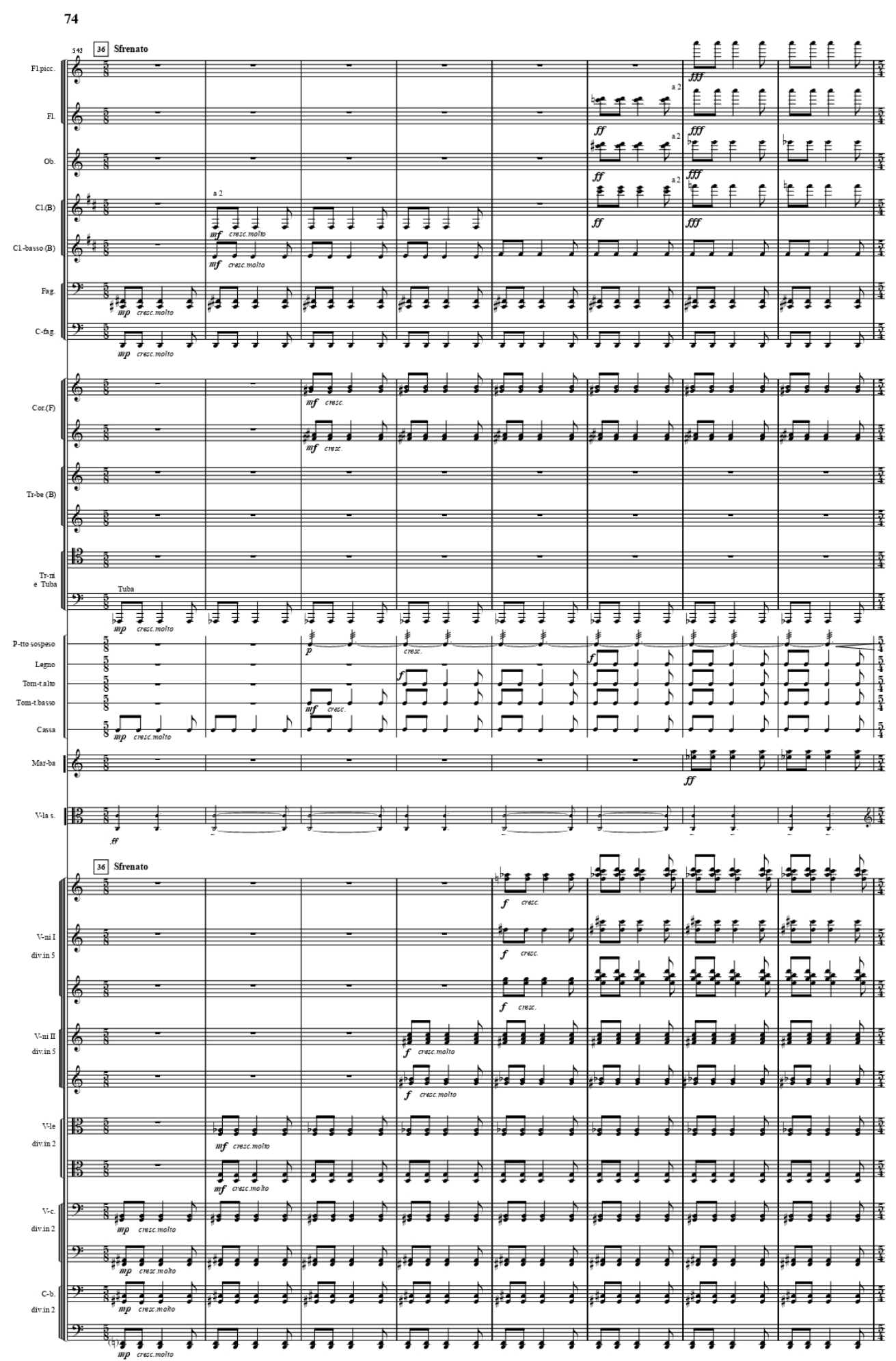




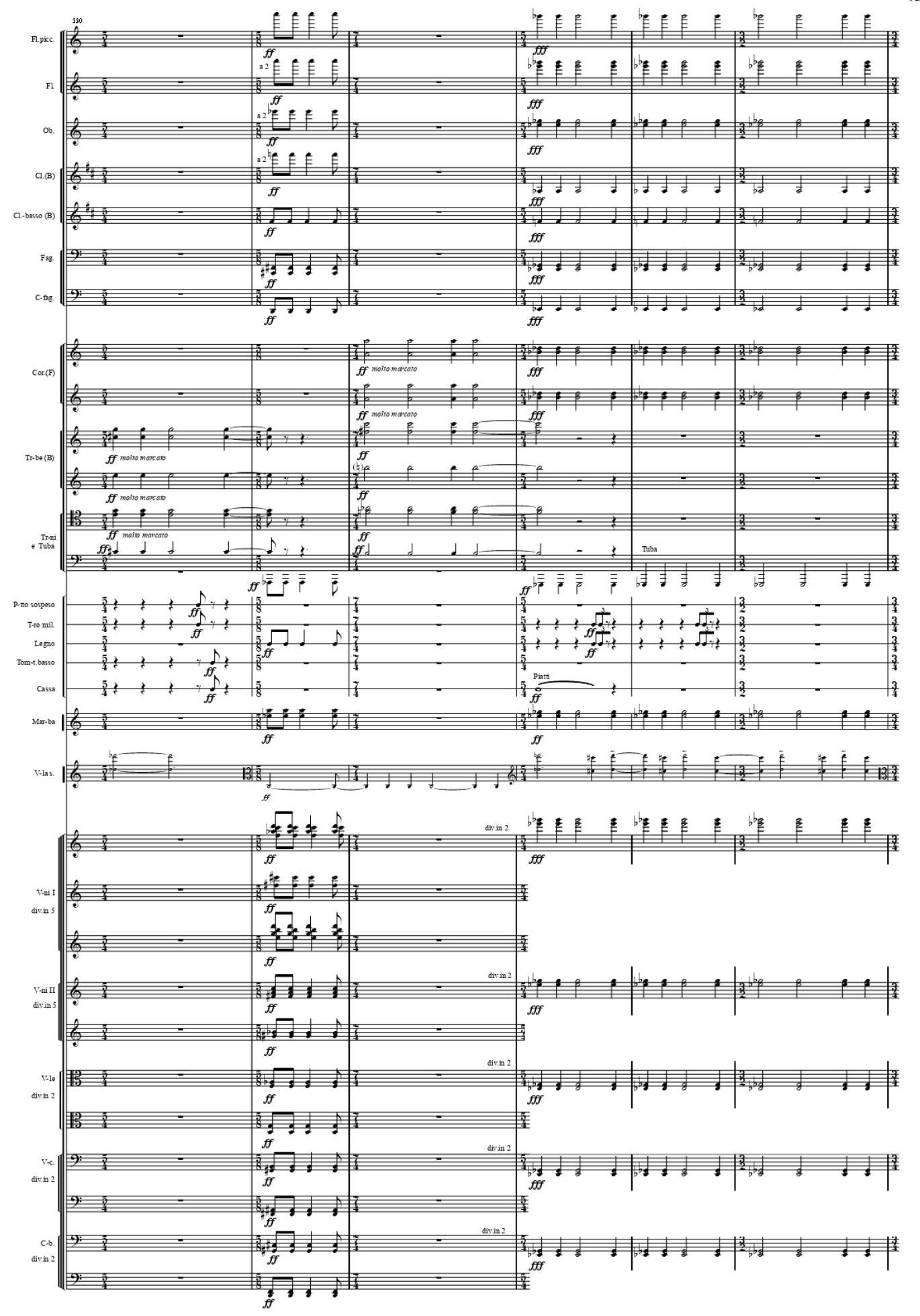



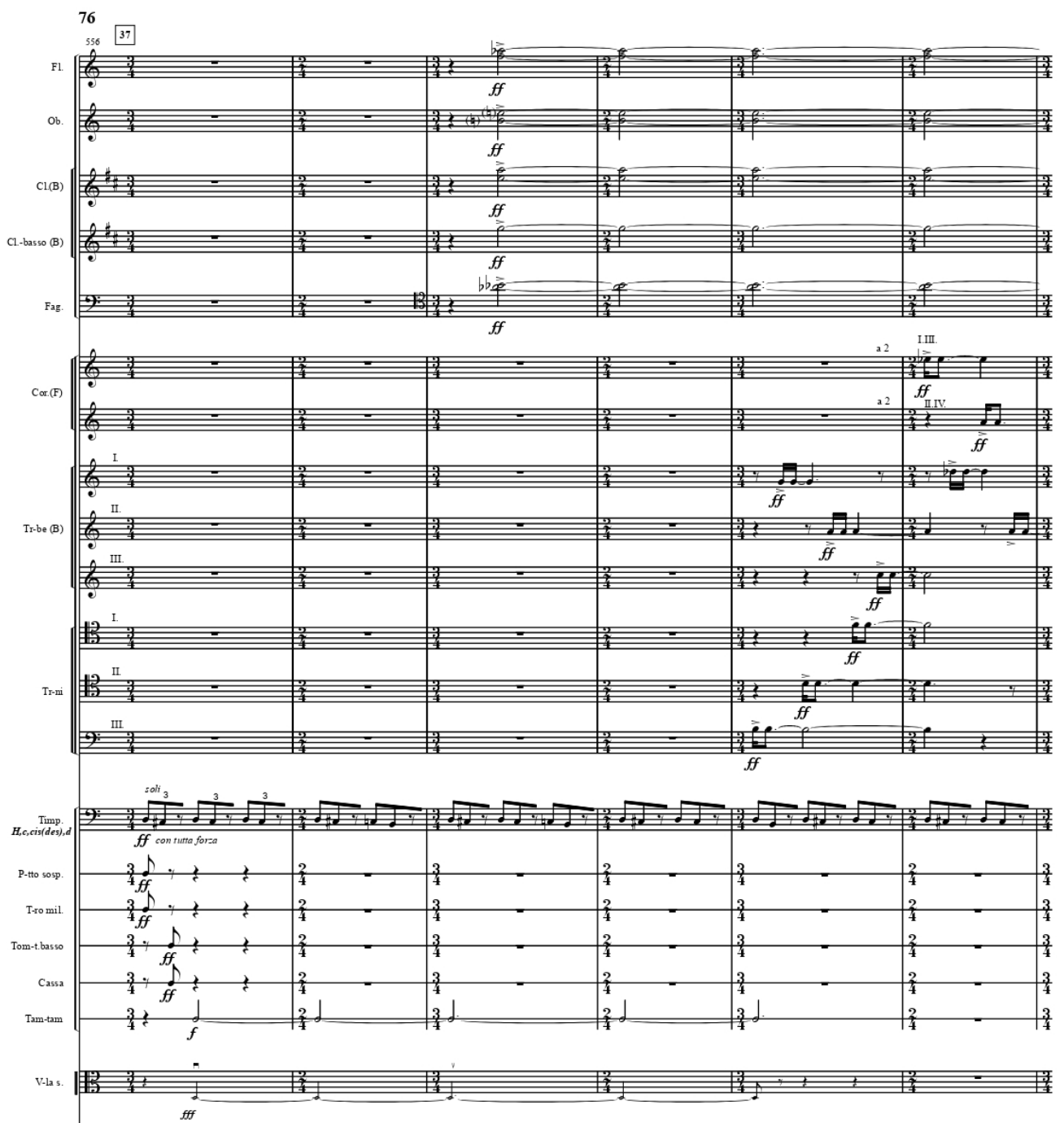

37

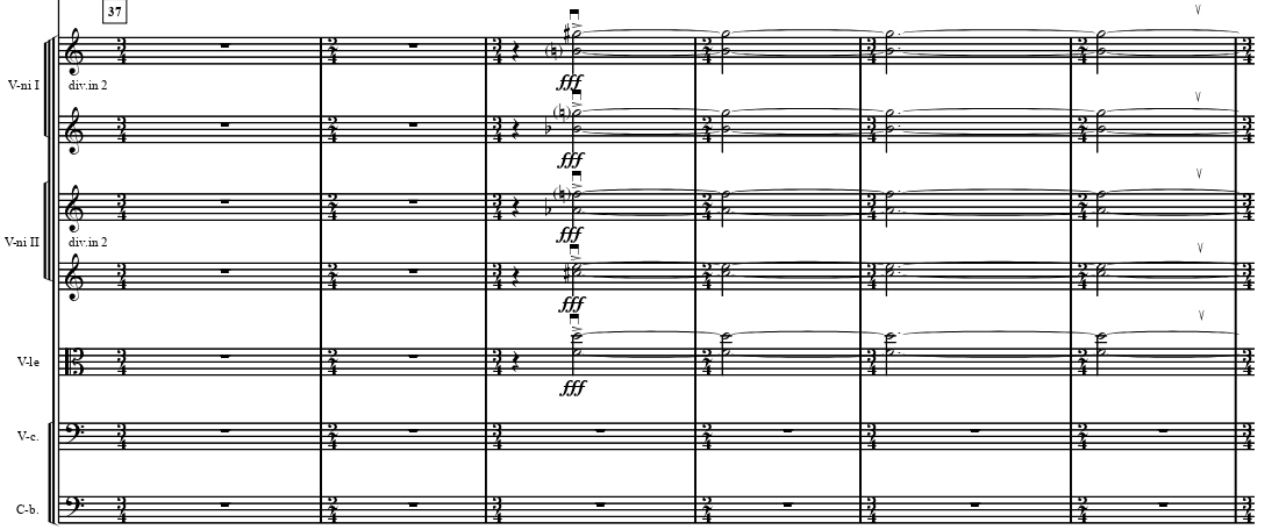




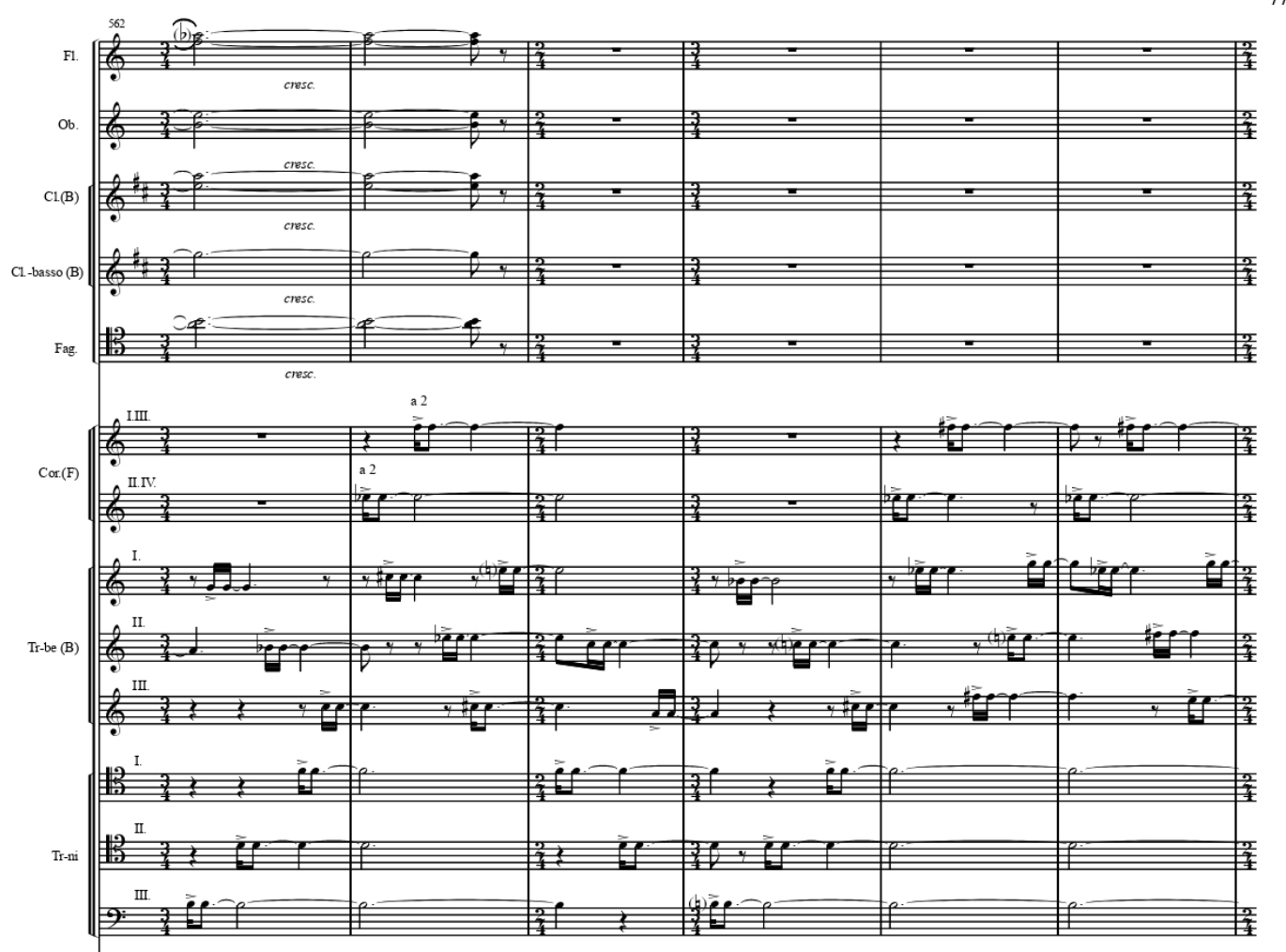

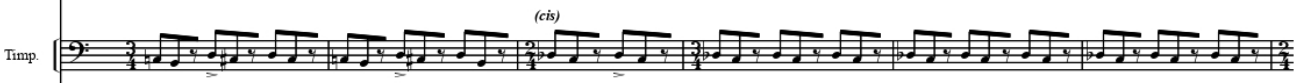

v.has

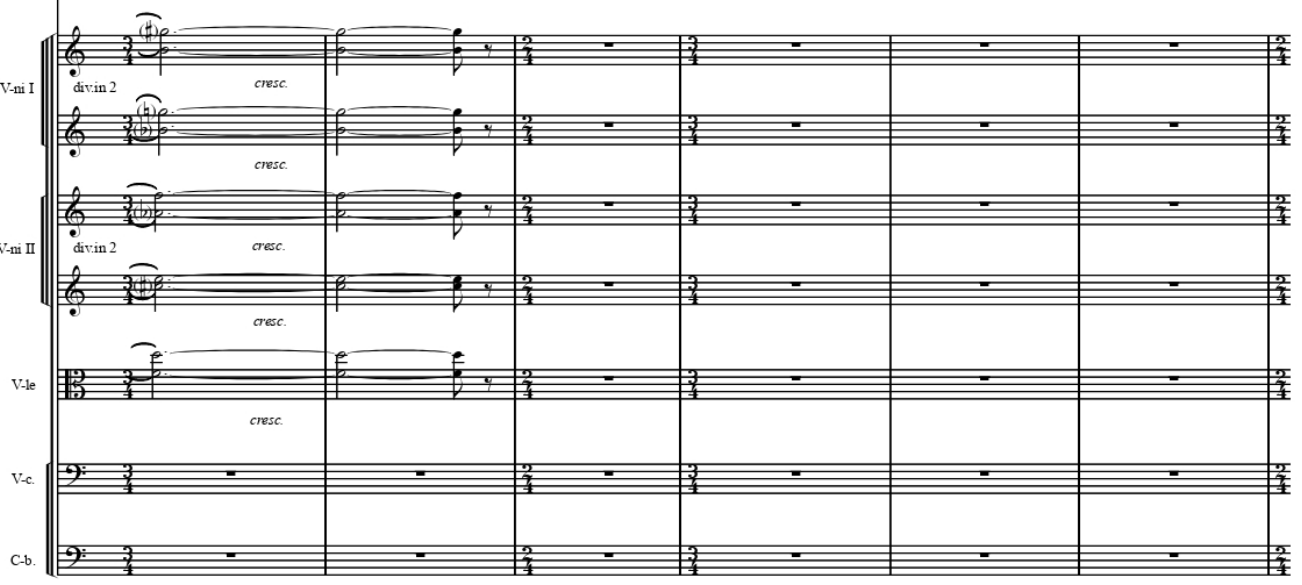




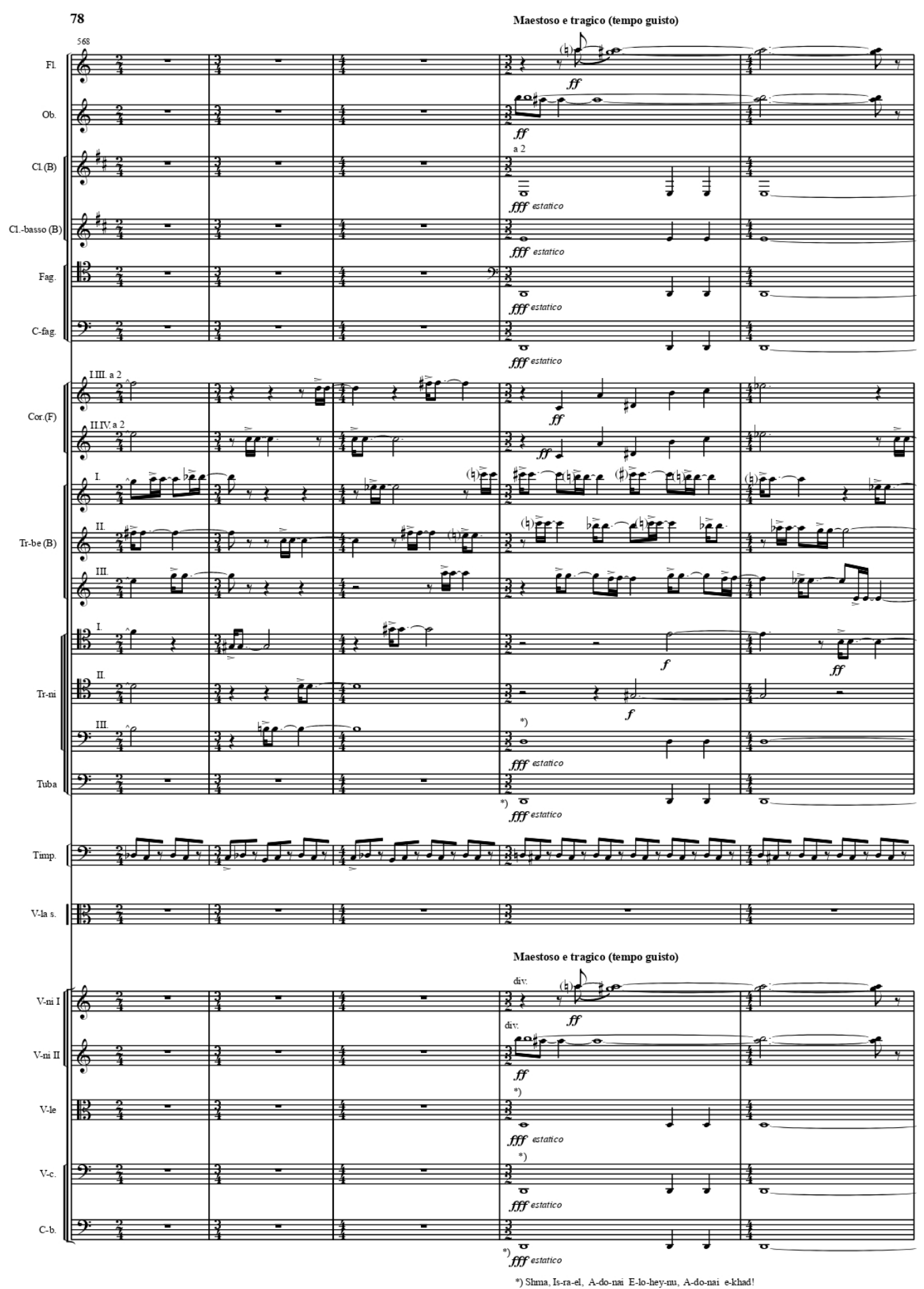




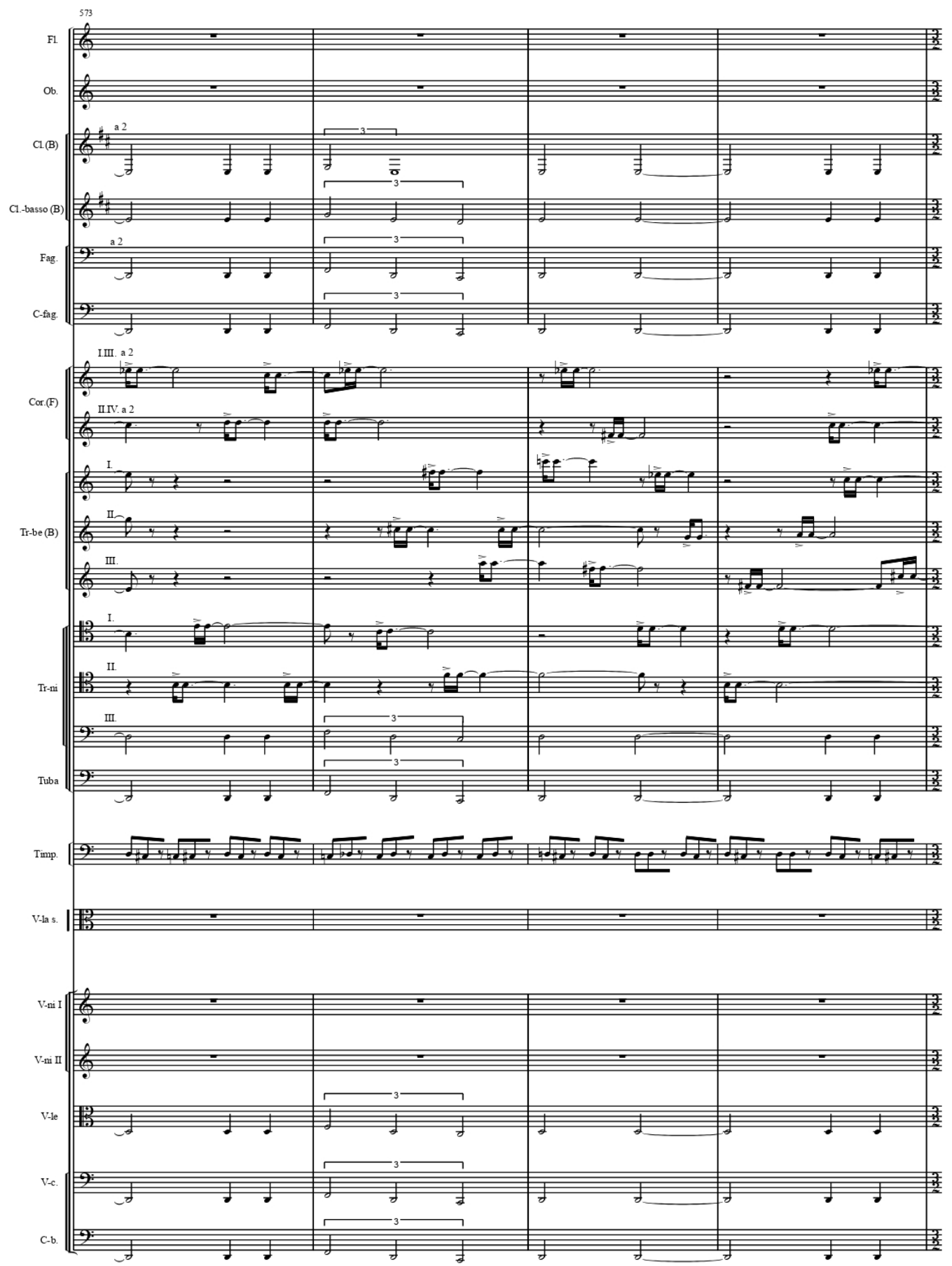




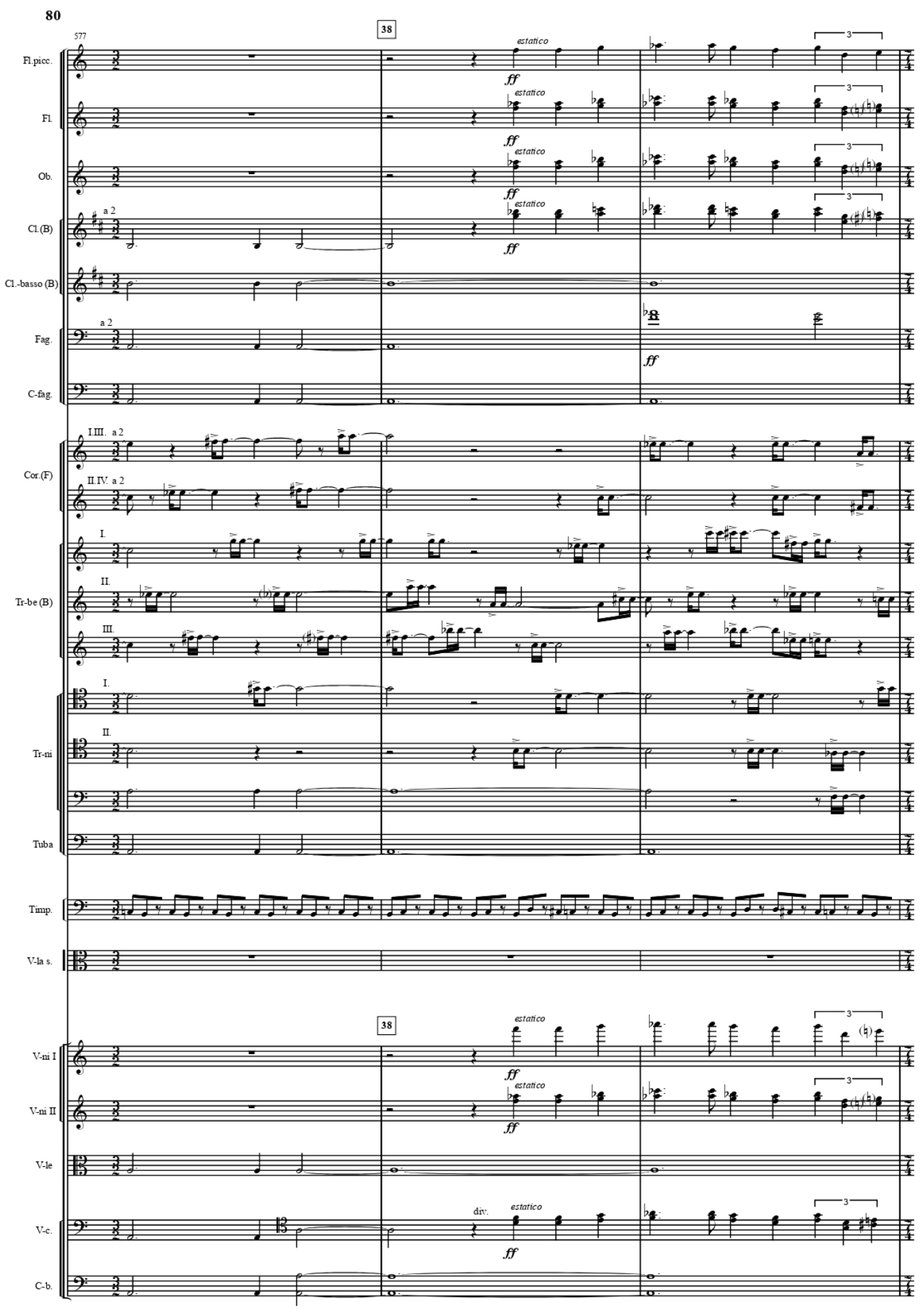




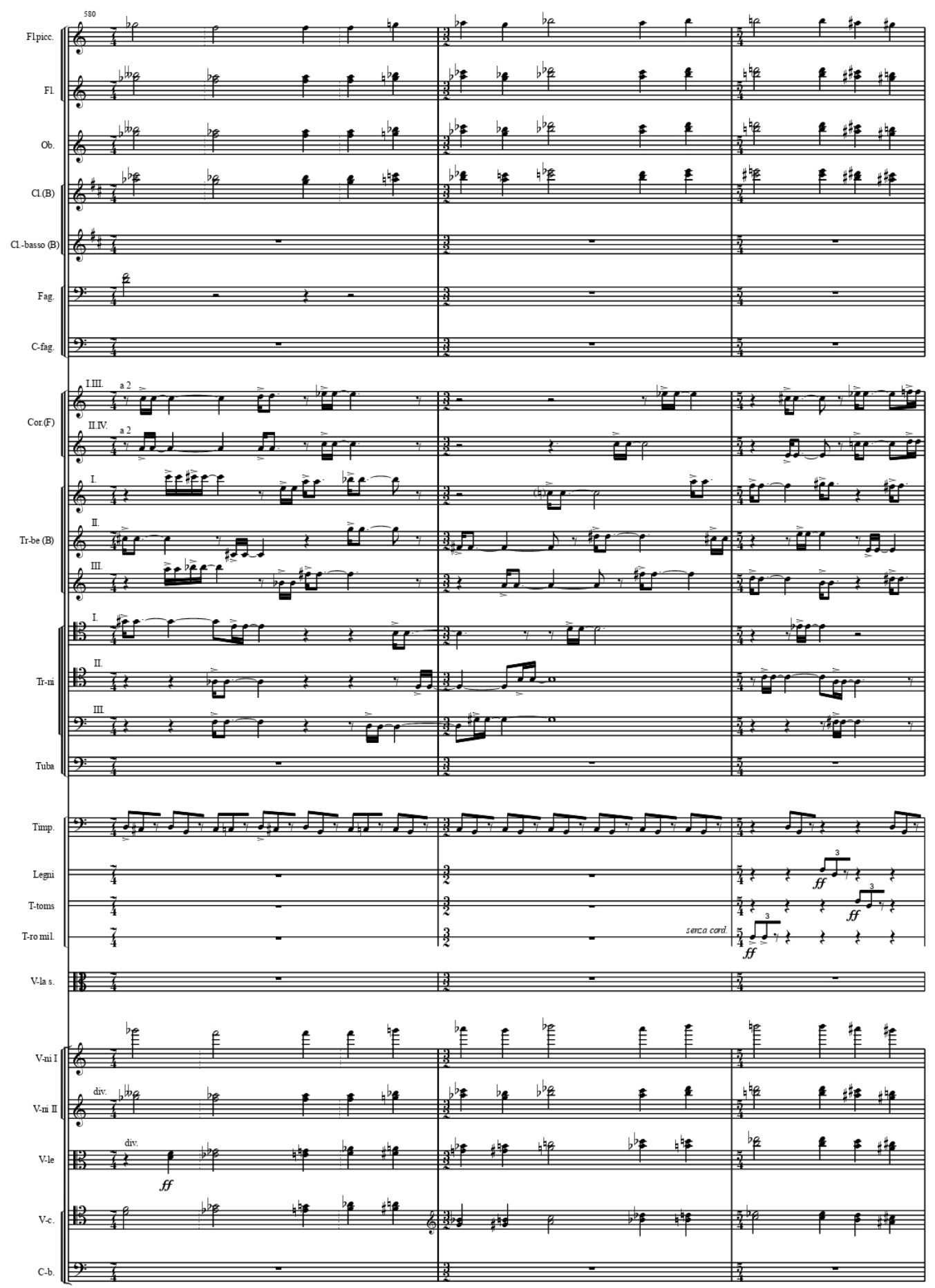




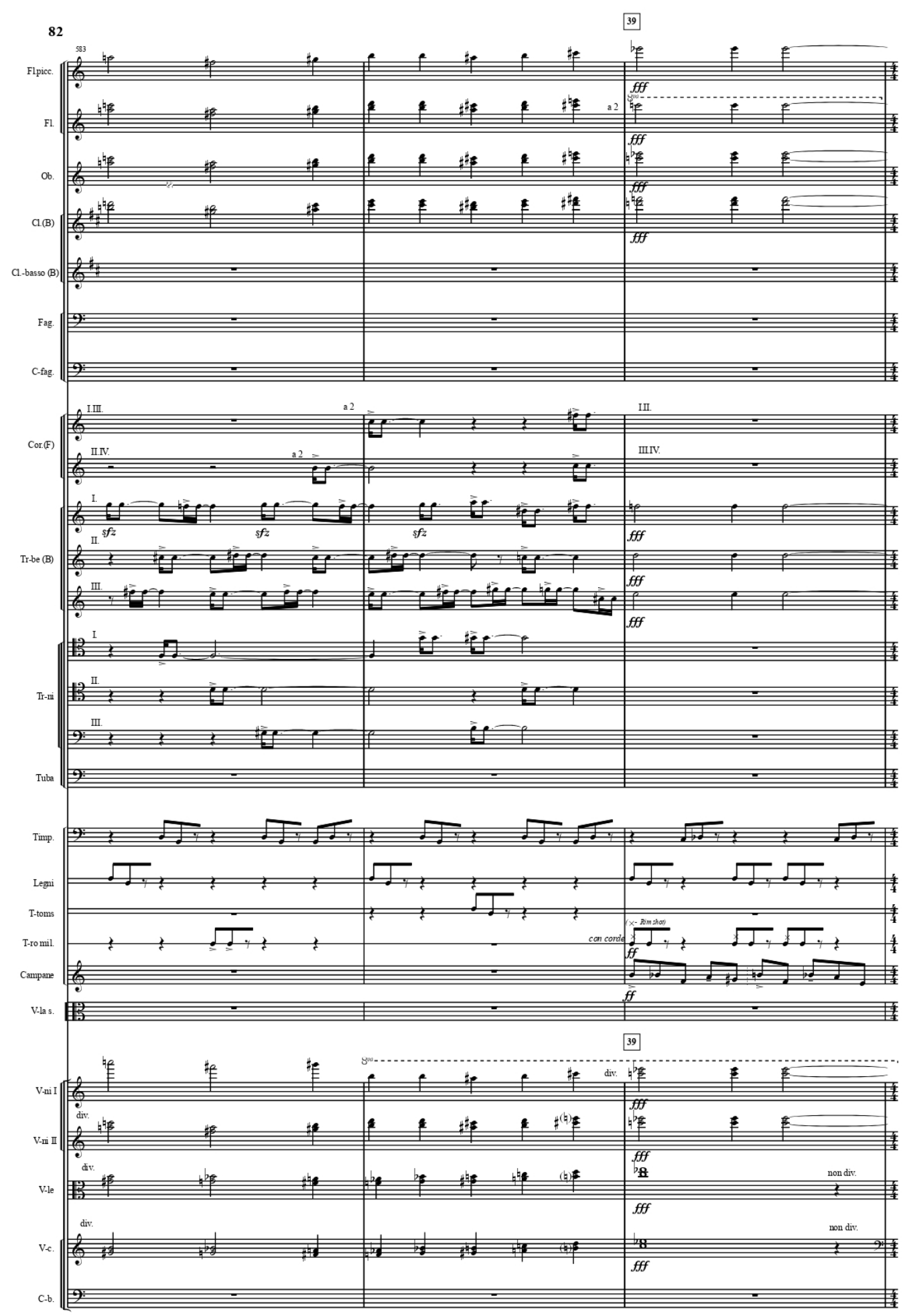




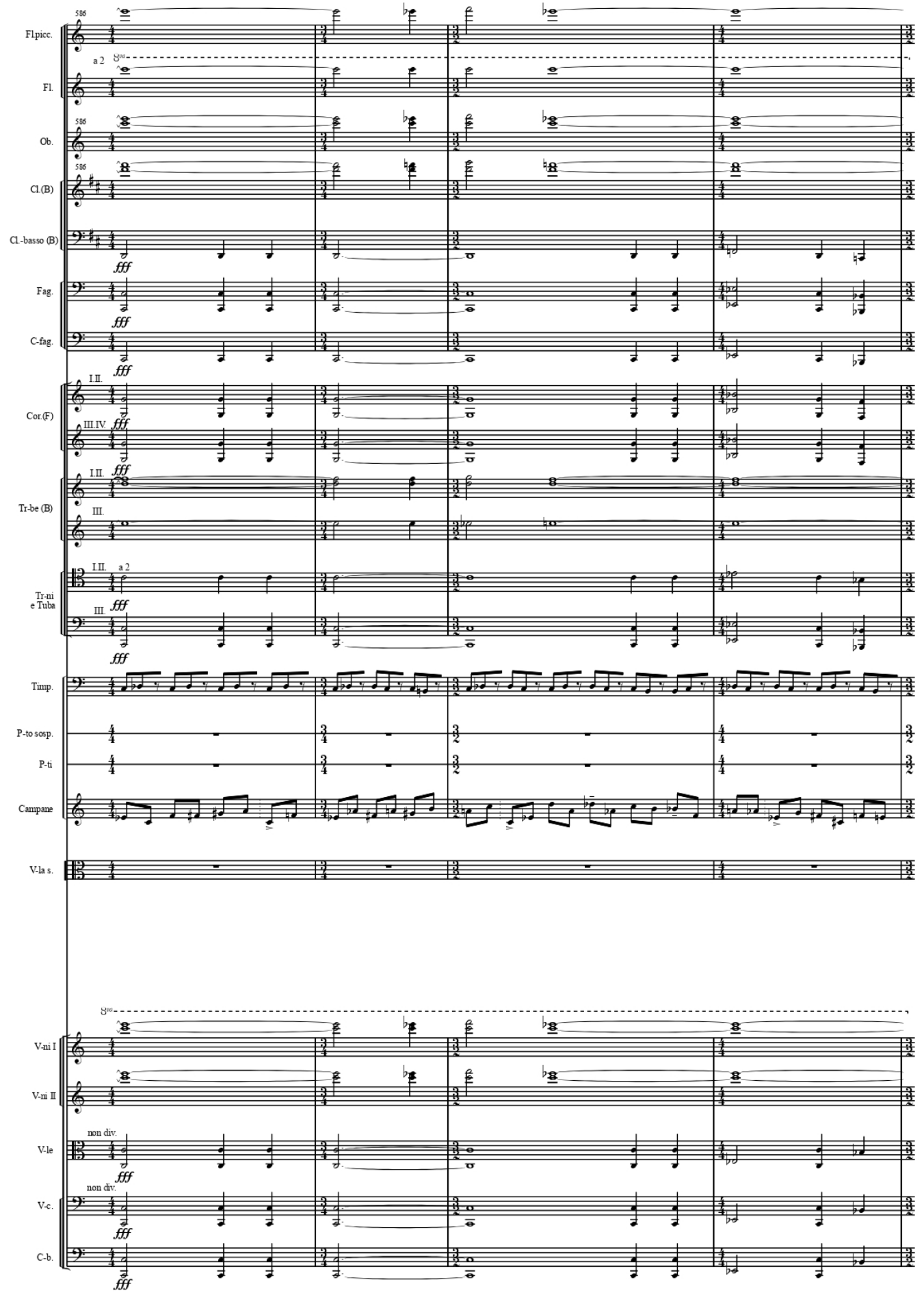



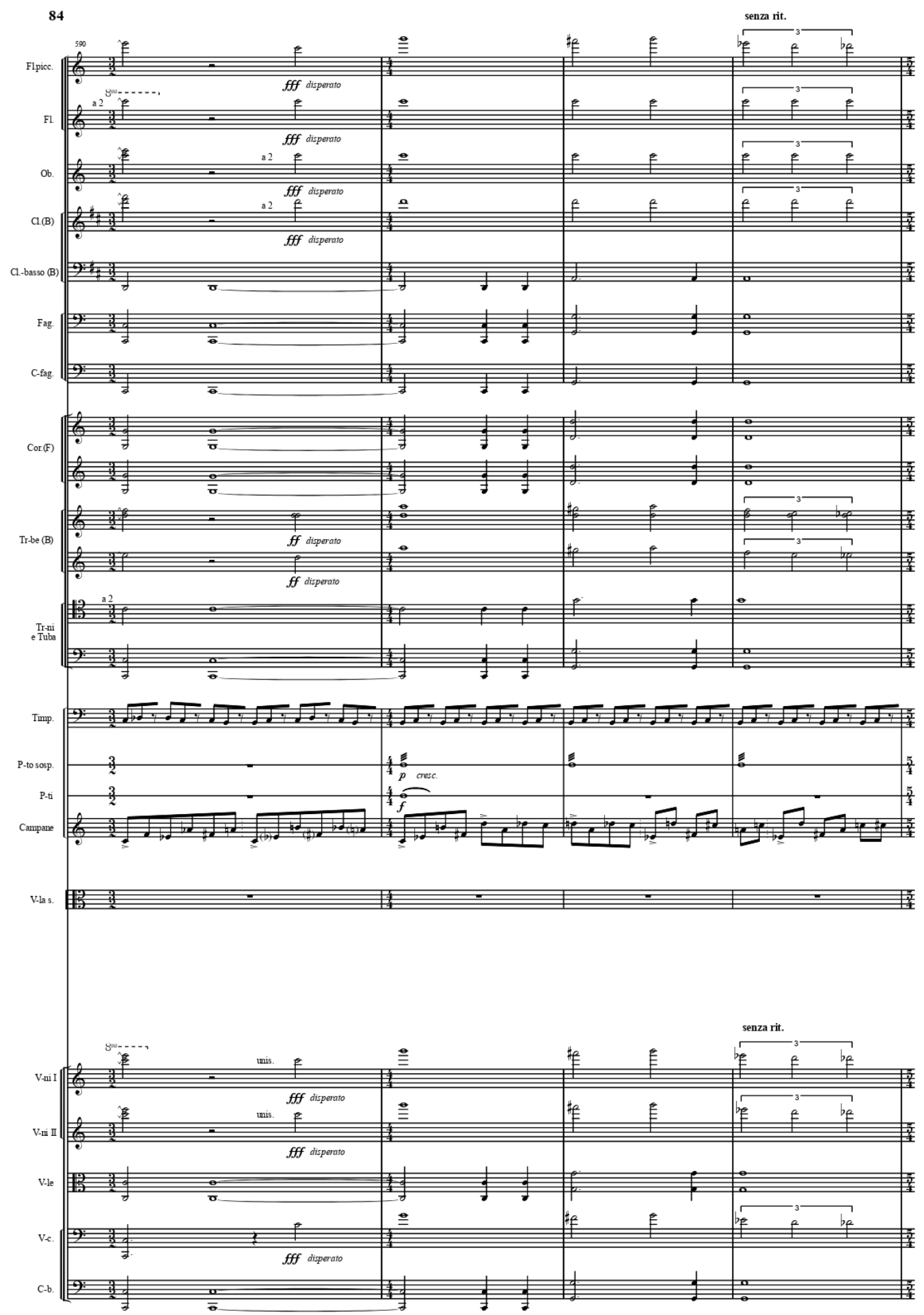

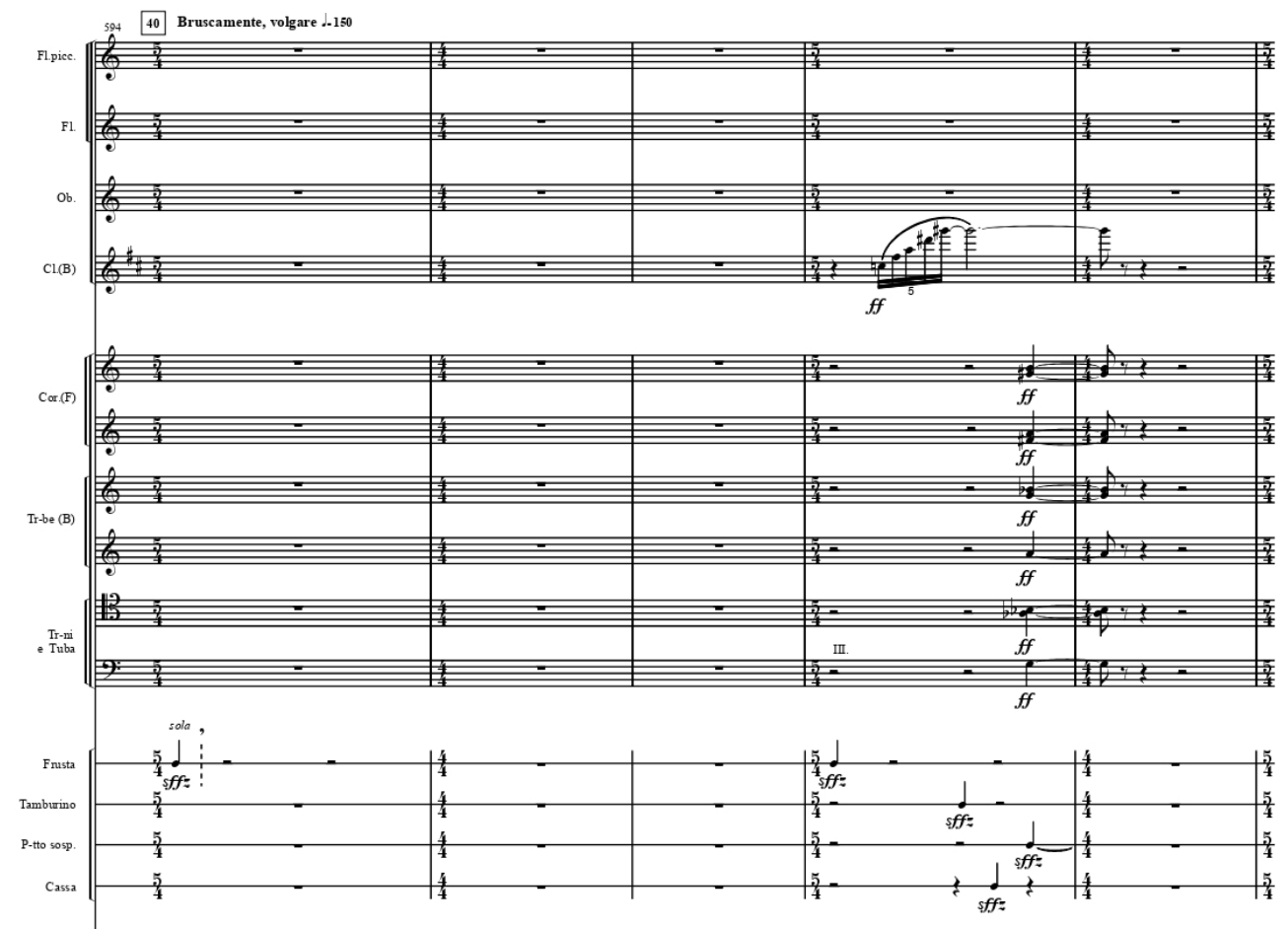

Pino

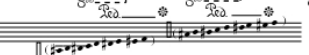

40 Bruscamente, volgare. .150

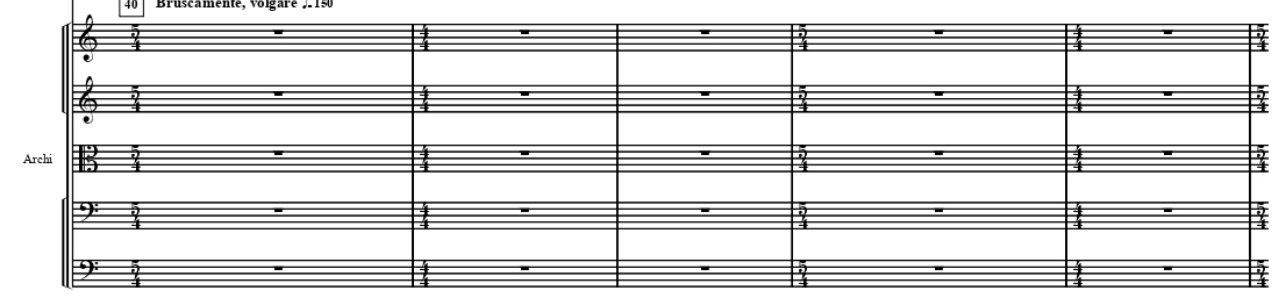



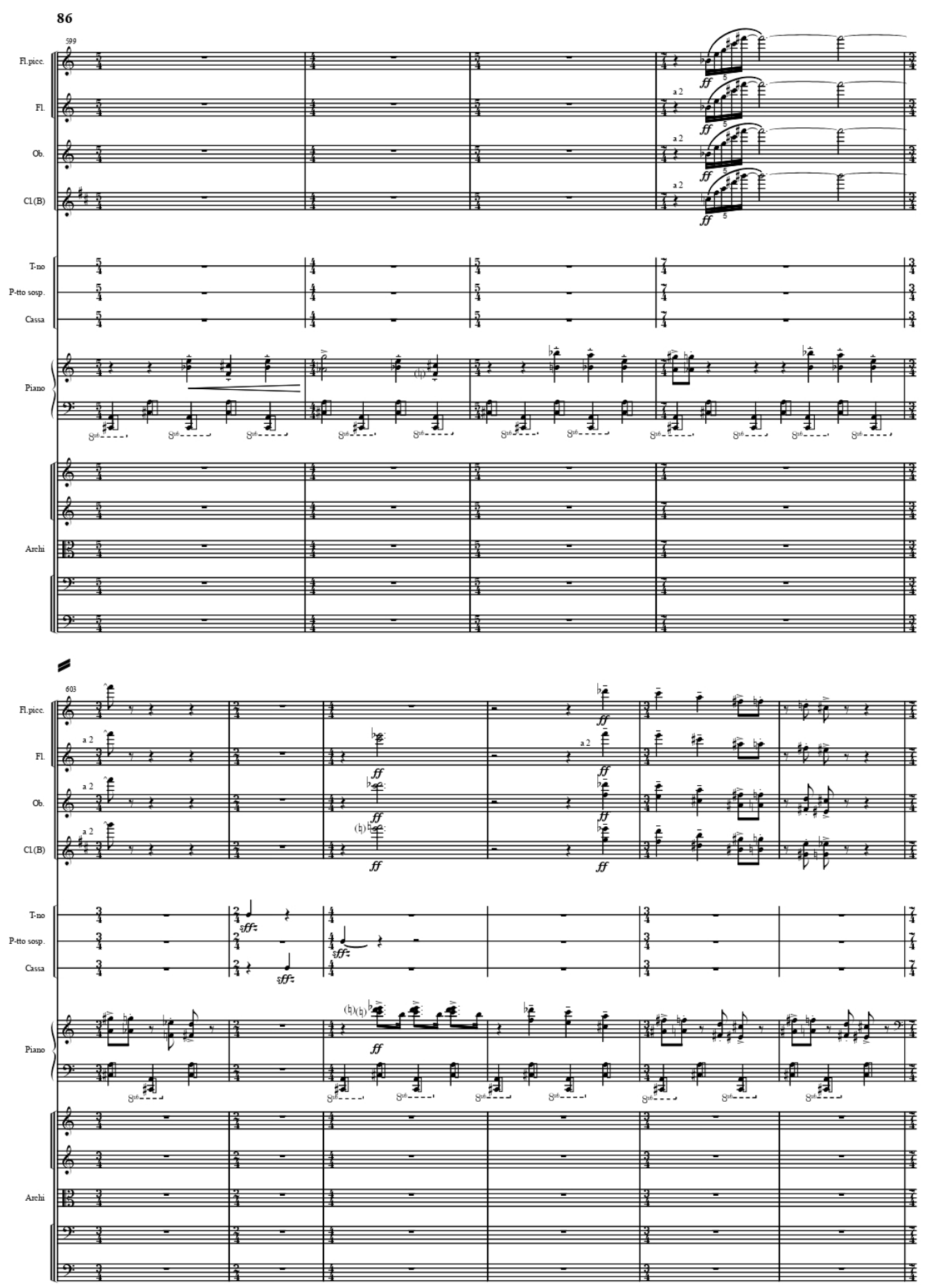

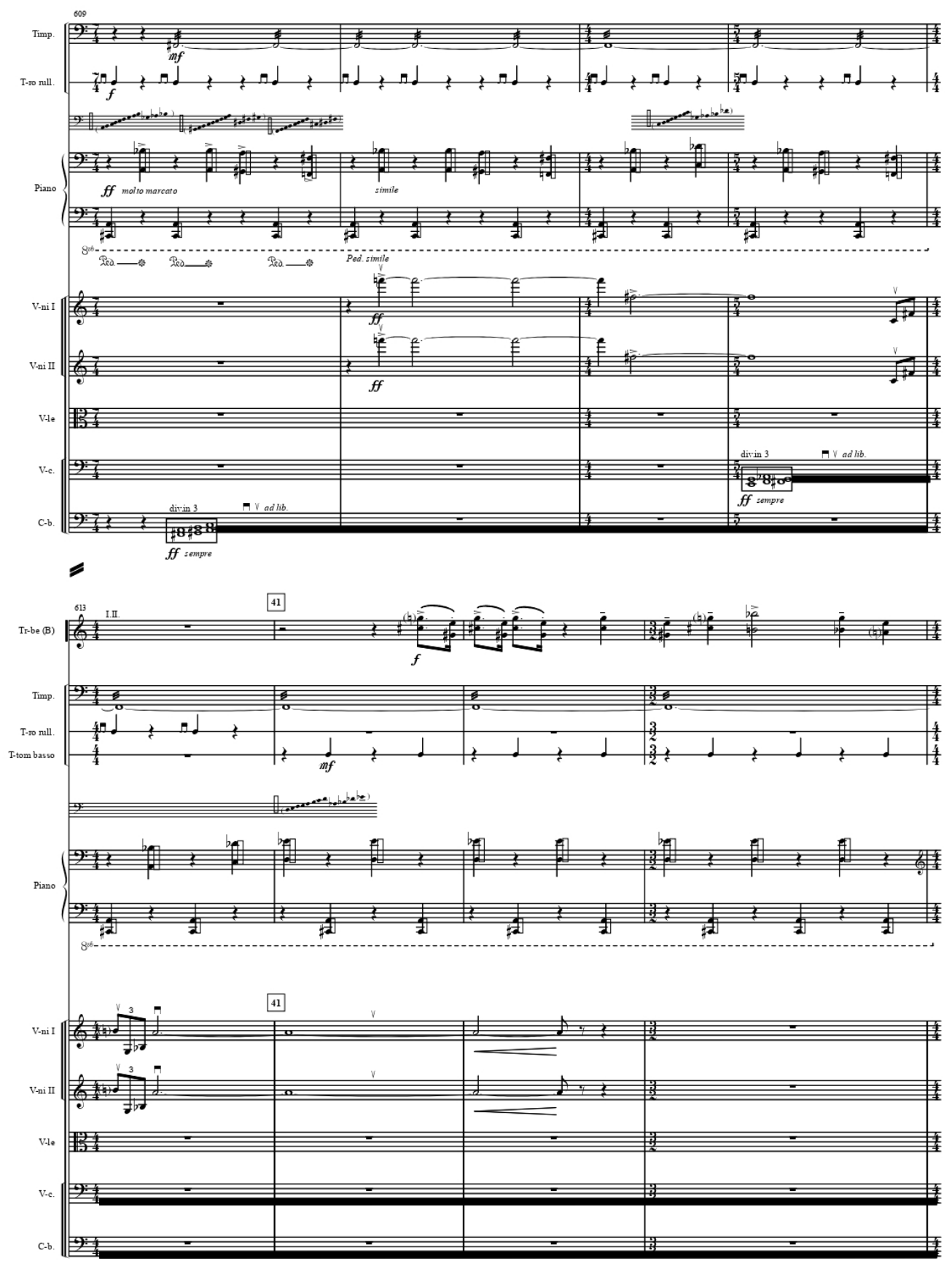

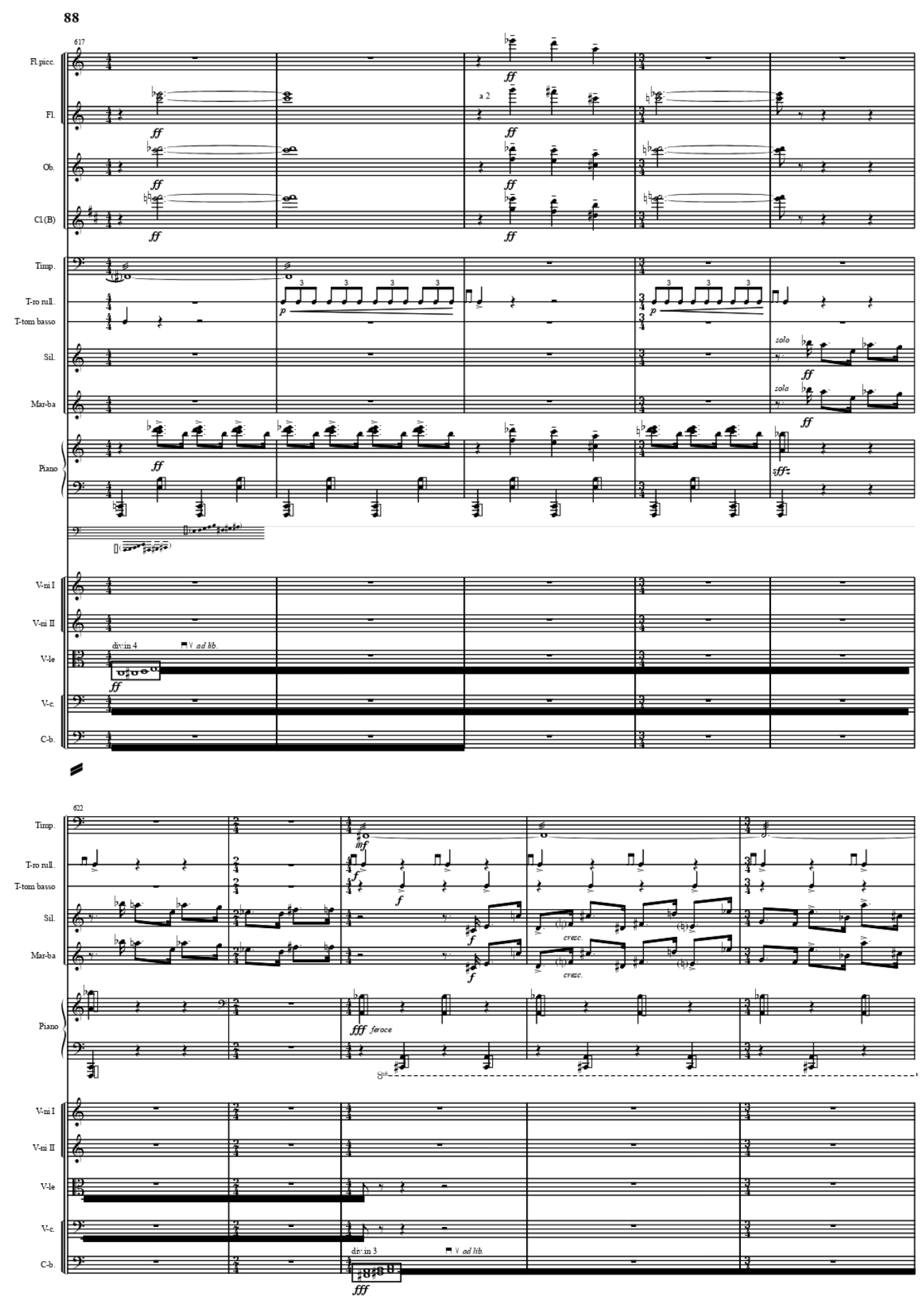


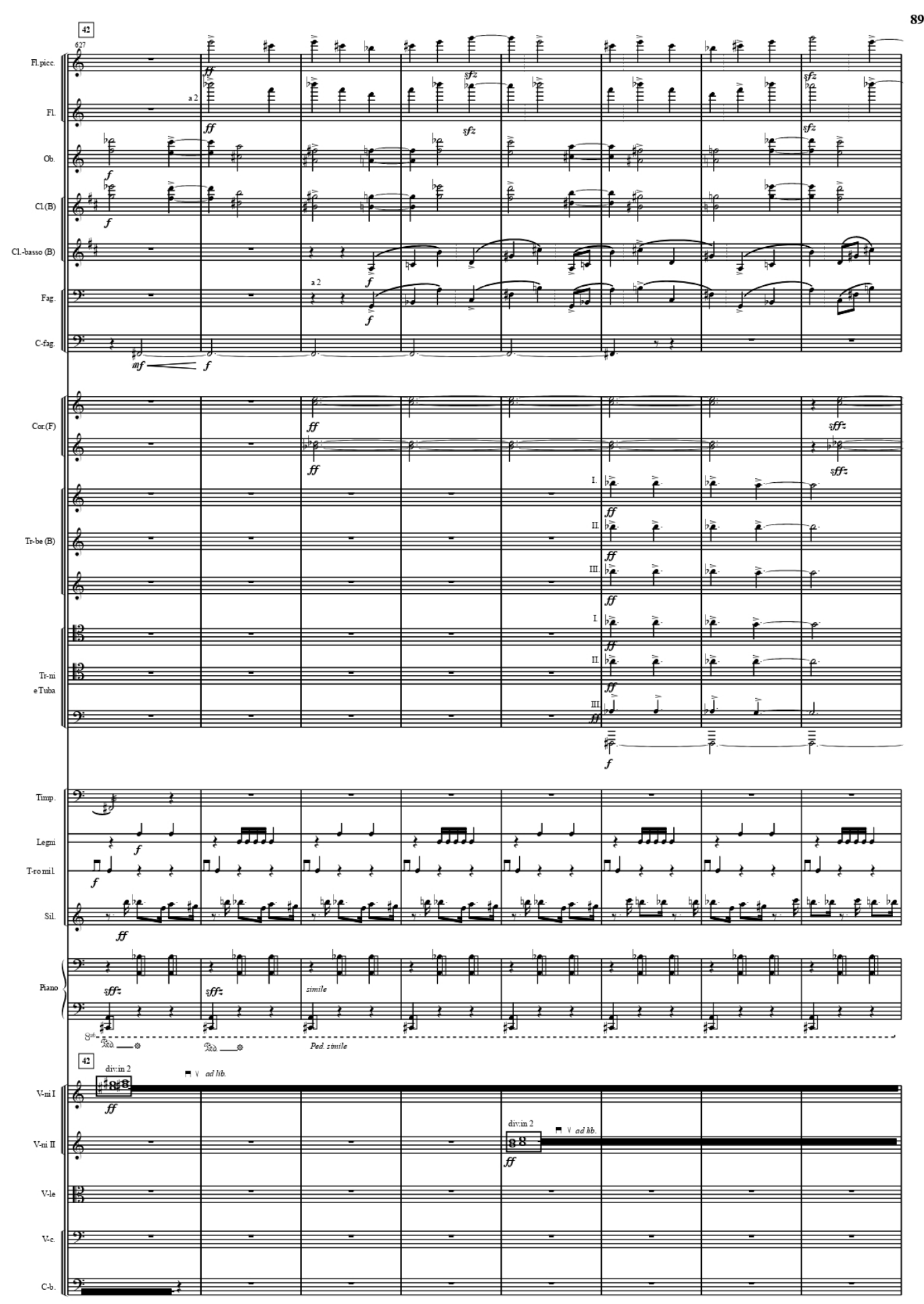




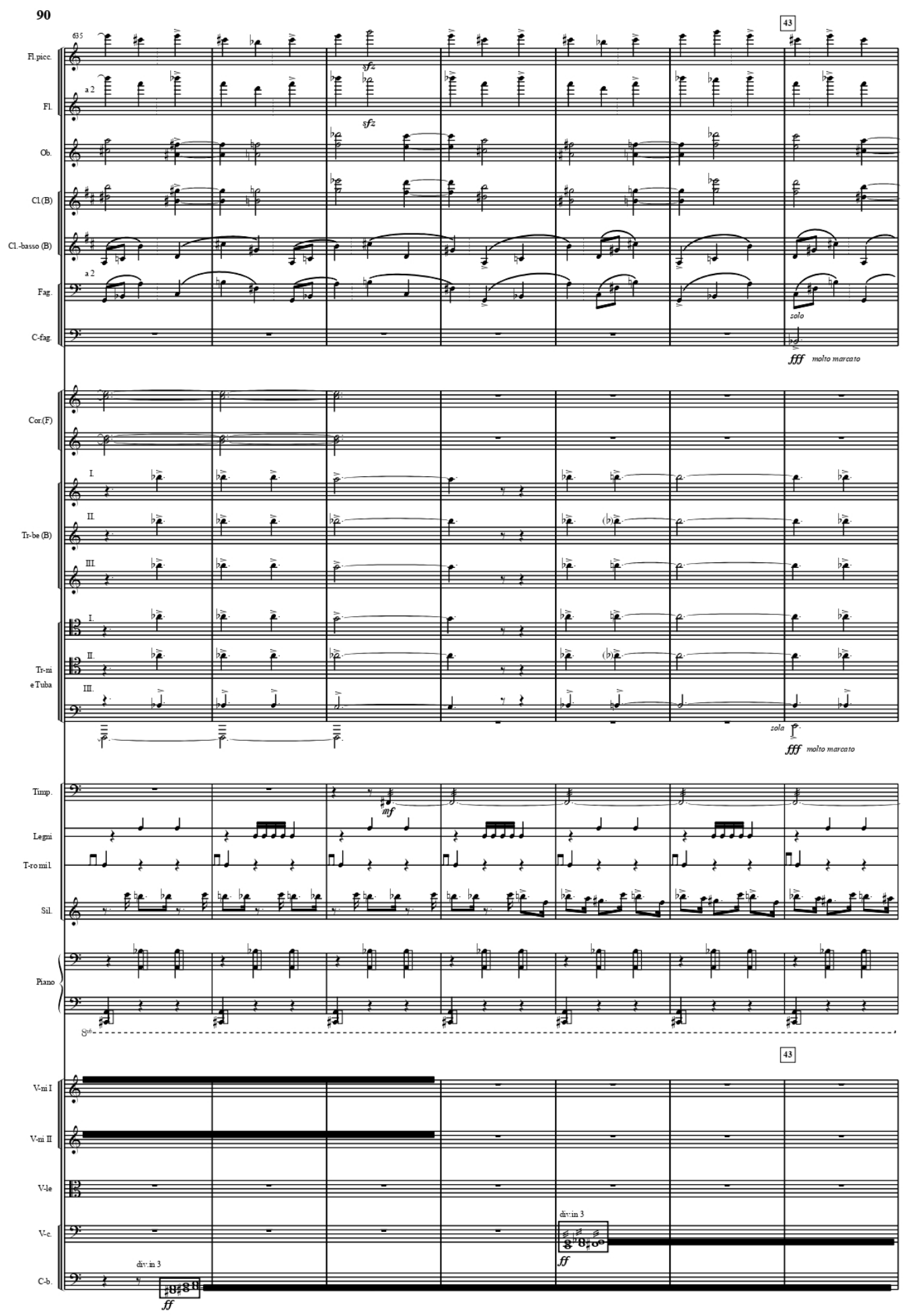




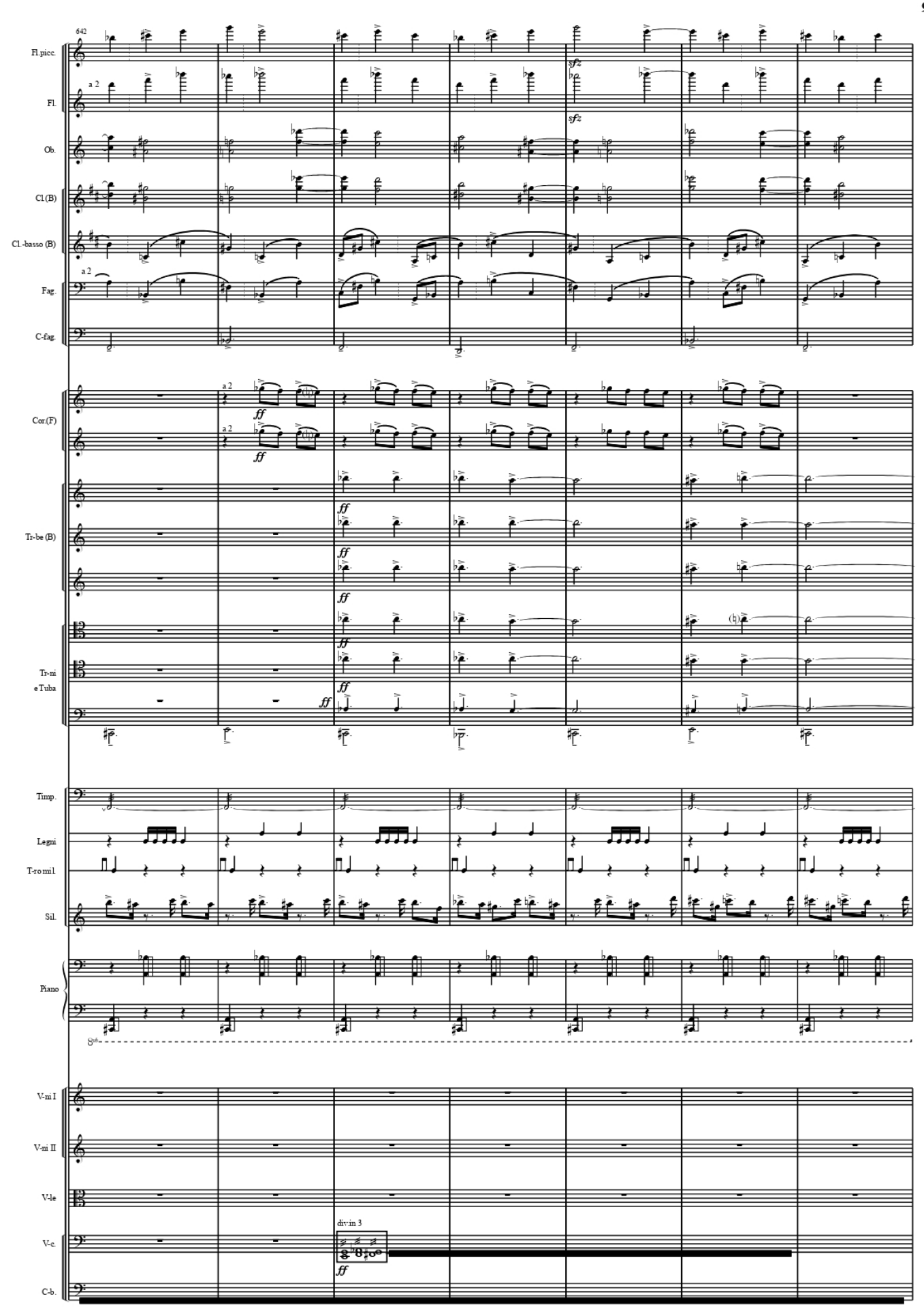




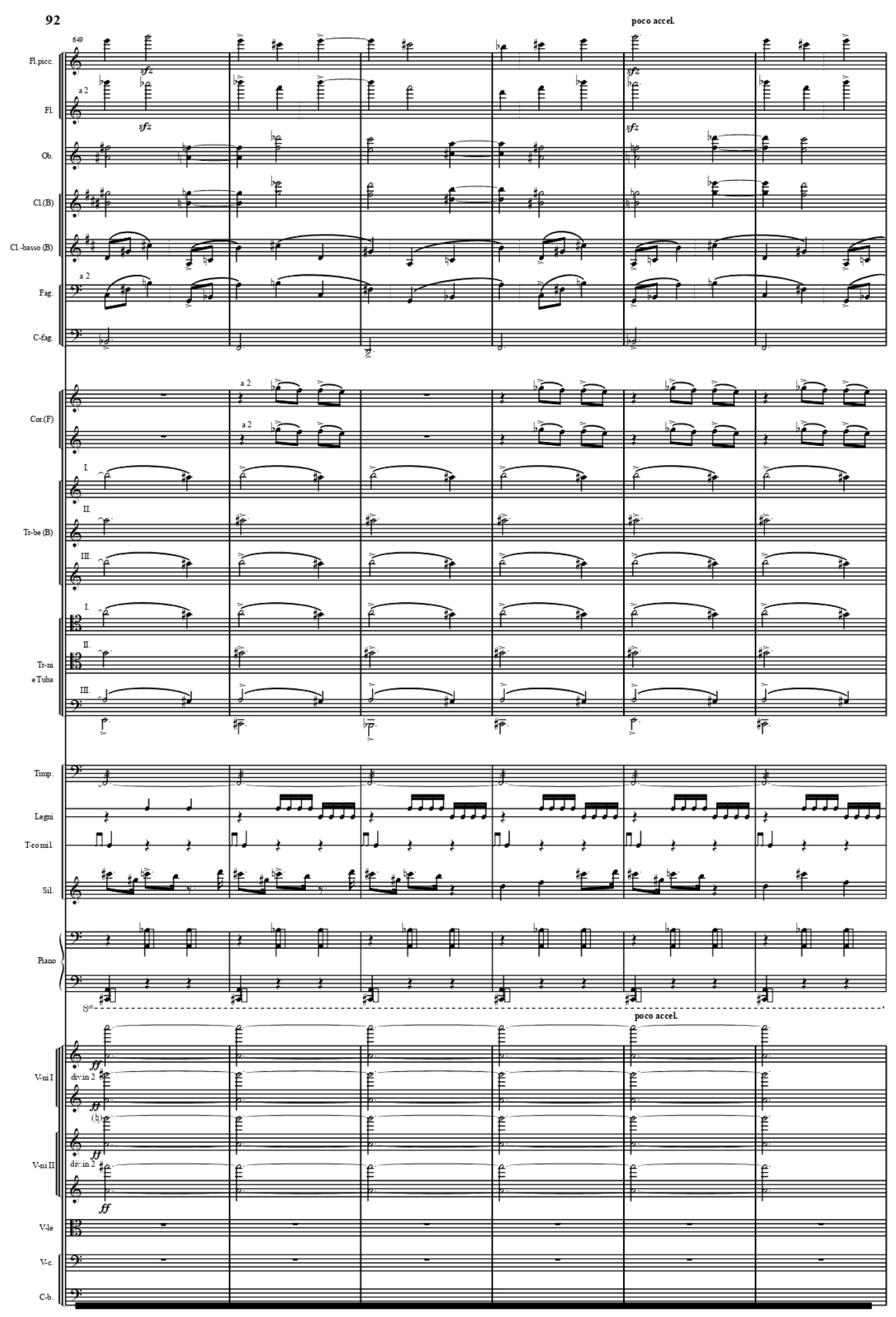



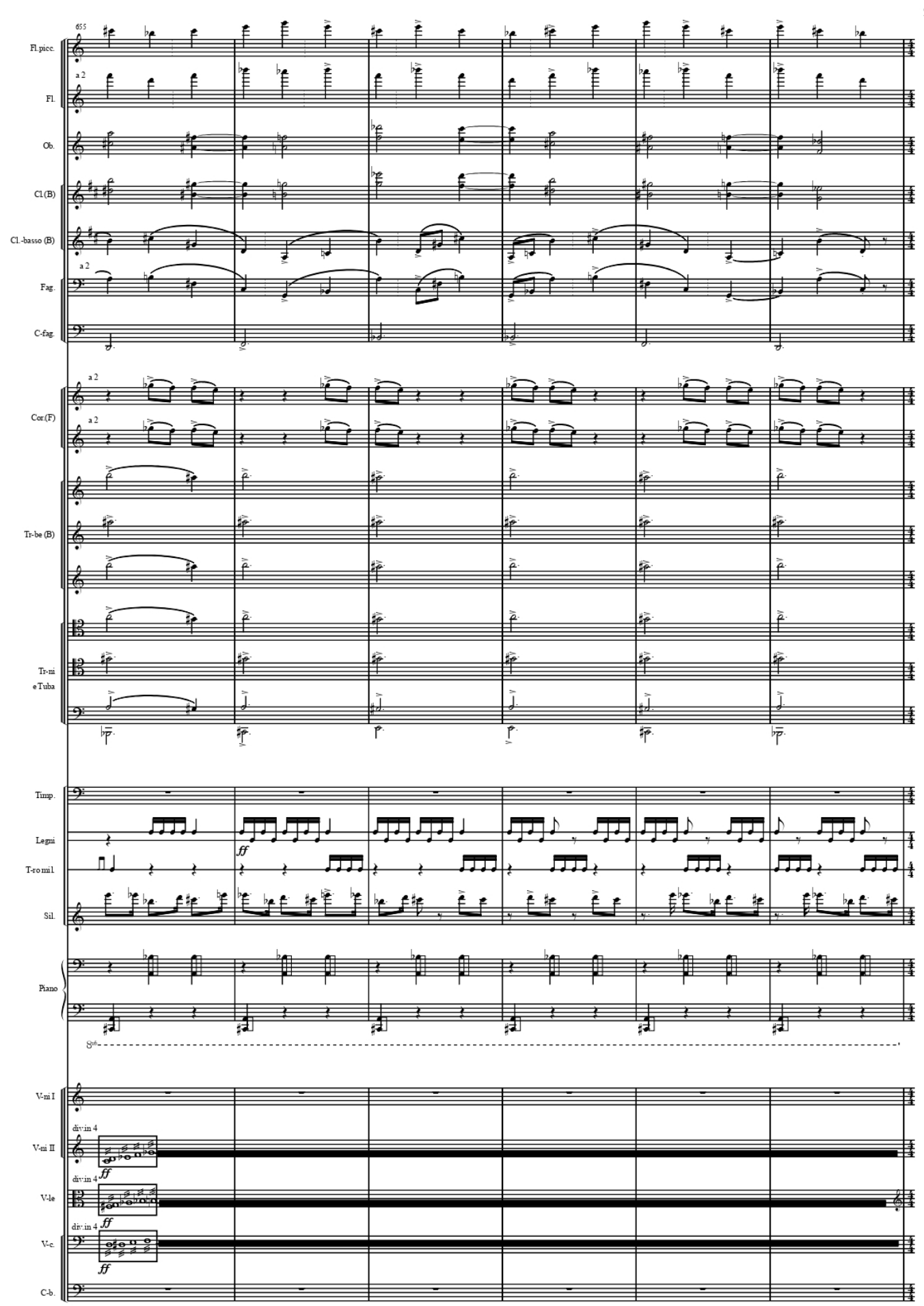


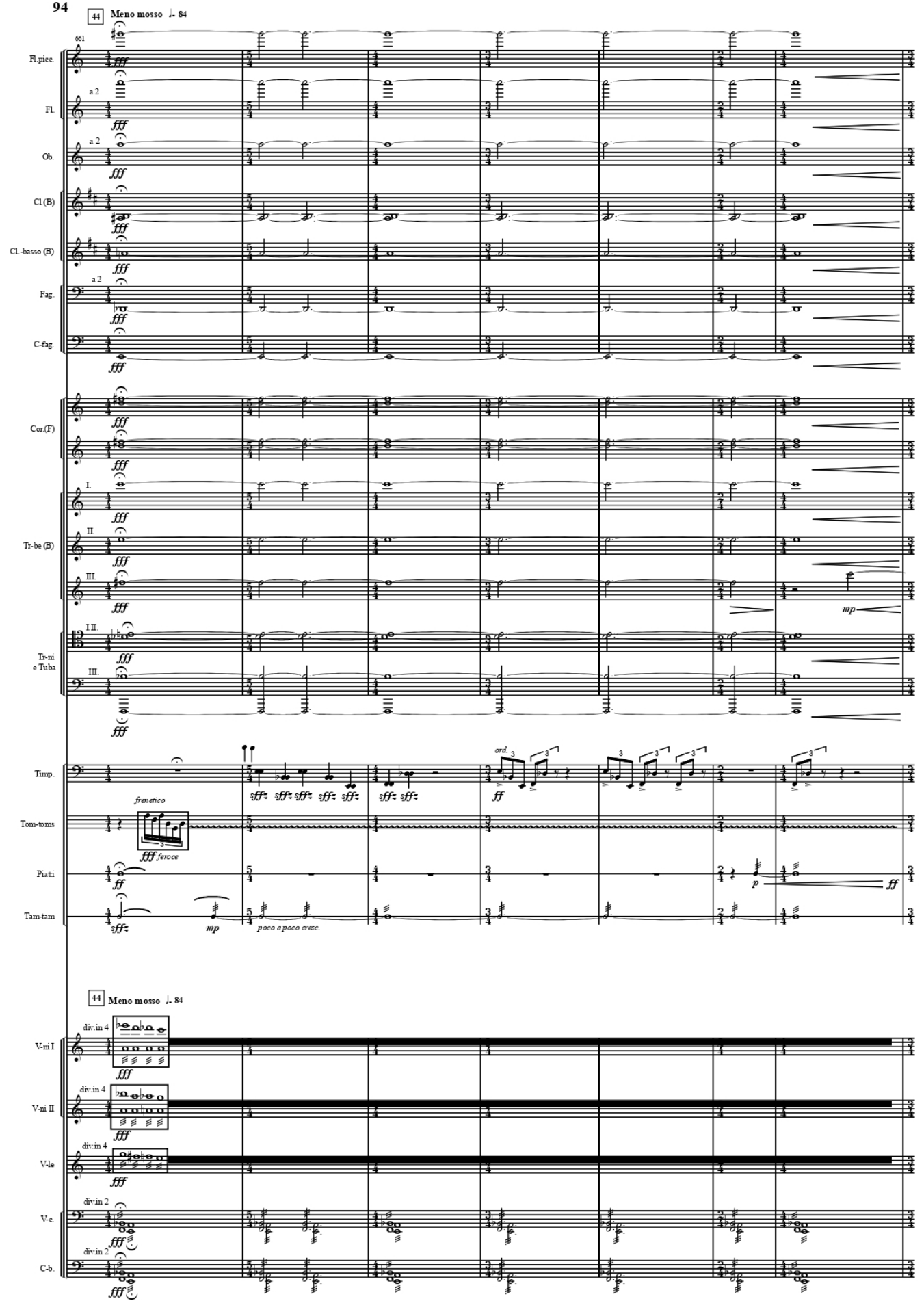




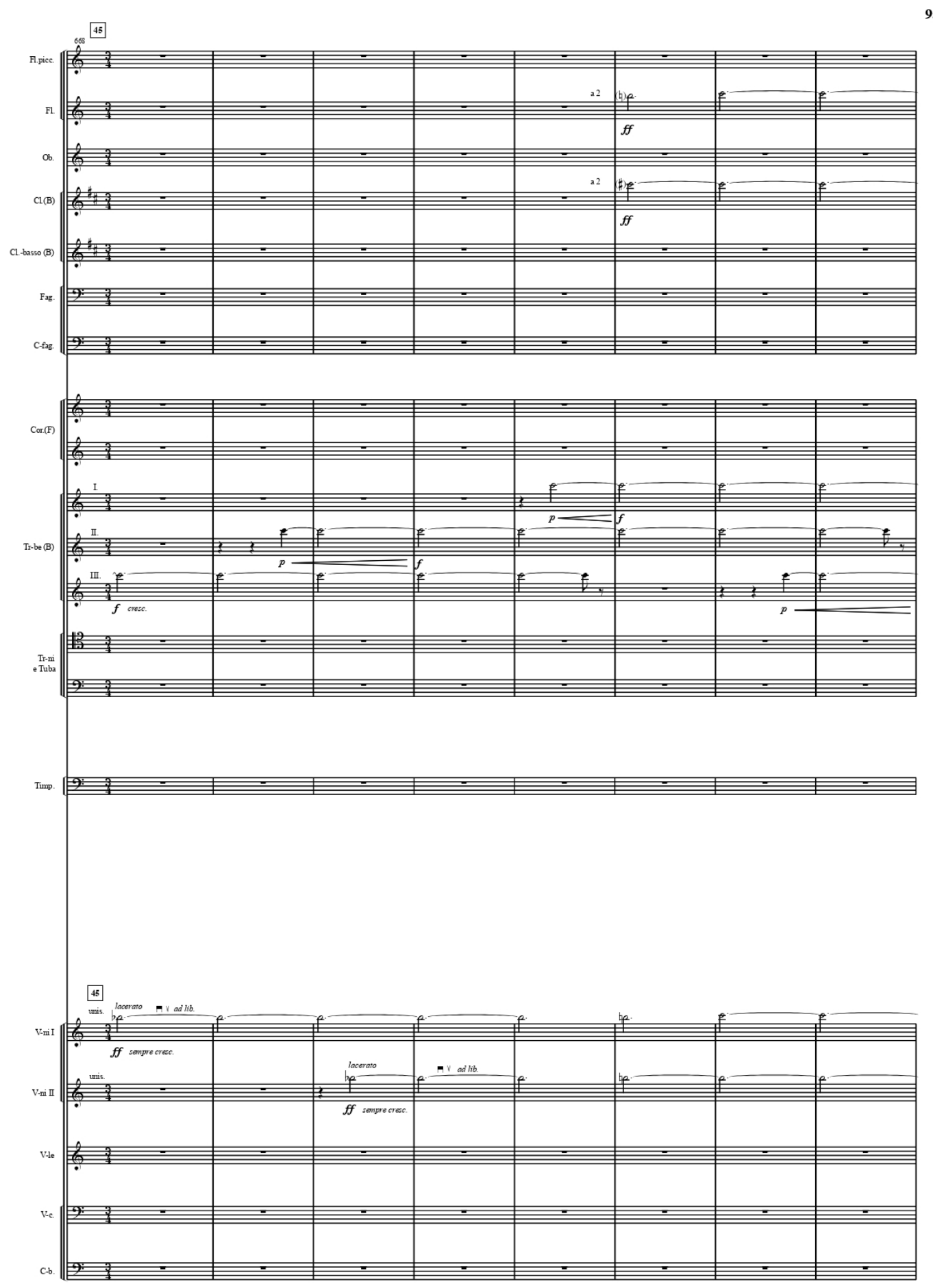




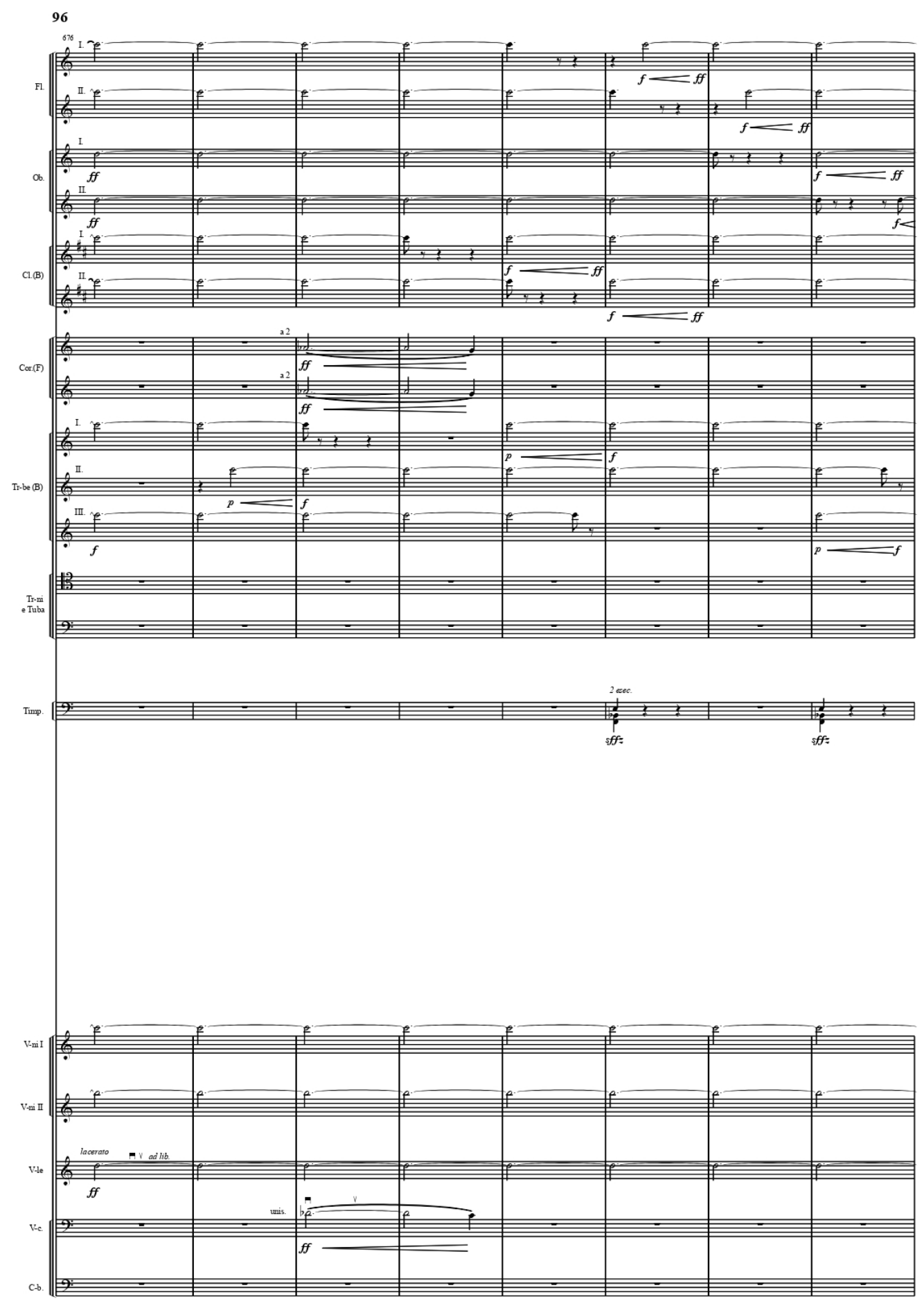



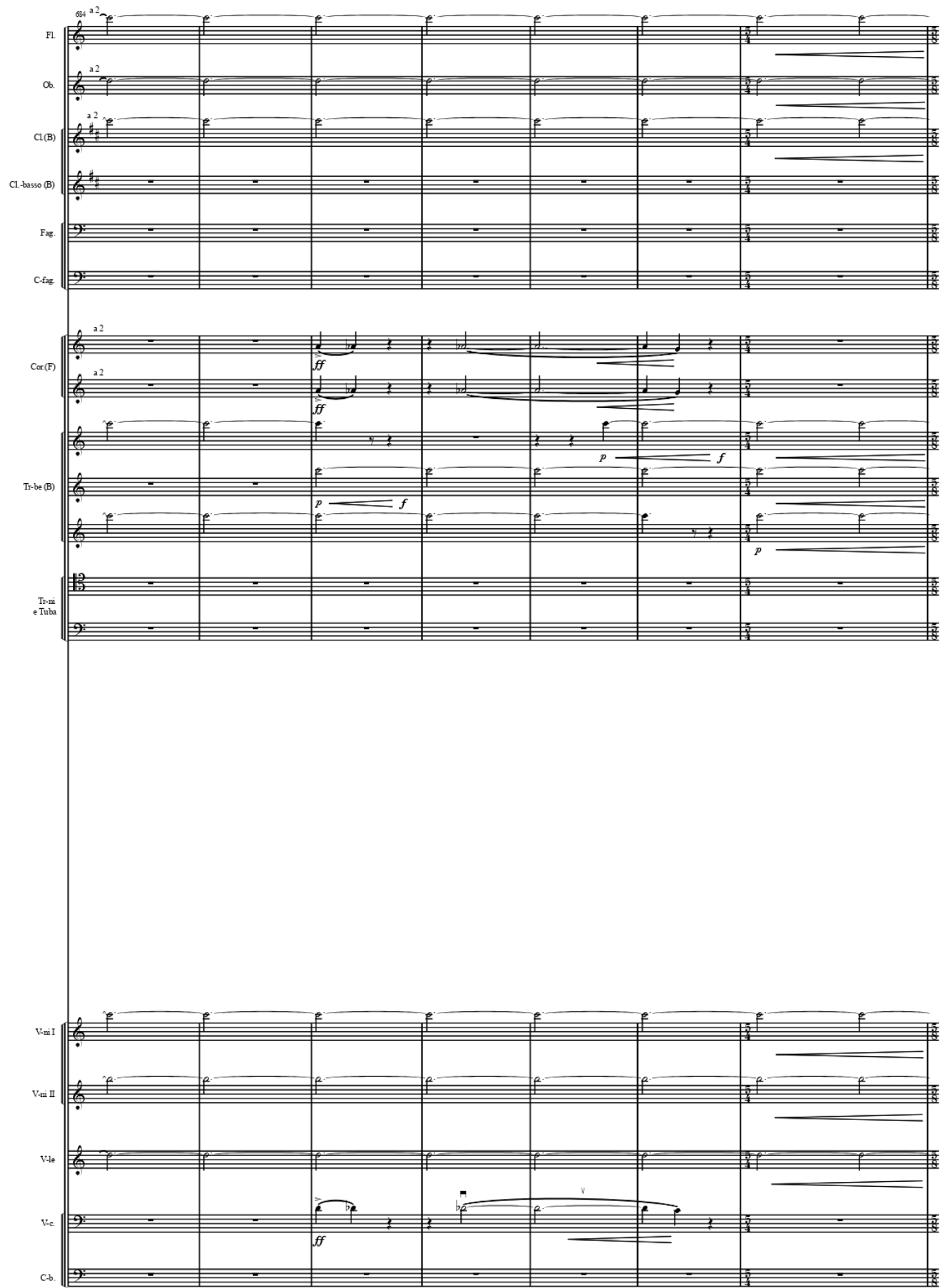


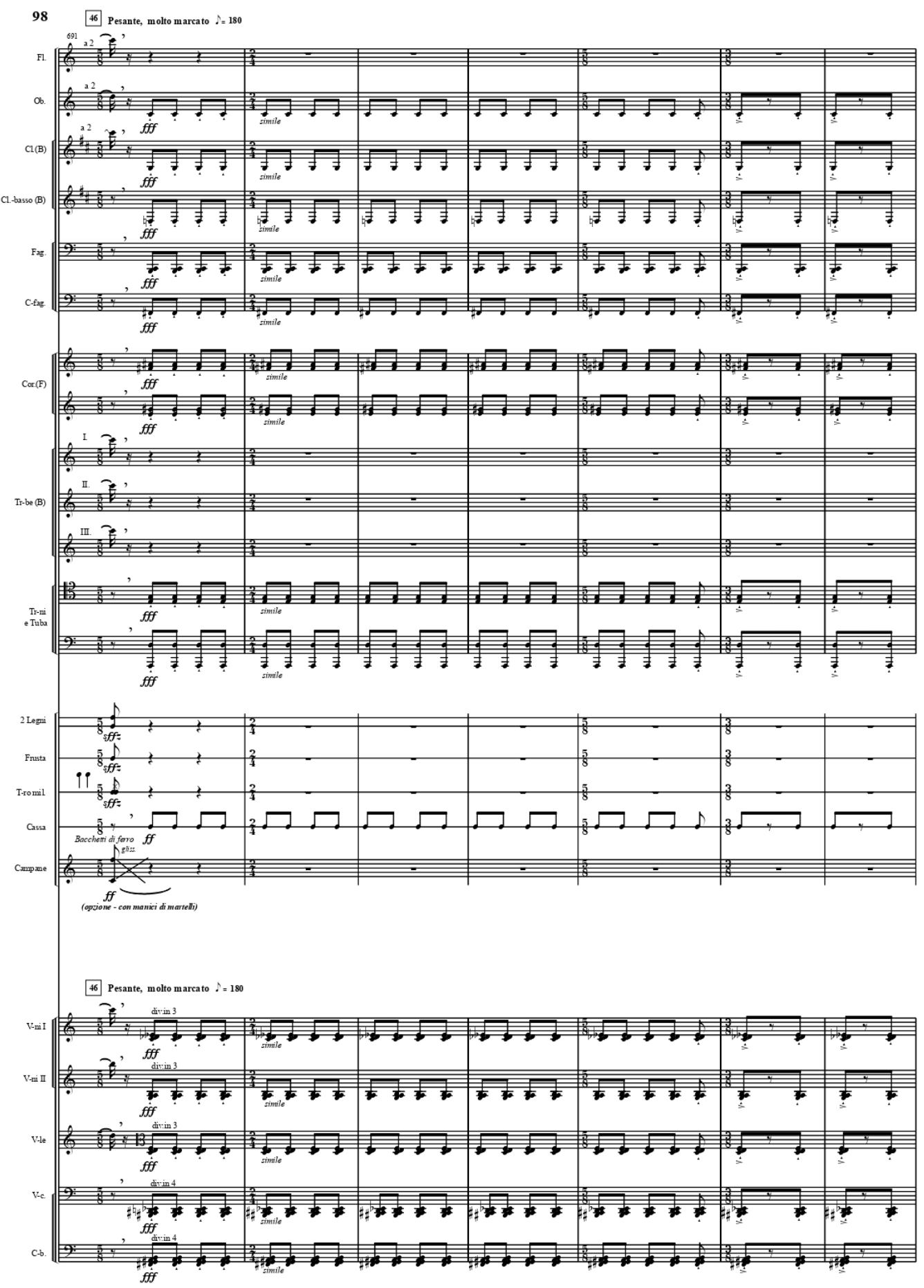



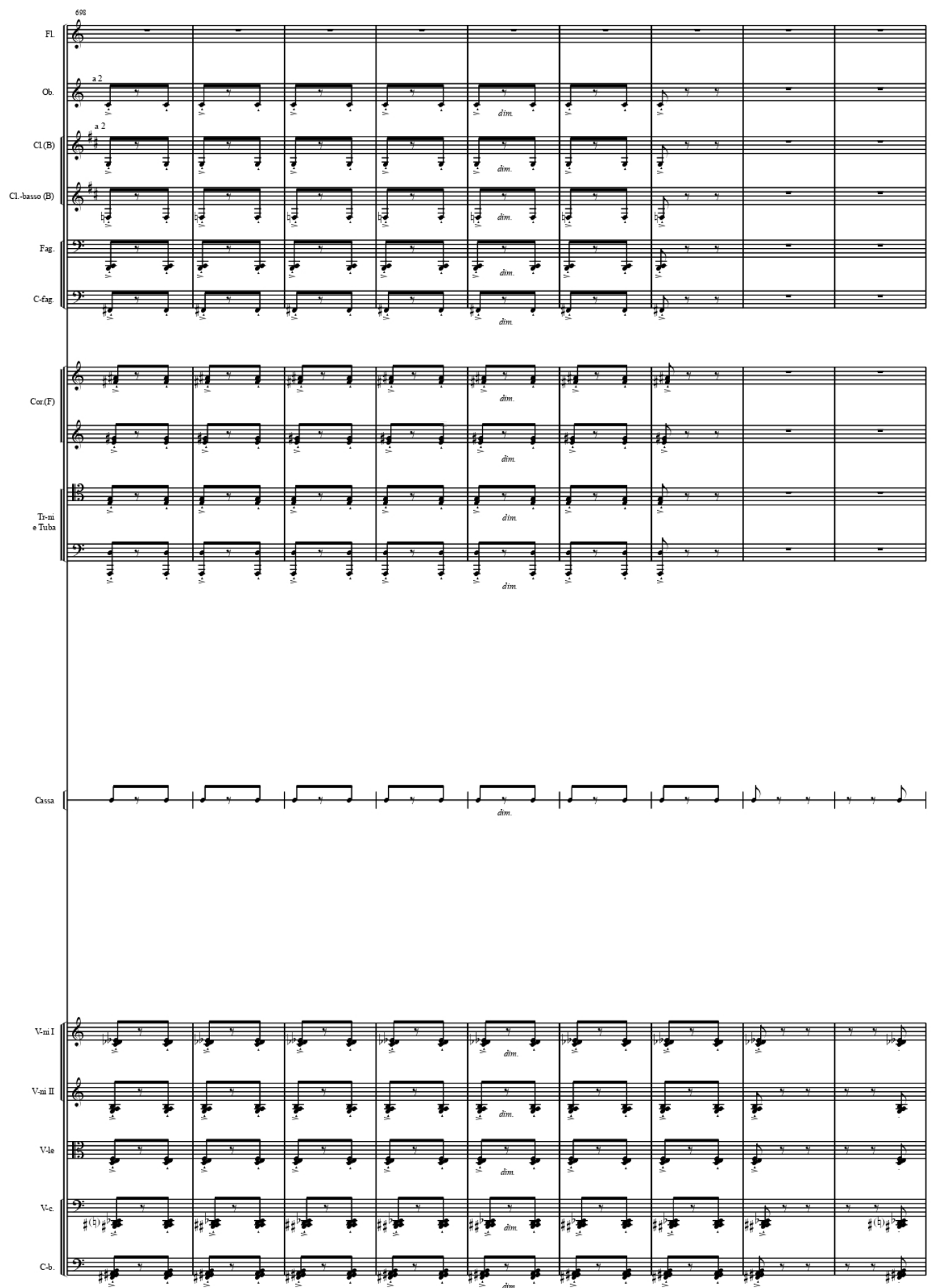


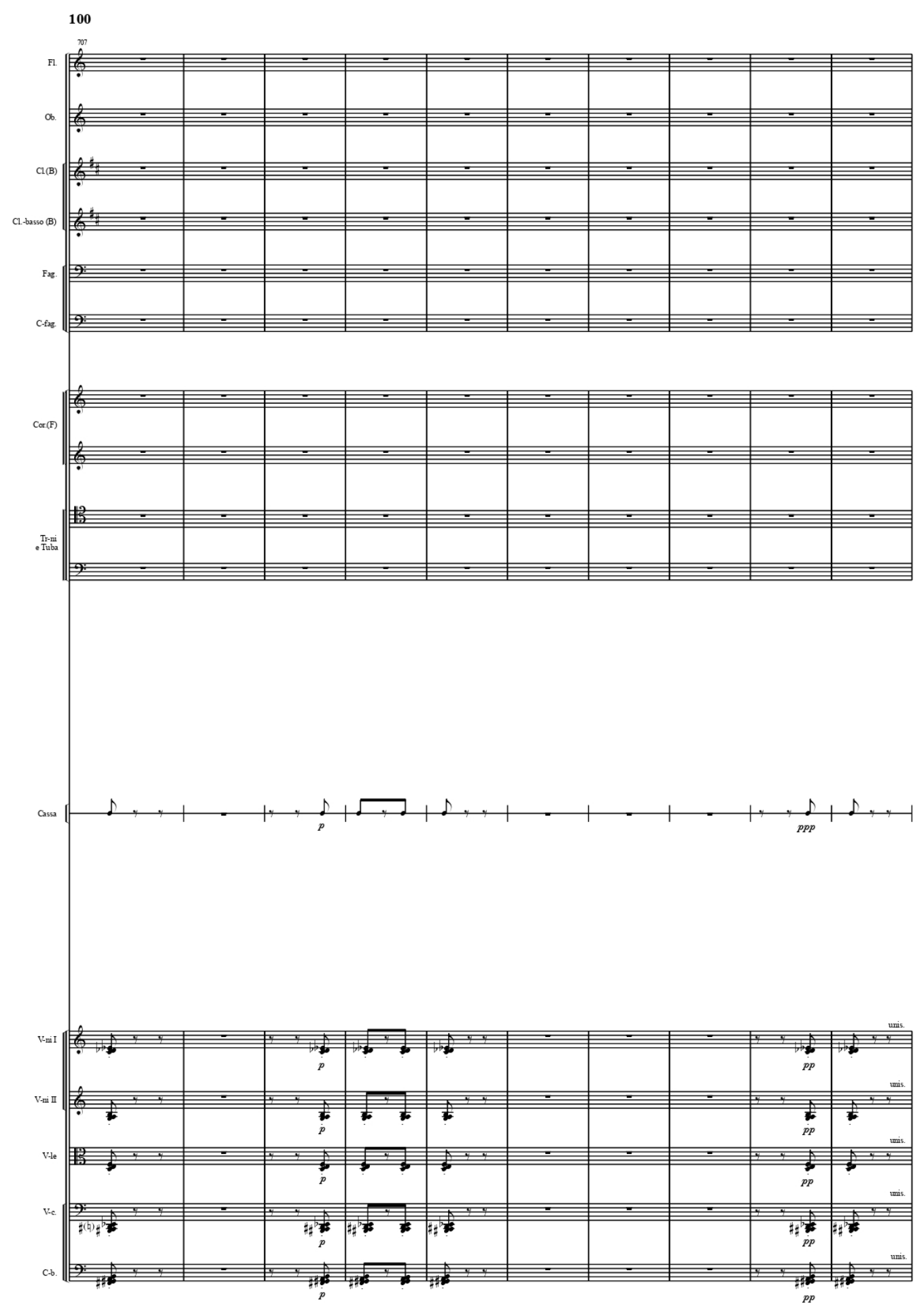



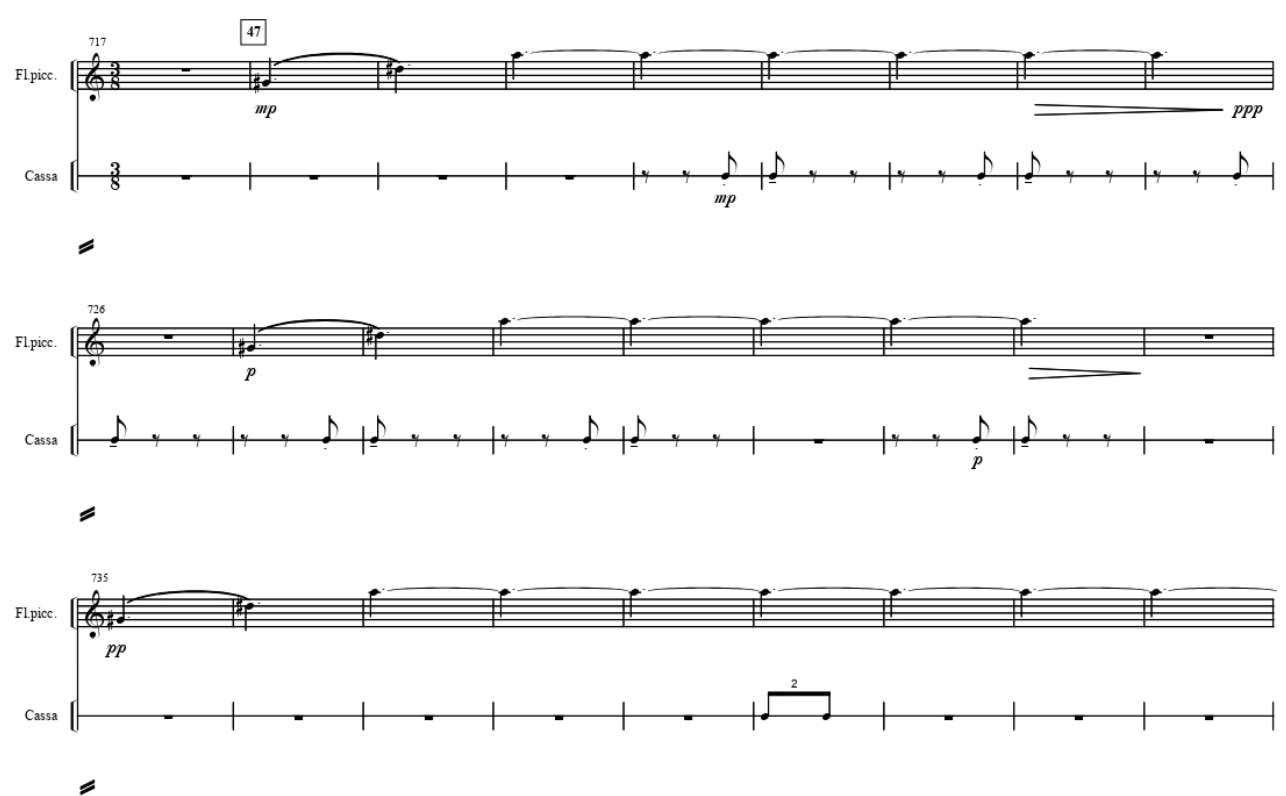

48
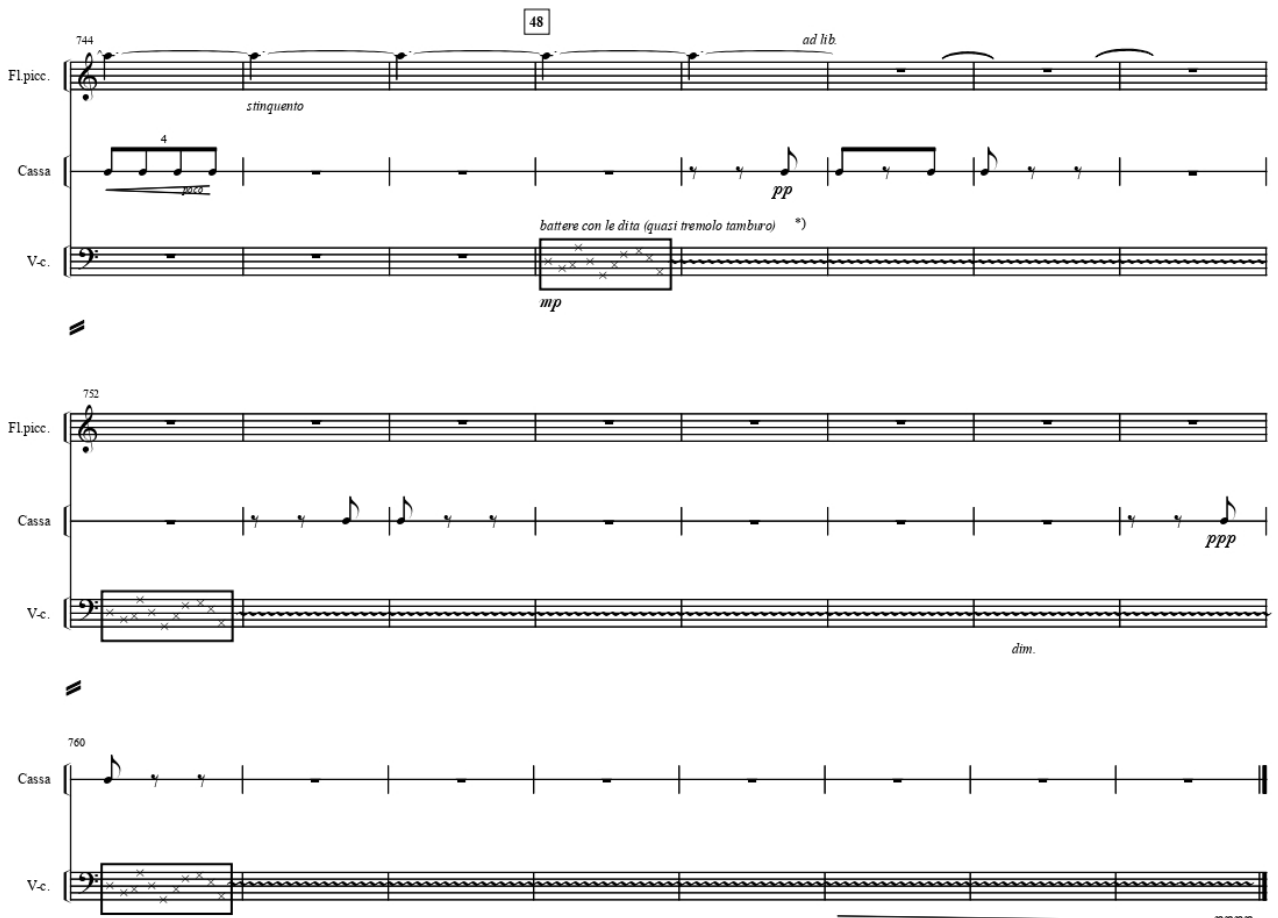


\section{III. "Lacrimosa"}

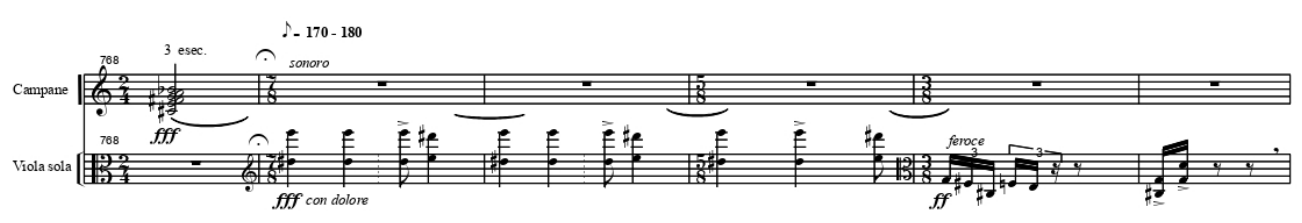

Vins

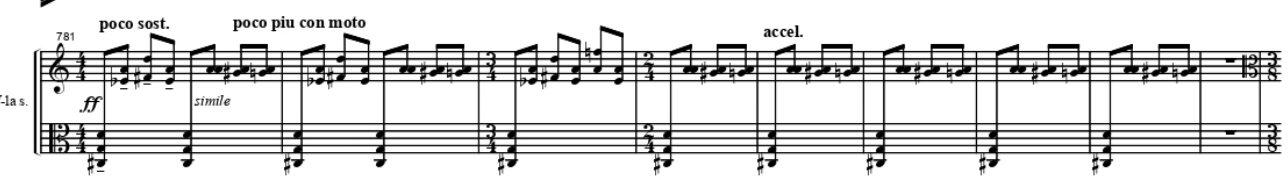

Iffroce

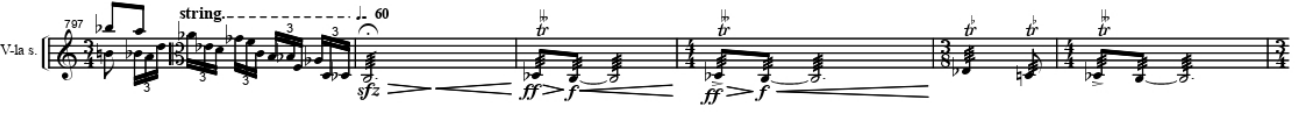

Vins

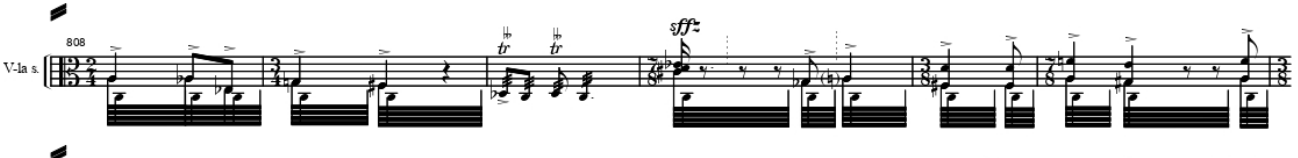

V:as sill

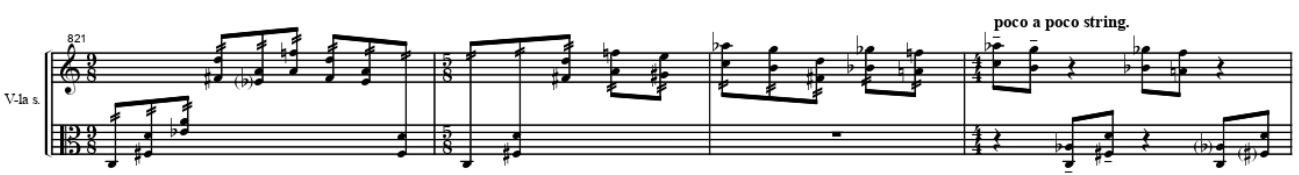




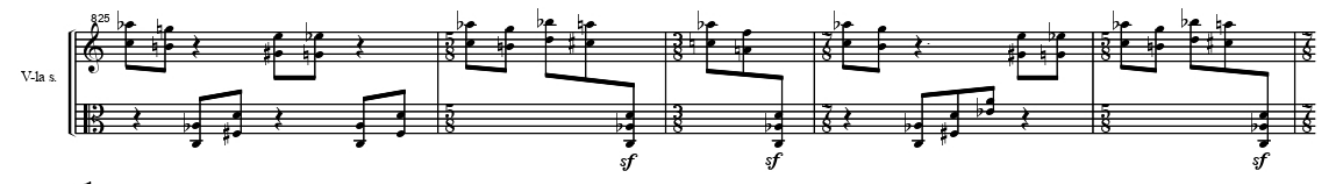

Vias

Vins Vilas as

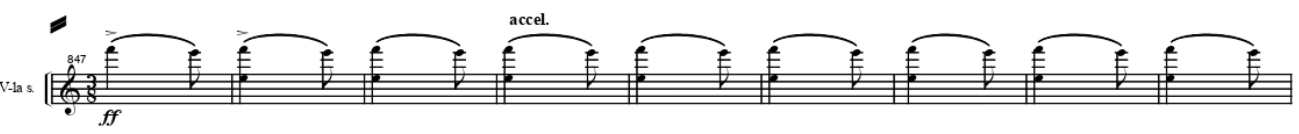

V.la s.

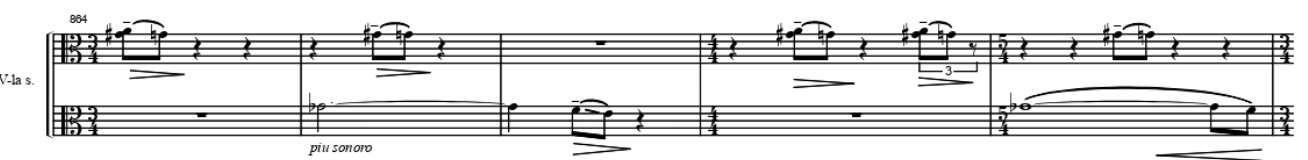

V.a.

V.has 
500.66

Timp.

Sas 1

C.b.

Iimp 1

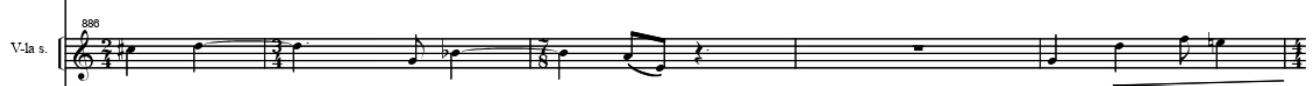

c.b.

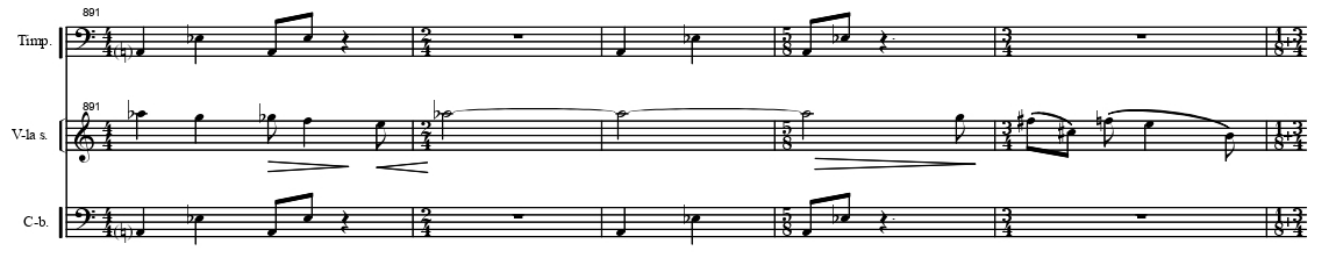

C.b. (ausi Valea, tempo precedente) 


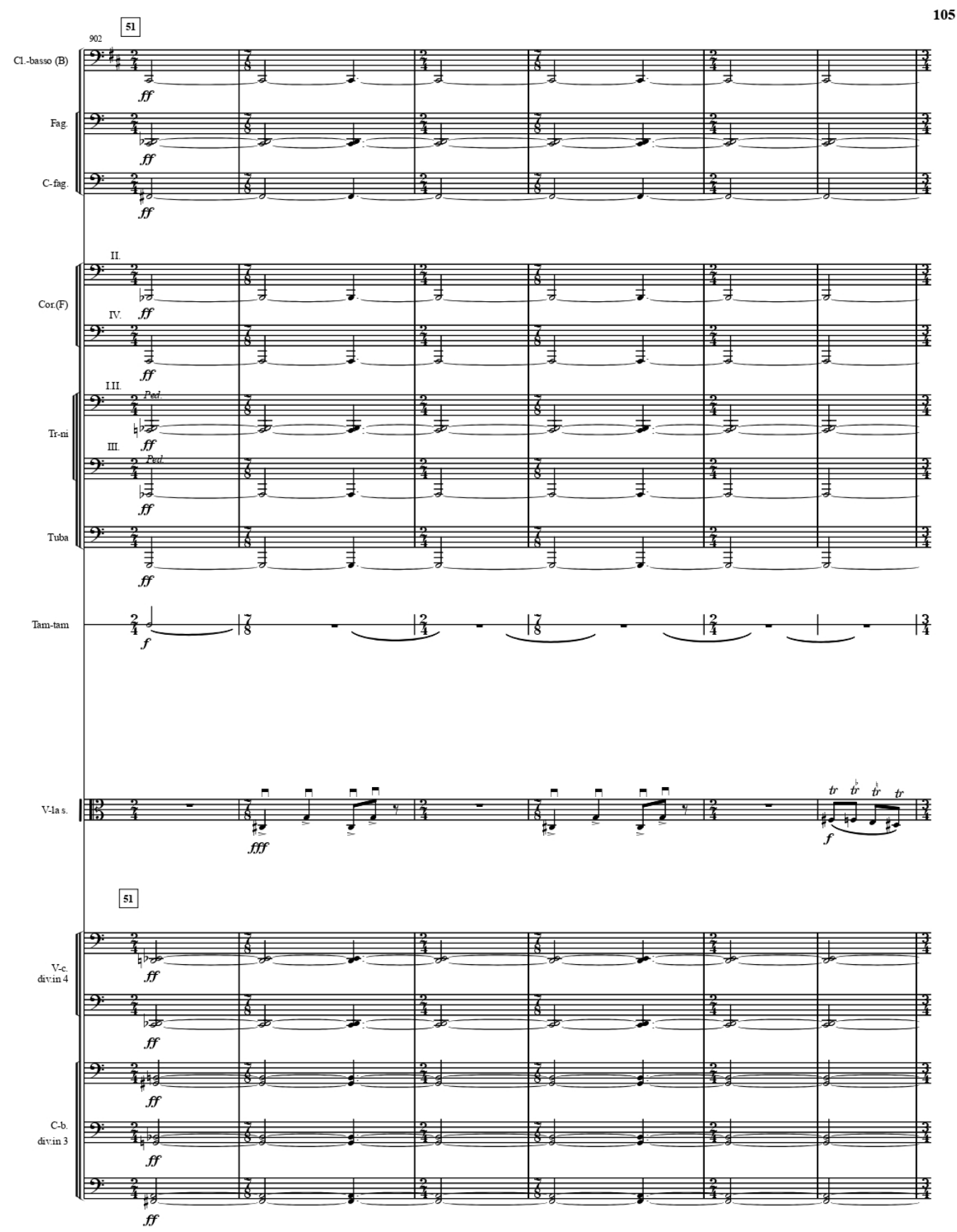




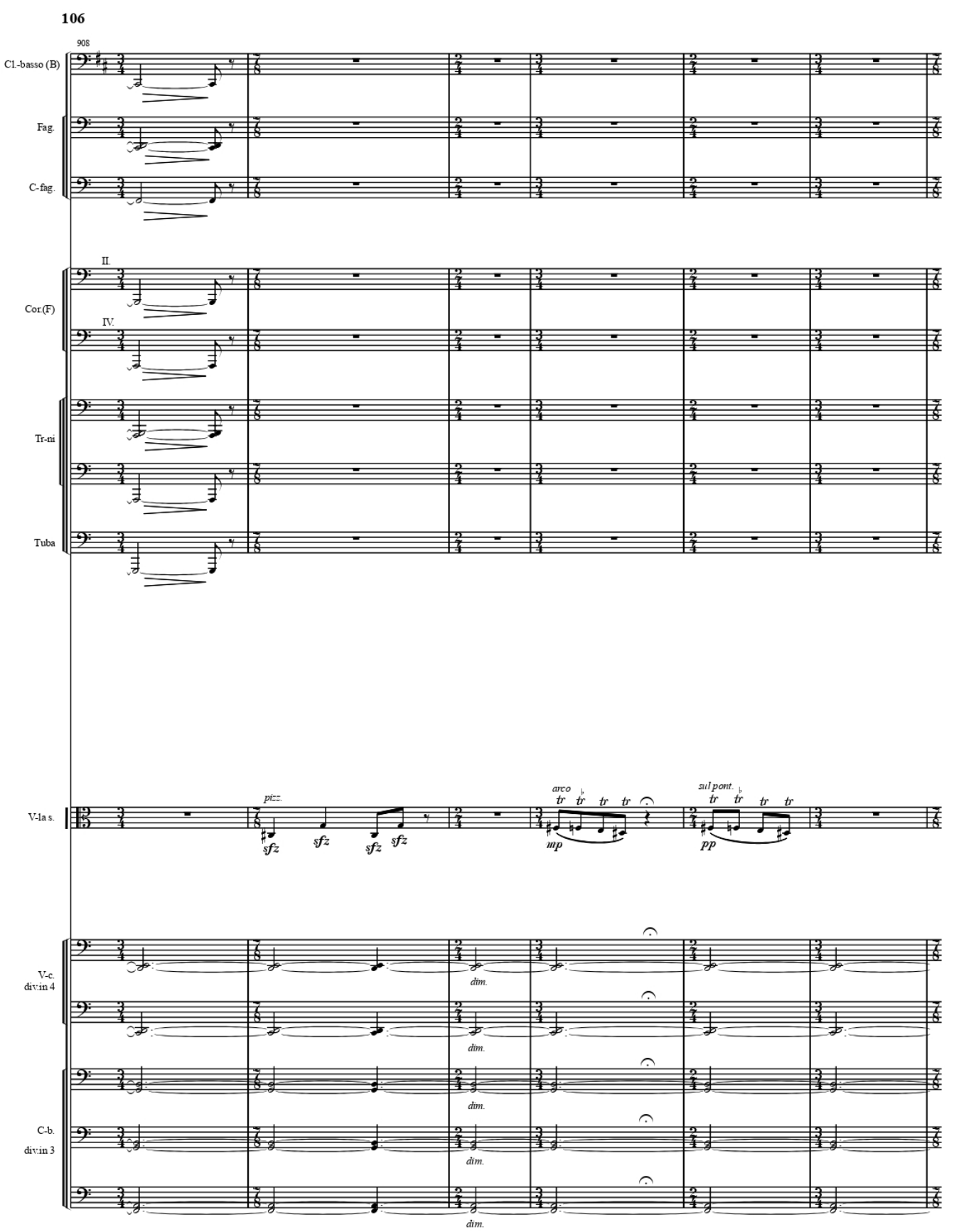




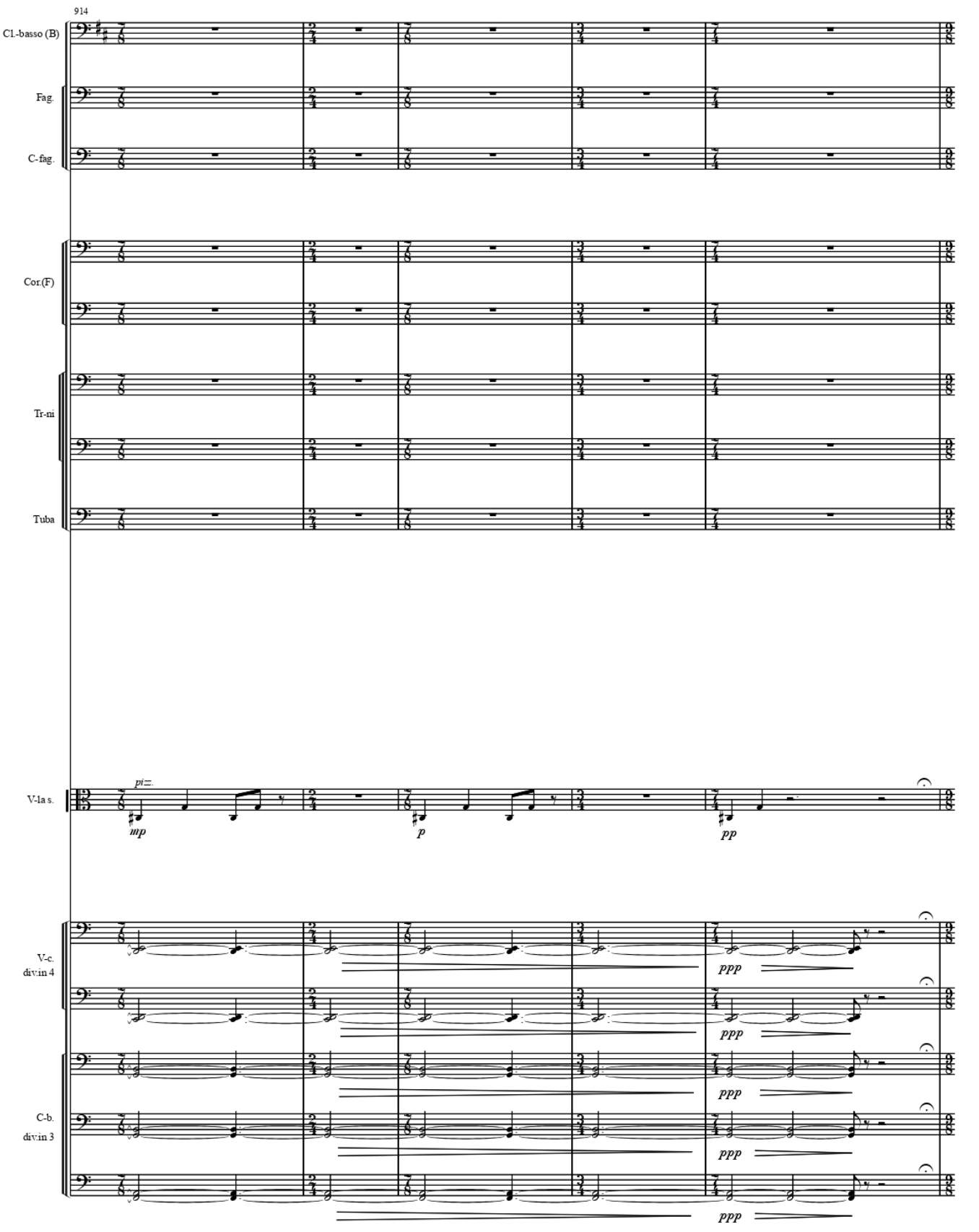


52 Adagio doglioso $\mathrm{J}=24-30$
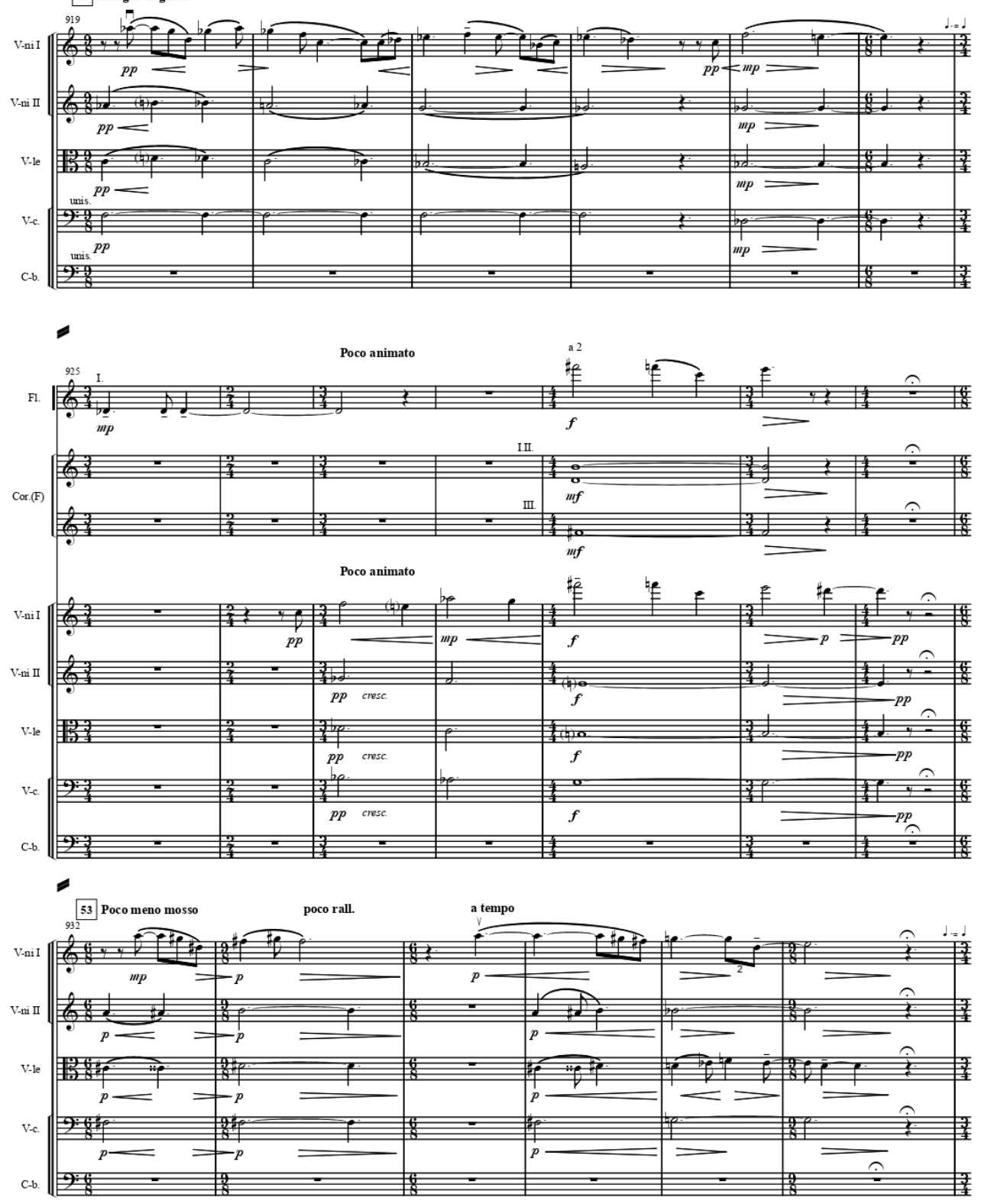

Cor(F) 
IV. "Lux aeterna"

(When performing "Lux Aeterna" as an independent work,

please begin in measure 938 with the French Horn solo)
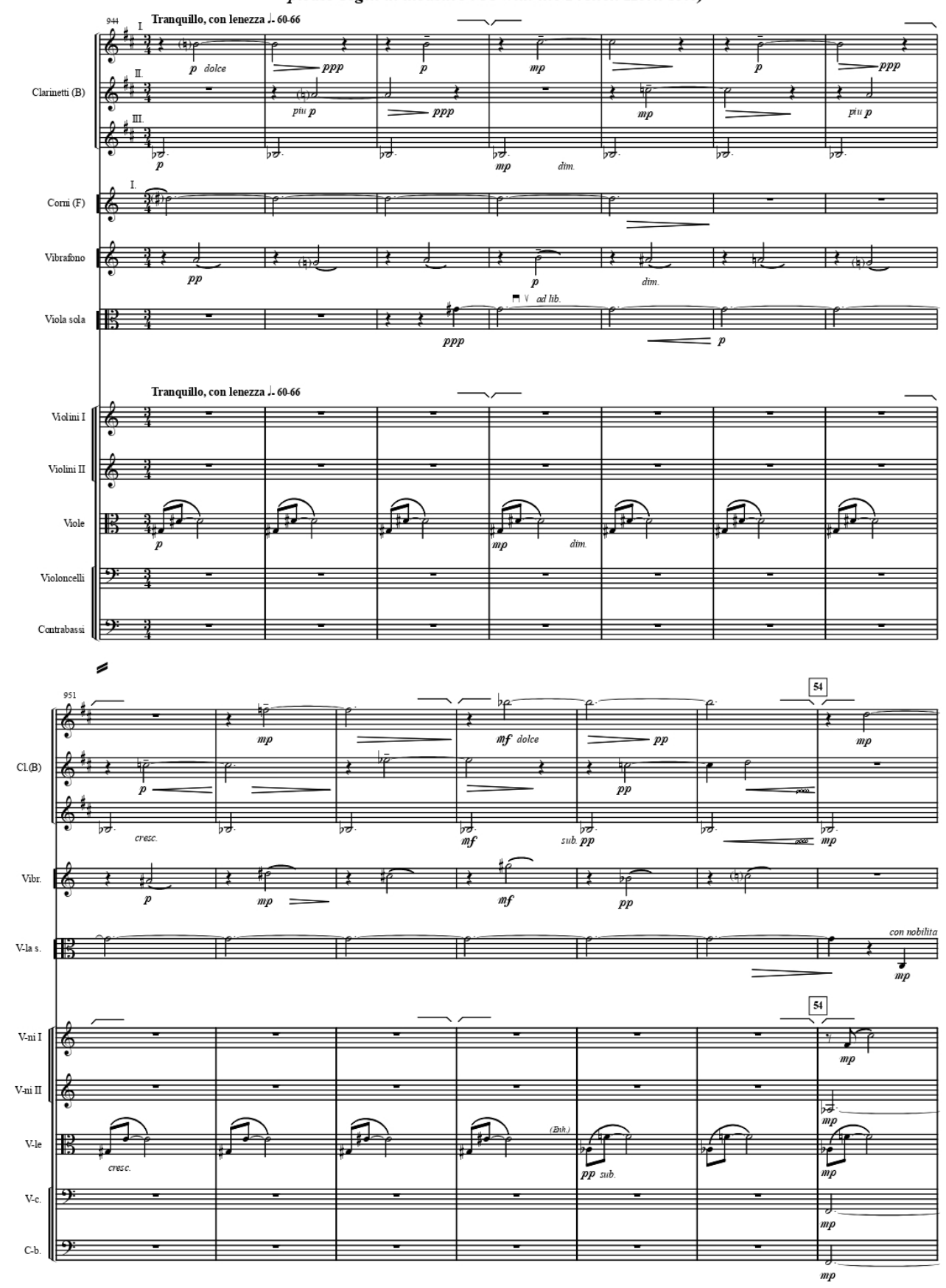

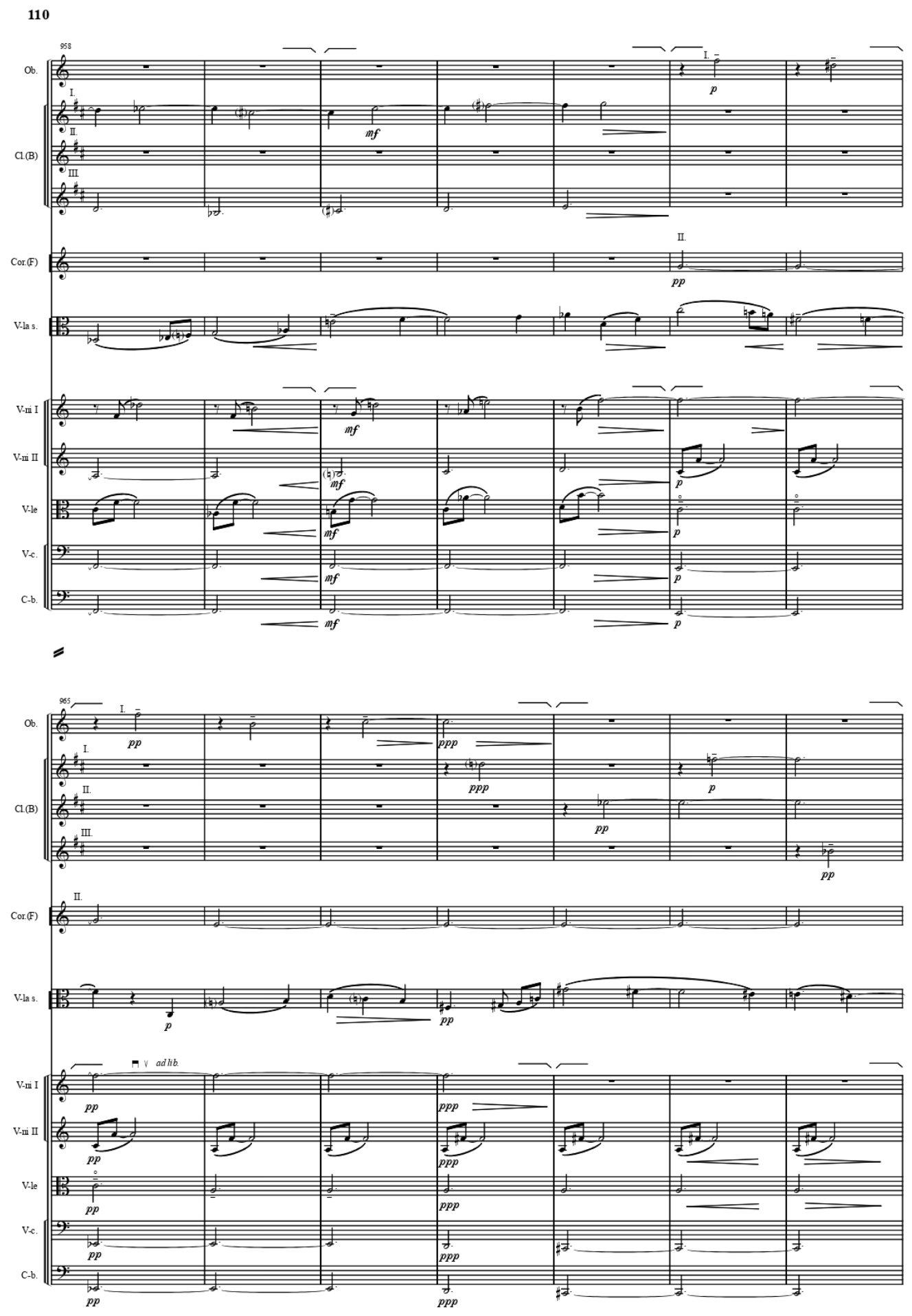

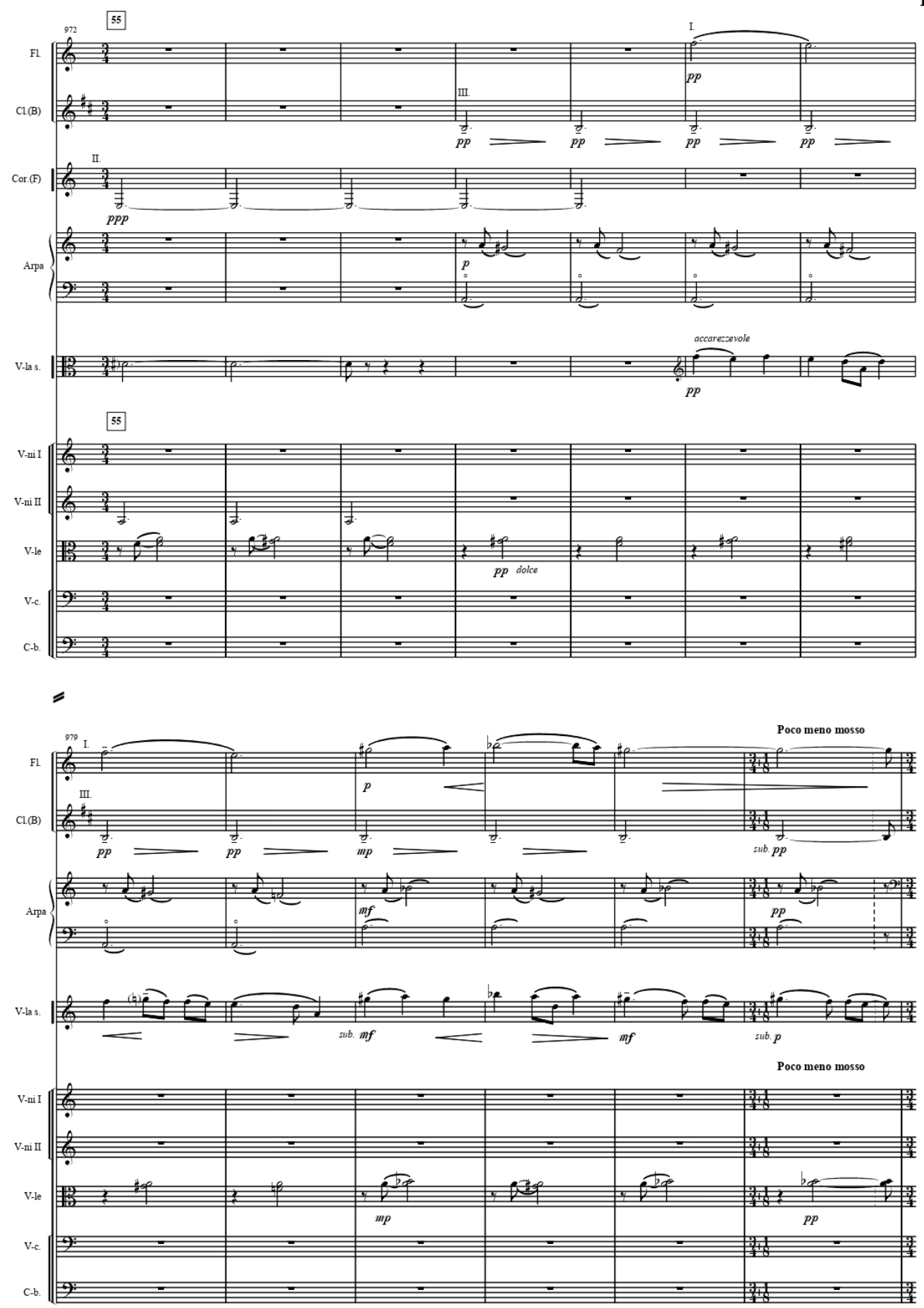


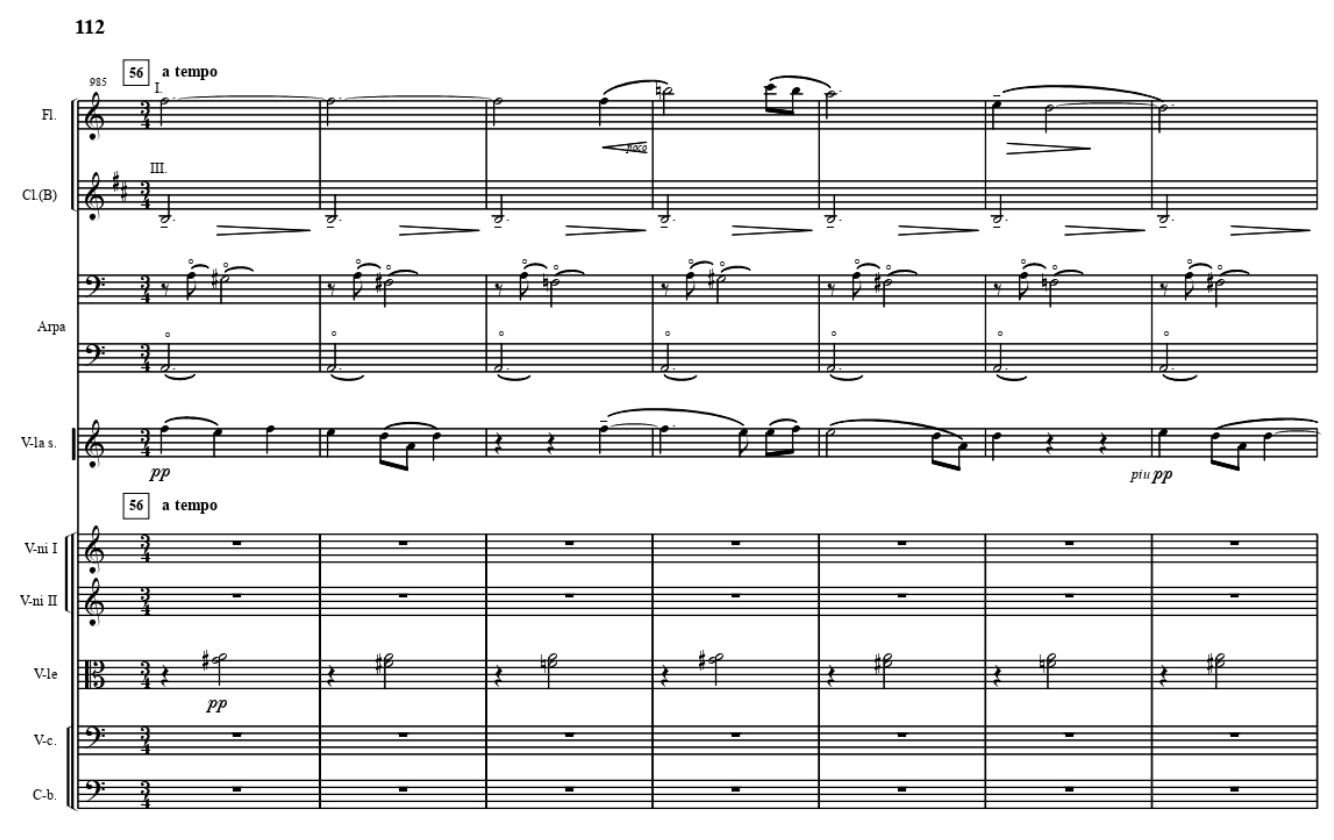

57

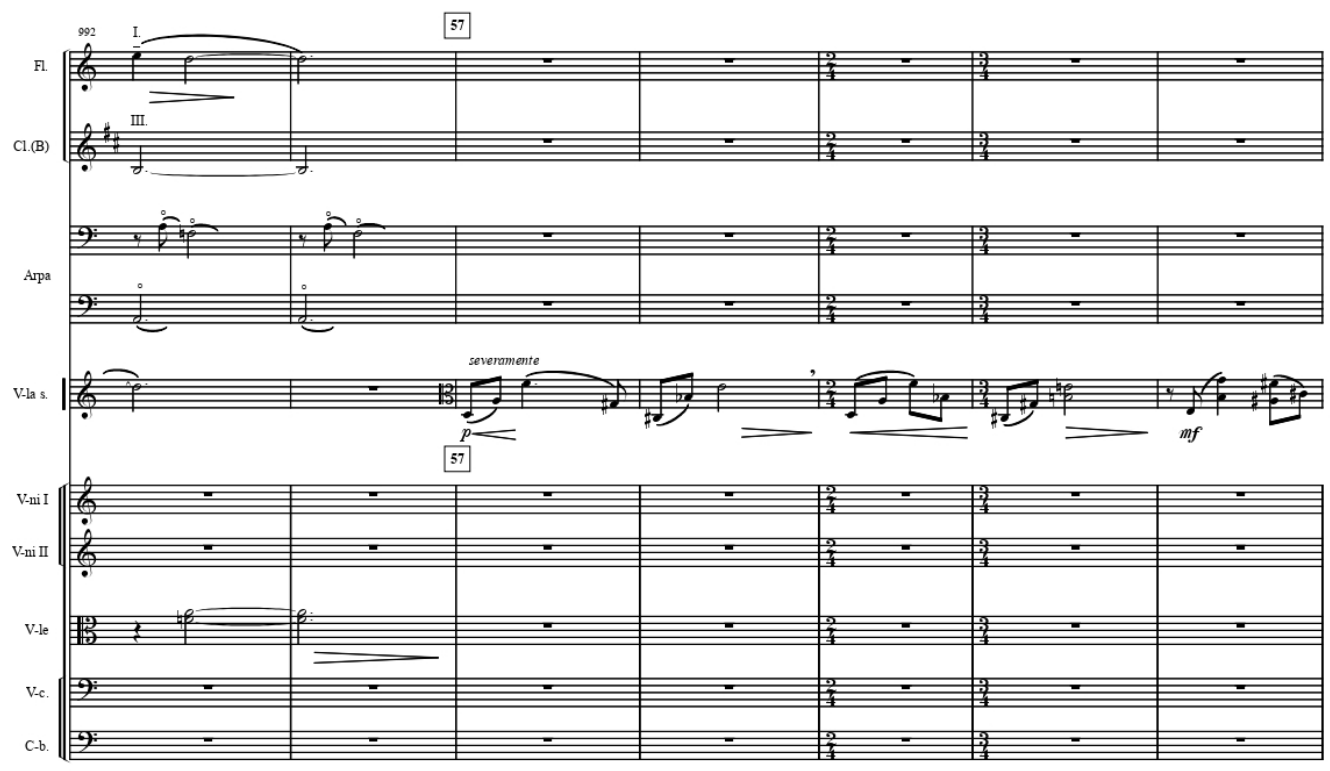

V.as. 

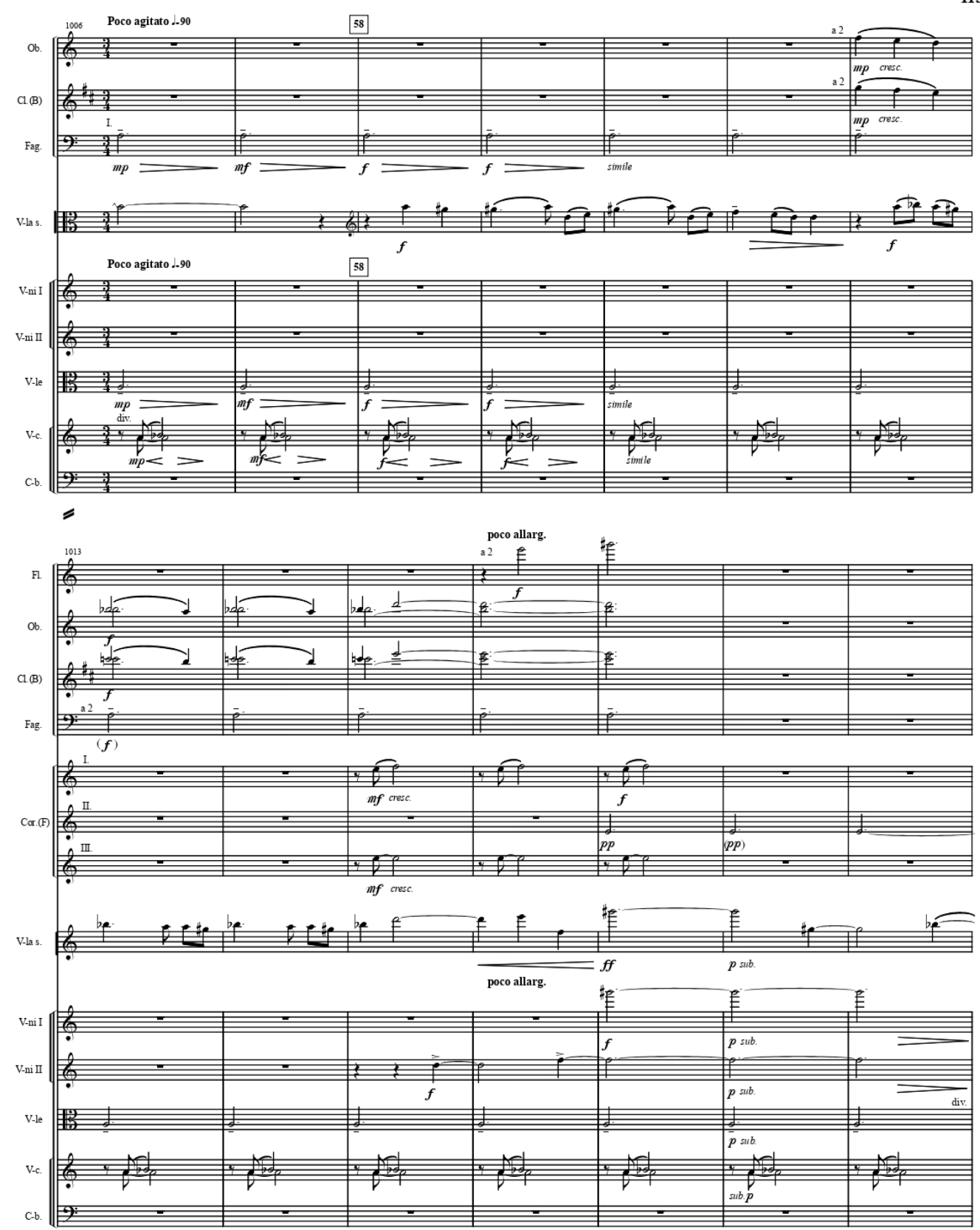

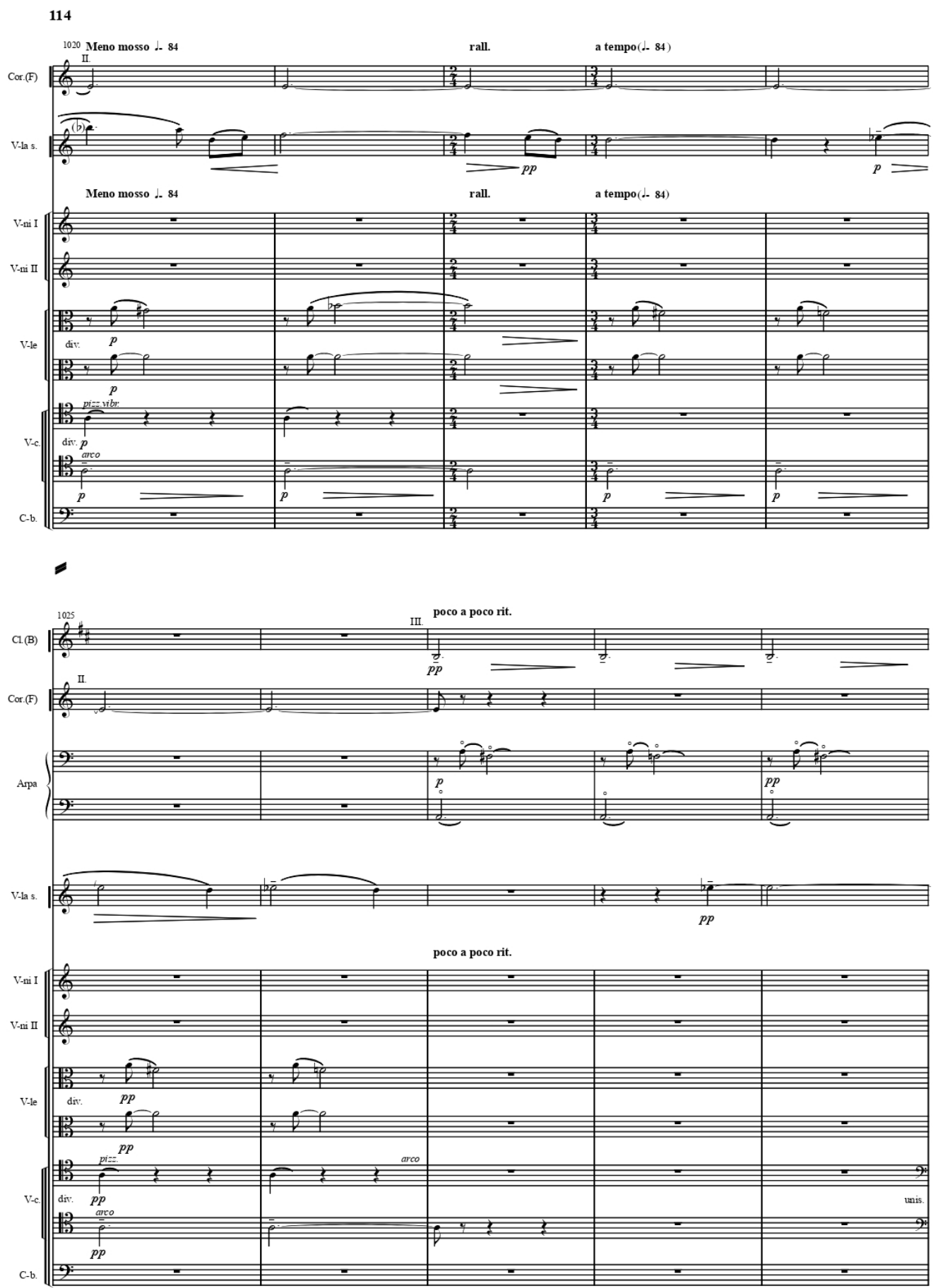

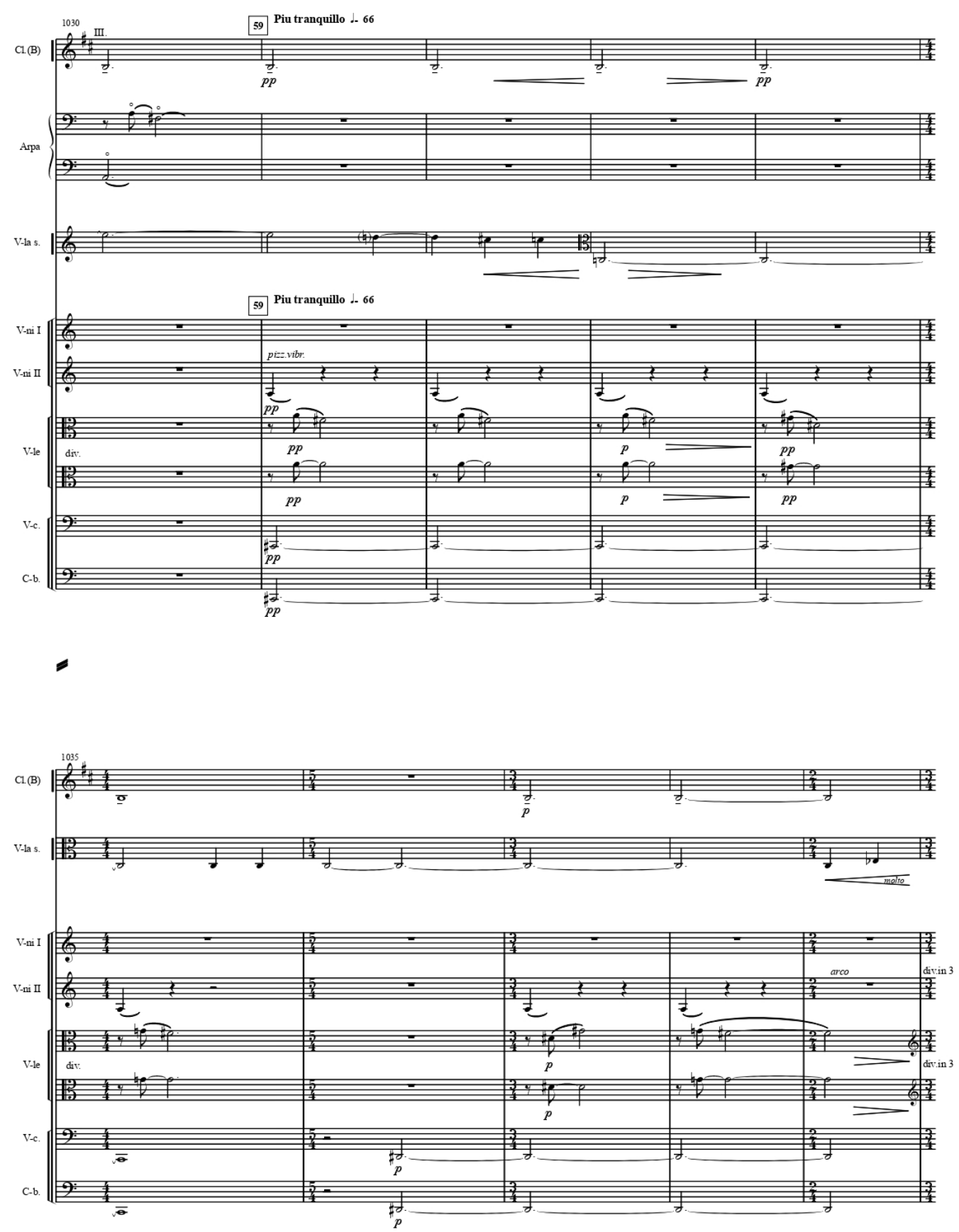

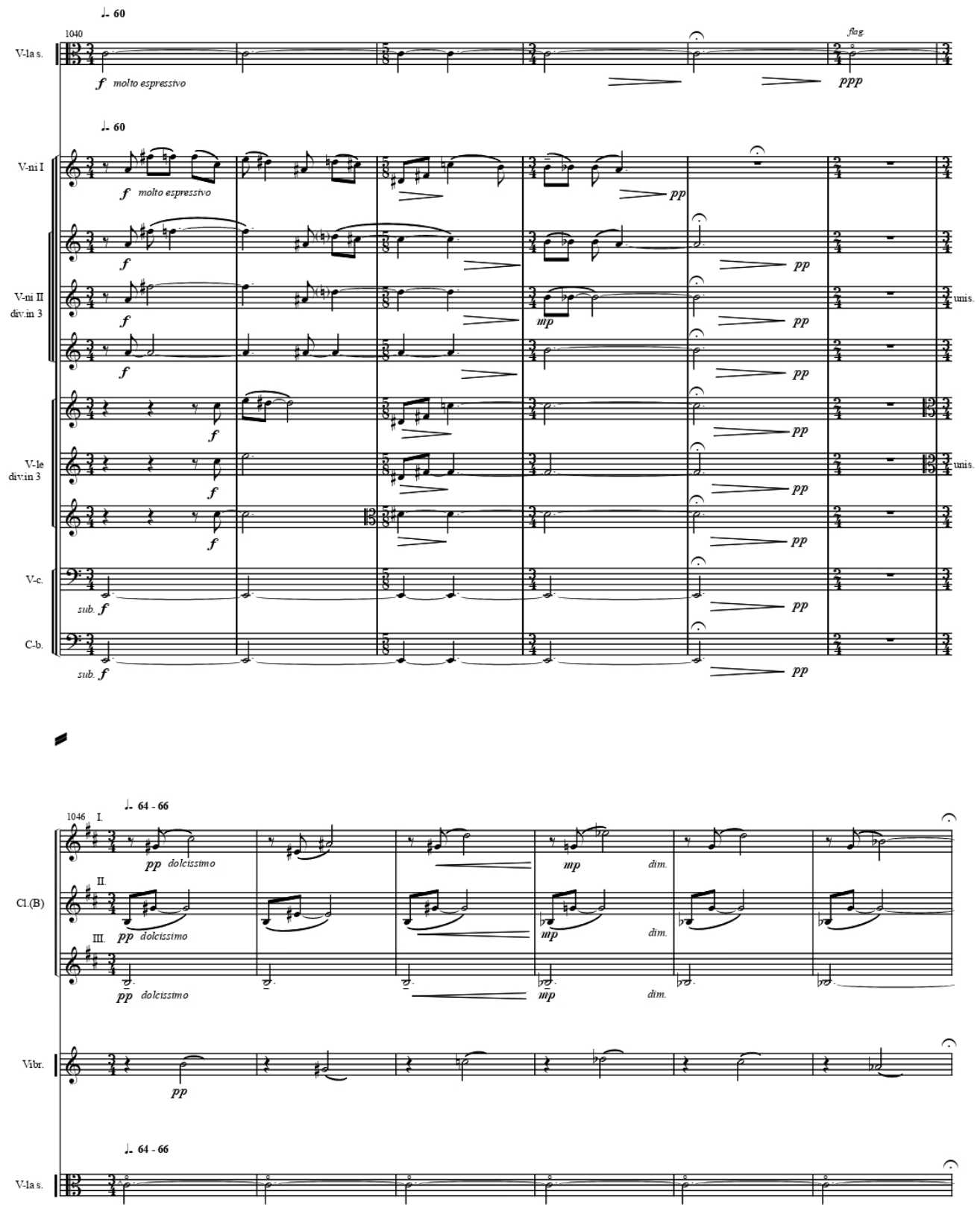

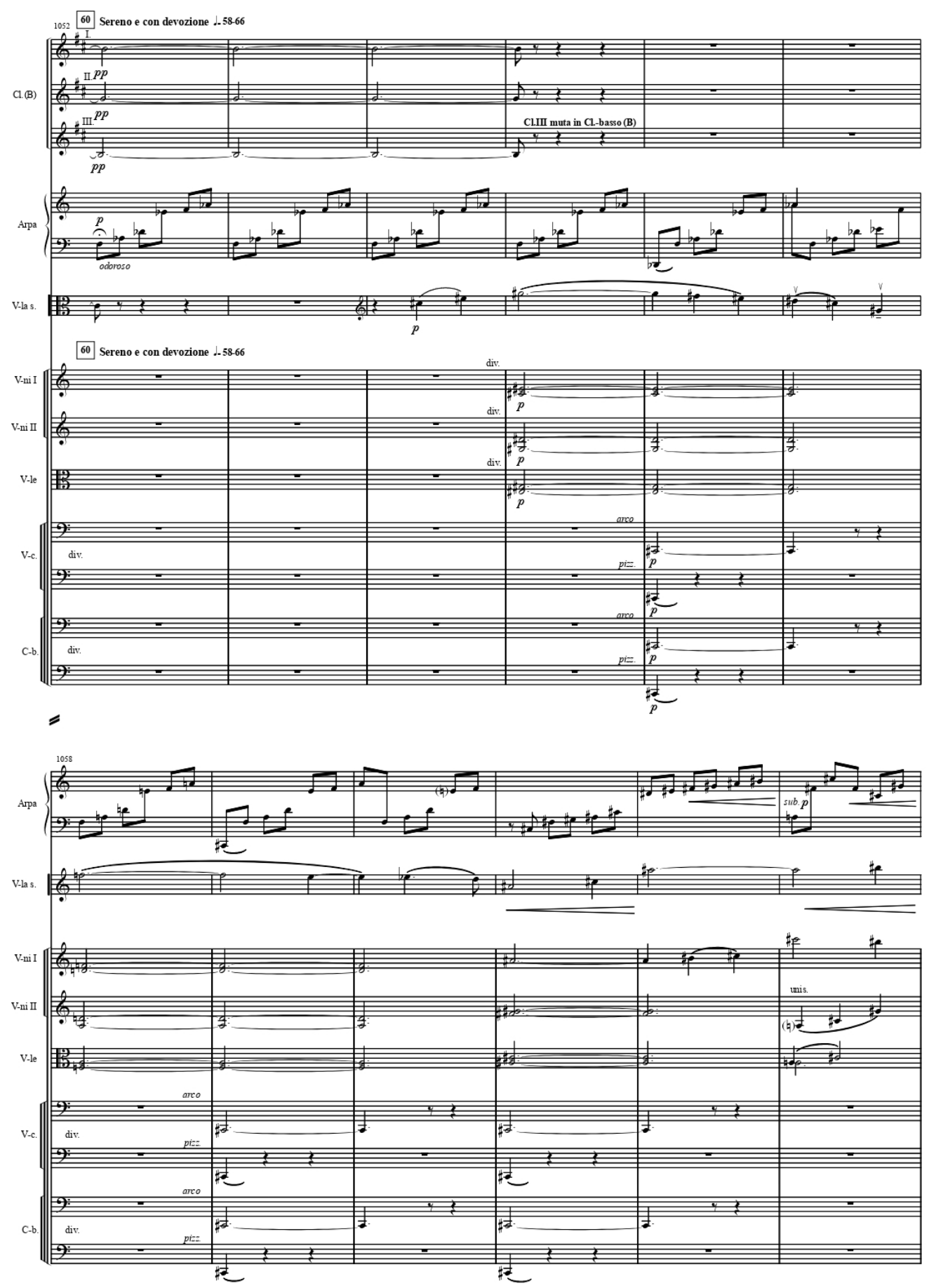

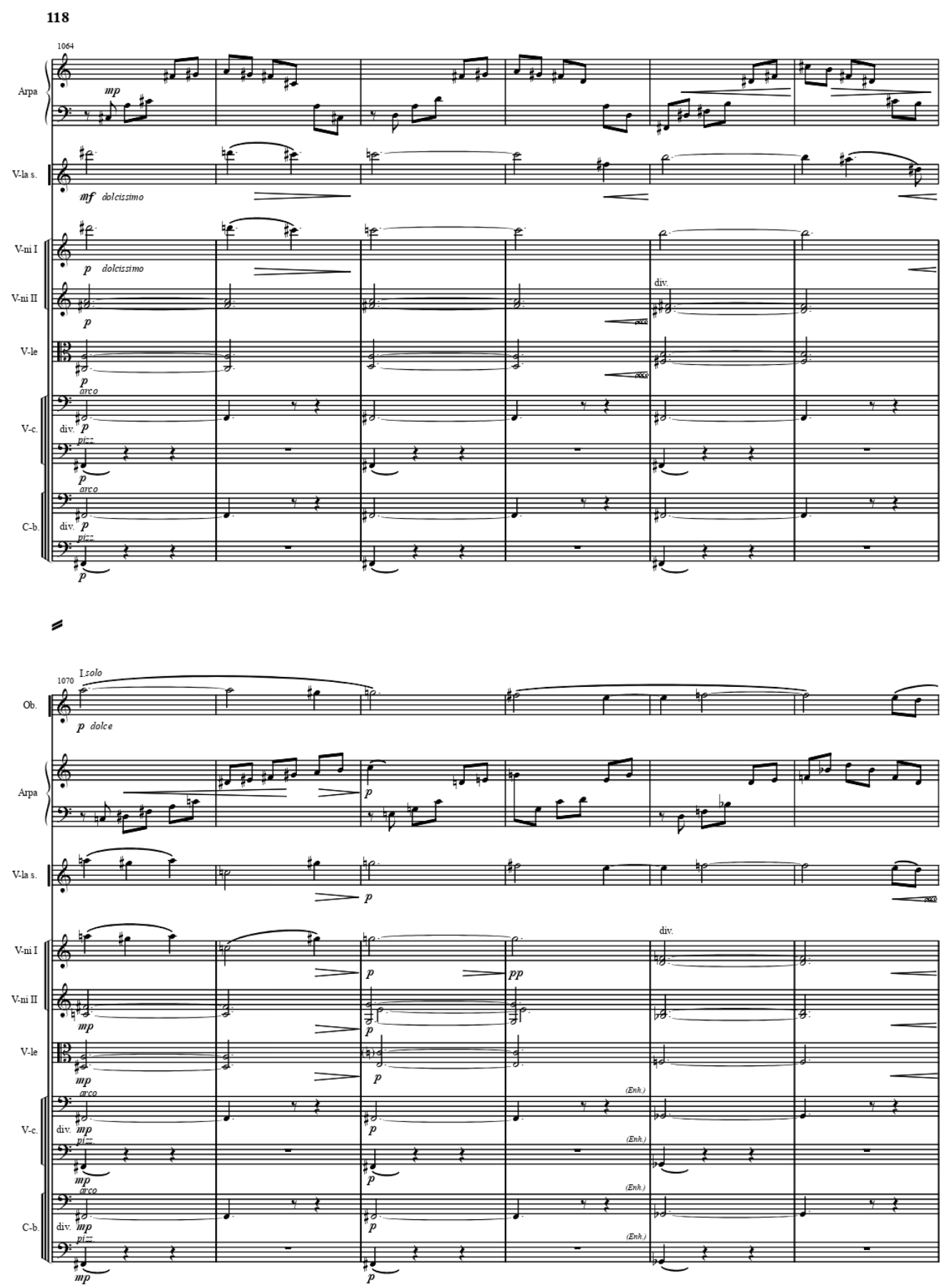

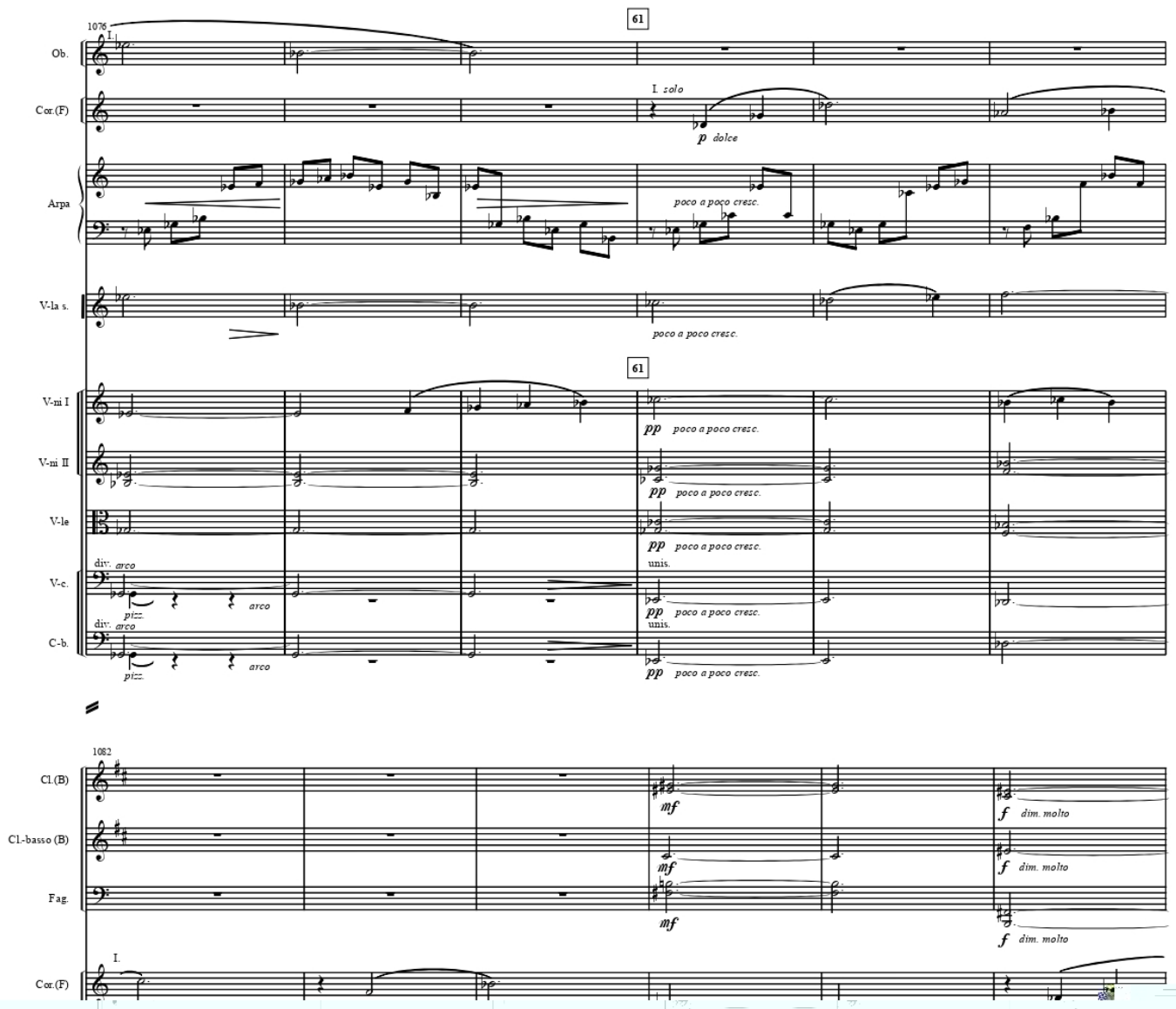


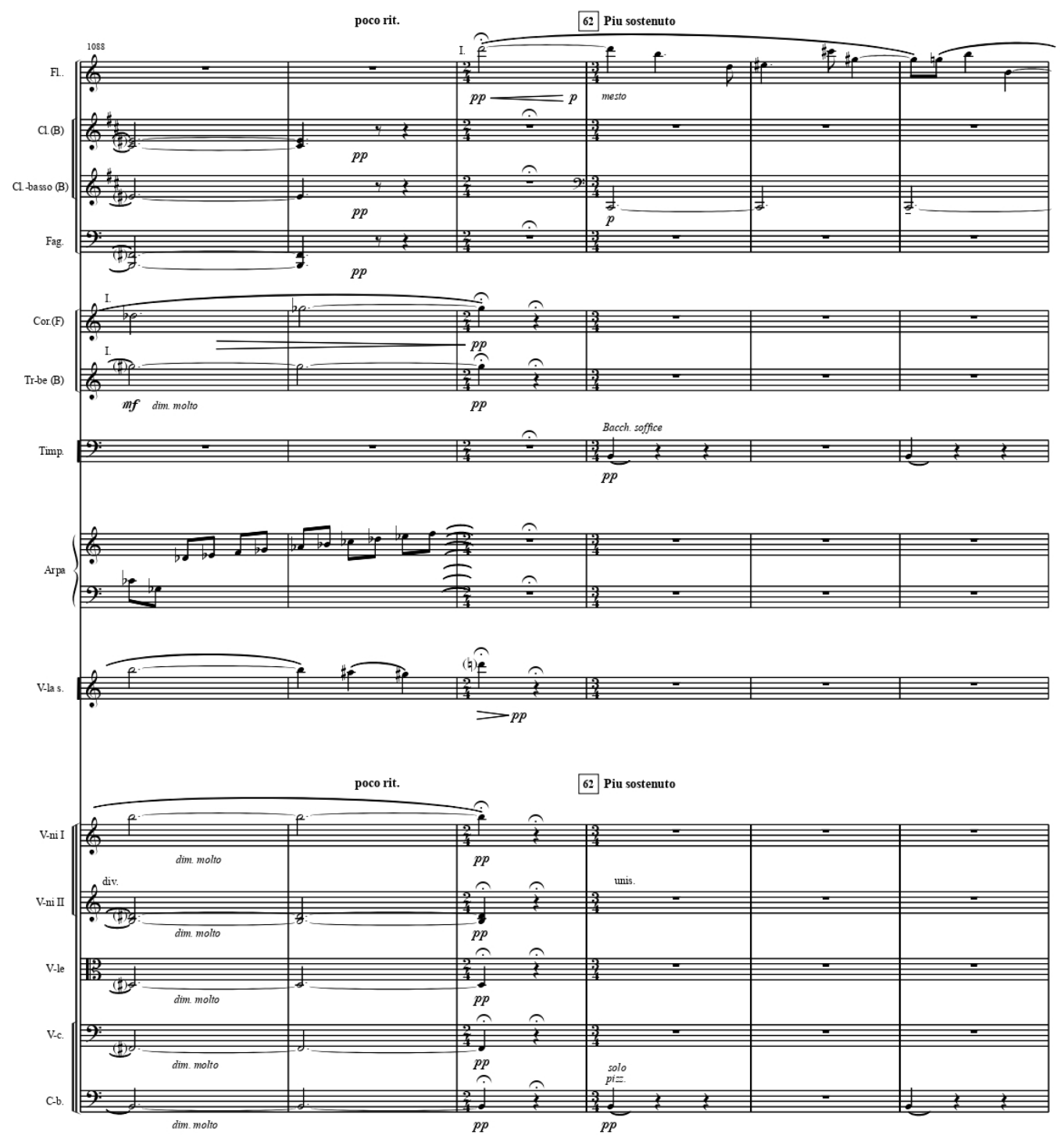



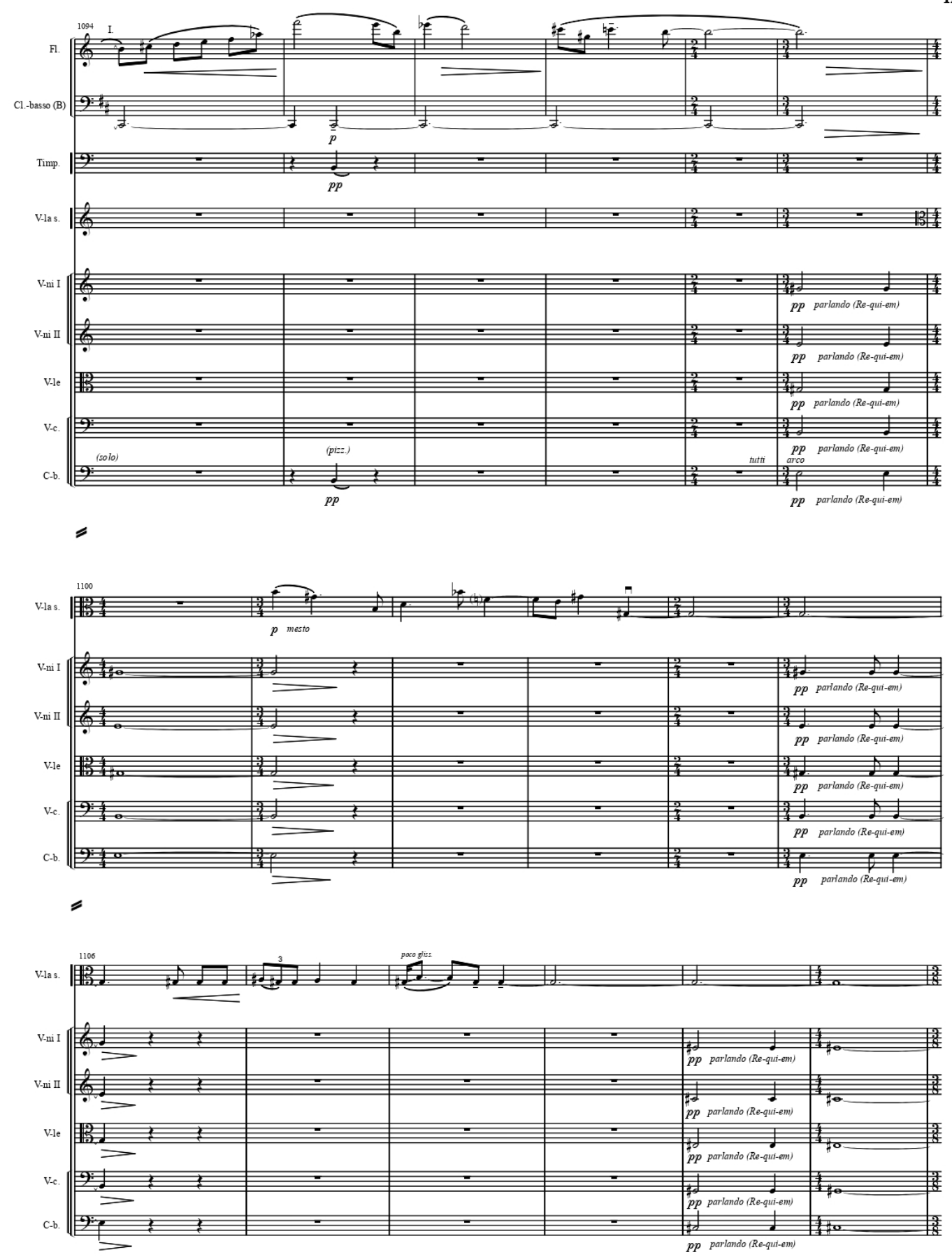


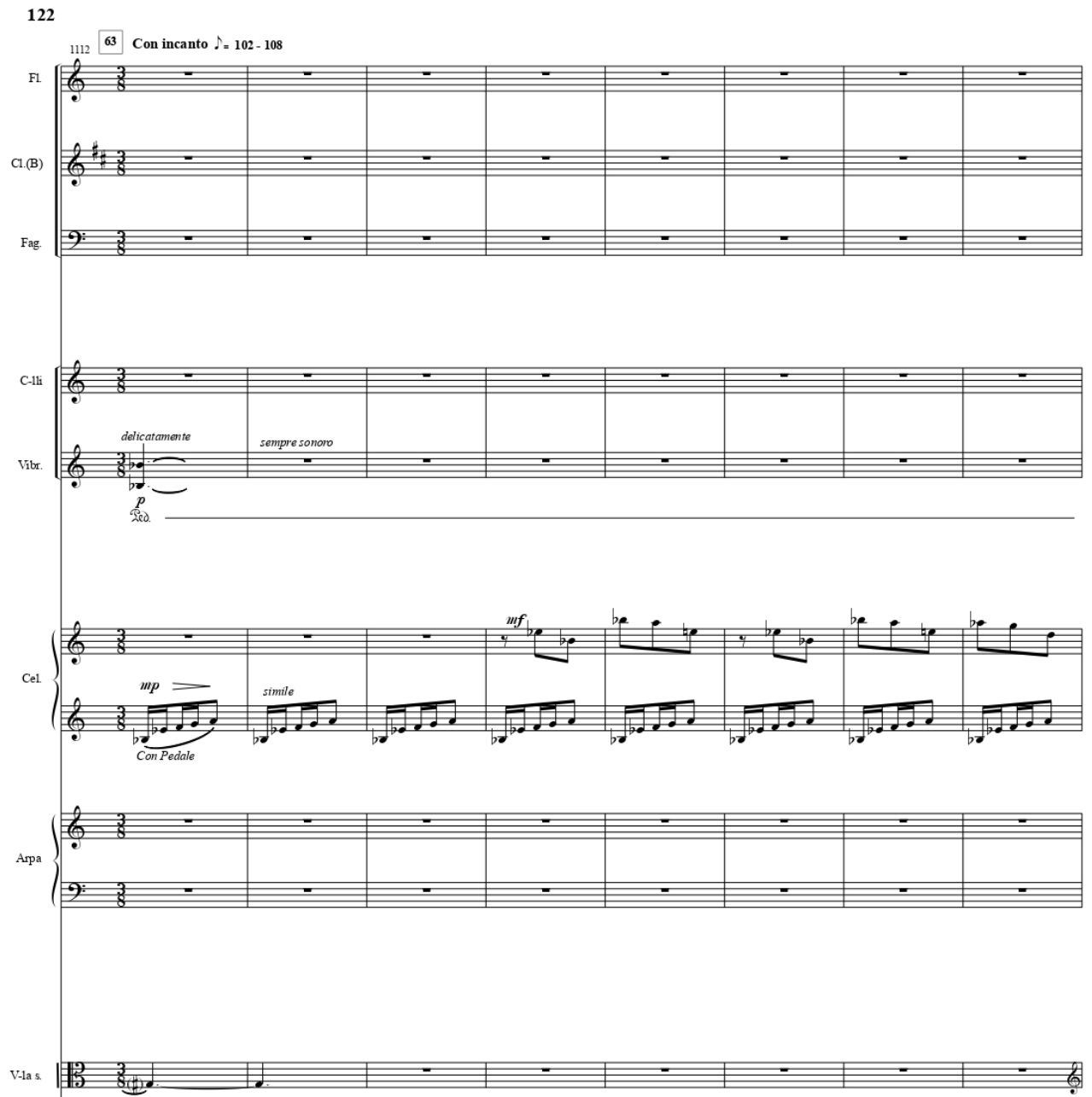

63 Con incanto $\delta=102-108$

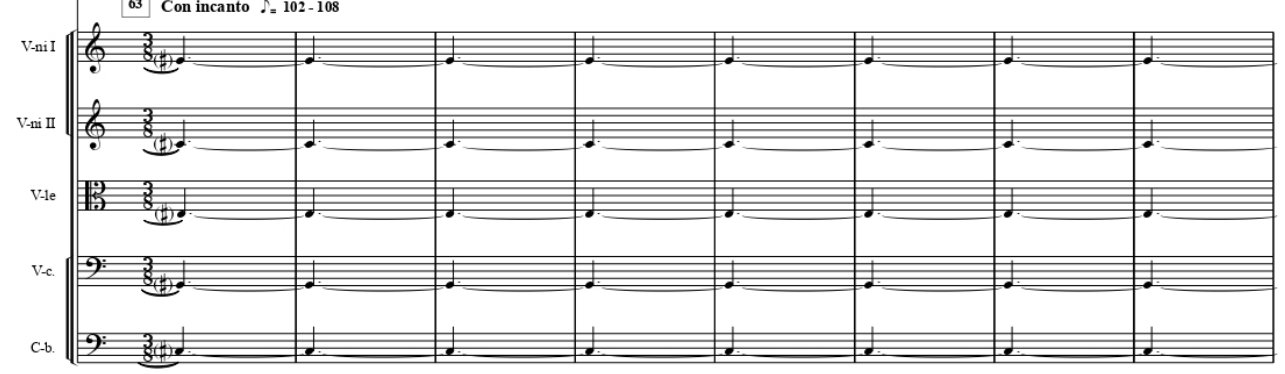




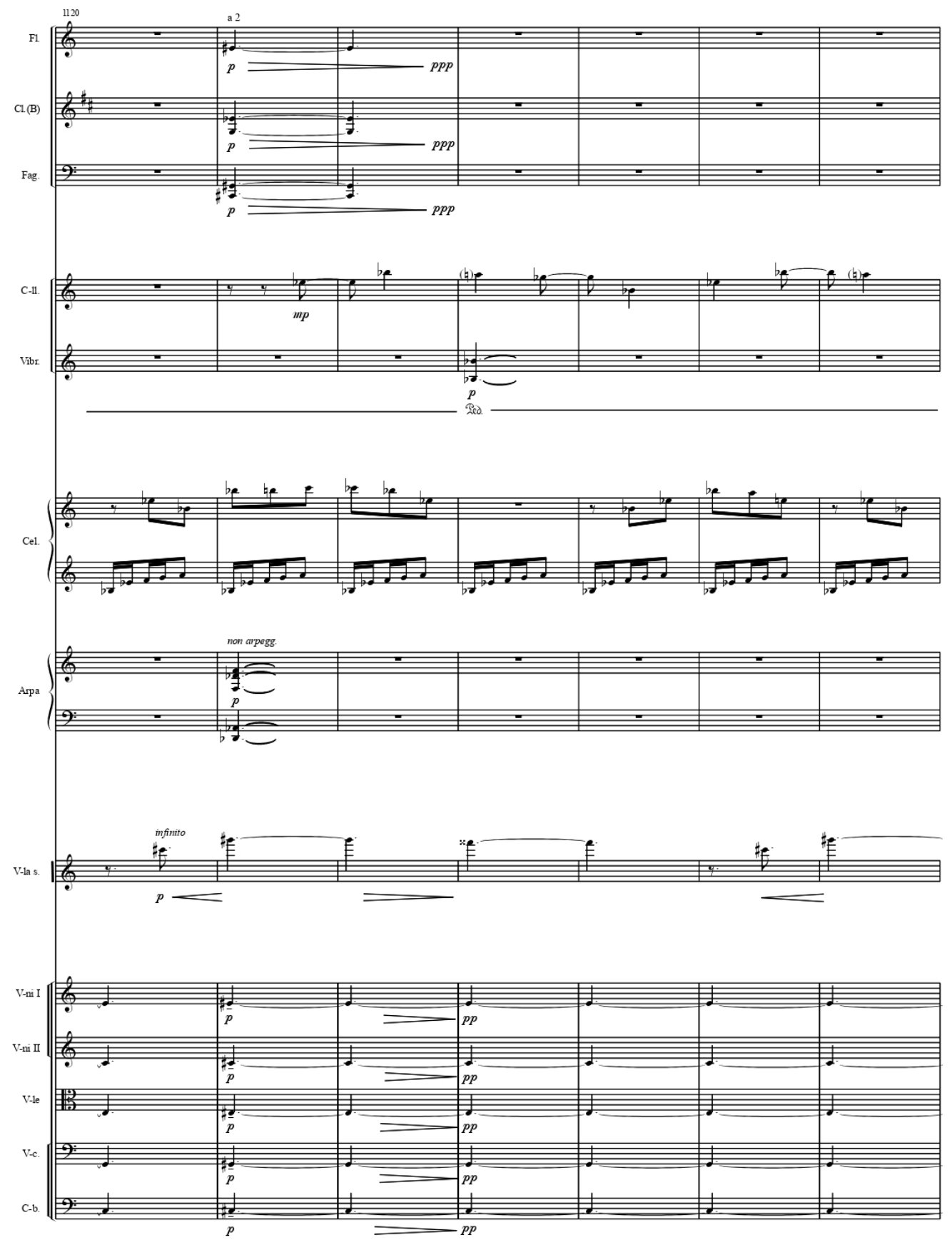




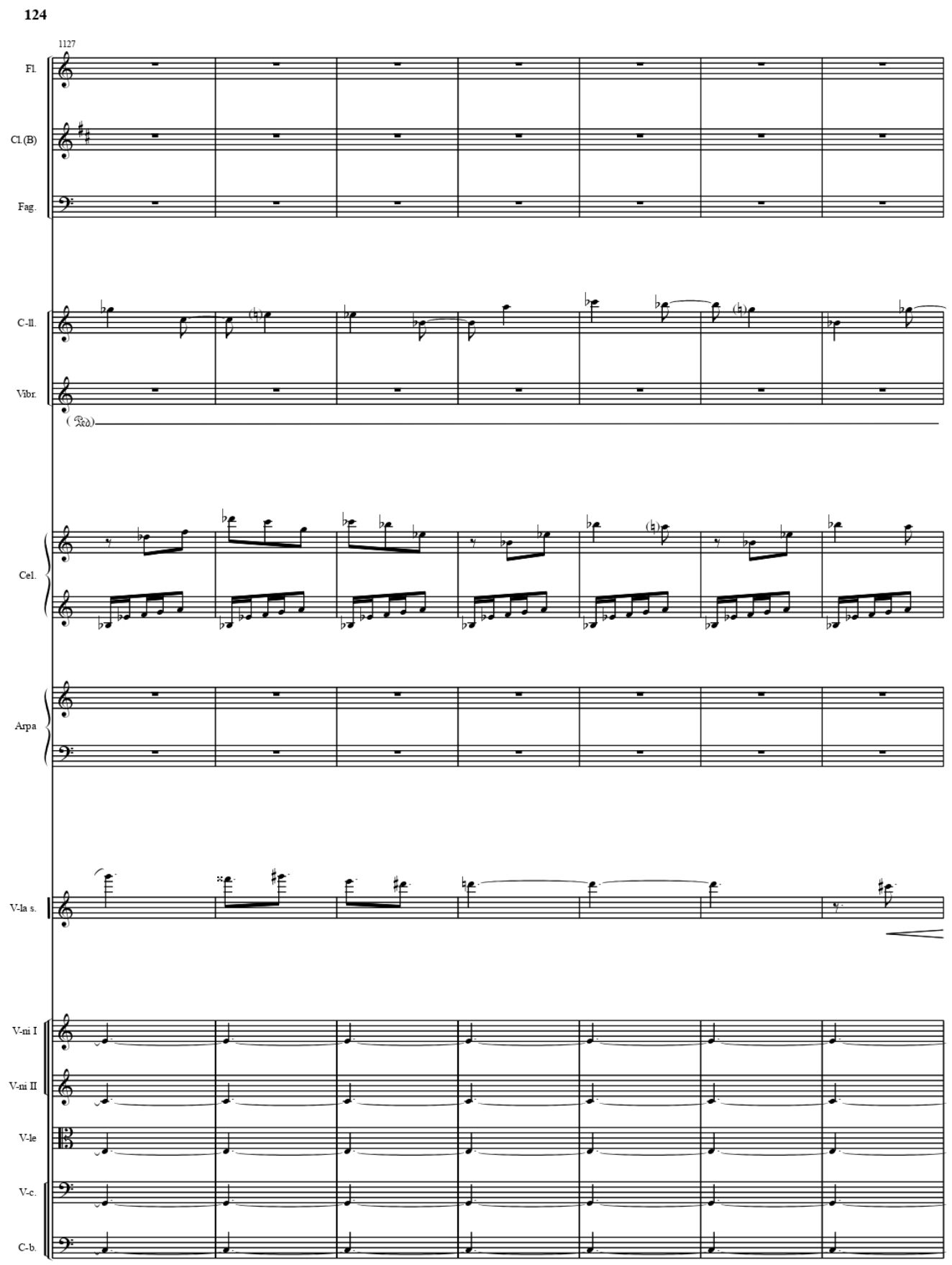


回

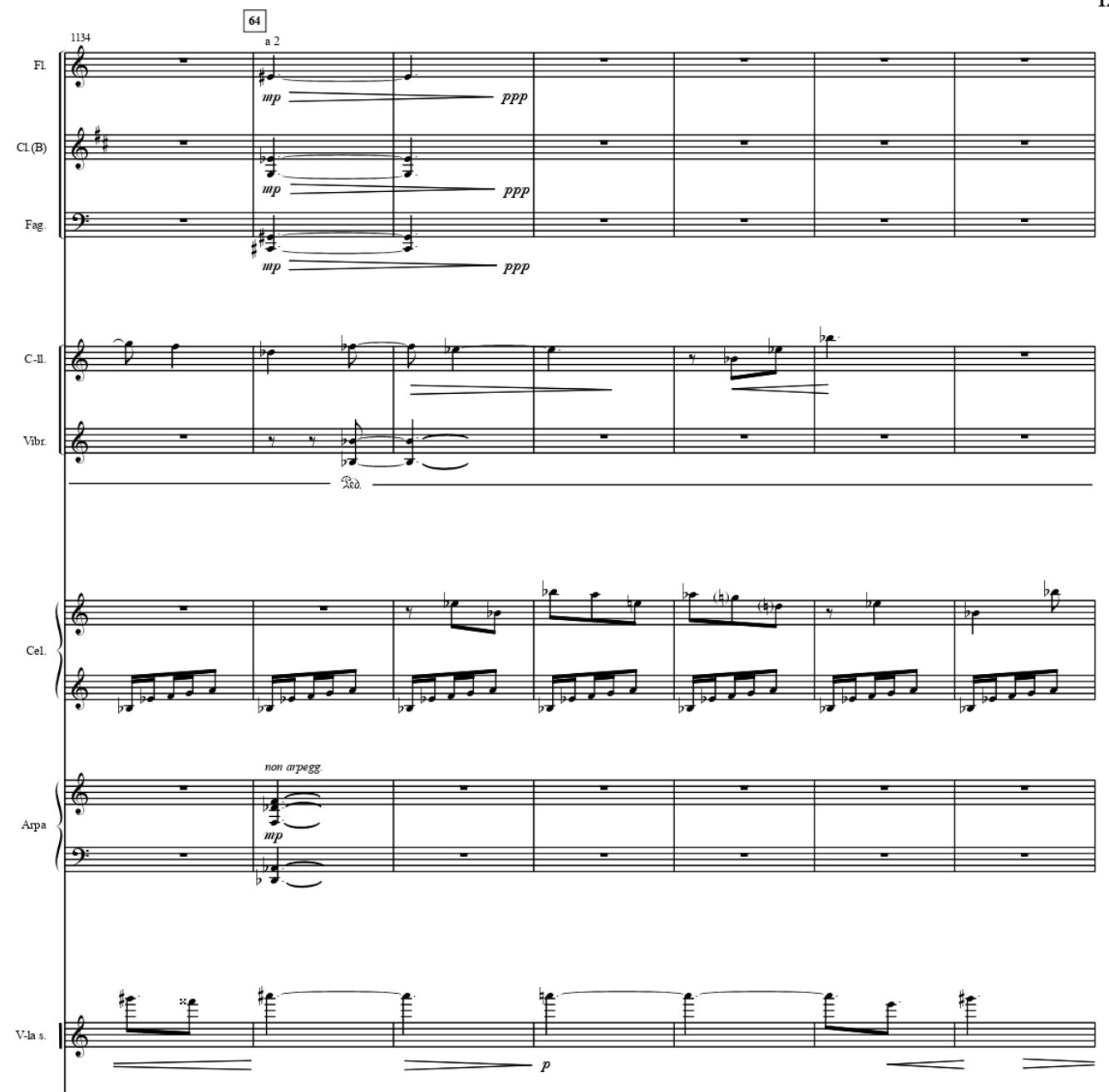

6

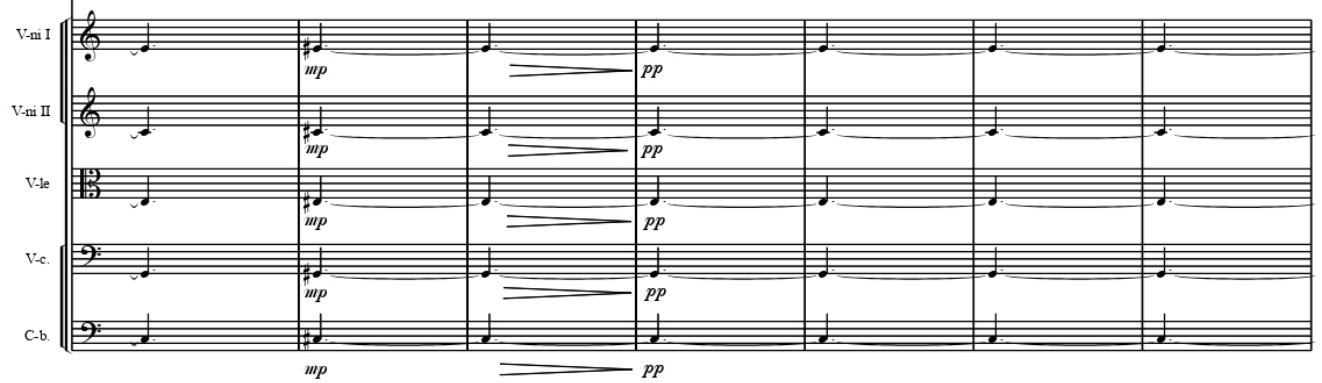




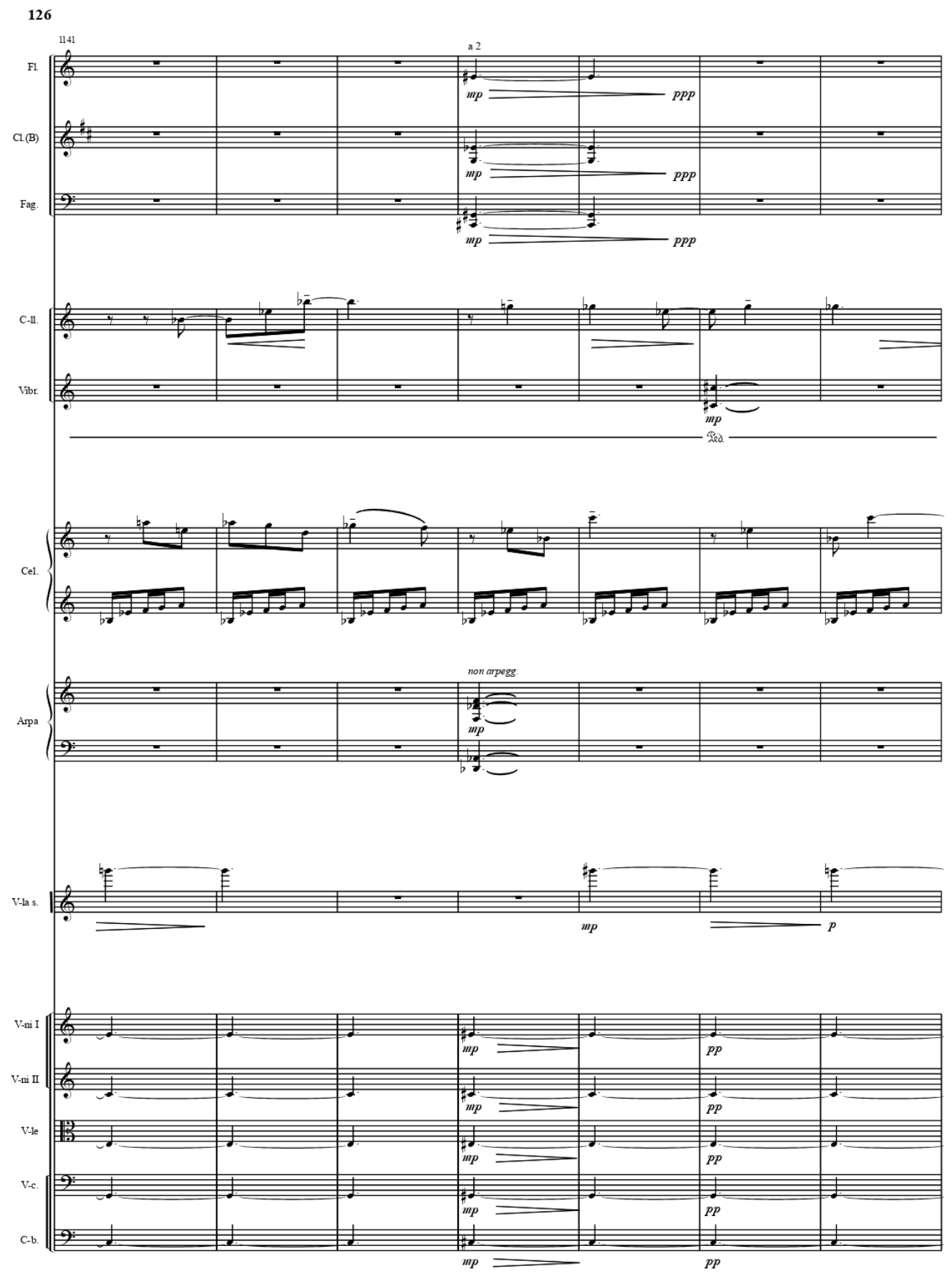




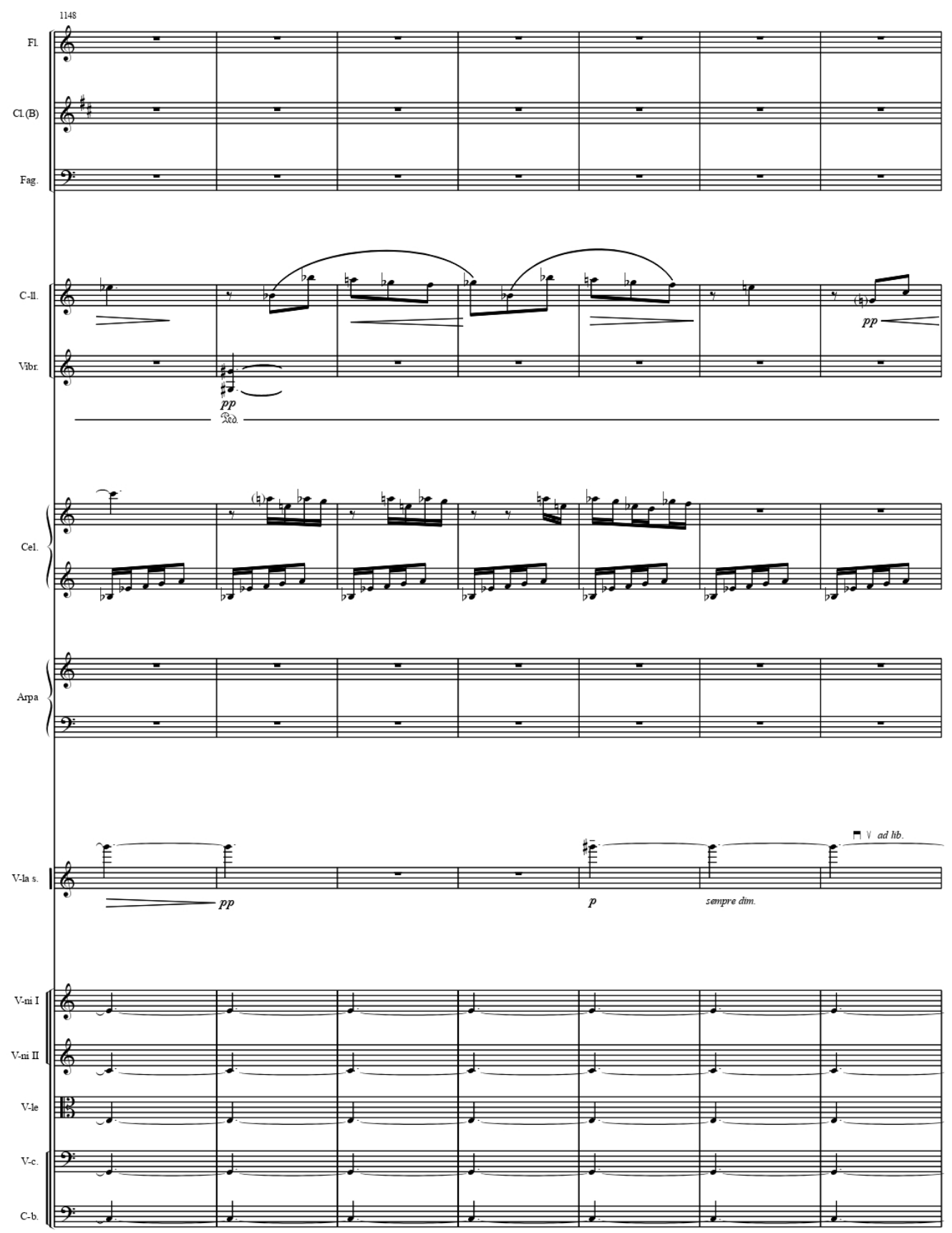




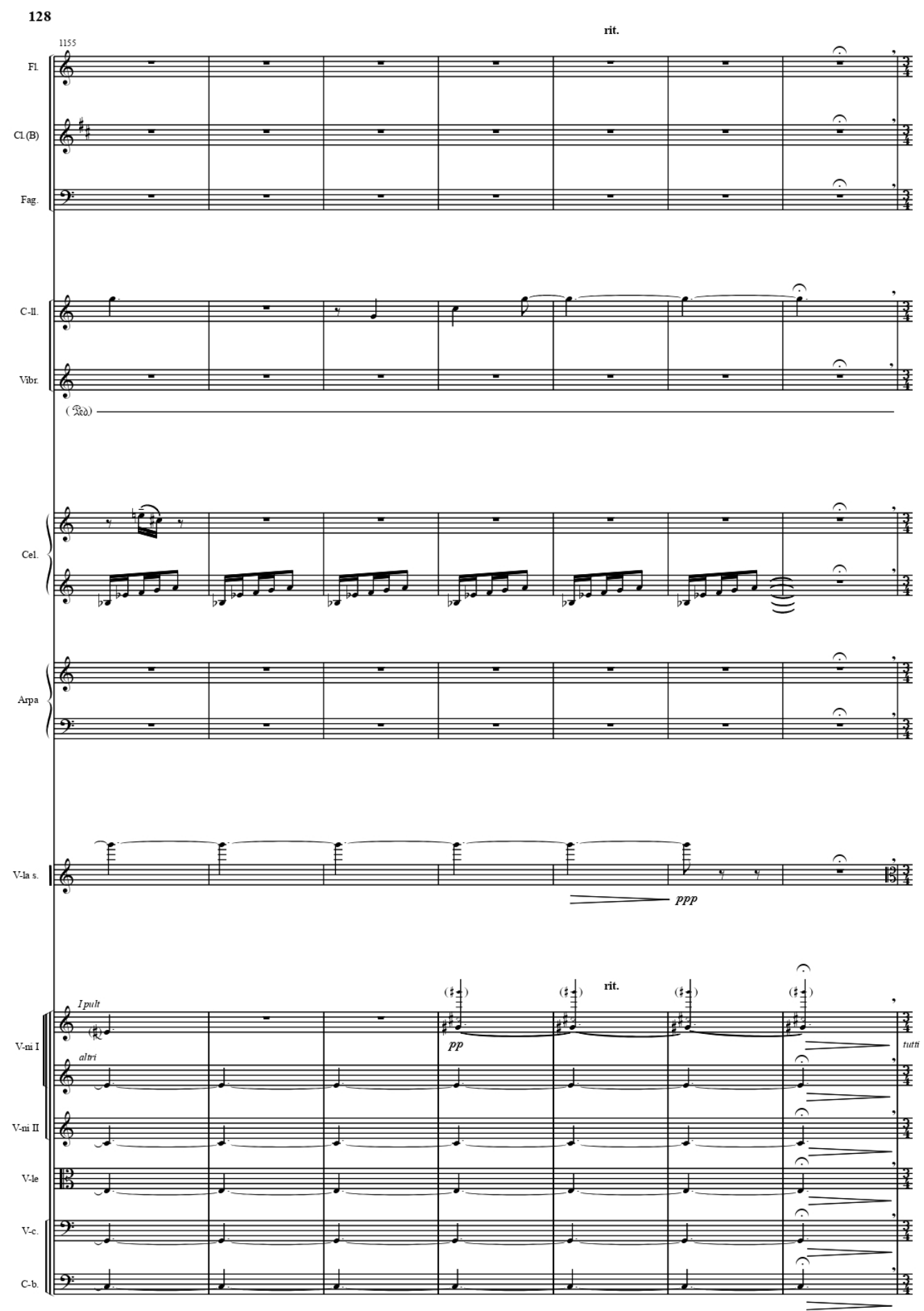




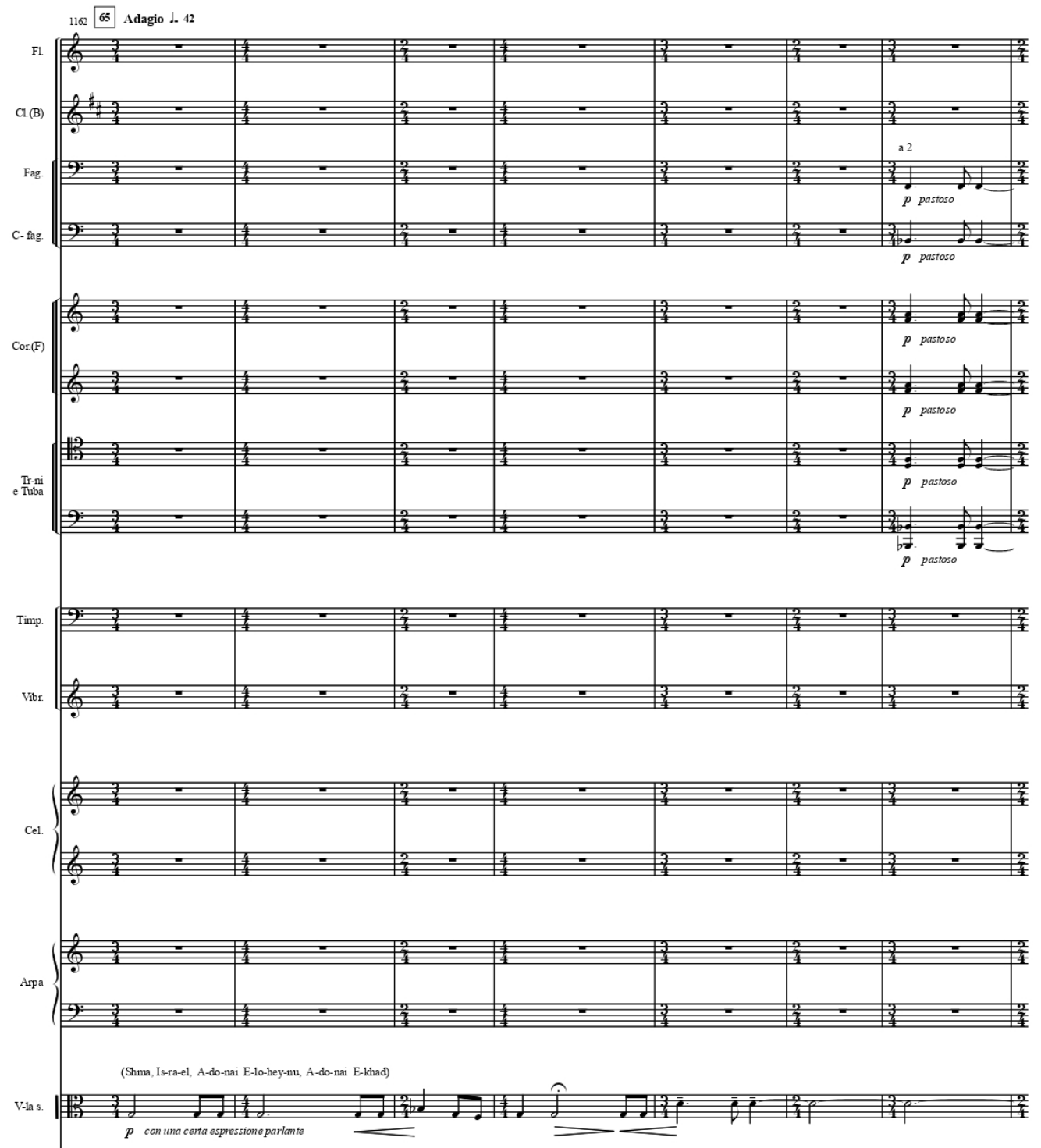

65 Adagio ㄱ. 42

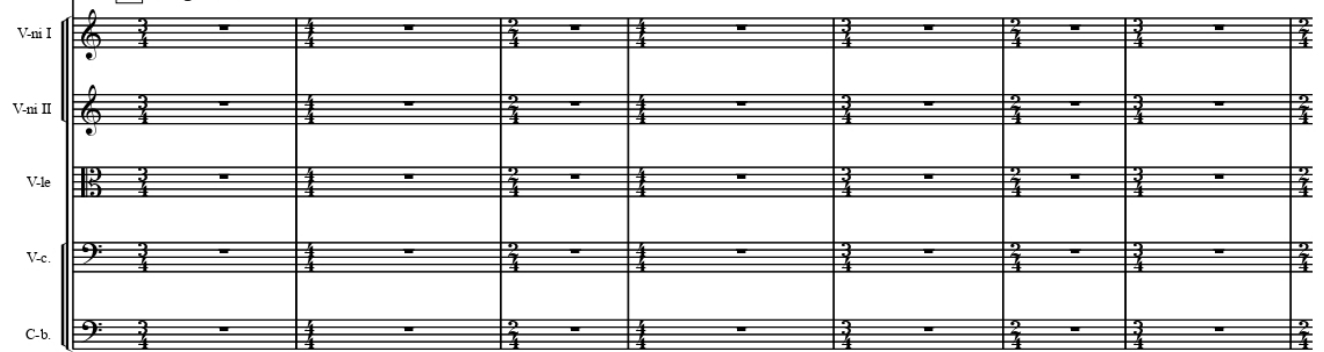




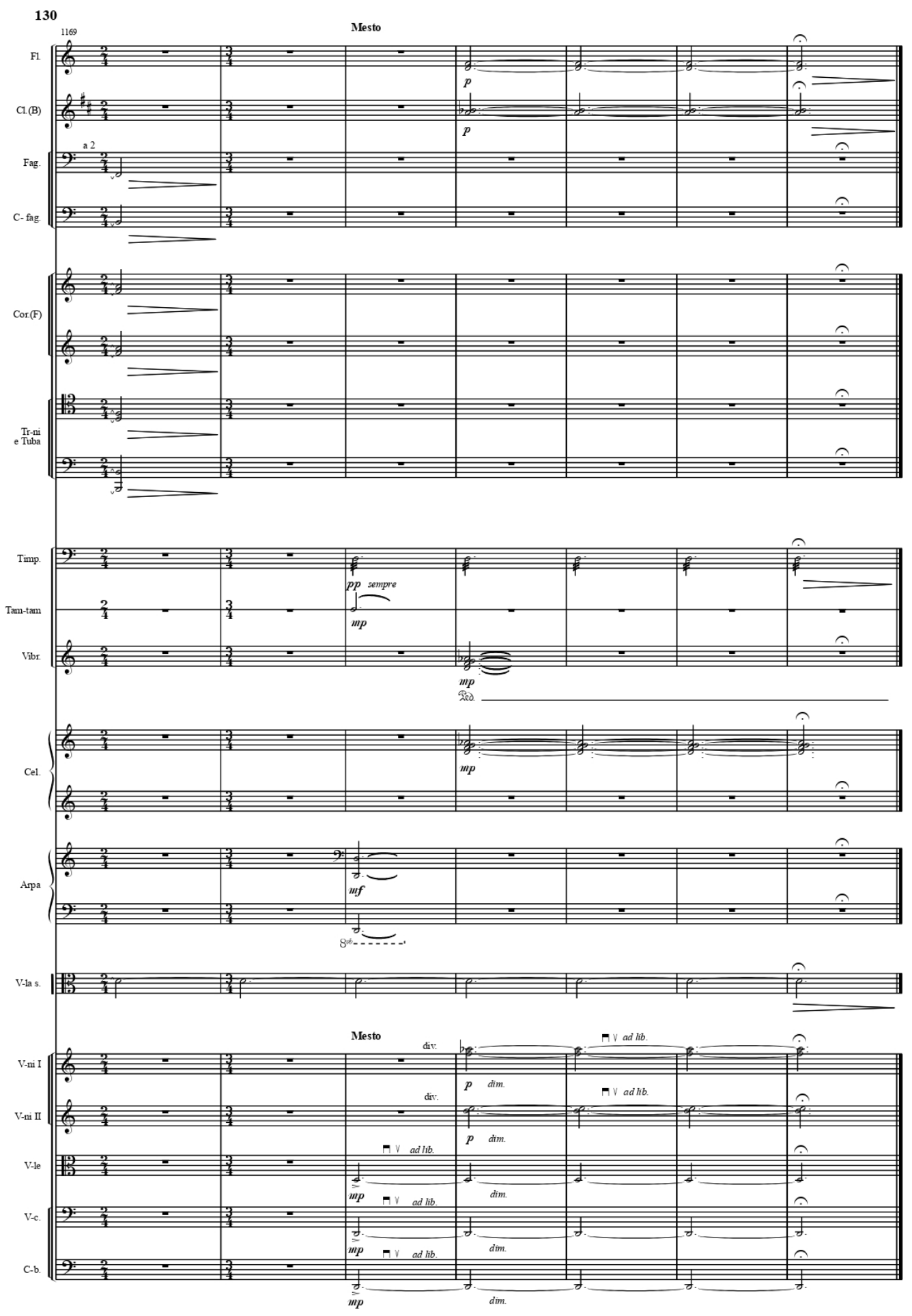




\section{Appendix 5}

\section{Full transcript of the interview with Boris Pigovat about Holocaust Requiem}

Xi Liu: What are the structures in each movement of the Requiem? How does it work?

Boris Pigovat: Good, I will talk separately for each movement. The first movement, If we talk about its formal structure, then you can see a three-part form, because there is a reprise - the first material returns at the end. And here, in principle, this is a purely formal thing, that you can see a three-part form.

I didn't set out to write a three-part form, a sonata form or some other traditional form. There are practically no traditional forms in Requiem. What did I want? I wrote a sequence of different episodes, in some cases, I returned back to write themes when I felt that it was necessary, but I did not want to write in some standard form.

In order for the work not to "fall apart" in perception, it is necessary to combine various themes with some elements, some connecting elements. Such elements are three motives found in a variety of themes. The first motive is like this (the clarinet motive is played in bars 6-7), suppose we denote it as Motive "a". The second motive (motive " $b$ ") can be added under it. It's like a rhythm of singing the word Requiem with a sequence- Requiem aeternam (Figure 2 is played). The third motive (motive " $c$ ") appears a little later, and it is very important for the development. (Bar 122 is played), this is from the beginning of the development section, downward movement in minor seconds. In principle, this third motive was actually born from the first motive ("a"), because if you remove the jumps, you will get down in minor seconds ( $a$, a flat, $g, f$ sharp). But here this leap (A-flat - E-flat) is very important, therefore it is as a separate motive (motive "a").

So we have motives "a", "b", "c", which are held in a variety of fragments of themes. There is an introduction, a main part, a development part and a reprise of the main 
theme. There is an element " $a$ " in the introduction (bars 12-13). In the sequence, when the viola solo begins (bar 31 onwards) as a new theme, but further on (bars 35-36), the element "a" appears again. This theme is new, unfamiliar, but the element "a" appears inside it, and after that the element " $b$ " first appears (Figure 2 is played). As an answer to this element "a" appears (bars 47-49). Then again the alternation of these two motives comes out (bars 53 - 62).

Then a completely new theme appears (Figure 3). But where does it start? It starts like this (played bars 64-67) - the "a" element, and the theme is new, the music is something completely new. But in the continuation of the theme, again the element "a" appears (bars 69-71) and there is also a hint of the element " $c$ ". So these elements are all the time in all themes, and penetrate into all places. Suppose here (bars 82-84 are played) as a variant of the element " $a$ " , then the most significant places of the elements " $a$ " and " $b$ " is at the very end of the first section. When the viola has the motive "a" (bars 110-111) and the trombones answer the Requiem again. This concludes the first section and begins a big development.

The development section has many episodes, the third element is still dominating in these episodes (bar 122 is played). The Affanato theme develops (plays bar 126), and the viola movement is built on Figure 7. After two episodes it slightly recedes, the 5/8 movement appears, which is based on the element "a" (bar 189). This is repeated as ostinato, and at the same time the theme "Requiem" (element "b") appears in the horns.

The first climax appears (Figure 11), and the viola has a theme with the element "a" twice and at the end with the element " $c$ ". Figure 12 is the second climax with the element "a". This is how the development section ends.

The next comes the reprise of the first section, we can find the element "a" again, but there is a very bright insertion of the element " $c$ " (bar 233 is played). Then it continues with the "b" element (Requiem) twice in bars 247-248 and 251. 
All the materials of the first movement are somehow permeated by these three elements: the "a" element, which appears in one theme, then in another, then at the beginning of the theme, then in the continuation of the theme, the " $b$ " element is Requiem, and the " $c$ " element is the movement in seconds. Sometimes they go as the development, and sometimes they become part of the melodic theme, and then these motives increase (bars 210-212).

The second movement ("Dies Irae"), in fact, is the story of the Holocaust. This is not an understanding of the Holocaust, but a story about it. I would like to simply cite the words from "Dies Irae" as a character of music and as an image of music - "Day of Wrath", the day will turn the world to ashes. At the same time, in the Jewish memorial prayer Izkor which is read in memory of those who died in the Holocaust. It is said: "Remember the rivers of blood pouring like water." And another phrase that may reflect the nature of this work: "The sword is ruining outside, and the specter of death is inside", this is from the "Lamentation of Jeremiah." I felt some kind of inner horror when I wrote it.

There are two stylistic layers. On the one hand, this is the theme of "Dies Irae", which can actually be the subtext (in the traditional text of the Latin prayer). I tried to make it as if the choir sings with the text (the theme from c.17 is played and hummed). The theme of "Dies Irae" takes place several times in the second movement. On the other hand, a theme appears that can be subtext at the culmination (figures 37-39) with the words of the Jewish prayer "Shema Israel" (the theme of bass notes $571-577$ is played and hummed).

In addition to these themes, a lot of music appears with pronounced Jewish intonation and Jewish dance. However, at the same time, the main feeling that I tried to convey in music is the feeling horror of what is happening. Besides, it's important to emphasize the feeling of MECHANISM of this horror, that it is a murder MACHINE, a machine that grinds human lives and human destinies. I tried to convey this mechanism here, too. 
Again there are a lot of episodes in "Dies Irae". How do episodes relate to each other? There is an episode, if there is another episode after it as a variation not on the previous episode, then we get the principle of sub-variation - variation on variation, more precisely variation on episode. Therefore, the whole does not "break up", because there is always a connection between the episodes, when the next episode looks like a variation on the previous one, not on the main theme, but a variation on the previous episode. In addition, in the second movement there are a lot of ostinatos of repeating rhythmic formulas. Ostinato always gives the possibility of a sensation of binding material. We have this type of ostinato (the ostinato of bars 388-389 is played, then it will be in the figure 29) and a lot of this (the ostinate formula from bar 522 is played). And these ostinatos are repeated in different versions passing one into another, and always a feeling that the development is continuing and underway. Again formula "a" (element "a") appears many time, despite they are in a completely new theme. Also comes out the Requiem formula (element "b") and the formula c (element "c"). Figuring up these formulas (element "a", "b" and "c"), that I called the formula " $d$ " (element "d"). What is this formula? Formula " $d$ " is a jump to a reduced fifth, a triton. The first time this formula appears at the end of the first Dis Irae theme (bars 295-297). Then it appears as an accompaniment to the second theme (figure 18 is played). In the theme itself there is an element "a" (bars 300-301, 303, 304). The " $d$ " element will then appear in the horns (figure 19, bars 307-309). These formulas "a", "b", "c", " $d$ " penetrate almost all sections, plus the Dies Irae theme (bars 325-327 are played). Element "c" presents in bars $340-341,345,346$.

Now I also want to draw attention to another important theme, which appears in bars 349,350 - 354. This theme is connected with the Jewish tradition, it is like the theme of the Hasidic Nigun (350 - 351 bars are played). This theme appears for the first time in figure 22 , it will continue to appear. The last time it is at the very end of the Requiem, when the coda is already coming suddenly we hear it (bars 1120-1132 
are played). This is a theme from the second movement (bars 350 - 351 are played again).

I will not show all the elements in all sections of the second movement in details, but I wanted to pay attention - whenever something new appears, we can find something familiar: on the one hand - Dies Irae (bars 379-380 are played, alto part), and on the other hand (bar 384, Marimba is played) - "a". Or when some ostinato begins (the Ostinate formula, bar 388 - 390 is played), suddenly in this Ostinato we hear the element " $d$ ".

Suddenly, the Requiem theme appears (bars 427-433, French horns are played) on the background of "a" (bars 430-431 flutes are played). In figure 27 we have four parts: the accompaniment to the theme Dies Irae, Requiem Aeternam ("b"), element "a", and element "c" (Viola part is played, bars 430-431). Everything is concentrated on one such small segment.

In figure 28 , this is some kind of dance music (bars $443-444$ are played). What is this element? This is the " $c$ ". But in the music, we don't feel this is " $c$ " until we analyze it. What is this (the bass ostinato is played in figure 29)? Actually Ostinato is based on (within) the element " $d$ ". At the same time, here (bars $449-450$ are played) is Dies Irae. Dies Irae turned into some kind of "devilish dance." In general, this part is built in such a way as to gradually bring the music to the "Dance of Death" - "Danse Macabre" (in French) - (Dance of Death - English). It turns out a dance like a polka Dies Irae turns into such a dance (bars 449-450 are played again), and this gradually leads to such a similarity of the Waltz of Death. At first (figure 34 is played) it was the element " $c$ " along with ostinato. But the most important waltz begins in figure 42 when such a waltz rhythm is given (the piano part is played) - the sarcastic waltz and added the ostinato band, and it sounds like the Death Waltz. At the same time, the theme of Dies Irae appears (bars 635-638, trumpets and trombones parts are played). What happens in the background? Amid all this horror, there is an "a" element (xylophone part is played). 
Figures 42 and 43: Dies Irae (several times, at pipes and horns), a lot of different ostinatos (1 flutes + piccolos, 2 Oboes + Clarinets, 3 Bass clarinet + Bassoons, 4 xylophone, 5 drums, 6 piano, 7 figure 43 French horns).

What is ostinato here for? Ostinato is mechanistic, and my task was to show the mechanistic nature in order to depict the "death machine".

Finally, the last episode was very important to me as the ending of the second movement. The rhythm of the heartbeat is depicted starting from bar 696 to show how many hearts of people are combined into one huge heart beat. Gradually this heart beat begins to die.

I even asked a doctor, a cardiologist, "What does the heart beat look like, what are the last beats when it dies?" He told me this: "At some point it becomes like the rhythm is depicted as in bars $740-744$. I passed this beat to the bass drum part (the bass drum part is played from the figure 47) to try to convey this rhythm of a dying heart as he told me.

What is the original reason of this episode? This episode is associated with a fragment from the book "Life and Fate" by Vasily Grossman. One terrible moment describes how a huge amount of people are driven into a gas chamber, and how gradually they died. An awful place! This image had been emotionally acting in my mind. Now I tried to convey this feeling in this work here after I read it.

Now, the third movement should be crying - Lacrimosa. At first I wanted to write the traditional "Lacrimosa" - quiet music with intonations of tears and crying. However, at some point I felt that after the horrors I tried to portray in the second movement, it is impossible to go to the usual "Lacrimosa". A person cannot just cry, be strangled by the anger, or be strangled by the pain. No tears here! So this formed the concept of the third movement. At the beginning, music should express the pain, the anger, and the despair. When the despair is already expressed - all the forces go to this 
crying, there is no more strength left, remains only the moan powerlessly (figure 49, starting from bar 862).

When nothing is left and everything is "burnt out", a person wants to forget himself to go into oblivion. He is going crazy or some kind of temporary insanity, and such a strange waltz begins (bars $880-881$ are played). As if a person is "not in himself", he is "not in this world." When I was doing this fragment, I remembered a scene from Prokofiev's opera "Semyon Kotko". In the story, a moment when one guy is executed, and his bride who was supposed to marry him, she cannot accept that he died. She walks around him, around his body. She lost her mind and said: "No, it's not Vasillyok. No, it's not Vasillyok." She does not believe that her fiancé died. This is a feeling of some kind of madness. Or like Ophelia, she goes crazy because she is shocked by the death of her father.

I tried to convey the same feeling here (bars $880-888$ are played). At the beginning is just very strange music, and at some point it turns into a waltz (bars 896 - 901 are played). At some point this madness obsession leaves and again an explosion of emotions, and return to realities (figure 51 is played).

Only after this explosion of emotions, when everything fades away tears "open". Only after all this horror, the energy of anger and the emotion of pain have "splashed out", it is the time for crying. Then the music of the typical "Lacrimosa" appears from the very beginning. I tried to somehow reflect the mood of the Mozart "Lacrimosa" (bars 919-920 are played).

On the one hand, this is Lacrimosa. On the other hand, Requiem is a symphony concert for viola and orchestra, so it needs a Cadenza.

I wrote this movement as a Cadenza for a solo instrument. But if it is a Cadenza, what is the characteristic of it? Cadenza always collects materials from all previous 
parts, right? Cadenza is usually built on the materials of everything that made before. In this work, it contains all important contents that we had before.

Dies Irae theme comes in (bars 768-769 are played), then comes the elements "a" (bar 772) and "d" (bar 773), then again goes "a" and Dies Irae. A new material appears (bars 781-789), and again “a” $(790,792)$ and Dies Irae (794-796). The next section contains Dies Irae $(804,807)$ and "a" $(808-809,814-815,823)$.

" $C$ " element is in bars 824,825 . C still continues (bars 830-833 are played). Element "a" comes here (bars $835-837$ are played). The chord in bar 838 is as a derivative of bar 773 (the " $d$ " element is played from bars 294-297 - the second movement of the Requiem). Again " $a$ " is in bars 841,842 . After that, the material at the beginning of the second movement sounds (bars $843-845$ are played). That is, all the previous elements appear in this movement (the theme at the beginning of the second movement is played, bars 261-262). In comparison with this are bars $843-845$ of the third movement. Now we proceed to the completion of this first section in third movement. What's going on here (bars 858 and 861 are played)? This is element " $d$ ". Then begins the "groan", and in the music of the groan suddenly "a" appears (bars 868-872 are played). The same elements are in bars 874 and $876-878$.

Now begins the "music of insanity." Bars $880-883$ are based on the element " $d$ ". This is Ostinato, and it goes all the time of element " $d$ ". Inside the viola theme (bar 891 is played) is "c", and after that is "a" (bars 894-895, 897-898, 889-891). Finally a surge of emotions come out again (figure 51). Against the background of an orchestral low chord, the element appears in the soloist -" $d$ " (bars 902-904 are played), and "c" (bar 906), then these elements repeat again (bars 909-918).

The impression of the "Lacrimosa" is a completely new music (bars 919-922 are played). But what do we see from the very beginning (the melody of bars 919-920 are played)? It is the version of element "a". It's just that the motive comes to the sound of "fa" later. 
Moreover, the Requiem motif of element " $b$ " still appears in bar 925. This melodic line rises, and again sounds "a" (bars 929-931).

This movement ends up with the theme "Shema Israel" (bars 938-943).

In the cadence, there are a lot of reminders of both the main motives "a", " $b$ ", "c", " $d$ " and the main themes "Dies Irae" and "Shema Israel". At the same time there are elements from "Requiem Aeternam" the first movement of the Requiem. This is the third movement.

The fourth movement, "Lux Aeterna", was supposed to be the lightest and most serene part of the entire work. This is the final part of the Requiem, therefore some moments from the whole composition should be reflected here. At the same time, for this movement the perception is "tired" from the abundant repetition of the elements that took place in the first three movements ("a", "b", "c", " $d$ "). Therefore, as a composer, I had a need to write a completely new to the music. There are actually four new themes.

The first theme begins with the accompaniment, the viola enters with this theme in the figure 54 (bars 957-963 are played and so on). After this first new theme, another new theme appears, which was not listened before (bars 975-982 are played). This is "Jewish intonation" in this subject, but there are no quotes from previous "Jewish" themes that were in the second movement. There were also themes with Jewish intonations, but here it is a different theme. That is, this second theme in the fourth movement is new. Since the fourth movement is the completion of the whole Requiem, it becomes necessary to make a "bridge" with the first movement. A theme from the first movement appears in the viola monologue (bars 994-995 are played). When quotes from the first movement appear, the main elements from the first movement also appear here as part of this quoted theme. An element " $a$ " is in bars 998-1001 and an element " $b$ " - Requiem is in bar 1004. But I repeat again: these elements appear here as components of the theme, which is 
quoted from the first movement. Bars 994-1004 are not actually a theme of the fourth movement, they are an "insert" from the first movement in order to throw a "bridge" from the fourth to the first (Bridge - figure 57).

Two bars before figure 58 begins the development of the second theme. It was with such accompaniment (bars 977-978 are played), and now it was with such accompaniment (bars 1006-1007 are played). This is the development of the second theme (bars 1008-1011 are played). It is a kind of Jewish lullaby. Gradually there is a decline, and the initial texture of the part returns (bars 1046-1051 are played).

After this, another new theme appears in figure 60. This is an alto solo on the background of the harp (bars 1052-1059 are played ... and so on). This theme goes on and develops, and only after this third new theme ends does something familiar appear. What it is familiar here? This is a quote from the first movement again, and this is the introduction theme of the first movement (figure 62). As a result of this quote, the Requiem theme appears in bars 1099-1110.

But again, this is like part of the music from the first movement. This has nothing to do with themes that are inside the fourth movement. That is, once again I repeat: the fourth movement was "called upon" to give new materials and new themes. Three new themes have already appeared.

Since this movement is the final part for the whole cycle, for the entire work, themes are introduced here as quotes from the first movement. Above all, it is from the initial section of the first movement (the introduction and the first theme). Therefore, here appears the flute of the introduction theme, and the element " $b$ " Requiem as if uttered by the choir (bars 1099-1100 are played again). The monologue from the first movement in bars 1101-1104 continues and, and Requiem in bars 1105-1106 and bars 1110-1111. The key of C sharp major is adjusted, and new theme begins. There is a celesta - an instrument that was not previously in this work, appears for the first time of this timbre paint. It is perceived as something 
completely new. Against the background is the C sharp major (Lydian E flat major, bars 1111-1119 are played).

Actually this is just the background for the theme, but the theme from the second movement appears next with a completely changed character. That theme in the second movement (figure 22) was energetic (bars 349-353 are played). Now in the fourth movement, this theme is completely ephemeral in a very high register (the beginning of this theme is played - bars 1120-1124). Someone prefers to play it with a large vibrato in a high register, Donald decided to intensify the "incorporeal" paint that it is something "unearthly" and played all with flagollets. I accept with both. The main thing is that the nature of this theme is completely different than it was in the second movement.

Why does this theme appear here (theme from the second movement)? Because this is already the coda of the fourth movement, and at the same time it is the coda of the whole composition. The coda should collect materials from different places of the whole work. Therefore, using the theme of the second movement here is my conscious compositional decision. Since this work is about the Holocaust, about the fate of the Jewish people, and this theme is with a vibrant Jewish character. Therefore, I decided to give it here, it was a conscious choice.

After this section ends with the celesta and this theme, the very last section of this coda begins. What is it includes?

On the one hand, the viola part is the theme of "Shema Israel", which appeared in the climax of the second movement (bars 571-577), then it was between the third and fourth movements (bars 938-943) - completed "Lacrimosa" and connected with the fourth movement (the horn, bars 938-943 are played). Now the third time in the end, it is the viola solo (figure 65 is played). It was singing as if with the text Requiem (bars 1168-1169 are played). At the very end, two lines of this composition are 
connected: on the one hand, it is the traditional Requiem, on the other hand, it is a work about the Holocaust of the Jewish people with the theme "Shema Israel".

You asked that it is like "a better life" referring to the image of the fourth movement. No, this is just like an appeal to God so that the souls of the dead go to a bright paradise. That is the "eternal light" (Lux Aeterna). (The Russian translation of the Latin text that Pigovat gave me is read.) (Then the text from the Jewish prayer "Izkor", which I also have, is read out). It should be clean, calm, beautiful music, this is about music character. That is not how you thought that "this is the best life after the war." No, this is all connected with the souls of the dead. Simply this is a request that the souls of the dead had been given the eternal light, the nature of the music should be connected with this.

Now regarding the material, we had so many materials that are connected with each other by the motives "a", "b", "c", "d", at this moment in the fourth part I felt it was necessary that the music should be completely different, so there was no connection.

Therefore, four completely new themes that are not related with the themes of the previous movements appear here. We do not feel connected. There is a connection after all, I will show later. There is a connection, but it is "hidden". At the same time this is the conclusion of the whole work, you need to make a "bridge" to the beginning of this Requiem. Therefore, elements from the first part appear here, and gradually we begin to feel that this Lux Aeterna is the coda of the whole composition. 